Claudius de Sousa Barbosa

\title{
RESISTÊNCIA E DEFORMABILIDADE DE BLOCOS VAZADOS DE CONCRETO, PRISMAS E PAREDES E SUAS CORRELAÇÕES COM AS PROPRIEDADES MECÂNICAS DOS MATERIAIS CONSTITUINTES
}

Tese apresentada à Escola de Engenharia de São Carlos, como parte dos requisitos para obtenção do Título de Doutor em Engenharia de Estruturas.

Orientador: Prof. Titular João Bento de Hanai

São Carlos 


\section{AUTORIZO A REPRODUÇÃO E DIVULGAÇÃO TOTAL OU PARCIAL DESTE TRABALHO, POR QUALQUER MEIO CONVENCIONAL OU ELETRÔNICO, PARA FINS DE ESTUDO E PESQUISA, DESDE QUE CITADA A FONTE.}

Ficha catalográfica preparada pela Seção de Tratamento da Informação do Serviço de Biblioteca - EESC/USP

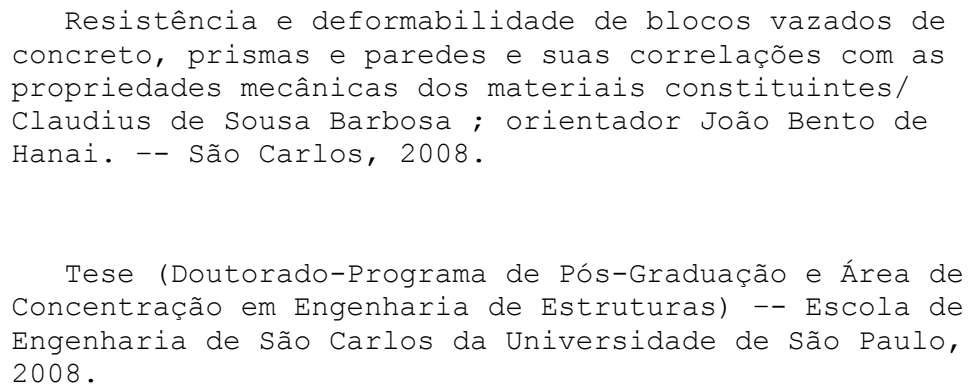

1. Alvenaria estrutural. 2. Blocos vazados de concreto. 3. Prismas. 4. Paredes. 5. Propriedades mecânicas dos materiais. 6. Modelos numéricos. 7. Análise teórica e experimental. I. Titulo. 
FOLHA DE JULGAMENTO

Candidato: Engenheiro CLÁUDIUS DE SOUZA BARBOSA

Tese defendida e julgada em 21/07/2008 perante a Comissão Julgadora:

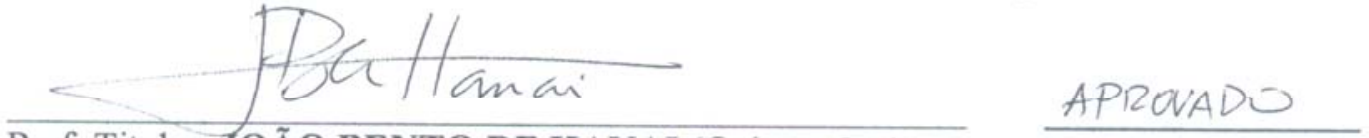

Prof. Titular JOÃO BENTO DE HANAI (Orientador)

(Escola de Engenharia de São Carlos/USP)

O EXAMINADAR PARTICIPOU POR VIDEO-CONFERËNGIA APROVADO Prof. Dr. HUMBERTO RAMOS ROMAN

(Universidade Federal de Santa Catarina/UFSC)

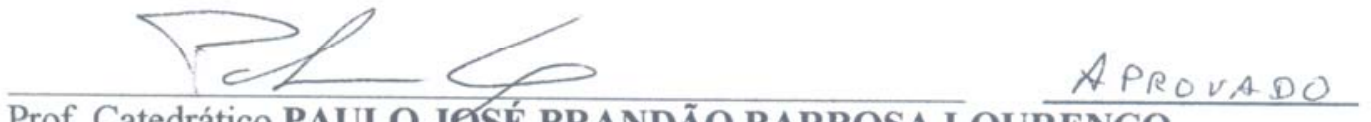

Prof. Catedrático PAULO JOSÉ BRANDÃO BARBOSA LOURENÇO

(Universidade do Minho/Portugal)

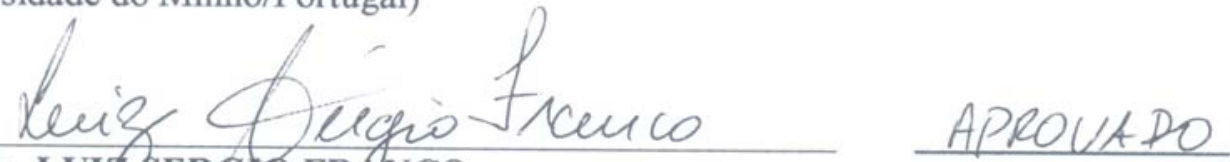

Prof. Dr. LUIZSERGIO FRANCO

(Escola Politécnica/USP)

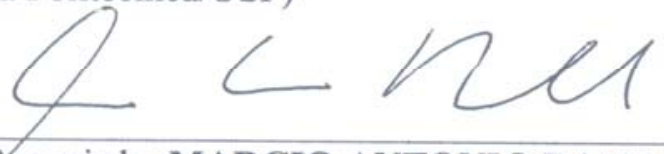

Prof. Associado MARCIO ANTONIO RAMALHO

APROUADO

(Escola de Engenharia de São Carlos/USP)

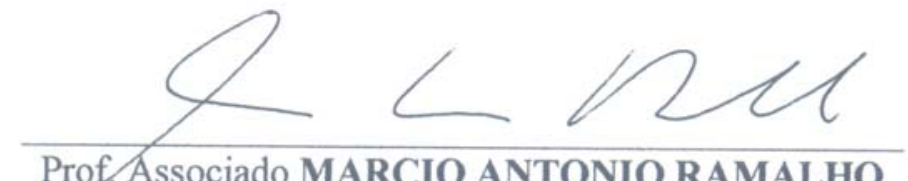

Prof. Associado MARCIO ANTONIO RAMALHO

Coordenador do Programa de Pós-Graduação em

Engenharia Civil (Engenharia de Estruturas)

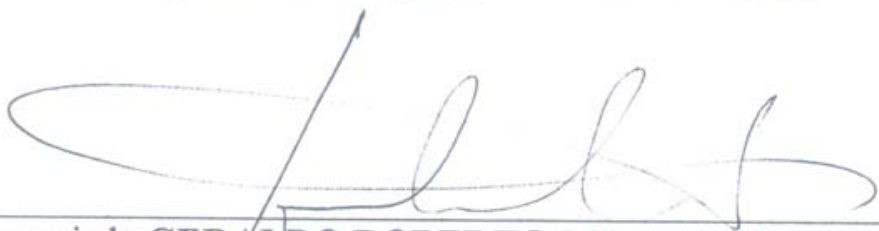

Prof. Associado GERALDO ROBERTO MARTINS DA COSTA Presidente da Comissão de Pós-Graduação 
"Sê humilde se queres adquirir sabedoria; sê mais humilde ainda, quando a tiveres adquirido."

Aos meus pais, Eunice e Cláudio, pela humilde sabedoria transmitida ao longo de minha vida. Sem elas, as minhas conquistas não seriam as mesmas. 


\section{AGRADECIMENTOS}

Meu eterno agradecimento a Deus por sempre estar ao meu lado, pela saúde, bênçãos constantes e, principalmente, por oferecer caminhos alternativos nos momentos mais difíceis.

Ao meu orientador, Professor João Bento de Hanai, a quem muito admiro profissionalmente. Obrigado pela cuidadosa orientação deste trabalho, pelas oportunidades oferecidas, pelos ensinamentos e pela confiança em mim depositada. Nesses seis anos de convivência foram muitos os aprendizados os quais levarei ao longo da minha carreira. Obrigado também pela amizade e apoio constantes.

Ao Professor Paulo Lourenço, pela dedicada co-orientação e contribuições que enriqueceram esta Tese. Agradeço a hospitalidade com que fui recebido na Universidade do Minho e as oportunidades então oferecidas.

Aos meus pais, exemplos em minha vida, pela educação e ensinamentos. Minhas conquistas são e serão fruto do seu amor incondicional, da dedicação ímpar que tiveram em minha formação e, sem dúvida, das lições com vocês aprendidas.

A minha querida irmã Tatiana, pelo constante incentivo e por sempre acreditar nas minhas aspirações.

À Larissa, por seu amor e carinho. Agradeço a sua paciência e compreensão que muito contribuíram para a conclusão deste trabalho.

A todos aqueles que sempre estiveram presentes em minha vida, contribuindo para mais este êxito. Dentre tantos, alguns agradecimentos especiais tornam-se indispensáveis.

Aos meus grandes amigos Eduardo Toledo e Marcus André, que mesmo distante sempre me apoiaram, incentivaram e foram cúmplices da minha luta para a conclusão deste trabalho.

Ao Walter, grande amigo que São Carlos me propiciou, pela amizade constante durante esses seis anos, e à minha amiga Suzana, os quais tornaram a minha passagem por São Carlos mais prazerosa. A Gustavinho que, mesmo sem saber, tornou a conclusão deste trabalho menos sacrificante.

À Raïssa e Rodrigo, pela amizade ímpar e apoio irrestrito, indispensáveis nessa longa caminhada.

Ao amigo de todas as horas, Gustavo Tristão, por seu companheirismo, entusiasmo e apoio incondicional. 
Às novas amizades que fiz durante a passagem por São Carlos: Adriana Gomes, Alexandre Sudano, Alex Sander, André Doria, Andrés Idiart, Daniel Maciel, Elian, Eimair, Gustavo Codá, Gustavo Siqueira, Jefferson Klauss, Josafá, Karenina, Lorença Tristão, Luciano Montedor, Luiz Eduardo Teixeira, Manoel Dênis, Mônica Vianna, Oscar Begambre, Ricardo Carrazedo, Rodrigo Paccola, Rômulo Faria, Sandra Almeida, Saulo Almeida, Silvana e Wesley Góis.

Aos amigos Jerônymo Pereira e Petrus Nóbrega, exemplos de pesquisadores, dos quais muito me orgulho em ter a amizade.

Ao Luciano Montedor, grande amigo, com quem muito aprendi durante esses anos.

Aos funcionários e amigos do Laboratório de Estruturas pelo apoio durante as análises experimentais: Amauri, Fabiano, Dr. Luiz Vareda, Mário, Mauri, Romeu e Valdir.

Ao Dito, funcionário do Laboratório de Mecânica das Rochas do Departamento de Geotecnia, pela receptividade e paciência durante parte das minhas análises experimentais.

Aos funcionários do Departamento de Engenharia de Estruturas pelo apoio durante a minha passagem, em especial: Nadir, Dr. Rodrigo Paccola, Rosi e Toninho. Aos seus professores, não só pelos ensinamentos acadêmicos, mas principalmente pelo grato convívio nesse período: Profa. Ana Lúcia, Prof. Libânio Pinheiro, Prof. Márcio Corrêa, Prof. Mounir El Debs, Prof. Roberto Gonçalves, Prof. Samuel Giongo, Prof. Toshiaki Takeya e Prof. Wilson Venturini.

Aos amigos que conheci durante a minha estadia na bela e inesquecível cidade de Guimarães, pelas ajudas e a convivência que tornaram a saudade do Brasil menos intensa: Adílson Lessa, Ana Cecília, Ana Maria, Armando, Aurélio Sabino, Bona e Juliana, Caio, Caroline Vilar, Ché, Cornélia, Cris, Daniela, Eimair, Francisco Pereira, Gihad e Andréa, Gláuber Freitas, Guio Lize, Igor Andryl, Ismael Basílio, João Gouveia, Júlio Souza, Késio Palácio, Konrad Krakowiac, Luciana Mascaro, Luciano e Sofia, Marcinkus, Marco António, Mariusz Król, Rafael Volski, Regis de Bel, Rosângela Caldas, Vincenzo Bianco, Vladimir Haach e Vítor. A época vivida sempre estará em minha memória, na esperança de um reencontro breve.

À Fundação de Amparo à Pesquisa do Estado de São Paulo - FAPESP - pela bolsa de Doutorado e Auxílio-Pesquisa concedidos.

À CAPES - Coordenação de Aperfeiçoamento de Pessoal de Nível Superior - pelo suporte financeiro fornecido para a realização do estágio de Doutorado na Universidade do Minho, em Guimarães, Portugal. 


\section{ÍNDICE}

1. INTRODUÇÃO — 13

1.1 Justificativas ___ 17

1.2 Objetivos _ 17

1.3 Metodologia _ 20

1.3.1 Análise experimental _ 20

1.3.2 Análise teórica __ 21

1.4 Estrutura do texto _ 22

2. ANÁLISE EXPERIMENTAL E TEÓRICA DOS ELEMENTOS DE ALVENARIA _ 23

2.1 Ensaios do material que constitui a unidade de alvenaria __ 23

2.2 Influência das placas de ensaio __ 34

2.3 Acabamento das superfícies dos elementos ___ 41

2.4 Modelos numéricos para alvenaria estrutural___ 48

\section{PROPRIEDADES MECÂNICAS DA ARGAMASSA PARA A ALVENARIA} ESTRUTURAL

3.1 Comportamento sob compressão triaxial___ 63

3.2 Perda de água da argamassa para as unidades de alvenaria __ 78

4. PRODUÇÃO E ENSAIO DOS ELEMENTOS DE CONCRETO E ARGAMASSA _ 91

4.1 Materiais utilizados __ 91

4.1.1 Cimento _ _ 92

4.1.2 Agregado miúdo _ 92

4.1.3 Agregado graúdo _ 92

4.1.4 Cal 92

4.1.5 Água 92

4.2 Caracterização do concreto e argamassa ___ 92

4.3 Produção dos elementos e preparação para ensaio____ 93

4.3.1 Blocos de concreto __ 95

4.3.2 Prismas constituídos por três blocos _ـ 97

4.3.3 Miniparedes _ 99

4.3.4 Corpos-de-prova__ 100 
4.4 Ensaios mecânicos 103

4.4.1 Blocos de concreto 104

4.4.1.1 Compressão uniaxial___ 104

4.4.1.2 Ensaios à tração indireta___ 106

4.4.2 Prismas constituídos por três blocos _ 108

4.4.3 Miniparedes 109

4.4.4 Corpos-de-prova 110

4.4.4.1 Corpos-de-prova cilindricos _ 110

4.4.4.2 Vigas com entalhe __ 113

5. ANÁLISE DOS RESULTADOS EXPERIMENTAIS _ 115

5.1 Comportamento mecânico dos blocos vazados de concreto ___ 116

5.1.1 Ensaio modificado com redução do efeito de confinamento __ 120

5.1.2 Módulo de elasticidade do concreto e deformações no bloco vazado___ 124

5.2 Comportamento mecânico dos prismas ___ 131

5.2.1 Propriedades mecânicas dos prismas e seus materiais constituintes ___ 131

5.2.2 Distribuição de deformações nos prismas____ 134

5.3 Comportamento mecânico das miniparedes __ 138

5.3.1 Propriedades mecânicas das miniparedes e de seus materiais constituintes __ 138

5.3.2 Análise das deformações nas miniparedes _ـ 139

5.4 Valores da energia de fratura___ 140

5.4.1 Energia de fratura do concreto ___ 140

5.4.2 Energia de fratura da argamassa __ 145

6. MODELAGEM NUMÉRICA___ 149

6.1 Estratégia numérica __ 150

6.1.1 O modelo de Drucker-Prager _ 150

6.1.2 O modelo de Fissuração Dispersa___ 152

6.1.3 Resolução do sistema de equações não-lineares_ 155

6.1.4 Elementos finitos utilizados __ 156

6.2 Corpos-de-prova de concreto___ 157

6.2.1 Distribuição das tensões no corpo-de-prova de concreto ___ 159

6.2.2 Distribuição de deformações no corpo-de-prova de concreto ___ 161

6.3 Blocos vazados de concreto___ 162

6.3.1 Análise de tensões e deformações _ 169

6.3.2 Distribuição das tensões no bloco vazado de concreto ___ 169

6.3.3 Distribuição das deformações no bloco vazado de concreto _ _ 177 
6.4 Prismas de blocos vazados de concreto 184

6.4.1 Discussão sobre as distintas abordagens 188

6.4.2 Comportamento dos prismas na abordagem tridimensional 193

6.4.3 Distribuição de tensões e deformações 194

6.4.3.1 Análise das tensões 195

6.4.3.2 Análise das deformações plásticas 200

6.4.3.3 Ilustração da distribuição de tensões e deformações na ruína 202

6.4.4 Refinamento da malha e modo de ruína 204

6.5 Argamassa submetida ao comportamento triaxial 206

6.6 Miniparedes 208

7. Análise teórica com aplicação de modelos algébricos 215

7.1 Sobre os blocos vazados de concreto 215

7.1.1 Resistência do concreto que constitui o bloco vazado 216

7.1.2 Disposição de instrumentos de medição nos ensaios com blocos vazados 217

7.1.3 Deformabilidade do concreto que constitui o bloco vazado 220

7.1.4 Previsão da resistência e deformabilidade do concreto que constitui o bloco vazado 222

7.1.5 Propriedades mecânicas do concreto que constitui o bloco vazado 225

7.2 Prismas constituídos por três blocos 225

7.2.1 Resistência do prisma e de seus materiais constituintes 225

7.2.2 Avaliação da perda de água da argamassa durante a cura 227

7.2.3 Avaliação do efeito de confinamento da argamassa 228

7.2.4 Deformabilidade dos materiais que constituem os prismas 230

7.2.5 Propriedades mecânicas dos materiais que constituem o prisma 232

7.3 Miniparedes 233

8. CONCLUSÃO 235

8.1 Comportamento dos blocos vazados de concreto 236

8.2 Comportamento dos prismas 237

8.3 Comportamento das miniparedes 238

8.4 Proposta para pesquisas futuras 238 


\section{RESUMO}

Barbosa, C.S. (2008). Resistência e deformabilidade de blocos vazados de concreto, prismas e paredes e suas correlações com as propriedades mecânicas dos materiais constituintes. Tese (Doutorado) - Escola de Engenharia de São Carlos, Universidade de São Paulo.

O objetivo deste trabalho é identificar e correlacionar as propriedades mecânicas do concreto e da argamassa de assentamento com o comportamento estrutural de blocos vazados de concreto, prismas e paredes, por meio de modelagem física e numérica. Realizou-se detalhada investigação experimental, recorrendo à premissa metodológica de se utilizar um mesmo concreto, de consistência plástica, para a moldagem de blocos vazados e corpos-deprova cilíndricos, para assegurar propriedades idênticas dos materiais em cada série de ensaios. Analisou-se o efeito de confinamento que se apresenta nos ensaios de blocos isolados, o qual induz uma distribuição não-uniforme de deformações e acarreta aumento da sua capacidade resistente em relação à resistência à compressão do concreto. Em ensaios nos quais se reduziu o efeito de confinamento, constatou-se que os blocos apresentam menor capacidade resistente e alteração do modo de ruína, decorrente da distribuição mais uniforme das deformações, similar àquela que se observa nos blocos centrais dos prismas e paredes. Analisou-se também a influência do efeito de confinamento e do processo de cura das juntas de argamassa e se associou parâmetros indicativos do seu comportamento à capacidade resistente e ao modo de ruína de prismas e paredes. As propriedades mecânicas dos materiais, obtidas experimentalmente, foram implementadas em um modelo numérico de elementos finitos, que se mostrou capaz de representar o comportamento dos diversos elementos de alvenaria submetidos à compressão, com boa predição da resistência, deformabilidade e modo de ruína. Com base nos resultados numéricos e experimentais, estabeleceu-se um modelo de interpretação da distribuição de tensões e deformações nos blocos vazados de concreto, o que resultou na recomendação de um procedimento para determinação de sua rigidez axial. Associou-se também o efeito da resistência e da deformabilidade da argamassa no comportamento estrutural dos prismas e paredes. Correlações e formulações algébricas foram estabelecidas para análise do comportamento e previsão quantitativa da resistência e da deformabilidade de blocos, prismas e paredes.

Palavras-chave: Alvenaria estrutural, blocos vazados de concreto, prismas, paredes, propriedades mecânicas dos materiais, modelos numéricos, análise teórica e experimental. 


\begin{abstract}
Barbosa, C.S. (2008). Strength and deformability of hollow concrete blocks, prisms and walls and their correlation to mechanical properties of constituent materials. $\mathrm{PhD}$ Degree Thesis - School of Engineering of Sao Carlos, University of Sao Paulo.

This work aims to identify and correlate the mechanical properties of concrete and bedding mortar to the structural behavior of hollow concrete blocks, prisms and walls, by mean of physical and numerical modeling. A detailed experimental investigation was carried out by assuming as a premise the use of plastic consistency concrete to produce hollow blocks and cylindrical samples. This was done to assure the same material properties in each test series. Confinement effect in block compression tests causes a non-uniform strain distribution through face-shells and webs. This effect induces an increase of the block ultimate load. Modified block tests by reducing the confinement effect were performed. The results showed that confinement reduction brings a more uniform strain distribution, which is similar to the observed one in the central blocks of prisms and walls. A decrease of compressive strength and changes the failure mode were also evidenced. Confinement effect and influence of water loss during the curing of mortar joints were also considered. Indicative parameters about bedding mortar behavior were obtained and the resistant capacity and the failure mode of prisms and walls were associated to them. The mechanical properties of materials obtained in tests were implemented in a finite elements numerical model to analyze the behaviour of masonry elements under compression. The numerical analysis gave good predictions of strength, deformability and failure mode. Based on the numerical and experimental results, a stress and strain distribution model was realized, which enabled an experimental procedure for the determination of the block axial stiffness. Correlations and algebraic formulation were proposed for the behavior analysis and quantitative evaluation of strength and deformability of blocks, prisms and walls.
\end{abstract}

Keywords: Structural masonry, hollow concrete blocks, prisms, walls, mechanical properties of materials, numerical models, theoretical and experimental analysis. 



\section{INTRODUÇÃO}

Os métodos de dimensionamento e verificação da segurança estrutural da alvenaria ainda se baseiam em dados empíricos, em muitos aspectos. Por exemplo, embora as normas brasileiras estejam em fase adiantada de revisão, o Método das Tensões Admissíveis ainda é o preconizado pela norma em vigor NBR 10837 (1989) para o dimensionamento de pilares de alvenaria e paredes solicitadas à compressão axial.

O Método dos Estados Limites, empregado na análise de estruturas de concreto há pouco mais de 30 anos, representa um avanço em relação ao Método das Tensões Admissíveis. Ele vem sendo implementado em diversos manuais e em normas técnicas sobre alvenaria em países estrangeiros. Entretanto, o conhecimento atual ainda não permite o estabelecimento límpido de um conjunto de parâmetros e seus respectivos coeficientes de

ponderação e de segurança. É preciso avançar, investigando mais detalhadamente os fatores que se referem aos materiais, aos processos de produção dos componentes, aos processos construtivos dos elementos estruturais e à estrutura como um todo.

Para a aplicação do conceito de estados limites, é necessário isolar e conhecer melhor cada uma das variáveis que intervêm no comportamento estrutural em serviço e estado limite último. É preciso estabelecer coeficientes de ponderação a essas variáveis, como os coeficientes de minoração da resistência dos materiais, coeficientes de ponderação relativos à correlação de resistências dos corpos-de-prova e blocos e argamassas de assentamento, à transposição de situações peculiares à produção/controle dos blocos, aos efeitos de ações de longa duração, aos efeitos de escala e de forma, etc. É necessário também definir coeficientes de segurança para situações específicas. 
Cabe aqui enfatizar que a aplicação do Método dos Estados Limites - ou ainda do Método Probabilístico Puro, em um futuro ainda mais distante - depende do conhecimento das propriedades dos materiais envolvidos e das unidades de alvenaria. É necessário também que sejam conhecidas as relações de natureza constitutiva dos materiais bem como o comportamento resistente do conjunto da alvenaria, envolvendo basicamente blocos e argamassa de assentamento. Mais ainda, é preciso que sejam determinadas ou avaliadas as interferências e variabilidades no desempenho estrutural da alvenaria em decorrência dos processos produtivos dos insumos, dos processos construtivos das paredes e da estrutura como um todo. A complexidade do sistema estrutural de um edifício em alvenaria envolve ainda diversos outros aspectos, fora do escopo do presente trabalho, como a interação entre paredes, a uniformização das cargas verticais, a resistência às ações horizontais por meio de lintéis, etc. - ver Nascimento Neto (2003), Capuzzo Neto (2005), Andolfato (2006) e Moreira (2007).

Lourenço e Pina-Henriques (2006) ressaltam que os avanços na Mecânica Computacional, conquistados ao longo das últimas décadas, permitiram o crescimento da utilização de ferramentas numéricas com a padronização de modelos não-lineares em diversos programas baseados em elementos finitos. Apesar disso, as micro-modelagens são limitadas pela falta de dados experimentais relativos às propriedades não-lineares dos materiais: “(...) os ensaios com unidades à compressão fornecem uma resistência que não é a real devido à restrição ocasionada pelas placas de ensaios, as diferentes formas das unidades não permitem o estabelecimento de uma correlação entre a resistência à tração e resistência à compressão; além disso, são escassos os ensaios que apresentam o comportamento pós-pico dos elementos e, em relação às argamassas, os corpos-de-prova são obtidos a partir de ensaios padronizados em fôrmas metálicas tendo o efeito da absorção da água das unidades ignorado." (LOURENÇO, 1996).

Nessa linha, Stewart e Lawrence (2007) comparam o projeto de estruturas de alvenaria com os dados existentes de ensaios com paredes para estimar um modelo de erro em termos probabilísticos para essas estruturas submetidas à compressão, abordando modelos para as propriedades dos materiais e carregamentos. O objetivo do trabalho é o desenvolvimento de um modelo probabilístico para determinação da confiabilidade estrutural, mostrando tanto a importância do aprofundamento do conhecimento das propriedades dos materiais como do entendimento do carregamento atuante. Na mesma linha, Graubner e Glowienka (2008) apresentam um modelo de incertezas com parâmetros e modelos 
estatísticos para consideração probabilística de estruturas de alvenaria submetidas à compressão axial.

A alvenaria é um meio contínuo heterogêneo com características ortotrópicas, por possuir juntas de argamassa que acarretam planos de fraqueza, o que gera uma grande dificuldade na modelagem numérica desse tipo de estrutura. Um modelo robusto para alvenaria só pode ser desenvolvido por meio da realização de uma descrição precisa dos materiais, o que se torna muito difícil diante da escassez destes resultados.

As dificuldades encontradas na interpretação do comportamento estrutural de uma simples parede são comentadas por Oliveira (2001), e aqui são reapresentadas de modo resumido:

a) os blocos de alvenaria são constituídos por material de comportamento nãolinear, sendo sujeitos a processos de micro e macrofissuração, apresentando perdas graduais de rigidez e resistência ao longo da história de carregamento;

b) como os blocos são peças separadas, que nas paredes são montadas e unidas por meio de camadas de argamassa de assentamento, estas também interferem no comportamento do conjunto devido à sua disposição, às dimensões e às condições de solicitação e deformação;

c) a resistência de uma parede não fica diretamente condicionada à resistência da argamassa de assentamento, medida em ensaios de compressão axial, porque ela, na parede, trabalha em camadas de pequena espessura que sofrem o efeito positivo do confinamento;

d) as juntas verticais podem introduzir focos de concentração de tensões e também constituir caminhos preferenciais para a fissuração;

e) os blocos podem ser vazados, constituídos por paredes delgadas, o que exige as devidas considerações no cálculo da deformabilidade e introduz uma complexidade ainda maior no comportamento estrutural de uma parede;

f) no caso de blocos vazados, como a superfície de contato com a argamassa de assentamento é menor, o efeito de concentração das tensões é maior, assim como as conseqüências de falhas localizadas de assentamento e de materiais estranhos na argamassa de assentamento;

g) a capacidade resistente de uma parede passa então a ser determinada por um conjunto de fatores que não são necessariamente independentes entre si, o que torna a sua previsão complexa. A ruína pode se dar pelo fendilhamento dos septos transversais dos 
blocos, pelo fendilhamento dos blocos na face maior da parede ou ainda pelo esmagamento ou cisalhamento da argamassa de assentamento;

h) portanto, a capacidade resistente de uma parede de alvenaria sob compressão axial é menor do que o produto da resistência do material dos blocos pela sua área líquida, mas ela é maior do que o produto da resistência da argamassa de assentamento pela sua área líquida;

i) de acordo a indicação da NBR 10837 (1989), que determina a capacidade resistente de uma parede de alvenaria por meio da resistência obtida em ensaios com prismas, a resistência de uma parede é menor do que a resistência do prisma que, por sua vez, é menor do que a resistência do bloco.

As deformações inelásticas da alvenaria são resultantes de um processo dissipativo no qual a energia de fratura é liberada durante a ocorrência da fissuração interna. A argamassa começa a apresentar deformações plásticas muito antes das unidades e a maior parte das deformações não-lineares da alvenaria, até antes da ruptura, ocorre apenas nas juntas. Contudo, o mecanismo de ruína à compressão dos materiais quase-frágeis é muito complexo, especialmente quando comparado com a ruína devida à tração. A ruína à compressão é caracterizada pela união e crescimento de microfissuras difusas, por progressivas deformações localizadas e o desenvolvimento de macrofissuras livres de tração. Em um estágio mais avançado, um modo contínuo e distribuído de fissuras de separação e cisalhamento é formado, resultando na ruína.

É preciso lembrar, ainda, que as propriedades dos materiais dos componentes não são variáveis independentes, pois:

i.) a argamassa de assentamento influi na fissuração do bloco e aumenta, portanto, a sua deformabilidade;

ii.) o bloco introduz tensões de confinamento na argamassa de assentamento e, portanto, a torna menos deformável que a mesma argamassa moldada no corpo-de-prova;

iii.) por outro lado, os materiais dos blocos são porosos e tendem a absorver água da argamassa de assentamento, o que pode alterar a resistência dessa argamassa (comparada com a avaliada em ensaios de corpos-de-prova moldados);

iv.) as condições de cura dos blocos e das paredes e prismas nem sempre são ideais, dada a grande superfície exposta e os inconvenientes de aplicação de água sobre as paredes, mesmo em laboratório; 
v.) os métodos de ensaio de blocos, prismas e corpos-de-prova de argamassa de assentamento acarretam diferentes condições de vinculação no topo e na base e, portanto, distintas condições de confinamento transversal, inclusive alterando e estado de tensões sobre o elemento.

\subsection{Justificativas}

Apresenta-se sinteticamente no Quadro 1.1 a seguir um conjunto de referências composto por premissas iniciais, ações de pesquisa a serem empreendidas e limitações de abrangência, as quais orientam o desenvolvimento deste trabalho.

\subsection{Objetivos}

Pretende-se com o presente trabalho investigar detalhadamente os efeitos de algumas das variáveis e dos demais aspectos comentados que influenciam o comportamento da alvenaria, empregando-se métodos de análise teórica e experimental, partindo do estudo de blocos isolados, prismas e miniparedes.

Em um horizonte mais distante do desenvolvimento científico da Tecnologia de Alvenaria Estrutural, as seguintes condições podem ser vislumbradas:

- os materiais empregados poderão ter melhor definidos os parâmetros de interesse para a análise estrutural e suas respectivas equações constitutivas. Tais dados poderão referir-se tanto ao comportamento imediato quanto ao comportamento ao longo do tempo, levando-se em conta os efeitos de viscosidade e plasticidade;

- modelos algébricos e numéricos serão aperfeiçoados, possibilitando a análise de estruturas de alvenaria sob diversas condições de solicitação, inclusive considerando os efeitos dependentes do tempo;

- modelos estatísticos e determinísticos poderão representar mais adequadamente os fenômenos físicos envolvidos e as variabilidades dos processos de produção de componentes e execução de elementos estruturais;

- $\quad$ procedimentos de controle da qualidade serão aperfeiçoados;

- um método mais adequado de verificação da segurança estrutural estará disponível. 


\begin{tabular}{|c|c|c|}
\hline \multicolumn{3}{|c|}{ Quadro 1.1 - Quadro inicial de referência. } \\
\hline Premissa & Ação & Limitação \\
\hline $\begin{array}{l}\text { A grande maioria dos estudos existentes de correla- } \\
\text { cionamento entre resistência à compressão do concreto } \\
\text { medida em corpos-de-prova cilíndricos e a resistência à } \\
\text { compressão de blocos vazados de concreto é de natureza } \\
\text { empírica, isto é, eles não analisam com o detalhe } \\
\text { necessário os efeitos de forma (geométrica) e o efeito de } \\
\text { confinamento no topo e na base, tanto dos blocos como } \\
\text { dos próprios corpos-de-prova. }\end{array}$ & $\begin{array}{l}\text { A partir das simulações experimentais previas, realizadas } \\
\text { por Barbosa (2004), com blocos de concreto vazados e } \\
\text { corpos-de-prova, coletaram-se dados para futuras } \\
\text { análises teóricas. Entretanto, a variação do material } \\
\text { utilizado como capeamento influencia no comportamento } \\
\text { desses elementos. Esse estudo será baseado em análises } \\
\text { experimentais alterando as condições de topo e base. }\end{array}$ & $\begin{array}{l}\text { São poucas as pesquisas que realizaram esse tipo de } \\
\text { ensaio, portanto é possível que, as séries de ensaio } \\
\text { sejam limitadas e não atendam a todas as condições } \\
\text { para a generalização das conclusões. Mesmo assim, } \\
\text { deverão ter grande utilidade como referência para } \\
\text { simulações numéricas iniciais e outros estudos } \\
\text { futuros. }\end{array}$ \\
\hline $\begin{array}{l}\text { No ensaio de blocos isolados, o processo de acabamento } \\
\text { do topo e da base (argamassa, chapa de madeira, papelão, } \\
\text { enxofre, etc.) influi no efeito de confinamento e na } \\
\text { resistência e deformabilidade dos blocos. }\end{array}$ & $\begin{array}{l}\text { Analisar os diferentes processos de acabamento dos } \\
\text { blocos para ensaio e tentar desenvolver um novo método } \\
\text { científico para análise do problema, que focalize com o } \\
\text { maior detalhe possível o fenômeno e permita o } \\
\text { estabelecimento de indicações práticas para a conside- } \\
\text { ração dos seus efeitos nos ensaios de blocos. }\end{array}$ & $\begin{array}{l}\text { Tendo em vista a ausência de precedentes em } \\
\text { métodos especiais de avaliação (como o novo método } \\
\text { científico desejado), é possível que ela se limite à } \\
\text { comparação de resultados empíricos, obtidos em } \\
\text { algumas séries de ensaios de blocos. }\end{array}$ \\
\hline $\begin{array}{l}\text { A simulação numérica sobre blocos vazados, prismas e } \\
\text { paredes, na forma de microanálise, ainda necessita de } \\
\text { maior desenvolvimento, especialmente na consideração } \\
\text { mais precisa das propriedades dos materiais e no } \\
\text { estabelecimento das condições de contorno no topo e na } \\
\text { base. }\end{array}$ & $\begin{array}{l}\text { Realizar pesquisa bibliográfica e simulações numéricas } \\
\text { com o Método dos Elementos Finitos (MEF) sobre } \\
\text { blocos isolados, prismas e miniparedes, em distintas } \\
\text { condições de contato no topo e na base. }\end{array}$ & $\begin{array}{l}\text { As simulações numéricas devem ser realizadas com } \\
\text { análise não-linear, mas tendo em vista as dificuldades } \\
\text { inerentes à aplicação do MEF, tais análises poderão } \\
\text { ficar limitadas à aplicação de programas } \\
\text { computacionais generalistas e comerciais. }\end{array}$ \\
\hline
\end{tabular}




\begin{tabular}{|c|c|c|}
\hline \multicolumn{3}{|c|}{ Quadro 1.1 - Quadro inicial de referência (continuação). } \\
\hline Premissa & Ação & Limitação \\
\hline $\begin{array}{l}\text { As dimensões da camada de argamassa de assentamento } \\
\text { e suas propriedades de deformação longitudinal e } \\
\text { transversal influem no comportamento estrutural e no } \\
\text { modo de ruptura dos blocos, prismas e paredes. }\end{array}$ & $\begin{array}{l}\text { Realizar pesquisa bibliográfica e simulações numéricas e } \\
\text { experimentais. Métodos científicos deverão ser } \\
\text { desenvolvidos para determinar de forma mais realista as } \\
\text { propriedades da argamassa de assentamento, buscando } \\
\text { conhecer melhor os efeitos de absorção, cura } \\
\text { diferenciada, efeito de confinamento, etc. }\end{array}$ & $\begin{array}{l}\text { O estudo mais detalhado de deformabilidade de } \\
\text { camadas de argamassa de assentamento de pequena } \\
\text { espessura pode se mostrar uma tarefa árdua, } \\
\text { especialmente por envolver a aplicação de elementos } \\
\text { de contato pelo MEF. No entanto, com certeza } \\
\text { contribuições originais deverão ser alcançadas. }\end{array}$ \\
\hline $\begin{array}{l}\text { Prismas e paredes são elementos estruturais de com- } \\
\text { ponentes mistos (blocos e argamassa de assentamento). } \\
\text { Estudos prévios demonstraram que análises simplificadas } \\
\text { por meio de simulação de componentes em série podem } \\
\text { oferecer previsões satisfatórias do seu comportamento } \\
\text { estrutural no regime elástico (macro-modelagem). }\end{array}$ & $\begin{array}{l}\text { Realizar simulações numéricas e experimentais sobre } \\
\text { prismas e miniparedes, no sentido de estabelecer } \\
\text { correlações teóricas entre seu comportamento estrutural e } \\
\text { as propriedades de resistência e de deformação dos } \\
\text { blocos e das argamassas de assentamento. Dirigir os } \\
\text { resultados para o desenvolvimento futuro da macro- } \\
\text { modelagem. }\end{array}$ & Tentar-se-á desenvolver ao máximo esta análise. \\
\hline $\begin{array}{l}\text { Diversos outros fatores relacionados à prática corrente, } \\
\text { como condições de produção e controle da qualidade dos } \\
\text { blocos, variabilidade nas propriedades da argamassa de } \\
\text { assentamento durante a própria execução da parede, } \\
\text { condições reais de cura, aderência, etc., influem no } \\
\text { comportamento estrutural dos blocos, prismas e paredes. }\end{array}$ & $\begin{array}{l}\text { O alvo principal deste trabalho é a identificação e a } \\
\text { quantificação dos fenômenos estruturais inerentes ao } \\
\text { comportamento de blocos isolados, prismas e paredes, e } \\
\text { suas correlações com os principais parâmetros de } \\
\text { resistência e deformabilidade dos blocos e argamassas de } \\
\text { assentamento. Não é objetivo analisar variáveis de } \\
\text { produção e construção. }\end{array}$ & $\begin{array}{l}\text { A maior parte das variáveis relacionadas à produção } \\
\text { de blocos e à execução de paredes e prismas deverá } \\
\text { ser isolada. O trabalho limitar-se-á ao estudo do } \\
\text { comportamento estrutural dos blocos, prismas e } \\
\text { paredes (na medida do possível), correlacionando-o } \\
\text { com os parâmetros de resistência e deformabilidade } \\
\text { dos blocos e argamassas de assentamento. A } \\
\text { aderência entre argamassa e bloco também não será } \\
\text { abordada já que sua influência é maior nos elementos } \\
\text { estruturais submetidos aos esforços de tração e } \\
\text { cisalhamento }\end{array}$ \\
\hline
\end{tabular}


A contribuição que o trabalho pretende trazer é nada mais do que responder a algumas perguntas ou tornar mais claros os conhecimentos existentes.

Os objetivos específicos estão listados a seguir:

1. Identificar e interpretar teórica e experimentalmente os efeitos de forma (geométrica) e de distribuição de tensões em blocos vazados de concreto (microanálise numérica e experimental de blocos), implementando modelos numéricos de análise não-linear com adequados critérios de resistência;

2. No ensaio de blocos isolados, analisar o efeito de confinamento no topo e na base, em função dos distintos processos de acabamento, tentando desenvolver métodos científicos para melhor caracterização do efeito de confinamento causado por diferentes materiais de capeamento;

3. Desenvolver um método de determinação da rigidez axial de blocos isolados, com vistas à aplicação dos resultados na análise estrutural de prismas e paredes;

4. Analisar o efeito da resistência e da deformabilidade das argamassas de assentamento no comportamento estrutural, inclusive modos de ruína, de prismas e miniparedes. Desenvolver métodos especiais para caracterização da argamassa de assentamento, considerando o efeito da absorção dos blocos e o confinamento da argamassa na camada de pequena espessura;

5. Estabelecer correlações, ou pelo menos identificar os fatores interdependentes, entre os parâmetros usuais referentes aos materiais (resistência à compressão e à tração, módulo de elasticidade e curva tensão-deformação de concretos e argamassas) e o comportamento estrutural de blocos, prismas e paredes.

\subsection{Metodologia}

Paralelamente à análise de trabalhos científicos e tecnológicos que abordam assuntos muito próximos dos objetivos da pesquisa, foram realizadas duas etapas distintas, porém, que têm seus resultados e análises conexas.

\subsubsection{Análise experimental}

Foram realizados ensaios com blocos vazados de concreto, prismas, miniparedes e argamassa. A análise experimental envolveu os procedimentos e as técnicas seguintes:

- estudo de modelos físicos representativos de blocos vazados de concreto, 
dimensionamento, seleção de materiais, dosagem dos concretos e argamassas;

- moldagem de blocos em laboratório, utilizando fôrmas especialmente projetadas, com boa precisão dimensional. A idéia central e diferenciada do que se conhece neste aspecto refere-se ao uso do mesmo concreto, de consistência plástica, com o qual foram moldados tanto os blocos como os corpos-de-prova cilíndricos. Com isso, pretende-se estabelecer correlações entre os resultados experimentais em conjunto com uma análise teórica do comportamento estrutural dos blocos, utilizando-se os mesmos materiais, que foram adensados e curados da mesma forma;

- estabelecimento do método de ensaio dos blocos e dos corpos-de-prova cilíndricos de concreto, com vistas à obtenção de parâmetros válidos para análise estrutural, com atenção especial às formas de acabamento do topo e da base;

- estudo da resistência e da deformabilidade das argamassas de assentamento, especialmente tendo em vista a interpretação do seu comportamento em camadas de pequena espessura, inclusive sob ação da sucção dos blocos e sob efeito de confinamento analisando a influência na resistência, na deformabilidade e no modo de ruína de prismas e miniparedes;

- estudo experimental de prismas e miniparedes para observação do comportamento estrutural conjunto desses elementos, visando o estabelecimento de correlações teóricas e experimentais.

\subsubsection{Análise teórica}

Compreende investigações por meio de métodos algébricos e numéricos, com o desenvolvimento de análises numéricas empregando o programa DIANA (2005).

Por meio dessas análises desenvolveram-se modelos que representam o comportamento experimental, inclusive considerando o efeito de confinamento no topo e base dos elementos ensaiados.

A análise numérica, como já se indicou no item 1.1, está limitada em seu aprofundamento e complexidade devidos às dificuldades existentes. Por exemplo, até mesmo a micromodelagem de um simples ensaio de prisma de blocos de concreto envolve a falta de conhecimento das propriedades do concreto do bloco, da argamassa de assentamento que passa por condições mal definidas de absorção e cura, das condições de confinamento junto ao topo e à base do elemento em função dos materiais empregados no capeamento, etc. 


\subsection{Estrutura do texto}

Os Capítulos 2 e 3 apresentam uma revisão sobre o estado-da-arte da Alvenaria Estrutural, enfatizando os assuntos diretamente relacionados com os objetivos do presente trabalho. No Capítulo 2 disserta-se sobre os principais fatores intervenientes no comportamento estrutural dos elementos de alvenaria, as propriedades mecânicas dos materiais que constituem as unidades e sobre as pesquisas que utilizam modelos matemáticos para a previsão da resistência e deformabilidade destas estruturas. O comportamento mecânico da argamassa é abordado no Capítulo 3, no qual já são apresentados os resultados experimentais obtidos para este material.

A parte metodológica da pesquisa é detalhada no Capítulo 4, destacando-se os ensaios realizados com elementos de concreto - blocos e corpos-de-prova, prismas e miniparedes. Apresentam-se ainda os procedimentos adotados na análise experimental e o comportamento dos elementos nos respectivos ensaios.

A discussão dos resultados experimentais é apresentada no Capítulo 5, no qual as correlações entre as propriedades mecânicas dos materiais são estabelecidas e seus valores apresentados a fim de dar subsídio às análises teóricas.

As simulações numéricas são destacadas no Capítulo 6, discutindo-se as estratégias adotadas e a validação dos modelos com base nos dados obtidos na análise experimental.

O Capítulo 7 apresenta a análise teórica embasada nos resultados experimentais e nos resultados provenientes da análise numérica. Finalmente, o Capítulo 8 destina-se à síntese das conclusões deste trabalho. 


\section{ANÁLISE EXPERIMENTAL E TEÓRICA DOS ELEMENTOS DE ALVENARIA}

Há uma diversidade de fatores que influenciam os resultados experimentais dos elementos de alvenaria, tais como a forma geométrica e a resistência da unidade, a espessura da junta de argamassa e o procedimento de ensaio adotado, os quais são extensamente abordados em diversas publicações técnicas (ver Barbosa, 2004).

No presente capítulo, aprofunda-se a discussão em relação às propriedades mecânicas dos materiais que constituem as unidades de alvenaria, comparando os resultados de ensaios realizados diretamente em corpos-de-prova do material com os obtidos em seus respectivos blocos vazados, semelhantes aos empregados comercialmente. Discute-se ainda a influência da placa de ensaio na resistência e nas deformações dos elementos de alvenaria, além do efeito de confinamento ocasionado pelas formas de acabamento das superfícies de carregamento dos elementos, comumente observado em ensaios de compressão axial.

Por fim, apresentam-se os modelos numéricos utilizados na previsão da capacidade resistente e da deformabilidade desses elementos, enfatizando-se as estratégias de modelagem utilizadas em diversas pesquisas, suas capacidades e limitações, e alguns modelos mais atuais propostos para este tipo de análise.

\subsection{Ensaios do material que constitui a unidade de alvenaria}

Marzahn (2003) recorda que a capacidade resistente da alvenaria é determinada a partir das propriedades mecânicas dos seus componentes, obtidas por meio de ensaios padronizados.

Entretanto, complementa o autor, para uma investigação mais profunda do comportamento estrutural, aquelas propriedades, obtidas pelos métodos de ensaios usuais, 
podem não se mostrarem adequadas para uma micromodelagem numérica dos elementos e simulação computacional das condições de ruína da alvenaria.

Algumas pesquisas tratam da correlação entre a resistência do material concreto e do bloco que este constitui. Todavia, apenas poucas delas abordam tal correlação como objetivo principal, e as que o fazem, geralmente analisam a capacidade resistente de blocos não padronizados procurando estabelecer correlações diretas com as resistências obtidas de corpos-de-prova extraídos dos seus septos.

Becica e Harris (1983) realizaram análises experimentais com blocos de concreto, prismas e corpos-de-prova extraídos do bloco. Apesar das análises do bloco e do material não serem o enfoque principal dos experimentos, nota-se o empenho dos autores em conhecer as propriedades do concreto que constitui o bloco já que, além da simples correlação entre as resistências do material e do bloco, foi obtida a curva tensão-deformação dos corpos-deprova, bem como estudada a maneira de instrumentá-los.

Ensaiaram-se no trabalho de Becica e Harris (1983) blocos vazados de concreto com dimensões nominais de 200 × 200 × 390 mm e com relação entre a área líquida e área bruta igual a 0,54. Os corpos-de-prova foram extraídos da unidade, obtendo-se a resistência do concreto (material constituinte do bloco) e suas propriedades mecânicas. Ensaiaram-se $10 \mathrm{CPs}$ com relação altura/comprimento variando entre 1:1 e 2:1, permanecendo a espessura e sua geometria com a mesma inclinação encontrada nos blocos. A resistência à compressão média foi de 18,4 N/mm². A Figura 2.1 apresenta as curvas tensão-deformação obtidas a partir do ensaio de três corpos-de-prova, com instrumentação na face interna e externa. Os autores evidenciam a mudança de comportamento das curvas quando as deformações são medidas na parte externa ou interna - que possui inclinação em torno de $2 \%$. As curvas apresentam um trecho linear seguido de um trecho com não-linearidade até a tensão máxima. Os trechos lineares mais extensos são os das curvas nas quais a medição foi realizada na parte externa do CP.

Realizaram-se também ensaios com blocos e prismas constituídos de três blocos. As resistências médias e as deformações últimas para cada um desses elementos ensaiados estão agrupadas na Tabela 2.1. A Figura 2.2 apresenta uma comparação entre as curvas tensãodeformação dos elementos ensaiados.

A deformação última dos corpos-de-prova extraídos de concreto é bem maior que a dos outros dois elementos, o que indica uma perda de ductilidade, em virtude do menor confinamento a que os blocos e os prismas estão submetidos (BECICA e HARRIS, 1983). 
A ruína dos corpos-de-prova de concreto extraídos do bloco foi do tipo cisalhamento diagonal em suas faces. Ocorreu também o fendilhamento em algumas amostras. Os autores relatam que a ruína se mostrou dúctil e, em alguns casos, um encurtamento significativo foi verificado.

Ganzerli et al. (2003) também realizaram ensaios com corpos-de-prova extraídos das unidades. Esse tipo de ensaio é uma das modificações que a ASTM C 140 (1996) permite para ensaios de unidades não padronizadas que são largamente empregadas nos Estados Unidos. Estes tipos de unidades possuem, por exemplo, uma maior projeção das paredes longitudinais, maiores alturas e interrupções nos septos transversais.

O trabalho também apresenta um histórico das pesquisas referentes aos ensaios de compressão com corpos-de-prova extraídos dos blocos de concreto, realizados nos últimos anos no estado da Califórnia. Estas pesquisas buscavam avaliar quais proporções dos corposde-prova forneciam melhores resultados comparados com os obtidos em ensaios com blocos, submetidos à compressão. Dentre eles, constam os ensaios realizados:

a) por Timothy Mallis, em 1986, que relata que as melhores concordâncias entre resistência à compressão de CPs (1:4, relação espessura:comprimento) e blocos são obtidas quando extraídas amostras com dimensões na proporção de 1:3:4 (espessura:altura:comprimento), enfatizando ainda que o tipo de capeamento utilizado influencia nestes resultados;

b) em 1987, na Riverside Cement Association, com CPs de diversas proporções. As amostras nas proporções de 1:3:5 (espessura:altura:comprimento) mostraram-se mais correlatas com as unidades de dimensões nominais de 200 x 200 x 400 mm. 

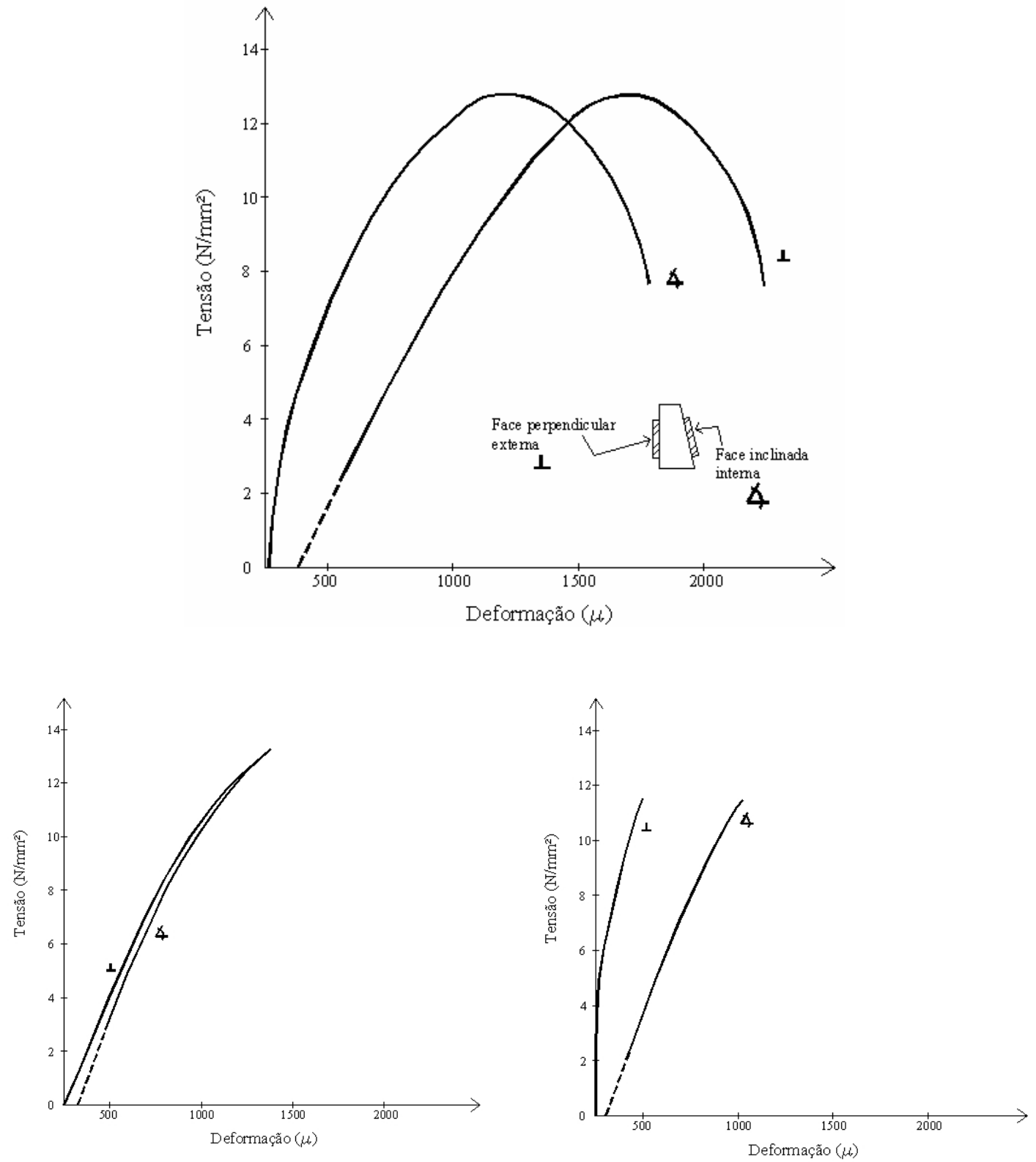

Figura 2.1 - Curvas tensão-deformação obtidas no ensaio de corpos-de-prova extraídos dos blocos de concreto com indicação do posicionamento dos extensômetros (na face externa ou interna), adaptada de Becica e Harris (1983).

Tabela 2.1 - Resistência e deformação dos blocos, prismas e corpos-de-prova de concreto.

\begin{tabular}{cccc}
\hline \multirow{2}{*}{ Elemento ensaiado } & \multicolumn{2}{c}{ Resistência $\left(\mathrm{N} / \mathrm{mm}^{2}\right)$} & \multirow{2}{*}{ Deformação $(\mu)$} \\
& Área bruta & Área líquida & \\
\hline Corpo-de-prova & - & 18,4 & 2094 \\
Bloco & 9,8 & 15,1 & 1805 \\
Prisma & 5,2 & 8,0 & 1652 \\
\hline
\end{tabular}




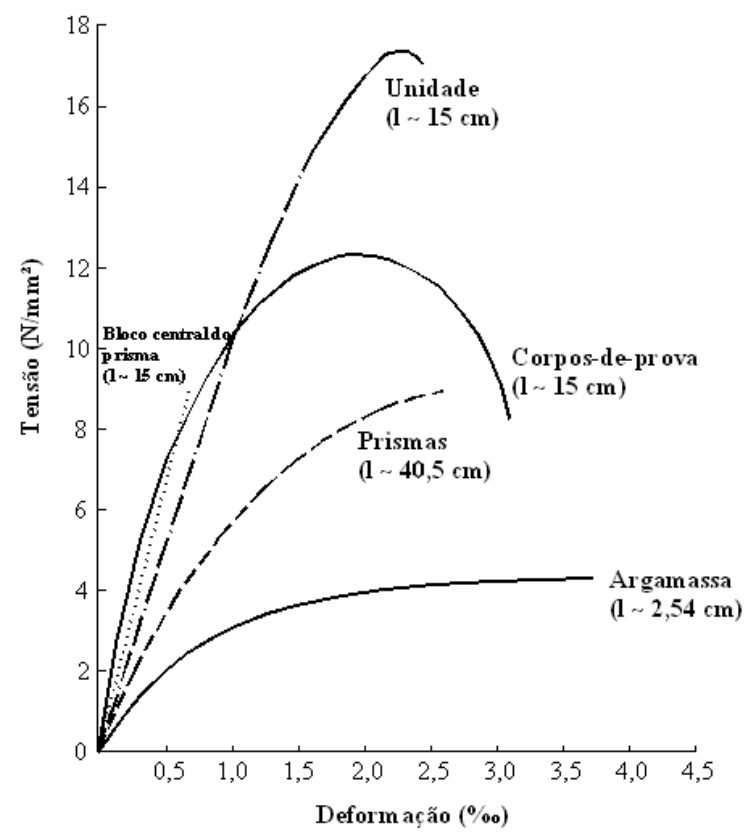

Figura 2.2 - Curvas tensão-deformação dos materiais e elementos com o comprimento da base de medida utilizada nos ensaios, adaptada de Becica e Harris (1983).

Segundo Ganzerli et al. (2003), as proporções de CPs 1:5 apresentaram os resultados mais próximos aos encontrados nos ensaios com blocos, comprovando também que a variação das dimensões é capaz de alterar de forma significativa estes resultados. Citam ainda que nas prescrições da ASTM C 140 (1996), ensaiando-se CPs nas proporções de 1:2:4 (espessura:altura:comprimento), encontraram-se resistências de CPs 16\% menores e 32\% maiores que a resistência dos blocos, devendo ser notado que a localização de extração do CP (topo, base ou seção média) influencia significativamente nos resultados.

Análise semelhante foi realizada por Hawk et al. (1997), que executou ensaios com uma unidade de largura nominal de $250 \mathrm{~mm}$, na qual as paredes longitudinais se estendiam além dos encontros com os septos transversais, que não possuíam altura constante. Para a realização dos ensaios utilizaram-se três modelos de blocos: (i) sem modificações, com os septos transversais com altura inferior à do bloco e paredes longitudinais projetadas além dos septos transversais externos (ii) com altura do bloco nivelada com a menor altura dos septos transversais e (iii) com o bloco com altura nivelada e com a projeção das paredes longitudinais cortadas. Foram extraídos corpos-de-prova da unidade, obtendo-se resistência à compressão média de $21,9 \mathrm{~N} / \mathrm{mm}^{2}$, enquanto que as resistências dos modelos i, ii e iii foram respectivamente $23,8 \mathrm{~N} / \mathrm{mm}^{2}, 23,5 \mathrm{~N} / \mathrm{mm}^{2}$ e $25,4 \mathrm{~N} / \mathrm{mm}^{2}$, calculadas em relação à área líquida. Nesse caso particular, a resistência do CP foi menor que a resistência de qualquer um dos três modelos de blocos. 
Nos ensaios realizados por Ganzerli et al. (2003) utilizaram-se blocos de concreto de dimensões de $200 \times 200$ × $400 \mathrm{~mm}$. Além da forma padronizada, foram adotados outros quatro tipos - todos com suas dimensões adaptadas, removidas as projeções das paredes. Para cada forma, ensaiaram-se três blocos à compressão e outros três foram utilizados para a extração de corpos-de-prova, do topo e da base das paredes longitudinais. A relação entre espessura, altura e comprimento foi de 1:2:4 (aproximadamente $35 \times 70 \times 140 \mathrm{~mm}$ ). Os valores obtidos para o bloco padrão estão na Tabela 2.2.

De forma geral, a resistência à compressão, tanto dos blocos padronizados quanto das outras formas de bloco foi menor que as dos respectivos corpos-de-prova. Ganzerli et al. (2003) justificam tal fato devido à diferença de forma entre os dois modelos, pois enquanto os CPs são maciços e com dimensões bem menores que os blocos, estes possuem vazios (que modifica a sua superfície de carregamento) com paredes longitudinais esbeltas. Além disso, por possuírem menores dimensões, os CPs têm uma menor probabilidade de possuírem falhas no seu interior.

Tabela 2.2 - Resultados dos ensaios à compressão com blocos e seus respectivos corpos-de-prova extraídos, adaptada de Ganzerli et al. (2003).

\begin{tabular}{cccc}
\hline Elemento & $\begin{array}{c}\text { Resistência à } \\
\text { compressão média na } \\
\text { área líquida }\left(\mathrm{N} / \mathrm{mm}^{2}\right)\end{array}$ & $\begin{array}{c}\text { Desvio padrão } \\
\left(\mathrm{N} / \mathrm{mm}^{2}\right)\end{array}$ & $\begin{array}{c}\text { Coeficiente } \\
\text { de variação } \\
(\%)\end{array}$ \\
\hline Bloco 200 x 200 x 400 mm & 34,8 & 1,31 & 3,8 \\
Corpo-de-prova (topo) & 49,1 & 0,14 & 0,3 \\
Corpo-de-prova (base) & 39,0 & 3,65 & 9,4 \\
\hline
\end{tabular}

Tomando-se a média entre as resistências dos corpos-de-prova, observa-se que essa é em torno de $26 \%$ maior que a resistência dos blocos, considerando-se a área líquida. A diferença entre as resistências obtidas nos corpos-de-prova extraídos do topo e da base provavelmente é ocasionada em virtude da variação do grau de compactação nas camadas dos blocos.

Marzahn (2003) realizou análise experimental com blocos silico-calcários (identificados por A e B) e de concreto autoclavados (sendo C e D suas identificações) com ar incorporado, extraindo-se corpos-de-prova cilíndricos de ambos. Esses ensaios objetivavam investigar mais detalhadamente as propriedades mecânicas das unidades de alvenaria. Realizaram-se com os blocos ensaios à compressão axial $\left(f_{b}\right)$ e de resistência à tração (indireta, $\mathrm{f}_{\mathrm{bt}}$, e na flexão, $\mathrm{f}_{\mathrm{bt}, \mathrm{fl}}$ ). Além do ensaio padronizado à compressão, ensaiou-se o bloco com o plano de carregamento paralelo ao seu comprimento, denominado pelo autor de 
ensaio à compressão longitudinal $\left(f_{b, 1}\right)$. Os blocos utilizados eram maciços, com dimensões e massas específicas apresentadas na Tabela 2.3, juntamente com os resultados dos ensaios à compressão. Os valores obtidos no ensaio-padrão foram corrigidos, levando em consideração o fator de forma dos blocos; esta correção também se deu no cálculo da resistência à tração na flexão para levar em conta a distorção devido ao cisalhamento nas seções transversais do bloco. No ensaio à tração indireta, a força foi aplicada longitudinalmente, paralela ao comprimento do bloco. Os resultados dos ensaios à tração são apresentados na Tabela 2.4.

Extraíram-se corpos-de-prova 100 x $200 \mathrm{~mm}$ dos blocos, os quais foram submetidos à compressão axial, medindo-se os seus deslocamentos longitudinal e transversal. Observouse por meio das curvas tensão-deformação que o aumento da resistência conduz a um aumento da inclinação inicial da curva, além de uma ruína menos dúctil com as deformações atingindo maiores valores. Marzahn (2003) sugere que o módulo de deformação longitudinal do bloco $\left(E_{b}\right)$, definido pela inclinação da reta que une a origem do eixo ao ponto de tensão equivalente a $33 \%$ da tensão máxima, seja calculado por meio da Equação (2.1):

$$
\mathrm{E}_{\mathrm{b}}=450 \mathrm{f}_{\mathrm{b}, \mathrm{cil}}
$$

onde $\mathrm{f}_{\mathrm{b}, \text { cil }}$ é a resistência à compressão axial obtida em CPs cilíndricos extraídos do bloco.

Tabela 2.3 - Resistência à compressão dos blocos e corpos-de-prova, adaptada de Marzahn (2003).

\begin{tabular}{cccccccc}
\hline Bloco & $\begin{array}{c}\text { Dimensões } \\
(\mathrm{mm})\end{array}$ & $\begin{array}{c}\text { Massa } \\
\text { específica } \\
\left(\mathrm{kgf} / \mathrm{cm}^{3}\right)\end{array}$ & $\mathrm{f}_{\mathrm{b}}$ & $\begin{array}{c}\mathrm{f}_{\mathrm{b}, \mathrm{l}} \\
\left(\mathrm{N} / \mathrm{mm}^{2}\right)\end{array}$ & $\mathrm{f}_{\mathrm{b}, \mathrm{cil}}$ & $\mathrm{E}_{\mathrm{b}}$ & $\frac{\mathrm{f}_{\mathrm{b} . \mathrm{il}}}{\mathrm{f}_{\mathrm{b}}}$ \\
\hline $\mathrm{A}$ & $238 \times 240 \times 500$ & 1857 & 25,9 & - & 17,1 & 10088 & 0,66 \\
$\mathrm{~B}$ & & 1864 & 20,9 & 10,3 & 12,8 & 9908 & 0,61 \\
$\mathrm{C}$ & & 544 & 4,1 & 3,2 & 3,9 & 1938 & 0,95 \\
$\mathrm{D}$ & $200 \times 240 \times 500$ & 450 & 3,2 & 1,8 & 2,8 & 1516 & 0,86 \\
\hline
\end{tabular}

Tabela 2.4 - Resistência à tração dos blocos e corpos-de-prova, adaptada de Marzahn (2003).

\begin{tabular}{ccccc}
\hline Bloco & $\mathrm{f}_{\mathrm{bt}, \mathrm{fl}}$ & $\begin{array}{c}\mathrm{f}_{\mathrm{bt}} \\
\left(\mathrm{N} / \mathrm{mm}^{2}\right)\end{array}$ & $\mathrm{f}_{\mathrm{bt}, \mathrm{ax}}$ & $\mathrm{f}_{\mathrm{bt}} / \mathrm{f}_{\mathrm{b}}$ \\
\hline $\mathrm{A}$ & 2,21 & 1,19 & 1,42 & 0,04 \\
$\mathrm{~B}$ & 1,99 & 0,95 & 1,56 & 0,04 \\
$\mathrm{C}$ & 0,93 & 0,33 & 0,95 & 0,08 \\
$\mathrm{D}$ & 0,57 & 0,27 & 0,46 & 0,08 \\
\hline
\end{tabular}


O coeficiente de Poisson vale 0,10 e 0,20 para os CPs extraídos do bloco sílicocalcários e do bloco de concreto, respectivamente.

Realizaram-se também ensaios de tração direta $\left(f_{b t, a x}\right)$ com corpos-de-prova cilíndricos de 100 x 100 mm, sendo sugerida a Equação (2.2) para relacionar a resistência entre dois corpos-de-prova similares quando ensaiados à tração direta e à compressão axial:

$$
\mathrm{f}_{\mathrm{bt,ax}}=0,26 \mathrm{f}_{\mathrm{b}, \mathrm{cil}}
$$

Pode-se observar que os CPs apresentaram resistências que valem de $60 \%$ a $65 \%$ do valor do bloco sílico-calcário e de $85 \%$ a $90 \%$ do valor dos blocos de concreto. Nos ensaios à compressão longitudinal, com a diminuição do valor da resistência, essa relação tende a aumentar, passando os CPs a possuírem maior resistência que o bloco. A resistência à tração indireta vale aproximadamente $4 \%$ da resistência à compressão dos blocos sílico-calcários e 8\% da resistência dos blocos de concreto. Marzahn (2003) justifica que a escolha dessa geometria de corpos-de-prova se deu em virtude destes serem amplamente aceitos no estudo das propriedades mecânicas do concreto, oferecendo a vantagem de uma variedade de relações altura/diâmetro.

As resistências à compressão e à tração do concreto, medidas em corpos-de-prova, de acordo com Neville (1997), estão estreitamente relacionadas. Entretanto, não se pode estabelecer uma proporcionalidade direta, em virtude da influência do nível de resistência do concreto nesta relação. Quando se aumenta a resistência à compressão, a resistência à tração também aumenta, mas em uma razão decrescente. Cita ainda que, depois de cerca de um mês da fabricação do concreto, a resistência à tração aumenta mais lentamente do que a resistência à compressão.

Como a resistência à tração pode ser determinada por ensaios distintos (tração na flexão, tração direta e tração indireta), a relação com a resistência à compressão também possui diferentes valores.

Marzahn (2003) sugere as Equações (2.3) e (2.4) para correlacionar as resistências à tração obtidas pelos diferentes métodos de ensaio:

$$
\begin{gathered}
\mathrm{f}_{\mathrm{bt}, \mathrm{ax}}=0,72 \mathrm{f}_{\mathrm{bt}} \\
\mathrm{f}_{\mathrm{bt}, \mathrm{ax}}=0,50 \mathrm{f}_{\mathrm{bt}, \mathrm{fl}}
\end{gathered}
$$

Utilizando-se também blocos silico-calcários e de concreto autoclavado, Graubohm et al. (2008) determinam as propriedades mecânicas dos materiais por meio de ensaio com corpos-de-prova cilíndricos e prismáticos extraídos dos blocos, submetidos à compressão 
axial e flexão em três pontos, respectivamente. Dessa forma, obtiveram-se a resistência à compressão, o módulo de elasticidade, o coeficiente de Poisson, a resistência à tração e a energia de fratura, contudo, nenhuma comparação é realizada com os valores obtidos diretamente a partir dos ensaios com blocos.

Uma nova metodologia de correlação entre resistência do corpo-de-prova e dos blocos de concreto foi desenvolvida por Frasson Júnior (2000). Utilizaram-se fôrmas cilíndricas para a moldagem dos corpos-de-prova de 50 x $100 \mathrm{~mm}$ e a partir dos seus ensaios e correlações com os blocos de concreto, desenvolveu-se uma metodologia de dosagem e controle do processo produtivo para os blocos.

Apesar de tal estudo ser apenas uma das etapas da pesquisa, é interessante perceber a busca do autor não só por um método menos dispendioso para a caracterização das propriedades mecânicas, mas também na visão que teve ao buscar conhecimentos sobre o material empregado na produção para se caracterizar o componente estrutural. As facilidades dos ensaios com CPs são evidentes se comparadas com os ensaios e estudos com blocos que utilizam estritamente a fábrica, pois este se torna um procedimento que encarece e dificulta a dosagem, havendo a necessidade da definição de uma forma simples e eficaz (FRASSON JÚNIOR, 2000).

A moldagem dos CPs ocorreu durante a produção dos blocos nas fábricas, com o mesmo concreto seco utilizado para confecção dos blocos. Os elementos eram colocados juntos na cura a vapor, garantindo dessa forma a semelhança entre eles.

A análise experimental consistiu na moldagem de três séries de blocos de dimensões 140 × 190 x 390 mm, duas geometrias (com paredes "grossas" e "finas") e três distintas resistências $\left(6 \mathrm{~N} / \mathrm{mm}^{2}, 9 \mathrm{~N} / \mathrm{mm}^{2}\right.$ e $\left.12 \mathrm{~N} / \mathrm{mm}^{2}\right)$. Para cada uma das séries de blocos foram produzidos 4 CPs.

A Tabela 2.5 apresenta os valores das resistências dos CPs e dos blocos, sendo as comparações realizadas em relação à área líquida.

Tabela 2.5 - Correlação entre as resistências dos CPs e dos blocos de concreto, adaptada de Frasson Júnior (2000).

\begin{tabular}{ccccccc}
\hline & \multicolumn{4}{c}{ Resistência $\left(\mathrm{N} / \mathrm{mm}^{2}\right)$} \\
$\begin{array}{c}\text { Resistência } \\
\text { Nominal }\end{array}$ & Bloco & CP & $\begin{array}{c}\text { CP/Bloco } \\
(\%)\end{array}$ & Bloco & CP & $\begin{array}{c}\text { CP/Bloco } \\
(\%)\end{array}$ \\
\hline 6 & 18,5 & 14,5 & 78,4 & 16,4 & 13,0 & 79,3 \\
9 & 27,0 & 21,0 & 77,8 & 21,4 & 17,4 & 81,3 \\
12 & 32,4 & 26,0 & 80,2 & 32,8 & 25,3 & 77,1 \\
\hline
\end{tabular}


Com base nos resultados, Frasson Júnior (2000) conclui que, para um corpo-de-prova cilíndrico de 50 x $100 \mathrm{~mm}$, de mesmo traço e mesma massa específica que um determinado bloco de concreto, sua resistência é em torno de $80 \%$ da resistência do bloco, considerada a área líquida.

Buttler (2007) realiza ensaios com o objetivo de avaliar a incorporação de agregados reciclados de concreto em blocos estruturais de concreto. Para isso, foram analisadas as propriedades físicas e mecânicas de corpos-de-prova cilíndricos $(50 \times 100 \mathrm{~mm})$ produzidos com concreto de consistência seca (de características similares ao empregado nos blocos estruturais) com o intuito de definir um intervalo de correlação entre a resistência à compressão de corpos-de-prova e blocos vazados de concreto com dimensões de 140 x 190 x $290 \mathrm{~mm}$. Determinaram-se os traços de concreto a serem utilizados para a produção dos blocos a partir das propriedades mecânicas obtidas nos ensaios com corpos-de-prova, analisando-se a umidade, a composição do material, a energia de adensamento, o tipo de cura, a condição de umidade da amostra no momento do ensaio e o procedimento de mistura.

Considerando-se as resistências nominais do bloco, de 4,5 N/mm², 6,0 N/mm² e 8,0 $\mathrm{N} / \mathrm{mm}^{2}$, a relação entre a resistência dos corpos-de-prova e dos blocos de concreto, levando-se em conta a área líquida, foi de $0,98,0,88$ e 0,73, respectivamente. $\mathrm{O}$ autor cita que um das dificuldades encontradas empregando-se essa metodologia é assegurar a uniformização da energia de adensamento, uma vez que esta pode variar de acordo com o operador de moldagem. Assim, para o emprego dessa metodologia, Buttler (2007) propõe como solução a adaptação de um dispositivo mecânico que uniformize a energia de adensamento por meio da queda livre de uma massa a partir de uma determinada altura. Por fim, destaca que no processo produtivo dos blocos, diferentemente do que ocorre com os corpos-de-prova, a distribuição dos materiais nas fôrmas não ocorre de maneira uniforme, o controle de umidade dos materiais não é realizado de maneira adequada e os tempos de vibro-prensagem são variáveis resultando em diferentes condições que podem influenciar a variabilidade das propriedades mecânicas destes elementos.

Prado (2006) complementa a pesquisa realizada por Buttler (2007) estabelecendo o coeficiente 0,90 como sendo a relação entre a resistência à compressão do corpo-de-prova e do bloco. Este valor, que é função da resistência à compressão dos blocos, depende da equivalência entre massa específica, absorção de água e índice de vazios de ambos os elementos. 
Acredita-se que existam fatores que são desconhecidos e que possam ser correlacionados com as unidades das estruturas de alvenaria e talvez até com as próprias estruturas.

As pesquisas que objetivam caracterizar as propriedades mecânicas do material que constitui a unidade de alvenaria encontraram várias dificuldades, principalmente pelo fato dos blocos de concreto sofrerem um processo de moldagem diferente dos convencionalmente adotados para os concretos plásticos. Assim, os equipamentos a que se destinam a moldagem e adensamento do concreto plástico não satisfazem, em tese, os procedimentos utilizados para adensamento do concreto "seco". Por esse motivo, algumas pesquisas utilizam corpos-deprova extraídos do próprio bloco, garantindo dessa forma, a igualdade entre as características dos materiais (no bloco e no corpo-de-prova). A extração dos CPs, apesar de garantir as propriedades mecânicas do material que constitui o bloco, é um método que requer um trabalho mais cuidadoso, demandando maiores custos e tempo, além da possibilidade da ocorrência de danos ao CP durante a extração.

Uma maior padronização quanto aos CPs mostra-se necessária, visto que a restrição ocasionada pelos pratos da prensa e a própria geometria exercerão influência significativa nos resultados obtidos. Nos valores encontrados por Becica e Harris (1983) e Ganzerli et al. (2003), a resistência dos corpos-de-prova é em torno de $24 \%$ maior que a resistência dos blocos, enquanto que Frasson Júnior (2000) encontra resistências de corpo-de-prova aproximadamente $20 \%$ menores que as resistências dos blocos. Nos ensaios de Marzahn (2003) este valor de resistência variou entre $60 \%$ a $95 \%$ da resistência do bloco, dependendo do tipo de unidade considerada. É evidente que cada caso tem suas peculiaridades, sendo utilizados CPs com geometrias distintas, prismáticas e cilíndricas - que possui uma maior esbeltez e configuração que sofre menor atuação do confinamento -, além de diferirem nas dimensões de base e altura e na sua forma de obtenção, se por moldagem ou extração a partir dos blocos.

Entretanto, para avançar em busca de outras correlações faz-se necessária a definição de um corpo-de-prova que melhor represente o comportamento do bloco quando submetido a ensaios de compressão. Em relação ao processo de adensamento, é essencial pleno domínio da técnica a fim de se obter uma energia próxima a qual estão submetidos os blocos na vibroprensagem.

Prudêncio Júnior (2003) cita ainda que como a resistência do bloco, mesmo em área líquida, depende fundamentalmente da espessura de suas paredes e também da conicidade dos 
furos, a relação encontrada no trabalho de Frasson Júnior (2003) não é absoluta e deve ser pesquisada caso a caso.

\subsection{Influência das placas de ensaio}

O objetivo da utilização das placas nos ensaios é o de prover uma distribuição uniforme de tensão e deformação no elemento. Conforme relatam Kleeman e Page (1990), devido à restrição ocasionada pelas placas, um complexo estado de tensão é criado nas regiões próximas ao topo e à base das unidades. Assim, um aumento da resistência é induzido por um estado triaxial de tensões, a menos que a unidade tenha comprimento suficiente para que esses efeitos tornem-se insignificantes. Citam ainda que, se apenas algumas partes da unidade são carregadas - como nas unidades com carregamento apenas nas paredes longitudinais - a distribuição de tensões é sempre não uniforme. Porém, Atkinson (1991) ressalta que o grau de uniformidade obtido é influenciado também pela flexão e cisalhamento da placa, sendo necessário uma espessura mínima a fim de se evitar deformações excessivas. O autor apresenta uma série de prescrições de normas (americanas, canadenses e européias) em que se recomenda o diâmetro mínimo do disco de carregamento da extremidade da prensa variando entre $127 \mathrm{~mm}$ e $152 \mathrm{~mm}$ e a espessura mínima das placas - para unidades de $200 \mathrm{x} 400 \mathrm{~mm}$ e diâmetro de carregamento de $165 \mathrm{~mm}$ - variando entre $48 \mathrm{~mm}$ e $145 \mathrm{~mm}$. Alguns dos valores apresentados são específicos para unidades ou prismas. Também se define o fator K, que varia entre 0,33 e 1 nas normas consultadas. Esse fator parece ser de adequada utilização, pois avalia simultaneamente o diâmetro da extremidade de carregamento da prensa e as dimensões em planta das placas. A Equação (2.5) define o fator K e a Figura 2.3 ilustra as variáveis consideradas.

$$
\mathrm{e}=\mathrm{K}(\mathrm{D}-\mathrm{R})
$$

e: a espessura da placa de ensaio;

D: distância entre o centro da circunferência da extremidade da célula de aplicação de carga à quina da placa;

R: raio da célula de aplicação de carga. 

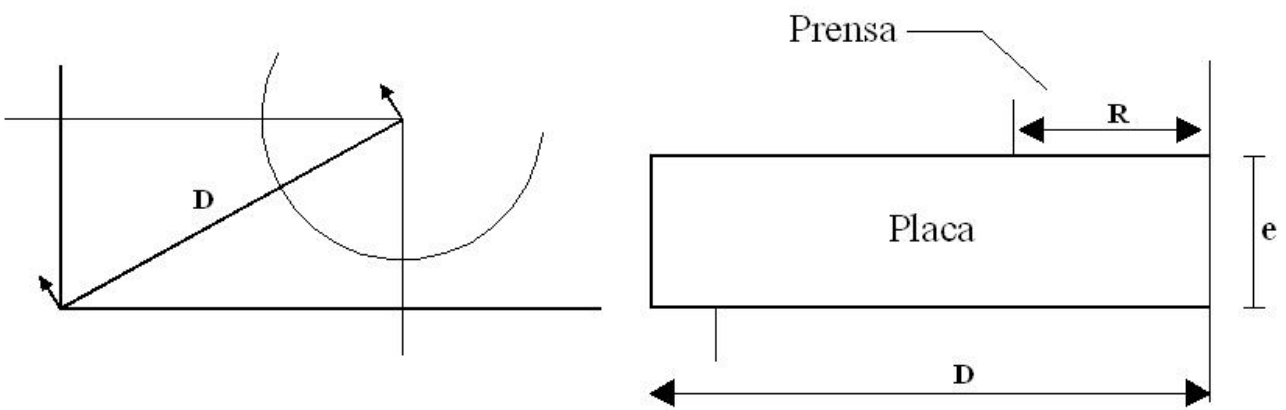

Figura 2.3 - Variáveis para definição do fator de cálculo $K$ da espessura das placas de ensaio, adaptada de Atkinson (1991).

Render (1986) ${ }^{1}$ apud Medeiros (1993) define em $75 \mathrm{~mm}$ a espessura mínima das placas de carregamento, evitando assim que possíveis deformações dissipem parte do carregamento. Já a NBR 7184 (1992) recomenda que as superfícies das placas devem ser planas e rígidas, não apresentando desníveis superiores a $8 \times 10^{-2} \mathrm{~mm}$ para cada $4 \times 10^{2} \mathrm{~mm}$, indicando a espessura de, no mínimo, um terço da distância entre a borda do prato de apoio e o canto mais afastado do corpo-de-prova, porém nunca inferior a $25 \mathrm{~mm}$.

Nos ensaios realizados por Self (1975), com o aumento da espessura da placa de 25 $\mathrm{mm}$ para $83 \mathrm{~mm}$, foi identificado um decréscimo nas deformações das paredes longitudinais, entre o centro e os extremos, de 50\%. Aumentando-se o diâmetro da extremidade da prensa de $216 \mathrm{~cm}$ para $254 \mathrm{~cm}$ houve um aumento de resistência entre $7 \%$ e 13\%. Essa variação também é identificada por Barbosa e Hanai (2008b), por meio de análises experimentais e de um modelo matemático considerando o comportamento linear do concreto.

Hamid e Chukwunenye (1986), por meio de simulações pelo Método dos Elementos Finitos, identificaram diferenças nas tensões de tração lateral em prismas quando utilizadas placas de $50 \mathrm{~mm}, 100 \mathrm{~mm}$ e $200 \mathrm{~mm}$. As diferenças consideráveis foram apontadas quando feitas comparações entre as placas de $50 \mathrm{~mm}$ e $100 \mathrm{~mm}$ e de $50 \mathrm{~mm}$ e $200 \mathrm{~mm}$. O diâmetro da superfície de carregamento foi de $140 \mathrm{~mm}$ e os prismas eram constituídos por três blocos vazados, com juntas totalmente preenchidas. Por fim, concluem que a maior flexibilidade da placa de $50 \mathrm{~mm}$ de espessura foi a responsável por tais diferenças.

A influência da restrição das placas na resistência à compressão de unidades maciças, de acordo com Page e Kleeman (1991), é bem conhecida e correções da resistência "aparente" podem ser feitas por meio da aplicação de fatores que geralmente são expressos em função da relação altura/largura do elemento ensaiado. A norma australiana AS 3700 (1998) adota essa

\footnotetext{
${ }^{1}$ RENDER, S. (1986). The compressive strength of masonry walls built using blocks laid flat. In: PRATICAL DESIGN OF MASONRY STRUCTURES, 1986, London. Proceedings. Thomas Telford, pp. 319-36.
} 
correção para as unidades maciças. No caso de unidades vazadas, a distribuição de tensões se torna muito mais complexa. O Eurocode 6 (2005) define a resistência normalizada à compressão de uma unidade como sendo a resistência obtida por analogia ao ensaio com uma unidade padrão, em forma de cubo de $100 \mathrm{~mm}$ de aresta. Essa resistência é determinada por meio de ensaios à compressão e multiplicada pelo fator $\delta$ que caracteriza as unidades de diferentes dimensões. Tal fator é obtido em função da altura e da menor dimensão da unidade ensaiada por meio de tabelas fornecidas pela norma. Hendry (1998) afirma que a Equação (2.6) leva a valores muito similares que os fornecidos pela referida norma.

$$
\delta=(\mathrm{h} / \sqrt{\mathrm{A}})^{0,37}
$$

$\mathrm{h}$ é a altura da unidade;

A é a área carregada.

Uma série de estudos relativos ao fator de forma dos elementos de alvenaria é apresentada por Brameshuber et al. (2007), Gregorie (2007), Sahlin (2007) e Vermeltfoort (2007), reunidos em uma edição especial do periódico Masonry International. Os objetivos desses trabalhos são similares, sendo realizados ensaios com unidades maciças e vazadas de concreto, sílico-calcárias e cerâmicas. As pesquisas partem do pressuposto de que, para um projeto mais adequado de alvenaria, é necessária a obtenção do valor da resistência à compressão das unidades sem o efeito da restrição ocasionada pelas placas de ensaio - não presente em uma parede de alvenaria. Apresentam-se comparações entre os valores do fator de forma obtidos em seus respectivos programas experimentais e os prescritos na normalização européia. Concluem que mais investigações devem ser realizadas por meio de novas abordagens para determinação da influência da forma das unidades e ainda que os fatores de forma da norma européia apresentam muitas vezes valores não coincidentes com os obtidos experimentalmente e dependem, além das características geométricas do elemento, do material que os constituem.

Page e Shrive (1988) esclarecem que, em um ensaio à compressão uniaxial representativo, a resistência não pode ser influenciada pelo efeito de esbeltez ou restrição das placas de ensaio. Como exemplo, descrevem a distribuição das tensões em um prisma homogêneo, considerando uma análise plana, tendo o elemento altura suficiente para que uma distribuição uniforme de tensões ocorra a alguma distância das extremidades, conforme indica a linha pontilhada da Figura 2.4. Pela imposição de deslocamento no topo do elemento e devido ao coeficiente de Poisson, a tendência de expansão lateral dessa região será restringida dependendo das dimensões e rigidez da placa, que ocasionarão o atrito. Cria-se a força $S_{0}$ na 
superfície do topo do elemento e uma força equivalente $\mathrm{C}$ logo abaixo dessa superfície a fim de equilibrar o momento no ponto A. O equilíbrio do sistema é obtido com o aumento da força $\mathrm{C}$ além de $\mathrm{S}_{0}$, em magnitude, e com o movimento da força $\mathrm{P}$ em direção à extremidade lateral. Podem ocorrer, devido a este efeito, alterações nas tensões e deformações verticais. Os equilíbrios verticais, horizontais e relativos aos momentos podem ser determinados a partir das distribuições e equivalências de força simplificadas apresentadas.

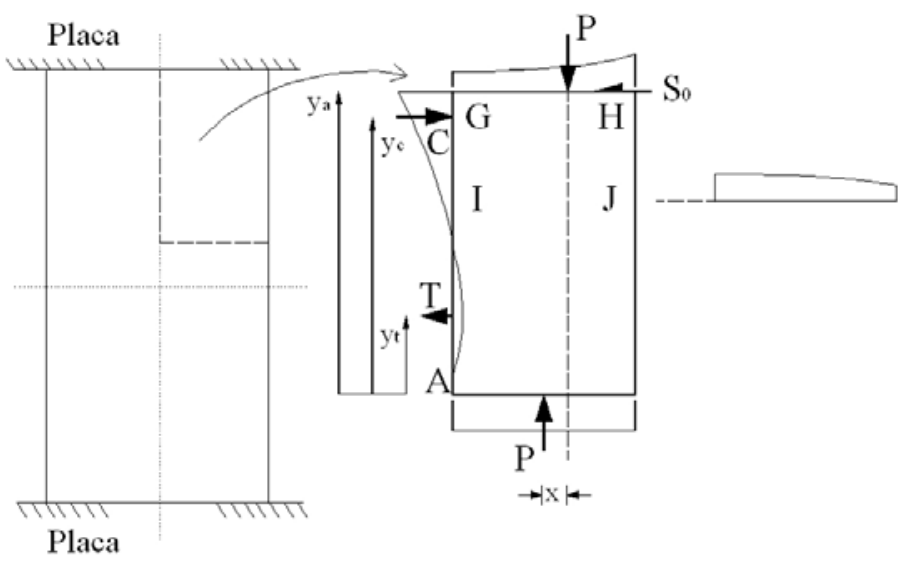

Figura 2.4 - Esquema da distribuição de tensão vertical em uma determinada altura de um prisma, adaptada de Page e Shrive (1988).

Os equilíbrios vertical e horizontal são representados pelas Equações (2.7) e (2.8):

$$
\begin{gathered}
\mathrm{P}-\mathrm{P}=0 \\
\mathrm{C}-\mathrm{S}_{0}-\mathrm{T}=0
\end{gathered}
$$

Já a Equação (2.9) define o equilíbrio em torno do ponto A.

$$
\mathrm{P} \cdot \mathrm{x}-\mathrm{S}_{0} \cdot \mathrm{y}_{\mathrm{s}}+\mathrm{C} \cdot \mathrm{y}_{\mathrm{c}}-\mathrm{T} \cdot \mathrm{y}_{\mathrm{t}}=0
$$

Os autores consideram que a argumentação anterior para o plano deve ser estendida às direções ortogonais do elemento - o que levaria a um estado triaxial em um cilindro. As distribuições tornam-se, evidentemente, muito mais complexas em um modelo tridimensional além de serem afetadas por sua geometria. Alertam ainda que um capeamento muito flexível pode reverter as direções das forças $\mathrm{S}_{0}$ e $\mathrm{C}$ apresentadas na Figura 2.4, sendo $\mathrm{C}$ convertido em uma força de tração que induzirá à separação do elemento.

Uma investigação sobre o efeito de confinamento nos ensaios à compressão com elementos de alvenaria foi realizada por Page e Kleeman (1991), com a realização de uma série de ensaios com unidades e prismas. Utilizaram-se dois métodos de ensaio, dentre eles o método padrão com placas maciças de aço. O outro método utiliza uma placa modificada, 
constituída por uma série de filamentos de aço delgados (denominada pelos autores brush platens), que transmite a carga em sua extremidade. Essas placas modificadas minimizam o efeito da restrição lateral, pois cada filamento é capaz de transmitir individualmente a sua parte da força vertical, fletindo-se lateralmente com a expansão do espécime devido à sua baixa rigidez ao cisalhamento. A Figura 2.5 ilustra a placa-escova (a) e o modo de ruína de um tijolo (b).

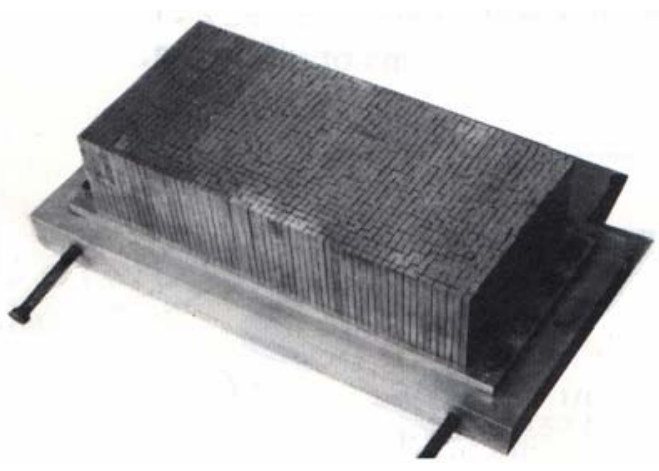

(a)

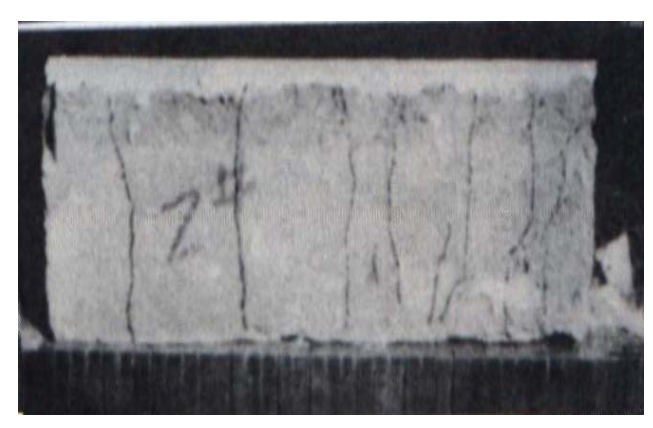

(b)

Figura 2.5 - Ensaio à compressão axial em unidades de alvenaria utilizando a placa-escova (a) e o modo ruína do bloco (b), Drysdale et al. (1994).

Os ensaios foram realizados com unidades de 200 x 200 x 400 mm, instrumentandose os 3 septos transversais para medição da fissuração.

A fissuração das unidades no ensaio padronizado iniciou-se na base dos septos transversais externos a 33\% da força última. Esse fenômeno foi seguido por uma progressiva fissuração dos três septos transversais e finalmente pela separação das paredes longitudinais na região entre o septo transversal central e o septo transversal externo. Nos ensaios utilizando a placa-escova, a primeira fissuração ocorreu na base do septo transversal central a $35 \%$ da força última. Com o aumento da força houve aumento da fissuração e novas fissuras surgiram nos demais septos transversais. Na força última, as fissuras nestes septos progrediram até o topo da unidade e em ambos os casos houve separação na base das paredes longitudinais (PAGE e KLEEMAN, 1991). A Tabela 2.6 agrupa os resultados obtidos nestes ensaios.

Os resultados mostram que houve restrição significativa das placas no ensaio padrão, indicado pelos valores mais baixos da carga de fissuração e da carga última em relação aos ensaios com a placa-escova. Essa diferença é evidente embora o modo de ruína seja semelhante, afirmam Page e Kleeman (1991).

Observa-se uma redução em torno de $28 \%$, tanto na carga de fissuração quanto na carga última, se comparados os resultados do ensaio padrão com os resultados do ensaio com placas-escova. 
Tabela 2.6 - Resultados dos ensaios com unidades e prismas, adaptada de Page e Kleeman (1991).

\begin{tabular}{cccc}
\hline Tipo do ensaio & $\begin{array}{c}\text { Carga média } \\
\text { de fissuração } \\
(\mathrm{kN})\end{array}$ & $\begin{array}{c}\text { Carga média } \\
\text { última } \\
(\mathrm{kN})\end{array}$ & $\begin{array}{c}\text { Relação } \\
\mathrm{f}_{\mathrm{fiss}} / \mathrm{f}_{\mathrm{u}}{ }^{1}\end{array}$ \\
\hline Bloco (padrão) & 165 & 490 & 0,33 \\
Bloco (placa-escova) & 120 & 348 & 0,35 \\
Prisma (padrão) & 105 & 409 & 0,26 \\
\hline
\end{tabular}

${ }^{1} \mathrm{f}_{\text {fiss }}$ : carga de fissuração

$\mathrm{f}_{\mathrm{u}}$ : carga última

Page e Kleeman (1991) comparam o comportamento dos blocos durante os ensaios, descrevendo que "[...] a fissuração no ensaio padrão não propagou livremente devido à restrição da expansão lateral. A ruína ocorreu no momento em que foram desenvolvidas tensões suficientes para iniciar a fissuração nas paredes longitudinais. Houve ainda uma variabilidade maior na localização da primeira fissura no septo transversal. Nos ensaios com placa-escova a fissuração ocorreu em toda altura da unidade e em todos os septos transversais, surgindo apenas uma pequena fissuração nas paredes laterais."

Também foram realizados ensaios a fim de comparar o comportamento dos blocos isolados com o comportamento dos blocos quando formam um prisma de três elementos. Para monitorar a fissuração dos septos transversais, o bloco central foi instrumentado de forma semelhante aos blocos quando ensaiados isoladamente. Foi observado que os blocos de topo e base sofreram pouca fissuração devido à restrição da prensa. Na Tabela 2.6 também estão apresentados os resultados obtidos nos ensaios com prismas.

Utilizando-se o conceito de fator de eficiência - relação entre a resistência do prisma e a do bloco $-\mathrm{f}_{\mathrm{p}} / \mathrm{f}_{\mathrm{b}}$ ), aplicado aos valores da resistência do bloco obtida por meio do ensaio com placa-escova, e do prisma obtida por meio do ensaio convencional, encontra-se $f_{p} / f_{b}=$ 1,18 , ou seja, a resistência do prisma é aproximadamente $18 \%$ maior que a resistência dos blocos, não condizendo com os resultados encontrados em diversas bibliografias. Cavalheiro e Gomes (2002) resumem valores encontrados para blocos de concreto em que o fator de eficiência entre o prisma e o bloco varia de 0,69 a 0,86, uma redução entre $14 \%$ e $31 \%$ na resistência dos prismas. Entretanto, nos ensaios com prismas de Page e Kleeman (1991) o bloco central está mais distante dos efeitos de restrição das placas e devido à sua maior relação h/t, em relação aos blocos, acredita-se que exista uma redução mais significativa do 
efeito de confinamento exercido sobre os prismas. A utilização de placa-escova nesse ensaio acarretaria menores diferenças que as obtidas nos ensaios com blocos.

Nestes ensaios, observa-se um aumento de resistência em torno de 40\%, comparando-se o ensaio com placas-escova com o ensaio padrão. A resistência obtida por meio de ensaios padronizados - resistência "aparente" - para esse bloco em particular, seria em torno de $40 \%$ superior à resistência "real" do bloco.

É recomendado por Drysdale et al. (1994) que nos ensaios científicos sejam utilizados modelos mais exatos, utilizando-se capeamentos mais deformáveis, lâminas de teflon (resina sintética) e placas engraxadas.

De acordo com Crouch et al. (1998), o estado triaxial de tensões que é gerado em uma parte dos elementos ensaiados depende da sua geometria, podendo aumentar ou diminuir a resistência à compressão do material próximo das placas dependendo da rigidez e da resistência do material de capeamento. A Figura 2.6 ilustra a área aproximada da região sob o estado triaxial de tensões em elementos com formas distintas, na qual são comparadas as regiões sob efeito de confinamento de um corpo-de-prova cilíndrico de concreto e de uma unidade maciça de alvenaria. Observa-se que em função da relação altura:diâmetro do cilindro ser igual a 2:1, uma parte do elemento encontra-se também no estado uniaxial de tensões, diferentemente do observado com o tijolo.
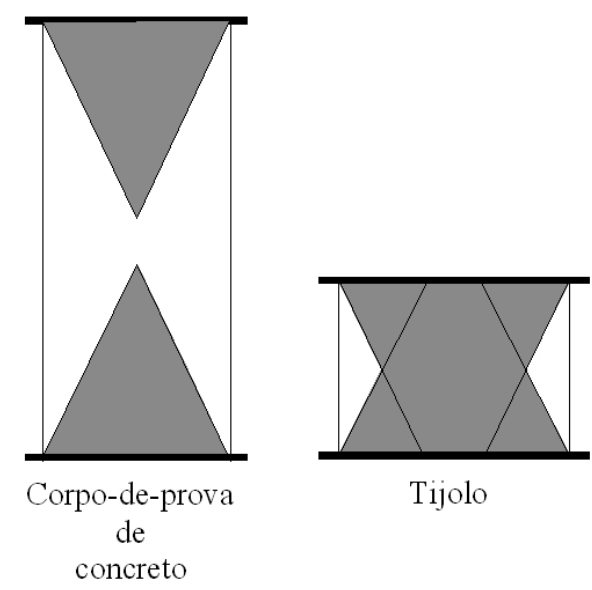

Tijolo

Figura 2.6. - Alcance aproximado do estado de tensão triaxial, adaptada de Crouch et al. (1998).

Ferro (2006) apresenta os resultados dos ensaios com corpos-de-prova cilíndricos de relação altura/diâmetro igual a um $(\mathrm{h} / \mathrm{t}=1)$ e cinco dimensões características: $10 \mathrm{~mm}, 23 \mathrm{~mm}$, $45 \mathrm{~mm}, 100 \mathrm{~mm}$ e $190 \mathrm{~mm}$, extraídos todos de uma mesma estrutura de concreto já existente a fim de assegurar a uniformidade das propriedades mecânicas do material. Nos ensaios foram utilizadas duas camadas de teflon e óleo para reduzir o atrito. O autor explica que quando os 
ensaios são realizados com placas rígidas, as extremidades dos espécimes são forçadas a ter a mesma deformação lateral que a placa de ensaio, sendo desenvolvidas tensões de cisalhamento entre eles, o que origina um estado tridimensional de tensões nesta região. $\mathrm{O}$ caso oposto ocorre quando se utiliza placa de carregamento com baixa rigidez e elevado coeficiente de Poisson, sendo desenvolvidas forças aparentes de cisalhamento direto nas interfaces, produzindo fissuras locais de separação. A ilustração desses mecanismos está apresentada na Figura 2.7.

A principal conclusão de Ferro (2006) é de que com redução do efeito de confinamento, a resistência à compressão não é claramente afetada pelo efeito de escala como ocorre, por exemplo, nos ensaios à tração. $\mathrm{O}$ autor constata ainda que se o atrito entre as placas de ensaio ou espécimes é evitado, ou pelo menos reduzido, a resistência à compressão do corpo-de-prova de concreto independerá das dimensões utilizadas em uma mesma relação $\mathrm{h} / \mathrm{t}$.

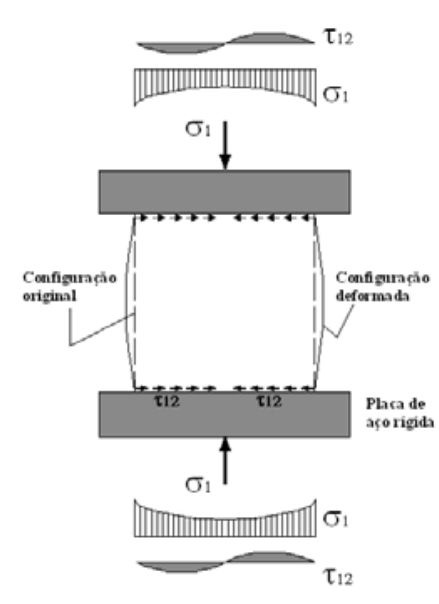

(a)

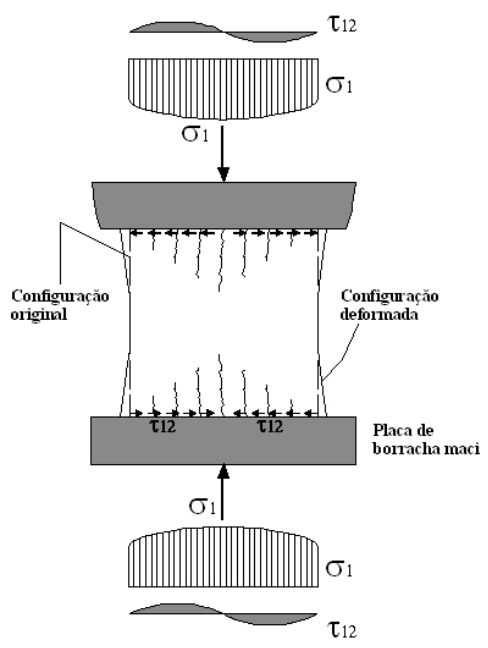

(b)

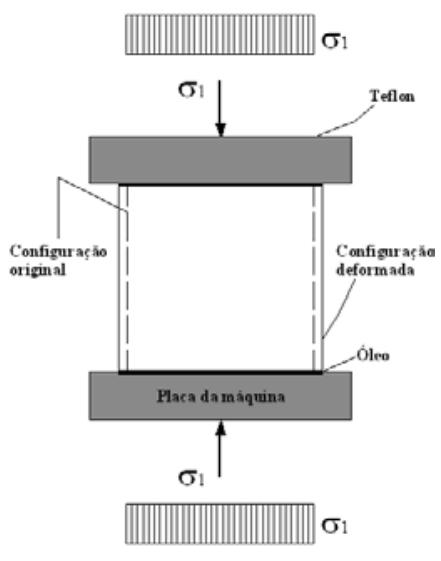

(c)

Figura 2.7 - Efeito da reação da placa de carregamento: placas rígidas de aço (a), placa de borracha (b) e placa com camada de teflon (c), adaptada de Ferro (2006).

\subsection{Acabamento das superfícies dos elementos}

Os capeamentos são finas camadas de um determinado material, dispostas entre o elemento a ser ensaiado e as placas da máquina de ensaio, que reduzem os efeitos das irregularidades no topo e base do corpo-de-prova, propiciando dessa maneira uma distribuição mais uniforme das tensões. Os diferentes materiais usados como capeamento levam a significativas variações nas resistências dos blocos, considerando as diferentes propriedades de deformação desses materiais. 
Como visto, devido às restrições ocasionadas pela placa da máquina de ensaio, um estado triaxial é criado nas unidades, e quando é colocada uma camada de material entre a unidade e a placa, o estado de tensões passa a ser influenciado também pelas propriedades de deformação do material de capeamento. A resistência aparente das unidades pode aumentar ou diminuir de acordo com a rigidez relativa do material de capeamento (sua espessura e módulo de elasticidade) e da unidade. Kleeman e Page (1990) exemplificam que um material muito deformável apresentará deformações laterais com valores superiores aos da unidade, nela induzindo tensões laterais de tração, resultando disso uma ruína prematura por fendilhamento. De modo oposto, a maior rigidez do material de capeamento induzirá tensões de compressão lateral que retardarão a ruína. As tensões induzidas dependem da espessura e das propriedades de deformação do material sob tensão normal e cisalhante.

As normas de cada país recomendam a utilização de diferentes tipos de capeamento. No Brasil, a NBR 7184 (1992) indica, para a regularização das faces de trabalho do elemento a ser ensaiado, a utilização de pastas ou argamassas capazes de apresentar no momento do ensaio resistência à compressão em corpos-de-prova cilíndricos $(50 \times 100 \mathrm{~mm})$ superior à prevista do bloco a ensaiar. As pastas ou argamassas podem ser à base de gesso, enxofre, cimento, pozolana ou quaisquer outros materiais granulares que atendam aos requisitos de uniformidade e resistência exigidos pela norma, não devendo exceder espessura média de 3 mm. Na Austrália utiliza-se o compensado (madeira compensada) ou a chapa de fibra prensada, com espessura entre $4 \mathrm{~mm}$ e $6 \mathrm{~mm}$. A ASTM C 140 (1996) especifica uma fina camada de argamassa de gesso ou enxofre como capeamento rígido. Drysdale et al. (1994) citam o uso de placas de fibra, compensado ou outro material relativamente deformável como alternativas. A norma australiana AS 3700 (1998) exige que as unidades vazadas e os prismas constituídos por estas unidades sejam ensaiados usando capeamento unicamente nas paredes longitudinais, sendo os prismas construídos também com argamassa apenas nessas faces.

Os capeamentos mais comuns (argamassa, enxofre, pasta de gesso e chapa de fibra), segundo Maurenbrecher (1978), geram resultados semelhantes, desde que as superfícies de carregamento sejam perfeitamente horizontais. Materiais tipo borracha não são adequados, pois induzem a um rompimento prematuro.

Maurício (2003) também realizou ensaios à compressão com blocos vazados de concreto (140 x 190 x $290 \mathrm{~mm}$ ) com dois traços distintos (A e B) e capeados com diferentes tipos de material. Os resultados estão apresentados na Tabela 2.7.

Nos blocos com capeamento de borracha, a fissuração começou a baixas cargas, tornando-se intensa no decorrer do ensaio, sendo a ruína caracterizada ora por intensa 
fissuração, ora pelo cisalhamento diagonal (MAURÍCIO, 2003). Os capeamentos com enxofre e gesso acarretam as maiores resistências nos dois tipos de blocos.

Tabela 2.7 - Resistência dos blocos vazados de concreto com diferentes tipos de capeamento, adaptada de Maurício (2003).

\begin{tabular}{ccccccc}
\hline & \multicolumn{3}{c}{ Traço A } & \multicolumn{3}{c}{ Traço B } \\
Material de & $\mathrm{f}_{\mathrm{b}}$ & $\mathrm{f}_{\mathrm{bk}}$ & $\mathrm{C} . \mathrm{V}$. & $\mathrm{f}_{\mathrm{b}}$ & $\mathrm{f}_{\mathrm{bk}}$ & $\mathrm{C} . \mathrm{V}$. \\
& $\left(\mathrm{N} / \mathrm{mm}^{2}\right)$ & $(\%)$ & $\left(\mathrm{N} / \mathrm{mm}^{2}\right)$ & $(\%)$ \\
\hline Enxeamento & 10,8 & 8,9 & 11 & 4,0 & 3,3 & 11 \\
Gesso & 10,7 & 8,9 & 10 & 3,7 & 3,1 & 9 \\
Argamassa & 8,0 & 6,7 & 10 & 3,4 & 2,9 & 10 \\
Pasta de cimento & 8,2 & 6,8 & 11 & 3,3 & 2,3 & 18 \\
Forro pacote & 9,7 & 7,8 & 12 & 3,0 & 2,4 & 12 \\
Papelão & 8,6 & 7,0 & 12 & 2,7 & 1,7 & 22 \\
Borracha & 5,9 & 5,0 & 9 & 2,0 & 1,5 & 18 \\
\hline
\end{tabular}

$\mathrm{f}_{\mathrm{b}}$ : resistência média à compressão do bloco

$\mathrm{f}_{\mathrm{bk}}$ : resistência característica à compressão do bloco

C.V.: coeficiente de variação

Levando-se em conta as análises feitas por Page e Kleeman (1991), em que os materiais que apresentam maior rigidez ao cisalhamento permitem aos blocos maiores cargas de compressão, e com os dados disponíveis de Maurício (2003), nota-se que os resultados obtidos com os ensaios do bloco tipo B são mais coerentes se comparados com os resultados obtidos com os blocos tipo A. Os valores mais altos encontrados para os blocos capeados com enxofre e gesso são justificados pela maior rigidez que esses materiais possuem frente aos demais e talvez pelo maior atrito proporcionado às placas da prensa. Os baixos resultados obtidos nos ensaios com argamassa do bloco tipo A podem ter sido ocasionados pelo esmagamento precoce do material de capeamento, fato relatado por Maurício (2003). Por ser o material mais deformável, já se esperavam as menores resistências para os blocos capeados com a borracha. As teorias citadas por Maurenbrecher (1978) e Kleeman e Page (1990) explicam tal fenômeno.

Khalaf e Hendry (1990) realizaram análise experimental com tijolos de resistências à compressão distintas (identificados de T1 à T5) e com blocos vazados de concreto (B1 e B2) utilizando quatro tipos de acabamento para as superfícies: regularização mecânica, argamassa, chapa de madeira e a pasta dental. Na Tabela 2.8 estão apresentados os resultados obtidos e seus respectivos coeficientes de variação. 
Tabela 2.8 - Resistência à compressão de unidades de alvenaria com distintos materiais de capeamento, adaptada de Khalaf e Hendry (1990).

\begin{tabular}{cccccccc}
\hline Tipo de & \multicolumn{7}{c}{ Resistência à compressão $\left(\mathrm{N} / \mathrm{mm}^{2}\right)^{1}$} \\
\cline { 2 - 7 } Capeamento & $\mathrm{T} 1$ & $\mathrm{~T} 2$ & $\mathrm{~T} 3$ & $\mathrm{~T} 4$ & $\mathrm{~T} 5$ & $\mathrm{~B} 1$ & $\mathrm{~B} 2$ \\
\hline \multirow{2}{*}{ Retífica $^{2}$} & 114,4 & 46,7 & 55,4 & 38,7 & 31,0 & 22,1 & 14,6 \\
& $(8,1 \%)$ & $(7,9 \%)$ & $(8,8 \%)$ & $(7,5 \%)$ & $(11,1 \%)$ & $(8,2 \%)$ & $(11,5 \%)$ \\
Argamassa & 91,8 & 46,0 & 52,0 & 41,4 & 33,2 & 23,0 & 15,1 \\
& $(21,6 \%)$ & $(15,4 \%)$ & $(8,2 \%)$ & $(6,0 \%)$ & $(8,2 \%)$ & $(9,8 \%)$ & $(10,2 \%)$ \\
Chapa de & 75,5 & 37,0 & 39,9 & 26,8 & 21,6 & 25,4 & 16,7 \\
madeira & $(6,5 \%)$ & $(6,9 \%)$ & $(11,1 \%)$ & $(13,2 \%)$ & $(12,8 \%)$ & $(10,3 \%)$ & $(10,4 \%)$ \\
Pasta de & 71,4 & 32,9 & 39,3 & 24,5 & 22,2 & 20,0 & 16,2 \\
moldagem & $(12,1 \%)$ & $(11,8 \%)$ & $(10,9 \%)$ & $(11,1 \%)$ & $(11,7 \%)$ & $(10,5 \%)$ & $(10,0 \%)$ \\
\hline
\end{tabular}

${ }^{1}$ Entre parênteses: coeficiente de variação

${ }^{2}$ Retífica: processo de regularização mecânica

${ }^{3}$ Substância pastosa que endurece mediante secagem, utilizada na fabricação de moldes odontológicos

Em relação ao tijolo com resistência mais alta (T1), a superfície regularizada apresenta resistência à compressão $25 \%, 52 \%$ e $60 \%$ maior que as unidades com capeamentos com argamassa, chapa de madeira compensada e pasta dental. A tendência de aumento da relação entre as resistências é clara e coerente com a deformabilidade de cada material utilizado no acabamento das superfícies.

Os demais grupos de resistência apresentam a mesma tendência, entretanto, as diferenças em relação à unidade sem capeamento são menores, conforme está ilustrado na Figura 2.8. Este gráfico representa as relações entre a resistência à compressão de uma unidade que foi submetida a um processo de regularização mecânica e uma unidade capeada com argamassa $\left(f_{b, r e t} / f_{b, a r g}\right)$ em função do valor da resistência efetiva, adotada, neste caso, como sendo o valor da resistência à compressão da unidade $\mathrm{T} 1$ considerando o processo retificado. Observa-se que para um mesmo tipo de unidade, ao se aumentar o valor de sua resistência, as diferenças entre a resistência à compressão também aumentam, ou seja, quanto maior a resistência de uma unidade, mais atuante será o efeito de confinamento. 


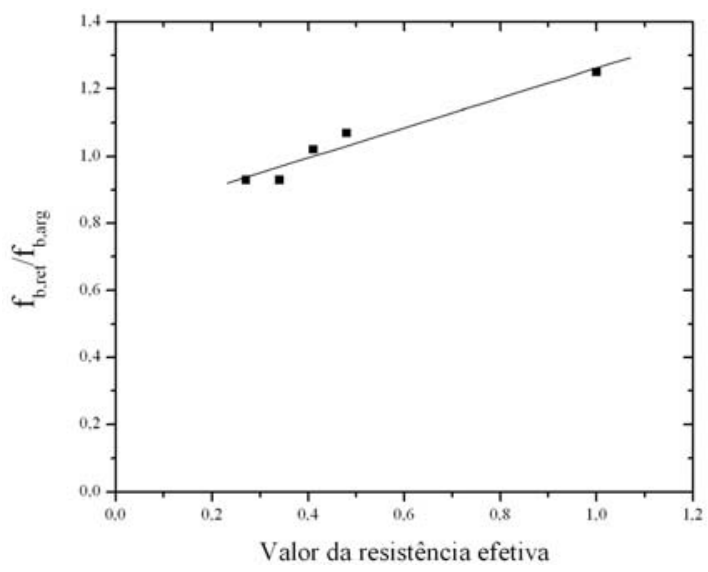

Figura 2.8. - Relação entre a resistência à compressão de unidades retificadas e com capeamento de argamassa em função de sua resistência efetiva.

De controverso, destacam-se as pequenas diferenças (próximas a 10\%) obtidas nos ensaios com blocos vazados de concreto, aceitas e justificadas pelos autores em virtude do efeito menos pronunciado das condições de contorno da face horizontal em unidades com maior altura. Uma comparação direta com os ensaios de Maurício (2003) e utilizando o conhecimento básico acerca da equivalência dos materiais de capeamento utilizados nas duas pesquisas, esperava-se que essas diferenças, considerando um material rígido e outro mais flexível (argamassa e borracha, por exemplo), fossem de pelo menos 30\%. Em relação aos blocos vazados de concreto em particular, os resultados obtidos por Khalaf e Hendry (1990) vão ao desencontro com as conclusões obtidas nas demais pesquisas. Como motivos para esta tendência podem-se citar as diferenças entre as geometrias dos blocos de concreto e uma possível má execução da regularização da superfície. Além disso, nenhuma análise mais detalhada em relação às rigidezes dos materiais de regularização foi realizada a fim de se quantificar a influência de cada um deles.

A utilização de placa-escova reduz de forma significativa o efeito triaxial de tensões, contudo, Crouch et al. (1998) relatam que elas não estão disponíveis comercialmente e sua produção não é um processo prático. O programa experimental desenvolvido pelos autores tem como objetivo determinar a eficiência de diversas técnicas de capeamento e analisar a possibilidade do desenvolvimento de um sistema de capeamento não aderente. Apresentam-se na Tabela 2.9 os tipos de capeamentos utilizados e na Tabela 2.10 os valores de resistência à compressão obtidos. Realizaram-se 50 ensaios com cada tipo de capeamento em tijolos com três furos e dimensões de $200 \times 92 \times 57 \mathrm{~mm}$. 


$\begin{gathered}\text { Tabela 2.9 } \\
\text { nos ensaios realizados por Crouch et al. (1998). }\end{gathered}$
\begin{tabular}{cc} 
Referência & Capeamento \\
\hline A & Argamassa de enxofre $1^{1}$ \\
B & Argamassa de enxofre 2 \\
C & Argamassa de enxofre 3 \\
D & Gesso de alta resistência \\
E & Chapa de borracha 6,35mm \\
F & Sem capeamento \\
\hline
\end{tabular}

${ }^{1}$ As argamassas de enxofre se diferem pelo valor da resistência à compressão $(\mathrm{A}>\mathrm{B}>\mathrm{C})$

Tabela 2.10 - Resistência à compressão de unidades de alvenaria em função do tipo de capeamento, adaptada de Crouch et al. (1998).

\begin{tabular}{ccccccc}
\hline & \multicolumn{7}{c}{ Tipo de capeamento } \\
& A & B & C & D & E & F \\
\hline $\mathrm{f}_{\mathrm{b}}\left(\mathrm{N} / \mathrm{mm}^{2}\right)$ & 86,6 & 80,1 & 87,3 & 87,3 & 47,0 & 52,5 \\
C.V. $(\%)$ & $3,9 \%$ & $2,5 \%$ & $7,3 \%$ & $4,6 \%$ & $3,1 \%$ & $8,0 \%$ \\
\hline
\end{tabular}

As resistências obtidas utilizando os capeamentos A, C e D são similares, entretanto, utilizando-se o capeamento B, o valor caiu em torno de 8,2\% em relação aos demais ensaios realizados com capeamento rígido. A diferença encontrada entre os capeamentos com a argamassa de enxofre e o com gesso é muito pequena. Como esperado, a menor resistência foi obtida quando se utiliza um capeamento mais flexível (capeamento E). Em relação às unidades sem capeamento, observa-se ainda que as unidades com capeamento rígido apresentam um incremento de mais de $60 \%$ em sua resistência, enquanto que uma redução de $10 \%$ é encontrada com capeamento mais flexível.

A comparação entre os valores de resistência à compressão utilizando-se distintos tipos de capeamento quase sempre é realizada de forma superficial, ou seja, muitas vezes sem parâmetros que justifiquem a maior redução ou aumento de resistência no ensaio com elementos similares. Por exemplo, provavelmente os capeamentos A, B, C e D utilizados por Crouch et al. (1998) tenham rigidez suficiente para aumentar a resistência à compressão de uma unidade, comparando-se com o ensaio sem capeamento. Analogamente, nos resultados obtidos por Khalaf e Hendry (1990), observa-se que a argamassa não foi capaz de aumentar a resistência à compressão em relação aos ensaios sem capeamento. Nesse caso, fica o 
questionamento sobre as propriedades mecânicas dos materiais, argamassa e gesso, por exemplo, e sua real influência no fenômeno. É necessário avançar nessa questão a fím de definir de forma mais precisa a influência da variação das propriedades mecânicas dos materiais na condição de confinamento dos elementos, avaliando-se isoladamente o comportamento do material de regularização das superfícies.

No tocante ao questionamento levantado anteriormente, destaca-se o minucioso trabalho de Page e Kleeman (1991), que realizaram ensaios de compressão em unidades vazadas de concreto e cerâmicas (com diferentes dimensões) e em prismas. Como material de capeamento foram usados o compensado e as chapas de fibra prensadas, variando-se a sua espessura entre $4 \mathrm{~mm}$ e $6 \mathrm{~mm}$. Em ensaios realizados anteriormente por Kleeman e Page (1990), os materiais apresentaram rigidez de 22 e $68 \mathrm{~N} / \mathrm{mm}^{2} / \mathrm{mm}$ e módulo secante de cisalhamento de $250 \mathrm{~N} / \mathrm{mm}^{2}$ e $240 \mathrm{~N} / \mathrm{mm}^{2}$, respectivamente.

Os valores de resistência com o capeamento constituído por chapa de fibra prensada, além de ter uma alta variabilidade, principalmente no caso das unidades cerâmicas, levaram a menores valores de resistência que os elementos ensaiados com capeamento de compensado. Page e Kleeman (1991) concluem que os resultados são coerentes com os encontrados na caracterização dos materiais utilizados no capeamento, nos quais o módulo secante de cisalhamento da chapa de fibra prensada tende a ser menor que o do compensado.

Neville (1997) cita que ao invés de serem capeadas, as superfícies podem ser esmerilhadas utilizando-se um abrasivo, o que conduz a resultados satisfatórios. O esmerilhamento leva a valores de resistência à compressão maiores que os obtidos com capeamento, pois se elimina a perda de resistência devida à camada de material intermediária entre o elemento e as placas de ensaio.

Por fim, Drysdale et al. (1994) afirmam que nenhuma das relações entre os ensaios com diversos tipos de capeamento encontradas pode ser válida em virtude das diferentes propriedades dos materiais de capeamento e dos diferentes efeitos que dependem tanto da espessura do capeamento como da tensão de ruína. Citam ainda que capeamentos deformáveis, que são totalmente prensados a cargas bem inferiores às cargas de ruína, podem causar um efeito semelhante ao da condição imposta pelo capeamento mais rígido naquele estágio. 


\subsection{Modelos numéricos para alvenaria estrutural}

Os recursos computacionais são muito valiosos na análise de estruturas, já que com um modelo numérico adequado é possível realizar uma detalhada análise do seu comportamento sem a necessidade da elaboração de análises experimentais, o que propicia redução de custos e soluções mais rápidas. Todavia, o sucesso desta técnica depende da boa validação do modelo constitutivo.

Uma ferramenta numérica é completa para a análise de um determinado tipo de estrutura quando é capaz de prever o seu comportamento desde o estágio linear, passando pela fissuração e degradação, até que seja atingida a completa perda de resistência, possibilitando, dessa forma, o controle dos estados limites, o completo entendimento dos mecanismos de ruína e a determinação da segurança estrutural. Estes objetivos apenas são alcançados se os modelos constitutivos dos materiais e de suas interfaces forem complementados com procedimentos de solução avançados dos sistemas de equações que resultam da discretização dos elementos finitos (LOURENÇO, 1996).

Destaca-se nas últimas décadas uma grande quantidade de estudos teóricos desenvolvidos sobre o comportamento das estruturas de alvenaria, principalmente quando submetidas a carregamento no próprio plano, sejam eles estáticos ou dinâmicos. A anisotropia, decorrente principalmente do arranjo das unidades, juntas de argamassa e interfaces, impõe uma notável dificuldade na obtenção de um modelo teórico fiel, que subsidie a análise numérica. As dimensões das unidades, a espessura e disposição das juntas, a qualidade dos materiais e a influência da mão-de-obra são fatores que também contribuem para este comportamento complexo.

Um modelo bastante simplificado para a alvenaria estrutural é a abordagem no estado plano de tensões (EPT), com o material representado por um meio contínuo elástico linear. Todavia, os modelos elásticos lineares fornecem respostas satisfatórias apenas nos casos em que o nível de tensões não se aproxima dos valores obtidos na ruína, sendo geralmente utilizado em análises mais simplificadas em que não ocorre o fenômeno de localização de deformações. Este é o caso do trabalho de Arantes et al. (2003), que apresenta análise com diversos tipos de prismas de blocos cerâmicos grauteados, variando as propriedades mecânicas dos materiais constituintes obtidas experimentalmente. As análises lineares limitam-se à comparação entre os valores de tensão obtidos ao longo dos elementos.

Outra consideração pertinente, ainda em relação aos modelos bidimensionais, diz respeito à adoção de condições de contorno que conduzam o modelo a um estado plano de 
deformações (EPD), conforme é relatado por Pina-Henriques (2005). Algumas vezes, a abordagem plana leva a resultados condizentes com o comportamento da alvenaria, principalmente quando são analisadas as estruturas constituídas por unidades maciças, ou pelo menos quando a porcentagem de vazios das unidades não seja significativa em relação à área total da unidade. Caso contrário, uma abordagem mais detalhada - tridimensional ou bidimensional avançada - torna-se necessária para uma melhor representação do comportamento da estrutura.

Uma estratégia correntemente utilizada nos últimos anos considera a alvenaria constituída por um único material, homogeneizado, que é resultado da média entre as propriedades dos distintos materiais que constituem a estrutura, e que é destinada com grande eficácia para a avaliação do comportamento global da alvenaria. Neste caso, uma lei macroconstitutiva é obtida a partir de uma lei micro-constitutiva e da geometria do material composto que passa a ser considerado como único e anisotrópico. Obtendo-se essa relação, o comportamento da alvenaria é determinado e alterações na sua geometria podem ser manipuladas numericamente sem a necessidade de um número excessivo de ensaios. Estes macro-modelos, apesar de apresentarem equações relativamente mais complicadas, necessitam de menor esforço computacional e quantidade de dados de entrada, contudo, a abordagem torna-se claramente fenomenológica. Inúmeras pesquisas que tratam da macromodelagem numérica e técnicas de homogeneização podem ser melhor analisadas por meio dos trabalhos de Lourenço, de Borst e Rots (1997), Lourenço e Rots (1997a), Lourenço e Rots (1997b), Lourenço, Rots e Blaaywendraad (1997) e Lourenço, Rots e Blaaywendraad (1998), referentes às unidades maciças, e Wu e Hao (2007), que deriva as propriedades do material equivalente da alvenaria de blocos vazados de concreto.

Lourenço (1996) define que a micro-modelagem numérica fornece uma detalhada análise da alvenaria e deve incluir a representação das unidades, da argamassa e da interface entre unidade e argamassa. Este tipo de análise, que avalia bem o comportamento local da alvenaria, é voltado para pequenas estruturas, nas quais se deseja determinar os estados de tensões e deformações heterogêneos, sendo a alvenaria representada a partir das propriedades mecânicas de cada material e da interface com dados obtidos de análises experimentais. Este tipo de modelagem apresenta equações relativamente simples, entretanto, necessita de grande esforço computacional e entrada de dados. Um fato corrente neste tipo de análise é que a interação entre a unidade e a argamassa é geralmente desconsiderada em relação ao comportamento estrutural global. 
Assim, a escolha da estratégia numérica depende do nível de exatidão requerida, tendo-se basicamente as seguintes opções, ilustradas pela Figura 2.9, segundo Lourenço (1996):

a) Micromodelagem detalhada: as unidades e a argamassa nas juntas são representadas por elementos contínuos e a interface unidade-argamassa é representada por elementos descontínuos;

b) Micromodelagem simplificada: as unidades, que são expandidas, são representadas por elementos contínuos e o comportamento da junta da argamassa e da interface está atrelado a elementos descontínuos;

c) Macromodelagem: as unidades, argamassa e interfaces são dispersas no contínuo.

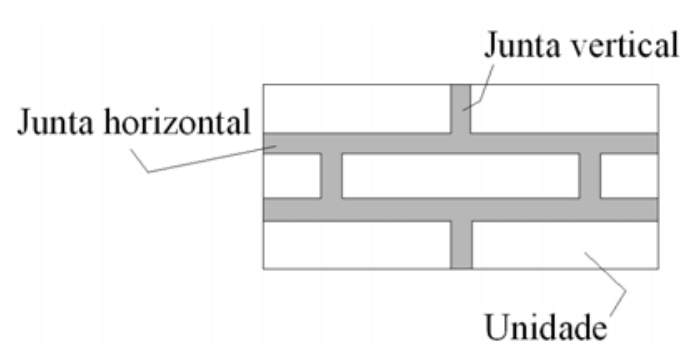

(a)

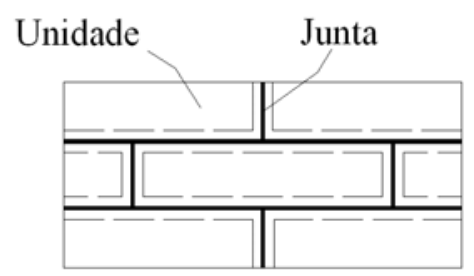

(c)

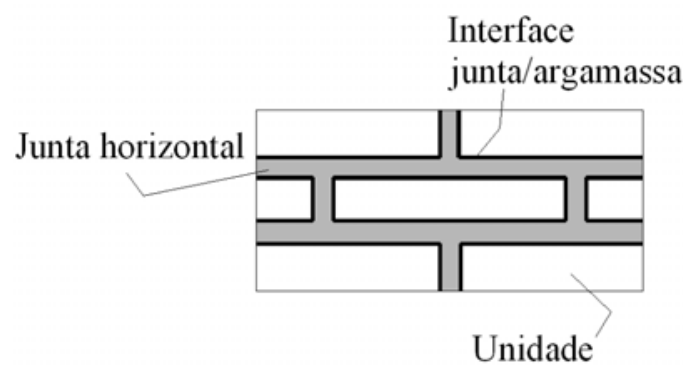

(b)

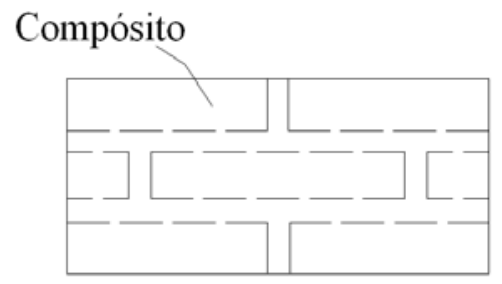

(d)

Figura 2.9 - Estratégias de modelagem para estruturas de alvenaria: estrutura de alvenaria e seus distintos materiais (a), micromodelagem detalhada (b), micromodelagem simplificada (c) e macromodelagem (d). Adaptada de Lourenço (1996).

As estruturas de alvenaria estão comumente submetidas a forças de compressão combinadas com forças laterais, caso que necessita de um modelo numérico mais preciso. Esse melhoramento do modelo dá-se principalmente em relação à aderência junta-argamassa, em que as juntas necessariamente devem receber um tratamento especial, por exemplo, com a utilização de elementos de interface ou de contato, conforme é descrito por Lotfi e Shing (1994). 
Seja qual for a estratégia adotada, uma definição precisa das propriedades mecânicas dos materiais por meio de um extenso programa experimental torna-se fundamentalmente necessária.

De acordo com Ali e Page (1988), muitos modelos não-lineares foram desenvolvidos para a análise dos materiais, inclusive alvenaria, utilizando-se a Teoria da Plasticidade e a Mecânica do Dano como embasamento teórico para formular modelos constitutivos. Relaciona-se a Teoria da Plasticidade com as deformações permanentes ocorridas na estrutura e a Mecânica do Dano Contínuo com a descrição da perda de resistência progressiva do material devido ao surgimento e crescimento de microfissuras. Atualmente, é comum a Teoria da Plasticidade ser utilizada com modelos de Fissuração Distribuída, onde são introduzidos os conceitos de Mecânica da Fratura e a Teoria do Dano para se obter melhores resultados no comportamento pós-pico.

Lourenço (1996) indica ainda a possibilidade do comportamento inelástico na tração e compressão ser descrito por uma integral do diagrama obtido nos respectivos ensaios. Estas quantidades denotadas, respectivamente, como energia de fratura $\mathrm{G}_{\mathrm{f}}$ (Modo $\mathrm{I}$ ) e energia de fratura à compressão $G_{c}$ são propriedades dos materiais utilizados. Diversas relações entre esses valores e a resistência do material são apresentados por Lourenço (2008).

A ruptura de um material quase-frágil é considerada quando a tensão máxima solicitante atinge a resistência do material. Entretanto, a máxima tensão não depende apenas das propriedades mecânicas, mas também da geometria e das condições de contorno do ensaio e, portanto, o critério de ruptura por resistência em termos de tensão nominal não é apropriado para material com este tipo de comportamento. Sendo assim, o processo de falha para materiais quase-frágeis pode ser descrito pela dissipação de energia na estrutura, a qual é obtida em ensaios com controle de deslocamento.

Manos et al. (2003) apresentam detalhada análise sobre o comportamento de juntas de argamassa em elementos de alvenaria constituídos por unidades maciças e submetidos a distintos tipos de carregamento, inclusive forças verticais e horizontais combinadas. Apresentam-se três modelagens: na primeira, as unidades e as juntas de argamassa são representadas por elementos contínuos de oito nós no estado plano de tensões, dentro do regime elástico linear, e por duas linhas de elementos de interface dispostas entre o elemento de alvenaria e a junta de argamassa; consideração alternativa é realizada com a expansão geométrica das unidades de alvenaria na espessura da junta de argamassa, representada por uma linha de elementos de contato. Por fim, utiliza-se um modelo similar ao primeiro, 
entretanto, com elementos de interface não-lineares. A envoltória de ruína para este elemento é a de Mohr-Coulomb, capaz de reproduzir a abertura de fissuras e o seu deslizamento no plano. Em todos os casos o modelo numérico foi satisfatório, comparando-se com os resultados obtidos por outros pesquisadores. Lourenço (1994) ${ }^{2}$ apud Lourenço (1996) também detalha bem a utilização de elementos de interface nas estruturas de alvenaria.

Lourenço e Pina-Henriques (2006) discutem a capacidade dos métodos numéricos contínuos baseados na plasticidade e fissuração, destacando os mecanismos de transferência de cargas nos elementos de alvenaria e o padrão da ruína obtido no modelo numérico. Enfatizam que as condições de contorno e o arranjo do teste experimental afetam o ensaio de compressão uniaxial, principalmente no comportamento pós-pico, além de influenciar o valor da carga máxima e o comportamento do trecho descendente. Destacam ainda que a utilização da área elementar representativa - região simplificada para representar uma determinada estrutura - é apenas uma aproximação da geometria do modelo e que a resposta numérica não é real, e sim fenomenológica. Por isso, a exata comparação entre o modo de ruína experimental e numérico não é possível. Em particular, a localização de deformações, os efeitos devido às condições de contorno do espécime e os modos não simétricos de ruína não são capturados pela análise numérica. No trabalho desenvolvido pelos referidos autores, os modelos numéricos tridimensionais não são considerados por serem demasiadamente custosos.

Tzamtzi e Asteris (2003a) citam que os primeiros modelos numéricos desenvolvidos para a alvenaria datam as décadas de 1960 e 1970, apresentados por Rosenhaupt e Sokal $(1965)^{3}$ e Saw $(1974)^{4}$, aperfeiçoando-se nas décadas seguintes, com a inclusão de modelos de falha. Os autores apresentam também uma completa revisão dos diversos métodos e modelos em elementos finitos já desenvolvidos.

Page (1978) já considerava o comportamento não-linear da alvenaria, discretizando as unidades e juntas de argamassa da estrutura. Análises não-lineares com a possibilidade de representação de ruína progressiva considerando-se o meio contínuo, segundo a média das propriedades dos materiais e modelos lineares considerando a junta e as unidades separadamente, foram desenvolvidos por Dhanasekar, Page e Kleeman (1984).

\footnotetext{
${ }^{2}$ LOURENÇO, P.B. (1994). Analysis of masonry structures with interface elements: Theory and applications. Report 03-21-22-0-01, Delft University of Technology, Delft, The Netherlands.

${ }^{3}$ ROSENHAUPT, S.; SOKAL, Y. (1965). Masonry walls on continuous beams, Journal of Structural Division, ASCE. v. 91, pp. 155-71.

${ }^{4}$ SAW, C.B. (1974). Linear elastic finite element analysis of masonry walls on beams, Building Science. v. 9 , pp. 299-307.
} 
O critério de ruína de Mohr-Coulomb - modificado para levar em conta a dependência não-linear da resistência ao cisalhamento na tensão normal em altos níveis de compressão - foi empregado com sucesso por Andreaus (1996). O autor utilizou um código computacional em elementos finitos para realizar análise plana e os resultados foram validados por meio da comparação com resultados experimentais, confrontando a capacidade de carga, os modos de ruína e as combinações de tensões.

O regime elástico linear foi ainda abordado por Hamid e Chukwunenye (1986), que realizam análises tridimensionais com elementos finitos utilizando o pacote computacional ANSYS. Essa pesquisa objetivou estudar o comportamento de prismas de alvenaria de blocos vazados de concreto antes da fissuração e os efeitos de distintos parâmetros, como por exemplo, a variação da disposição da argamassa. Ganesan e Ramamurthy (1992) também avaliam o comportamento de prismas de blocos vazados de concreto utilizando elementos finitos tridimensionais no regime linear. Cheema e Klingner (1986), por meio de análise numérica com elementos finitos, prevêem a capacidade e os mecanismos de ruína de prismas de blocos de concreto submetidos à compressão axial. Um modelo mais simples, utilizando elementos de membrana para discretizar o bloco em uma análise elástica-linear é proposto por Ganesan, Kalayanasundaram e Ambalavanan (1990) para análise de paredes de alvenaria. Os elementos (estado plano de tensões) podem ser retangulares ou quadrilaterais, substituem os elementos tridimensionais - que geram modelos não práticos nem econômicos para propósitos de projeto - e fornecem resultados satisfatórios da distribuição de tensões alterando-se a geometria e condições de contorno.

Berto et al. (2005) realizaram análises numéricas tridimensionais e planas (considerando o EPT) com prismas de tijolos maciços. É observado que o modelo 2-D subestima a resistência à compressão dos prismas devido à ausência de tensões na direção ortogonal ao plano de análise, com a ruína ocorrendo por esmagamento da junta de argamassa. A implementação de uma formulação para considerar estas tensões no modelo 2-D é efetuada e o prisma passa a apresentar comportamento semelhante ao modelo 3-D, em que a ruína ocorre no centro do bloco intermediário. Estes resultados estão em concordância com os obtidos por Lourenço e Pina-Henriques (2006).

Um modelo não-linear em elementos finitos tridimensionais foi proposto por Tzamtzis e Asteris (2003b), considerando o tijolo maciço e a junta de argamassa separadamente, com a possibilidade de ruína local em cada um dos materiais. A influência da junta de argamassa também é considerada pela utilização de elementos de interface, levando- 
se em conta a não-linearidade dos materiais e descontinuidade da superfície de contato. A validação do modelo proposto é realizada comparando-se com modelos experimentais submetidos a carregamentos estáticos e dinâmicos.

Wawrzynek, Ciñcio e Fedorowicz (2006), com o intuito de realizar análise não-linear com degradação do material, adaptaram para a alvenaria o Modelo de Barcelona, já utilizado para o concreto. Este modelo é caracterizado por uma superfície de ruína que é uma extensão do modelo de Drucker-Prager com uma seção transversal não circular, função de escoamento não associativa e diferentes teorias para o endurecimento isotrópico não-linear, independentes no caso de tração e compressão. O modelo representa bem o comportamento da alvenaria submetida a cargas cíclicas, assim como fornece uma boa representação dos danos que ocorrem nos elementos.

Drobiec (2005) apresenta os resultados de um micro-modelo que utiliza a superfície de ruína de Willam-Warnke, tanto para a unidade quanto para a argamassa, e elementos de contato na junta de argamassa horizontal. O autor realiza extenso programa experimental, com ensaios uniaxiais para ambos os materiais e ensaios triaxiais com a argamassa, para obter as propriedades mecânicas do tijolo e da argamassa a serem implementadas no modelo numérico. A comparação com resultados experimentais mostra que os níveis de danificação em ambos os casos são próximos, contudo, o modelo numérico não é capaz de representar a força máxima do ensaio, pois, sua interrupção no trecho ascendente não evidencia qual a capacidade máxima do modelo numérico, superestimando ou subestimando os valores experimentais. Esse modelo foi extrapolado para a utilização de barras de aço horizontais na junta de argamassa por Drobiec (2006).

Em relação ao colapso numérico, quando não há convergência do processo de iteração, Souza (2004) enfatiza que muitas vezes não há nenhuma relação com o colapso real da estrutura. $\mathrm{O}$ autor recomenda uma interpretação cuidadosa da resposta obtida, por meio do diagrama carga-deslocamento de algum ponto notável da estrutura. Dessa forma, a partir do momento em que a estrutura atinge o seu pico de resistência, podem-se introduzir decréscimos de carregamento com o intuito de obtenção do trecho descendente desta curva. Por fim, indica que um diagrama carga-deslocamento que apresenta o amolecimento da estrutura está claramente relacionado ao colapso da estrutura. Se o trecho descendente do diagrama carga-deslocamento não é obtido, o sistema pode ter divergido antes de atingir a carga máxima e pode-se erroneamente ocorrer dedução precipitada da carga de colapso. 
Gomes (2001) realiza detalhada simulação numérica tridimensional com prismas de blocos vazados de concreto, considerando as propriedades mecânicas da interface entre a junta de argamassa e as unidades. As propriedades elásticas e plásticas foram obtidas a partir da análise experimental efetuada por Mohamad (1998) e Romagna (2000). O trabalho apresenta uma ampla discussão em relação ao valor adotado para o ângulo de atrito dos materiais, às relações entre os módulos de elasticidade do bloco e argamassa e sobre o tipo de assentamento da argamassa. Utilizou-se o modelo de Drucker-Prager com fisssuração dispersa, encontrando-se diferenças em forças máximas entre o modelo numérico e experimental de 5\%. Entretanto, como ocorre no trabalho de Drobiec (2005), o modelo numérico apresenta interrupção da curva tensão-deformação ainda no trecho ascendente, o que pode indicar falta de convergência e não que tenha sido atingido o estado limite último do conjunto. $\mathrm{O}$ autor destaca ainda que o modelo não é capaz de representar a ruptura por esmagamento da argamassa ou a combinação desta ruptura com o fendilhamento do bloco.

Um modelo elastoplástico não-linear em elementos finitos para alvenaria de unidades vazadas de concreto, utilizando-se elementos de casca isoparamétricos, é apresentado por Sayed-Ahmed e Shrive (1996a). O comportamento não-linear da alvenaria devido à fissuração progressiva e à não-linearidade geométrica são considerados pelo modelo. Realizam-se análises numéricas de prismas com três unidades de altura e os resultados em termos de tensão, deformação e deslocamento foram comparados com valores experimentais, apresentando boa concordância. A geração da malha é executada no programa ANSYS e o processamento dos sistemas de equações assim como o pós-processamento são executados no programa ABAQUS. Como critérios de ruína adotam-se o modelo de Drucker-Prager e o de fissura discreta, com elementos de interface entre o septo transversal e uma superfície rígida. Segundo os autores, a ruptura das paredes de alvenaria de unidades vazadas se inicia pela fissuração dos septos verticais no plano da parede. Concluem que a análise tridimensional é necessária para a previsão do estágio inicial de ruína, mas que não é capaz de representar o mecanismo de ruína completo para o caso em que a argamassa está disposta apenas nas paredes laterais. Já a análise com elementos de casca possibilita a rotação das paredes longitudinais dos blocos após a separação do septo transversal, aproximando o modo de ruína experimental. Utiliza-se também um elemento de casca que incorpora os modelos de fendilhamento dos septos, comportamento não-linear da argamassa e o início da instabilidade final da alvenaria fissurada. Assim, de acordo com os autores, o modelo tem condições de simular o comportamento da alvenaria vazada desde o aparecimento da primeira fissura até o instante próximo à ruptura total, incluindo o comportamento não-linear físico e geométrico. 
A robustez dos elementos disponíveis nos programas ANSYS e ABAQUS, mais especificamente sua capacidade em representar o comportamento da alvenaria, foi discutida por Peleteiro (2002). Considerou-se o modelo de materiais frágeis disponível no ANSYS, o qual considera a fissuração e o esmagamento, mas que não tem a capacidade de caracterizar o fenômeno do amolecimento. Em relação aos modelos disponíveis no ABAQUS, testaram-se o modelo elastoplástico clássico, que pode funcionar bem caso a não-linearidade ocorra devido ao esmagamento e não à fissuração, e o elastoplástico para o concreto, que considera a fissuração como aspecto importante, a qual é definida nos pontos de integração dos elementos. A autora conclui que o modelo fornecido pelo pacote computacional ABAQUS representa bem o comportamento não-linear da alvenaria de unidades maciças de concreto e que, apesar de ser um modelo específico para este tipo de material, é possível utilizá-lo para fazer uma análise satisfatória das estruturas em alvenaria. A fissuração, um aspecto muito importante na análise dessas estruturas, é representada coerentemente pelo modelo. Com base nos resultados de Juste (2001), realizam-se simulações numéricas com paredes de 800 x 800 mm. Utilizou-se o programa ABAQUS para as análises numéricas tridimensionais com elemento plano, de quatro nós, com três graus de liberdade por nó, o qual não apresentou resultado satisfatório. Essa limitação é justificada pela forma de ruína apresentada nas miniparedes, em que os septos laterais dos blocos se rompem. Assim, Peleteiro (2002) afirma que o modelo tridimensional torna-se mais representativo e, embora ele não consiga simular de forma exata o fenômeno de ruína, o comportamento é melhor captado quando comparado com o resultado obtido com o elemento plano. Nas simulações utilizando-se o modelo elastoplástico clássico e o modelo elastoplástico para o concreto, a autora obtém resultados satisfatórios, com o modelo numérico apresentando força de ruptura em relação aos resultados experimentais maior 18\% no modelo elastoplástico clássico e menor 15\% no elastoplástico para o concreto.

A mesma autora verificou ainda que com o ABAQUS foi possível estimar com suficiente precisão a força de ruptura experimental tanto com elemento plano quanto com elemento tridimensional. Já com o ANSYS, não se conseguiu atingir a força de ruptura experimental, obtendo-se um comportamento global bastante incoerente com deformações excessivas e irreais para a alvenaria, mesmo em um nível baixo de carregamento. A Figura 2.10 ilustra os gráficos tensão-deformação obtidos nas análises numérica e experimental. Nota-se que alguns destes não atingem o patamar de ruptura, o que não garante a máxima capacidade do modelo numérico e sim uma possível representação da ausência de convergência do sistema de equações. 


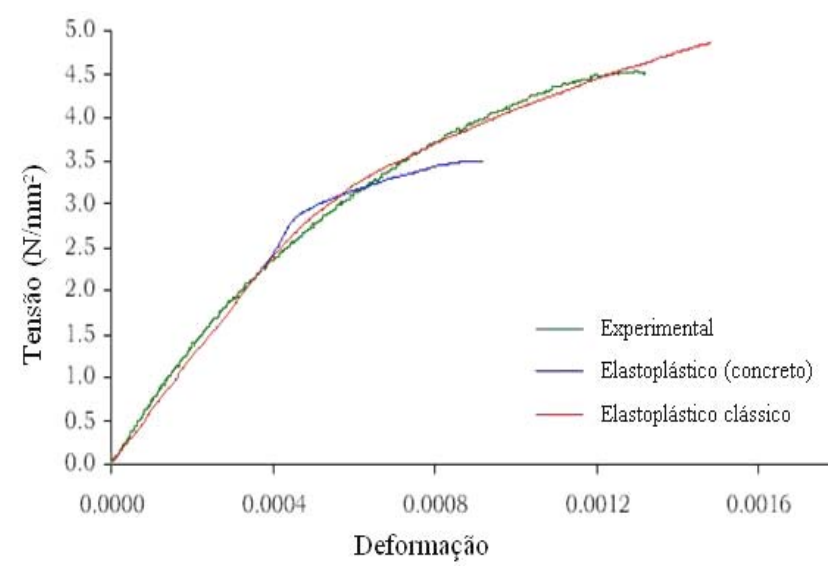

Figura 2.10 - Curvas tensão-deformação numéricas e experimental, adaptada de Peleteiro (2002).

Köksal et al. (2005) realizam análise numérica tridimensional não-linear com elementos finitos, abordando os materiais por meio dos modelos elastoplástico e de dano isotrópico. O objetivo da pesquisa é fornecer a melhor descrição para o comportamento último e o mecanismo de ruína dos prismas de blocos vazados de concreto submetidos à compressão. Utiliza-se o modelo de Drucker-Prager com os valores da coesão e do ângulo de atrito obtidos a partir de formulações disponíveis na literatura técnica, assim como os parâmetros para a consideração de dano dos materiais. Comparando-se os resultados obtidos por meio dos modelos numéricos, a partir do pacote computacional LUSAS, obtêm-se resultados satisfatórios em relação ao mecanismo de ruína e força máxima baseados em uma série de modelos experimentais. Paralelamente, apresenta-se uma relação analítica para a previsão da resistência dos prismas. Os autores defendem que uma avaliação realística da distribuição de tensões em blocos de concreto só pode ser alcançada por meio de análise nãolinear, crucial para a descrição do modo de ruína. Observa-se ainda que o modelo de dano isotrópico leva a padrões ideais do nível de tensões e deformações, sendo capaz de produzir o mecanismo de ruína.

Ressalta-se que a grande quantidade de pesquisas nessa área trata de alvenaria constituída por unidades maciças, sejam elas tijolos ou blocos de concreto ou cerâmico.

Freitas (2006) apresenta como objetivo geral de seu trabalho o estabelecimento numérico da curva tensão-deformação por meio de parâmetros obtidos experimentalmente para os seus componentes - unidades e argamassa, e, por conseqüência, da carga de ruptura para elementos não grauteados de alvenaria submetidos à compressão. $\mathrm{O}$ autor utiliza um procedimento numérico não-linear baseado na danificação dos materiais e validado pelos resultados experimentais obtidos. Por meio de modelos de materiais não-lineares, que 
contemplam a danificação do material alvenaria, ajusta curvas de tensão-deformação que possam exprimir o comportamento dos materiais envolvidos. Freitas et al. (2008) apresentam a simulação do comportamento de prismas baseado no comportamento dos blocos e juntas de argamassa com a utilização de um modelo numérico de dano não-local desenvolvido para os materiais quase-frágeis. Obtiveram-se diagramas tensão-deformação a partir dos resultados teóricos e experimentais coincidentes desde os estágios iniciais de cargas até a ruína completa dos prismas. A diferença máxima entre a capacidade de carga teórica e experimental é de $16 \%$.

Mohamad (2007) realiza simulações de prismas de blocos vazados de concreto no estado plano de tensões. O bloco e argamassa apresentam comportamento não-linear e estão conectados entre si pela interface, com não-linearidades devidas ao atrito e coesão entre as superfícies em que a fissuração ocorre quando a tração normal excede a resistência à tração do material, resultando em boa concordância com a tensão última obtida experimentalmente.

A partir das propriedades mecânicas dos materiais que constituem o bloco de concreto autoclavado e silico-calcário, obtidas em ensaios com corpos-de-prova, Graubohm et al. (2008) utilizam o programa DIANA para simular numericamente o comportamento dos respectivos prismas, comparando-os com os valores obtidos experimentalmente. As propriedades mecânicas da argamassa foram obtidas a partir de ensaios com corpo-de-prova cilíndricos padronizados e após o contato deste material com os blocos. O modelo considerando as propriedades mecânicas da argamassa após o contato com as unidades apresenta curva tensão-deformação próxima à obtida experimentalmente, tanto em relação à rigidez quanto à capacidade de carga, para ambos os tipos de blocos. Já se considerando o ensaio padronizado com argamassa obtém-se uma superestimativa tanto da rigidez quanto da capacidade de carga.

$\mathrm{Na}$ análise numérica realizada por Lourenço e Pina-Henriques (2006), considerandose o estado plano de tensões, a alvenaria deforma-se livremente para fora do plano, condição que geralmente é verdadeira na superfície do elemento. Já no estado plano de deformação, que é a condição limite no centro da espessura do espécime, tais deformações são impedidas. Devido aos campos fortemente não-homogêneos, principalmente quando encontradas grandes diferenças entre as propriedades mecânicas da unidade e da argamassa, ocorrem graves problemas de convergência. Observa-se ainda que, quanto maior a relação entre a resistência da unidade e a resistência da argamassa, maiores são as diferenças da forca máxima obtida 
nos modelos no EPT e EPD. Isso significa que na ausência de tensões na direção fora do plano, as argamassas mais fracas sofrem danos a cargas muito precoces.

As curvas numéricas obtidas demonstram rigidez muito maior que nos modelos reais pelo fato da rigidez da argamassa da junta apresentar valor diferente daquela que é moldada em corpos-de-prova para ensaio, a partir da qual são obtidos os dados experimentais. Além disso, a força de ruptura teórica geralmente é superestimada em relação ao valor experimental mesmo quando a deformação correspondente ao pico de resistência é próxima à obtida no ensaio. Por isso, realizou-se um ajuste por processo inverso da rigidez da argamassa que leva a melhores resultados sem considerar a possibilidade de ajuste da resistência, pois a relação direta entre a resistência e rigidez não foi estabelecida devido ao complexo caso de cura da argamassa, compactação e troca de umidade. Encontram-se valores muito próximos em relação à curva tensão-deformação, à deformação máxima e ao modo de ruína nos casos da abordagem no EPD e EPD modificado - estado intermediário entre o EPT e o EPD -, com redução da tensão vertical nas juntas horizontais próxima às juntas verticais como conseqüência da pequena rigidez da argamassa. Os autores concluem que a modelagem em elementos finitos contínuos na maioria das vezes superestima a resistência e a deformação na ruína dos prismas e que as distintas abordagens conduzem a diferentes resistências e diferentes modos de ruína.

Por fim, destacam-se as simulações numéricas realizadas por Pina-Henriques (2005) com modelos contínuos de prismas de alvenaria constituídos por tijolos maciços com distintas abordagens planas, utilizando o estado plano de tensões, o estado plano de deformações e um estado intermediário, próximo ao tridimensional. As principais conclusões acerca dos resultados, comparando-os com dados experimentais, são:

a) os modelos contínuos superestimam a resistência à compressão e deformação na ruína do prisma;

b) as distintas abordagens levam a diferentes mecanismos de ruína, fisicamente não realísticos, contudo numericamente correto, recomendando-se ainda a utilização de modelos similares ao estado intermediário ou tridimensionais;

c) devem ser estudados modelos alternativos para representar a microestrutura dos componentes de alvenaria a fim de se ter uma previsão confiável de sua resistência. Estes modelos devem se basear em um programa experimental mais avançado, que caracterize as propriedades mecânicas da argamassa na junta. 
$\mathrm{O}$ autor propõe ainda um modelo reticulado para representar a micro estrutura dos componentes de alvenaria e reproduzir adequadamente o comportamento desta sob compressão. Enfatiza-se que neste modelo ocorrem destacáveis vantagens em comparação ao modelo contínuo, que é baseado na plasticidade e fissuração, em relação à resistência à compressão e à deformação última.

O modelo de partículas tem como idéia central a discretização do contínuo em uma estrutura constituída por elementos de viga ou de treliça. Comumente, partículas triangulares, regulares ou aleatórias são adotadas e as duas dimensões ajustadas para que a rigidez elástica e o coeficiente de Poisson do conjunto completo de partículas representem o meio contínuo. Uma simulação é dividida em diversos passos de carga e em cada um são realizadas análises elásticas lineares. Ao final de cada passo de carga a lei de ruína adotada é avaliada e os elementos que não satisfazem tal critério são removidos da treliça (PINA-HENRIQUES e LOURENÇO, 2006). Esse modelo vem sendo muito utilizado na avaliação da propagação da fratura em ensaio de tração do concreto e estão bem detalhados por Schlangen $(1993)^{5}$, van Mier et al. (1995) ${ }^{6}$, Bazant and Planas (1998) ${ }^{7}$, Van Vliet (2000) ${ }^{8}$ e Wang (2002).

Diante do exposto, enfatiza-se a dificuldade que é proceder à simulação numérica de uma estrutura de alvenaria, seja pelo tipo de carregamento existente, pela complexidade do comportamento dos seus materiais em conjunto ou pela estratégia numérica a adotar. Sendo assim, a escolha do modelo e a sua abordagem em cada estudo depende do objetivo da análise e do grau de precisão necessário. Entretanto, é unânime a necessidade da adoção de modelos não-lineares quando se objetiva analisar a ruína, a redistribuição de tensões e seus estados limites últimos. Muitas vezes os modelos tridimensionais são imprescindíveis para o melhor entendimento do comportamento estrutural e é de extrema necessidade conseguir que o modelo represente a capacidade de carga em sua totalidade, incrementando-se os métodos de iteração e/ou convergência a fim de que estes não levem ao equívoco entre não convergência do sistema de equações e máxima capacidade resistente.

5 SCHLANGEN, E. (1993). Experimental and numerical analysis of fracture processes in concrete. Heron, v. 38 n. 2, pp. 1-117.

6 van MIER, J.G.M.; SCHLANGEN, E.; VERVUURT, A. (1995). Lattice type fracture models for concrete. In: Mühlhaus, H. (Ed.), Continuum Models for Materials with Microstructure, Wiley, New York, USA, pp. 34177.

7 BAZANT, Z.P.; PLANAS, J. (1998). Fracture and size effect in concrete and other quasi-brittle materials. CRC Press, Boca Raton, USA.

8 van VLIET, M. (2000). Size effect in tensile fracture of concrete and rock. PhD thesis, Delft University of Technology, Delft. 


\section{PROPRIEDADES MECÂNICAS DA ARGAMASSA PARA ALVENARIA ESTRUTURAL}

A argamassa, apesar de corresponder a uma pequena parcela do volume de uma estrutura de alvenaria, influencia diretamente a resistência, a deformabilidade e o modo de ruína deste tipo de estrutura. De acordo com Beningfield (1986), as propriedades efetivas da argamassa são muitas vezes relegadas a um segundo plano ou simplesmente omitidas. Como funções primordiais deste material, na forma de junta horizontal, destacam-se a solidarização das unidades, a transmissão de esforços axiais e a resistência aos esforços laterais.

A qualidade de uma alvenaria depende da qualidade da argamassa, contudo não há uma determinada composição de argamassa que seja boa para todos os tipos de alvenaria (WAKEFIELD, 1996). A relação entre as propriedades mecânicas da argamassa com a resistência e o comportamento das estruturas de alvenaria é notória, necessitando-se de uma adequada caracterização desse material para de entender o complexo comportamento da alvenaria estrutural e ponderar seus fatores intervenientes.

O comportamento eficiente da alvenaria depende de algumas propriedades da argamassa de assentamento, tais como:

a) resistência suficiente, compatível com a resistência das unidades de alvenaria;

b) aderência satisfatória aos blocos, permitindo à zona de interface resistir aos esforços de cisalhamento e de tração;

c) resiliência adequada com baixo módulo de deformação, podendo assim, acomodar sem fissurar tanto as deformações intrínsecas quanto as provocadas por pequenos movimentos estruturais na alvenaria. 
Para facilitar a preparação da argamassa e melhorar a sua trabalhabilidade, muitas vezes a quantidade da água de amassamento utilizada é maior do que a quantidade necessária à hidratação do cimento. No entanto, na caracterização das propriedades mecânicas das argamassas, na tentativa de se ter um maior domínio sobre as variabilidades a que o material está sujeito, depara-se com a sua desconformidade no estado endurecido, na forma de junta, e as obtidas em corpos-de-prova obtidos a partir de ensaios normalizados. Sucintamente, tem-se que:

a) a argamassa de assentamento influi na fissuração do bloco e aumenta, portanto, a sua deformabilidade;

b) o bloco introduz tensões de confinamento na argamassa de assentamento e, portanto, torna-a menos deformável que a mesma argamassa moldada no corpo-de-prova;

c) os materiais dos blocos são porosos e tendem a absorver água da argamassa de assentamento, o que pode alterar a resistência dessa argamassa (comparada com a resistência obtida em ensaios com corpos-de-prova padronizados);

d) as condições de cura dos blocos, prismas e das paredes nem sempre são ideais, dada a grande superfície exposta e a inconveniência de aplicação de água sobre as paredes, mesmo em laboratório.

Portanto, os ensaios padronizados para a determinação das principais propriedades da argamassa no estado endurecido não representam as propriedades mecânicas efetivas resultantes na junta de assentamento. A maneira como a argamassa está disposta quando na forma de junta leva à influência de dois fenômenos que induzem à mudança de seu comportamento: a perda de água para as unidades durante o processo de cura e o efeito de confinamento devido à sua geometria. Estes fenômenos parecem melhorar o desempenho da argamassa quando está submetida à compressão axial, com o aumento de sua resistência (BARBOSA e HANAI, 2008a).

O estado triaxial da argamassa só pode ser bem representado em uma análise, como por exemplo, em modelos matemáticos, se as propriedades multiaxiais constituintes da argamassa e unidades forem conhecidas. Torna-se também indispensável a quantificação do fenômeno de transporte e sua influência nas características da argamassa.

Ressalta-se ainda uma região de comportamento complexo e importante na alvenaria: a interface. Ela representa uma área de adesão diferenciada, localizada entre a unidade e a junta de argamassa, a partir da qual se desenvolvem os modos de ruptura geralmente observados na alvenaria. Essa interface está sujeita à danificação causada por retração e 
deformação devida à variação de temperatura, diferente no bloco e na argamassa. Além disso, a hidratação da argamassa é diferenciada no centro da junta e na interface, decorrente da sucção de água por parte do substrato.

Neste capítulo discutem-se os fenômenos que influenciam o comportamento da argamassa, apresentando os principais resultados encontrados na literatura. Paralelamente, apresenta-se um programa experimental no qual se procura destacar a influência dos efeitos da secagem e do confinamento separadamente, de modo a disponibilizar indicativos da variação quantitativa das propriedades físicas e mecânicas da argamassa de assentamento.

\subsection{Comportamento sob compressão triaxial}

Na Mecânica das Rochas e na Mecânica dos Solos, diversos tipos de análise consideram a superposição da compressão axial com a pressão de confinamento lateral para representar um estado de tensão padrão para os respectivos materiais. As juntas de argamassa da alvenaria submetidas à compressão também estão sujeitas a um estado de tensão semelhante, que não reflete as condições a que estão submetidos os corpos-de-prova nos ensaios uniaxiais para determinação da resistência à compressão e módulo de elasticidade do material. Ainda assim, as análises que levam em conta tal fenômeno são limitadas à obtenção de dados experimentais, verificando-se apenas casos específicos de carregamento.

Litewka e Szojda (2005) entendem que são ainda necessários detalhados estudos experimentais para a obtenção teórica mais realística da resposta do material submetido à compressão triaxial. Os autores realizaram um programa experimental para determinar os valores do módulo de elasticidade inicial, coeficiente de Poisson e resistência do material em dois distintos esquemas de testes triaxiais. Em ambos os casos, o estágio I de carregamento corresponde ao aumento monotônico da pressão hidrostática até o valor ' $p$ '. A tensão vertical $\sigma_{\mathrm{v}}$, no estágio II, no esquema de teste A, é elevada até a ruína do material; no esquema de teste $\mathrm{B}$, duas componentes horizontais $\sigma_{\mathrm{h}}$ são aumentadas simultaneamente até a ruína do material. Essa nova metodologia de ensaio foi proposta pelos autores a fim de se obter um melhor detalhamento sobre a resposta do material, contudo, para sua aplicação é necessário um método especial de compensação para o efeito da pressão hidrostática que afeta diretamente os extensômetros de resistência colados aos corpos-de-prova. Realizaram-se também ensaios com corpos-de-prova cilíndricos extraídos de tijolos. Modelos teóricos baseados na Mecânica do Dano Contínuo possibilitaram a descrição do modelo experimental e a determinação das propriedades mecânicas dos materiais. Dessa forma, os autores 
consideram que a técnica experimental adotada e o modelo fenomenológico utilizado apresentam precisão suficiente para obtenção das informações necessárias e entendimento do fenômeno observado nos ensaios triaxiais com materiais frágeis.

A partir desses dados obtidos experimentalmente, Litewka e Szojda (2006) determinam a envoltória de ruína da argamassa e do tijolo, utilizando-as numa posterior análise matemática de uma parede. O modelo numérico foi validado pela comparação com os resultados experimentais obtidos por Drobiec et al. (2000) ${ }^{1}$, que estão apresentados na Figura 3.1 .

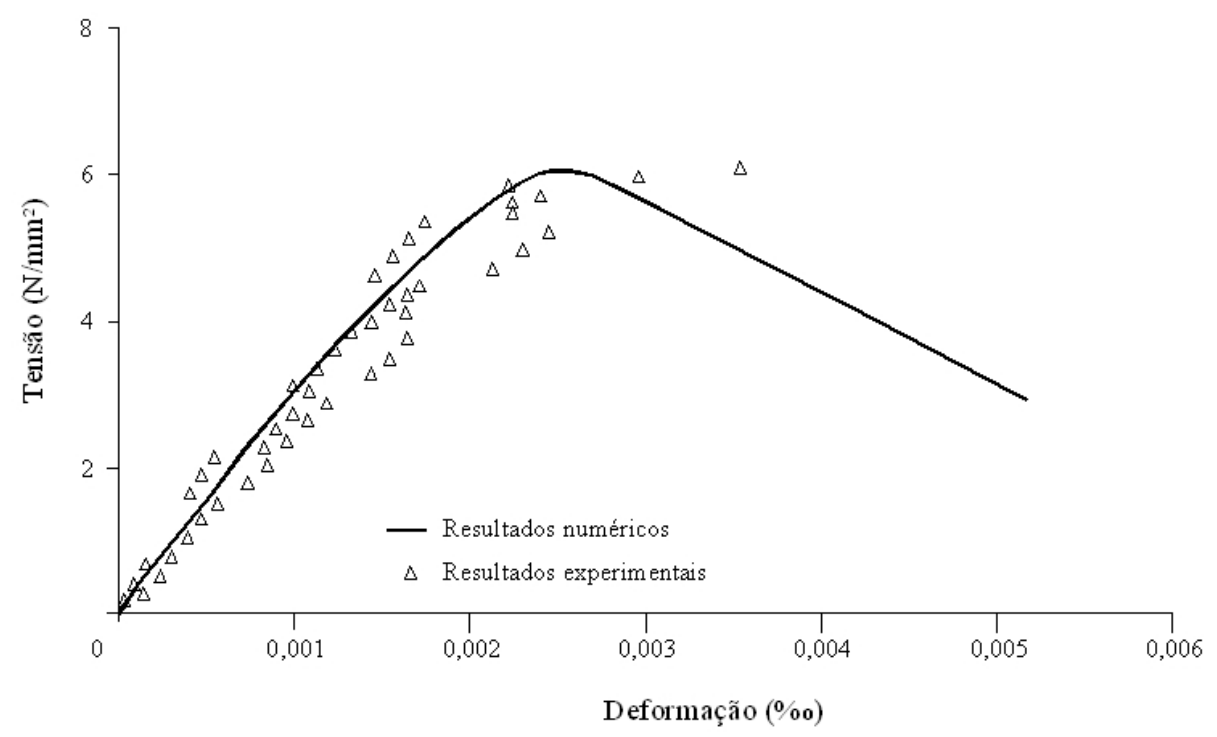

Figura 3.1 - Curvas tensão-deformação numérica e experimental obtidas na análise de paredes de tijolos maciços, adaptada de Litewka e Szojda (2006).

Não só a argamassa está sujeita ao estado triaxial de tensões na alvenaria, já que quando grauteadas o material inerte também fica sujeito a este fenômeno. A fim de melhor caracterizar o graute utilizado neste tipo de estrutura, Guo e Drysdale (1995) desenvolveram ensaios triaxiais utilizando cinco níveis diferentes de tensão lateral de confinamento. $\mathrm{O}$ método de ensaio consiste na aplicação, em primeiro lugar, da tensão lateral $\left(3 \mathrm{~N} / \mathrm{mm}^{2}, 7\right.$ $\mathrm{N} / \mathrm{mm}^{2}, 10 \mathrm{~N} / \mathrm{mm}^{2}$ ou $14 \mathrm{~N} / \mathrm{mm}^{2}$ ) até o nível desejado e, em seguida, na aplicação da força vertical. Identificou-se um aumento na resistência à compressão em comparação com o ensaio uniaxial próximo a 4,5 vezes. Obteve-se ainda aumento da ductilidade do material. Os autores enfatizam que a melhora no comportamento dos materiais depende da relação entre a

\footnotetext{
${ }^{1}$ DROBIEC, L.; JASINSKI, R.; KUBICA, J. (2000). Preliminary study of various methods of repair of cracked masonry walls subjected to compression. Final report BK-259/RB-2/97. Silesian University of Technology, Faculty of Civil Engineering, Departament of Structures, Gliwice, Poland. (in Polish).
} 
resistência à compressão do material no ensaio uniaxial e a tensão de confinamento, e não unicamente da tensão lateral.

Bierwirth, Stöckl e Kupfer (1993) propõem a extração de partes da junta da argamassa para a realização dos ensaios triaxiais, mas alertam que a melhor avaliação da resistência uniaxial desses exemplares deve desconsiderar o efeito da restrição ocasionada pelo atrito das placas. Detalhado programa experimental foi realizado com quatro tipos de argamassa sob quatro níveis distintos de tensões de confinamento, segundo a relação $\sigma_{\mathrm{h}} / \sigma_{\mathrm{v}} \mathrm{e}$ com valores iguais a $0,0,05,0,1$ e 0,3. Observou-se o aumento da resistência à compressão e da deformação vertical na ruína em torno de seis vezes no nível mais alto de confinamento, acompanhado da mudança de inclinação do trecho descendente da curva, que se torna mais horizontal com o aumento das relações $\sigma_{h} / \sigma_{v}$, conforme ilustrado na Figura 3.2.

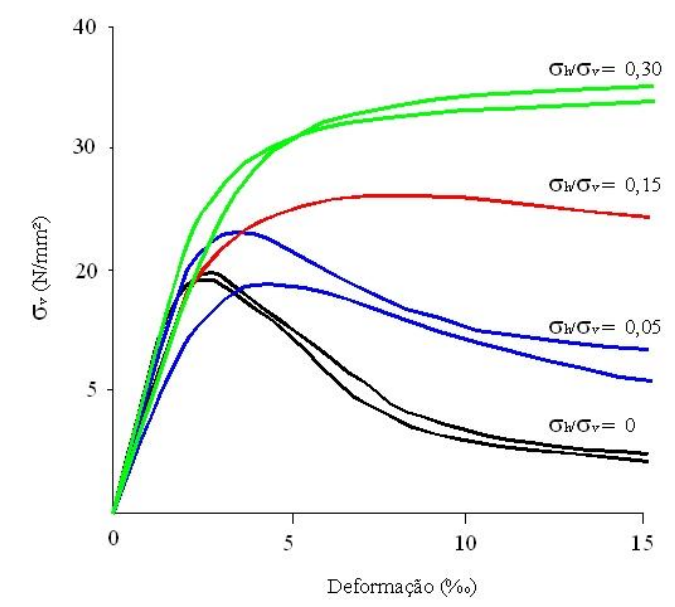

(a)

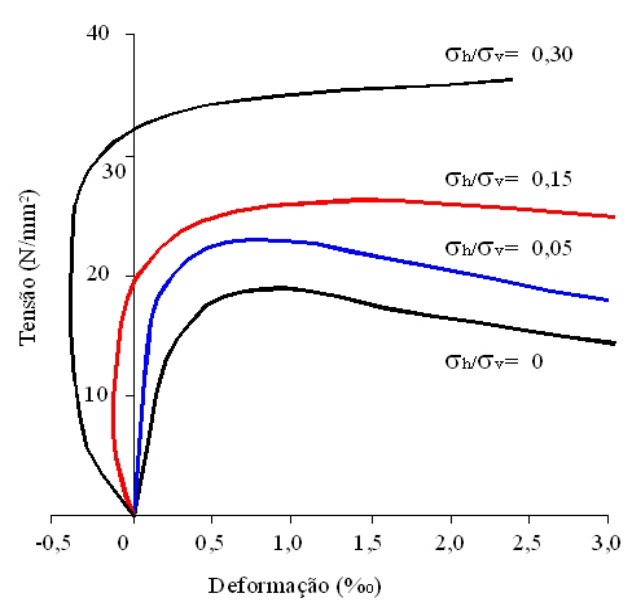

(b)

Figura 3.2 - Curvas tensão-deformação longitudinal (a) e lateral (b) da argamassa em distintos níveis de tensão lateral, adaptada de Bierwirth, Stöckl e Kupfer (1993).

Os autores enfatizam ainda que a formulação para a determinação do $E$ e do $v$ nos ensaios multiaxiais é um pouco mais complexa, pois as deformações em todas as direções de carga são influenciadas por suas direções perpendiculares, conforme é apresentado nas Equações (3.1) e (3.2).

$$
\begin{gathered}
E=\frac{1}{\varepsilon_{1}}\left(\sigma_{1}-2 \sigma_{\mathrm{r}}\right) \\
v=\frac{\varepsilon_{1} \sigma_{\mathrm{r}}-\varepsilon_{\mathrm{r}} \sigma_{1}}{\varepsilon_{1} \sigma_{\mathrm{r}}+\varepsilon_{1} \sigma_{\mathrm{r}}-2 \varepsilon_{\mathrm{r}} \sigma_{\mathrm{r}}}
\end{gathered}
$$

O índice "l" refere-se ao sentido longitudinal e o índice o índice "r" ao sentido radial. 
O comportamento do material sob estado de compressão triaxial, considerando-se um material homogêneo e isotrópico, é representado pelo módulo do volume $\mathrm{K}$ e módulo de cisalhamento G que, para CP's cilíndricos sobre uma pressão lateral homogênea $\sigma_{2}=\sigma_{3}=\sigma_{\mathrm{r}}$ e tensão vertical $\sigma_{1}=\sigma_{\mathrm{v}}$, são definidos pelas Equações (3.3) e (3.4). O índice "v" indica o sentido vertical.

$$
\begin{gathered}
K=\frac{\sigma_{\mathrm{v}}+2 \sigma_{\mathrm{r}}}{3\left(\varepsilon_{\mathrm{v}}+2 \varepsilon_{\mathrm{r}}\right)} \\
\mathrm{G}=\frac{\sigma_{\mathrm{v}}-\sigma_{\mathrm{r}}}{2\left(\varepsilon_{\mathrm{v}}-\varepsilon_{\mathrm{r}}\right)}
\end{gathered}
$$

Os princípios do teste proposto por Bierwirth, Stöckl e Kupfer (1993) e o maior detalhamento do aparato utilizado no ensaio podem ser encontrados nos procedimentos da RILEM TC 127-MS (1998). Neste documento, uma série de recomendações para avaliar o comportamento triaxial da argamassa para alvenaria é apresentada, indicando, para a avaliação das propriedades mecânicas da argamassa, a geometria cilíndrica e a extração do CP da própria junta de argamassa como sendo o caso mais representativo. A altura do CP é determinada pela espessura da junta e seu diâmetro que, de forma geral, deve ser próximo a $30 \mathrm{~mm}$. A placa-escova é indicada para redução da restrição lateral nos ensaios. O procedimento de produção dos CP's apresenta moldagem da argamassa entre as unidades de alvenaria para que sejam considerados os efeitos da sucção, utilizando-se papel filtro na interface para facilitar a extração.

Stöckl, Beckhaus e Fritsche (1998) apresentam os valores obtidos para o módulo de elasticidade da argamassa sob compressão triaxial, variando-se a dimensão dos corpos-deprova e a disposição do instrumento de medição. Dispuseram-se extensômetros elétricos de resistência no centro da altura do corpo-de-prova e transdutores de deslocamento na máquina de ensaio. Moldaram-se corpos-de-prova cilíndricos em três geometrias: 30 x 12 mm, 30 x 20 mm e 30 x $58 \mathrm{~mm}$ (diâmetro x altura). Na série com o CP de 30 x $12 \mathrm{~mm}$ considerou-se ainda um grupo de amostras extraídas diretamente das juntas de argamassa. As curvas tensãodeformação foram corrigidas eliminando-se a deformação inicial ocasionada pelo equipamento de teste e placa-escova e a deformação do capeamaneto.

É observado que os resultados obtidos por meio dos transdutores, considerando-se a altura total dos elementos, apresentam valores entre $25 \%$ e $50 \%$ dos obtidos com extensômetros, situados na altura média do CP. Além disso, nota-se que com o aumento da 
altura do corpo-de-prova, o valor médio do módulo de elasticidade reduz de $9500 \mathrm{~N} / \mathrm{mm}^{2}$ para $8500 \mathrm{~N} / \mathrm{mm}^{2}$ com a medição efetuada por extensômetros e aumenta de $2470 \mathrm{~N} / \mathrm{mm}^{2}$ para 4300 $\mathrm{N} / \mathrm{mm}^{2}$ considerando-se o grupo com transdutores.

Os CP's extraídos da junta de argamassa, que estavam em contato com o bloco durante a cura, têm o valor do módulo de elasticidade incrementado, atingindo $14000 \mathrm{~N} / \mathrm{mm}^{2}$ e $5000 \mathrm{~N} / \mathrm{mm}^{2}$, respectivamente, para medição apenas na altura central e em toda a altura do CP. Essa tendência segue, obviamente, o aumento do valor da resistência à compressão devido à redução de sua altura. Particularmente para este grupo, identifica-se um alto índice de variabilidade dos resultados, devendo qualquer tipo de extrapolação ser realizada com cautela.

A variação do valor do módulo de elasticidade, segundo sua forma de obtenção, está relacionada com a distribuição das tensões nos corpos-de-prova e, evidentemente, influenciada pelas características geométricas do elemento. A distribuição de tensões nos corpos-de-prova, resultantes de uma análise elástica-linear, está apresentada na Figura 3.3 e os valores numéricos obtidos são apresentados na Tabela 3.1. Nestas simulações, considerou-se o módulo de elasticidade do material de $9000 \mathrm{~N} / \mathrm{mm}^{2}\left(\mathrm{E}_{\mathrm{a}}\right)$.

\begin{tabular}{cccc}
\multicolumn{4}{c}{ Tabela 3.1 - Variação do módulo de elasticidade em função } \\
da geometria do corpo-de-prova.
\end{tabular}




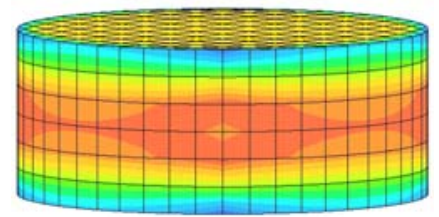

-18.2
-18.8
-19.4
-20
-20.6
-21.2
-21.8
-22.3
-22.9
-23.5
-2

(a)
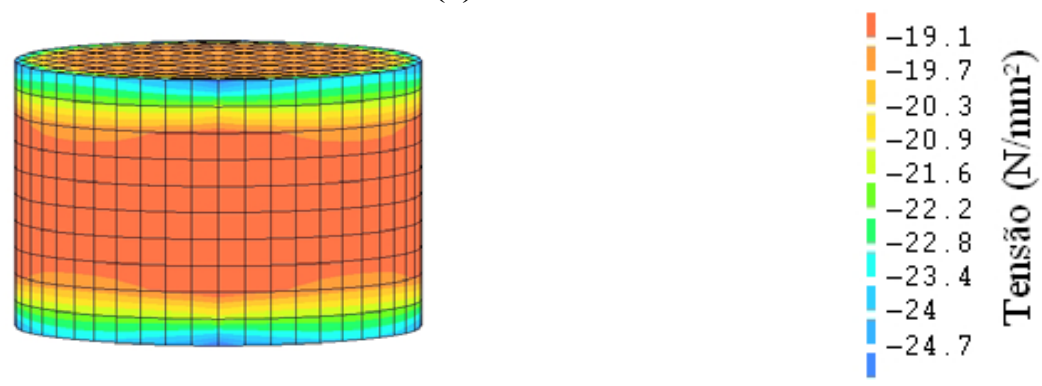

(b)
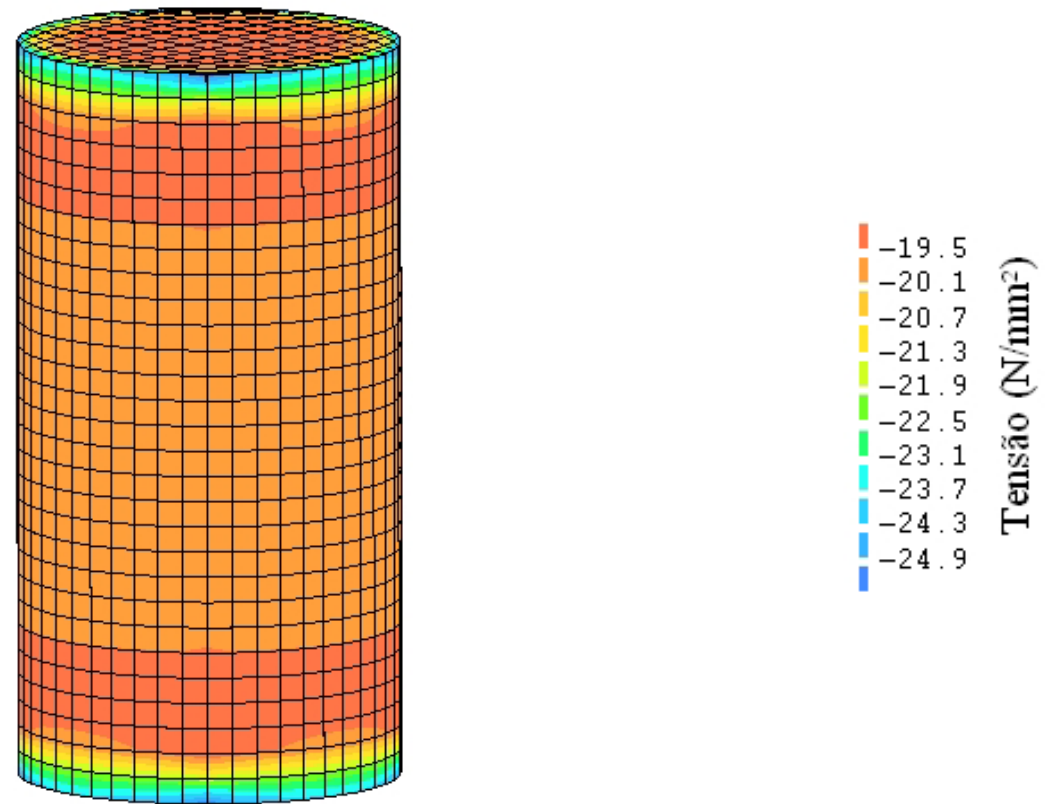

(c)

Figura 3.3 - Distribuição de tensões em corpos-de-prova com diferentes alturas: 30 x 12 mm (a), 30 x 20 mm (b) e 30 x 58 mm (c).

O comportamento interpretado por meio da análise teórica mostra que o aumento da altura de medição nos corpos-de-prova leva à obtenção de um menor valor do módulo de elasticidade, sendo a diferença entre valores mais significativa quanto menor é a altura do CP. Realizando-se a medida do módulo de elasticidade no centro dos CP's, identifica-se a redução do valor do módulo de elasticidade com o aumento da altura do elemento, em concordância 
com os resultados experimentais de Stöckl, Beckhaus e Fritsche (1998). Entretanto, praticamente não ocorre variação quando é considerada a base de medida como sendo a altura total do corpo-de-prova.

A partir do gráfico da Figura 3.4, pode-se ter uma previsão do comportamento do valor do módulo de elasticidade quando medido em um corpo-de-prova - usualmente realizada na altura média - e quando medido diretamente na junta de argamassa no elemento de alvenaria. Associando-se nesta análise os resultados do CP $30 \times 58 \mathrm{~mm}$ e do CP $30 \times 12$ $\mathrm{mm}$ respectivamente ao corpo-de-prova e à junta de argamassa, nota-se que o valor do módulo de elasticidade deste reduz-se, apesar do considerável aumento de sua resistência à compressão. Com o intuito de mensurar tal fenômeno, os autores realizam testes com prismas de cinco blocos, com as mesmas características dos quais foram extraídos os corpos-de-prova 30 x $12 \mathrm{~mm}$. A medição das deformações apenas na altura da junta de argamassa resultou em um módulo de elasticidade igual a $1200 \mathrm{~N} / \mathrm{mm}^{2}$, valor em torno de $28 \%$ do obtido nos ensaios com corpos-de-prova. Justifica-se essa redução pela existência de uma zona fraca de contato entre a argamassa da junta e a unidade que compõe o prisma, problema que existe apenas em parte dos exemplares extraídos. Portanto, quanto maior a base de medida das deformações maior foi o valor obtido para o módulo de elasticidade. Da mesma forma, maiores valores foram obtidos para os CP's extraídos da junta de argamassa em relação àqueles de mesma geometria e moldados de forma convencional.

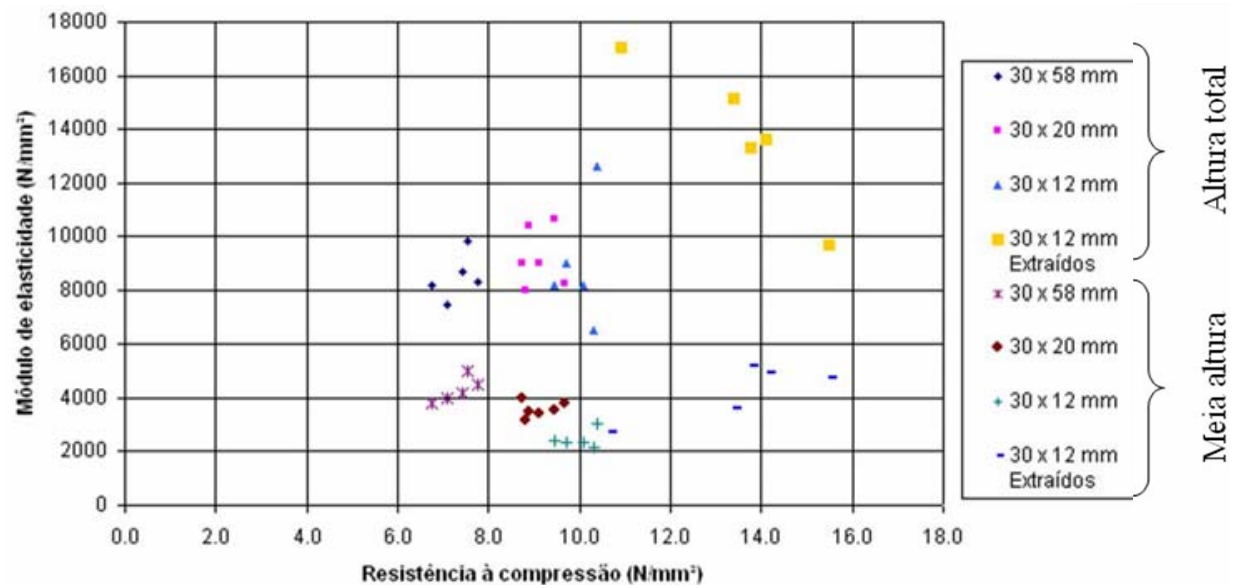

Figura 3.4 - Comparação entre os valores do módulo de elasticidade de um tipo de argamassa, variando-se as dimensões dos corpos-de-prova e a base de medida de instrumentação, adaptada de Stöckl, Beckhaus e Fritsche (1998).

Ainda em relação ao efeito de confinamento em argamassas, destacam-se duas pesquisas pioneiras, realizadas por Khoo (1972), com ensaios triaxiais em corpos-de-prova cilíndricos de 38 x $102 \mathrm{~mm}$, com argamassas de traço 1:0.25:3 e 1:1:6, e por McNary (1984), 
que utilizou quatro traços de argamassas em suas análises experimentais (1:0.25:3, 1:0.25:4.5, 1:1:6 e 1:2:9) e corpos-de-prova cilíndricos com 54 x $108 \mathrm{~mm}$. No Brasil, seguindo essa mesma linha, Mohamad (1998) realiza ensaios com argamassas submetidas à compressão triaxial com cilindros de 50 x $100 \mathrm{~mm}$ e com os mesmos traços utilizados por McNary (1984).

Nos três trabalhos supracitados obteve-se comportamento não-linear para todos os níveis de tensão de confinamento com distintas formas de ruptura. Caracterizou-se o comportamento como frágil na ausência de tensão lateral, sendo que com o incremento de carga lateral ocorreu uma sensível mudança para um comportamento mais dúctil. Identifica-se ainda a redução das deformações laterais e o aumento das deformações longitudinais com o aumento do nível da tensão de confinamento do ensaio. Foi possível a obtenção de uma envoltória de ruptura linear, que relaciona a resistência à compressão normal com o nível de pressão lateral.

Hayen et al. (2004) identificam dois tipos de ruína nas argamassas submetidas à compressão triaxial, sujeitas à tensão vertical $\sigma_{v}$ e à tensão radial $\sigma_{h}$. Quando $\sigma_{h} / \sigma_{v}<0,25$, a ruína resulta de mecanismos de cisalhamento, com decréscimo inicial de volume seguido pelo seu aumento. Quando $\sigma_{\mathrm{h}} / \sigma_{\mathrm{v}}>0,25$, o mecanismo de poro-colapso leva o material a uma ruína sob um constante decréscimo de volume.

Mohamad, Lourenço e Roman (2006) afirmam que o uso de um valor constante do coeficiente de Poisson não representa a mudança no volume do material devida às tensões de confinamento, sendo a forma de ruína dos prismas nos ensaios à compressão iniciada pela propagação de fissuras, que podem começar na argamassa, devido à alta porosidade e aos diferentes tamanhos de vazios encontrados. Conforme os autores, provavelmente, há um decréscimo no volume causado pelo fechamento de falhas e vazios; após isso, o coeficiente de Poisson aumenta significativamente até a ruína. $\mathrm{O}$ início da fissuração ocorre quando a coesão do material atinge um nível de tensão suficiente para quebrar a aderência intermolecular. Os autores propõem um modelo simples para representar a mudança no coeficiente de Poisson, por meio de tensões normalizadas baseada no fenômeno do poro-colapso, apresentado na Figura 3.5. O modelo, modificado a partir do proposto por Ottosen (1979) ${ }^{2}$, é regido por dois comportamentos distintos. Um decréscimo no coeficiente de Poisson pode ser observado até $\beta_{1}$ (relação entre tensão vertical e resistência à compressão) ser alcançado, seguido por um suave acréscimo até o colapso no caso "a". Neste caso, o mecanismo de ruína é desenvolvido

\footnotetext{
${ }^{2}$ OTTOSEN, N. S. (1979). Constitutive model for short-time loading of concrete. Journal of Engineering.
} Mechanics. v.105, n.2. pp.127-41. 
por cisalhamento. A mudança de comportamento no caso " $b$ " ocorre depois que o coeficiente de Poisson alcança o valor $\beta_{1}$, instante em que pode ser observado um aumento bastante repentino do valor do poro-colapso e perda de coesão dos grãos. Os autores enfatizam que o modelo depende das propriedades físicas, da porosidade e do teor de cimento da argamassa.

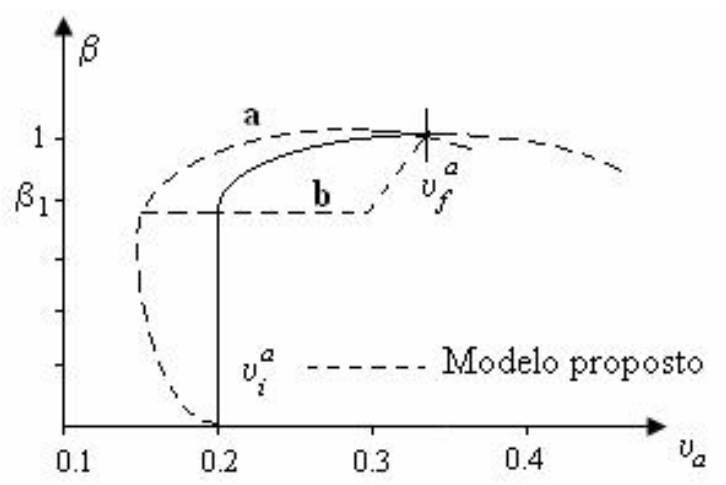

\section{Figura 3.5 - Representação do comportamento do coeficiente de Poisson da argamassa sob confinamento, adaptada de Mohamad, Lourenço e Roman (2006).}

Apresentam-se a seguir os resultados obtidos na análise experimental triaxial de argamassas juntamente com a comparação e discussão com alguns trabalhos realizados nesta linha: Khoo (1972), McNary (1984) e Mohamad (1998). O referido estado de tensão leva a uma mudança no comportamento do material podendo inclusive alterar a forma de ruína da alvenaria, do esmagamento da argamassa para a fissuração das unidades.

Para avaliar este efeito, CP's 50 x $100 \mathrm{~mm}$ de argamassa são submetidos à compressão triaxial em três níveis de confinamento - 1,5 N/mm², 3,0 N/mm² e 4,0 N/mm². Moldaram-se corpos-de-prova de argamassa constituídos por traços na proporção de cimento:cal:areia de 1:0,25:3 e 1:0,5:4,5. A desmoldagem realiza-se no dia seguinte à concretagem e os CP's são deixados sob condições de laboratório até o dia do ensaio. Para o traço 1:0,25:3 foram moldados corpos-de-prova em fôrmas de gesso a fim de avaliar a influência da perda de água que ocorre nas juntas de argamassa.

$\mathrm{Na}$ presente pesquisa, os ensaios com confinamento foram realizados na célula triaxial com máquina servo-hidráulica MTS 815 com capacidade total de $2700 \mathrm{kN}$, apresentada na Figura 3.6a. Utiliza-se o sistema de aquisição de dados System $\mathbf{5 0 0 0}$ ligado a um microcomputador e conectados à máquina de ensaios e instrumentos de medição. Os corpos-de-prova foram ensaiados sob taxas de carregamento de $0,5 \mathrm{kN} / \mathrm{s}$. A carga partiu do zero e seguiu até a ruptura, sendo a pressão de confinamento mantida em valores prédeterminados e constantes durante todo o ensaio. Utilizam-se dois extensômetros elétricos de 
resistência para obtenção das deformações longitudinais e dois para obtenção das deformações transversais.

O modo de ruína dos CP's ocorre por cisalhamento diagonal, conforme ilustração da Figura 3.6b.

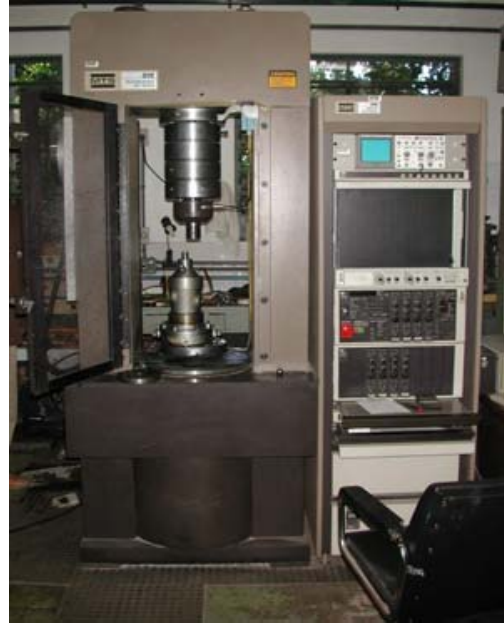

(a)

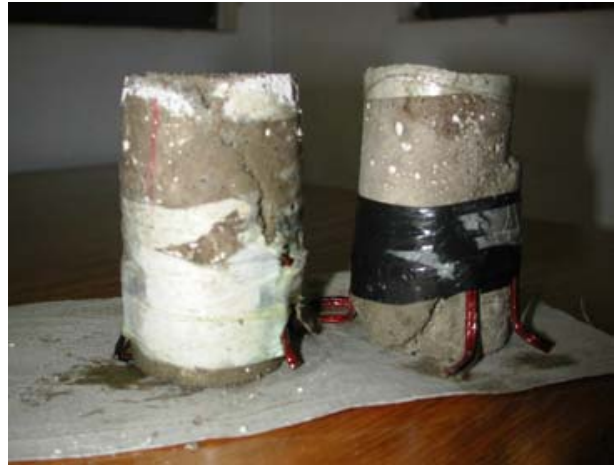

(b)

Figura 3.6 - Câmara triaxial (a) e forma de ruína dos corpos-de-prova (b).

Os resultados obtidos nas análises experimentais indicam que o aumento na tensão lateral produz um aumento na resistência à compressão do corpo-de-prova e nas deformações longitudinais últimas. As curvas apresentam trecho próximo a uma reta até $40 \%-60 \%$ da resistência à compressão, ocorrendo a partir deste ponto, como conseqüência das falhas de aderência na interface pasta-agregado, o início de uma maior microfissuração. Isso leva ao aumento das deformações com o surgimento de um trecho fortemente não-linear com significativa alteração de rigidez do material. Em virtude do comportamento fortemente nãolinear da argamassa no estado triaxial, os valores do módulo de elasticidade e do coeficiente de Poisson dependem do nível desse estado de tensões, mas também podem ser influenciados pela quantidade de cimento.

Identifica-se ainda que a deformação lateral decresce com o aumento da tensão de confinamento e em cada análise a envoltória da resistência última pode ser representada por uma linha (envoltória de Mohr-Coulomb).

Além da não-linearidade apresentada pelas curvas tensão-deformação, diferenças significativas entre os comportamentos podem ser destacadas, separando-as em três grupos: o frágil, o dúctil e o bilinear, dependendo do nível de confinamento e da resistência da argamassa. 
A Figura 3.7 apresenta as curvas tensão-deformação obtidas nos ensaios. Todas as curvas apresentam um comportamento claramente não-linear destacando-se o comportamento frágil na ausência de tensão lateral, o comportamento dúctil ao primeiro incremento de carga lateral e, com os posteriores aumentos de tensão lateral, a mudança para o comportamento bilinear. Destacam-se ainda, com o incremento da tensão lateral, o aumento das deformações longitudinais e a redução das deformações transversais na ruína. Um comportamento não esperado é identificado para o nível de tensão lateral de 3,5 N/mm². Esta curva apresenta maiores valores de deformação que os obtidos na argamassa sob tensão lateral 4,5 N/mm², para um mesmo nível de tensão.

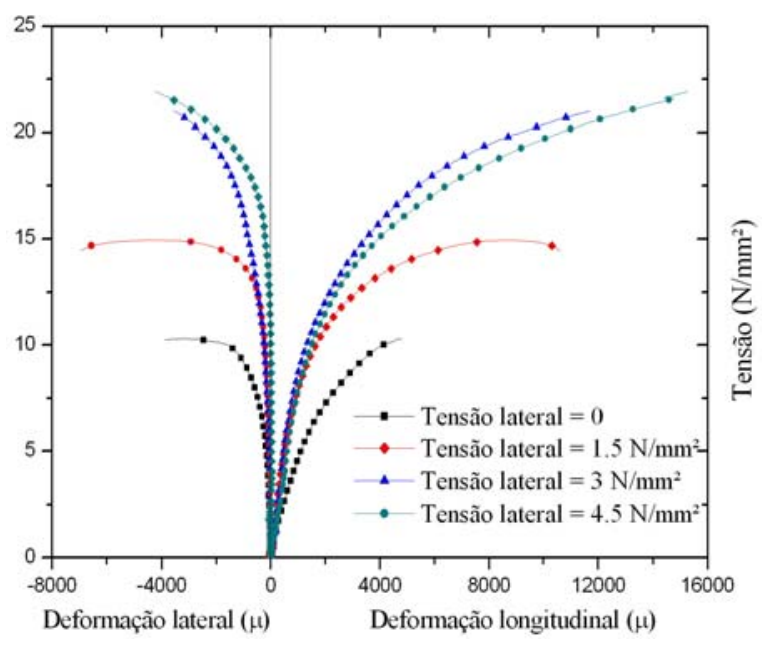
Figura 3.7 - Curvas tensão-deformação (longitudinal e lateral) das argamassas obtidas nos
ensaios à compressão triaxial.

As envoltórias de ruína para os ensaios citados anteriormente são ilustradas na Figura 3.8, sendo representadas por uma boa aproximação linear na maioria dos casos. Os menores valores de resistência à compressão apresentados na Figura 3.8a devem-se às idades mais baixas nas quais foram realizados os ensaios e a diferença entre a inclinação das curvas, em comparação com os demais casos, é atribuída às distintas características dos materiais que provavelmente modificam sua microestrutura. O comportamento sob confinamento é altamente dependente da porosidade e tamanho dos vazios. Dessa forma, a argamassa de traço 1:0,25:3, que teve seu processo de cura influenciado pela perda de água, tem também sua porosidade alterada e seu comportamento modificado em relação ao traço original. 


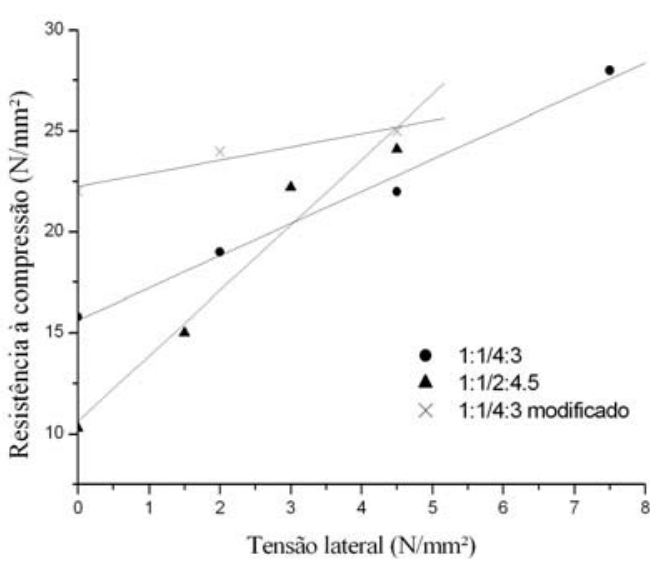

(a)

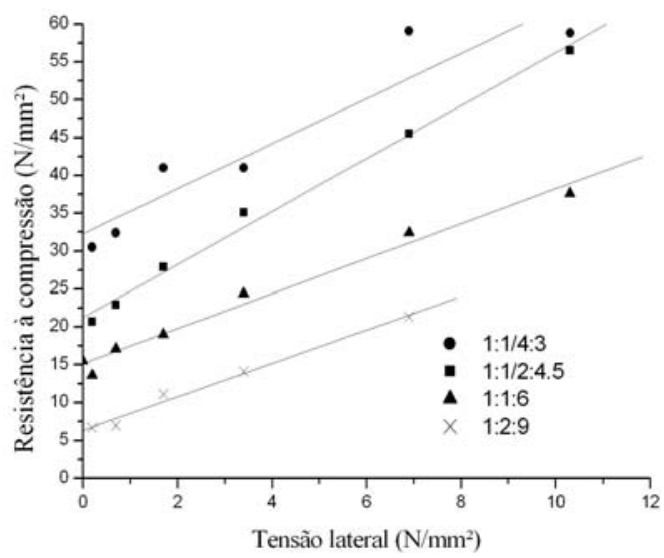

(c)

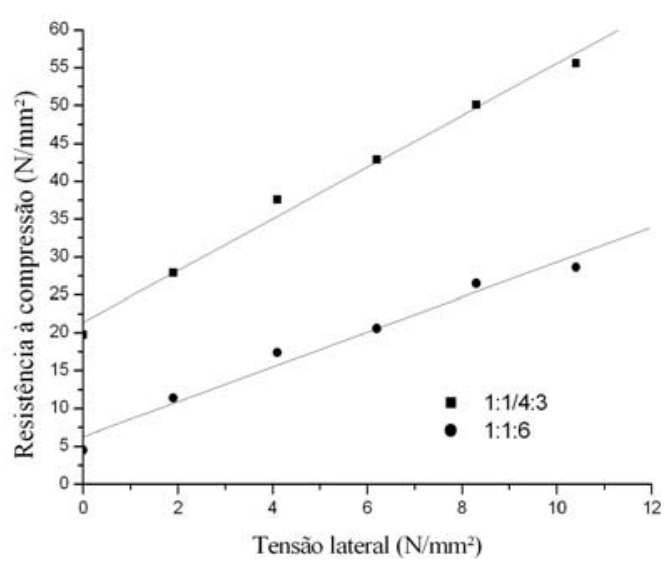

(b)

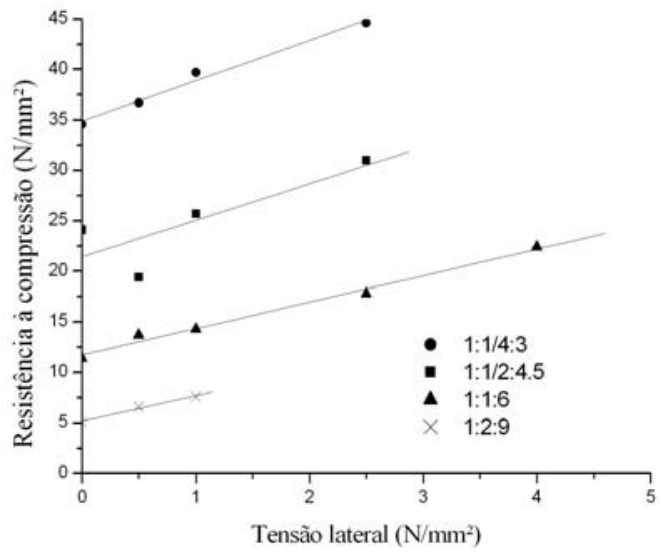

(d)

Figura 3.8 - Regressões obtidas a partir de ensaios triaxiais com argamassas. Presente pesquisa (a), Khoo (1972) (b), McNary (1984) (c) e Mohamad (1998) (d).

As equações que representam as envoltórias lineares de ruína para todos os ensaios e suas respectivas tensões laterais estão sumarizadas na Tabela 3.2.

Apesar das satisfatórias relações obtidas e apresentadas na Figura 3.8 e na Tabela 3.2, deve-se enfatizar que não foram consideradas as relações $\sigma_{1} / \sigma_{0}$ e $\sigma_{3} / \sigma_{0}$, sendo $\sigma_{0}$ a resistência à compressão axial, $\sigma_{1}$ a resistência à compressão triaxial e $\sigma_{3}$ a tensão de confinamento. O gráfico apresentado na Figura 3.9 considera simultaneamente a comparação dessas tensões para 63 ensaios triaxiais, variando-se o traço da argamassa e a tensão de confinamento, no qual se obteve uma boa aproximação polinomial de segunda ordem. 
Tabela 3.2 - Envoltórias de ruína para os distintos tipos de argamassa e condições de confinamento. Presente pesquisa (1), Khoo (1972) (2), McNary (1984) (3) e Mohamad (1998) (4).

\begin{tabular}{cccc}
\hline & Tensão lateral $\sigma_{3}\left(\mathrm{~N} / \mathrm{mm}^{2}\right)$ & Argamassa & Envoltória de ruína \\
\hline 1 & 2,$0 ; 4,5 ; 7,5$ & $1: 1 / 4: 3$ & $\sigma_{1}=\sigma_{0}+1.6 \sigma_{3}$ \\
1,$5 ; 3,0 ; 4,5$ & $1: 1 / 2: 4.5$ & $\sigma_{1}=\sigma_{0}+3.2 \sigma_{3}$ \\
2,$0 ; 4,5 ; 7,5$ & $1: 1 / 4: 3^{*}$ & $\sigma_{1}=\sigma_{0}+0.7 \sigma_{3}$ \\
& 1,$9 ; 4,1 ; 6,2 ; 8,3 ; 10,4$ & $1: 1 / 4: 3$ & $\sigma_{1}=\sigma_{0}+3.4 \sigma_{3}$ \\
& & $1: 1: 6$ & $\sigma_{1}=\sigma_{0}+2.3 \sigma_{3}$ \\
& & $1: 1 / 4: 3$ & $\sigma_{1}=\sigma_{0}+3 \sigma_{3}$ \\
& & $1: 1 / 2: 4.5$ & $\sigma_{1}=\sigma_{0}+3.5 \sigma_{3}$ \\
& & $1: 1: 6$ & $\sigma_{1}=\sigma_{0}+2.3 \sigma_{3}$ \\
& & $1: 2: 9$ & $\sigma_{1}=\sigma_{0}+2.2 \sigma_{3}$ \\
& & $1: 1 / 4: 3$ & $\sigma_{1}=\sigma_{0}+4 \sigma_{3}$ \\
& & $1: 1 / 2: 4.5$ & $\sigma_{1}=\sigma_{0}+3.6 \sigma_{3}$ \\
& & $1: 1: 6$ & $\sigma_{1}=\sigma_{0}+2.6 \sigma_{3}$ \\
& & $1: 2: 9$ & $\sigma_{1}=\sigma_{0}+2.5 \sigma_{3}$ \\
\hline
\end{tabular}

* Processo modificado de cura.

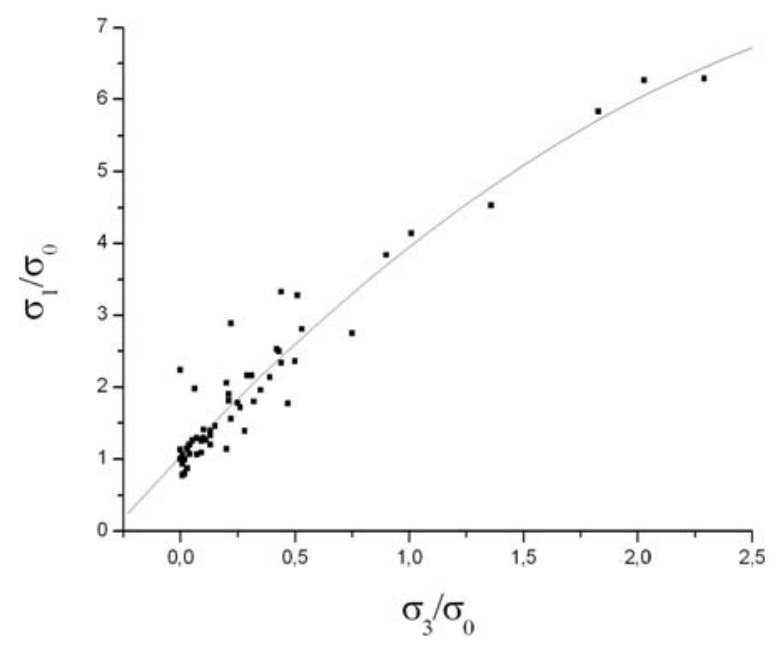

Figura 3.9 - Relações entre as tensões principais nos ensaios triaxiais com argamassas. 
De forma geral, não foi possível definir, com base nos dados experimentais analisados, a variação do módulo de elasticidade ${ }^{3}$ resultante do aumento da tensão lateral. Em relação aos traços mais fortes (Figura 3.10a), não há uma tendência bem definida para os dados obtidos na presente análise experimental e por Mohamad (1998), ocorrendo aumento do valor do módulo de elasticidade com o primeiro aumento de tensão lateral, seguido por um decréscimo decorrente do segundo incremento da tensão confinante. A aleatoriedade destes valores foi encontrada por Khoo (1972). Já McNary (1984) não identificou variação alguma com o aumento das tensões laterais. O decréscimo do valor com o aumento das tensões de confinamento pode ser atribuído à micro-fissuração do material durante o ensaio e ao tipo de instrumentação utilizada, em virtude do atrito entre a membrana que envolve o corpo-deprova e os extensômetros.

A Figura 3.10b, relativa aos traços mais fracos de argamassa, permite observar a tendência de decréscimo dos valores obtidos para o módulo de elasticidade com o aumento da tensão lateral nos experimentos de Khoo (1972) e Mohamad (1998), contrastando com os valores de McNary (1984). Em função da maior porosidade encontrada nas argamassas mais fracas, algumas fissuras podem surgir com a aplicação da tensão confinante, reduzindo a rigidez do corpo-de-prova.

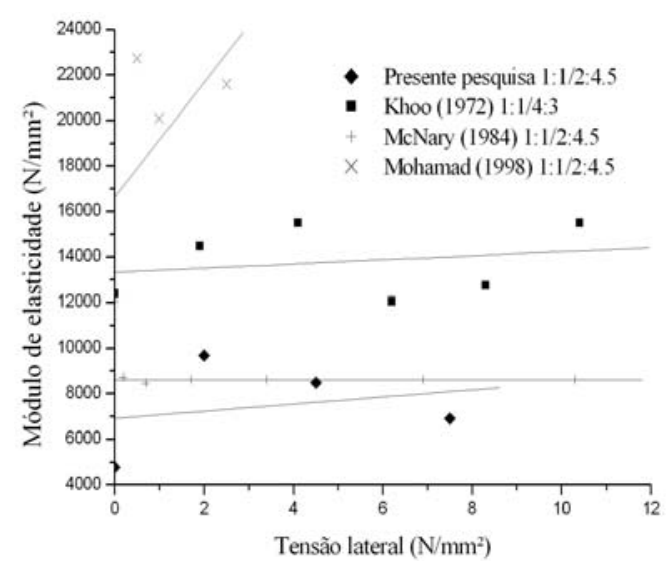

(a)

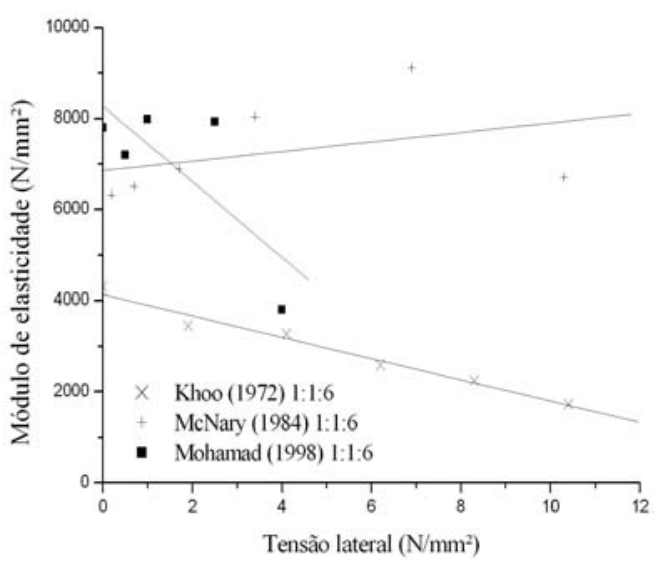

(b)

Figura 3.10 - Variação do valor do módulo de elasticidade obtido com o aumento da tensão lateral.

\footnotetext{
${ }^{3} \mathrm{O}$ módulo de elasticidade da argamassa não se altera com o aumento da tensão lateral nem qualquer outra solicitação. Este é um parâmetro fixo e intrínseco do material e o que ocorre é uma mudança na relação entre as tensões e deformações devidas à introdução de solicitações adicionais ao elemento. Contudo, essa expressão não conveniente é comum para relatar tal modificação.
} 
Observa-se uma tendência linear de decréscimo nos valores obtidos para o coeficiente de Poisson ${ }^{4}$ com o aumento das tensões laterais, com duas exceções: o traço de argamassa utilizado por McNary (1984) apresentou tendência de aumento e o traço mais fraco do programa experimental desenvolvido por Khoo (1972) apresentou decréscimo exponencial (Figura 3.11a). Na Figura 3.11b está representada a variação dos valores do coeficiente de Poisson para os traços de argamassa fortes de todos os programas experimentais.
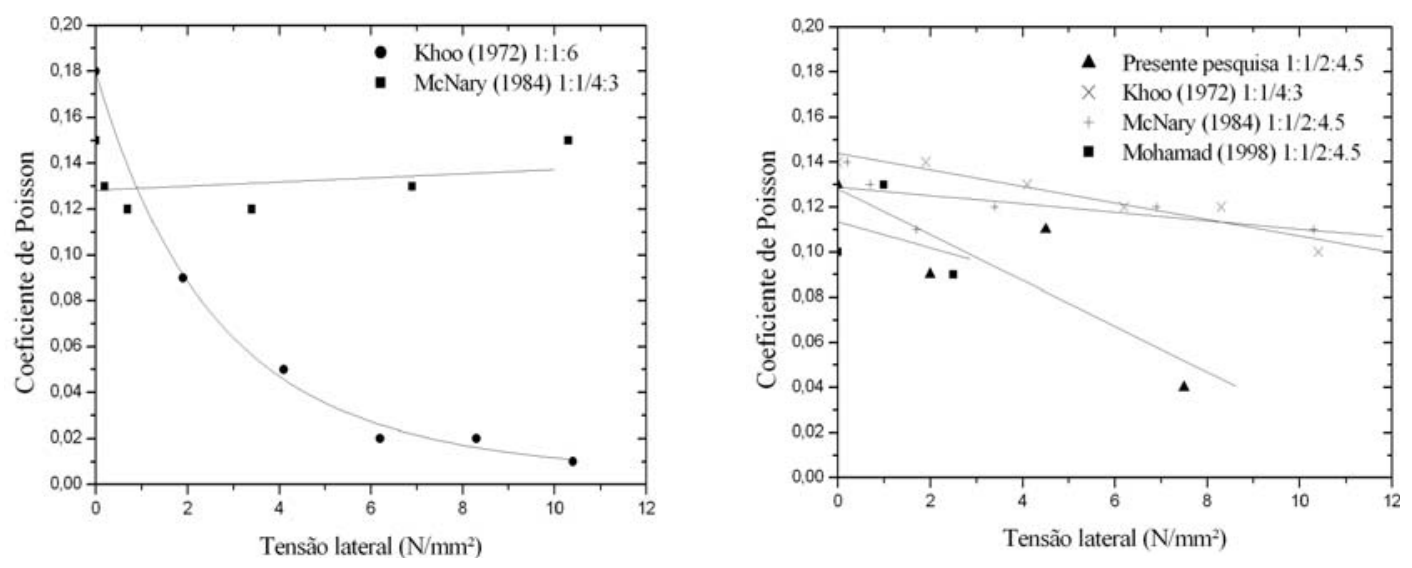

Figura 3.11 - Variação do valor do coeficiente de Poisson com o aumento da tensão lateral.

A Figura 3.12 apresenta a relação entre a deformação transversal e a deformação longitudinal dos corpos-de-prova de argamassa em quatro níveis de tensões laterais. Para os dois níveis mais altos de tensão de confinamento, a configuração da curva foi afetada pela deficiência na medição das deformações, conforme apresentam os gráficos da Figura 3.12b. Na Figura 3.12a, um valor constante da relação $\varepsilon_{\mathrm{t}} / \varepsilon_{1}$ é obtido no trecho inicial dos gráficos; posteriormente, quando se atinge um dado nível de tensão $\beta$ - relação entre a tensão vertical e a resistência à compressão, denominado de $\beta_{1}-$, observa-se um aumento destas relações até a ruína do corpo-de-prova. Essa mudança no comportamento do diagrama parece ser dependente do nível de tensão lateral: quando não há tensão confinante, $\beta_{1}$ é próximo a 0,5 e quando há tensão lateral de $1,5 \mathrm{~N} / \mathrm{mm}^{2}, \beta_{1}$ atingiu um valor próximo a 0,9 .

\footnotetext{
${ }^{4} \mathrm{O}$ mesmo raciocínio relativo à definição de "módulo de elasticidade" é válido em relação ao coeficiente de Poisson.
} 


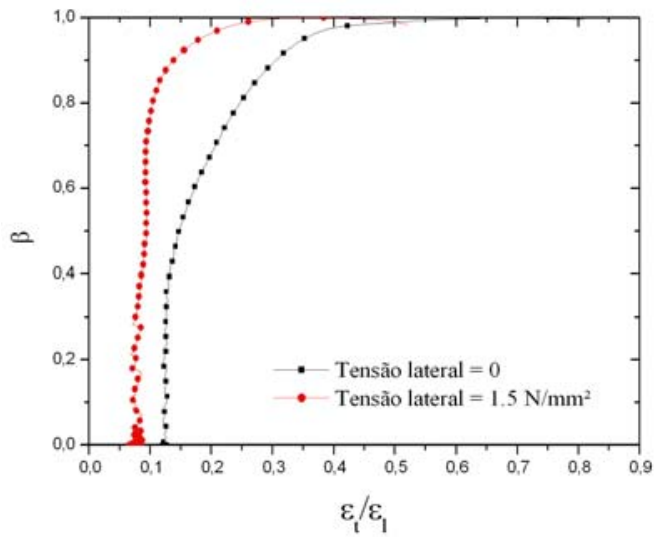

(a)

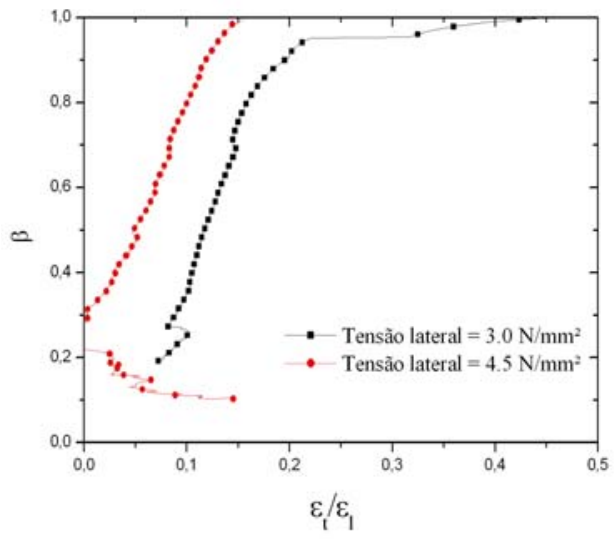

(b)

Figura 3.12 - Relação $\varepsilon_{\mathrm{t}} / \varepsilon_{1}$ durante o ensaio triaxial variando-se a tensão confinante.

\subsection{Perda de água da argamassa para as unidades de alvenaria}

As unidades de alvenaria tendem a absorver água da argamassa e do graute em decorrência da porosidade natural dos materiais que as constituem, como por exemplo, o concreto e a argila. Esse efeito tem magnitude dependente tanto das propriedades de absorção das unidades (disposição dos poros, da textura da unidade e do seu índice de absorção inicial) como das propriedades da argamassa no seu estado fresco (capacidade da retenção de água, dosagem e porcentagem de ar existente).

Portanto, algumas das características desejáveis à argamassa referem-se e dependem das características da unidade de alvenaria utilizada, não existindo parâmetros bem definidos para as propriedades da argamassa isoladamente.

A argamassa deve apresentar mínima capacidade de retenção de água quando em contato com os blocos, desconsiderando-se a perda por evaporação; caso contrário, um baixo índice de retenção de água pode ocasionar prejuízos ao assentamento. De acordo com Solórzano (1994), esse fenômeno de transporte pode ocasionar ainda a expansão do bloco, o que aumenta a possibilidade de posterior retração por secagem. Além disso, a aderência bloco-argamassa ficará prejudicada, com a argamassa apresentando maior módulo de deformação quando endurecida, o que resultará em menor capacidade de absorver deformações. Sathish, Ramamurthy e Ambalavanan (1998) destacam ainda que a capacidade de retenção, além de prevenir a saída de água da argamassa, evita o endurecimento anterior à colocação das unidades de alvenaria.

A perda de água da argamassa em seu estado fresco é destacada por diversos autores, sendo sugeridas muitas formas de quantificar esse fenômeno ou pelo menos incrementar 
conhecimentos, conforme relato dos trabalhos de Gallegos (1991), Ioppi et al. (1995), Casali (2003) e Casali et al. (2005).

Baseado no conhecimento de que as propriedades da argamassa moldada em fôrmas metálicas não são as mesmas daquela que estão entre as unidades de alvenaria, Bertram e Martens (2005) realizaram experimentos para analisar a interação entre a argamassa de alvenaria e os tijolos cerâmicos, observando que a densidade da argamassa influencia o processo de perda de água para as unidades.

Em relação à capacidade de retenção de água da argamassa, a cal tem um importante papel na composição de seu traço, aumentando essa capacidade e favorecendo a hidratação do cimento.

Segundo Rocha e Oliveira (1999), os componentes de alvenaria são submetidos a um processo de embebição inicial quando a argamassa de assentamento é disposta sobre eles, o que origina, posteriormente, diferentes intensidades de perda de água de amassamento da argamassa, gerando contração volumétrica. Observam ainda por meio de ensaios, em que foram utilizados cinco traços distintos de argamassas mistas e blocos com dois diferentes índices de absorção por capilaridade, que a resistência de aderência da argamassa aumenta com o aumento da capacidade de absorção capilar do bloco cerâmico.

Utilizando-se a porosimetria por intrusão de mercúrio em corpos-de-prova de dois traços distintos de argamassa, extraídos da interface e de uma região intermediária após assentamento em blocos de concreto e cerâmico, Paes, Bauer e Carasek (2005), observam que ao se retirar água da argamassa ocorre uma redução da relação água-cimento e conseqüentemente uma diminuição da dimensão dos poros. Relatam também que o tipo de substrato, com seu maior ou menor poder de sucção, juntamente com a porosidade das argamassas influem diretamente sobre a resistência de aderência da argamassa - de revestimento no caso desta pesquisa -, aumentando de $76 \%$ a $130 \%$ esta resistência nos blocos de concreto em relação às obtidas no caso de blocos cerâmicos. 
A sucção (ou velocidade inicial de absorção) expressa quanto os poros capilares (e não porosidade total) da face de assentamento da unidade absorvem água nos momentos iniciais em contato com a argamassa, contudo não representa a capacidade de absorção durante todo esse processo. Este parâmetro define ainda a capacidade de adesão entre a unidade e argamassa. Resumidamente, as etapas do processo que consolida a união mecânica entre a argamassa e as unidades de alvenaria são apresentadas a seguir, segundo Gallegos (1995):

- dependendo da estrutura de poros da unidade, esta absorve água da argamassa em pouco tempo após o contato dos materiais;

- ocorre transporte de materiais cimentícios pela água, os quais são introduzidos nos poros capilares da unidade;

- com a cristalização dos materiais cimentícios nestes poros, cria-se um "engrenamento" mecânico entre a argamassa e a unidade.

O autor afirma que em virtude do processo executivo da alvenaria, a água da argamassa, contendo os aglomerantes em dissolução, é absorvida primeiramente pela unidade inferior do conjunto bloco-argamassa; a unidade de cima absorverá menos água já que a argamassa encontrar-se-á mais seca. Dessa forma, justifica-se a ruptura na interface superior durante o ensaio de tração direta de um prisma.

Portanto, o processo de absorção das unidades sobre a argamassa além de alterar suas propriedades mecânicas, pode ocasionar modificação da tensão de adesão do conjunto, que dependerá também de outros fatores como a qualidade da mão-de-obra e a capacidade de retenção da argamassa.

Destaca-se a importância de sempre associar a sucção da unidade às características de retenção de água da argamassa ante a complexidade do fenômeno: a água absorvida pela unidade faz parte de um meio poroso inicialmente saturado que gradualmente torna-se mais seco ao mesmo tempo em que a unidade tem sua velocidade de sucção alterada pela absorção de água, variando-se o fluxo do transporte.

A quantidade de água perdida da argamassa pelo contato com unidades cerâmicas é apresentada na Figura 3.13. Estes resultados são provenientes dos ensaios realizados por Davidson (1961) e indicam que a partir do nível de sucção de $40 \mathrm{~g} / 200 \mathrm{~cm}^{2} / \mathrm{min}$ a taxa de perda de água da argamassa começa a decrescer. 


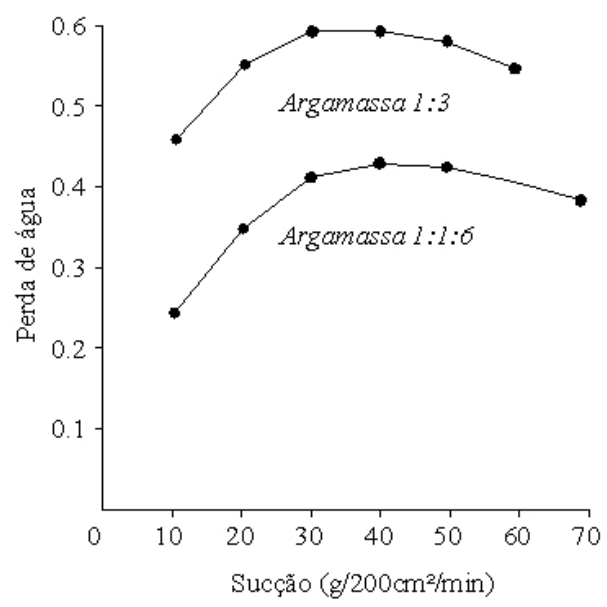

Figura 3.13 - Perda de água da argamassa quando em contato com unidade de argila diferentes valores de sucção inicial, Davidson (1961).

Geyer e Greven (1996) realizam análise em que o concreto é moldado em fôrmas com têxtil colocado como revestimento interno, permitindo a passagem da água contida no concreto e impedindo a saída das partículas finas. Os autores enfatizam que a quantidade de água necessária à completa hidratação do cimento no concreto é aproximadamente $30 \%$ do peso do cimento, sendo a quantidade de água excedente dispensável. Assim, justificam que a redução do fator a/c melhora a resistência do concreto, além de outras propriedades.

Por meio de ensaios de esclerometria, os autores observam que a face do concreto em contato com a fôrma drenante apresentou resistência à compressão média 2,4 vezes maior que o concreto em contato com a fôrma convencional. As faces em contato com a fôrma convencional apresentaram grau de absorção duas vezes maior que a face de concreto em contato com a fôrma drenante. Apesar desta pesquisa não considerar ensaios com argamassa, os resultados servem como parâmetros indicativos.

A influência da perda de água e a conseqüente alteração da resistência à aderência entre unidades e argamassa é tema de diversas pesquisas, principalmente por ser de grande relevância nas estruturas solicitadas à flexo-compressão. A fim de compreender esse fenômeno, alguns trabalhos utilizam a intrusão com mercúrio para avaliar a porosidade e microscopia da interface. Muitas das teorias e resultados obtidos sobre a perda de água buscam associar o fenômeno às mudanças na aderência (ver Page e Lawrence (1998), Lange et al. (1999) e Sarangapani et. al. (2002)). Todavia, eles podem ser adotados para o caso de estruturas submetidas unicamente à compressão axial. 
Segundo Jennings et al. (2000), este mecanismo, proveniente da interação dinâmica entre a junta de argamassa e a unidade, é de grande relevância e causa dois processos: a densificação e a desumidificação (Figura 3.14).

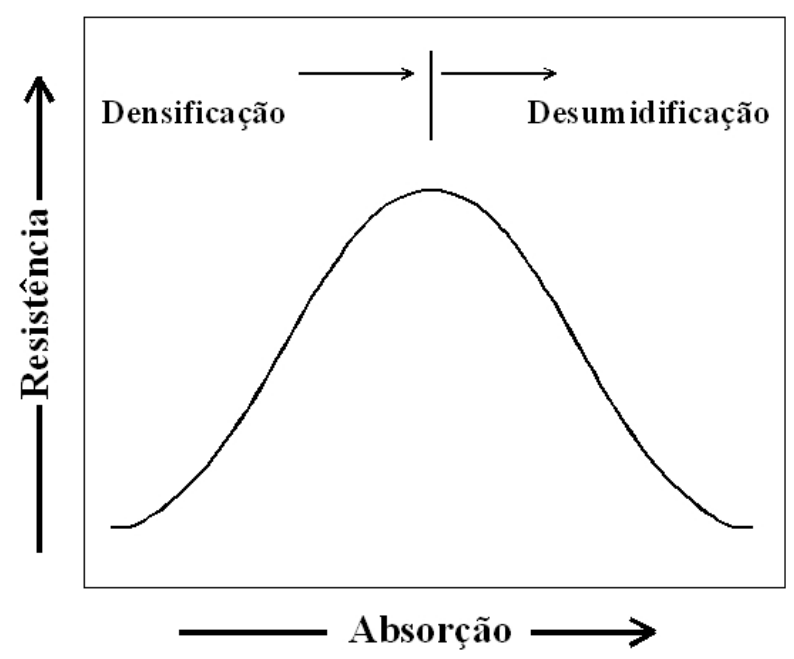

Figura 3.14 - Fenômeno de densificação e desumidificação, adaptada de Jennings et al. (2000).

A densificação representa a consolidação das fases sólidas da argamassa, com a redução dos vazios da microestrutura e a prevenção da perda de água em excesso que poderia criar uma zona fraca na interface. De maneira oposta, a desumidificação acarreta a perda da quantidade de água disponível para hidratação da argamassa, com a criação de vazios. O primeiro processo melhora a resistência de aderência devido à compactação da argamassa; já o segundo, reduz essa resistência devido às fragilidades resultantes da quantidade de vazios e à diminuição do grau de hidratação. A possível redução da resistência da argamassa também é citada por Sabbatini (1984), pois tanto a hidratação do cimento quanto a carbonatação da cal seria incompleta.

Jennings et al. (2000) ainda relatam o extenso programa experimental desenvolvido para determinar como as propriedades da argamassa e de tijolos cerâmicos afetam o mecanismo de transporte de água. Utilizaram-se três tipos de argamassa e tijolos, variando-se os materiais que a compõem e o índice de absorção, respectivamente, a fim de se analisar o grau de absorção, o grau de retenção de ar, o módulo de ruptura e a trabalhabilidade da argamassa. Dentre as diversas conclusões, os autores citam que:

a) a interação entre a unidade e a argamassa altera sua microestrutura e as propriedades de endurecimento;

b) existe um ponto ótimo de absorção que resulta em uma resistência máxima da argamassa; 
c) o índice de absorção do bloco, apesar de ser um importante parâmetro nestas análises, não descreve completamente o fenômeno da unidade em contato com a argamassa fresca.

Apresenta-se na Figura 3.15 o aumento do módulo de ruptura para três tipos de argamassas analisadas, denominadas PC (tipo I), PCL (tipo I) e MC (tipo S), compostas por cimento Portland, cimento Portland e cal hidratada e cimento para alvenaria, respectivamente. Para a determinação do módulo de ruptura executaram-se ensaios à flexão em corpos-deprova com dimensões de 13 x 13 × $76 \mathrm{~mm}$ extraídos de camadas consolidadas em contato com determinado tipo de unidade.

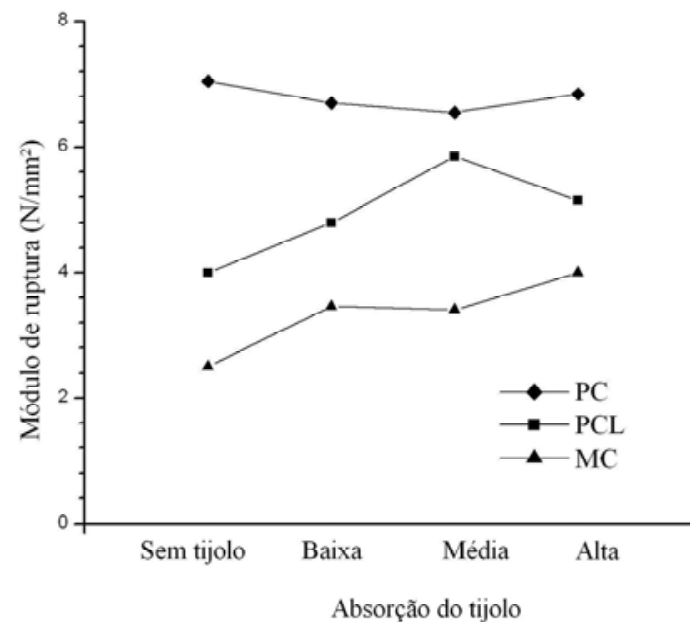

Figura 3.15 - Variação do módulo de ruptura em função do tipo de tijolo e argamassa, adaptada de Jennings et al. (2000).

Guo e Drysdale (1995) utilizaram blocos como fôrmas, além das fôrmas metálicas e de plástico com objetivo de mensurar a influência da perda de água do graute durante a cura. Adotaram-se dois tipos de placas nos ensaios: as placas de aço padronizadas (maciças) e as placas-escova que permitem a redução do efeito de confinamento sobre as amostras. Considerando-se três grupos com valores médios de resistência à compressão de $13 \mathrm{~N} / \mathrm{mm}^{2}$, $37 \mathrm{~N} / \mathrm{mm}^{2}$ e $54 \mathrm{~N} / \mathrm{mm}^{2}$, obtiveram-se valores no ensaio com placa padrão $10 \%$, $18 \%$ e $26 \%$ maiores que os obtidos nos ensaios com placa-escova. Entretanto, ressalta-se que estes valores representam os ensaios com as distintas fôrmas e diferentes corpos-de-prova - prismáticos de 75 x 75 × $150 \mathrm{~mm}$ e cilíndricos de 50 × $100 \mathrm{~mm}$ e 75 × $150 \mathrm{~mm}$, o que não permite conclusões mais precisas sobre o efeito de confinamento neste caso.

Nesta análise, o fato de maior destaque é a relação entre as resistências à compressão quando utilizadas as fôrmas de blocos de concreto. Consideraram-se dois tipos de corpos-de- 
prova prismáticos: o extraído do centro do graute, moldado e endurecido no vazio do bloco de concreto, e o corpo-de-prova que foi desmoldado a partir da fôrma organizada pela disposição dos blocos de concreto. Considerando-se o graute mais fraco, com maior valor de relação água/cimento $(\mathrm{a} / \mathrm{c}=1,10)$, os $\mathrm{CP}$ 's desmoldados apresentam resistência à compressão aproximadamente $40 \%$ maior que a obtida nos ensaios com CP's extraídos. Por outro lado, a resistência à compressão destes corpos-de-prova são maiores, $15 \%$ e 5\%, respectivamente, quando considerados os grautes de resistência intermediária e forte. Os dados provenientes desta análise estão sumarizados na Tabela 3.3, em que se pode notar que o valor da diferença entre a resistência à compressão no ensaio padrão e no ensaio modificado com placas-escova aumentam com o aumento da resistência da argamassa.

Tabela 3.3 - Resistência à compressão de corpos-de-prova de argamassa, adaptada de Guo e Drysdale (1995).

\begin{tabular}{ccccc}
\hline Traço & Tipo do CP & $\mathrm{f}_{\mathrm{a}}^{2}\left(\mathrm{~N} / \mathrm{mm}^{2}\right)$ & Placa utilizada $^{3}$ & Relação \\
\hline \multirow{4}{*}{$1: 5(1,10)^{1}$} & Extraído & $12,3(2,7 \%)$ & Padrão & 1,12 \\
& Extraído & $11,0(11,1 \%)$ & Modificada & \\
& Desmoldado & $17,1(10,7 \%)$ & Padrão & 1,10 \\
& Desmoldado & $15,5(1,9 \%)$ & Modificada & \\
& Extraído & $45,9(6,3 \%)$ & Padrão & 1,14 \\
$1: 0,1: 3(0,51)^{1}$ & Extraído & $40,2(3,7 \%)$ & Modificada & \\
& Desmoldado & $39,8(3,1 \%)$ & Padrão & 1,15 \\
& Desmoldado & $34,6(10,0 \%)$ & Modificada & \\
& Extraído & $61,8(2,0 \%)$ & Padrão & 1,11 \\
$1: 1(0,36)^{1}$ & Extraído & $55,9(6,1 \%)$ & Modificada & \\
& Desmoldado & $63,0(2,0 \%)$ & Padrão & 1,26 \\
& Desmoldado & $50,2(0,8 \%)$ & Modificada & \\
\hline
\end{tabular}

\footnotetext{
${ }^{1}$ Traço em volume, com a respectiva relação a/c

${ }^{2}$ Resistência média à compressão da argamassa obtida no ensaio com três CP's

${ }^{3}$ Placa modificada: placa-escova
}

Os autores concluem que não é benéfica a perda de água das argamassas mais fortes, já que devida ao seu menor fator a/c, a hidratação do cimento pode ser prejudicada em ambientes de cura seca.

Apesar dos resultados anteriores referirem-se ao graute, que apresenta uma constituição diferente da argamassa principalmente em relação à ausência da cal, este comportamento pode ser comparado qualitativamente com o da argamassa. Por exemplo, fica evidente que a diferença entre um corpo-de-prova moldado entre blocos e as propriedades mecânicas a serem obtidas na própria junta de argamassa são distintas, principalmente pelo 
fato da área de contato e a geometria nas duas análises serem diferentes e influenciarem na perda de água.

Uma pesquisa detalhada sobre as propriedades macro e microscópicas dos materiais que constituem as unidades e argamassas é apresentada por Kingsley, Tulin e Noland (1985) que indicam que a quantidade de água total absorvida do graute por uma unidade cerâmica vazada parece depender mais da quantidade de água inicial desse material do que das propriedades de absorção da unidade. $\mathrm{O}$ estudo baseou-se no desenvolvimento de um método para a previsão da quantidade final de água no graute em contato com unidades cerâmicas, originando uma função da relação água-cimento dependente do tempo de contato entre os materiais.

Por fim, Graubohm et al. (2008) apresentam os resultados obtidos a partir da extração de corpos-de-prova diretamente da junta de argamassa, com $18 \mathrm{~mm}$ de espessura, após contato com blocos silico-calcários e de concreto autoclavado. Destaca-se o aumento da resistência à compressão entre 1,25 e 2 vezes em relação ao valor obtido nos ensaios com corpos-de-prova cilíndricos padronizados. Particularmente para o bloco silico-calcário, algumas amostras provenientes de juntas com $12 \mathrm{~mm}$ de espessura apresentaram valores inferiores aos obtidos no processo padrão. Essa redução de resistência é atribuída ao alto grau de sucção do material que constitui o bloco associado à menor espessura da junta, resultando em maior perda de água na argamassa o que reduz a quantidade de água necessária para a hidratação do material.

O efeito de perda de água que ocorre na junta de argamassa quando em contato com blocos de concreto foram simulados nesta pesquisa, idealizando-se fôrmas cilíndricas e cúbicas constituídas de gesso e concreto para induzir a perda de água da argamassa ainda em seu estado fresco. Para obtenção de dados comparativos de absorção do gesso e do concreto, utilizaram-se fôrmas cúbicas (com $100 \mathrm{~mm}$ de aresta) compostas por blocos de concreto (Figura 3.16).

Destaca-se a absorção de parte da água de amassamento da argamassa pelo bloco no qual esta foi assentada, identificada pela região úmida próxima à junta apresentada na Figura 3.17a. Na Figura 3.17b são apresentados os corpos-de-prova 50 x $100 \mathrm{~mm}$ moldados em fôrmas metálicas. 

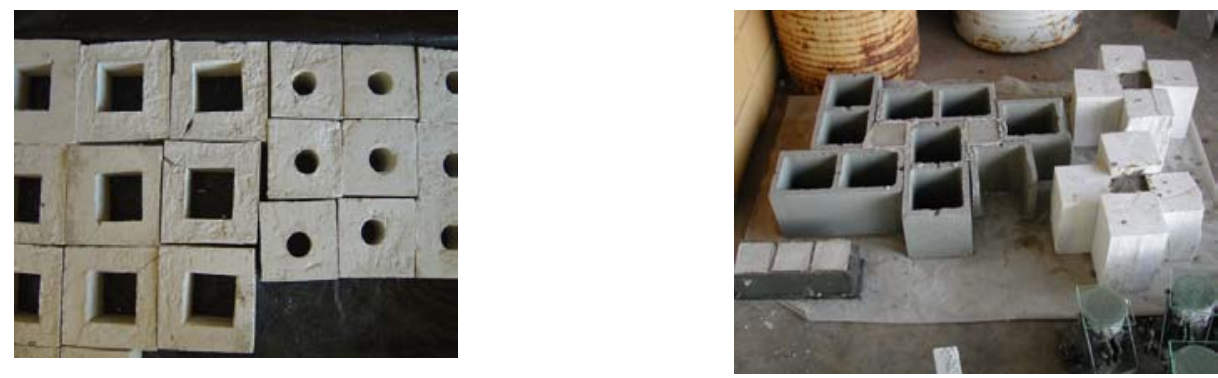

Figura 3.16 - Fôrmas cilíndricas e cúbicas de gesso e concreto utilizadas para a moldagem de corpos-de-prova de argamassa.

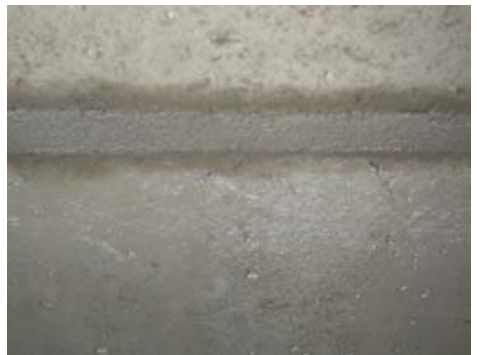

(a)

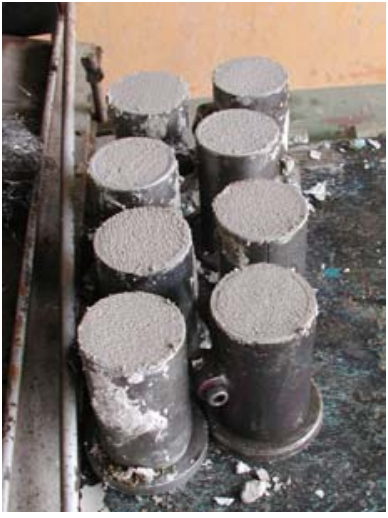

(b)

Figura 3.17 - Ensaio de compressão triaxial de argamassas (a). Absorção de água da argamassa pelo bloco (b) fôrmas cilíndricas padronizadas de argamassa (c).

Os resultados apresentados foram obtidos por meio da análise experimental de Barbo, Barbosa e Hanai (2004), Barbosa, Hanai e Barbo (2005a), Barbosa, Hanai e Barbo (2005b) e Guimarães, Barbosa e Hanai (2006) em que os corpos-de-prova foram moldados com argamassa de um único lote de mistura nas fôrmas disponíveis, em cada série de ensaios.

No dia seguinte à moldagem, os corpos-de-prova das fôrmas metálicas foram retirados e os que estavam em contato com material absorvente permaneceram nas fôrmas até o dia anterior ao ensaio. Foram utilizados sempre os mesmos tipos de materiais, portanto esta pesquisa não focalizou a influência da qualidade dos materiais constituintes da argamassa.

Em todos os casos analisados, o contato com a fôrma de gesso induziu à perda de água da argamassa, acarretando aumento na sua resistência à compressão axial, em relação ao processo padrão. $\mathrm{O}$ fenômeno é justificado pelo fato de que a quantidade de água adicionada aos materiais secos é superior à necessária para a hidratação dos materiais aglomerantes, devida à necessidade da trabalhabilidade da argamassa; com a redução da relação a/c, obtevese um aumento da resistência à compressão do material. $\mathrm{O}$ coeficiente de variação não foi 
superior a 5\% e 10\% nos processos padrão e modificado, respectivamente. A Tabela 3.4 apresenta os resultados de cada análise separadamente.

Tabela 3.4 - Resistência à compressão média da argamassa em corpos-de-prova cilíndricos adotando-se o processo padrão e o processo modificado.

\begin{tabular}{ccccc}
\hline $\begin{array}{c}\text { Traço }^{1} \\
(\text { em volume })\end{array}$ & $\begin{array}{c}\text { Data } \\
\text { Ensaio } \\
(\text { dias })\end{array}$ & $\begin{array}{c}\text { Processo Padrão } \\
\left(\mathrm{N} / \mathrm{mm}^{2}\right)\end{array}$ & $\begin{array}{c}\text { Processo } \\
\text { Modificado }^{3}\left(\mathrm{~N} / \mathrm{mm}^{2}\right)\end{array}$ & $\begin{array}{c}\text { Relação } \\
\text { entre } \\
\text { resistências }\end{array}$ \\
\hline $1: 1: 2$ & 7 & $7,2(5)$ & $9,8(5)$ & 1,36 \\
$1: 1,4: 4,9$ & 7 & $6,9(6)$ & $9,0(6)$ & 1,30 \\
$1: 1: 5$ & 15 & $19,3(9)$ & $39,5(9)$ & 2,04 \\
$1: 2,5: 4,4$ & 7 & $6,1(3)$ & $8,2(12)$ & 1,34 \\
$1: 0,25: 3$ & 7 & $15,1(5)$ & $28,9(5)$ & 1,91 \\
$1: 0,25: 3$ & 14 & $17,3(5)$ & $31,1(5)$ & 1,80 \\
$1: 1: 5$ & 15 & $18,6(3)$ & $39,8(3)$ & 2,14 \\
\hline $\begin{array}{l}{ }^{1} \text { cimento:cal:areia } \\
{ }^{2} \text { Fôrma de aço }\end{array}$ \\
$\begin{array}{l}{ }^{3} \text { Fôrma de gesso } \\
\text { Os números entre parênteses representam a quantidade de corpos-de-prova de cada ensaio. }\end{array}$
\end{tabular}

A Figura 3.18 apresenta a evolução da resistência à compressão no processo modificado em função da resistência à compressão alcançada no ensaio normalizado, obtendo-se uma relação exponencial com baixa variabilidade. Todavia, salienta-se que a alteração do índice de retenção de água, dependente das características dos materiais utilizados, deve influenciar na quantidade da perda de água de uma determinada argamassa e, consequentemente, no valor final da sua resistência quando executado o processo modificado.

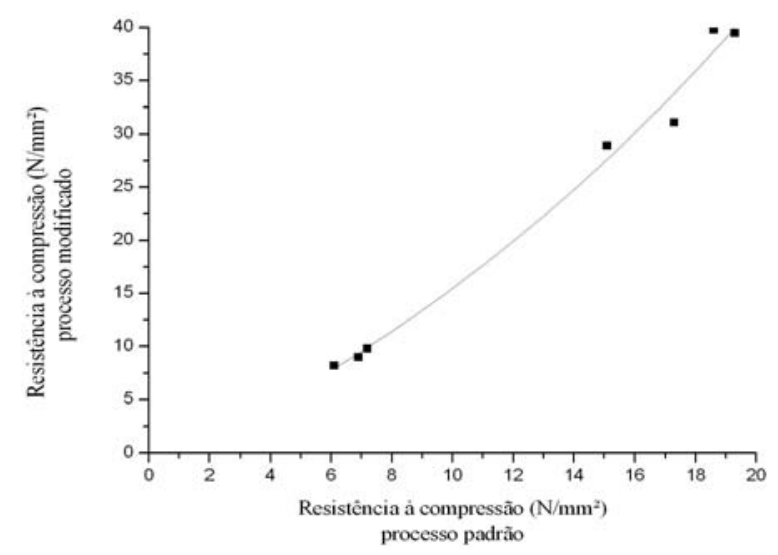

Figura 3.18 - Evolução da resistência à compressão da argamassa no processo modificado em função da resistência obtida por meio do processo padrão. 
Procurou-se avaliar a capacidade de absorção de água do gesso empregado e compará-la com o concreto dos blocos por meio da realização de ensaios à compressão de corpos-de-prova cúbicos, moldados em fôrmas de gesso e de concreto (composta pela disposição de quatro blocos). A resistência à compressão obtida com cubos provenientes da fôrma de concreto apresentou valor médio $3 \%$ maior que o obtido com cubos provenientes da fôrma de gesso, indicando que os materiais apresentam índices de absorção semelhantes.

Os resultados dos ensaios com cubos moldados em fôrmas de gesso estão na Tabela 3.5 e apresentam correlação semelhante com os corpos-de-prova cilíndricos nos dois traços analisados. Em ambos os casos observa-se aumento do valor da resistência à compressão no ensaio modificado. Contudo, a relação entre a resistência de um cubo e seu respectivo cilindro para um mesmo traço é diferente em virtude das distintas relações entre a área de contato com a fôrma e o volume dos corpos-de-prova.

Tabela 3.5 - Resistência à compressão da argamassa em corpos-de-prova cúbicos.

\begin{tabular}{lcccc}
\hline $\begin{array}{c}\text { Traço }^{1} \\
(\text { em volume })\end{array}$ & $\begin{array}{c}\text { Data ensaio } \\
\text { (dias) }\end{array}$ & $\begin{array}{c}\text { Processo Padrão } \\
\left(\mathrm{N} / \mathrm{mm}^{2}\right)\end{array}$ & $\begin{array}{c}\text { Processo Modificado } \\
{ }^{3}\end{array}$ & $\begin{array}{c}\text { Relação entre } \\
\text { resistências }\end{array}$ \\
\hline $1: 1: 5$ & $3 \mathrm{dd}$ & $5,2(3)$ & $10,8(3)$ & 2,07 \\
$1: 0,25: 3$ & $7 \mathrm{dd}$ & $15,7(3)$ & $28,5(3)$ & 1,82 \\
\hline${ }^{1}$ cimento:cal:areia \\
${ }^{2}$ Fôrma de aço \\
${ }^{3}$ Fôrma de gesso \\
Os números entre parênteses representam a quantidade de corpos-de-prova de cada ensaio.
\end{tabular}

A alteração na constituição do traço original também modifica as demais propriedades mecânicas da argamassa, como a resistência à tração e o módulo de elasticidade, conforme os resultados da Tabela 3.6. O módulo de elasticidade apresenta aumento de mais de duas vezes, seguindo o crescimento obtido no valor da resistência à compressão. $\mathrm{O}$ aumento da resistência à tração é próximo a $25 \%$.

Tabela 3.6 - Resistência à tração e módulo de elasticidade da argamassa obtido em corpos-de-prova cilíndricos.

\begin{tabular}{lccccc}
\hline $\begin{array}{c}\text { Traço } \\
\text { (em volume) }\end{array}$ & $\begin{array}{c}\text { Data ensaio } \\
\text { (dias) }\end{array}$ & $\mathrm{f}_{\mathrm{at}}$ & $\mathrm{f}_{\mathrm{at}}^{*}$ & $\mathrm{E}_{\mathrm{a}}$ & $\mathrm{E}_{\mathrm{a}}^{*}$ \\
\hline $1: 1: 5$ & $15 \mathrm{dd}$ & $2,3(3)$ & $2,9(3)$ & $12510(3)$ & $26422(3)$ \\
& $1,7(3)$ & $2,1(3)$ & - & - \\
\hline $\begin{array}{l}\text { 1 cimento:cal:areia } \\
\text { * Processo modificado } \\
\text { Os números entre parênteses representam a quantidade de corpos-de-prova de cada ensaio. }\end{array}$
\end{tabular}


Apresentam-se na Tabela 3.7 os resultados de uma análise adicional realizada para avaliar as mudanças nas propriedades físicas do material ocasionada pelas diferentes condições de cura. Quanto menor a quantidade de água para a hidratação do cimento e da cal, supostamente o que ocorre no processo modificado, menor é o índice de vazios nos corposde-prova, sendo maior a massa específica e menor o índice de absorção destes.

Um aspecto adicional deve ser enfatizado: as dimensões de uma junta de argamassa são distintas dos corpos-de-prova utilizados nos ensaios, originando diferentes relações entre a área em contato com o bloco e o volume da argamassa. Isto pode acarretar distintos índices de perda de água, possivelmente com maior perda na junta de argamassa por esta possuir pequena espessura. Além do mais, um corpo-de-prova envolvido por gesso deve estar sujeito a uma melhor condição de cura até a data do ensaio, ao contrário dos CP's que são desmoldados e deixados nas condições ambientes no ensaio padrão.

Tabela 3.7 - Propriedades físicas da argamassa: ensaios de referência e modificado.

\begin{tabular}{cccc}
\hline Condição & Absorção & Massa específica $\left(\mathrm{g} / \mathrm{cm}^{3}\right)$ & Índice de vazios \\
\hline Processo padrão & $12,3 \%$ & 1,92 & 0,24 \\
Processo modificado & $8,7 \%$ & 2,07 & 0,18 \\
\hline
\end{tabular}





\section{PRODUÇÃO E ENSAIO DOS ARGAMASSA}

Apresenta-se neste capítulo a metodologia utilizada na análise experimental dos blocos vazados de concreto, prismas e paredes e seus respectivos corpos-de-prova de concreto e argamassa. Descreve-se o processo de produção, a preparação dos elementos para a realização dos ensaios e sua execução e a instrumentação utilizada.

Juntamente com a descrição do processo de ensaios caracteriza-se o comportamento de cada elemento quando submetidos à compressão uniaxial, à compressão diametral e à flexão em três pontos.

Os valores de resistência apresentados referem-se sempre à área líquida dos elementos, salvo quando houver outra indicação.

\subsection{Materiais utilizados}

Descreve-se sucintamente a caracterização dos materiais utilizados na produção do concreto e da argamassa para a confecção dos elementos de alvenaria e seus respectivos corpos-de-prova.

A idéia central e diferenciada adotada neste trabalho é a utilização de um mesmo concreto, de consistência plástica, com o qual são moldados tanto os blocos quanto os corposde-prova cilíndricos. Embora se saiba que para a produção de blocos em fábricas o concreto empregado é de consistência seca e não plástica, a premissa de se utilizar, nos ensaios ora descritos, um mesmo concreto tanto nos blocos como nos corpos-de-prova, possibilita confrontar resultados com a garantia de que se trata de um único material. 


\subsubsection{Cimento}

Como aglomerante na produção do concreto e argamassa, utilizou-se o cimento Portland de alta resistência inicial (CP V-ARI) com o objetivo de alcançar determinada resistência aos 14 dias, intervalo médio em que estavam programados os ensaios após cada concretagem.

\subsubsection{Agregado miúdo}

Utiliza-se areia quartzosa classificada segundo a NBR 7217 (1987) como sendo da zona 3 (média). A areia apresenta módulo de finura igual a 2,08 e massa específica e unitária iguais a $2,48 \mathrm{~g} / \mathrm{cm}^{3}$ e $1,48 \mathrm{~g} / \mathrm{cm}^{3}$, respectivamente. A caracterização do material segue as recomendações da NBR 7251 (1982) e da NBR 9776 (1987). A dimensão máxima do agregado é de $2,4 \mathrm{~mm}$.

\subsubsection{Agregado graúdo}

Proveniente de rochas basálticas, o agregado graúdo é classificado como de graduação 0 (pedrisco).

Seguindo as indicações da NBR 7251 (1982) e da NBR 9776 (1987), determinaramse a massa específica e a massa unitária que valem respectivamente $2,71 \mathrm{~g} / \mathrm{cm}^{3}$ e $1,37 \mathrm{~g} / \mathrm{cm}^{3}$; o módulo de finura vale 2,78. A dimensão máxima do agregado é 9,5 mm, com absorção de $1,23 \%$.

\subsubsection{Cal}

Também com função aglomerante, nas argamassas utilizou-se a cal hidratada $\mathrm{CH}$, que segue as especificações da NBR 7175 (2003) e é comercialmente produzida para assentamentos e rebocos.

\subsection{5 Água}

Utilizou-se água corrente do sistema de abastecimento de São Carlos para a produção do concreto e da argamassa.

\subsection{Caracterização do concreto e argamassa}

Como justificado, utilizou-se cimento Portland de alta resistência inicial em função das baixas idades em que se realizariam os ensaios, estipulando-se três níveis de resistência para o concreto e a argamassa. 
De acordo com a NBR 6136 (2007), os blocos vazados de concreto são classificados em função da resistência à compressão característica em relação à área bruta. Definiram-se três níveis de resistência à compressão do concreto $\left(\mathrm{f}_{\mathrm{c}}\right)$, determinado pelo ensaio à compressão em corpos-de-prova cilíndricos 100 x 200 mm que resultassem em níveis distintos de resistência de blocos de concreto. Os traços utilizados são apresentados na Tabela 4.1.

Tabela 4.1 - Traços utilizados na produção do concreto referentes aos três grupos de resistência.

\begin{tabular}{cccc}
\hline \multirow{2}{*}{ Grupo } & $\mathrm{f}_{\mathrm{c}}$ previsto & \multicolumn{2}{c}{ Traço $^{1}$} \\
& $\mathrm{~N} / \mathrm{mm}^{2}$ & Massa & Volume \\
\hline B1 & $6,5-15$ & $1: 4,0: 2,4: 0,82$ & $1: 4,0: 2,4: 0,82$ \\
B2 & $17,5-25$ & $1: 3,2: 2,8: 0,66$ & $1: 3,2: 2,8: 0,66$ \\
B3 & $27,5-35$ & $1: 2,0: 2,7: 0,67$ & $1: 2,0: 2,7: 0,67$ \\
\hline
\end{tabular}

${ }^{1}$ Proporção de cimento:areia:brita:água

A partir dos níveis de resistência do concreto, definiram-se as faixas de valores da resistência à compressão da argamassa $\left(\mathrm{f}_{\mathrm{a}}\right)$, obtida no ensaio com corpos-de-prova 50 x 100 mm, a ser utilizada na execução de prisma e paredes. $\mathrm{O}$ valor da resistência da argamassa deve estar entre $70 \%$ e $100 \%$ da resistência prevista do bloco, resultando nas proporções apresentadas na Tabela 4.2.

Tabela 4.2 - Traços de argamassa referentes aos três grupos de resistência.

\begin{tabular}{cccc}
\hline \multirow{2}{*}{ Grupo } & $\mathrm{f}_{\mathrm{a}}$ previsto & \multicolumn{2}{c}{ Traço $^{1}$} \\
& $\mathrm{~N} / \mathrm{mm}^{2}$ & Massa & Volume \\
\hline A1 & $5,3-7,5$ & $1: 1,3: 5,3: 1,4$ & $1: 1,3: 5,3: 1,4$ \\
A2 & $8,8-12,5$ & $1: 0,6: 4,21: 0,88$ & $1: 0,6: 4,21: 0,88$ \\
A3 & $12,3-17,5$ & $1: 0,3: 3,0: 0,78$ & $1: 0,3: 3,0: 0,78$ \\
\hline
\end{tabular}

${ }^{1}$ Proporção de cimento:cal:areia:água

\subsection{Produção dos elementos e preparação para ensaio}

Apresentam-se a seguir as etapas de produção dos elementos desde a concretagem das unidades e corpos-de-prova, detalhando-se a instrumentação utilizada. Os blocos de concreto são produzidos em um dos três níveis de resistência - B1, B2 ou B3 -, e, quando sob 
forma de prismas ou paredes, associam-se com as argamassas A1, A2 ou A3, respectivamente.

Cada série produzida destina-se a um tipo de ensaio, o qual pode se referir aos blocos isolados, prismas constituídos por três blocos ou miniparedes. Na Tabela 4.3 apresenta-se a quantidade de elementos produzidos para cada série de ensaio.

Tabela 4.3 - Quantidade de elementos produzidos em cada série.

\begin{tabular}{cccccc}
\hline & \multicolumn{2}{c}{$\mathrm{CP}^{1}$} & \multicolumn{2}{c}{ Viga } \\
Série & Bloco & $\begin{array}{c}\text { Concreto } \\
100 \times 200 \mathrm{~mm}\end{array}$ & $\begin{array}{c}\text { Argamassa } \\
50 \times 100 \mathrm{~mm}\end{array}$ & $\begin{array}{c}\text { Concreto } \\
150 \times 150 \times 500 \mathrm{~mm}\end{array}$ \\
\hline Bloco & 10 & 12 & - & 6 & - \\
Prisma & 10 & 12 & 12 & 6 & 4 \\
Miniparede & $14^{2}$ & 12 & 12 & 6 & 4 \\
\hline${ }^{1}$ CP: corpo-de-prova cilíndrico & & & & \\
${ }^{2}$ Blocos e meio-blocos & & & &
\end{tabular}

Realizaram-se ensaios com nove blocos, sendo seis à compressão axial e três à tração indireta. Dos seis blocos destinados aos ensaios à compressão axial, três são destinados ao ensaio-padrão e três ao ensaio com placa-escova, o qual será detalhado mais adiante. A definição da quantidade de elementos a serem ensaiados foi estabelecida com base em ensaios preliminares utilizando-se seis elementos, nos quais foram obtidos coeficientes de variação com valores baixos, próximos a 5\%.

$\mathrm{Na}$ série de prismas destinam-se nove blocos para a construção de três prismas, constituídos por três blocos, a serem submetidos à compressão axial. Cada miniparede é constituída por seis blocos e quatro meio-blocos, portanto, cada série possibilita a execução de apenas uma miniparede. Dar-se-á destaque sempre quando houver alteração da quantidade ou do procedimento descrito anteriormente.

Para obtenção dos deslocamentos e deformações dos elementos utilizam-se extensômetros mecânicos, relógios comparadores, transdutores de deslocamento e extensômetros elétricos de resistência. Os três primeiros destinam-se à medição de deslocamentos lineares, diferindo apenas pela forma de medição da grandeza, se mecânicas ou por variação da resistência. Os extensômetros elétricos de resistência medem, com grande precisão e sensibilidade, diretamente as deformações. As bases de medida utilizadas, específicas para cada ensaio, serão apresentadas na seqüência do texto. 


\subsubsection{Blocos de concreto}

Os blocos vazados de concreto possuem dimensões de 140 × 190 × $390 \mathrm{~mm}$, com área líquida de $30663 \mathrm{~mm}^{2}$, o que corresponde a aproximadamente 56\% de sua área bruta. A espessura das paredes longitudinais e dos septos transversais é de $28 \mathrm{~mm}$, com exceção do septo transversal central que possui $30 \mathrm{~mm}$ de espessura, conforme ilustra a Figura 4.1a. Os vazios dos blocos são definidos pela inserção de dois prismas de EPS (poliestireno expandido) escolhidos por prevenirem eventuais fissuras decorrentes do efeito de retração do concreto às primeiras horas, já que estes ficam em contato com as fôrmas por 24 h. Ensaios de absorção realizados previamente indicam que a quantidade de água absorvida por estes elementos não alteram a relação a/c original do traço de concreto.

$\mathrm{Na}$ Figura 4.1b ilustra-se a fôrma dos blocos (constituídas por chapas metálicas e parafusadas entre si), os prismas de EPS e a barra de travamento superior.

Produz-se também o "meio-bloco" (Figura 4.2), elemento utilizado na construção de paredes a fim de permitir a alternância das juntas verticais. Em cada fôrma são produzidos dois meio-blocos utilizando-se núcleo de EPS com menor largura a fim de que os septos transversais dos “meio-blocos" tenham de $28 \mathrm{~mm}$.

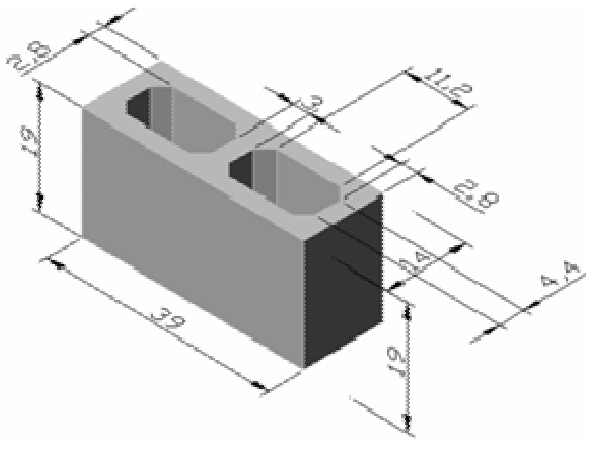

(a)

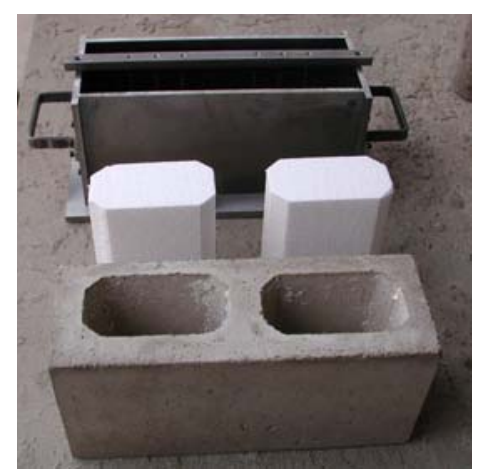

(b)

Figura 4.1 - Dimensões do bloco de concreto em centímetros (a) e fôrma para sua produção (b). 


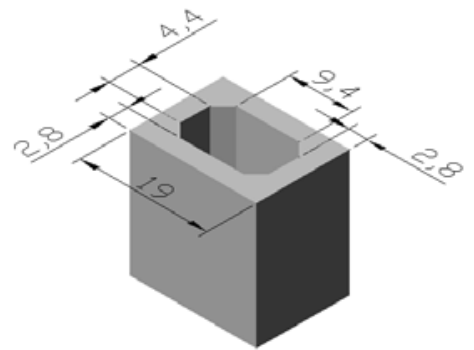

(a)

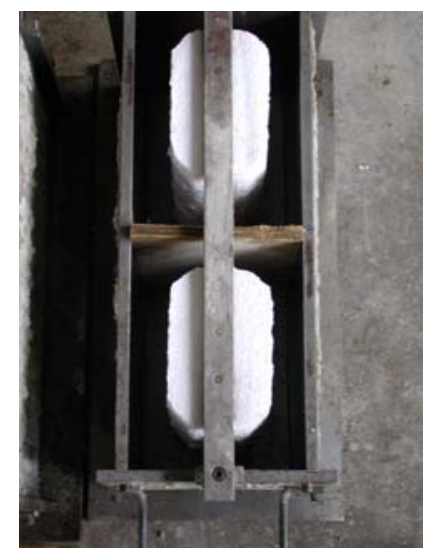

(b)

Figura 4.2 - Geometria do meio-bloco com dimensões em centímetros (a) e fôrma utilizada na sua produção (b).

As fôrmas são seqüencialmente preenchidas com concreto sobre mesa vibratória, recebendo posteriormente o acabamento da face superior. Decorridas 24 horas, os blocos são desmoldados e levados à câmara úmida onde permanecem sob umidade relativa constante de aproximadamente $95 \%$ por, pelo menos, sete dias. Antes da colocação em câmera úmida, os EPS são retirados dos blocos.

Após a cura dos blocos, procede-se a regularização do topo e base por processo mecânico (retífica) para que estas se tornem planas e paralelas, de modo que não seja necessária a utilização de algum tipo de capeamento para sua regularização. Na Figura 4.3 está apresentado o bloco durante e após o processo de retífica.

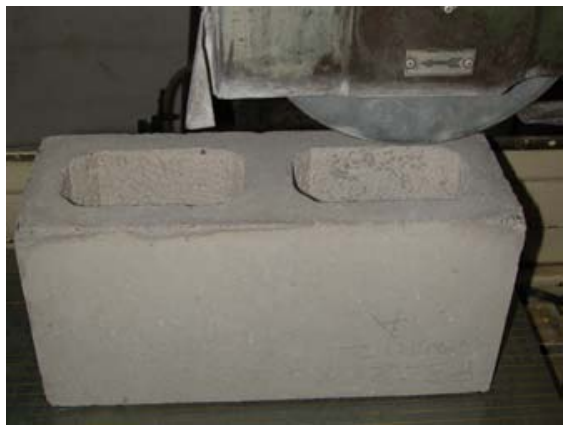

(a)

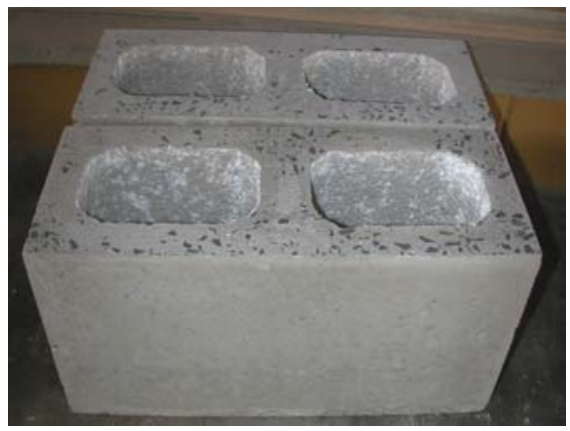

(b)

Figura 4.3 - Processo de retífica do bloco (a) e acabamento final de suas superfícies (b).

A etapa seguinte compreende a marcação dos pontos de instrumentação nos blocos para a fixação de extensômetros mecânicos, transdutores de deslocamento e relógios comparadores. Objetiva-se, dessa forma, obter os deslocamentos longitudinais e transversais ao longo das paredes dos blocos. Dois transdutores de deslocamento são utilizados para medir o deslocamento da placa-padrão, um em cada lado do bloco. A Figura 4.4 apresenta o detalhe 
da instrumentação. Os ensaios com blocos são realizados próximo aos 14 dias após a concretagem.
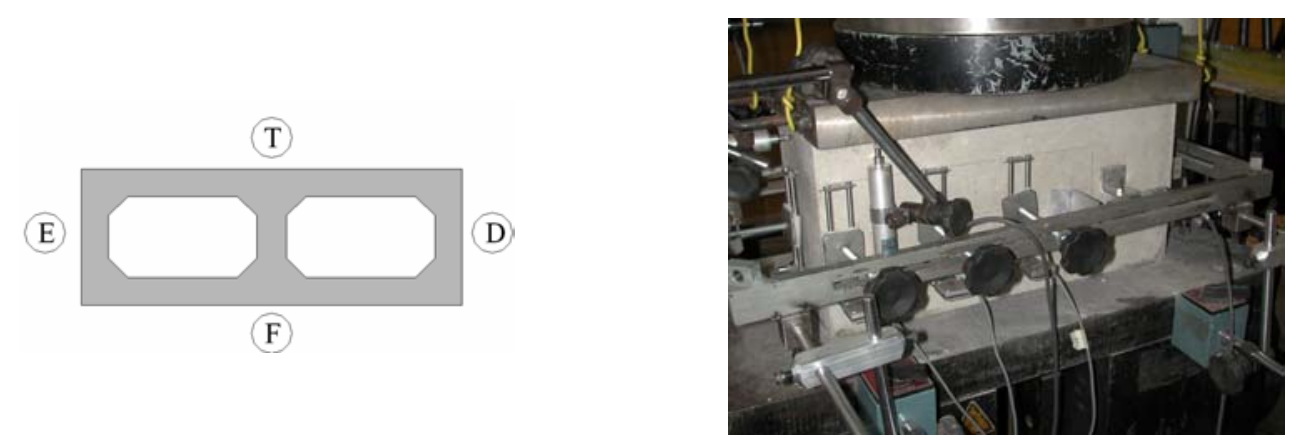

(F)

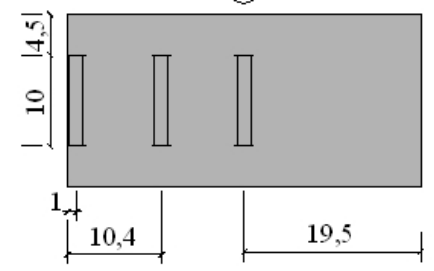

(D)

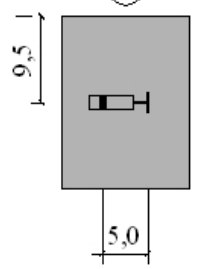

(T)

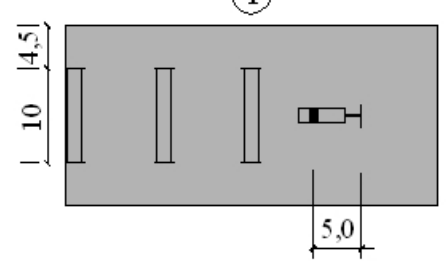

(E)

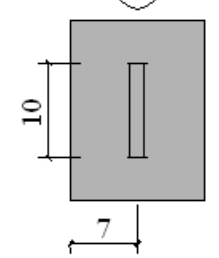

Figura 4.4 - Instrumentação utilizada nos ensaios de blocos vazados de concreto: extensômetros mecânicos (vertical) e transdutores de deslocamentos (horizontal). Vista frontal (F), lateral direita (D), vista posterior (T) e lateral esquerda (E)

\subsubsection{Prismas constituídos por três blocos}

São elementos formados por três blocos interligados por juntas de argamassa assentadas sobre os septos transversais e paredes longitudinais. As juntas têm espessura de $10 \pm 3$ mm conforme recomendação da NBR 8215 (1983), portanto, a altura total dos prismas é de $590 \mathrm{~mm}$.

O processo de produção dos blocos que constituem os prismas segue a metodologia anteriormente descrita. Entretanto, não há a necessidade do acabamento do topo e base do bloco já que este possui uma das superfícies plana que fica em contato com o fundo da fôrma metálica. Desta forma, os blocos extremos do prisma têm estas superfícies em contato com as placas de ensaio e as superfícies irregulares em contato com a junta de argamassa.

A construção dos prismas, cuja seqüência é apresentada na Figura 4.5, ocorre aproximadamente no sétimo dia decorrido da concretagem e o ensaio sete dias após sua construção. Utilizam-se nestes ensaios os mesmos aparelhos de medição adotados nos ensaios com blocos vazados, porém, com uma disposição diferenciada (Figura 4.6). Assim, procura-se analisar o comportamento global do prisma utilizando-se instrumentos com maior base de medição e o comportamento do bloco central com instrumentação específica para este. Para 
aferir o deslocamento da placa de ensaio, utiliza-se um relógio comparador de cada lado, próximo à região central do elemento.
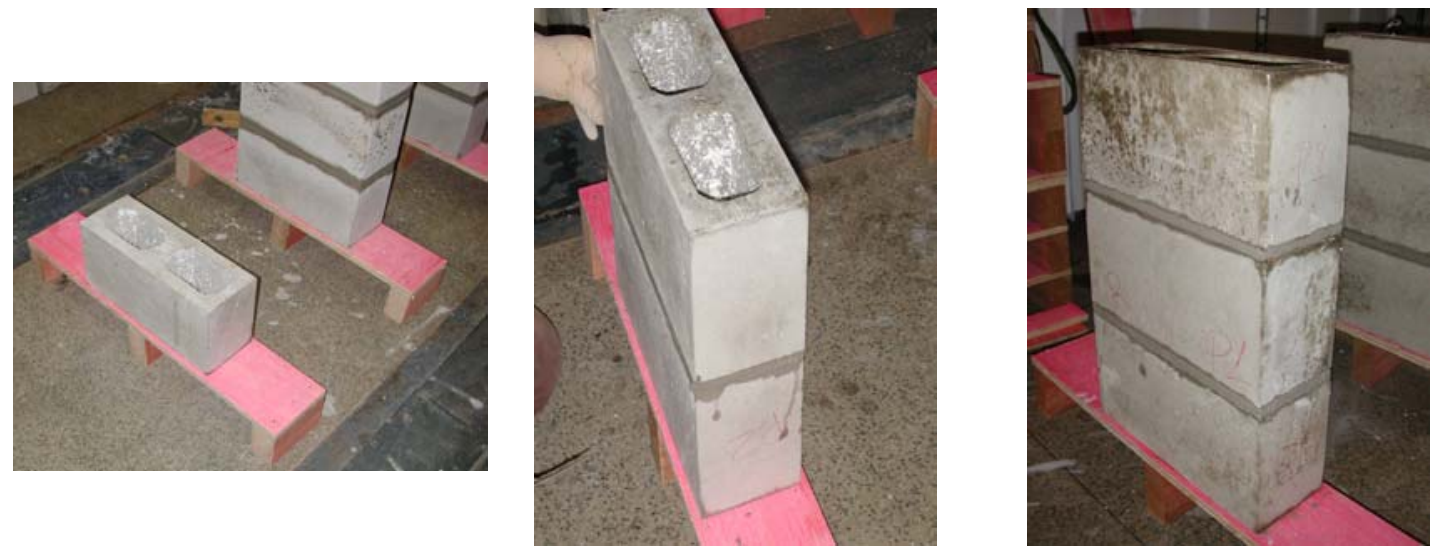

Figura 4.5 - Etapas da construção dos prismas.
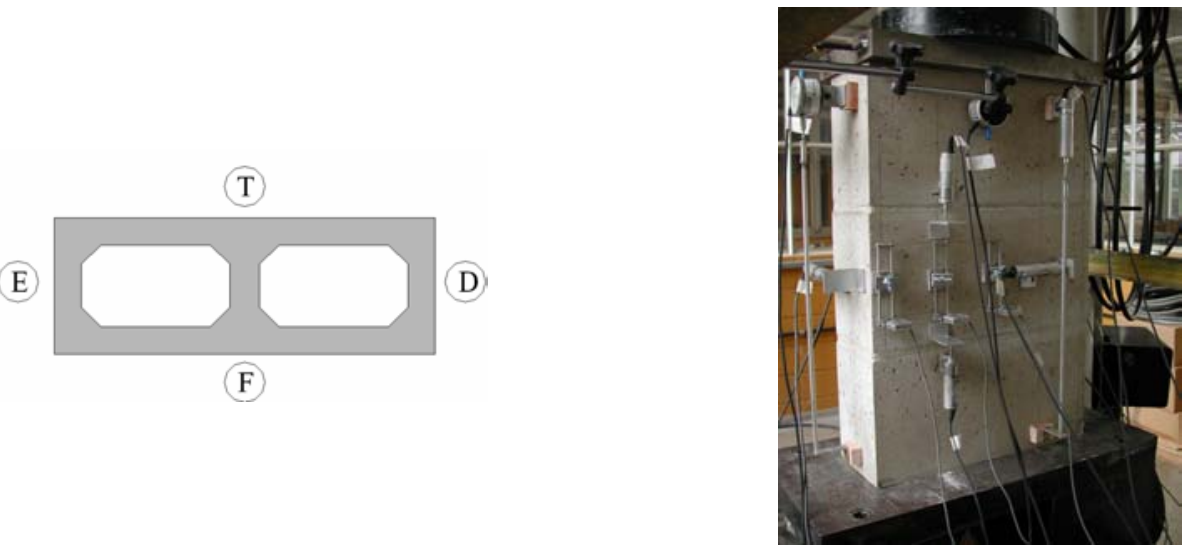

(F)

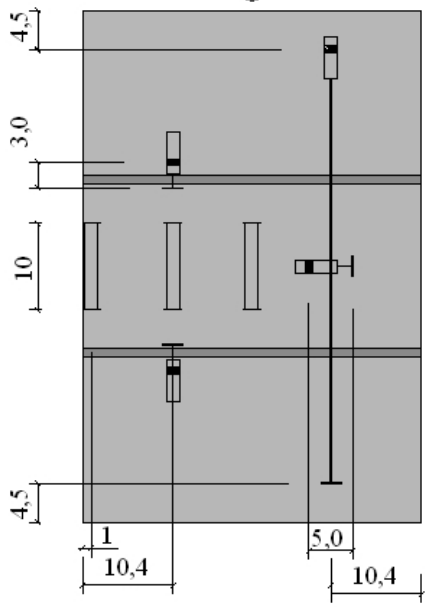

(D)

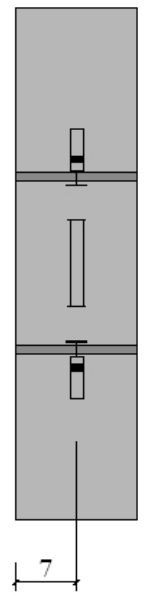

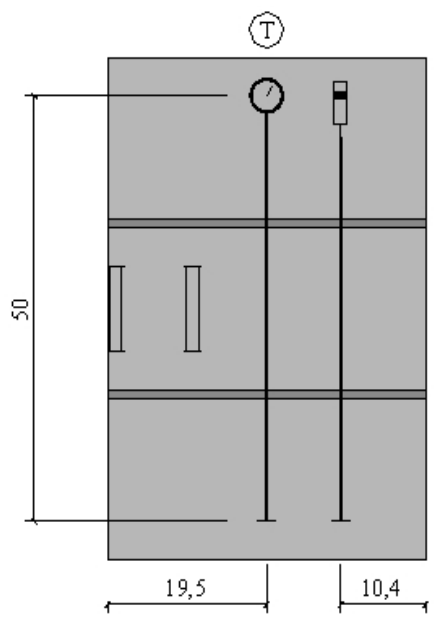

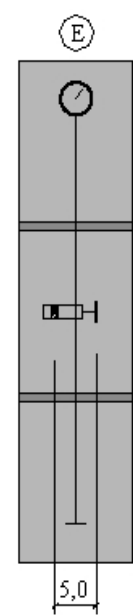

Figura 4.6 - Instrumentação utilizada nos ensaio dos prismas: extensômetros mecânicos (vertical), transdutores de deslocamento (vertical e horizontal) e relógios comparadores (vertical). Vista frontal (F), lateral direita (D), vista posterior (T) e lateral esquerda (E). 


\subsubsection{Miniparedes}

Estes elementos, constituídos por blocos e meio-blocos de concreto, foram idealizados para substituir os modelos prescritos pela NBR 8949 (1985). A vantagem da redução das dimensões é o custo mais baixo devido à redução de mão-de-obra e material, permanecendo a representação satisfatória do modelo normalizado. As miniparedes possuem dimensões de 790 x 790 mm e a disposição das unidades e juntas de argamassa está ilustrada Figura 4.7. Além das juntas horizontais de argamassa, as miniparedes possuem juntas verticais respeitando também a espessura de $10 \pm 3 \mathrm{~mm}$.
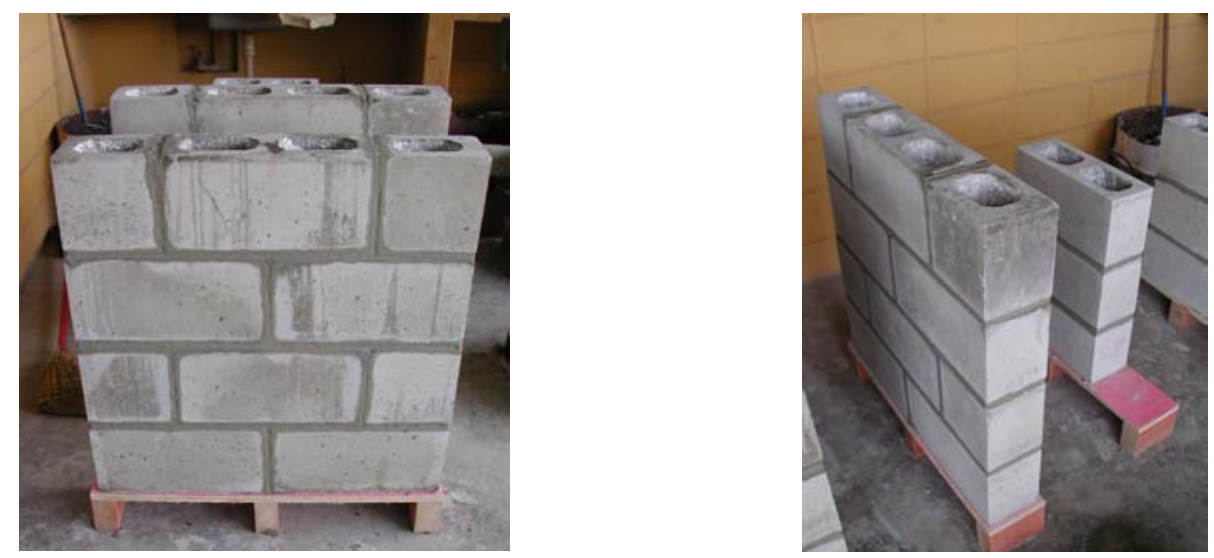

Figura 4.7 - Detalhe da miniparede de blocos de concreto.

A execução das miniparedes e o seu ensaio ocorrem, respectivamente, no $7^{\circ}$ e $14^{\circ}$ dia após a concretagem dos blocos. Com a instrumentação apresentada na Figura 4.8, possibilitase a análise do comportamento global da miniparede e do comportamento do bloco isolado. 
(E)
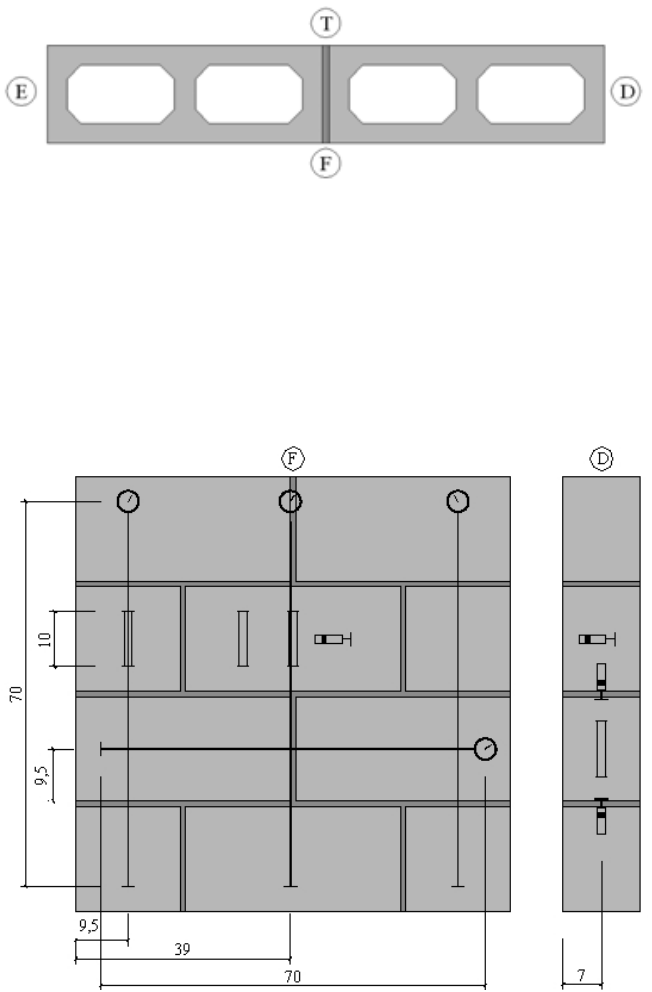

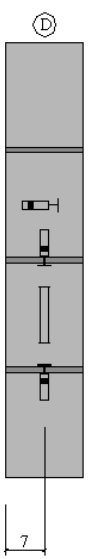

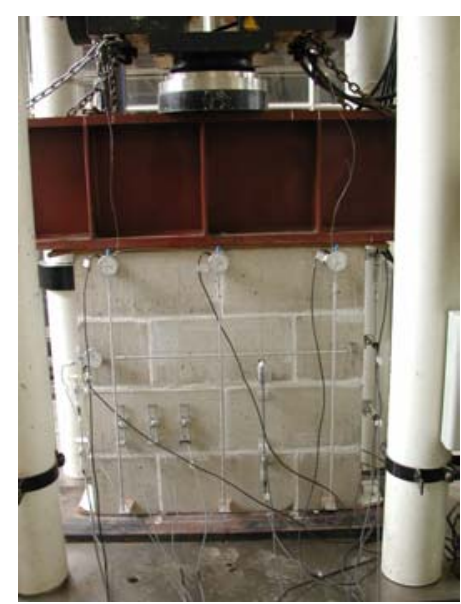
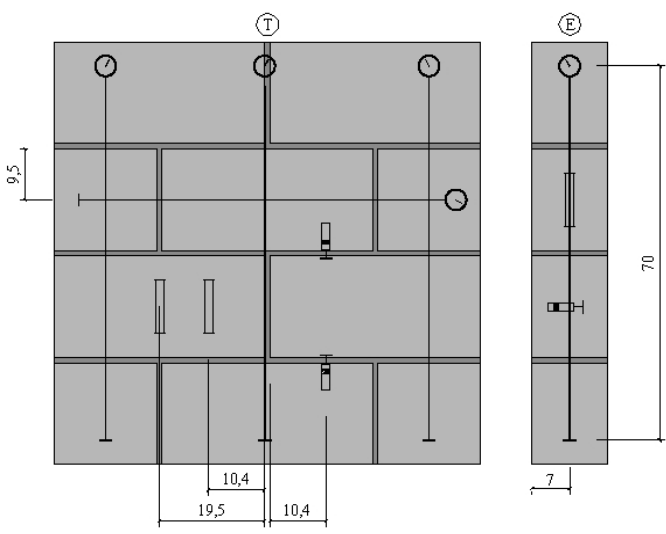

Figura 4.8 - Disposição dos instrumentos de medição utilizados nos ensaios de miniparedes: extensômetros mecânicos (vertical), transdutores de deslocamento (vertical e horizontal) e relógios comparadores (vertical). Vista frontal (F), lateral direita (D), vista posterior (T) e lateral esquerda (E).

\subsubsection{Corpos-de-prova}

Paralelamente à produção dos blocos de concreto e execução dos prismas e paredes, são moldados corpos-de-prova de concreto e argamassa.

Os corpos-de-prova cilíndricos de 100 x 200 mm (diâmetro x altura) e vigas com 150 x 150 x $500 \mathrm{~mm}$ (largura x altura x comprimento) são produzidas com o concreto do mesmo lote de mistura utilizado na moldagem dos blocos, adensados sobre mesa vibratória (Figura 4.9a e Figura 4.9b). Os CP's cilíndricos são destinados aos ensaios de compressão axial e compressão diametral, determinando-se a resistência à compressão, resistência à tração e o módulo de elasticidade do material. Realizam-se ensaios à flexão de três pontos em vigas de concreto com entalhe, obtendo-se o valor da resistência à tração e a energia de fraturamento. 


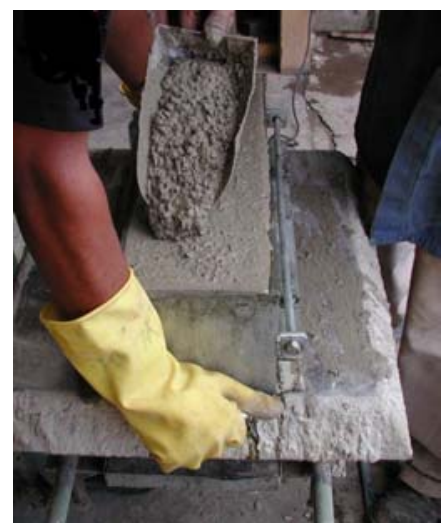

(a)

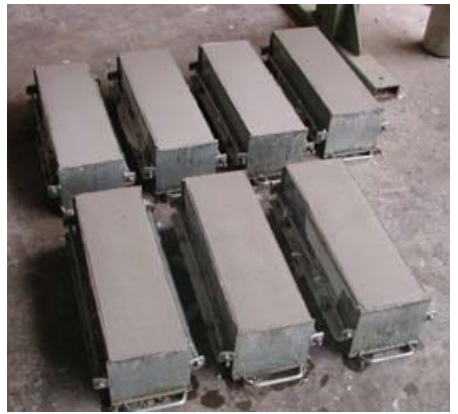

(b)

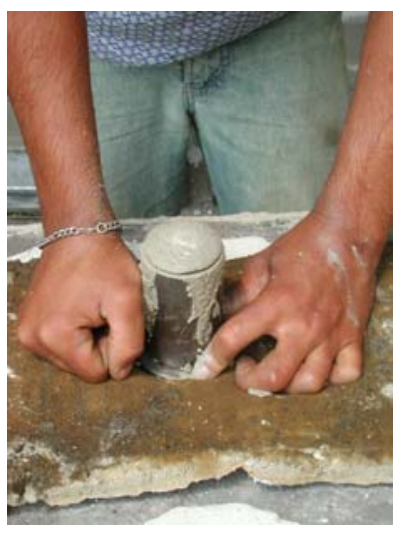

(c)

Figura 4.9 - Moldagem de corpos-de-prova de concreto (a e b) e argamassa (c).

Os corpos-de-prova de concreto permanecem em câmara úmida por sete dias e são retirados juntamente com os blocos. O acabamento das superfícies de ensaio dos CP's cilíndricos também é feito por meio do processo de retífica, conforme ilustra Figura 4.10. Após a retirada das vigas da câmara úmida, executa-se um entalhe na parte inferior, ao longo de sua largura e com profundidade de $25 \mathrm{~mm}$ (Figura 4.11a).

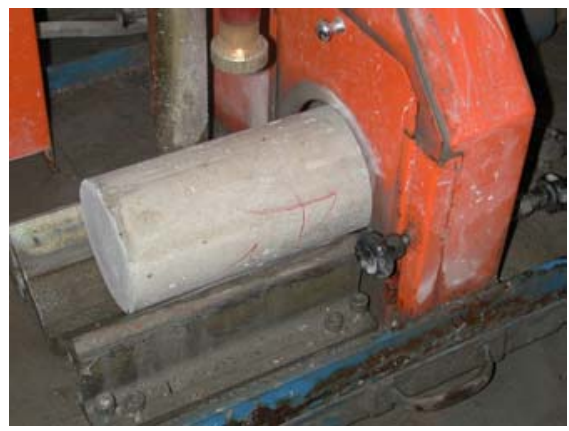

(a)

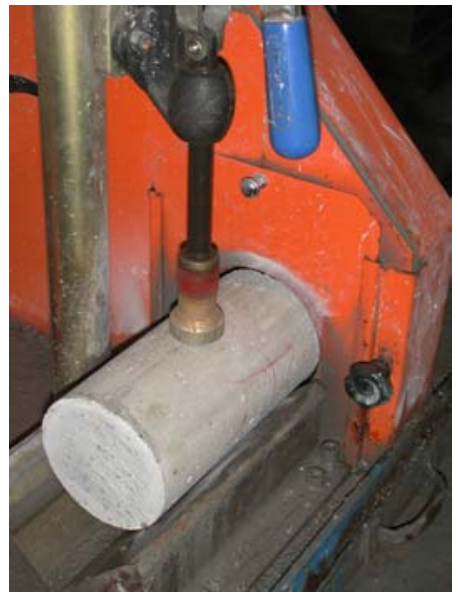

(b)

Figura 4.10 - Processo de retífica nos corpos-de-prova (a) e detalhe do acabamento (b).

Para a obtenção das propriedades mecânicas relativas à argamassa utilizada na construção de prismas e paredes, moldam-se corpos-de-prova cilíndricos 50 x $100 \mathrm{~mm}$ e vigas $150 \times 150 \times 500 \mathrm{~mm}$. O adensamento dos elementos também é realizado sobre mesa vibratória (Figura 4.9c). Os corpos-de-prova de argamassa permanecem em cura ao lado dos respectivos prismas e paredes, em ambiente de laboratório, conforme ilustra a Figura 4.11b. 


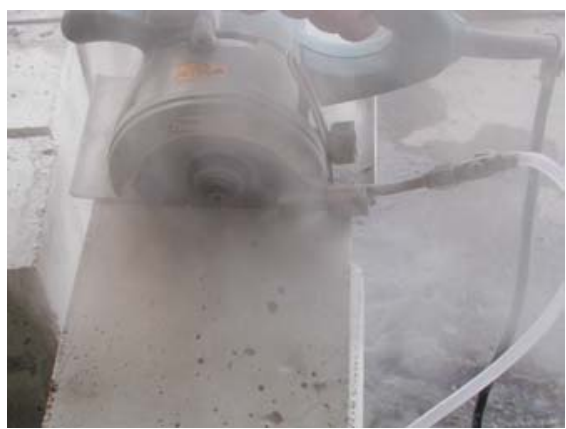

(a)

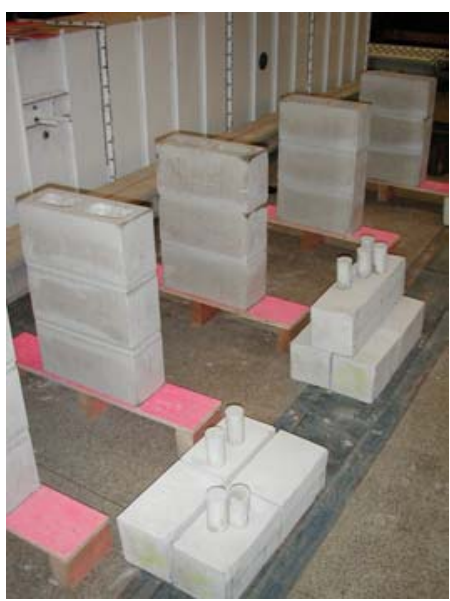

(b)

Figura 4.11 - Execução do entalhe nas vigas (a) e posterior armazenagem dos corpos-de-prova de argamassa ao lado dos prismas (b).

Os corpos-de-prova cilíndricos são instrumentados com dois extensômetros mecânicos, para obtenção dos deslocamentos longitudinais, com base de medida correspondendo à metade da altura do corpo-de-prova. Utilizam-se ainda, em alguns CP's, extensômetros elétricos de resistência para a obtenção da deformação longitudinal e transversal, no centro, topo e base do CP, conforme ilustra a Figura 4.12.

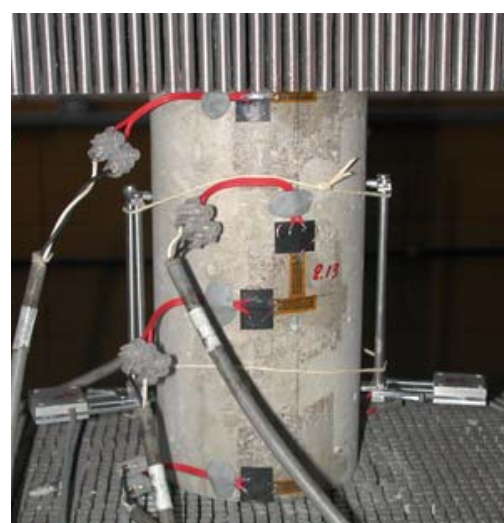

Figura 4.12 - Instrumentação utilizada nos corpos-de-prova cilíndricos de concreto.

O ensaio à flexão das vigas é realizado com controle de abertura do entalhe por meio de um extensômetro mecânico, tornando o ensaio mais estável. Mede-se ainda o deslocamento vertical do plano de carregamento com um relógio comparador conforme esquema apresentado na Figura 4.13. 


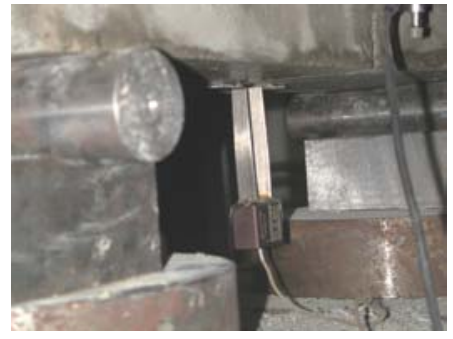

(a)

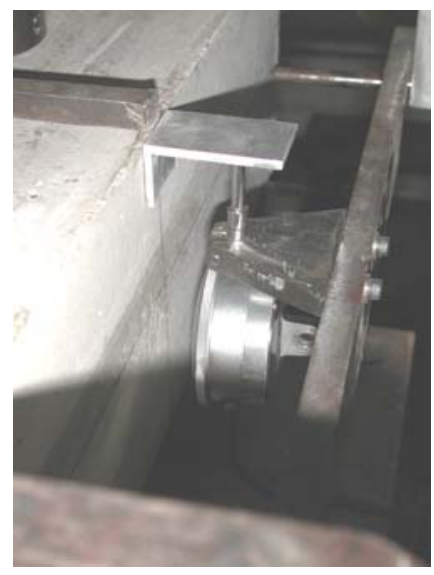

(b)

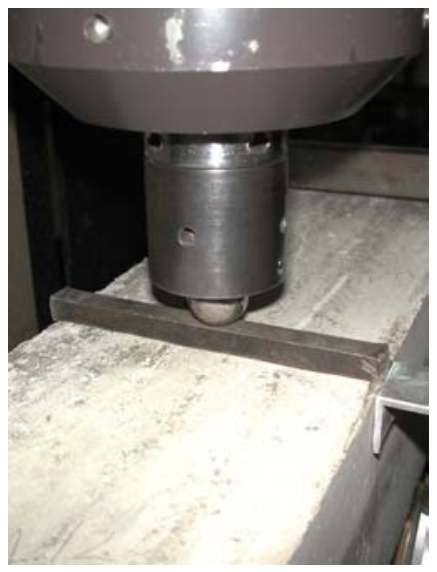

(c)

Figura 4.13 - Ensaio de vigas de concreto ou argamassa e instrumentação no entalhe da viga (a), relógio comparador para a medição do deslocamento da linha de carga (b) e sistema para aplicação de força (c).

\subsection{Ensaios mecânicos}

Os ensaios realizados com os elementos, o detalhamento da metodologia, os seus objetivos e o comportamento das amostras são apresentados nessa seção.

Foram realizados ensaios de compressão axial, tração indireta, flexão de três pontos e compressão triaxial (estes já discutidos no Capítulo 3). O resumo dos ensaios está apresentado na Tabela 4.4.

Tabela 4.4 - Ensaios realizados com os diversos elementos de concreto e argamassa.

\begin{tabular}{ccccc}
\hline Elemento/Ensaio & $\begin{array}{c}\text { Compressão } \\
\text { uniaxial }\end{array}$ & $\begin{array}{c}\text { Tração } \\
\text { indireta }\end{array}$ & Flexão & $\begin{array}{c}\text { Compressão } \\
\text { triaxial }\end{array}$ \\
\hline Bloco & $\mathrm{X}^{*}$ & $\mathrm{X}$ & - & - \\
CP $100 \times 200 \mathrm{~mm}$ & $\mathrm{X}^{*}$ & $\mathrm{X}$ & - & - \\
CP $50 \times 100 \mathrm{~mm}$ & $\mathrm{X}^{*}$ & $\mathrm{X}$ & - & $\mathrm{X}$ \\
Viga $150 \times 150 \times 500 \mathrm{~mm}$ & - & - & $\mathrm{X}$ & - \\
Prisma & $\mathrm{X}$ & - & - & - \\
Miniparede & $\mathrm{X}$ & - & - & - \\
\hline
\end{tabular}

*Ensaio realizado com placa-padrão e placa-escova

Destaca-se a realização do ensaio à compressão uniaxial com dois tipos de placa, a padrão e a denominada "placa-escova"- que reduz o confinamento ocasionado pelo atrito entre o topo e base dos elementos e as placas de ensaio. 
Grande parte da análise experimental é realizada na máquina universal de ensaios de marca Instron 8506, servo-hidráulica com capacidade de 3000 kN (carregamento estático). Utiliza-se o sistema de aquisição de dados System $\mathbf{5 0 0 0}$ ligado a um microcomputador e conectados à máquina de ensaio e instrumentos de medição. Os ensaios à flexão foram realizados na máquina servo-hidráulica MTS 815 com capacidade total de $2700 \mathrm{kN}$; utilizouse também o System $\mathbf{5 0 0 0}$ para aquisição de dados. Os ensaios sem instrumentação foram realizados na máquina de ensaios da marca ELE, modelo Autotest 2000, hidráulica, eletrônica, com controle de força e capacidade de $2000 \mathrm{kN}$.

\subsubsection{Blocos de concreto}

Estes ensaios visam à obtenção das propriedades mecânicas das unidades de alvenaria que serão utilizadas na confecção de prismas e paredes. Obtêm-se a resistência à compressão utilizando a placa de ensaio prescrita pela NBR 6136 (1992), a resistência à compressão com redução do efeito de confinamento, a resistência à tração indireta e as deformações longitudinais e transversais em diversos pontos do bloco.

\subsubsection{Compressão uniaxial}

O ensaio é realizado com controle de deslocamento a uma velocidade de $0,005 \mathrm{~mm} / \mathrm{s}$. Como pode ser observado na Figura 4.14, o bloco fica apoiado em uma base de aço e a aplicação da força pelo pistão da máquina de ensaio é transmitida por uma placa de aço de 35 x 200 x $400 \mathrm{~mm}$ (espessura x largura x comprimento) a fim de prover o deslocamento vertical uniforme do topo do bloco.

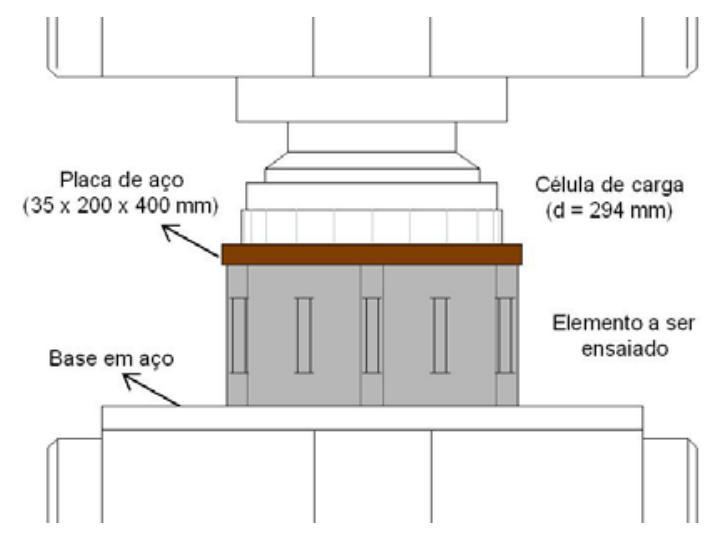

Figura 4.14 - Detalhe do ensaio com blocos vazados de concreto.

Na Figura 4.15 ilustra-se o ensaio com a placa-padrão e a placa-escova. O atrito entre o topo e base de um elemento - seja um corpo-de-prova ou um bloco de concreto-, levando 
em conta ainda a sua forma geométrica, origina tensões transversais confinantes que impedem a deformação transversal da região próxima às extremidades superior e inferior destes elementos, aumentando dessa forma o valor da resistência à compressão no ensaio. Apesar deste valor estar majorado, considera-se no projeto das estruturas de alvenaria a resistência obtida nos ensaios padronizados, muitas vezes ponderadas por coeficientes de correção. Contudo, para uma melhor caracterização do comportamento da unidade de alvenaria e do material que a constitui, é importante a avaliação da resistência à compressão e das relações tensão-deformação minimizando o efeito de confinamento.

Com este objetivo, projetou-se um aparato de ensaio denominado placa-escova que, por ser constituído por filamentos esbeltos de aço, permite maiores deformações transversais nas regiões próximas ao topo e base dos elementos, reduzindo dessa forma o efeito de confinamento e, por conseguinte, diminuindo o valor da resistência à compressão em relação ao ensaio padronizado. Cada filamento possui seção transversal circular com $5,1 \mathrm{~mm}$ de diâmetro e 110 mm de altura livre, o que assegura a redução da restrição lateral.

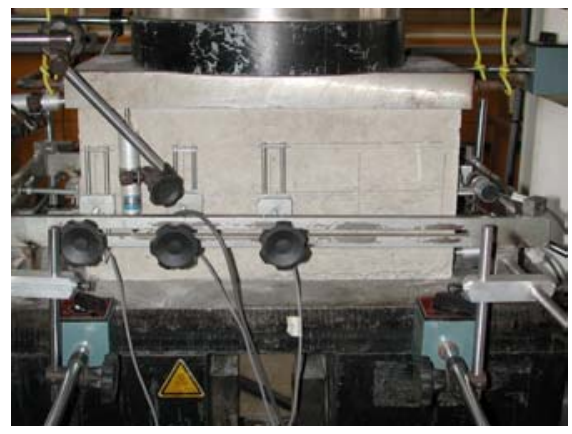

(a)

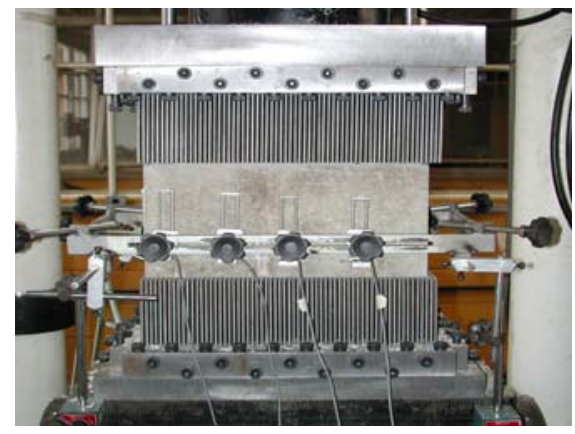

(b)

Figura 4.15 - Ensaio à compressão uniaxial de blocos vazados de concreto utilizando a placa de ensaio padronizada (a) e a placa-escova (b).

Nos ensaios-padrão, os blocos seguem até aproximadamente $90 \%$ da força máxima sem apresentar nenhuma fissura nas paredes externas. Quando surgem, estas são inclinadas e provocam o destacamento de lascas de concreto das paredes longitudinais e, após a força máxima, se manifestam por todo o bloco caracterizando o cisalhamento diagonal.

Já nos ensaios com placas-escova, as fissuras começam a aparecer a partir de $50 \%$ da força máxima do ensaio, nas paredes longitudinais, permanecendo verticais até a ruína, instante em que são identificadas fissuras nos septos transversais. Em seguida, as fissuras se generalizam pelas paredes dos blocos, inclinando-se e assemelhando-se ao estado de fissuração que ocorre nos ensaios com placa-padrão. Na Figura 4.16 apresenta-se a configuração das fissuras nesses ensaios. 


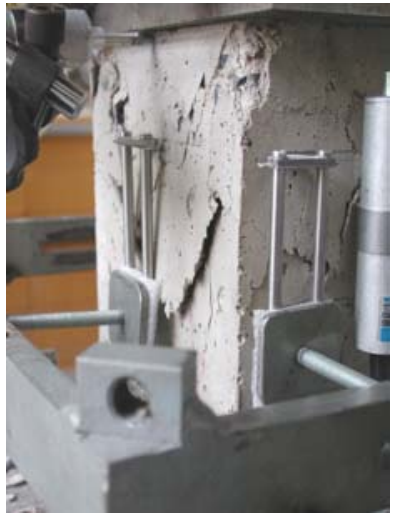

(a)

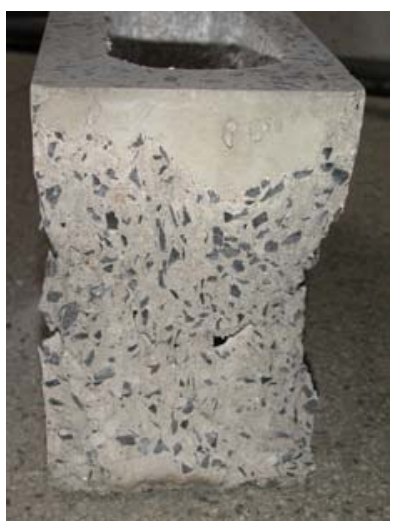

(b)

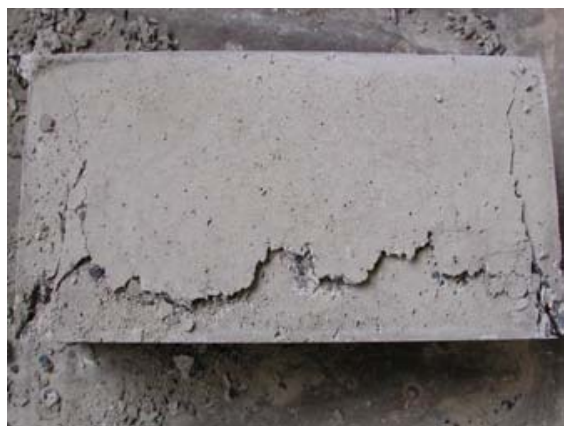

(c)

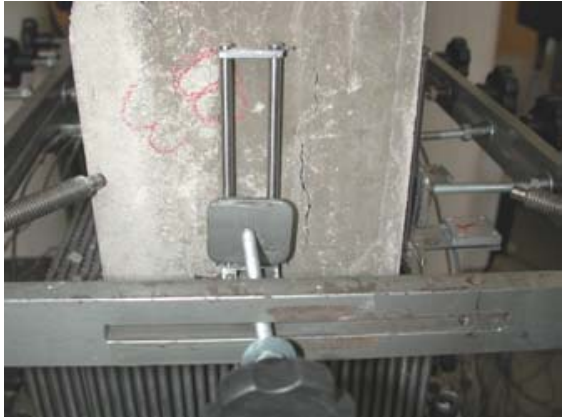

(d)

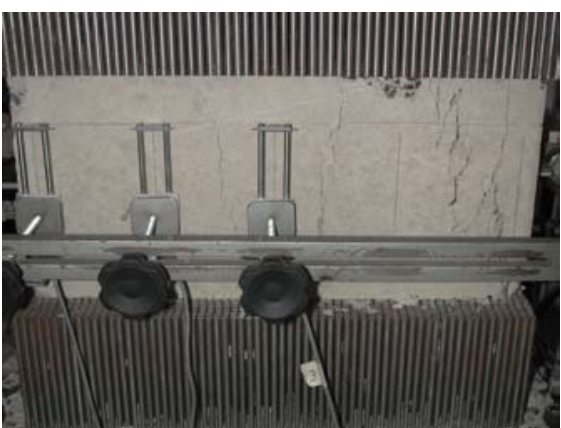

(e)

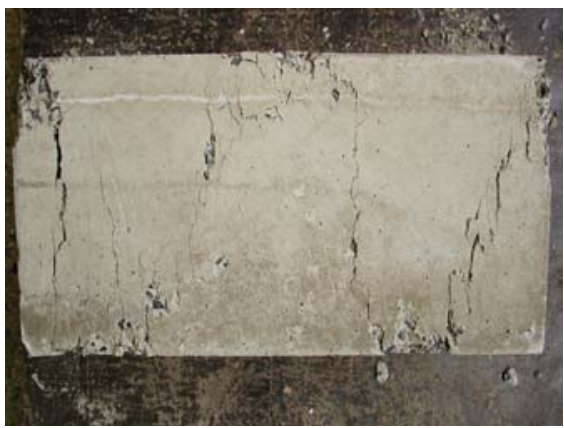

(f)

Figura 4.16 - Fissuração dos blocos de concreto e cenário pós-ruína quando submetidos à compressão uniaxial utilizando-se a placa-padrão (a), (b) e (c) e a placa-escova (d), (e) e (f).

\subsubsection{Ensaios à tração indireta}

Por não existir normalização nacional que trate de ensaios à tração com unidades de alvenaria, utilizou-se uma adaptação da ASTM C 1006 (1996) empregada para determinação da resistência à tração indireta em unidades maciças de alvenaria. Nestes ensaios obtém-se também a abertura da fissura para avaliar a energia de fraturamento do material. 
Um ensaio com o mesmo princípio da determinação da resistência à tração indireta em corpos-de-prova cilíndricos de concreto foi realizado. Para tal, foi aplicada força de compressão sobre o topo do bloco de concreto utilizando-se barras cilíndricas de aço $(\mathrm{d}=20$ $\mathrm{mm}$ ) no topo e base, na região central do seu vazio. O detalhe deste ensaio está apresentado na Figura 4.17. A aplicação da força ocorreu com velocidade constante de $0,001 \mathrm{~mm} / \mathrm{s}$ a fim de se evitar a ruína súbita e sua separação, o que ocorre algumas vezes nas proximidades do final do ensaio.

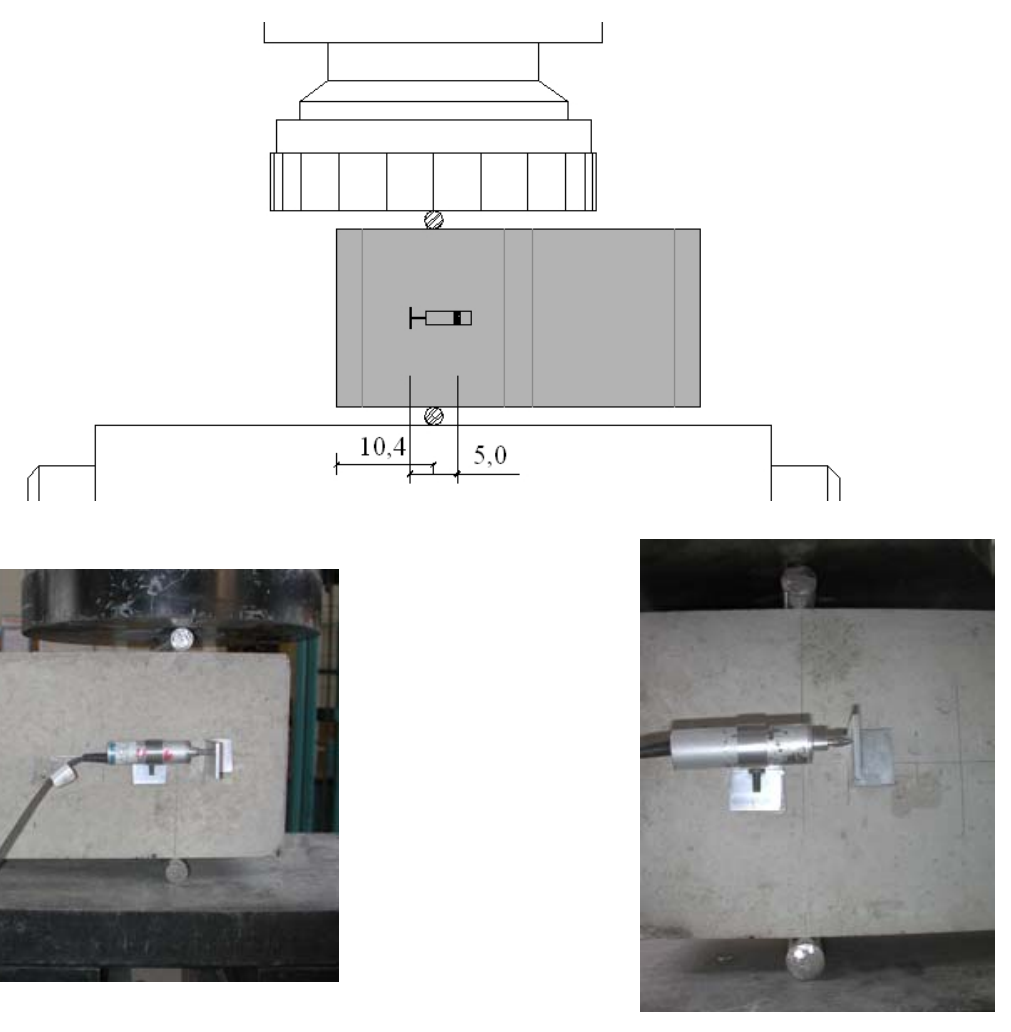

Figura 4.17 - Detalhe do ensaio para obtenção da resistência à tração indireta de blocos de concreto e medição da abertura de fissura.

A fissuração é perceptível apenas a partir de $90 \%$ da força máxima e surge abaixo da linha de aplicação da força, conforme apresentado na Figura 4.18. 

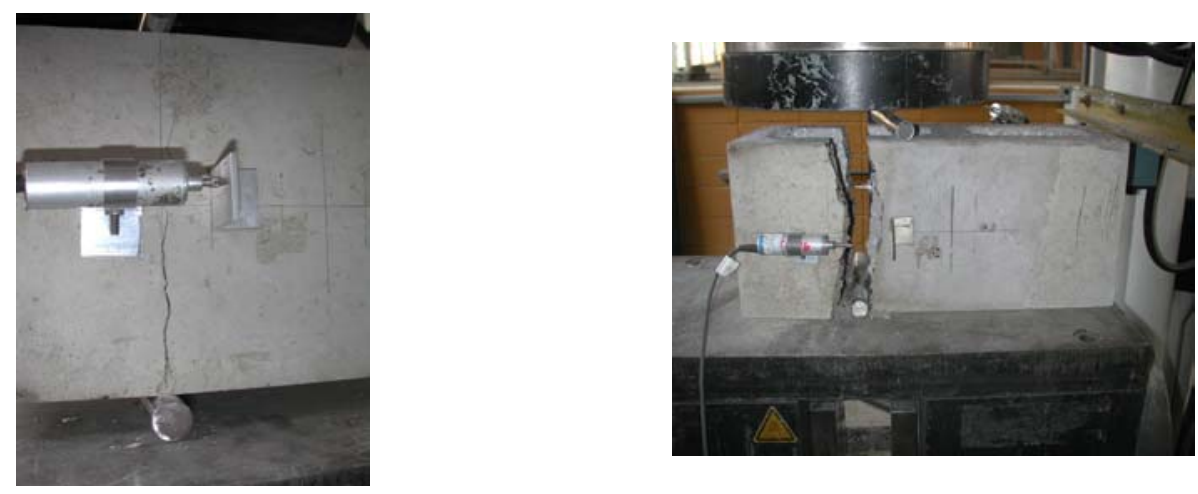

Figura 4.18 - Fissuração no bloco de concreto quando submetido à tração indireta.

\subsubsection{Prismas constituídos por três blocos}

Os prismas são submetidos unicamente à compressão axial, com velocidade de carregamento constante de $0,001 \mathrm{~mm} / \mathrm{s}$. Obtém-se a resistência à compressão axial e deformações do prisma, de seu bloco central e da junta de argamassa. A placa-escova não foi utilizada nestes ensaios, pois a altura do prisma permite a uniformização das tensões na região central, ou seja, no centro do prisma constituído por três blocos o efeito de confinamento é praticamente eliminado. Assim, os valores de resistência à compressão no ensaio padrão e com placa-escova são indiferentes.

A fissuração nos prismas é observada a $60 \%$ da força máxima do ensaio, localizada comumente em ambos os lados bloco intermediário, próximas à região do septo transversal central. Estas fissuras tendem, primeiramente, a se prolongar em direção a um dos blocos da extremidade; em alguns casos observam-se fissuras na região central do septo transversal do bloco central.

Com o aumento da força e iminência da ruína, as fissuras do bloco central aumentam sua abertura, e as localizadas no septo transversal expandem-se para os blocos das extremidades. Após o patamar da força máxima, a fissuração é generalizada, intensificando-se na fase de descarregamento do ensaio. Ocorre destacamento das paredes longitudinais dos blocos e, ao fim do ensaio, é nítida a tendência de separação nos septos transversais, instante em que também é identificado o esmagamento da argamassa da junta. A caracterização da ruína é ilustrada pela Figura 4.19.

Quando a argamassa apresenta baixa resistência à compressão, comprando-se com a resistência dos blocos, o modo de ruína dos prismas é alterado, com o esmagamento da argamassa sendo identificado anteriormente à fissuração dos prismas, que surgirá no prenúncio da ruína. 

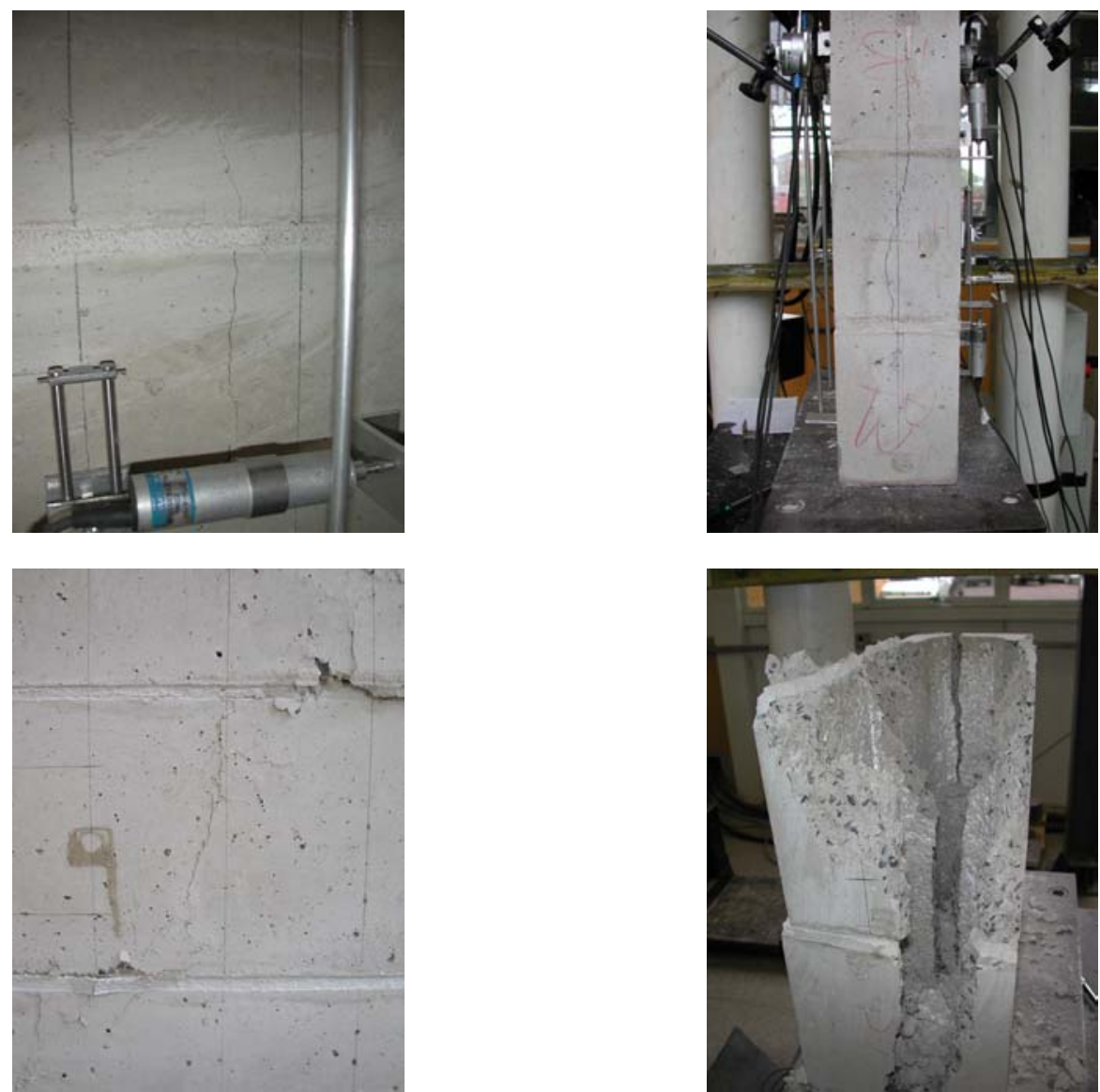

Figura 4.19 - Evolução da fissuração e cenário pós-ruptura nos ensaios de prismas de três blocos.

\subsubsection{Miniparedes}

Os ensaios foram realizados com controle de deslocamento na máquina de ensaios universal Instron 8506 a uma velocidade de $0,001 \mathrm{~mm} / \mathrm{s}$. A aplicação do carregamento é feita por meio de um perfil metálico disposto sobre o topo da parede. A elevada força de ruptura das paredes ocasiona sua ruína súbita com conseqüente redução brusca do valor da força aplicada.

As primeiras fissuras aparecem aleatoriamente na parte frontal e posterior da parede, conforme pode ser visto na Figura 4.20a e na Figura 4.20b. A Figura 4.20c apresenta as eventuais fissuras nos septos transversais dos blocos, próximas à força máxima ou após a ruína. O estado da parede após completo descarregamento (cenário pós-ruptura) está apresentado na Figura 4.20b. 


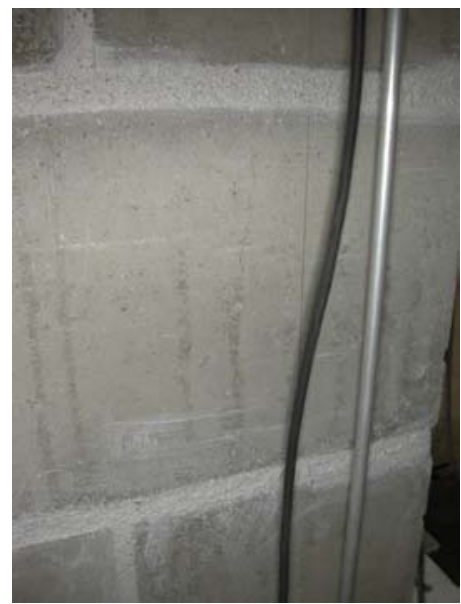

(a)

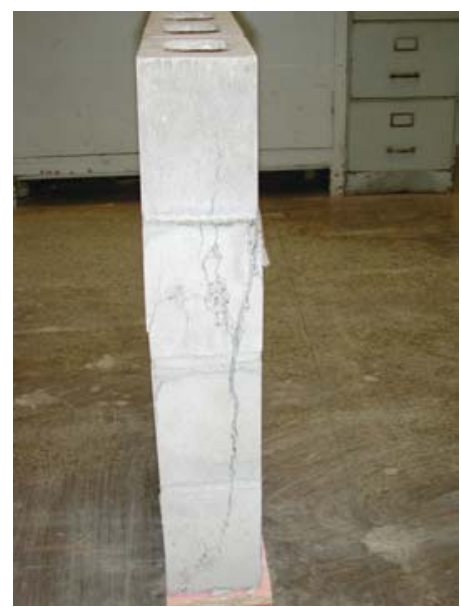

(c)

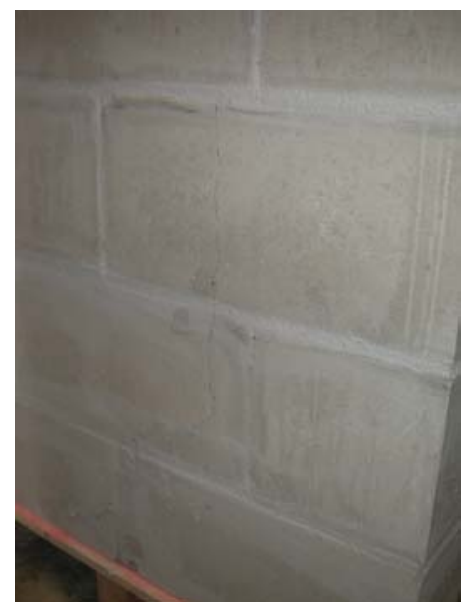

(b)

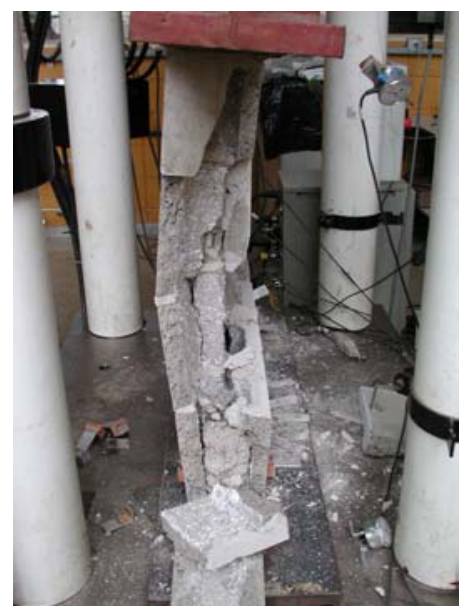

(d)

Figura 4.20 - Fissuração e cenário pós-ruptura das miniparedes.

\subsubsection{Corpos-de-prova}

As propriedades mecânicas do concreto e argamassa que constituem os blocos, prismas e paredes são obtidas a partir dos ensaios de corpos-de-prova. Realizam-se ensaios à compressão axial e compressão diametral com obtenção das deformações longitudinais e transversais. Nos ensaios à compressão axial utilizam-se a placa-padrão e a placa-escova e os ensaios à tração na flexão são realizados com as vigas de concreto e argamassa nos quais também se obtém a energia de fraturamento.

\subsubsection{Corpos-de-prova cilíndricos}

Os corpos-de-prova cilíndricos, tanto os de 100 x $200 \mathrm{~mm}$ (concreto) quanto os $50 \mathrm{x}$ 100 mm (argamassa), são submetidos à compressão axial e compressão diametral para a 
obtenção das resistências à compressão e tração, respectivamente. Nestes ensaios são medidas as deformações longitudinais e transversais, estas nas extremidades e centro do $\mathrm{CP}$, permitindo a determinação do módulo de elasticidade e do coeficiente de Poisson. Os ensaios à compressão axial são realizados a uma taxa de deslocamento constante de $0,005 \mathrm{~mm} / \mathrm{s}$ tanto com a placa-padrão quanto com a placa-escova.

A diferença primordial no comportamento dos CP's 100 × $200 \mathrm{~mm}$ nos distintos ensaios à compressão axial é quanto à fissuração inicial. Nos ensaios-padrão a fissura surge com uma inclinação de aproximadamente $45^{\circ}$ e nos ensaios com placa-escova aparecem praticamente paralelas ao eixo de carregamento. As fissuras verticais, que surgem na iminência da força máxima, proliferam-se por todo o corpo-de-prova e após a ruína apresentam inclinação com as características das fissuras decorrentes do ensaio-padrão. Ao fim dos ensaios, muitas vezes constata-se uma fissuração semelhante em ambos os casos. Contudo, nota-se uma significativa diferença entre as configurações: enquanto o CP submetido ao carregamento com placa-padrão apresenta um formato de ruína tronco-cônico, o que foi submetido à compressão com redução do efeito de confinamento apresenta uma ruína caracterizada por separação vertical, conforme ilustra a Figura 4.21. As fissurações nos ensaios com CP's 50 x 100 mm são proporcionalmente similares à descrição anterior. 


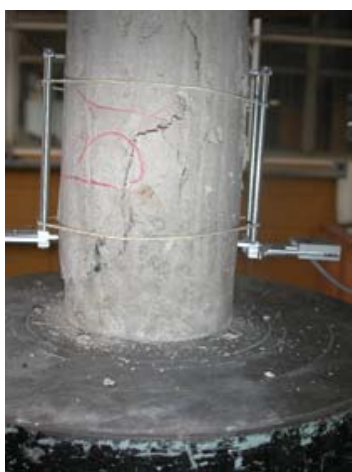

(a)

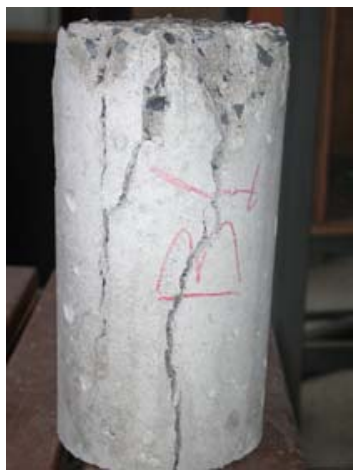

(c)

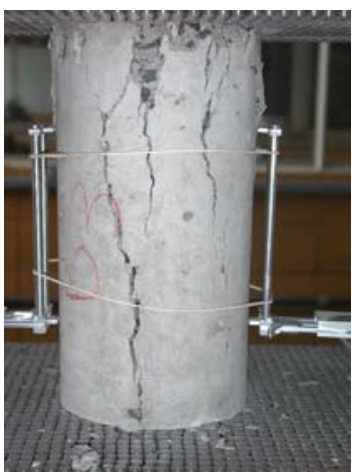

(b)

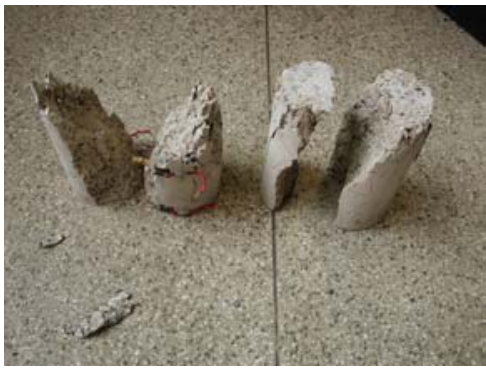

(d)

Figura 4.21 - Fissuração nos corpos-de-prova cilíndricos nos ensaios utilizando-se placa-padrão (a) e placa-escova (b) e (c). Comparação entre os modos de ruína (d).

Para obtenção da resistência à tração, aplica-se uma força na geratriz do corpo-deprova cilíndrico a uma taxa de deslocamento constante de $0,001 \mathrm{~mm} / \mathrm{s}$, possibilitando dessa forma a obtenção dos valores de abertura de fissura após a força máxima de ensaio. Como nos ensaios dos blocos, a caracterização completa do comportamento do material quando submetido a esforços de tração permite a obtenção da energia de fraturamento por um ensaio não padronizado e que deve ter os resultados cuidadosamente analisados.

Quando submetidos à compressão diametral, a fissuração nos CP's é vertical e ocorre abaixo da linha de carregamento, sendo identificada próxima a força máxima de ensaio. Devido à baixa velocidade utilizada, consegue-se evitar que a ruptura do elemento seja brusca e a separação ocorra apenas ao final do descarregamento. A Figura 4.22 ilustra o ensaio à compressão diametral. 


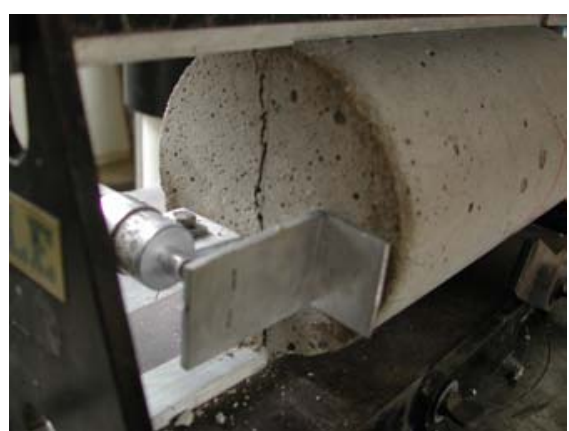

(a)

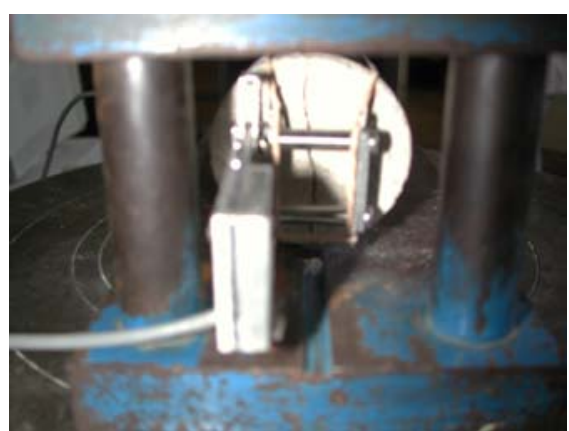

(b)

Figura 4.22 - Ensaio à compressão diametral de corpos-de-prova cilíndricos de concreto (a) e argamassa (b).

\subsubsection{Vigas com entalhe}

Estes ensaios foram planejados seguindo as recomendações da RILEM TC 50-FMC (1985) para obtenção da energia de fraturamento do concreto e da argamassa em ensaios de flexão de três pontos. Por ser um ensaio instável, optou-se por realizá-lo com controle de abertura do entalhe. Utilizaram-se duas taxas de abertura do entalhe durante o ensaio para que estes não se tornassem demasiadamente longos. A taxa utilizada no início do ensaio, até 50\% da força máxima, foi de $0,02 \mathrm{~mm} / \mathrm{min}$, sendo, a partir deste instante, elevada para $0,2 \mathrm{~mm} / \mathrm{min}$ até o completo descarregamento da viga.

A fissura, devido ao entalhe, aparece acima deste e prolonga-se até próximo à superfície de carregamento, contudo não permite a partição da viga. A separação em duas partes ocorre após o ensaio, para medição da área de ligamento que é obtida descontando-se a área de entalhe (medindo sua profundidade em três pontos) da área da seção transversal.

$\mathrm{Na}$ Figura 4.23 é apresentada, juntamente com esquema de ensaio, a fissura na viga e a área de ligamento observada após o ensaio. 


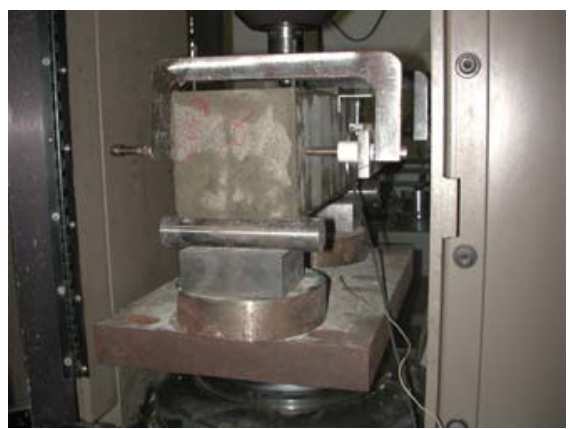

(a)

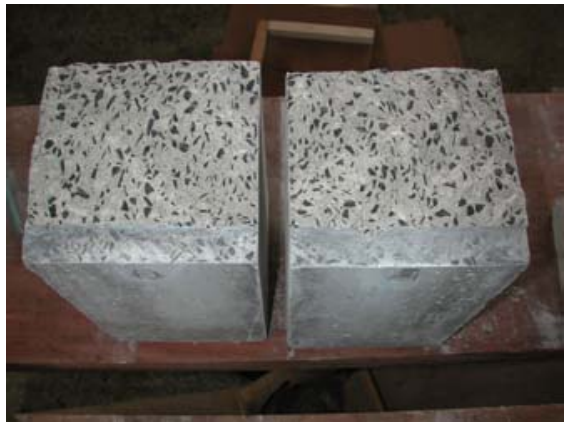

(c)

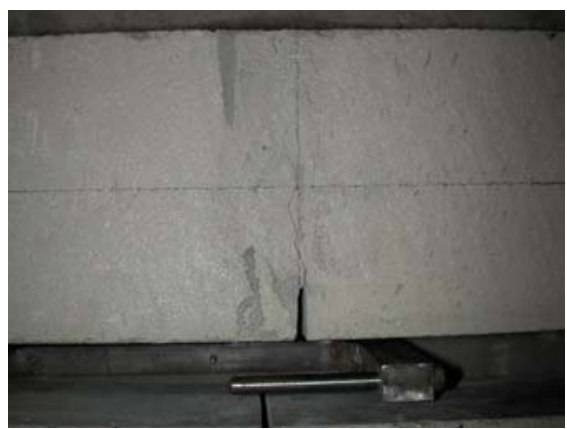

(b)

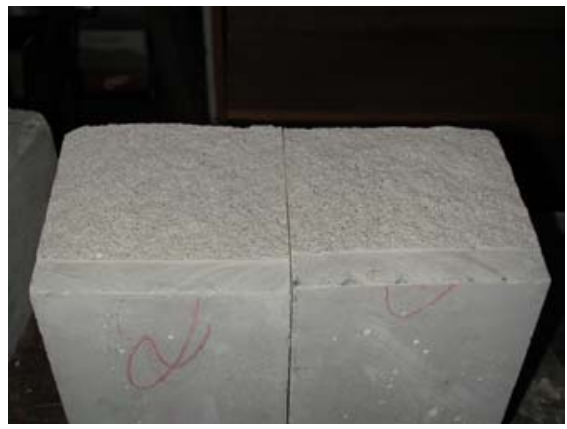

(d)

Figura 4.23 - Esquema de ensaio de flexão de viga em três pontos (a), fissura ocorrida nas vigas (b) e área de ligamento obtida após o término do ensaio com viga de concreto (c) e viga de argamassa (d). 


\section{ANÁLISE DOS RESULTADOS EXPERIMENTAIS}

São apresentados neste capítulo os resultados obtidos no programa experimental desenvolvido para a caracterização das propriedades mecânicas dos elementos de alvenaria e dos seus materiais constituintes.

De forma geral, estabelecem-se correlações entre as propriedades mecânicas de blocos e corpos-de-prova do material que constitui o bloco, tais como a resistência à compressão, resistência à tração e módulo de elasticidade, discutindo-se os valores obtidos em função da forma geométrica dos elementos. Apresenta-se a distribuição de tensões nos blocos e prismas, dedicando especial atenção à influência do efeito de confinamento, discernindo-se os resultados obtidos nos ensaios padronizados daqueles oriundos dos ensaios com placaescova - com alívio do confinamento. Discute-se sobre a deformabilidade das paredes em diferentes regiões, apresentando sua capacidade resistente em função dos parâmetros mecânicos dos materiais que a compõe.

Por fim, apresenta-se uma breve discussão sobre os parâmetros de energia de fratura, correlacionado os resultados obtidos para o concreto e argamassa, conforme as propostas de análise da literatura.

Os ensaios-piloto com blocos vazados de concreto e corpos-de-prova ofereceram resultados com coeficiente de variação satisfatório para este tipo de ensaio, sempre inferior a $10 \%$ e, em geral, próximo a 5\%. Por esta razão, definiu-se para cada grupo de resistência o ensaio de, no mínimo, três exemplares. Os dados apresentados a seguir são referentes à média obtida para cada análise acompanhada pelo respectivo coeficiente de variação. 


\subsection{Comportamento mecânico dos blocos vazados de concreto}

O comportamento mecânico dos elementos é avaliado por meio de dois procedimentos distintos de ensaio: o padronizado, com placas planas de aço maciças, e os ensaios com placa-escova, que possibilitam a redução do efeito de confinamento.

A resistência à compressão média de cada série de ensaios com blocos de concreto $\left(f_{b}\right)$ e seus respectivos corpos-de-prova $\left(f_{c}\right)$ está apresentada na Tabela 5.1. Nesta série, foram feitos ensaios com três blocos de concreto e quatro corpos-de-prova para cada grupo de resistência.

Tabela 5.1 - Resistência à compressão de blocos e corposde-prova - ensaio padrão.

\begin{tabular}{cccc}
\hline Grupo & $\mathrm{f}_{\mathrm{b}}{ }^{1}\left(\mathrm{~N} / \mathrm{mm}^{2}\right)$ & $\mathrm{f}_{\mathrm{c}}\left(\mathrm{N} / \mathrm{mm}^{2}\right)$ & $\mathrm{f}_{\mathrm{b}} / \mathrm{f}_{\mathrm{c}}$ \\
\hline $\mathrm{G} 1$ & $12,7(4,3 \%)$ & $13,4(6,1 \%)$ & 0,95 \\
$\mathrm{G} 2$ & $26,5(4,1 \%)$ & $22,1(4,9 \%)$ & 1,20 \\
G3 & $28,4(3,1 \%)$ & $26,0(2,2 \%)$ & 1,09 \\
G4 & $30,5(0,2 \%)$ & $30,9(6,2 \%)$ & 0,99 \\
GA & $22,6(4,9 \%)^{2}$ & $20,4(4,7 \%)^{3}$ & 1,11 \\
GB & $25,1(9,5 \%)$ & $23,6(3,0 \%)$ & 1,06 \\
GC & $27,1(2,1 \%)$ & $24,2(9,2 \%)$ & 1,12 \\
\hline
\end{tabular}

Entre parênteses: coeficiente de variação

${ }^{1} \mathrm{O}$ valor da resistência à compressão refere-se à área líquida do bloco

${ }^{2}$ Valor resultante do ensaio de oito blocos de concreto

${ }^{3}$ Valor resultante do ensaio de 12 corpos-de-prova

Observa-se que, na maioria dos grupos, o valor da resistência à compressão obtido nos ensaios com blocos de concreto é maior que o obtido para seu respectivo corpo-de-prova, ou seja, a estrutura do bloco, formada por paredes delgadas longitudinais e transversais e constituída por um concreto de determinada resistência à compressão, apresenta valor de resistência maior que o de um corpo-de-prova cilíndrico constituído pelo mesmo material.

O corpo-de-prova apresenta relação entre altura e maior dimensão transversal $(\mathrm{h} / \mathrm{t})$ igual a 2 , enquanto que o bloco possui $\mathrm{h} / \mathrm{t} \sim 0,5$. Assim, em decorrência das diferentes geometrias e das condições de confinamento no topo e na base, não ocorre uma distribuição de tensões ao longo da altura do bloco tão uniforme quanto a que ocorre nos CP's e, como conseqüência, os blocos apresentam maior capacidade resistente. A atuação do confinamento no bloco também é dependente de sua configuração geométrica - espessura das paredes e índice de vazios. 
A Figura 5.1 apresenta a evolução da resistência à compressão dos blocos de concreto em função da resistência à compressão dos corpos-de-prova, segundo uma tendência linear com interseção na origem e variabilidade $\mathrm{R}^{2}=0,90$, expressa pela Equação (5.1).

$$
\mathrm{f}_{\mathrm{b}}=1,078 \mathrm{f}_{\mathrm{c}}
$$

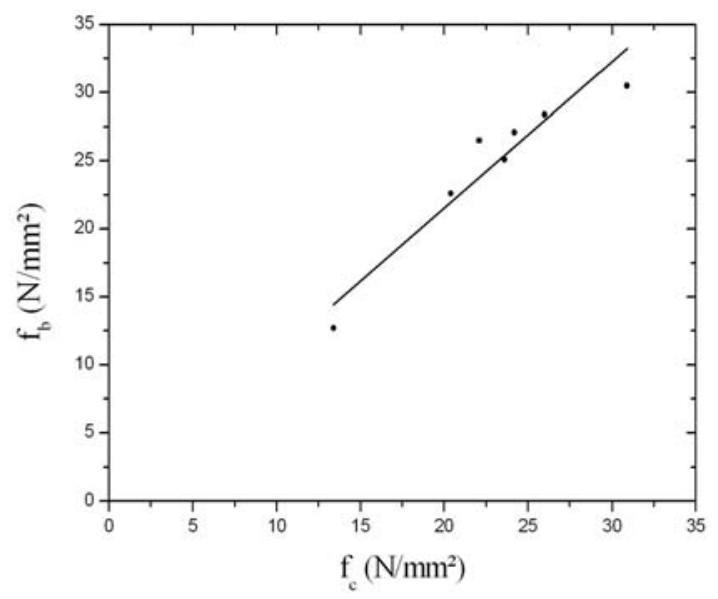

Figura 5.1 - Evolução da resistência à compressão dos blocos de concreto em função da resistência à compressão do concreto que o constitui - ensaio padrão.

Os grupos G1 e G4 apresentam resistência média à compressão do corpo-de-prova cilíndrico superior à do bloco, relação contrária à tendência geral. Esse comportamento pode ser atribuído à maior variabilidade dos resultados dos ensaios dos CP's, como conseqüência das imperfeições existentes na produção do concreto e de sua heterogeneidade.

Na Tabela 5.2 está o resumo dos valores dos ensaios à tração com blocos vazados de concreto $\left(f_{b t}\right)$, relacionados com os valores de sua resistência à compressão - obtidos a partir do ensaio de três amostras em cada grupo de resistência. É possível observar nestes dados que não houve diferença significativa entre a relação das resistências quando se realiza o ensaio de tração com aplicação da força no centro do vazio do bloco ou no septo transversal central. A resistência à tração dos blocos de concreto vale aproximadamente $6 \%$ da resistência à compressão destes, comportamento representado pela tendência linear da Figura 5.2a. 
Tabela 5.2 - Resistência à compressão e à tração de blocos de concreto.

\begin{tabular}{cccc}
\hline Grupo & $\mathrm{f}_{\mathrm{b}}\left(\mathrm{N} / \mathrm{mm}^{2}\right)$ & $\mathrm{f}_{\mathrm{bt}}\left(\mathrm{N} / \mathrm{mm}^{2}\right)$ & $\mathrm{f}_{\mathrm{bt}} / \mathrm{f}_{\mathrm{b}}$ \\
\hline $\mathrm{G} 1$ & $12,7(4,3 \%)$ & $0,8(10,3 \%)$ & $0,063^{*}$ \\
$\mathrm{G} 2$ & $26,5(4,1 \%)$ & $1,7(4,8 \%)$ & 0,064 \\
$\mathrm{G} 3$ & $28,4(3,1 \%)$ & $1,8(7,1 \%)$ & 0,063 \\
$\mathrm{G} 4$ & $30,5(0,2 \%)$ & $2,0(9,8 \%)$ & 0,066 \\
$\mathrm{GA}$ & $22,6(4,9 \%)$ & $1,6(7,9 \%)^{1}$ & $0,071^{*}$ \\
$\mathrm{~GB}$ & $25,1(9,5 \%)$ & $1,5(12,7 \%)$ & $0,060^{*}$ \\
$\mathrm{GC}$ & $27,1(2,1 \%)$ & $1,6(6,5 \%)$ & 0,059 \\
\hline
\end{tabular}

Entre parênteses: coeficiente de variação

${ }^{1}$ Valor resultante do ensaio de cinco blocos de concreto

* Aplicação da força ao longo do septo transversal central

A resistência média à tração do concreto $\left(\mathrm{f}_{\mathrm{ct}}\right)$, obtida nos ensaios de quatro $\mathrm{CP}$ 's, e as suas correlações com a resistência à compressão são apresentadas na Tabela 5.3. A correlação entre esses dois parâmetros é definida por uma tendência exponencial, apresentada na Figura 5.2b e definida pela Equação (5.2) com $\mathrm{R}^{2}=0,843$.

$$
\mathrm{f}_{\mathrm{ct}}=0,21 \mathrm{f}_{\mathrm{c}}^{0,77}
$$

Tabela 5.3 - Resistência à compressão e à tração dos corposde-prova de concreto.

\begin{tabular}{cccc}
\hline Grupo & $\mathrm{f}_{\mathrm{c}}\left(\mathrm{N} / \mathrm{mm}^{2}\right)$ & $\mathrm{f}_{\mathrm{ct}}\left(\mathrm{N} / \mathrm{mm}^{2}\right)$ & $\mathrm{f}_{\mathrm{ct}} / \mathrm{f}_{\mathrm{c}}$ \\
\hline $\mathrm{G} 1$ & $13,4(6,1 \%)$ & $1,5(5,5 \%)$ & 0,11 \\
$\mathrm{G} 2$ & $22,1(4,9 \%)$ & $2,3(12,6 \%)$ & 0,10 \\
$\mathrm{G} 3$ & $26,0(2,2 \%)$ & $2,6(10,9 \%)$ & 0,10 \\
G4 & $30,9(6,2 \%)$ & $2,8(11,3 \%)$ & 0,09 \\
GA & $20,4(4,7 \%)$ & $2,0(10,2)$ & 0,10 \\
GB & $23,6(3,0 \%)$ & $2,2(14,9 \%)$ & 0,09 \\
GC & $24,2(9,2 \%)$ & $2,8(0,1 \%)$ & 0,12 \\
\hline
\end{tabular}

Entre parênteses: coeficiente de variação

${ }^{1}$ Valor resultante do ensaio de dez corpos-de-prova 


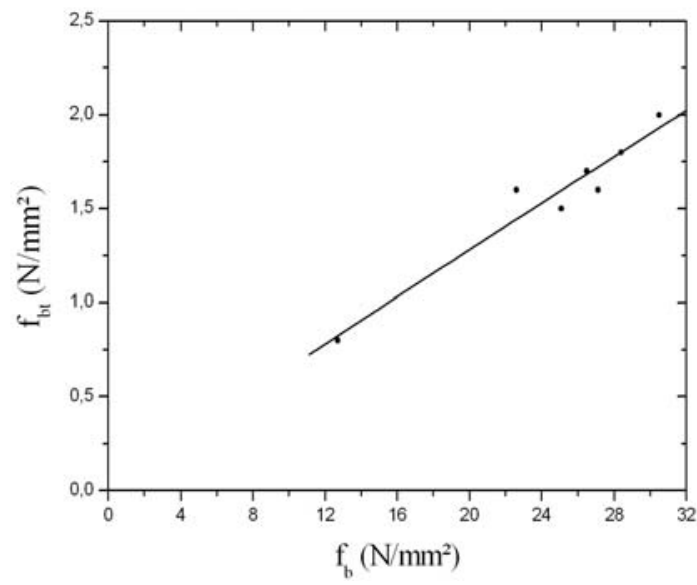

(a)

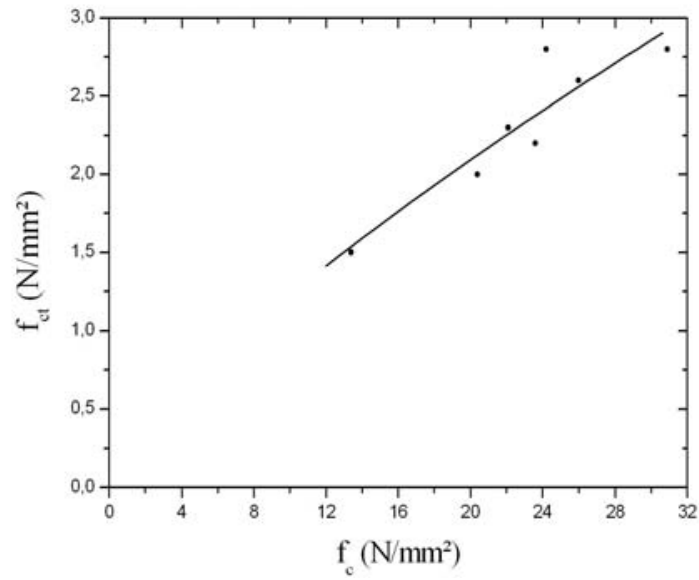

(b)

Figura 5.2 - Evolução da resistência à tração em função do aumento da resistência à compressão. Blocos de concreto (a) e corpos-de-prova (b).

Nota-se que os coeficientes de variação relativos aos ensaios à tração são mais altos que os da série de ensaios à compressão, principalmente por essa propriedade ser mais sensível às condições de ensaio e de produção, como por exemplo, o adensamento e a cura.

A resistência à tração do bloco de concreto é correlacionada com a resistência à tração do concreto por meio da Equação (5.3) $\left(\mathrm{R}^{2}=0,789\right)$, representada pelo gráfico da Figura 5.3.

$$
\mathrm{f}_{\mathrm{bt}}=0,68 \mathrm{f}_{\mathrm{ct}}
$$

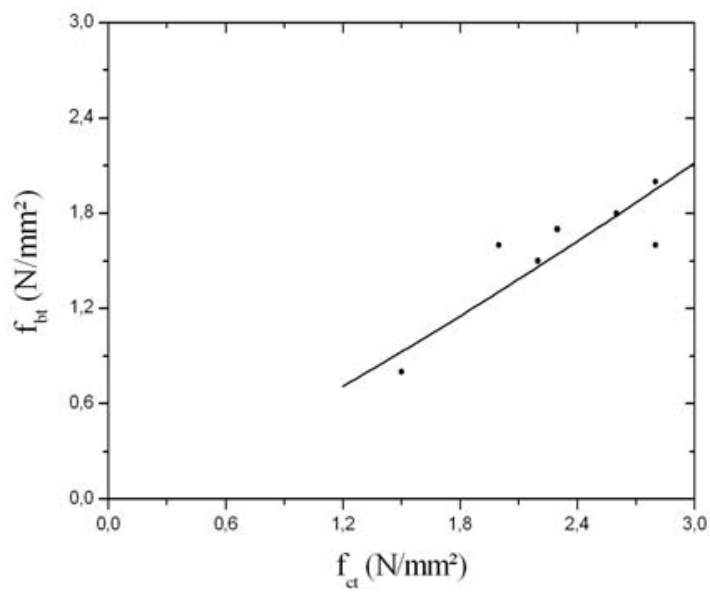

Figura 5.3 - Correlação entre a resistência à tração do corpo-de-prova e do bloco de concreto.

Há significativa diferença entre os valores obtidos de resistência à compressão e à tração quando se realizam ensaios com corpos-de-prova e blocos de concreto, ou seja, a 
obtenção de tais valores é fortemente dependente da forma geométrica dos elementos adotados.

Contudo, é possível estabelecer fatores interdependentes em função da forma de ensaio, ou seja, a partir do ensaio de um bloco vazado de concreto é possível prever as propriedades mecânicas do concreto que o constitui.

As propriedades mecânicas obtidas nos ensaios com blocos vazados de concreto diferem das obtidas diretamente em corpos-de-prova padronizados, conforme os métodos comumente utilizados na tecnologia do concreto para a caracterização de suas propriedades mecânicas. Salienta-se que o aprofundamento do conhecimento das propriedades mecânicas do concreto que constitui o bloco mostra-se importante para o entendimento do comportamento desses elementos além de possibilitar a elaboração de um modelo teórico mais preciso.

\subsubsection{Ensaio modificado com redução do efeito de confinamento}

A redução do efeito de confinamento nos ensaios com blocos de concreto é avaliada por meio do ensaio modificado, sendo os resultados apresentados na Tabela 5.4 juntamente com os valores obtidos nos ensaios de corpos-de-prova. Nesta série de ensaios ocorre uma inversão entre as correlações de resistência à compressão, em relação às obtidas nos ensaios padronizados, sendo o valor obtido para os corpos-de-prova $\left(f_{c, \text { mod }}\right)$ maior que para os blocos de concreto $\left(f_{b, \text { mod }}\right)$.

No ensaio padronizado os valores de resistência dos blocos são, em média, 8\% superiores aos obtidos em corpos-de-prova, enquanto nos ensaios modificados esses valores são aproximadamente $10 \%$ inferiores. Ou seja, o alívio do efeito de confinamento, mais efetivo nos blocos de concreto, tem maior influência na redução de sua resistência que nos corpos-de-prova. 
Tabela 5.4 - Resistência à compressão de blocos e corpos-deprova - ensaio modificado.

\begin{tabular}{cccc}
\hline Grupo & $\mathrm{f}_{\mathrm{b}, \bmod }\left(\mathrm{N} / \mathrm{mm}^{2}\right)$ & $\mathrm{f}_{\mathrm{c}, \bmod }\left(\mathrm{N} / \mathrm{mm}^{2}\right)$ & $\mathrm{f}_{\mathrm{b}, \bmod } / \mathrm{f}_{\mathrm{c}, \bmod }$ \\
\hline G1 & $10,4(11,1 \%)$ & $12,0(8,7 \%)$ & 0,87 \\
G2 & $19,5(7,0 \%)$ & $22,0(4,1 \%)$ & 0,89 \\
G3 & $22,7(3,2 \%)$ & $25,5(4,8 \%)$ & 0,89 \\
G4 & $23,7(2,5 \%)$ & $28,6(9,6 \%)$ & 0,83 \\
GA & $18,4(3,6 \%)^{1}$ & $19,1(3,6 \%)^{2}$ & 0,96 \\
GB & $19,9(1,6 \%)$ & $22,9(4,3 \%)$ & 0,87 \\
GC & $22,7(3,8 \%)$ & $22,5(5,4 \%)$ & 1,00
\end{tabular}

Entre parênteses: coeficiente de variação

${ }^{1}$ Valor resultante do ensaio de oito blocos de concreto

${ }^{2}$ Valor resultante do ensaio de 12 corpos-de-prova

Para o conjunto de resultados obtidos, a curva de correlação entre as resistências é definida pela Equação (5.4) e está apresentada na Figura 5.4 com variância $R^{2}=0,90$.

$$
\mathrm{f}_{\mathrm{b}, \text { mod }}=0,9 \mathrm{f}_{\mathrm{c}, \bmod }
$$

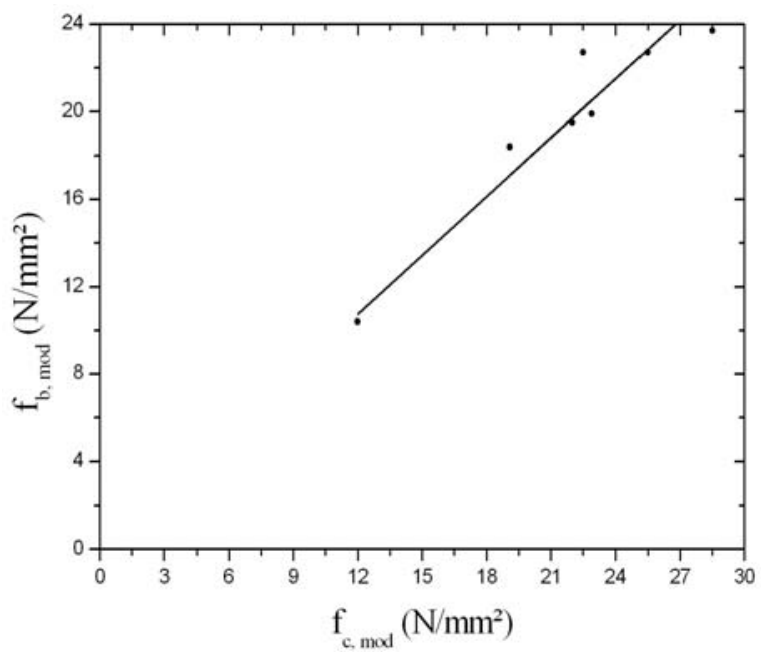

Figura 5.4 - Evolução da resistência à compressão dos blocos de concreto em função da resistência à compressão do concreto que o constitui - ensaio modificado.

A comparação entre os valores da Tabela 5.1 e da Tabela 5.4 indica que a resistência à compressão dos blocos obtidos por meio do ensaio-padrão $\left(\mathrm{f}_{\mathrm{b}}\right)$ apresenta aumento médio de $26 \%$ em relação à resistência à compressão dos blocos obtida com o ensaio modificado $\left(f_{b, \bmod }\right)$. Essa evolução linear é representada na Figura 5.5a e pela Equação (5.5). 
Procedendo-se a mesma análise para os CP's, uma menor diferença entre os valores de resistência é obtida devida à menor magnitude do efeito de confinamento quando submetidos ao ensaio padronizado, como já se discutiu. A Figura 5.5b ilustra os valores relativos aos ensaios com corpos-de-prova, obtidos no ensaio-padrão e ensaio modificado, os quais apresentam uma redução média de $5 \%$ do valor da resistência à compressão. A correlação deste caso é representada pela Equação (5.6).

$$
\begin{gathered}
\mathrm{f}_{\mathrm{b}, \bmod }=0,8 \mathrm{f}_{\mathrm{b}} \\
\mathrm{f}_{\mathrm{c}, \bmod }=0,95 \mathrm{f}_{\mathrm{c}}
\end{gathered}
$$

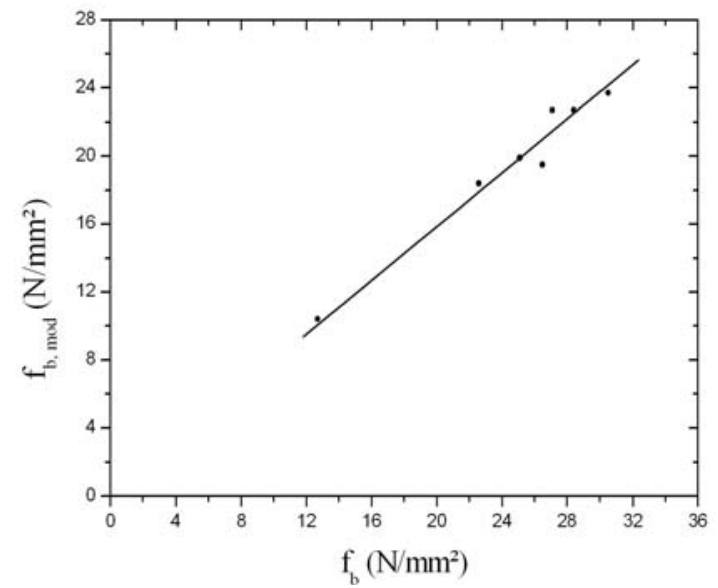

(a)

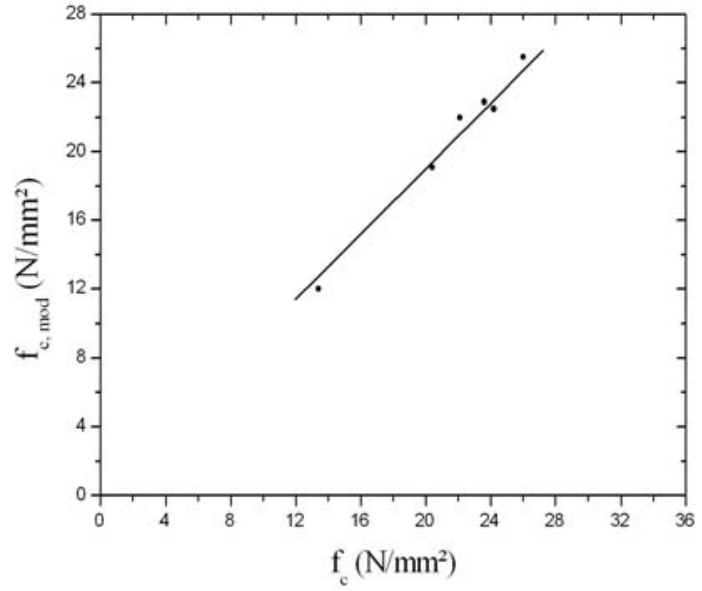

(b)

Figura 5.5 - Resistência à compressão obtida no ensaio modificado e no ensaio padrão: blocos de concreto (a) e corpos-de-prova (b).

O efeito de confinamento claramente modifica o valor da resistência à compressão de elementos constituídos por um mesmo material, mas de distintas geometrias. A configuração geométrica do elemento interfere na mudança do comportamento em função da maior ou menor influência da restrição das placas de ensaio, justificando assim, a inversão das correlações entre os valores de resistência à compressão de blocos e corpos-de-prova obtidos nos distintos procedimentos de ensaio - sendo que os valores obtidos para o corpo-de-prova praticamente não se alteram, situação oposta à encontrada nos ensaios com blocos.

O efeito de confinamento é oriundo da restrição lateral causada pelas forças de atrito entre as placas de ensaio e o elemento - bloco de concreto ou corpo-de-prova cilíndrico -, originando tensões transversais no topo e na base destes, induzindo-os a um estado multiaxial de tensões. A intensidade das tensões transversais provenientes da extremidade dos elementos é inversamente proporcional à relação $\mathrm{h} / \mathrm{t}$, com o conseqüente aumento da resistência à 
compressão. Isso significa que, aumentando-se a altura do elemento e mantendo-se as demais dimensões constantes, menores valores de resistência à compressão serão obtidos. A forma geométrica e a porcentagem de vazios do elemento, no caso de blocos vazados, também influenciam a configuração da distribuição de tensões.

Barbosa (2004), a fim de avaliar a redução da resistência à compressão em blocos vazados de concreto alterando-se apenas a altura dos elementos, realizou ensaios com prismas de dois e três blocos sem junta de argamassa, unindo-os por uma fina camada de adesivo à base de epóxi. A redução da resistência à compressão de um bloco de concreto, quando este tem sua altura aumentada em duas e três vezes, é da ordem de $20 \%$ e $40 \%$, respectivamente.

Page e Kleeman (1991) realizaram testes com bloco vazados de concreto utilizando placas constituídas por filamentos delgados de aço, similares às utilizadas na presente pesquisa, obtendo-se redução da resistência à compressão da ordem de $28 \%$. A maior redução da resistência à compressão obtida por estes pesquisadores, em relação aos valores obtidos da presente pesquisa, é atribuída às diferentes configurações geométricas dos blocos de concreto analisados.

Para este conjunto particular de resultados, dentro dos limites de resistência à compressão adotados, pode-se indicar um fator de correção da resistência do bloco vazado de concreto $(\eta)$ em função do efeito de confinamento. A Equação (5.7) é função da altura da unidade $(\mathrm{h})$ e das áreas líquida $\left(\mathrm{A}_{1}\right)$ e bruta $\left(\mathrm{A}_{\mathrm{b}}\right)$ do bloco, em milímetros. A formulação, obtida a partir da regressão dos dados experimentais, é mencionada apenas como referência para indicar as variáveis intervenientes no confinamento do bloco vazado de concreto e, como já se alertou, é de aplicação restrita a este conjunto de resultados.

$$
\eta=\frac{A_{b}}{A_{1}\left(10 h / \sqrt{A_{1}}\right)^{0,335}}
$$

Portanto, a resistência à compressão corrigida para os blocos vazados de concreto é obtida por meio da Equação (5.8).

$$
\mathrm{f}_{\mathrm{b}, \mathrm{corr}}=\eta \mathrm{f}_{\mathrm{b}}
$$

Uma vez demonstrada experimentalmente a influência do efeito de confinamento, enfatiza-se a necessidade de uma avaliação mais ampla, utilizando-se modelos teóricos para a simulação de diferentes geometrias de blocos de concreto. 


\subsubsection{Módulo de elasticidade do concreto e deformações no bloco vazado}

O módulo de elasticidade é o parâmetro que representa a proporcionalidade entre tensão e deformação em um material no regime elástico-linear. A forma de obtenção deste parâmetro varia entre as normas, seja no método de ensaio ou em relação à porcentagem de carga a considerar.

No caso de ensaio de corpos-de-prova cilíndricos de concreto, o módulo de elasticidade é obtido pela inclinação da reta que une dois pontos na curva tensão-deformação, definidos por um valor de deformação específica inicial igual a $50 \times 10^{-6}$ e a tensão equivalente a $30 \%$ da resistência à compressão do elemento.

A Figura 5.6 apresenta as relações obtidas entre a resistência à compressão dos corpos-de-prova cilíndricos e o valor do módulo de elasticidade. Essa relação é representada pela Equação (5.9), similar à sugerida pela NBR 6118 (2003), e que está sendo aplicada também aos resultados dos ensaios com redução do efeito de confinamento.

$$
\mathrm{E}_{\mathrm{c}}=5600 \mathrm{f}_{\mathrm{c}}^{0,45}
$$

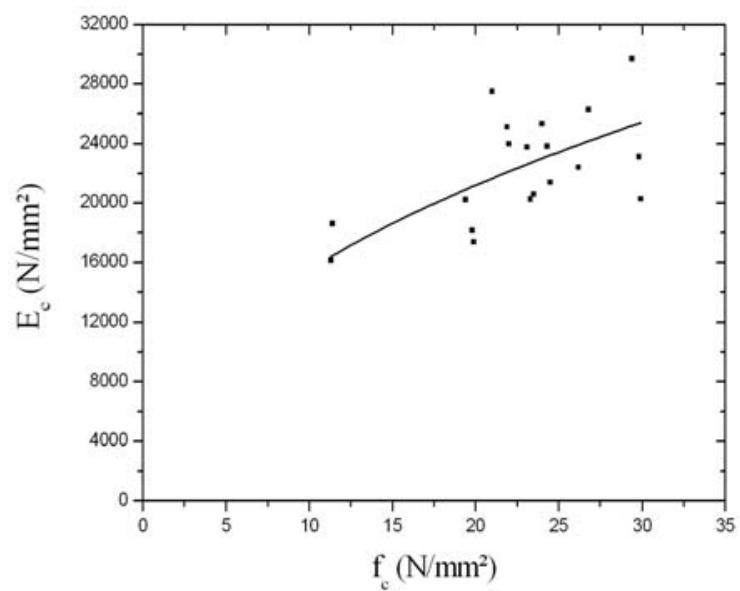

Figura 5.6 - Relação obtida entre a resistência à compressão e o módulo de elasticidade de corpos-de-prova cilíndricos.

No caso de blocos vazados, a distribuição de tensões ao longo das paredes longitudinais e septos transversais não é uniforme, portanto as deformações também não são. Como a distribuição de deformações no bloco de concreto é similar para os quatro grupos de resistência analisados (G1, G2, G3 e G4), apresenta-se a seguir a análise de apenas um deles. Adotam-se como referência os pontos indicados na Figura 5.7. 
(D)

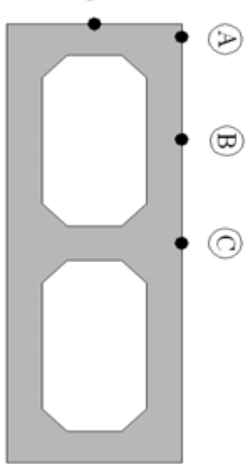

Figura 5.7 - Localização dos pontos adotados na análise das deformações no bloco de concreto.

Apresentam-se na Tabela 5.5 as propriedades mecânicas obtidas nos ensaios à compressão axial de blocos e corpos-de-prova cilíndricos do grupo G3. Nela também estão apresentados os valores de deformação em distintos pontos do bloco, em nível de carregamento equivalente a $30 \%$ de sua resistência à compressão. O valor médio do módulo de elasticidade do concreto, encontrado para este grupo, é $23787 \mathrm{~N} / \mathrm{mm}^{2}$.

Tabela 5.5 - Parâmetros obtidos nos ensaios com blocos vazados
e corpos-de-prova de concreto do grupo G3 - ensaio padrão.
\begin{tabular}{|ccccc}
\hline $\mathrm{f}_{\mathrm{c}}\left(\mathrm{N} / \mathrm{mm}^{2}\right)$ & $\mathrm{f}_{\mathrm{b}}\left(\mathrm{N} / \mathrm{mm}^{2}\right)$ & $\mathrm{E}_{\mathrm{c}}\left(\mathrm{N} / \mathrm{mm}^{2}\right)$ & $\varepsilon(\mu)\left(\right.$ para $\left.0,3 \mathrm{f}_{\mathrm{b}}\right)$ \\
\hline & & & $\mathrm{A}$ & 266 \\
\multirow{2}{*}{26,0} & \multirow{2}{*}{28,4} & 23787 & $\mathrm{~B}$ & 283 \\
& & & $\mathrm{C}$ & 316 \\
& & & $\mathrm{D}$ & 206 \\
\hline
\end{tabular}

$$
1 \mu=10^{-6} \mathrm{~mm} / \mathrm{mm}
$$

Os perfis de deformação do bloco, em três distintos níveis de carregamento, são apresentados na Figura 5.8.

As maiores deformações ocorrem na região central, nos pontos $\mathrm{B}$ e $\mathrm{C}$, contrastando com os menores valores na extremidade do bloco. Esse comportamento deve-se à geometria do bloco, o que leva a distintos valores de rigidez nas diversas regiões influenciadas pelo efeito de confinamento. Essa tendência é identificada até o nível de $70 \%$ da resistência do bloco, quando se altera significativamente devida à intensa fissuração e a conseqüente redistribuição de tensões. 


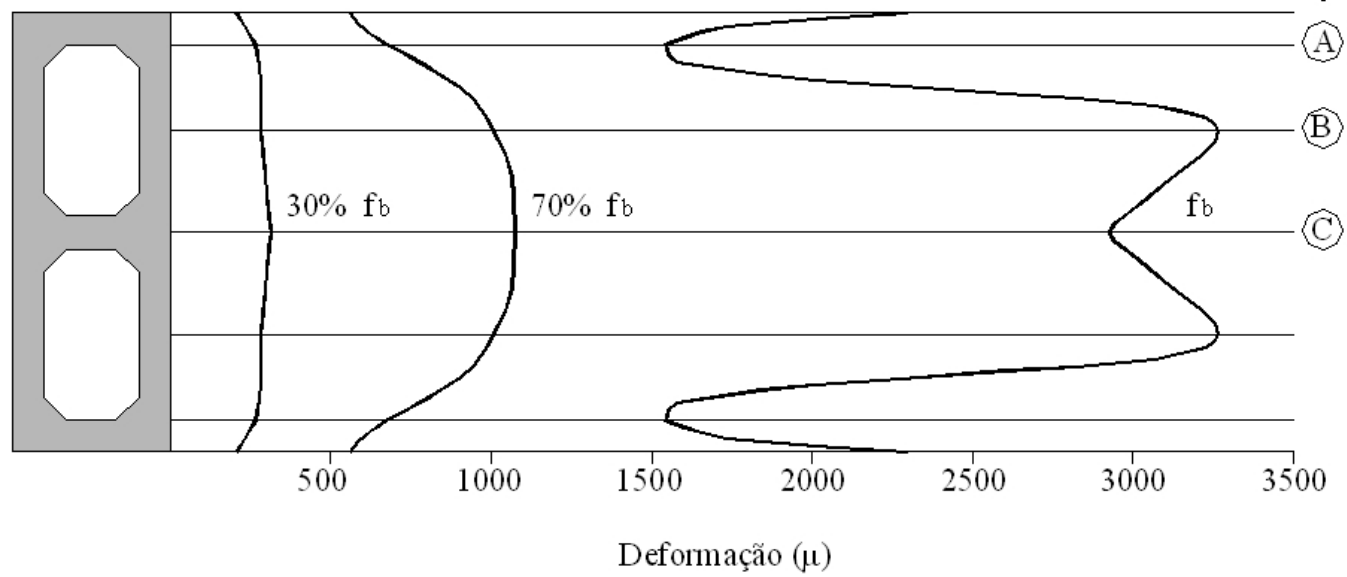

Figura 5.8 - Perfil de deformações ao longo do bloco em distintos níveis de carregamento do ensaio padrão - grupo G3.

Quanto ao valor do módulo de elasticidade dos blocos, cabe uma discussão mais detalhada. A distribuição não uniforme de tensões ao longo das paredes longitudinais e dos septos transversais ocasiona diferentes valores de deformação que, em um modelo experimental, podem ser mensurados por meio de instrumentos de medição - como os valores dados na Tabela 5.5. Por outro lado, os valores de tensão são desconhecidos e, por isso, para efeito de determinação do módulo de elasticidade do bloco, usualmente se adota um valor de tensão de referência - razão entre a força aplicada no topo do bloco e sua área líquida. Conceitualmente, o módulo de elasticidade assim obtido não representa a relação entre a tensão e deformação, já que o bloco, durante o ensaio-padrão, está submetido a tensões transversais que invalidam tal procedimento.

Como estudo de caso, com o intuito de elucidar essa questão, são apresentados na Tabela 5.6 os valores do módulo de elasticidade do bloco, que na verdade são apenas valores parentes $\left(\mathrm{E}_{\mathrm{b}, \mathrm{ap}}\right)$, ou convencionais - posto que resultam, enfatizando mais uma vez, da divisão da tensão de referência pela deformação medida nos ensaios em distintos pontos do bloco. Tais valores de módulo de elasticidade aparente do bloco variam entre $25979 \mathrm{~N} / \mathrm{mm}^{2}$ e $41558 \mathrm{~N} / \mathrm{mm}^{2}$. Apresenta-se também a relação entre os valores aparentes do bloco e o valor do módulo de elasticidade do concreto, obtido no ensaio de corpos-de-prova cilíndricos. 
Tabela 5.6 - Comparação entre o módulo de elasticidade do concreto e os valores aparentes obtidos em distintos pontos do bloco. Ensaio-padrão do grupo G3.

\begin{tabular}{cccc}
\hline $\mathrm{E}_{\mathrm{c}}\left(\mathrm{N} / \mathrm{mm}^{2}\right)$ & \multicolumn{2}{c}{$\mathrm{E}_{\text {b,ap. }}\left(\mathrm{N} / \mathrm{mm}^{2}\right)$} & $\mathrm{E}_{\text {b,ap. }} / \mathrm{E}_{\mathrm{c}}$ \\
\hline \multirow{2}{*}{23787} & $\mathrm{~A}$ & 32234 & 1,36 \\
& $\mathrm{~B}$ & 30290 & 1,27 \\
& $\mathrm{C}$ & 25979 & 1,09 \\
& $\mathrm{D}$ & 41558 & 1,75 \\
\hline
\end{tabular}

Os pontos centrais B e C apresentam os valores do módulo de elasticidade aparente mais próximo do valor obtido para o concreto, não diferindo mais que $30 \%$. Já os pontos extremos não fornecem valores condizentes ao encontrado para o concreto.

Essa distinção de valores relativos ao módulo de elasticidade reflete a dificuldade em se definir as propriedades mecânicas para o material que constitui um bloco vazado de concreto, tal como já visto em relação à previsão do valor da resistência do material que o constitui. Assim, a atribuição de um valor para o módulo de elasticidade do material deve ser realizada com extrema prudência, para que a metodologia adotada na determinação dessa propriedade seja a que forneça resultados de forma mais coerente.

Análise semelhante é efetuada para os blocos submetidos ao ensaio modificado, com placa-escova, cujos dados estão sumarizados na Tabela 5.7.

Tabela 5.7 - Parâmetros obtidos nos ensaios com blocos vazados e corposde-prova de concreto do grupo G3 - ensaio modificado.

\begin{tabular}{ccccc}
\hline $\mathrm{f}_{\mathrm{c}}\left(\mathrm{N} / \mathrm{mm}^{2}\right)$ & $\mathrm{f}_{\mathrm{b}, \bmod }\left(\mathrm{N} / \mathrm{mm}^{2}\right)$ & $\mathrm{E}_{\mathrm{c}}\left(\mathrm{N} / \mathrm{mm}^{2}\right)$ & $\varepsilon(\mu)$ para $\left(0,3 \mathrm{f}_{\mathrm{b}, \bmod }\right)$ \\
\hline & & & A & 286 \\
25,5 & 22,7 & 22869 & B & 283 \\
& & C & 307 \\
& & D & 318 \\
\hline
\end{tabular}

$1 \mu=10^{-6} \mathrm{~mm} / \mathrm{mm}$

O alívio do confinamento acarreta uma distribuição mais uniforme das deformações ao longo das paredes do bloco. É possível notar na Figura 5.9 que além da uniformização, os valores de deformação são bem inferiores aos obtidos no ensaio padronizado já que a forma de ruína dos ensaios é distinta. Enquanto no ensaio-padrão a fissuração dos blocos é diagonal, quase sempre atingindo os instrumentos de medição, nos ensaios modificados a direção das fissuras é vertical. 


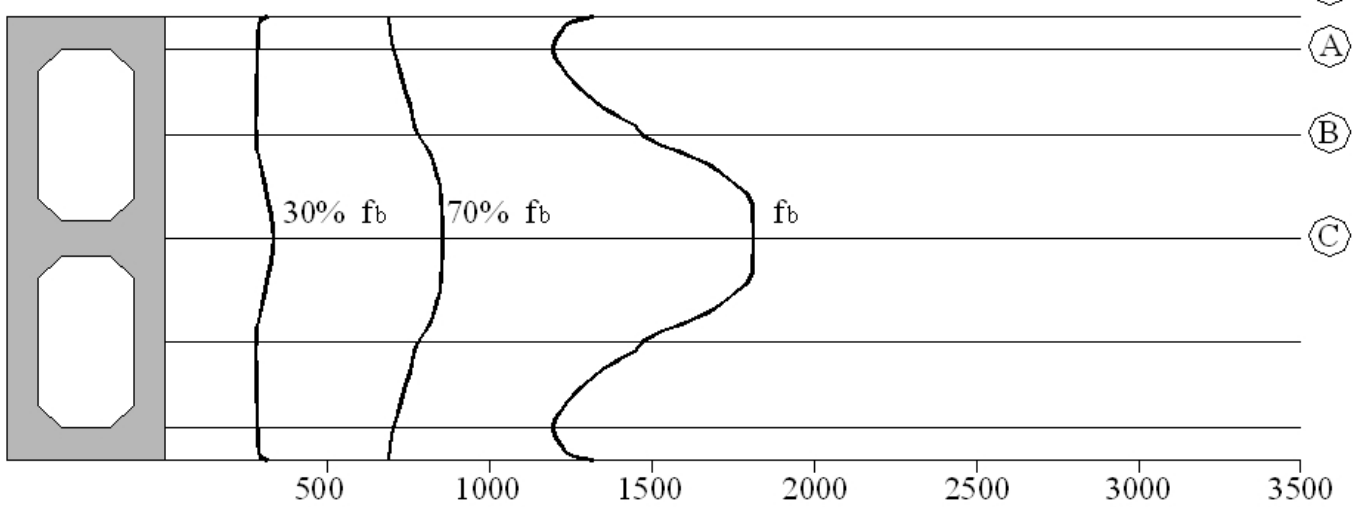

Deformação $(\mu)$

Figura 5.9 - Perfil de deformações ao longo do bloco em distintos níveis de carregamento do ensaio modificado - grupo G3.

Os valores do módulo de elasticidade aparente do bloco são próximos ao valor obtido para o concreto no ensaio com corpo-de-prova, não diferindo mais que 6\% (Tabela 5.8).

Tabela 5.8 - Comparação entre o módulo de elasticidade do concreto e os valores aparentes obtidos em distintos pontos do bloco. Ensaio modificado do grupo G3.

\begin{tabular}{cccc}
\hline $\mathrm{E}_{\mathrm{c}}\left(\mathrm{N} / \mathrm{mm}^{2}\right)$ & \multicolumn{2}{c}{$\mathrm{E}_{\text {b,ap. }}\left(\mathrm{N} / \mathrm{mm}^{2}\right)$} & $\mathrm{E}_{\text {b,ap. }} / \mathrm{E}_{\mathrm{c}}$ \\
\hline \multirow{2}{*}{22869} & A & 23836 & 1,04 \\
& B & 24073 & 1,05 \\
& C & 22160 & 0,97 \\
& D & 21424 & 0,94 \\
\hline
\end{tabular}

Comparando-se os comportamentos distintos dos blocos em decorrência das condições de contorno do ensaio, pode-se concluir que:

a) a maior uniformidade ao longo das etapas de carregamento prevalece nos ensaios modificados, contrapondo-se ao comportamento observado no ensaio-padrão;

b) quando atingida a tensão correspondente a $0,7 \mathrm{f}_{\mathrm{b}}$, o bloco submetido ao ensaiopadrão tem as diferenças entre os valores de deformações acentuadas, contrapondo-se à uniformidade da distribuição nos ensaios modificados;

c) as diferenças entre os valores de deformação são acentuadas na ruína, devidas ao aumento da fissuração em ambos os ensaios e em virtude da forma de ruína;

d) o ensaio com placa-escova, embora reduza o efeito de confinamento, não permite a sua completa anulação, pois ainda existe atrito, apesar de pequeno, 
entre cada haste de aço e a superfície do bloco. Assim, num suposto ensaio sem o efeito de confinamento, espera-se a uniformização total dos perfis de deformação.

Apresenta-se na Figura 5.10 o gráfico tensão-deformação obtido nos ensaios com o bloco vazado de concreto em distintos pontos de medição. É necessário enfatizar que a tensão considerada no gráfico refere-se à tensão de referência, que corresponde à relação entre o valor da força aplicada no topo do bloco e a sua área líquida. Enquanto no ensaio-padrão é nítida a diferença entre as curvas dos distintos pontos, no ensaio modificado esta diferença é pouco significativa.

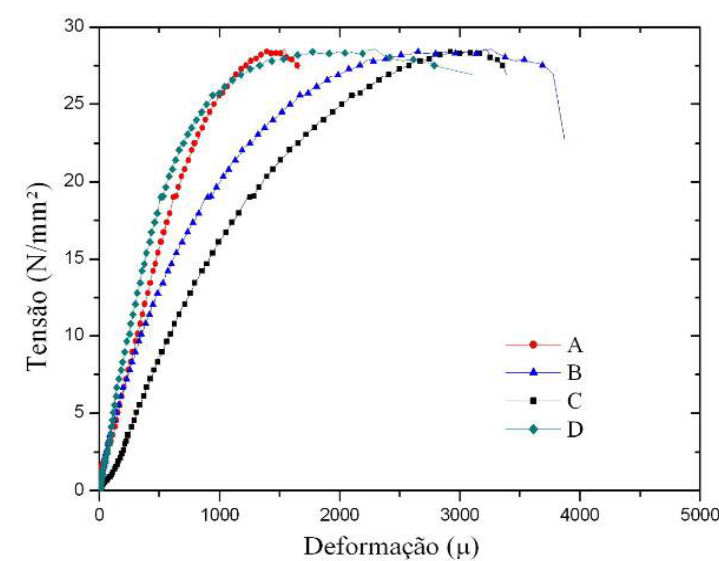

(a)

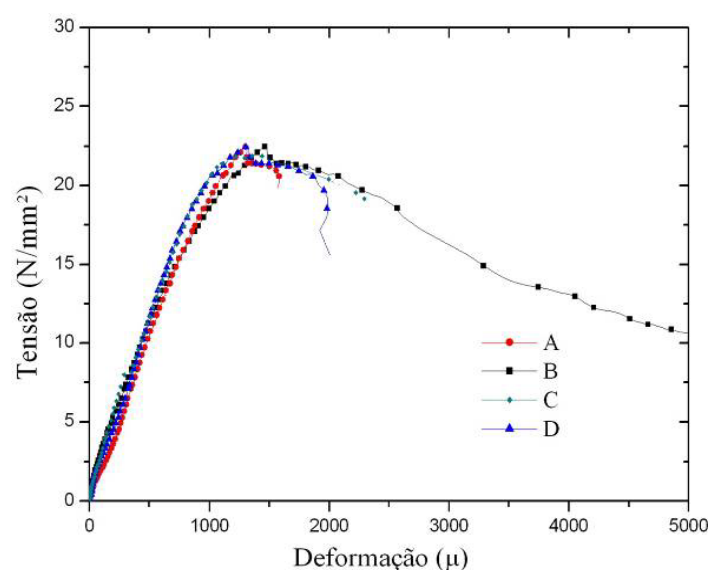

(b)

Figura 5.10 - Diagramas tensão-deformação dos blocos vazados de concreto obtido no ensaiopadrão (a) e ensaio modificado (b).

As diferenças entre ambos os ensaios com corpos-de-prova cilíndricos são mínimas e estão ilustradas na Figura 5.11. Como discutido, a relação entre o diâmetro e a altura do elemento já permite um estado de tensões no ensaio-padrão similar ao que ocorre durante o ensaio modificado, com ausência de tensões transversais na região central do elemento. 


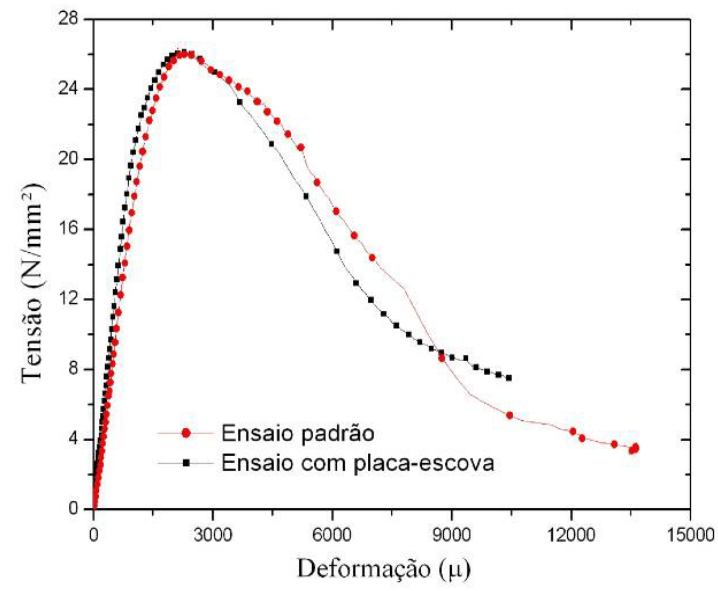

Figura 5.11 - Diagramas tensão-deformação obtidos no ensaio de corpos-de-prova cilíndricos com a alteração das condições de contorno do ensaio.

$\mathrm{Na}$ Figura 5.12a estão apresentados os diagramas tensão-deformação obtidos nos ensaios-padrão com blocos juntamente com os obtidos no ensaio com o corpo-de-prova de concreto. Em relação ao $\mathrm{CP}$, observa-se que seu diagrama está dentro da variação ocorrida entre as distintas curvas obtidas diretamente pela instrumentação nas paredes do bloco. $\mathrm{Na}$ Figura 5.12b, juntamente com os gráficos provenientes dos ensaios modificados com blocos, apresenta-se a curva obtida no ensaio do corpo-de-prova, agora, com o trecho inicial bastante similar aos diagramas obtidos nos ensaios com os blocos. Nota-se ainda a alternância do pico das curvas: enquanto no ensaio-padrão as curvas referentes aos blocos são as que atingem o maior valor, o contrário ocorre no ensaio modificado.

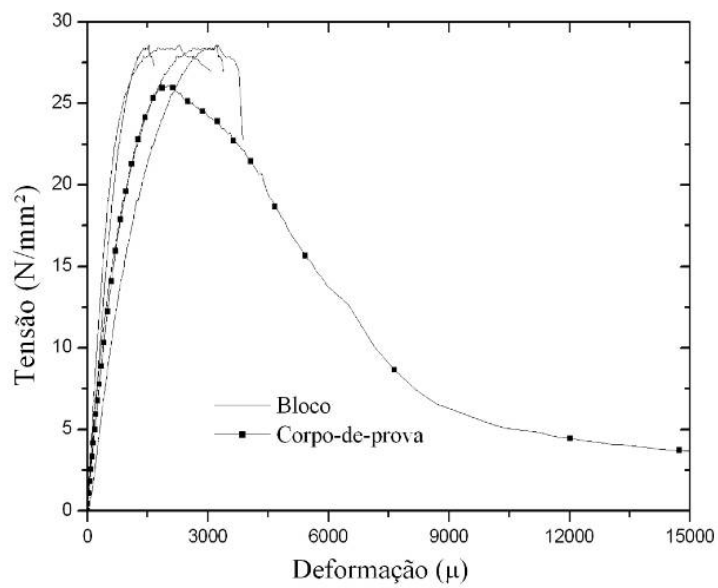

(a)

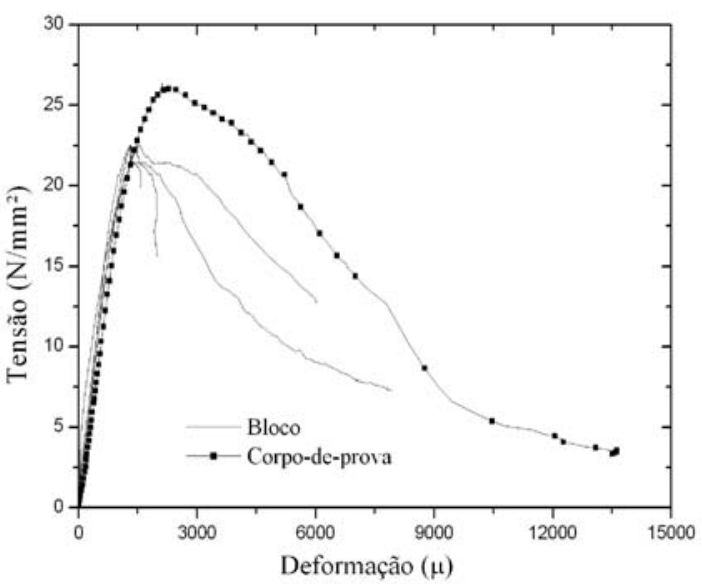

(b)

Figura 5.12 - Digrama tensão-deformação de blocos vazados de concreto, corpos-de-prova obtido no ensaio-padrão (a) e no ensaio modificado (b).

Observa-se na Figura 5.13 que o diagrama tensão-deformação transversal apresenta um trecho linear em que os valores obtidos no ensaio-padrão e no ensaio modificado são 
próximos. A ruína prematura do bloco no ensaio modificado é caracterizada por grandes valores de deformação transversal.

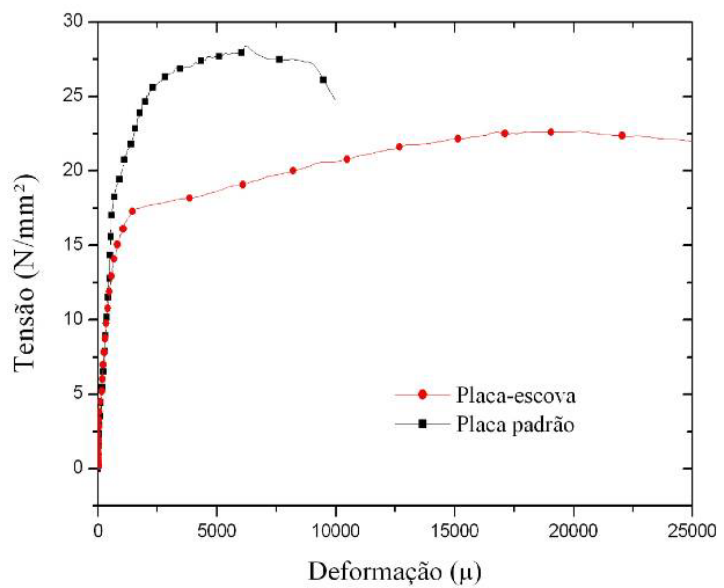

Figura 5.13 - Comparação entre os diagramas tensão-deformação transversal obtidos no ensaiopadrão e modificado.

A relação entre as deformações transversais e longitudinais, em um nível de tensão de 30\% da resistência máxima do bloco, apresenta valores de 0,07 e 0,25 referentes, respectivamente, ao septo transversal e longitudinal.

\subsection{Comportamento mecânico dos prismas}

Neste item são apresentadas as propriedades mecânicas dos prismas de blocos vazados de concreto e argamassas de assentamento, enfatizando-se a resistência à compressão, resistência à tração e as deformações. Destacam-se ainda os diagramas tensãodeformação obtidos nos distintos ensaios.

\subsubsection{Propriedades mecânicas dos prismas e seus materiais constituintes}

$\mathrm{Na}$ Tabela 5.9 estão apresentadas as resistências à compressão dos prismas $\left(f_{p}\right)$, dos seus respectivos componentes - blocos vazados de concreto $\left(f_{b}\right)$ e $\operatorname{argamassa}\left(f_{a}\right)-e$ as relações entre estes valores. Os dados referem-se às médias obtidas em ensaios com três prismas e cinco corpos-de-prova de argamassa. A resistência à compressão dos blocos foi obtida a partir da correlação estabelecida com a resistência dos corpos-de-prova de concreto no item 5.1. 
Tabela 5.9 - Resistência à compressão dos blocos, argamassas e prismas.

\begin{tabular}{ccccccc} 
Grupo & $\mathrm{f}_{\mathrm{p}}$ & $\mathrm{f}_{\mathrm{a}}$ & $\mathrm{f}_{\mathrm{b}}$ & $\mathrm{f}_{\mathrm{c}}$ & $\mathrm{f}_{\mathrm{p}} / \mathrm{f}_{\mathrm{b}}$ & $\mathrm{f}_{\mathrm{a}} / \mathrm{f}_{\mathrm{b}}{ }^{1}$ \\
& \multicolumn{7}{c}{$\mathrm{N} / \mathrm{mm}^{2}$} \\
\hline P1 & $17,8(3,7 \%)^{2}$ & $7,5(14,1 \%)^{3}$ & 20,0 & $18,6(4,4 \%)^{1}$ & 0,890 & 0,686 \\
P2 & $18,2(1,9 \%)$ & $9,4(10,5 \%)$ & 24,5 & $22,8(3,5 \%)$ & 0,743 & 0,683 \\
P3 & $21,5(4,8 \%)$ & $15,5(2,3 \%)$ & 26,8 & $24,9(4,0 \%)$ & 0,802 & 1,11 \\
P4 & $30,1(3,9 \%)$ & $22,2(7,0 \%)$ & 38,9 & $36,2(5,7 \%)$ & 0,773 & 1,09 \\
\hline
\end{tabular}

Entre parênteses: coeficiente de variação

${ }^{1}$ Valor relativo à área bruta do bloco

${ }^{2}$ Resultante do ensaio de 9 prismas

${ }^{3}$ Resultante do ensaio de 12 CP's

Os fatores de eficiência estão dentro dos intervalos obtidos por Mohamad (1998) e Romagna (2000) que utilizando distintas resistências de blocos vazados de concreto e argamassa obtiveram valores entre 0,56 e 1 . Gomes (2001) acredita que o fator de eficiência da alvenaria tende a decrescer com o aumento da resistência da unidade, mantendo-se a relação entre a resistência da argamassa e a resistência do bloco.

Entretanto, deve-se destacar o comportamento observado nos ensaios, quando se analisa os resultados dos prismas P1 e P2. É possível notar que houve um aumento da resistência à compressão do bloco e da argamassa de aproximadamente $25 \%$, enquanto a resistência do prisma permaneceu praticamente inalterada.

Produziram-se novos blocos para a série de ensaios com prismas. Na Tabela 5.10 estão apresentadas a resistência à compressão, à tração e o módulo de elasticidade do concreto que constitui os blocos. Os valores referentes ao concreto equivalem à média obtida no ensaio de oito e quatro CP's nos ensaios de compressão e tração, respectivamente. O coeficiente de Poisson em todos os grupos de resistência vale 0,2 . 
Tabela 5.10 - Resistência à compressão, à tração e módulo de elasticidade do concreto que constitui os blocos dos prismas.

\begin{tabular}{cccc}
\hline Grupo & $\mathrm{f}_{\mathrm{c}}$ & $\mathrm{E}_{\mathrm{c}}$ & $\mathrm{f}_{\mathrm{ct}}{ }^{3}$ \\
& & $\mathrm{~N} / \mathrm{mm}^{2}$ & \\
\hline BP1 & $18,6(4,4 \%)^{1}$ & 17449 & $1,7(12 \%)^{2}$ \\
BP2 & $22,8(3,5 \%)$ & 20595 & $2,2(10,1 \%)$ \\
BP3 & $24,9(4,0 \%)$ & 22175 & $2,4(9,3 \%)$ \\
BP4 & $36,2(5,7 \%)$ & 27104 & $3,1(10,8 \%)$ \\
\hline
\end{tabular}

Entre parênteses: coeficiente de variação

${ }^{1}$ Resultante do ensaio de 12 CP's

${ }^{2}$ Resultante do ensaio de 9 CP's

${ }^{3}$ Resistência à tração do concreto por meio de compressão diametral

Os valores médios da resistência à compressão $\left(f_{a}\right)$ e à tração indireta da argamassa $\left(f_{a t}\right)$ e seus respectivos módulos de elasticidade $\left(E_{a}\right)$ estão apresentados na Tabela 5.11, referidos à média obtida no ensaio de quatro, três e dois corpos-de-prova, respectivamente.

Tabela 5.11 - Resistência à compressão, módulo de elasticidade e resistência à tração na compressão diametral da argamassa.

\begin{tabular}{cccccc}
\hline Grupo & $\mathrm{f}_{\mathrm{a}}$ & $\mathrm{f}_{\mathrm{at}}$ & $\mathrm{E}_{\mathrm{a}}$ & $\mathrm{v}$ & $\mathrm{f}_{\mathrm{at}} / \mathrm{f}_{\mathrm{a}}$ \\
& \multicolumn{5}{c}{$\mathrm{N} / \mathrm{mm}^{2}$} \\
\hline AP1 & $7,5(14,1 \%)^{1}$ & $0,9(13,8 \%)^{2}$ & $8085(12,3 \%)^{3}$ & 0,13 & 0,120 \\
AP2 & $9,4(10,5 \%)$ & $1,1(8,3 \%)$ & $9745(5,0 \%)$ & 0,13 & 0,117 \\
AP3 & $15,5(2,3 \%)$ & $1,8(11,7 \%)$ & $13195(4,8 \%)$ & 0,15 & 0,118 \\
AP4 & $22,2(7,0 \%)$ & $2,6(4,8 \%)$ & $16672(7,5 \%)$ & 0,15 & 0,117 \\
\hline
\end{tabular}

Entre parênteses: coeficiente de variação

${ }^{1}$ Resultante do ensaio de $12 \mathrm{CP}$ 's

${ }^{2}$ Resultante do ensaio de 9 CP's

${ }^{3}$ Resultante do ensaio de 5 CP's

A relação entre a resistência à tração e à compressão permanece praticamente constante para todos os tipos de argamassa, já o crescimento do valor do módulo de elasticidade em função do aumento da resistência à compressão é definido pela Equação (5.10).

$$
\mathrm{E}_{\mathrm{a}}=2191 \mathrm{f}_{\mathrm{a}}^{0,66}
$$

Os gráficos que relacionam a resistência à tração indireta da argamassa e o módulo de elasticidade com a evolução da resistência à compressão estão apresentados na Figura 5.14. 


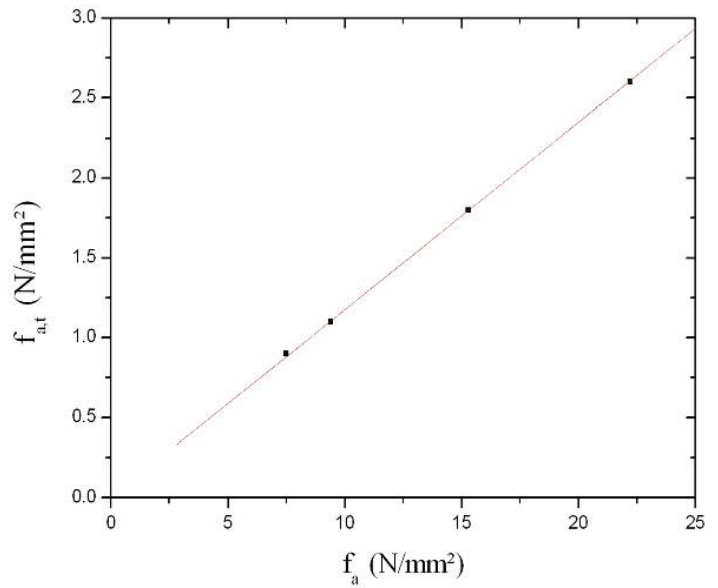

(a)

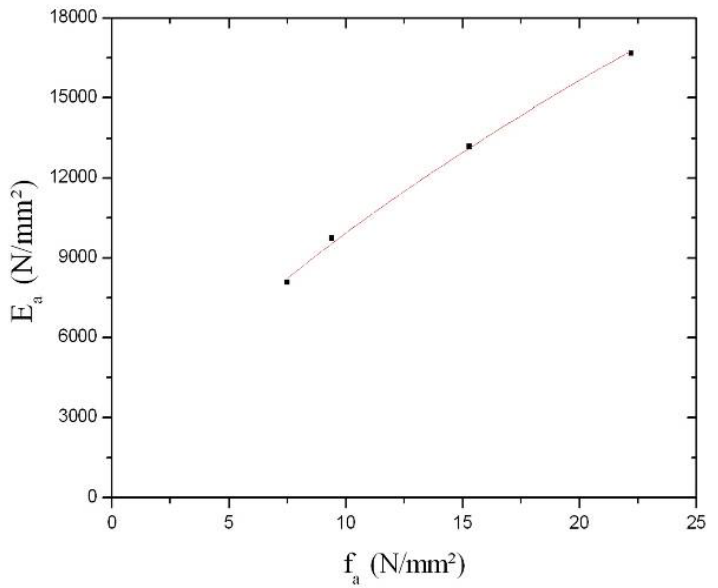

(b)

Figura 5.14 - Correlação entre a resistência à tração (a) e o módulo de elasticidade (b) com a resistência à compressão da argamassa.

\subsubsection{Distribuição de deformações nos prismas}

Adotam-se como referência os pontos indicados na Figura 5.15.

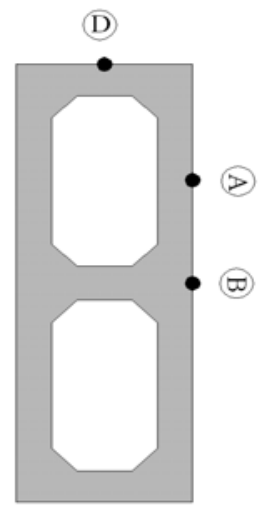

Figura 5.15 - Localização dos pontos adotados na análise das deformações do prisma.

Os resultados apresentados a seguir são referentes aos prismas do grupo P3. As deformações obtidas nos ensaios com prismas, em três níveis de tensão, são apresentadas na Figura 5.16a. O ponto central é o que apresenta os maiores valores de deformações, opondose aos encontrados no ponto D, na extremidade do prisma. Nota-se ainda que os valores de deformação obtidos nos pontos A e B tendem a se igualar quando é atingida a resistência máxima do ensaio em decorrência da fissuração e conseqüente redistribuição de tensões.

As deformações obtidas ao longo do bloco central estão apresentadas na Figura 5.16b. A maior uniformidade na distribuição das deformações no bloco central do prisma segue o comportamento dos blocos ensaiados com redução do efeito de confinamento. 
(D)

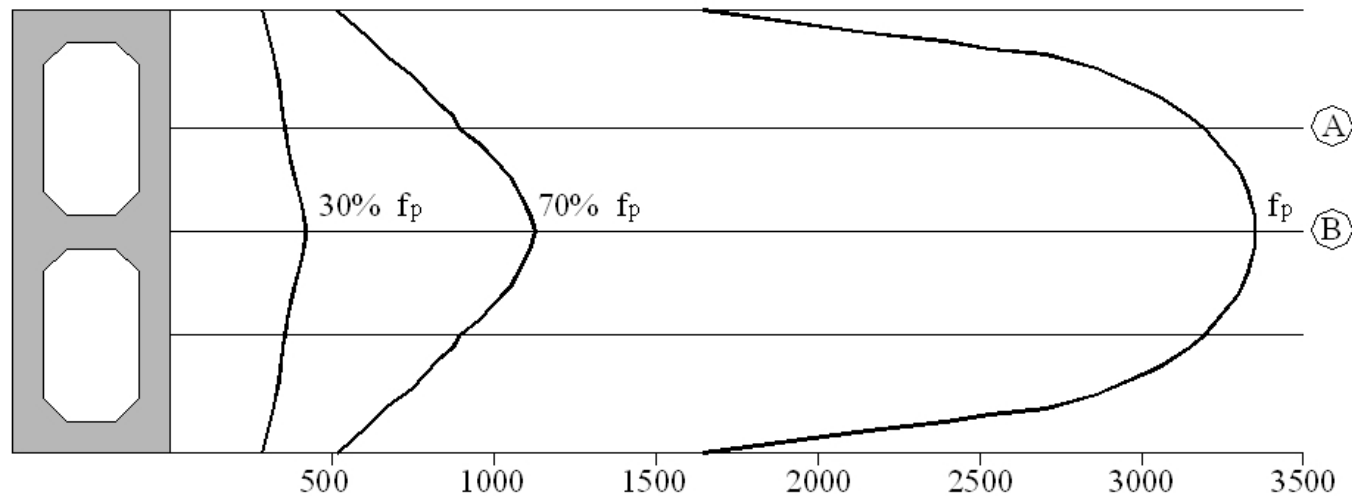

Deformação $(\mu)$

(a)

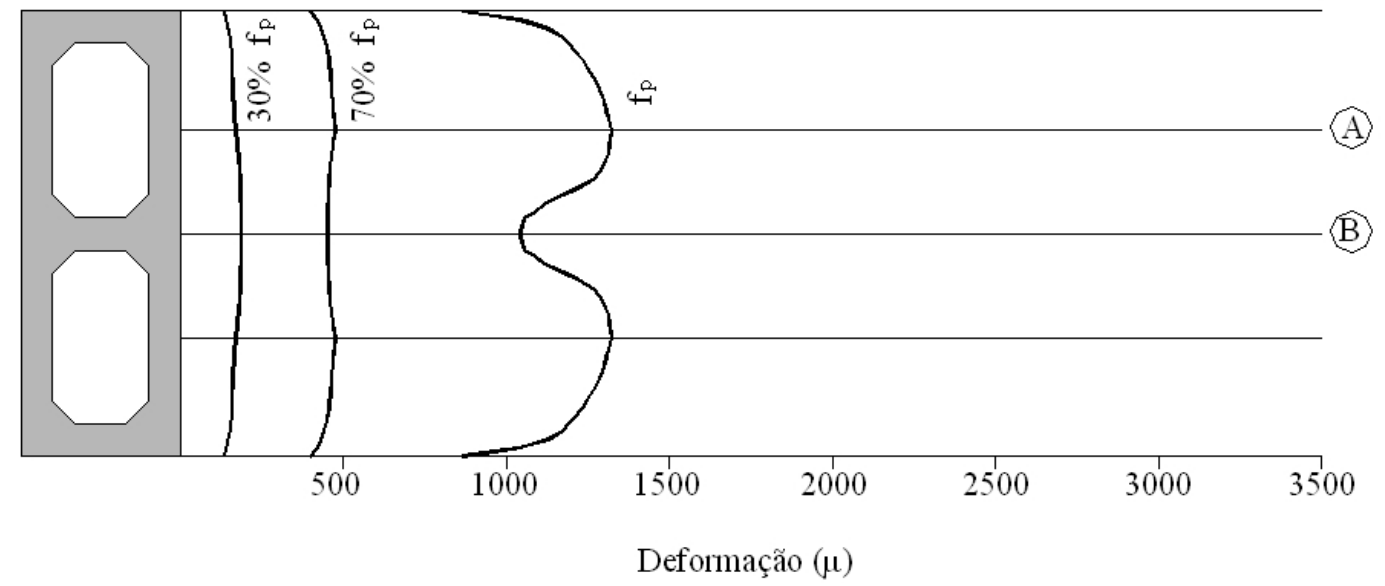

(b)

Figura 5.16 - Perfis de deformações ao longo da parede longitudinal dos prismas: prisma (a) e bloco central do prisma (b).

Utilizando-se mais uma vez o conceito de módulo de elasticidade aparente, agrupamse os referidos valores dos prismas na Tabela 5.12, na qual também são apresentadas as deformações últimas nos distintos pontos e os valores do módulo de elasticidade dos materiais que compõem o prisma. Os valores do módulo de elasticidade aparente dos prismas, $\mathrm{E}_{\mathrm{p}, \mathrm{ap}}$, apresentam-se sempre menores que $E_{c}$, entretanto maiores que $E_{a}$, demonstrando a influência considerável da camada de argamassa nas deformações do prisma. 
Tabela 5.12 - Propriedades mecânicas obtidas a partir dos ensaios com prismas e corpos-de-prova de concreto e argamassa.

\begin{tabular}{cccccc}
\hline $\mathrm{f}_{\mathrm{p}}\left(\mathrm{N} / \mathrm{mm}^{2}\right)$ & $\mathrm{E}_{\mathrm{c}}\left(\mathrm{N} / \mathrm{mm}^{2}\right)$ & $\mathrm{E}_{\mathrm{a}}\left(\mathrm{N} / \mathrm{mm}^{2}\right)$ & $\mathrm{E}_{\mathrm{p}, \text { ap. }}\left(\mathrm{N} / \mathrm{mm}^{2}\right)$ & $\varepsilon_{\text {ult. }}(\mu)$ \\
\hline \multirow{2}{*}{21,5} & & & $\mathrm{~A}$ & 16432 & 2636 \\
& \multirow{2}{*}{22175} & 13195 & $\mathrm{~B}$ & 19166 & 2569 \\
& & & $\mathrm{D}$ & 21239 & 1615 \\
\hline
\end{tabular}

$1 \mu=10^{-6} \mathrm{~mm} / \mathrm{mm}$

No gráfico da Figura 5.17a estão apresentadas as relações provenientes da medição de deslocamentos verticais do bloco central, em que há uma maior uniformização das deformações em relação à medição do comportamento global do prisma (Figura 5.17b). Estas curvas não apresentam um patamar com grandes deformações, o que caracterizaria a ruína do bloco por compressão. Como visto, a ruína do bloco central ocorre por tração com fissuras verticais, ou seja, a capacidade portante à compressão do bloco não é atingida. As deformações dos blocos apresentam valores na ruína entre $850 \mu$ e $1300 \mu$.

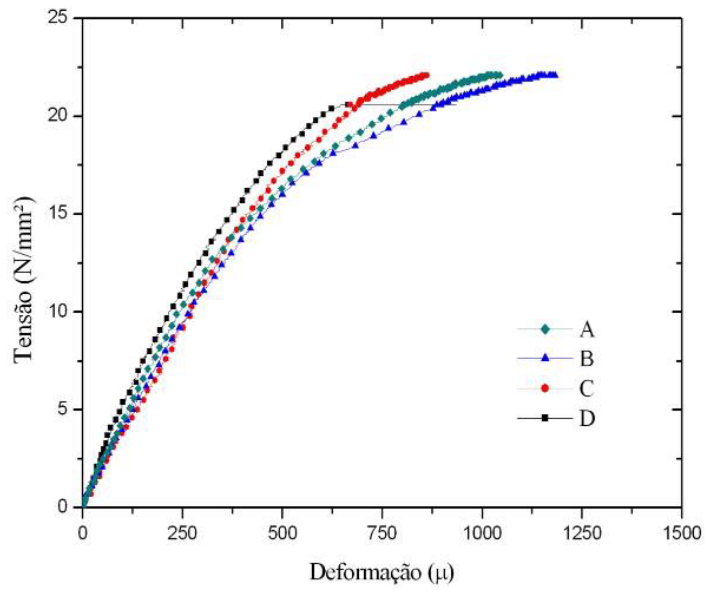

(a)

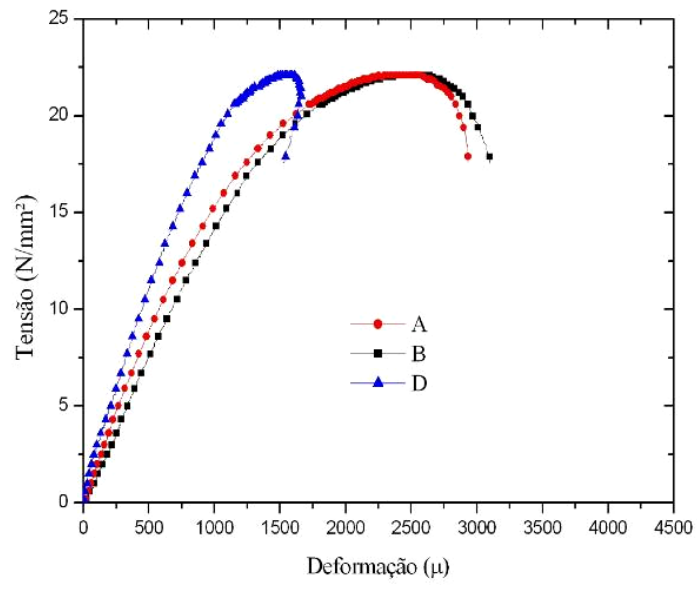

(b)

Figura 5.17 - Diagramas tensão-deformação referentes aos distintos pontos do bloco central do prisma (a) e obtidos em toda a altura do prisma (b).

Na Figura 5.18a é apresentado o diagrama tensão-deformação da argamassa obtido diretamente na junta de argamassa do prisma e no seu respectivo corpo-de-prova. Observa-se a maior capacidade de absorção de carga e deformação da junta de argamassa em comparação com o corpo-de-prova, conseqüência do efeito confinamento a que ela está submetida. Entretanto, o módulo de elasticidade inicial permanece praticamente inalterado. Não há mudança no comportamento da junta de argamassa no centro do vazio do septo transversal 
externo, comparando-se com a medição que ocorre no centro do vazio da parede longitudinal, inclusive com as rigidezes iniciais semelhantes.

A deformação transversal do bloco obtida na parede longitudinal é apresentada na Figura 5.18b, destacando-se o patamar horizontal na carga de ruína, que caracteriza o esgotamento da capacidade resistente do bloco à tração.

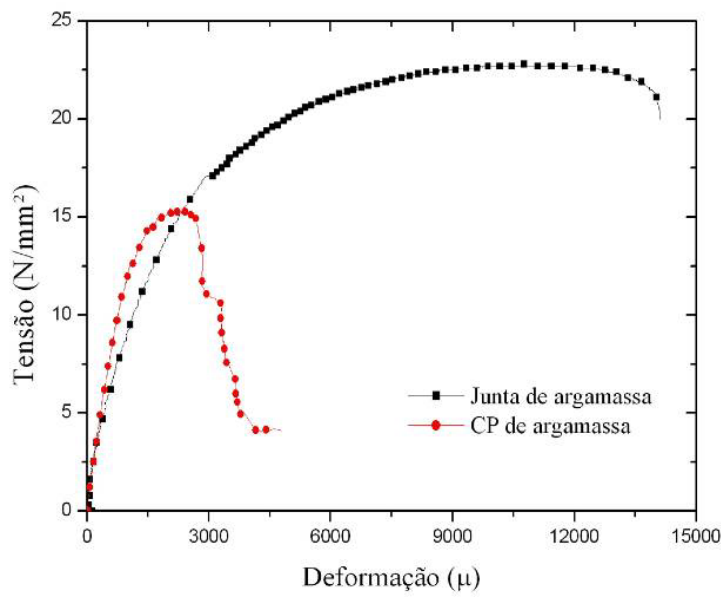

(a)

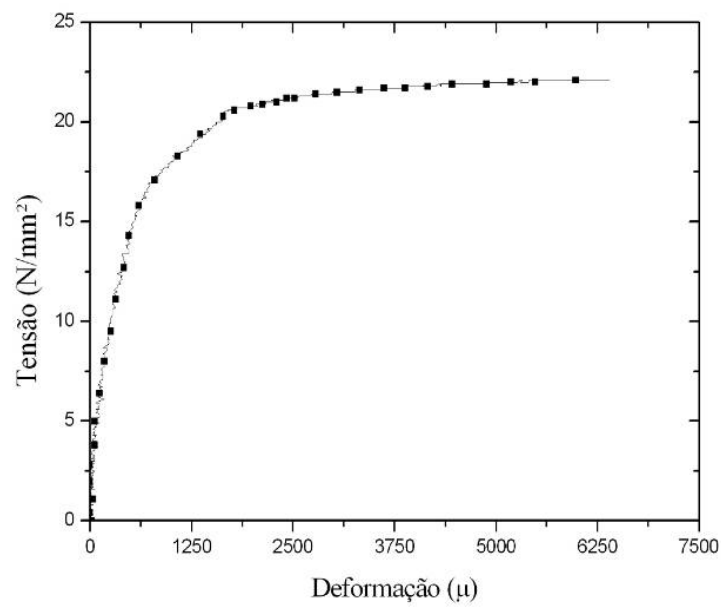

(b)

Figura 5.18 - Diagrama tensão-deformação da argamassa obtido no ensaio de corpo-de-prova e na junta do prisma (a). Diagrama tensão-deformação transversal do bloco de concreto (b).

As diferenças obtidas nos parâmetros referentes à argamassa por meio do ensaio de corpos-de-prova e diretamente na junta do prisma estão sumarizadas na Tabela 5.13.

Tabela 5.13 - Propriedades mecânicas da argamassa - obtidas no ensaio de corpo-deprova e diretamente na junta do prisma -, do bloco e do prisma.

\begin{tabular}{cccccc}
\hline Elemento & $\mathrm{f}_{\mathrm{c} \text {,elem }}$ & $\mathrm{E}_{\text {elem }}$ & $v_{\text {elem }}$ & $\begin{array}{c}\varepsilon_{\text {ult. }}{ }^{2} \\
(\mu)\end{array}$ & Comportamento \\
\hline Corpo-de-prova & 15,5 & 13195 & 0,15 & 2044 & dúctil \\
Junta do prisma & - & $7041^{1}$ & - & 10764 & trilinear \\
Bloco central & 27,6 & $37928^{1}$ & 0,84 & $1296(6403)^{3}$ & - \\
Prisma & 21,5 & $19166^{1}$ & 0,39 & 2569 & dúctil \\
\hline
\end{tabular}

\footnotetext{
${ }^{1}$ Módulo de elasticidade aparente, com instrumentação localizada no ponto A.

${ }^{2}$ Deformação longitudinal relativa a cada elemento na força máxima do prisma.

${ }^{3} \mathrm{O}$ número entre parênteses refere-se à deformação transversal.

$1 \mu=10^{-6} \mathrm{~mm} / \mathrm{mm}$
}

O gráfico da Figura 5.19a caracteriza a ruína do prisma devida à fissuração do bloco de concreto, representada pelos altos valores de deformação transversal ao contrário do mais baixo valor referente às deformações longitudinais. Em relação às deformações do conjunto e 
de seus componentes, ilustra-se na Figura $5.19 \mathrm{~b}$ a forte influência que a deformabilidade da argamassa exerce no comportamento do prisma.

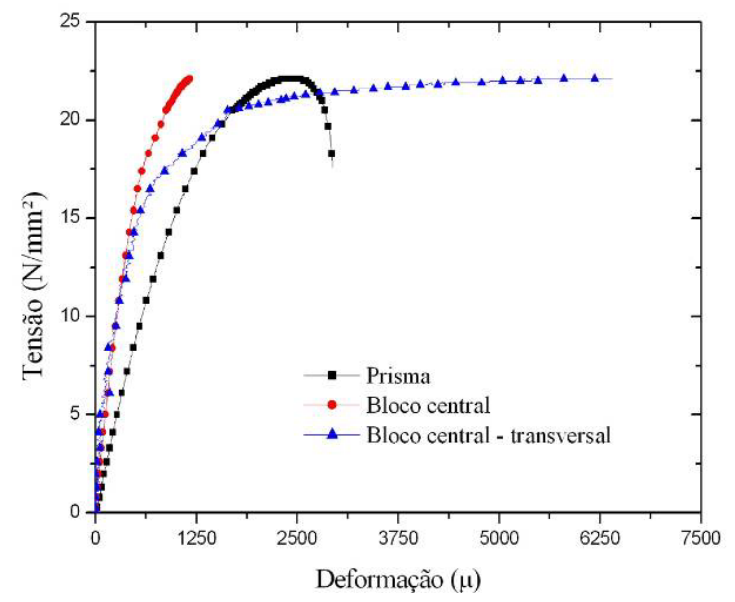

(a)

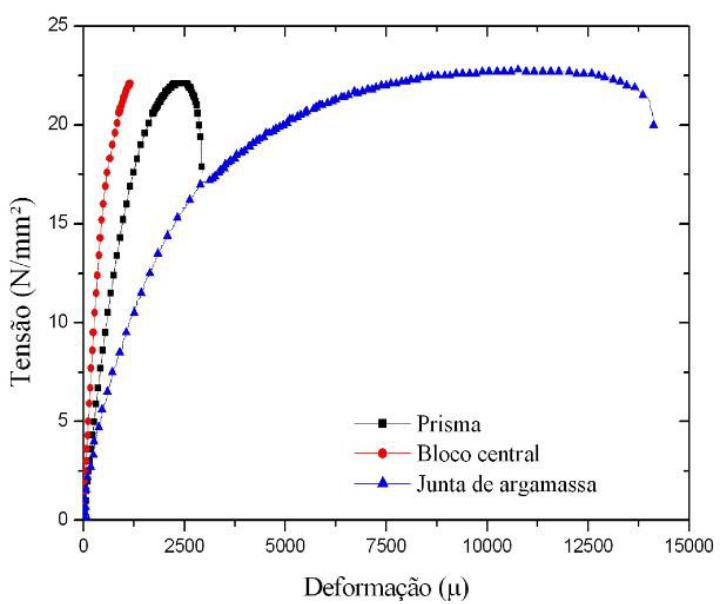

(b)

Figura 5.19 - Relação da deformação transversal do bloco com a ruína do prisma (a) e da deformabilidade da argamassa no comportamento do conjunto (b).

As solicitações mais significativas no bloco surgem devido à restrição que estes impõem à deformação transversal da junta de argamassa, com o conseqüente surgimento de tensões transversais de tração e posterior ruína do prisma.

\subsection{Comportamento mecânico das miniparedes}

Apresenta-se a seguir a análise das propriedades mecânicas das paredes de alvenaria e de seus materiais constituintes, com a realização de um exame sucinto das deformações obtidas em diversos pontos da estrutura durante os ensaios à compressão axial.

\subsubsection{Propriedades mecânicas das miniparedes e de seus materiais constituintes}

Executaram-se as miniparedes com um mesmo tipo de bloco de concreto e dois níveis distintos de resistência de argamassa. Os resultados apresentados, para cada grupo, são provenientes da análise de três miniparedes, dois prismas, 12 blocos, 20 corpos-de-prova de concreto e cinco corpos-de-prova de argamassa.

A resistência das miniparedes $\left(f_{\text {par }}\right)$, do prisma, do bloco de concreto e da argamassa é apresentada na Tabela 5.14. Observa-se que, apesar de um aumento significativo da resistência da argamassa, a resistência das paredes não varia na mesma proporção. $O$ mesmo ocorre em relação à resistência dos prismas deste grupo de ensaios, o que indica a baixa 
influência da resistência da argamassa - em comparação com a resistência dos blocos de concreto - na capacidade portante das estruturas de alvenaria.

Tabela 5.14 - Resistência à compressão dos blocos, argamassas, prismas e miniparedes.

\begin{tabular}{cccccc}
\hline Grupo & $\mathrm{f}_{\mathrm{par}}$ & $\mathrm{f}_{\mathrm{p}}$ & $\mathrm{f}_{\mathrm{a}}$ & $\mathrm{f}_{\mathrm{b}}$ & $\frac{\mathrm{f}_{\mathrm{par}}}{\mathrm{f}_{\mathrm{p}}}$ \\
\hline PAR 1 & $15,5(11,7 \%)$ & $19,3(11,1 \%)$ & $10,4(6,9 \%)$ & $24,9(15,2 \%)$ & 0,803 \\
PAR 2 & $16,5(6,5 \%)$ & $20,5(11,4 \%)$ & $18,1(6,8 \%)$ & $23,7(16,0 \%)$ & 0,805 \\
\hline
\end{tabular}

Entre parênteses: coeficiente de variação

Diferentes modos de ruína foram constatados: nas paredes de alvenaria do grupo PAR 1, ela ocorreu como conseqüência do esmagamento da argamassa; já no grupo PAR 2, sua capacidade resistente foi esgotada em função da ruína dos blocos, decorrente dos esforços internos de tração.

Na Tabela 5.15 estão sumarizados os demais parâmetros mecânicos dos materiais obtidos na análise experimental.

Tabela 5.15 - Resistência à tração, módulo de elasticidade e coeficiente de Poisson do concreto e argamassa.

\begin{tabular}{ccccccc}
\hline \multirow{2}{*}{ Grupo } & $\mathrm{f}_{\mathrm{ct}}$ & $\mathrm{E}_{\mathrm{c}}$ & $\mathrm{f}_{\mathrm{at}}$ & $\mathrm{E}_{\mathrm{a}}$ & $\mathrm{v}_{\mathrm{c}}$ & $\mathrm{v}_{\mathrm{a}}$ \\
& \multicolumn{6}{c}{$\left(\mathrm{N} / \mathrm{mm}^{2}\right)$} \\
PAR 1 & $2,1(10,6 \%)$ & $22174(2,1 \%)$ & $1,2(4,3 \%)$ & $9402(5,0 \%)$ & 0,20 & 0,12 \\
PAR 2 & $2,1(7,6 \%)$ & $22447(9,7 \%)$ & $1,6(9,1 \%)$ & $17553(4,4 \%)$ & 0,20 & 0,15 \\
\hline
\end{tabular}

Entre parênteses: coeficiente de variação

\subsubsection{Análise das deformações nas miniparedes}

As deformações foram obtidas em distintas regiões das paredes e com diferentes bases de medidas. Dessa forma, foi possível a obtenção dos valores de deformação vertical considerando a altura e largura total da parede, apenas o bloco de concreto e apenas a junta de argamassa.

Não foram observadas diferenças entre o comportamento na parte frontal da estrutura e na sua parte lateral, ou seja, nas paredes longitudinais e nos septos transversais do bloco de concreto. Como as curvas obtidas com uma mesma base de medida e em determinada região da estrutura apresentam comportamento semelhante, optou-se por apresentar apenas o valor médio das deformações em função da tensão de referência, atuante no topo da parede. 
Os gráficos apresentados a seguir referem-se ao grupo PAR 2, pois este foi o único nos quais se obtiveram as deformações da estrutura. Na Figura 5.20a estão representados o comportamento individual do bloco de concreto e da junta de argamassa. As deformações globais, verticais e transversais, da parede são ilustradas na Figura 5.20b.

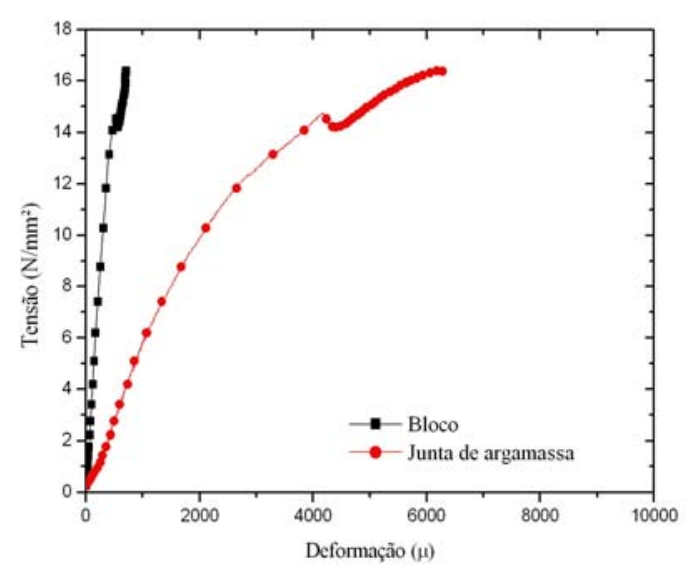

(a)

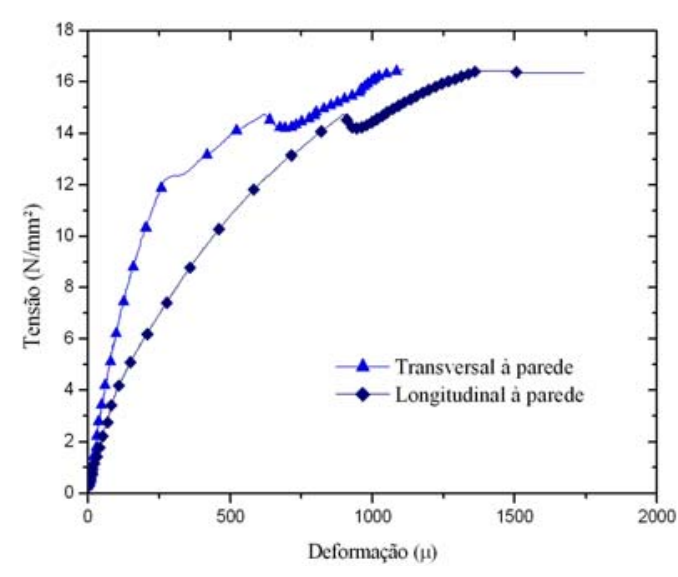

(b)

Figura 5.20 - Relação tensão-deformação dos elementos que compõem a paredes (a). Relação tensão-deformação vertical e transversal da miniparede (b).

Como esperado, a junta de argamassa apresenta maior deformabilidade que o bloco de concreto em função do seu menor módulo de elasticidade e da forma que está disposta. Observa-se que ambos os componentes não apresentam patamar nítido de ruína, o que indica que a estrutura atinge a sua máxima capacidade em função da fissuração dos blocos. Este patamar é nítido na análise das curvas que representam o comportamento global da parede, tanto na direção vertical quanto na horizontal - fortemente influenciada pela deformação transversal dos blocos.

\subsection{Valores da energia de fratura}

É apresentada a seguir uma breve discussão sobre os valores relativos à energia de fratura do concreto e da argamassa obtidos na análise experimental. Destaca-se a necessidade de estudos mais detalhados já que este parâmetro apresenta alta variabilidade e, em relação aos componentes de alvenaria, ainda é escassa a quantidade de dados disponíveis.

\subsubsection{Energia de fratura do concreto}

A taxa de liberação ou de dissipação de energia, envolvida no processo de fissuração é denominada energia de fraturamento e pode ser determinada a partir de ensaios de tração ou de compressão axiais, bem como por meio de ensaios de flexão de vigas entalhadas. $\mathrm{O}$ valor 
de $G_{F}$ é baseado na curva global carga-deslocamento vertical, cujo cálculo inclui, segundo o método da RILEM TC-50 (1985), não apenas a verdadeira energia de separação das superfícies das fissuras, $G_{f}$, mas também outra parcela de energia, muitas vezes predominante, dissipada para a formação da zona de processos inelásticos. Esta parcela é caracterizada pela região microfissurada à frente da ponta da fissura. Por outro lado, o valor de $G_{f}$, mais adequadamente definido como taxa crítica de liberação de energia, é determinado a partir da carga crítica atingida no ensaio e do comprimento de uma fissura de extensão crítica, denominada fissura elástico-equivalente ou elástico-efetiva. Segundo Bazant e Planas (1997), a relação entre esses diferentes parâmetros é definida segundo a Equação (5.11). A energia de fraturamento, denotada por $G_{f}$, representa a quantidade de energia liberada por unidade de área físsurada, ou seja, a energia necessária para a propagação de uma fissura unitária.

$$
\mathrm{G}_{\mathrm{f}}=0,52 \mathrm{G}_{\mathrm{F}}
$$

Aplica-se Equação (5.11) aos valores médios da energia de fratura $\left(G_{F}\right)$ obtidos experimentalmente, sendo os valores de $G_{f}$ apresentados na Tabela 5.16. Nesta, também constam os valores médios provenientes dos ensaios de resistência à tração na flexão $\left(\mathrm{f}_{\mathrm{ct} \text { ffl }}\right)$ e do ensaio à compressão diametral $\left(\mathrm{f}_{\mathrm{ct}}\right)$ em CP's cilíndricos 100 x $200 \mathrm{~mm}$.

Tabela 5.16 - Resistência à tração de corpos-de-prova de concreto e valores da energia de fratura à tração.

\begin{tabular}{cccc}
\hline Grupo & $\mathrm{f}_{\mathrm{ct}}\left(\mathrm{N} / \mathrm{mm}^{2}\right)$ & $\mathrm{f}_{\mathrm{ct}, \mathrm{fl}}\left(\mathrm{N} / \mathrm{mm}^{2}\right)$ & $\mathrm{G}_{\mathrm{f}}(\mathrm{N} / \mathrm{mm})$ \\
\hline G3 & 2,6 & $4,0(11,7 \%)$ & $0,122(16 \%)$ \\
G4 & 2,8 & $5,6(4,8 \%)$ & $0,154(7,6 \%)$ \\
GA & 2,0 & $3,8(15,7 \%)^{1}$ & $0,107(11,4 \%)^{1}$ \\
GB & 2,2 & $3,7(12,7 \%)$ & $0,092(14,5 \%)$ \\
P1 & 1,7 & $3,4(17 \%)^{1}$ & $0,106(17 \%)^{1}$ \\
P2 & 2,2 & $4,1(26,3 \%)$ & $0,128(26,9 \%)$ \\
P3 & 2,4 & $4,7(8,4 \%)$ & $0,138(10 \%)$ \\
P4 & 3,1 & $6,0(20,8 \%)$ & $0,155(14,6 \%)$ \\
\hline
\end{tabular}

Entre parênteses: coeficiente de variação

${ }^{1}$ Valor resultante do ensaio de seis corpos-de-prova

${ }^{2}$ Valor resultante do ensaio de cinco corpos-de-prova 
Os valores experimentais da energia de fratura $\mathrm{G}_{\mathrm{F}}$ forma calculados com auxílio do aplicativo TENAC, elaborado por Ferreira, Hanai e Bittencourt (2008).

A Figura 5.21a indica que o valor da resistência à tração obtida nos ensaios à flexão com vigas é aproximadamente 1,9 vezes maior que o obtido no ensaio à compressão diametral. Na Figura 5.21b, é possível notar a evolução do valor da energia de fratura em função do aumento da resistência à tração com a Equação $(5.12)\left(\mathrm{R}^{2}=0,80\right)$ representando a correlação entre esses parâmetros.

$$
\mathrm{G}_{\mathrm{f}}=0,028 \mathrm{f}_{\mathrm{ct}}
$$

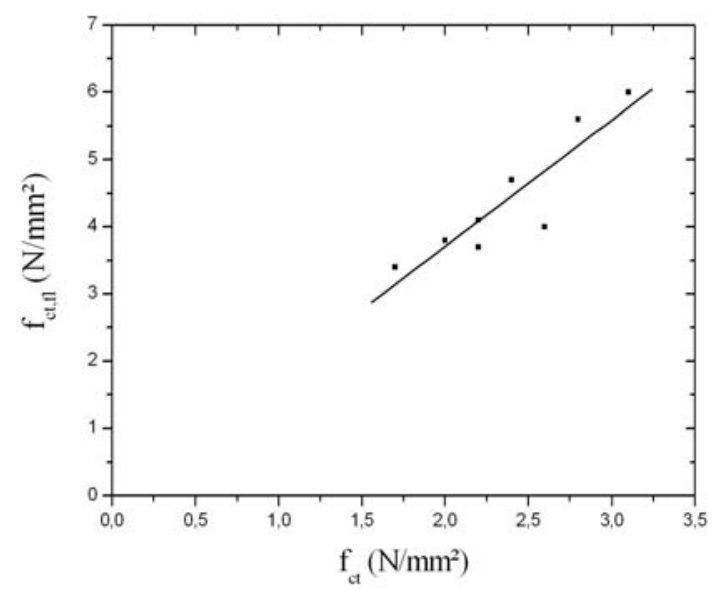

(a)

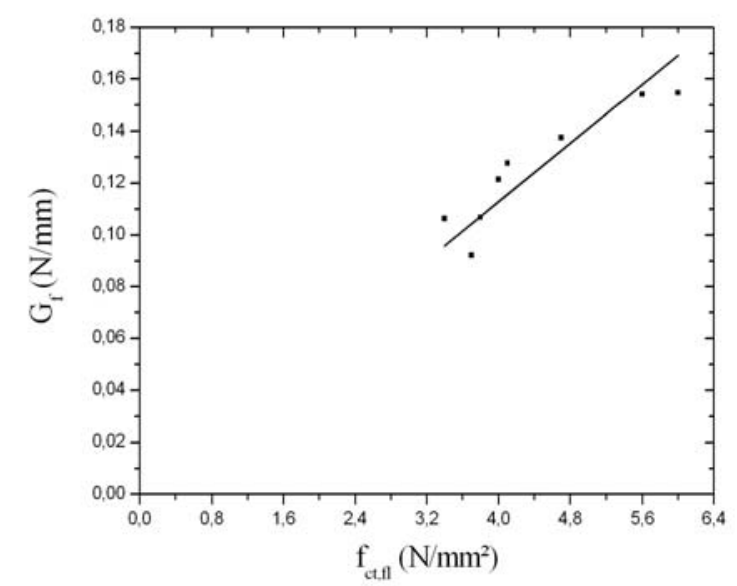

(b)

Figura 5.21 - Correlação entre a resistência à tração obtida em ensaios distintos (a). Relação entre a energia de fratura e a resistência à tração na flexão (b).

Lourenço (2006) sugere como índice de ductilidade à tração $\left(d_{u}=G_{f} / f_{c t}\right)$ de um tijolo o valor de $0,029 \mathrm{~mm}$, baseado na média entre os valores obtidos por Lourenço et al. (2004) e Pluijm (1999). O autor atribui a variabilidade de valores encontrados aos diferentes procedimentos de ensaio e às diferentes técnicas para calcular o valor da energia de fraturamento. Vasconcelos (2005) propõe a relação não linear $d_{u}=0,239 \mathrm{f}_{b t}^{-1,138}$, obtida em ensaios com granitos, que originará um valor quase duas vezes maior que o sugerido por Lourenço (2006); já o CEB-FIP Model Code 90 (1993) sugere para cálculo da energia de fratura à tração a Equação(5.13).

$$
\mathrm{G}_{\mathrm{f}}=0,025\left(\mathrm{f}_{\mathrm{c}} / 10\right)^{0,7}
$$

O índice de ductilidade obtido por meio da análise experimental realizada apresenta valores próximos ao proposto por Lourenço (2006), contudo, são 60\% menores em relação à 
formulação proposta pelo CEB-FIP Model Code 90 (1993). Um dos motivos para tal diferença, além dos expostos por Lourenço (2006), é o alto valor de resistência à tração obtido nos ensaios à flexão no presente trabalho. Os dados comparativos estão sumarizados na Tabela 5.17

Tabela 5.17 - Índice de ductilidade do concreto obtido em ensaios de resistência à tração e comparação com formulação do CEB-FIP (1993).

\begin{tabular}{ccccc}
\hline & & & \multicolumn{2}{c}{$\mathrm{d}_{\mathrm{u}}(\mathrm{mm})$} \\
$\mathrm{Grupo}$ & $\mathrm{f}_{\mathrm{ct}, \mathrm{fl}}\left(\mathrm{N} / \mathrm{mm}^{2}\right)$ & $\mathrm{G}_{\mathrm{f}}(\mathrm{N} / \mathrm{mm})$ & $\mathrm{G}_{\mathrm{f}} / \mathrm{f}_{\mathrm{ct}, \mathrm{fl}}$ & CEB-FIP (1993) \\
\hline $\mathrm{G} 3$ & 4,0 & 0,122 & 0,031 & 0,012 \\
$\mathrm{G} 4$ & 5,6 & 0,154 & 0,028 & 0,010 \\
$\mathrm{GA}$ & 3,8 & 0,107 & 0,028 & 0,011 \\
$\mathrm{~GB}$ & 3,7 & 0,092 & 0,025 & 0,012 \\
P1 & 3,4 & 0,106 & 0,031 & 0,011 \\
P2 & 4,1 & 0,128 & 0,031 & 0,011 \\
P3 & 4,7 & 0,138 & 0,029 & 0,010 \\
P4 & 6,0 & 0,155 & 0,026 & 0,010 \\
& Média & & 0,029 & 0,011 \\
\hline
\end{tabular}

Os valores da energia de fratura do concreto obtidos em ensaios à compressão axial com CP's cilíndricos de 100 x $200 \mathrm{~mm}$, relativos à média dos valores de dois corpos-deprova, estão detalhados na Tabela 5.18 .

Tabela 5.18 - Resistência à compressão de corpos-de-prova de concreto $\mathrm{e}$ valores da energia de fratura à compressão.

\begin{tabular}{ccccc}
\hline \multirow{2}{*}{$\mathrm{f}_{\mathrm{c}}\left(\mathrm{N} / \mathrm{mm}^{2}\right)$} & \multicolumn{2}{c}{$\mathrm{G}_{\mathrm{f}_{\mathrm{c}}}(\mathrm{N} / \mathrm{mm})$} & \multicolumn{2}{c}{$\mathrm{d}_{\mathrm{u}, \mathrm{c}}(\mathrm{mm})$} \\
& Experimental & CEB (1993) & Experimental & CEB (1993) \\
\hline 14,3 & 15,2 & 20,4 & 1,06 & 1,43 \\
20,4 & 28,8 & 22,7 & 1,41 & 1,09 \\
26,4 & 24,1 & 23,8 & 0,91 & 0,90 \\
32,8 & 29,1 & 25,2 & 0,89 & 0,77 \\
23,4 & 25,9 & 23,1 & 1,11 & 0,99 \\
38,0 & 27,0 & 26,1 & 0,71 & 0,69 \\
$17,7^{*}$ & $26,1(9,0 \%)$ & 21,5 & 1,47 & 1,21 \\
\hline
\end{tabular}

Entre parênteses: coeficiente de variação

* Valor resultante do ensaio de três corpos-de-prova 
A proposta do CEB-FIP Model Code 90 (1993) fornece um valor médio do índice de ductilidade à compressão de $0,68 \mathrm{~mm}$, havendo, contudo, uma variação significativa deste valor. É recomendada a formulação da Equação (5.14) para cálculo da energia de fratura à compressão.

$$
\mathrm{G}_{\mathrm{f}_{\mathrm{c}}}=15+0,43 \mathrm{f}_{\mathrm{c}}-0,0036 \mathrm{f}_{\mathrm{c}}^{2}
$$

A Figura 5.22 apresenta os gráficos relativos aos parâmetros anteriormente apresentados. Os resultados experimentais demonstram que há uma grande variação na correlação entre a resistência à compressão com a energia de fratura e o índice de ductilidade, devendo qualquer estimativa, sem valores experimentais, ser realizada de forma criteriosa.

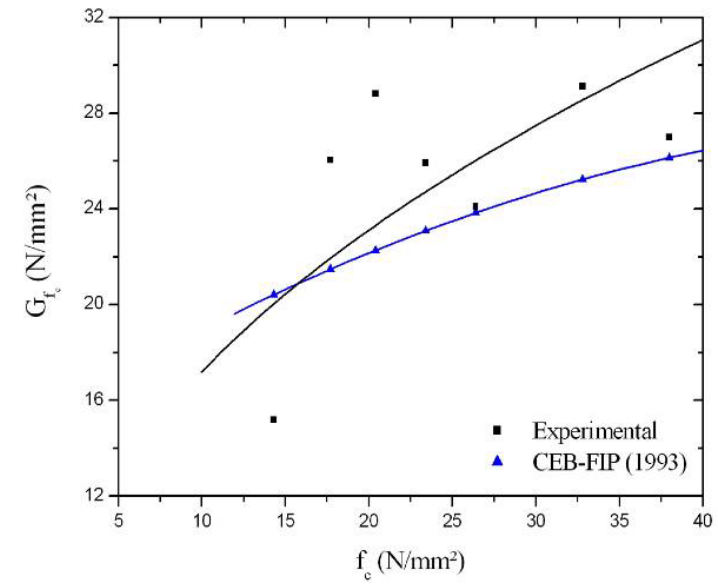

(a)

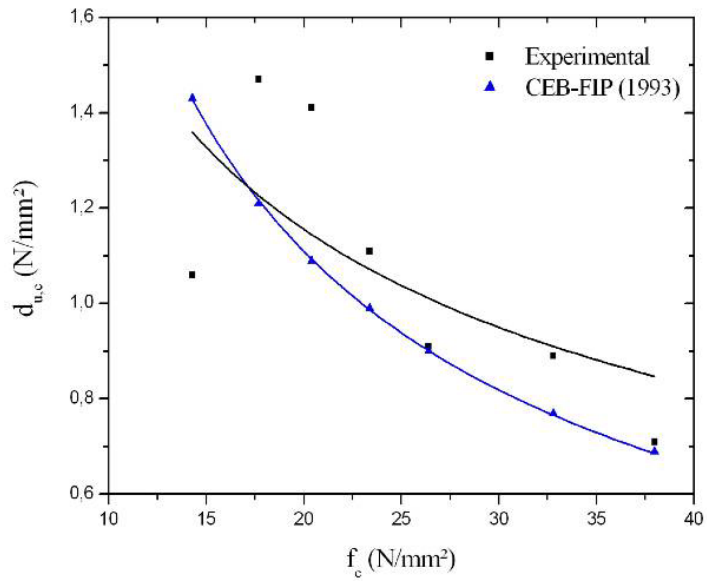

(b)

Figura 5.22 - Relação entre a resistência à compressão e os respectivos valores da energia de fratura (a) e índice de ductilidade (b).

A previsão da energia de fratura e, conseqüentemente, do seu índice de ductilidade, pode ser realizada diretamente por meio dos ensaios de blocos vazados de concreto. Para os parâmetros relativos à compressão, adotou-se o deslocamento entre placas, com correção do trecho inicial para obtenção do referido parâmetro. Essa estratégia mostra-se necessária já que, como observado na análise das deformações nos blocos, os diferentes pontos de medição apresentam valores distintos. Os valores apresentados na Tabela 5.19 são obtidos a partir da média de três ensaios. 
Tabela 5.19 - Resistência à compressão de blocos de concreto e valores da energia de fratura à compressão.

\begin{tabular}{ccccc}
\hline $\mathrm{f}_{\mathrm{b}}$ & \multicolumn{2}{c}{$\mathrm{G}_{\mathrm{f}_{\mathrm{c}}}(\mathrm{N} / \mathrm{mm})$} & \multicolumn{2}{c}{$\mathrm{d}_{\mathrm{u}, \mathrm{c}}(\mathrm{mm})$} \\
$\left(\mathrm{N} / \mathrm{mm}^{2}\right)$ & Experimental & CEB-FIP (1993) & Experimental & CEB-FIP (1993) \\
\hline 26,4 & 25,3 & 23,8 & 0,96 & 0,90 \\
28,6 & 31,5 & 24,4 & 1,10 & 0,85 \\
24,4 & 25,3 & 23,4 & 1,04 & 0,96
\end{tabular}

Os valores experimentais da energia de fratura diferem dos obtidos pela formulação teórica em até 30\%. Já o índice de ductilidade obtido a partir dos ensaios com blocos são, em média, 13\% inferiores aos obtidos nos ensaios com corpos-de-prova. A Figura 5.23 ilustra as correlações entre esses parâmetros.

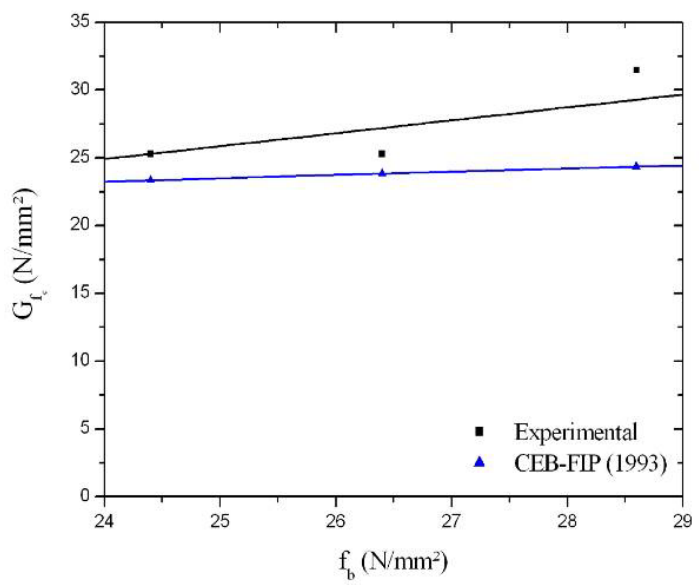

(a)

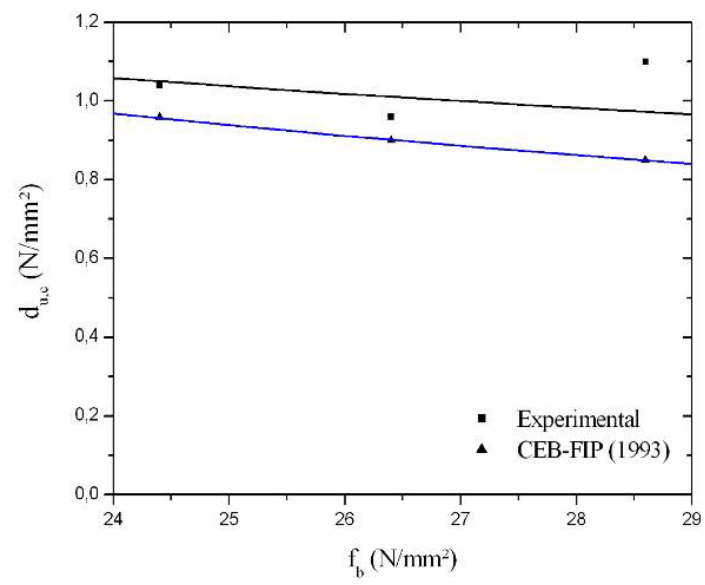

(b)

Figura 5.23 - Relação entre a resistência à compressão de blocos de concreto e a energia de fratura (a) e 0 índice de ductilidade (b).

\subsubsection{Energia de fratura da argamassa}

Em relação à argamassa, apresentam-se na Tabela 5.20 os valores da resistência à tração na flexão $\left(\mathrm{f}_{\mathrm{at}, \mathrm{fl}}\right)$, os valores da energia de fratura à tração, o índice de ductilidade e a comparação com a proposição teórica do CEB-FIP Model Code 90 (1993). Os valores da energia de fratura referem-se ao valor médio obtido em ensaios com três corpos-de-prova. 
Tabela 5.20 - Resistência à tração de corpos-de-prova da argamassa e valores da energia de fratura à tração.

\begin{tabular}{cccccc}
\hline Grupo & $\mathrm{f}_{\mathrm{at}}\left(\mathrm{N} / \mathrm{mm}^{2}\right)$ & $\mathrm{f}_{\mathrm{at}, \mathrm{fl}}\left(\mathrm{N} / \mathrm{mm}^{2}\right)$ & $\mathrm{G}_{\mathrm{f}}(\mathrm{N} / \mathrm{mm})$ & \multicolumn{2}{c}{$\mathrm{d}_{\mathrm{u}}(\mathrm{mm})$} \\
\hline AP1 & 0,9 & $1,2(13 \%)$ & $0,022(15,5 \%)^{1}$ & 0,024 & 0,017 \\
AP2 & 1,1 & $1,6(14,4 \%)$ & $0,023(14,4 \%)$ & 0,021 & 0,015 \\
AP3 & 1,8 & $2,3(16,4 \%)$ & $0,039(0,3 \%)$ & 0,021 & 0,015 \\
AP4 & 2,6 & $2,9(15,4 \%)$ & $0,065(11,4 \%)$ & 0,025 & 0,015 \\
& & Média & & 0,023 & 0,016 \\
\hline
\end{tabular}

Entre parênteses: coeficiente de variação

${ }^{1}$ Valor resultante do ensaio de nove corpos-de-prova

Os valores do índice de ductilidade apresentaram valor médio próximo ao recomendado por Lourenço (2006), contudo $20 \%$ inferior ao valor médio obtido para o concreto. A resistência à tração na flexão tem valor aproximadamente $30 \%$ maior que o valor obtido no ensaio à compressão diametral.

A evolução da energia de fratura é definida pela relação da Equação (5.15) e está ilustrada na Figura 5.24b.

$$
\mathrm{G}_{\mathrm{f}}=0,012 \mathrm{f}_{\mathrm{at}, \mathrm{fl}}^{1,55}
$$

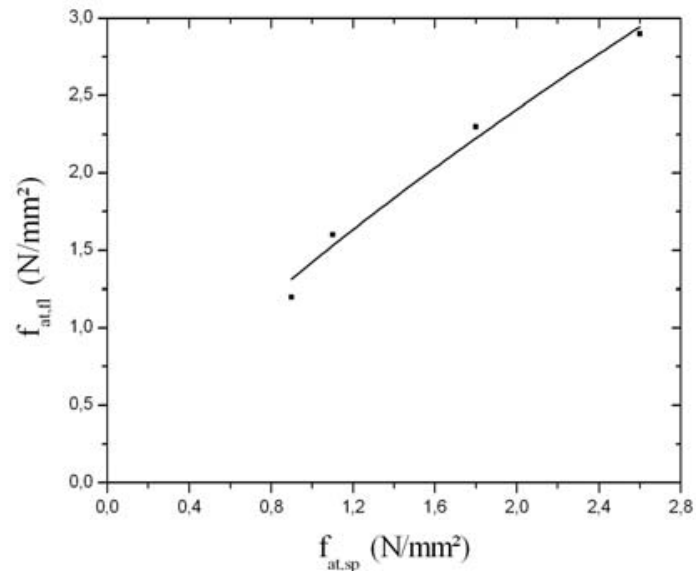

(a)

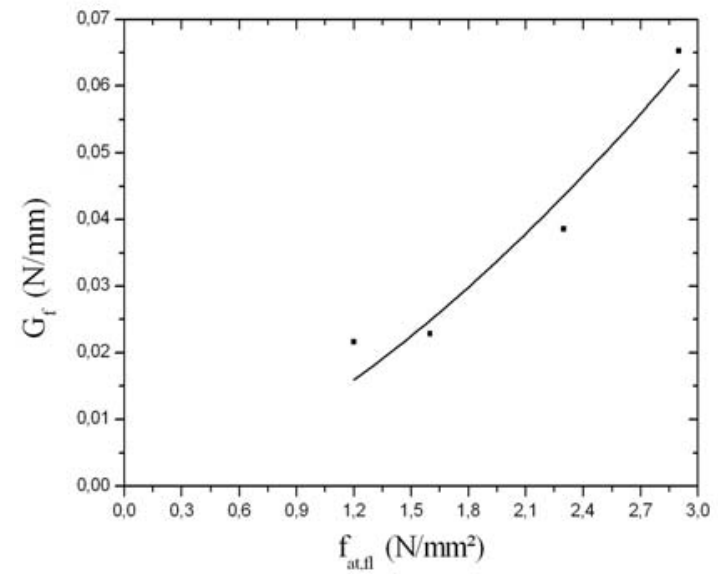

(b)

Figura 5.24 - Relação entre a resistência à tração na flexão e a obtida por compressão diametral (a) e crescimento do valor da energia de fratura em função da resistência à tração (b).

$\mathrm{Na}$ Tabela 5.21 estão sumarizados os valores referentes à energia de fratura obtida nos ensaios à compressão das argamassas. 
Tabela 5.21 - Resistência à compressão de corpos-de-prova de argamassa e valores da energia de fratura à compressão.

\begin{tabular}{cccccc}
\hline \multirow{2}{*}{ Grupo } & $\mathrm{f}_{\mathrm{a}}\left(\mathrm{N} / \mathrm{mm}^{2}\right)$ & \multicolumn{2}{c}{$\mathrm{G}_{\mathrm{f}_{\mathrm{c}}}(\mathrm{N} / \mathrm{mm})$} & \multicolumn{2}{c}{$\mathrm{d}_{\mathrm{u}, \mathrm{c}}(\mathrm{mm})$} \\
& & Experimental & CEB (1993) & Experimental & CEB (1993) \\
\hline AP1 & 7,5 & 10,2 & 18,0 & 1,36 & 1,60 \\
AP2 & 9,4 & 8,3 & 18,7 & 0,88 & 1,60 \\
AP3 & 15,5 & 15,5 & 20,7 & 1,01 & 1,36 \\
AP4 & 22,2 & 17,5 & 22,8 & 0,79 & 1,03 \\
\hline
\end{tabular}

A tendência de comportamento tanto da energia de fratura quanto do índice de ductilidade, em relação à evolução da resistência à compressão, é similar aos obtidos pela formulação teórica, apresentando, entretanto, valores mais baixos. Observa-se ainda que os valores do índice de ductilidade tanto na compressão quanto na tração são próximos aos obtidos nos ensaios com corpos-de-prova de concreto.

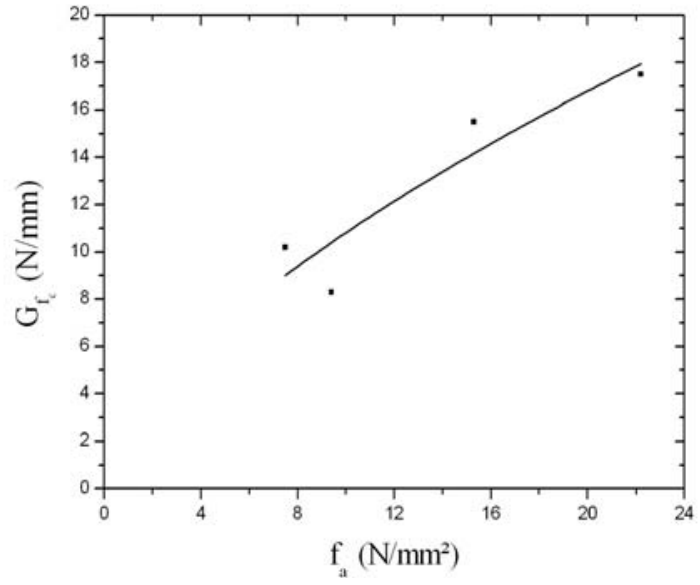

(a)

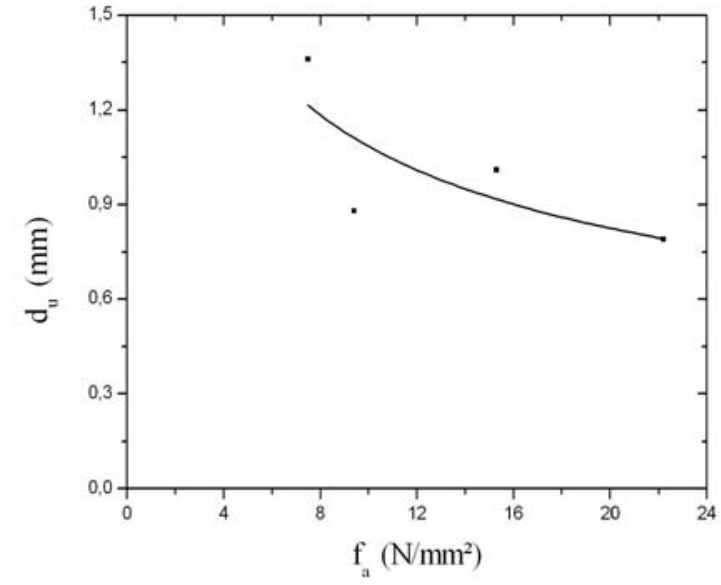

(b)

Figura 5.25 - Relação entre a resistência à compressão e: a energia de fratura (a) e o índice de ductilidade (b).

A equações (5.16) e (5.17) relacionam as variáveis apresentadas na Figura 5.25.

$$
\begin{aligned}
& \mathrm{G}_{\mathrm{f}_{\mathrm{c}}}=2,5 \mathrm{f}_{\mathrm{a}}^{0,64} \\
& \mathrm{~d}_{\mathrm{u}}=2,7 \mathrm{f}_{\mathrm{a}}^{-0,39}
\end{aligned}
$$





\section{MODELAGEM NUMÉRICA}

Apresenta-se neste capítulo a simulação do comportamento dos elementos de alvenaria de blocos vazados de concreto e corpos-de-prova submetidos à compressão axial por meio de análise numérica considerando-se o meio contínuo não-linear. Foram utilizados modelos tridimensionais na análise de blocos isolados, corpos-de-prova, prismas e miniparedes.

Nos modelos com blocos vazados de concreto, introduziram-se elementos finitos de interface para consideração do efeito de confinamento. Já na simulação de prismas, adotaramse três abordagens distintas: estado plano de tensões, estado plano de deformações e análise tridimensional. A análise das paredes considera as juntas verticais e os meio-blocos.

Adota-se a micromodelagem numérica não-linear de um meio contínuo para a previsão da resistência à compressão dos materiais. A validação dos modelos numéricos é efetuada com base nos resultados experimentais, quando é considerada a variação das propriedades mecânicas dos materiais e as condições de contorno dos modelos matemáticos. Os resultados das simulações numéricas são discutidos, atentando-se para a capacidade de representar o comportamento global e o modo de ruína obtido nos blocos e prismas.

A partir dos modelos matemáticos calibrados, foi analisada a distribuição de tensões e deformações por meio de perfis horizontais e verticais, destacando-se a influência da forma geométrica, da condição de vinculação, da junta de argamassa e de outros fatores intervenientes no comportamento global da estrutura.

Utiliza-se o programa computacional DIANA (2005) com o método de controle Arclength combinado com o método iterativo-incremental de Newton-Raphson e a técnica Line- 
search, introduzidos para a solução do sistema de equações não-lineares resultantes da discretização.

\subsection{Estratégia numérica}

O DIANA (2005) é um programa computacional baseado na formulação em deslocamentos do Método dos Elementos Finitos. Existente desde a década de 1970, destacase por ter seu desenvolvimento voltado para análise de estruturas civis, sendo uma ferramenta de grande potencial para análises de estruturas de concreto, inclusive contemplando fenômenos complexos tais como a fissuração, a plasticidade e a fluência.

O comportamento constitutivo dos materiais quase-frágeis é caracterizado pela fissuração em decorrência da tração e esmagamento sob compressão. Sendo assim, nas análises deve-se combinar um modelo de fissuração a um modelo de plasticidade. $\mathrm{O}$ comportamento dos materiais é representado pelo modelo de Drucker-Prager, sob compressão, e o modelo de Fissura Dispersa é utilizado como critério de ruptura à tração.

\subsubsection{O modelo de Drucker-Prager}

O critério de Drucker-Prager rege o comportamento do concreto quando submetido à compressão e é representado por uma aproximação suave da superfície de ruína de MohrCoulomb - superfície cônica no espaço das tensões principais -, conforme ilustra a Figura 6.1 (CHEN e HAN, 1988). Assume-se que $\sigma_{1}>\sigma_{2}>\sigma_{3}$.

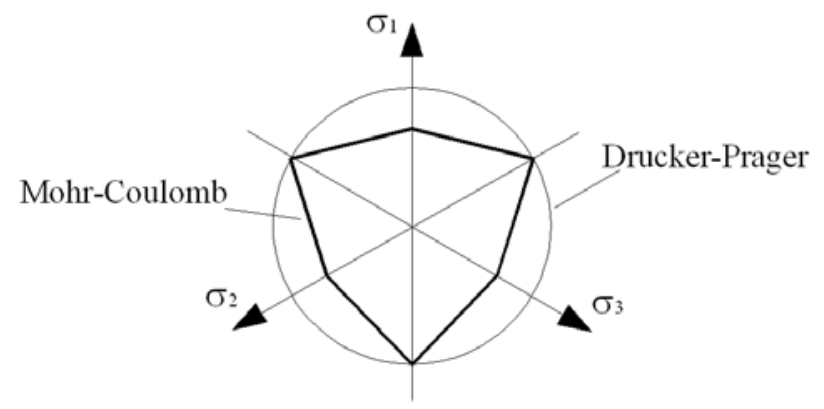

Figura 6.1 - Critérios de ruína de Mohr-Coulomb e Drucker-Prager no espaço de tensões principais, adaptada de DIANA (2005).

A formulação deste critério é descrita pela Equação (6.1), em que $\mathrm{P}$ e $\pi$ são, respectivamente, a matriz e o vetor de projeção.

$$
f(\sigma, \kappa)=\sqrt{\frac{1}{2} \sigma^{\mathrm{T}} \mathrm{P} \sigma}+\alpha_{\mathrm{f}} \pi^{\mathrm{T}} \sigma-\beta \mathrm{c}(\kappa)
$$


A coesão c é função da variável de estado interno $\kappa$. Dessa forma, a transformação dos dados experimentais de tensão-deformação, provenientes de um ensaio uniaxial, para as equivalentes relações coesão-variável de estado interno $(\mathrm{c}-\kappa)$ depende da hipótese de endurecimento. A Figura 6.2 representa a obtenção dos parâmetros plásticos a partir do ensaio experimental, considerando-se os ângulos de atrito $(\phi)$ e de dilatância $(\psi)$ constantes em relação à variável de estado interno, ou seja, $\phi(\kappa)=\phi_{0}$ e $\psi(\kappa)=\psi_{0}$. A relação entre a variável do estado interno e o processo de plastificação é definida pela hipótese de endurecimento, considerando-se apenas o endurecimento por deformação.

(a)

(b)

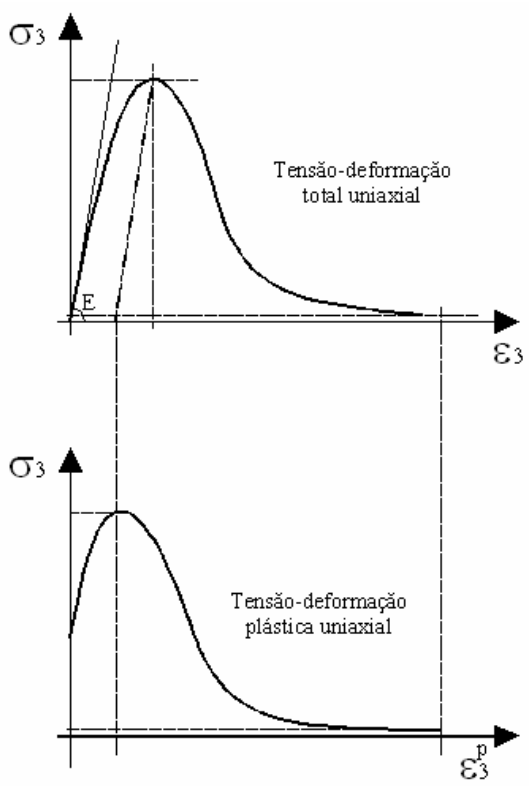

(c)

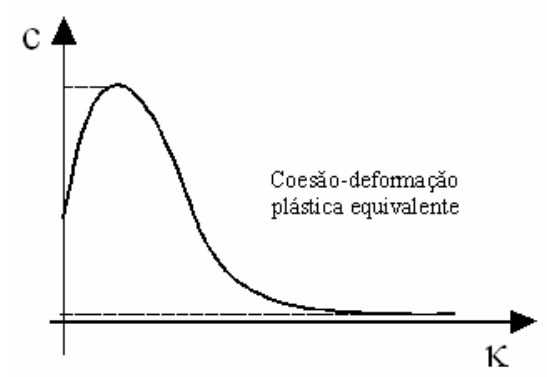

Figura 6.2 - Transformação das relações tensão-deformação para $c-\kappa$ a serem utilizadas no critério de Drucker-Prager, adaptada de DIANA (2005).

Analisando o diagrama tensão-deformação apresentado na Figura 6.2a, tem-se que a deformação plástica $\varepsilon_{3}^{\mathrm{p}}$ é obtida pela diferença entre a deformação total $\varepsilon_{3}$ e a deformação elástica $\varepsilon_{3}^{\mathrm{e}}$. O parâmetro escalar $\alpha_{\mathrm{g}}$, associado ao ângulo de dilatância $\psi$, é definido na Equação (6.2).

$$
\alpha_{\mathrm{g}}=\frac{2 \sin \psi(\kappa)}{3-\sin \psi(\kappa)}
$$

O diagrama tensão-deformação plástica resultante é apresentando na Figura $6.2 \mathrm{~b}$ e a taxa de deformação plástica uniaxial é dada pela Equação (6.3), levando-se em conta que $\varepsilon_{3}^{\mathrm{p}} \leq 0$ e que $\dot{\lambda}$ é o multiplicador que rege a evolução da plastificação. 


$$
\dot{\varepsilon}_{3}^{\mathrm{p}}=-\dot{\lambda}\left(1-\alpha_{\mathrm{g}}\right)
$$

Obtém-se a relação entre a deformação plástica uniaxial e a variável do estado interno por meio da Equação (6.4).

$$
\dot{\kappa}=\sqrt{\frac{1+2 \alpha_{g}^{2}}{1-\alpha_{g}}} \dot{\varepsilon}_{3}^{p}
$$

A relação entre $\sigma_{3}=-f_{c}$ e a coesão equivalente é obtida por meio da Equação (6.5).

$$
\overline{\mathrm{c}}=\mathrm{f}_{\mathrm{c}} \frac{1-\alpha_{\mathrm{f}}}{\beta}=\mathrm{f}_{\mathrm{c}} \frac{1-\operatorname{sen} \phi_{0}}{2 \cos \phi_{0}}
$$

Os parâmetros escalares $\alpha_{\mathrm{f}}$ e $\beta$ definem a superfície de ruptura do modelo de Drucker-Prager (Equações (6.6) e (6.7)).

$$
\begin{gathered}
\alpha_{f}=\frac{2 \sin \phi(\kappa)}{3-\sin \phi(\kappa)} \\
\beta=\frac{6 \cos \phi_{0}}{3-\sin \phi_{0}}
\end{gathered}
$$

Nesse critério de ruptura, os parâmetros de entrada, para cada material, são: a coesão, o seno do ângulo de atrito e o seno do ângulo de dilatância, que definem a superfície de ruína. O modelo ainda leva em consideração as relações entre os parâmetros de endurecimento e as coesões mobilizadas, o ângulo de atrito e o ângulo de dilatância.

\subsubsection{O modelo de Fissuração Dispersa}

Os modelos de plasticidade não conduzem a bons resultados sob regime de tração para materiais frágeis. Sendo assim, utilizou-se uma combinação do modelo de fissuração distribuída (smeared crack, tension cut, tension softening e shear retention) para representar o comportamento à tração. No modelo utilizado são introduzidos os conceitos de Mecânica da Fratura e da Teoria do Dano.

O comportamento à tração é representado pelo modelo de Fissuração Dispersa com decomposição de deformações. A formulação desta teoria considera os conceitos de Mecânica da Fratura e da Teoria do Dano para modelar o processo de amolecimento e é detalhada por Rots (1993). 
Em um modelo de fissuras decompostas, a deformação total é separada em deformação elástica $\varepsilon^{\mathrm{e}}$ e deformação da fissura $\varepsilon^{\mathrm{cr}}$. O surgimento da fissura é determinado por meio da combinação dos critérios em que se limita a tensão de tração, do amolecimento na tração e da retenção do cisalhamento.

A subdecomposição da deformação de fissuração $\left(\varepsilon^{\text {cr }}\right)$ fornece a possibilidade de modelar um determinado número de fissuras que ocorre simultaneamente. A característica básica do conceito de fissura multi-direcional orientada é que um par de tensão e deformação $\left(\sigma_{i}, \varepsilon_{i}^{\text {cr }}\right)$ existe no sistema de coordenadas n-t que é alinhado com cada fissura i (Figura 6.3).

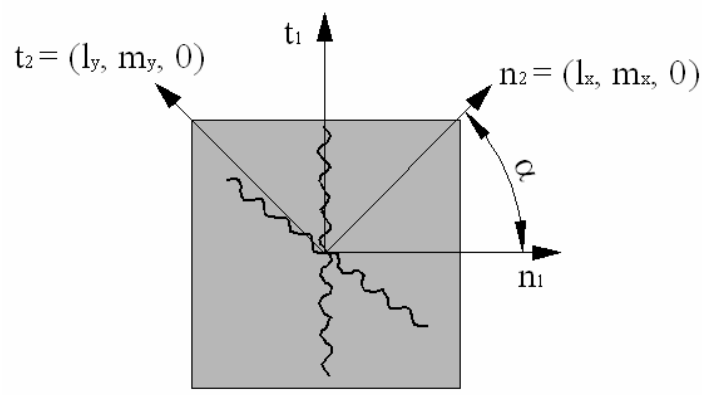

Figura 6.3 - Modelo de fissuras orientadas multi-direcionais, adaptada de DIANA (2005).

Quando o critério simplificado de ruptura à tração é satisfeito, surge uma fissura na direção perpendicular da tensão principal de tração que passará a ser controlada pelo modelo de Fissuração Dispersa.

No modelo de fissura distribuída o fraturamento é assumido como uma faixa de microfissuras distribuídas sobre um elemento finito. Assim que um elemento finito seja fissurado, a matriz de rigidez isotrópica é modificada para uma matriz ortotrópica. A rigidez na direção da tensão principal de tração é gradualmente reduzida a zero (BITTENCOURT, 1999).

No modelo de Fissuração Distribuída o material danificado ainda é considerado como um meio contínuo e as notações de tensão e deformação podem ser aplicadas sem a necessidade de se construir uma nova malha enquanto as fissuras se propagam. Com essa hipótese, o dano pode ser representado por um parâmetro relacionado com um comprimento equivalente da energia dissipada por unidade de área fissurada, $G_{f}$. Esta energia de fraturamento, o comprimento equivalente e a banda de fissuras são os parâmetros relacionados com a Mecânica da Fratura, introduzidos no modelo de Fissuração Distribuída. 
O início da fissura é governado por um critério de tração com interrupção - na qual o critério de ruptura do material é atingido - e pelo ângulo inicial entre duas fissuras consecutivas. Para iniciações sucessivas de fissuras, o programa DIANA (2005) considera dois critérios que devem ser satisfeitos simultaneamente:

a) a tensão principal de tração ultrapassa o limite do critério de tração;

b) o ângulo entre a fissura existente e a tensão principal de tração excede o valor de um ângulo pré-determinado.

Entretanto, de acordo com Rots (1997) ${ }^{1}$ apud DIANA (2005), é possível que a tensão de tração seja, momentaneamente, maior que três vezes a resistência à tração até que a limitação do ângulo inicial seja ultrapassada.

Usa-se o critério de tração com interrupção linear, conforme apresentado na Figura 6.4a. Por esse critério, a fissura surge quando a maior tensão principal de tração exceder o menor valor entre $f_{t}$ e $f_{t}\left(1+\sigma_{\text {lateral }} / f_{c}\right)$, sendo $\sigma_{\text {lateral }}$ a tensão principal lateral.

Lourenço (1996) define o amolecimento como um decréscimo gradual da resistência mecânica sob um contínuo aumento da deformação forçada ao material, associado à heterogeneidade do material devida à presença de diferentes fases, como falhas e vazios. $\mathrm{O}$ comportamento inelástico, tanto na tração quanto na compressão pode ser descrito por uma integral do diagrama $\sigma-\delta$, denotadas de energia de fratura e assumidas como propriedades mecânicas dos materiais.

O amolecimento sob tração é considerado linear, conforme modelo da Figura $6.4 \mathrm{~b}$, baseado na energia de fratura. $\mathrm{Na}$ Equação (6.8), $\varepsilon_{\mathrm{u}}^{\mathrm{cr}}$ é a deformação última do diagrama.

$$
\varepsilon_{\mathrm{u}}^{\mathrm{cr}}=\frac{2 \mathrm{G}_{\mathrm{f}}}{\mathrm{f}_{\mathrm{t}} \mathrm{h}_{\mathrm{cr}}}
$$

Onde:

$\mathrm{G}_{\mathrm{f}}$ : energia de fratura;

$\mathrm{h}_{\mathrm{cr}}$ : comprimento da banda de fissura estimada numericamente, relacionado com o volume do elemento do elemento finito.

\footnotetext{
${ }^{1}$ ROTS, J.G (Ed.) (1997). Structural Masonry - An Experimental/Numerical Basis for Practical Design Rules. Balkema, Rotterdam, The Netherlands.
} 


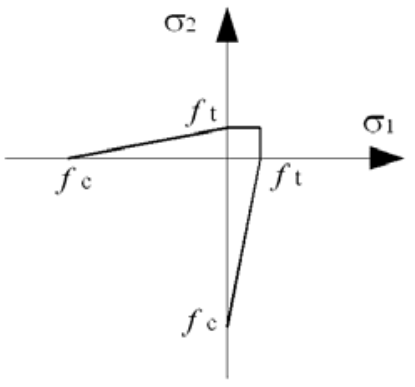

(a)

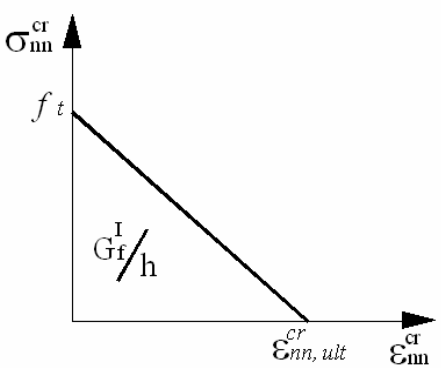

(b)

Figura 6.4 - Tração com interrupção no espaço bidimensional de tensões principais (a) e amolecimento linear na tração (b), adaptado de DIANA (2005).

Já a retenção do cisalhamento é o fenômeno associado à redução da rigidez do material em função de sua fissuração. Nestas análises, o módulo de cisalhamento elástico não é reduzido, ou seja, a rigidez ao cisalhamento secante da fissura é infinita, adotando-se a opção de retenção completa do cisalhamento.

\subsubsection{Resolução do sistema de equações não-lineares}

Quando as equações de equilíbrio não são lineares, um processo incrementaliterativo é utilizado para a solução do equilíbrio. Nestas análises adota-se o método de Newton-Raphson, que lineariza as condições de equilíbrio em cada iteração. Souza (2004) alerta que este método apresenta uma grande deficiência, pois não permite um comportamento global convergente e não consegue superar pontos limites na curva carga-deslocamento. Essa característica decorre da possibilidade do sistema de equações não-lineares convergir para qualquer ponto inicial.

Para superar alguns destes problemas que normalmente surgem em análises nãolineares, utilizam-se o método de procura de linhas (Line search) e o método de comprimento de $\operatorname{arco}($ Arc-length).

De acordo com Pereira (2005), o método de Procura de Linhas tem o objetivo de evitar a falha catastrófica do Método de Newton-Raphson e, em alguns casos, resulta na aceleração da convergência do processo iterativo. Esse método usa o cálculo de um multiplicador ótimo para o campo dos deslocamentos incrementais e é extremamente útil quando os processos ordinários de iteração não são suficientes.

O método de Comprimento de Arco é utilizado para resolver deficiências do processo incremental-iterativo por meio da introdução de restrições no sistema de equações, o 
que possibilita capturar o comportamento pós-pico da estrutura com utilização de incrementos decrescentes (CRISFIELD, 1981).

\subsubsection{Elementos finitos utilizados}

Os modelos tridimensionais que representam os blocos vazados de concreto, prismas e paredes são discretizados com os elementos finitos CHX60 (Figura 6.5a) com 20 nós, sendo 12 intermediários, adotando-se integração $3 \times 3 \times 3$ nos pontos de Gauss com interpolação quadrática.

Já na modelagem de corpos-de-prova de concreto e argamassa, adota-se o elemento finito CTP45, prismático, de 15 nós, sendo três deles intermediários, conforme ilustra a Figura $6.5 b$.

Quando considerada a interface entre o bloco de concreto e a placa de ensaio, são utilizados os elementos finitos CQ48I, específicos para serem dispostos entre dois planos numa configuração de análise tridimensional. O CQ48I baseia-se numa interpolação quadrática 4 x 4 Newton-Cotes (Figura 6.5c).

As análises bidimensionais com prismas utilizam elementos finitos quadrilaterais de 8 nós CQ16M, ilustrado na Figura 6.5d, fundamentado em uma interpolação quadrática, adotando-se integração de Gauss 3 x 3.

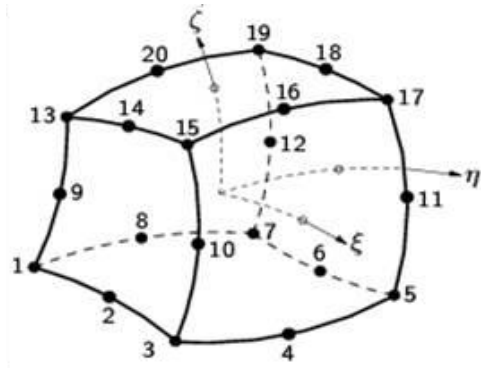

(a)

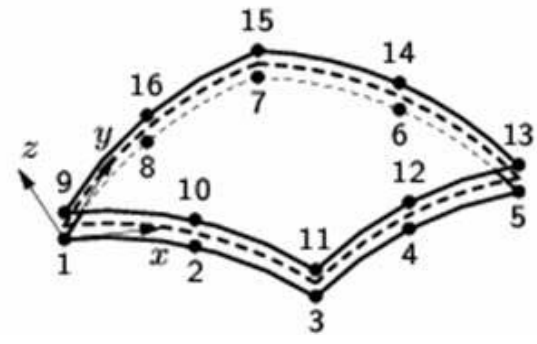

(c)

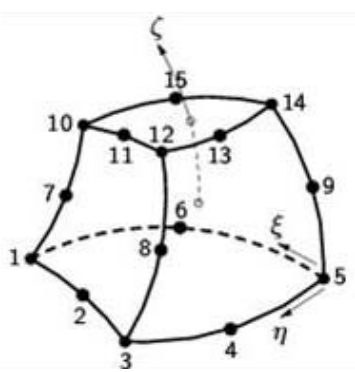

(b)

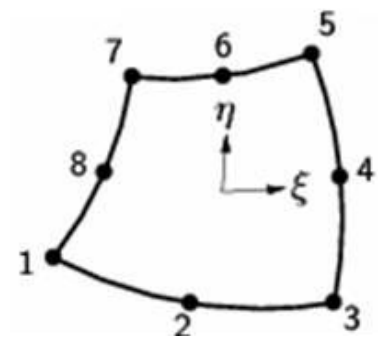

(d)

Figura 6.5 - Elementos finitos tridimensionais com 20 nós (a) e 15 nós (b) e plano com 16 nós (c), adaptado de DIANA (2005). 


\subsection{Corpos-de-prova de concreto}

Discretizou-se um oitavo da geometria real do corpo-de-prova com elementos finitos tridimensionais CTP45, resultando um modelo com 1000 elementos e 3201 nós. A Figura 6.6 apresenta a geometria real do $\mathrm{CP}$, as delimitações da região discretizada e a malha em elementos finitos resultante.

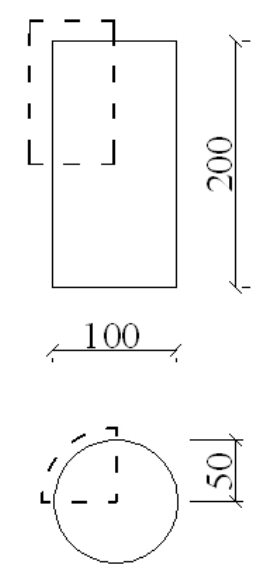

(a)

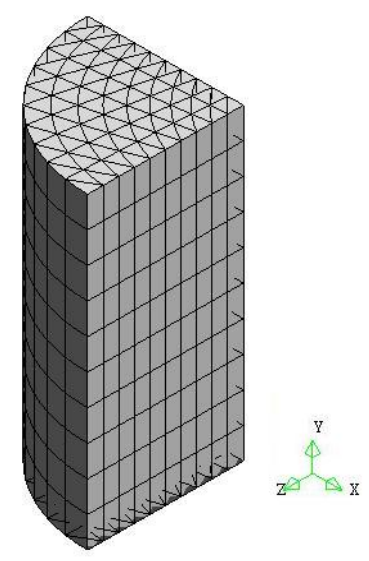

(b)

Figura 6.6 - Dimensões do modelo físico e região a ser discretizada (a). Malha em elementos finitos do modelo matemático (b).

A partir dos valores médios obtidos nas análises experimentais, foram definidos os parâmetros elásticos e inelásticos usados nas simulações numéricas, os quais são apresentados na Tabela 6.1, considerando-se quatro grupos de resistência. Os nós da base do modelo numérico tiveram seus deslocamentos impedidos no sentido dos eixos y e os nós do topo nos sentidos dos eixos x e $\mathrm{z}$, aproximando, desta forma, a condição relativa ao atrito entre as placas de ensaio e as extremidades do corpo-de-prova de concreto. São consideradas também as condições de contorno pertinentes à simetria. Adota-se o ângulo de atrito $(\phi)$ igual a $10^{\circ}$, de acordo com a proposição de DIANA (2005), com o valor da coesão obtido por meio da Equação (6.5). Com base no trabalho de Vermeer and de Borst (1984), assume-se o ângulo de dilatância $\psi$ igual a $5^{\circ}$. Os autores indicam que um valor mais alto de $\psi$ no estado plano de tensões, por exemplo, implicaria na superestimativa da resistência à compressão biaxial quando adotado o critério de ruptura de Drucker-Prager. 
Tabela 6.1 - Propriedades elásticas e inelásticas do concreto.

\begin{tabular}{cccccc}
\hline Grupo & $\mathrm{f}_{\mathrm{c}}$ & $\begin{array}{c}\mathrm{f}_{\mathrm{c}, \mathrm{t}} \\
\left(\mathrm{N} / \mathrm{mm}^{2}\right)\end{array}$ & $\mathrm{E}$ & $v$ & $\begin{array}{c}\mathrm{G}_{\mathrm{f}} \\
(\mathrm{N} / \mathrm{mm})\end{array}$ \\
\hline $\mathrm{CP} 1$ & 13,4 & 1,5 & 18080 & 0,20 & 0,093 \\
$\mathrm{CP} 2$ & 22,1 & 2,3 & 24476 & 0,20 & 0,1068 \\
$\mathrm{CP} 3$ & 26,0 & 2,6 & 23956 & 0,20 & 0,1215 \\
$\mathrm{CP} 4$ & 30,9 & 2,8 & 23004 & 0,20 & 0,1542 \\
\hline
\end{tabular}

$\mathrm{f}_{\mathrm{c}}$ : resistência à compressão do concreto

$\mathrm{f}_{\mathrm{c}, \mathrm{t}}$ : resistência à tração do concreto

E : módulo de elasticidade

$v$ : coeficiente de Poisson

$\mathrm{G}_{\mathrm{f}}$ : energia de fratura à tração

Conforme dados da Tabela 6.2, as forças máximas obtidas nos modelos matemáticos $\left(F^{\text {num }}\right)$ são, em média, 6\% inferiores às obtidas nas análises experimentais dos corpos-deprova de concreto $\left(\mathrm{F}^{\mathrm{exp}}\right)$. A rigidez inicial em ambas as análises também são coincidentes, apenas com ligeira divergência em relação à deformação última que na análise numérica $\left(\varepsilon_{u}^{\text {num }}\right)$ é aproximadamente $17 \%$ menor que o valor experimental $\left(\varepsilon_{u}^{\text {exp }}\right)$.

Tabela 6.2 - Força e deformação máxima obtida nas análises experimentais e teóricas de corpos-de-prova de concreto.

\begin{tabular}{|c|c|c|c|c|c|c|}
\hline \multirow{2}{*}{ Grupo } & $\mathrm{F}^{\exp }$ & $\mathrm{F}^{\text {num }}$ & $F^{\text {num }}$ & $\varepsilon_{\mathrm{u}}^{\mathrm{exp}}$ & $\varepsilon_{\mathrm{u}}^{\text {num }}$ & \multirow{2}{*}{$\frac{\varepsilon^{\text {num }}}{\varepsilon^{\exp }}$} \\
\hline & \multicolumn{2}{|c|}{$(\mathrm{kN})$} & $F^{\exp }$ & \multicolumn{2}{|c|}{$(\mu)$} & \\
\hline CP1 & 105 & 95 & 0,90 & 1707 & 1525 & 0,89 \\
\hline $\mathrm{CP} 2$ & 174 & 154 & 0,89 & 2293 & 1731 & 0,75 \\
\hline CP3 & 204 & 198 & 0,97 & 2013 & 1870 & 0,93 \\
\hline CP4 & 243 & 240 & 0,99 & 2367 & 1819 & 0,77 \\
\hline
\end{tabular}

Apresentam-se na Figura 6.7 os gráficos tensão-deformação do modelo numérico e as curvas obtidas experimentalmente para cada grupo de resistência. 


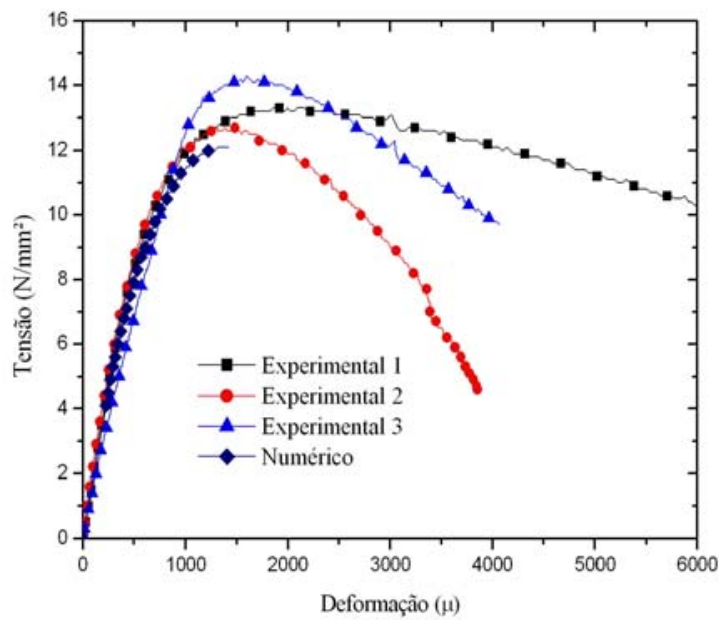

(a)

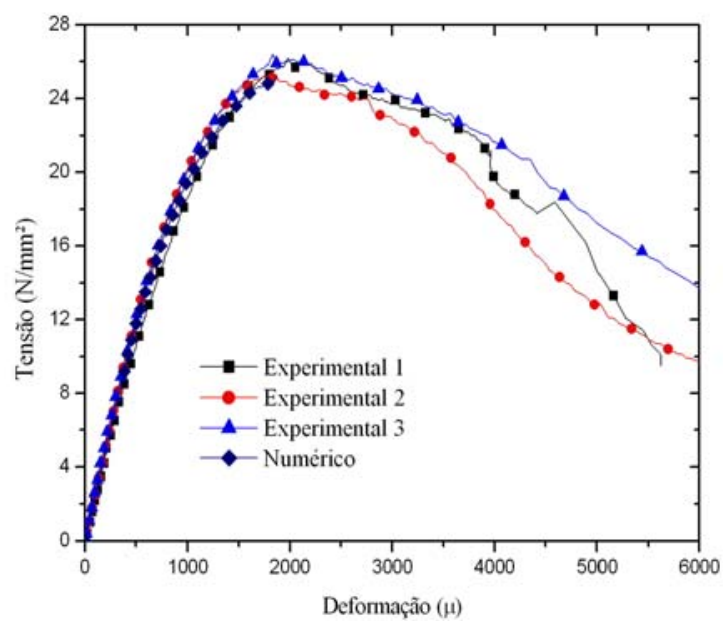

(c)

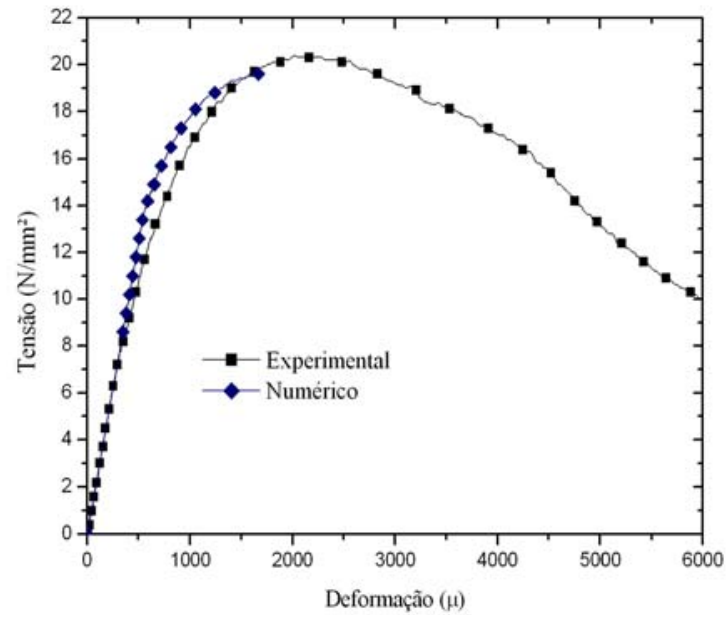

(b)

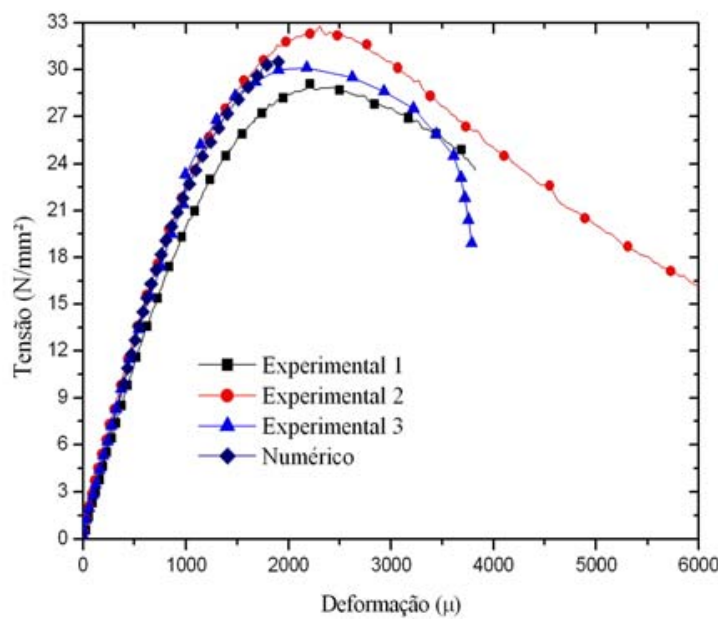

(d)

Figura 6.7 - Curva tensão-deformação ${ }^{2}$ experimental e numérica de corpos-de-prova cilíndricos de concreto: CP1 (a), CP2 (b), CP3 (c) e CP4 (d).

\subsubsection{Distribuição das tensões no corpo-de-prova de concreto}

Para a análise detalhada da distribuição de tensões e deformações foi adotado o grupo de resistência CP3. Definiram-se seções horizontais e transversais ao longo do plano yz definido pela curva que fica no plano da base do corpo-de-prova. H1, H2 e H3 são as seções horizontais enquanto que as seções verticais são definidas por V1, V2 e V3, conforme ilustração da Figura 6.8. Apresentam-se os resultados em relação a três níveis de

\footnotetext{
${ }^{2}$ As relações tensão-deformação apresentadas referem-se ao valor médio de tensão aplicado na superfície superior do modelo numérico, tanto nestas análises quanto nas subseqüentes com blocos, prismas e paredes.
} 
carregamento (1, 2 e 3$)$ relativos à tensão máxima de compressão obtida no modelo numérico, respectivamente associados a $0,3 f_{c}, 0,7 f_{c}$ e $f_{c}$.

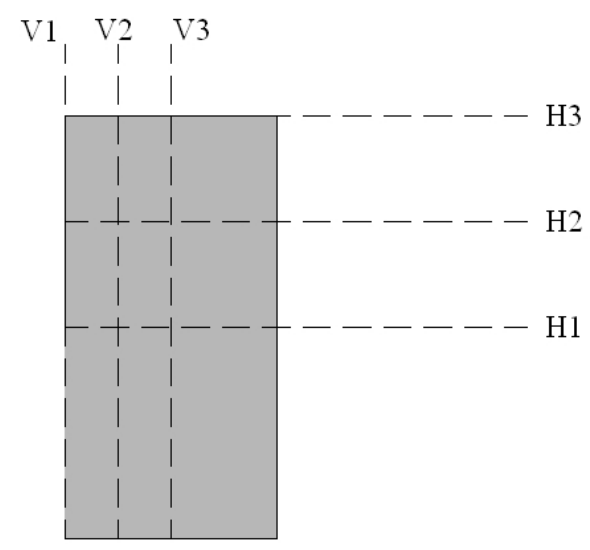

Figura 6.8 - Seções horizontais e verticais definidas para o corpo-de-prova.

De acordo com a Figura 6.9a, a distribuição de tensões na seção H1 mostra-se, para os três níveis de carregamento, bastante uniforme. Apenas no nível de carregamento 3 são obtidas diferenças máximas de 5\%. Na análise da seção H2 identifica-se maior intensidade no aumento dos valores das tensões em direção à região central, que difere em $5 \%$ no regime linear e em $8 \%$ no nível mais alto de carregamento dos valores obtidos nas extremidades (Figura 6.9b). A seção H3, que representa os valores de tensões no topo do corpo-de-prova e, portanto, é fortemente influenciada pelo efeito de confinamento causado pelas restrições impostas, apresenta as maiores variações de tensões, pois o efeito de confinamento é mais intenso no centro do corpo-de-prova.

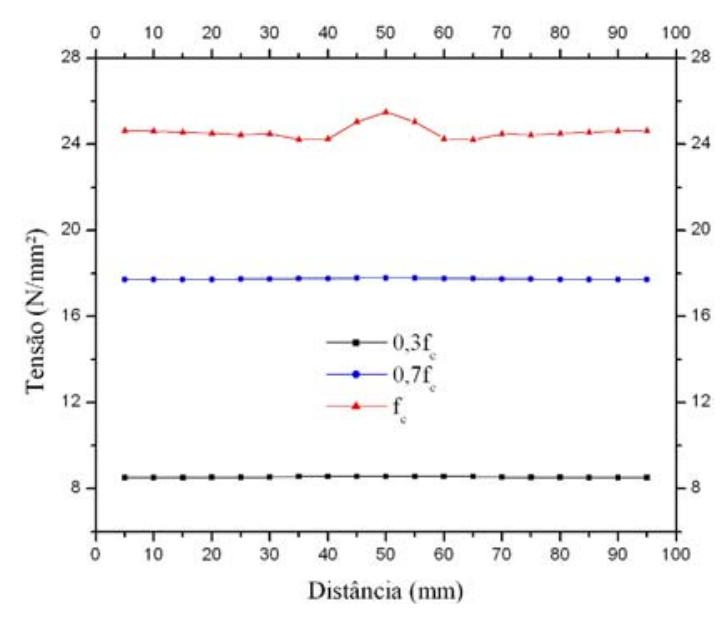

(a)

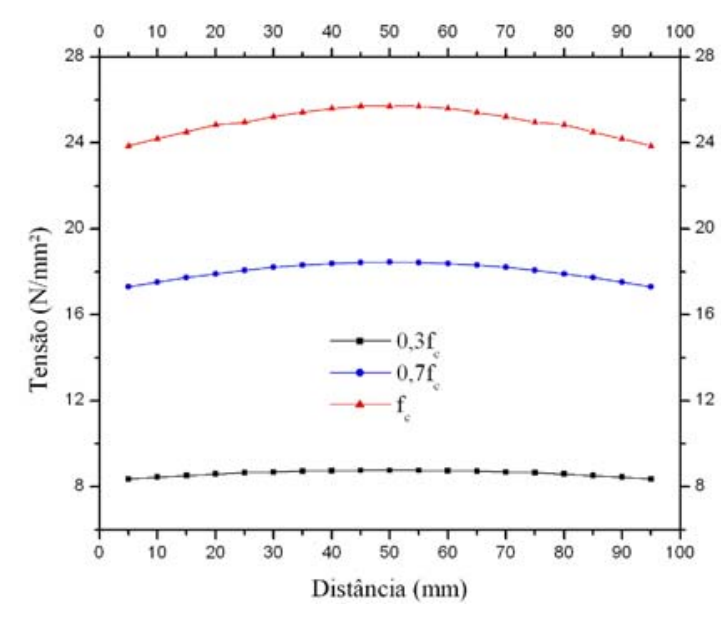

(b)

Figura 6.9 - Perfis H1(a) e H2 (b) das tensões principais mínimas efetivas. 
A análise das seções verticais V2 e V3, na Figura 6.10, indica uma tendência suave de redução de tensão em direção à altura média do $\mathrm{CP}$.

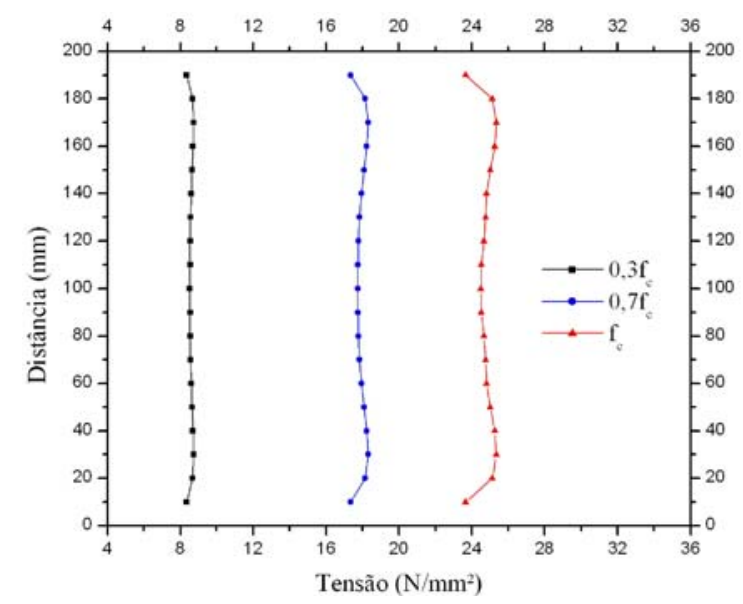

(a)

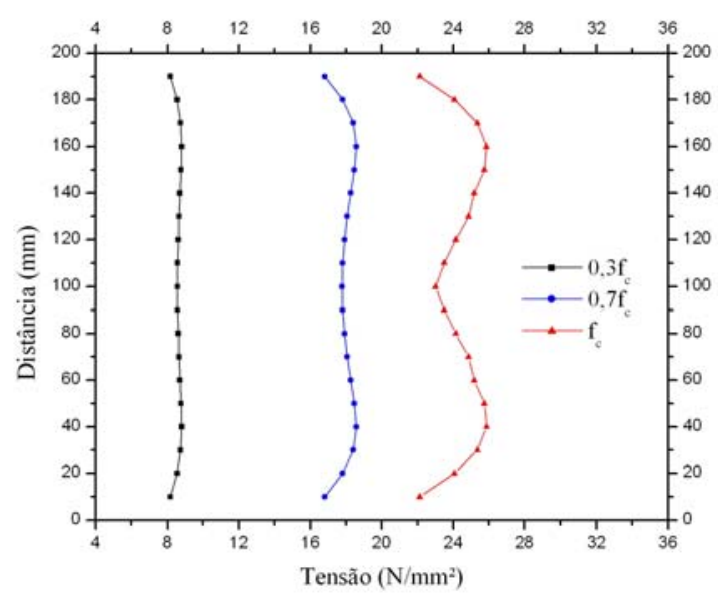

(b)

Figura 6.10 - Perfis V2 (a) e V3 (b) das tensões principais mínimas efetivas.

Apresenta-se na Figura 6.11 a ilustração geral da distribuição de tensões com destaque para o nível baixo de tensões transversais, caracterizando a ausência de confinamento na região próxima à altura média do corpo-de-prova.

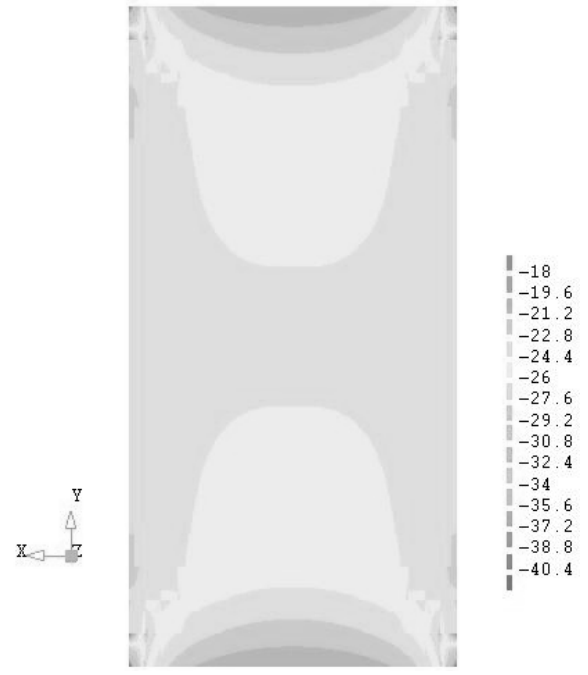

(a)

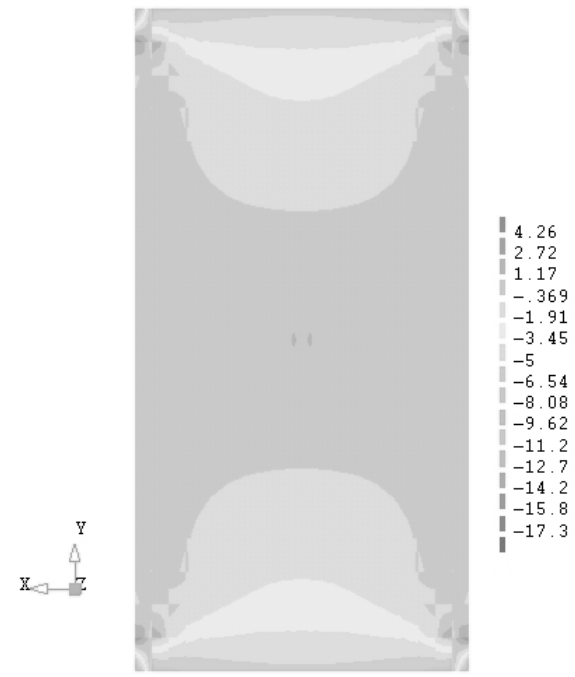

(b)

Figura 6.11 - Níveis de contorno das tensões principais mínimas (a) e tensões transversais (b) no corpo-de-prova.

\subsubsection{Distribuição de deformações no corpo-de-prova de concreto}

A distribuição de deformações segue a tendência da distribuição de tensões, com aumento do valor em direção à altura média do corpo-de-prova. Destaca-se o comportamento 
do perfil da seção $\mathrm{H} 2$, em relação às deformações plásticas, que apresenta diferenças entre $20 \%$ e $25 \%$ entre os valores máximos e mínimos nos níveis de carregamento 1 e 2 , respectivamente. De acordo com a Figura 6.12a, é evidente a diferença entre as deformações plásticas nas extremidades e na altura média do CP. Na Figura $6.12 \mathrm{~b}$ está apresentada a distribuição de deformações plásticas em níveis de contorno e a deformada incremental da malha de elementos finitos representando a ruína na altura no centro do modelo.

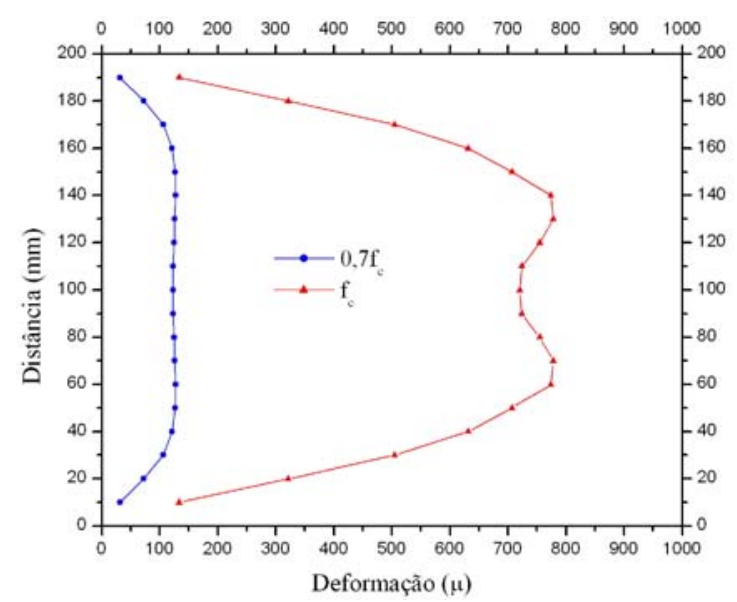

(a)

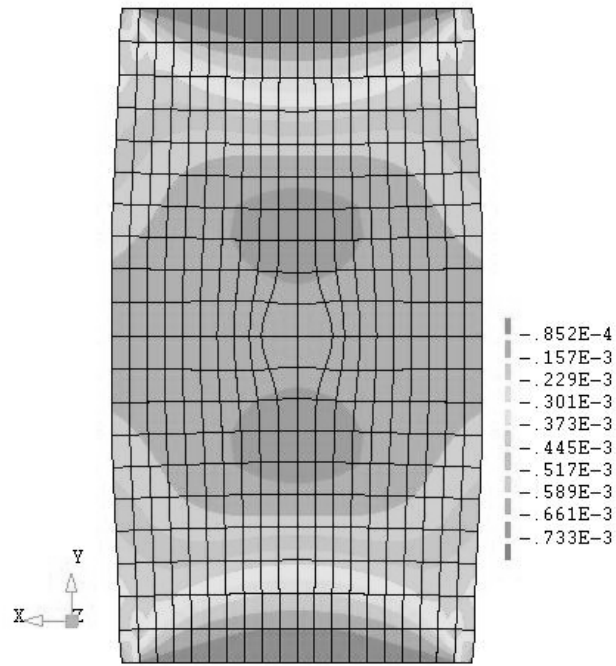

(b)

Figura 6.12 - Perfis V2 das deformações plásticas verticais (a). Deformações plásticas ao longo do corpo-de-prova com deformada incremental da malha do corpo-de-prova (b).

Por esta análise fica evidente a uniformidade dos campos de tensões e deformações na região central de um corpo-de-prova cilíndrico de concreto. A relação $h / t=2$ permite que o efeito de confinamento atue de forma menos intensa em direção à altura média do corpo-deprova, resultando em tensões uniformes.

\subsection{Blocos vazados de concreto}

A malha foi discretizada em 1320 elementos tridimensionais $\mathrm{CHX} 60$, totalizando 7441 nós. Simulou-se apenas um quarto do bloco com a consideração de sua altura real, conforme ilustrações da Figura 6.13. Aplicou-se tensão uniformemente distribuída na superfície superior do bloco forçando-se a igualdade dos deslocamentos no sentido do eixo y de todos os seus nós. 


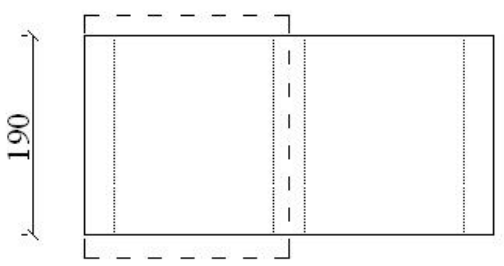

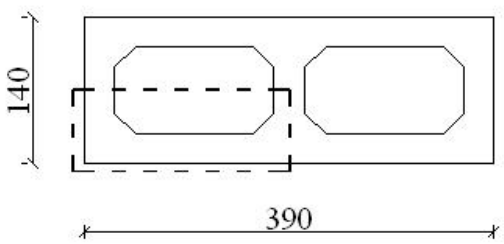

(a)

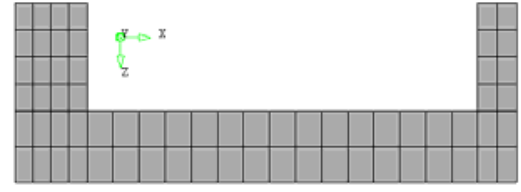

(b)

Figura 6.13 - Região do bloco vazado a ser discretizada (a) e malha em elementos finitos resultante (b).

As propriedades mecânicas do concreto foram obtidas a partir dos ensaios com corpos-de-prova cilíndricos e vigas de tamanho reduzido, conforme descrição apresentada nos Capítulos 4 e 5 . Os parâmetros elásticos e inelásticos do concreto utilizados nos modelos matemáticos estão apresentados na Tabela 6.1, sendo os grupos CP1, CP2, CP3 e CP4 associados aos grupos B1, B2, B3 e B4, dos blocos, respectivamente. Os ângulos de atrito e dilatância também não têm seus valores alterados.

Adotaram-se condições de contorno distintas com o objetivo de simular o atrito entre as placas de ensaio e o modelo físico e a conseqüente atuação do confinamento. Inicialmente, os nós da superfície inferior do modelo matemático tiveram seus deslocamentos restringidos nas direções $\mathrm{x}, \mathrm{y}$ e $\mathrm{z}$ e os nós da superfície superior nas direções $\mathrm{x}$ e $\mathrm{z}$, associando-o ao confinamento perfeito. Foi simulada a redução do efeito de confinamento por meio de um modelo mais refinado no qual são inseridos elementos finitos de interface entre as placas de aço - agora discretizada - e o bloco de concreto. Dessa forma, torna-se possível a alteração do nível de atrito entre as placas de ensaio e as extremidades do bloco vazado de concreto com a variação das propriedades de interface. Com a adição da interface e das placas de ensaio o modelo passa a ter 1716 elementos e 9399 nós (Figura 6.14). Utilizaram-se como elementos das placas de aço o CHX60 e na interface elementos planos CQ48I, tendo estes espessura nula.

Com essa abordagem, a análise de resultados de ensaios de blocos, com distintas condições de capeamento das superfícies de carregamento, pode ser feita de modo mais detalhado. 


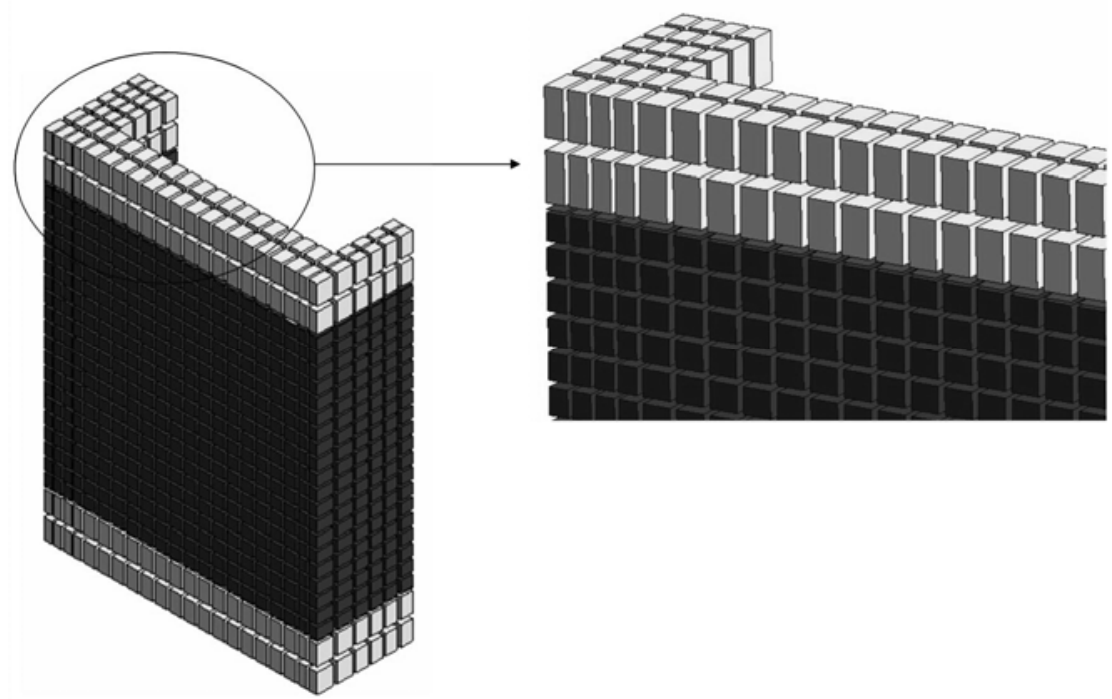

Figura 6.14 - Visualização do modelo discretizado com detalhe dos elementos de interface entre as placas de ensaio e as superfícies do bloco de concreto.

As propriedades dos materiais de capeamento atribuídas à interface bloco-placa de ensaio são determinadas a partir das análises experimentais realizadas por Kleeman e Page (1990), que analisaram distintos materiais de capeamento submetidos à compressão axial e ao cisalhamento. Detalhes desse programa experimental são apresentados no Capítulo 2 e contemplam cinco distintos níveis de carga axial em ambos os ensaios: $5 \mathrm{~N} / \mathrm{mm}^{2}, 10 \mathrm{~N} / \mathrm{mm}^{2}$, $15 \mathrm{~N} / \mathrm{mm}^{2}, 20 \mathrm{~N} / \mathrm{mm}^{2}, 25 \mathrm{~N} / \mathrm{mm}^{2}$ e $30 \mathrm{~N} / \mathrm{mm}^{2}$.

Nas análises a seguir, foram usadas as propriedades obtidas no ensaio com o material particle board, caracterizado como sendo uma chapa constituída por aglomerado de madeira e cola. O comportamento não-linear do material é apresentado na Figura 6.15 e os valores das rigidezes vertical e transversal constam na Tabela 6.3. Portanto, como parâmetros de entrada do modelo, definem-se as rigidezes linear vertical e transversal e um conjunto de relações multilineares entre as tensões, verticais e transversais, e seus respectivos deslocamentos. 


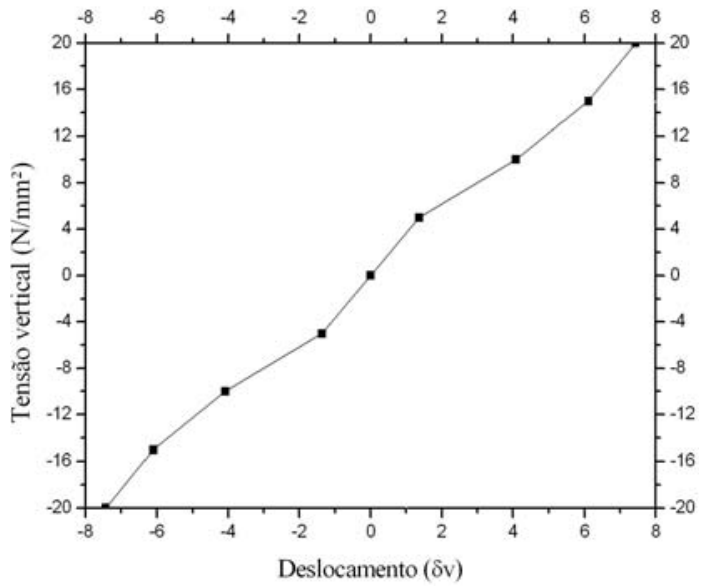

(a)

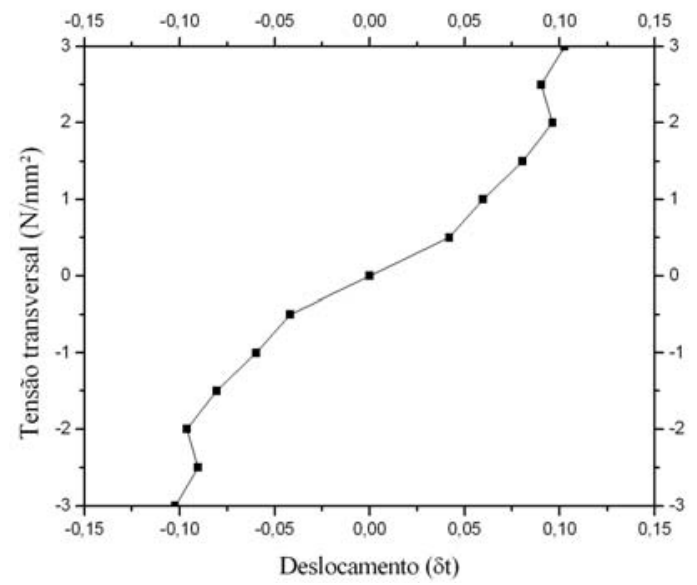

(b)

Figura 6.15 - Gráficos tensão-deslocamento verticais (a) e transversais (b) do particle board.

Por fim, introduz-se o comportamento linear de um material com propriedades mecânicas similares às da borracha natural, o qual permite o maior alívio do efeito de confinamento. Na Tabela 6.3 é apresentado um resumo das propriedades mecânicas lineares adotadas em cada modelo matemático representativo da condição de atrito entre as placas de ensaio e o bloco.

Tabela 6.3 - Modelos de confinamento e rigidez linear adotada.

\begin{tabular}{cccc}
\hline Modelo & Descrição & $\mathrm{k}_{\mathrm{v}}\left(\mathrm{N} / \mathrm{mm}^{3}\right)$ & $\mathrm{k}_{\mathrm{t}}\left(\mathrm{N} / \mathrm{mm}^{3}\right)$ \\
\hline A & Confinamento perfeito $^{1}$ & - & - \\
B & Confinamento intermediário & 2,89 & 11,91 \\
C & Ausência de confinamento & 0,61 & 0,11 \\
\hline
\end{tabular}

$\mathrm{k}_{\mathrm{v}}$ : rigidez vertical

$\mathrm{k}_{\mathrm{t}}$ : rigidez transversal

${ }^{1}$ Não se utiliza elemento finito de interface, considerando os nós das superfícies superior e inferior do bloco com deslocamentos transversais nulos.

Os resultados experimentais e numéricos são comparados considerando-se o confinamento perfeito (modelo A), obtendo-se, para os quatro grupos de resistência, força teórica de ruptura próxima aos valores experimentais. Os valores da Tabela 6.4 indicam que as diferenças são em média de $9 \%$. 


\begin{tabular}{|c|c|c|c|c|c|c|}
\hline \multirow{2}{*}{ Grupo } & $F^{\exp }$ & $\mathrm{F}^{\text {num }}$ & $\mathrm{F}^{\text {num }}$ & $\varepsilon_{\mathrm{u}}^{\exp }$ & $\varepsilon_{\mathrm{u}}^{\mathrm{num}}$ & \multirow{2}{*}{$\frac{\varepsilon^{\text {num }}}{\varepsilon^{\exp }}$} \\
\hline & \multicolumn{2}{|c|}{$(\mathrm{kN})$} & $\mathrm{F}^{\exp }$ & \multicolumn{2}{|c|}{$(\mu)$} & \\
\hline B1 & 389 & 399 & 1,03 & 883 & 1199 & 1,36 \\
\hline B2 & 813 & 650 & 0,80 & 1464 & 1580 & 1,08 \\
\hline B3 & 871 & 822 & 0,94 & 1727 & 1705 & 0,99 \\
\hline B4 & 935 & 1003 & 1,07 & 1437 & 1892 & 1,32 \\
\hline
\end{tabular}

Na Figura 6.16 são apresentados os gráficos tensão-deformação dos blocos vazados de concreto e as respectivas curvas experimentais dos quatro grupos de resistência. Em todos os casos o modelo numérico apresenta rigidez inicial mais baixa que o conjunto das curvas experimentais, e também uma variação de até $36 \%$ em relação aos valores de deformação última. Justifica-se este fato pela não representação específica das condições de contorno do modelo físico, dada a falta de dados experimentais relativos à interface bloco-placa de ensaio. Além disso, o modelo contínuo em elementos finitos pode não representar satisfatoriamente a forma de ruína dos blocos no pós-pico, o que pode ser aperfeiçoado com a utilização de modelos reticulados. A deformação última que o modelo numérico apresenta é geralmente maior que a obtida no modelo experimental, contrapondo-se à situação observada na análise dos CP's. Esse contraste é atribuído às formas geométricas distintas: enquanto o corpo-deprova está livre do confinamento nas regiões mais distantes das placas de ensaio, o bloco, em função de sua menor relação h/t, sofre influência deste fenômeno. 


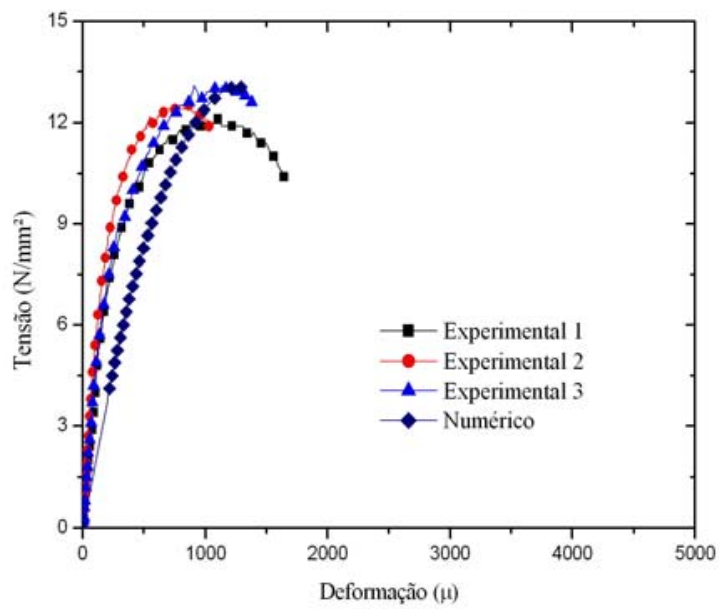

(a)

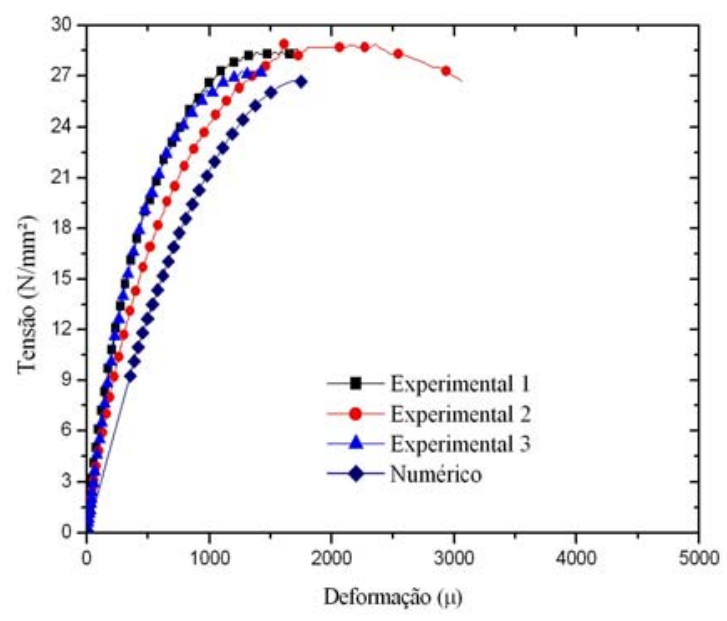

(c)

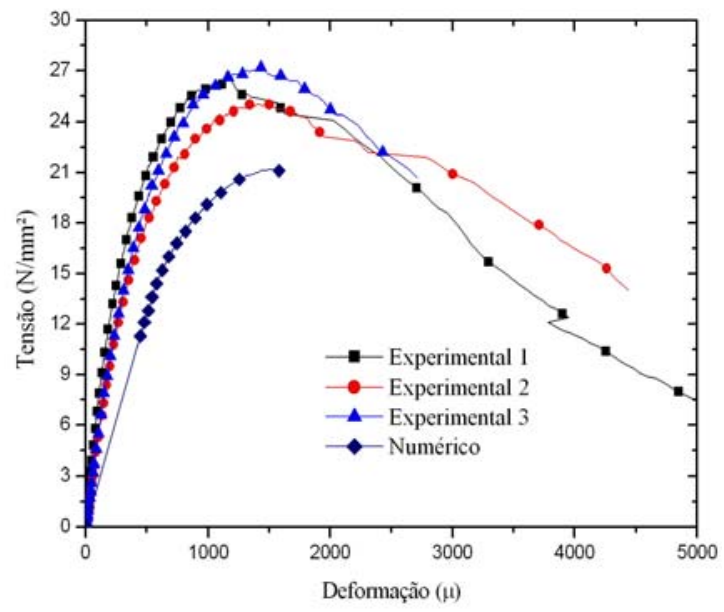

(b)

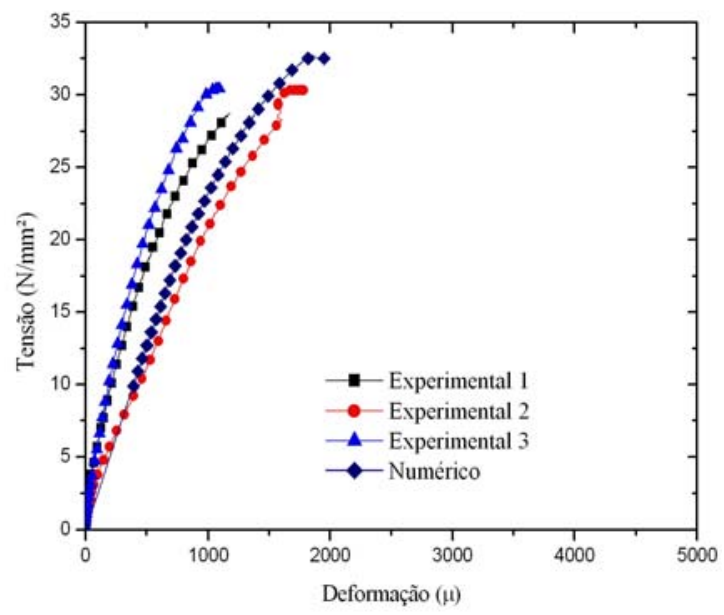

(d)

Figura 6.16 - Curva tensão-deformação experimental e teórica dos blocos vazados de concreto: B1 (a), B2 (b), B3 (c) e B4 (d).

É importante também destacar que o modo de ruína apresentado pelos modelos numéricos é associado à ocorrência experimental. Na Figura 6.17 representa-se a ruína do bloco com a deformação incremental de sua malha. É possível observar a formação de fissuras diagonais na parede longitudinal com a tendência de expulsão do material nas quinas superiores e inferiores. As partes internas das paredes longitudinais apresentam nível de esmagamento do concreto avançado, seguindo a tendência encontrada nos septos transversais. Nestes, a região da altura média é a mais danificada. Essa abordagem é fenomenológica, já que o modelo numérico não representa inteiramente o modelo experimental. 

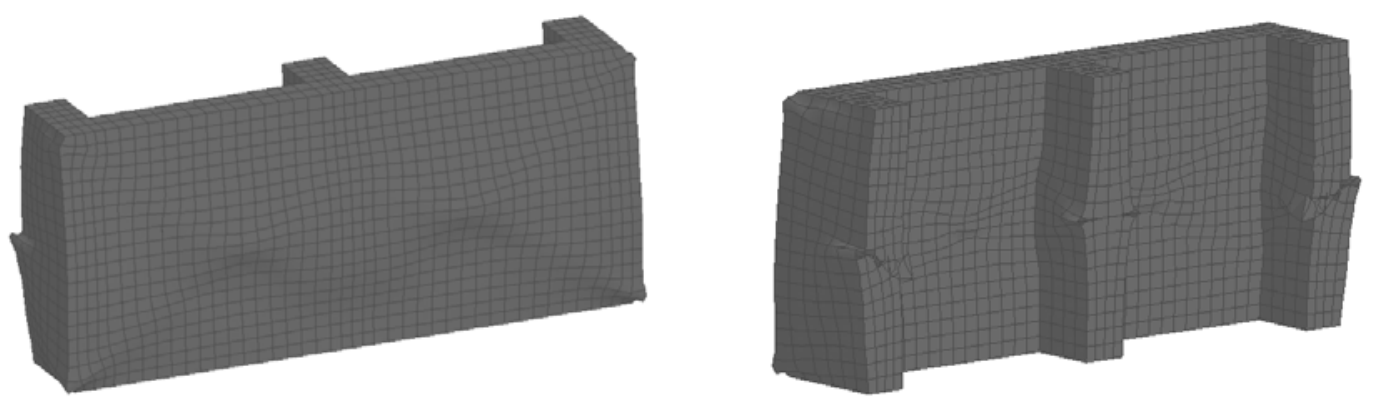

Figura 6.17 - Modo de ruína dos blocos submetidos à compressão.

A Figura 6.18 permite a comparação entre as curvas tensão-deformação numéricas dos modelos de confinamento A, B e C, apenas para o grupo B3. Como previsto, o maior valor de resistência à compressão é obtido no modelo $\mathrm{A}$, com confinamento perfeito, e o menor quando consideradas as propriedades mecânicas da borracha natural, material mais flexível.

Os valores de resistência dos modelos $\mathrm{B}$ e $\mathrm{C}$, com alívio de confinamento, diferem em apenas 1\%. O modelo A apresenta resistência à compressão maior $6 \%$ que a obtida com alívio do confinamento. A variação das condições de contorno dos modelos numéricos possibilitou a obtenção de distintos comportamentos dos blocos em relação à tensão máxima alcançada e sua rigidez, coerentes com as características de cada interface considerada.

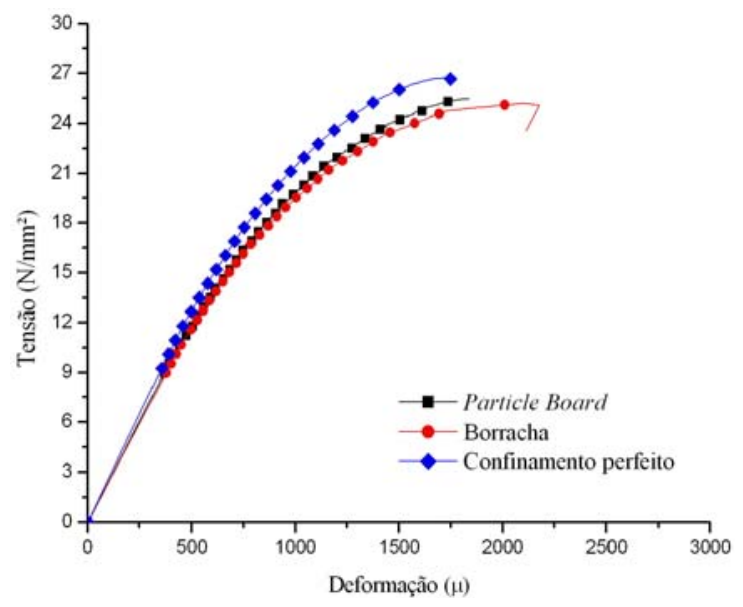

Figura 6.18 - Curva tensão-deformação dos blocos vazados de concreto considerando-se distintas condições de contorno do modelo numérico.

A análise considerando a interface entre o bloco e as placas de ensaio tem o objetivo de apresentar e discutir a distribuição de tensões e deformações ao longo das paredes longitudinais e septos transversais do bloco vazado de concreto, o que, conseqüentemente, influencia o nível de resistência obtido. Por exemplo, o modelo de bloco considerando o 
confinamento perfeito apresenta tensão máxima de $26,8 \mathrm{~N} / \mathrm{mm}^{2}$ enquanto o que leva em conta as propriedades mecânicas da borracha na interface apresenta resistência de $25,2 \mathrm{~N} / \mathrm{mm}^{2}$, ou seja, ocorre uma redução de 6\%. Este modelo, em que o efeito de confinamento é considerado mínimo, apresenta valor idêntico ao obtido na análise correspondente com o corpo-de-prova (Tabela 6.2) que, em função da sua geometria, também tem o efeito de confinamento aliviado. Dessa forma, a resistência do bloco, do modelo C, mostra-se dependente apenas da resistência do material que o constitui.

\subsubsection{Análise de tensões e deformações}

Para análise detalhada da distribuição de tensões e deformações adota-se o grupo de resistência B3, apresentando-se os valores obtidos com os modelos de confinamento A e B. Foram definidas seções horizontais e verticais ao longo da parede longitudinal e septo transversal do bloco, indicadas na Figura 6.19, sendo as seções verticais V1, V2 e V3 e a seção horizontal H1, relativas à parede longitudinal, e as seções vertical V4 e horizontal H2 associadas ao septo transversal externo.
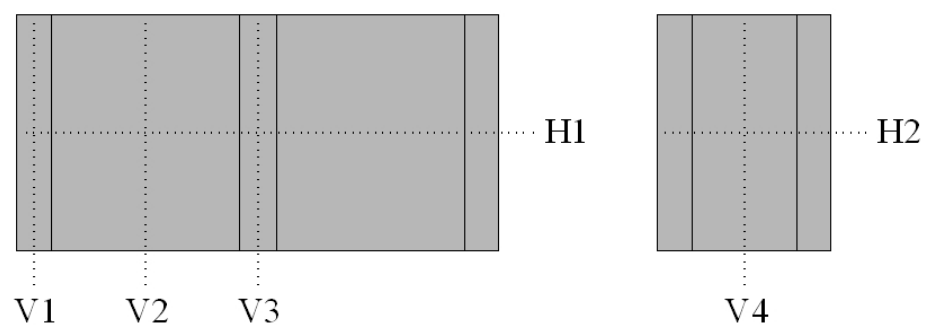

Figura 6.19 - Seções horizontais e verticais definidas para a análise dos blocos.

Da mesma forma da análise dos corpos-de-prova, estabelecem-se três níveis de carregamento $(1,2$ e 3$)$ relativos à resistência à compressão do bloco obtida no modelo numérico, respectivamente, $0,3 \mathrm{f}_{\mathrm{b}}, 0,7 \mathrm{f}_{\mathrm{b}}$ e $\mathrm{f}_{\mathrm{b}}$. As linhas verticais na cor cinza nos gráficos dos perfís das seções horizontais H1 e H2 representam os septos transversais e paredes longitudinais dos blocos, respectivamente.

\subsubsection{Distribuição das tensões no bloco vazado de concreto}

A intensidade das tensões principais mínimas diminui significativamente à medida que se aproxima das extremidades da parede longitudinal do bloco, conforme indicam os perfis da seção H1 da Figura 6.20a, relativa ao modelo A. Junto ao septo transversal central observa-se um ligeiro decréscimo. No modelo B, tendência semelhante é observada (Figura $6.20 b)$, entretanto, há maior uniformidade. 


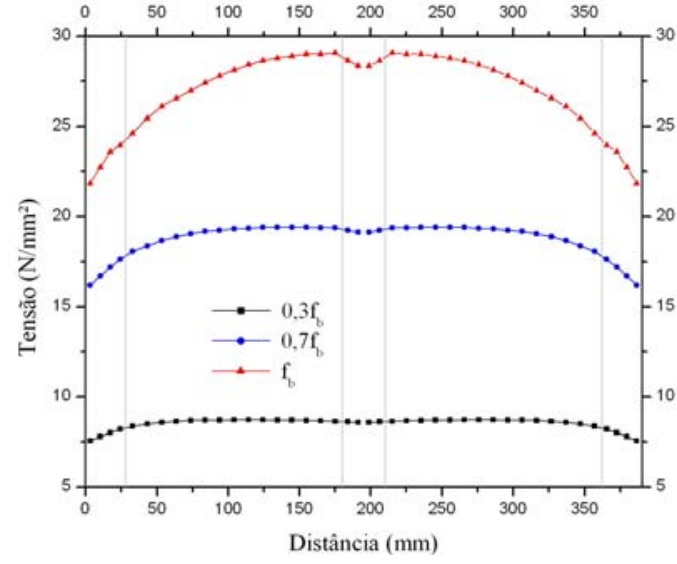

(a)

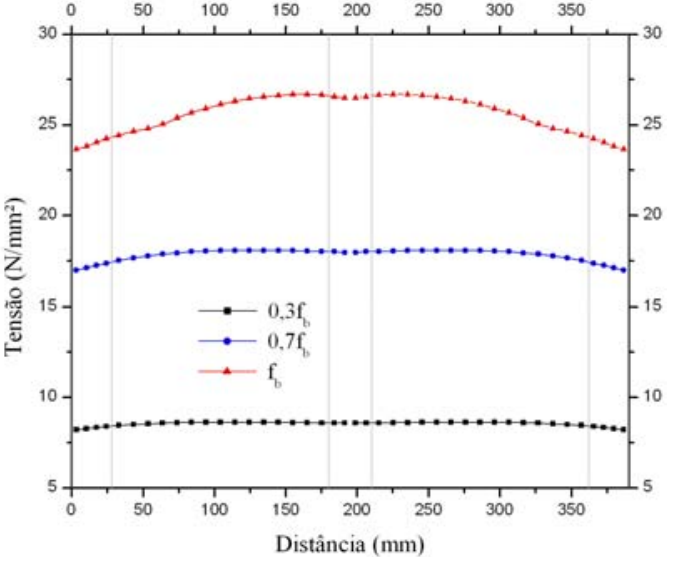

(b)

Figura 6.20 - Perfis H1 das tensões principais mínimas efetivas: modelo A (a) e modelo B (b).

Esta análise torna-se mais clara ao se considerar os valores relativos das tensões, obtidos pela razão entre a tensão efetiva ao longo dos perfis e a tensão uniforme aplicada na superfície superior do modelo matemático em distintos níveis de carregamento (Figura 6.21). Assim, em relação ao modelo A, nota-se um comportamento no qual a diferença entre a tensão na extremidade do bloco e a tensão no centro do bloco aumenta com o nível do carregamento, constatando-se, neste caso, tensões relativas na região central 17\%, 20\% e 33\% maiores que as obtidas nas extremidades, nos níveis de carregamento 1,2 e 3 , respectivamente. Observa-se que, mesmo no regime de comportamento linear, até $0,3 \mathrm{f}_{\mathrm{b}}$, as diferenças entre os valores de tensões são significativas. No modelo B, apesar da permanência desse comportamento, as diferenças são menores, de 5\%,10\% e 14\%.

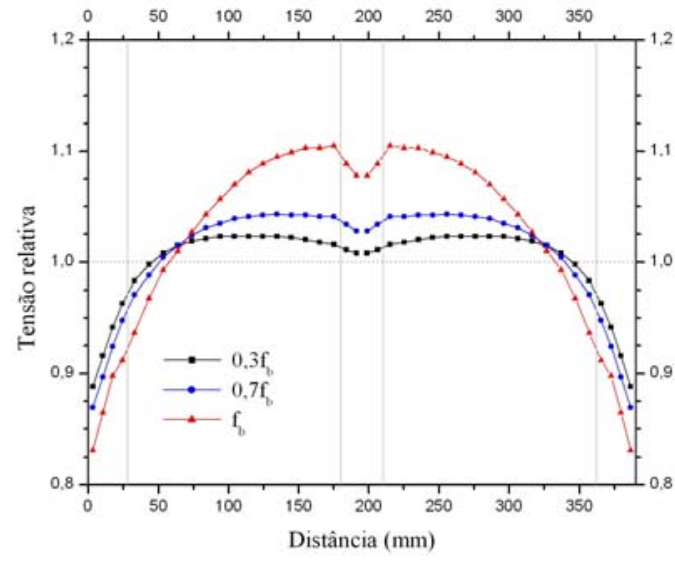

(a)

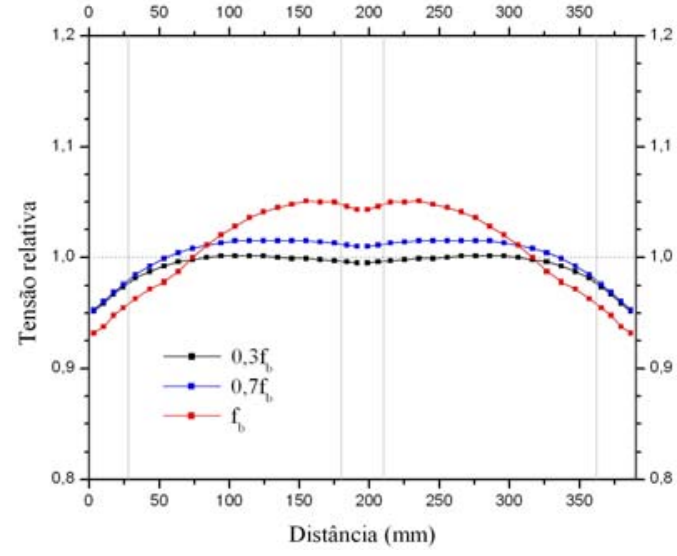

(b)

Figura 6.21 - Perfis H1 das tensões principais mínimas relativas: modelo A (a) e modelo B (b). 
No perfil da seção H2, a diminuição do nível de tensões ocorre a partir centro para as extremidades, conforme ilustra a Figura 6.22. Observa-se também nessa região maior uniformidade dos perfis no modelo B do que no modelo A.

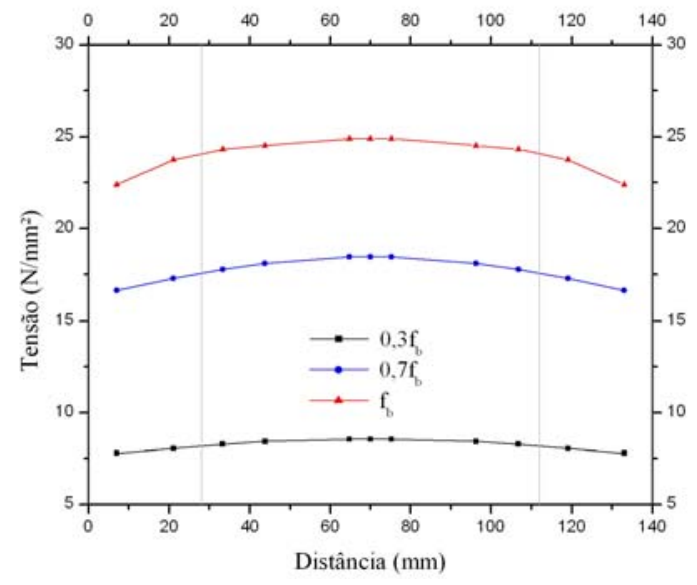

(a)

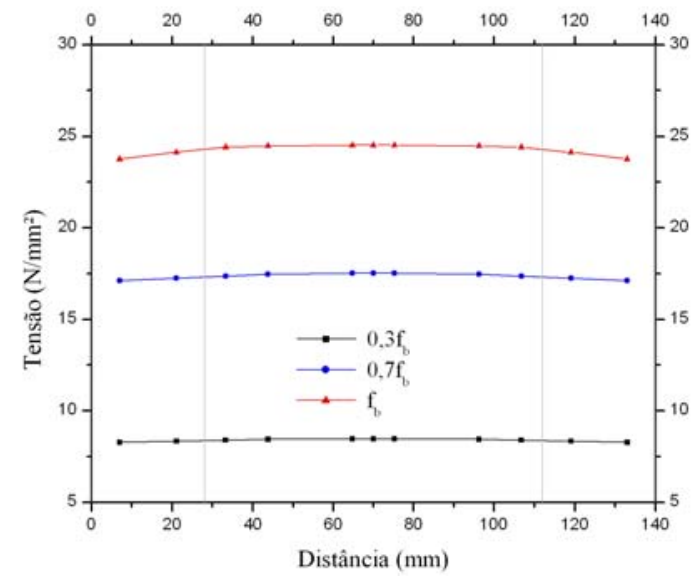

(b)

Figura 6.22 - Perfis H2 das tensões principais mínimas efetivas: modelo A (a) e modelo B (b).

De acordo com os gráficos da Figura 6.23, os valores de tensão encontrados são quase sempre inferiores à tensão aplicada no topo do bloco, com valores ainda menores à medida que se aproxima das extremidades. É interessante ressaltar que, com o aumento do nível de carregamento, a relação entre a tensão do perfil e o valor aplicado no topo do bloco é reduzida, ou seja, uma parcela do carregamento tende a migrar à parede longitudinal.

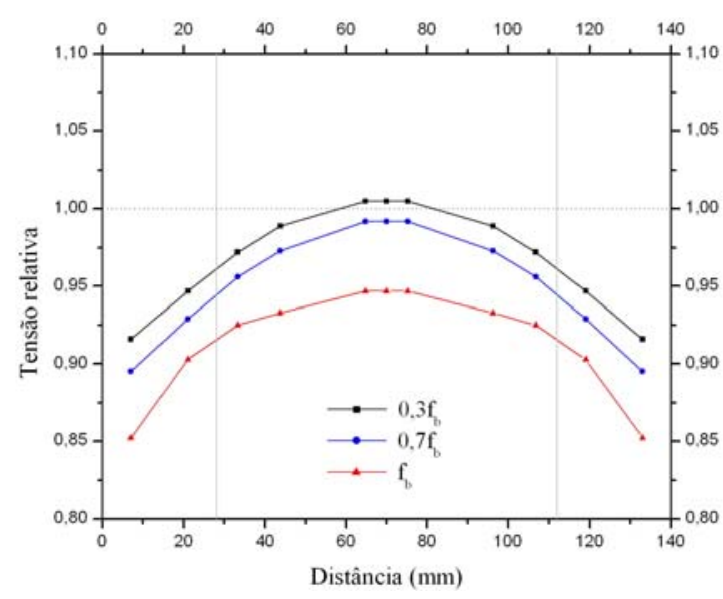

(a)

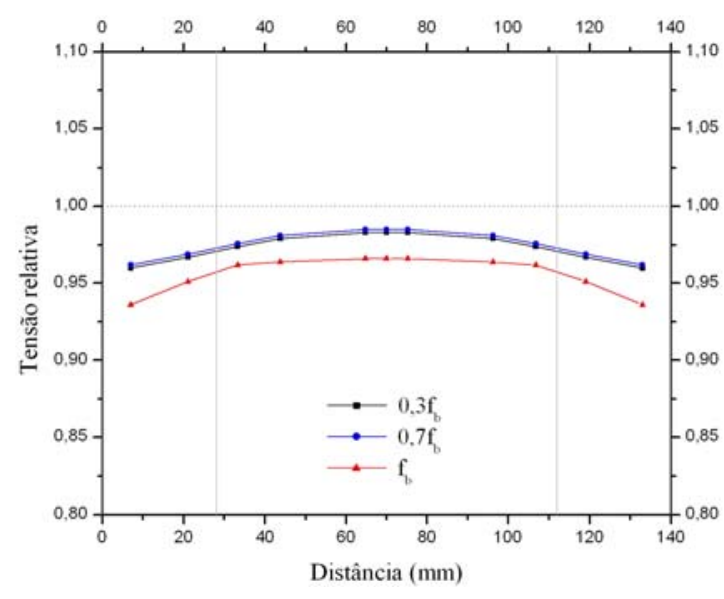

(b)

Figura 6.23 - Perfis H2 das tensões principais mínimas relativas: modelo A (a) e modelo B (b).

Do ponto de vista físico, um bloco solicitado à compressão está submetido a um deslocamento prescrito que induzirá uma determinada distribuição de tensões ao longo das paredes longitudinais e septos transversais. Entretanto, em decorrência de sua geometria e das 
condições de atrito entre as extremidades do bloco e as placas de ensaio, a não-uniformidade nos campos de tensões e deformações torna-se evidente. Assim, a tendência de uniformização dos valores de tensões é o fenômeno que caracteriza o alívio do confinamento no bloco de concreto, como se vê no decorrer das análises.

O estudo dos perfis verticais é realizado apenas em função das tensões relativas. Observam-se comportamentos distintos dos perfis V1, V2 e V3, ora com redução, ora com aumento dos valores das tensões em direção à meia-altura do bloco. $\mathrm{O}$ efeito de confinamento distingue o estado de tensões em uma região com dimensão da ordem de $20 \mathrm{~mm}$ a partir das extremidades, ocorrendo, a partir daí, tendência de uniformização no sentido da altura média.

O perfil V1 apresenta redução das tensões em direção à altura média do bloco com as tensões sempre inferiores à tensão média aplicada no topo. Os valores relativos diminuem com o aumento de carregamento, sendo os perfis do modelo B (Figura 6.24b) mais uniformes que os obtidos no modelo A (Figura 6.24a).

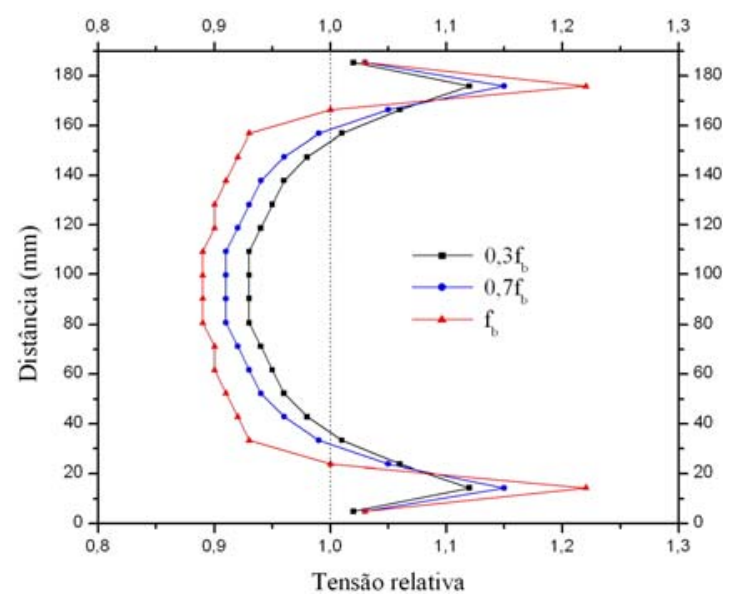

(a)

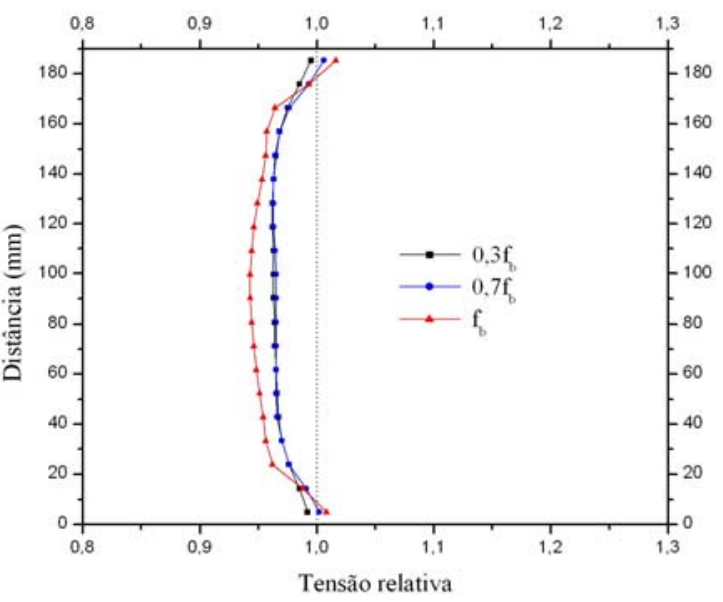

(b)

Figura 6.24 - Perfis V1 das tensões principais mínimas relativas: modelo A (a) e modelo B (b).

Os perfis apresentados na Figura 6.25, referentes à seção V2, mostram tendência diferente dos perfis de tensão V1, com aumento dos valores acompanhando os níveis de carregamento. O comportamento dos perfis da seção V3 (Figura 6.26) se assemelha ao obtido na seção V2. Os perfis do modelo B são caracterizados pela maior uniformidade de tensões e a redução da influência do confinamento nas extremidades. 


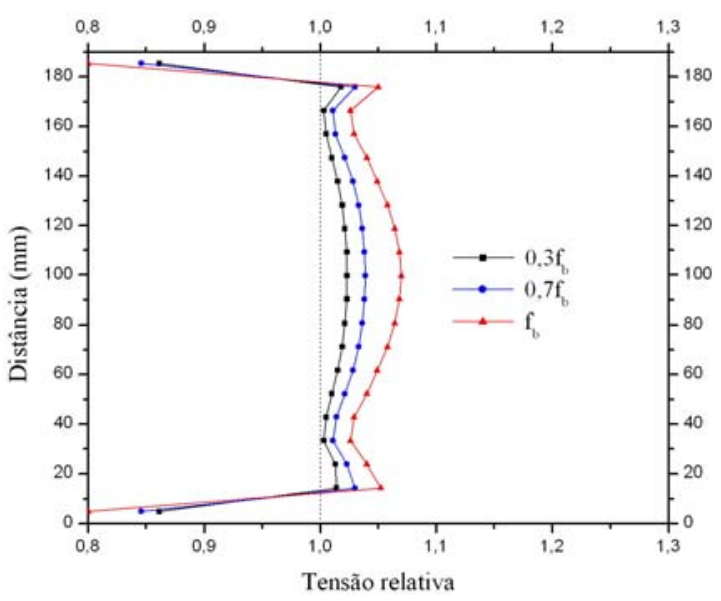

(a)

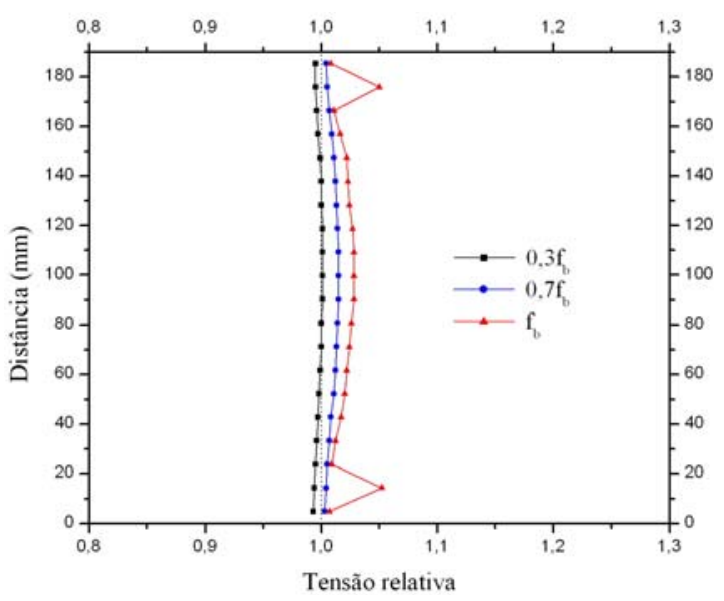

(b)

Figura 6.25 - Perfis V2 das tensões principais mínimas relativas: modelo A (a) e modelo B (b).

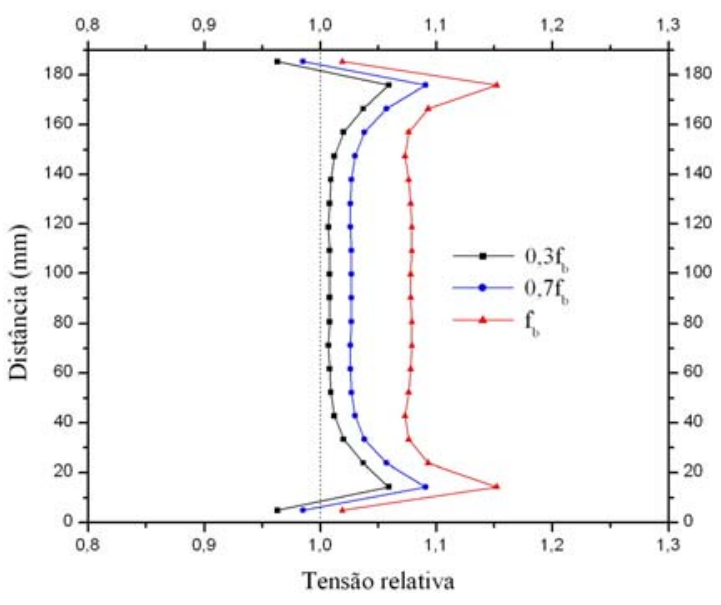

(a)

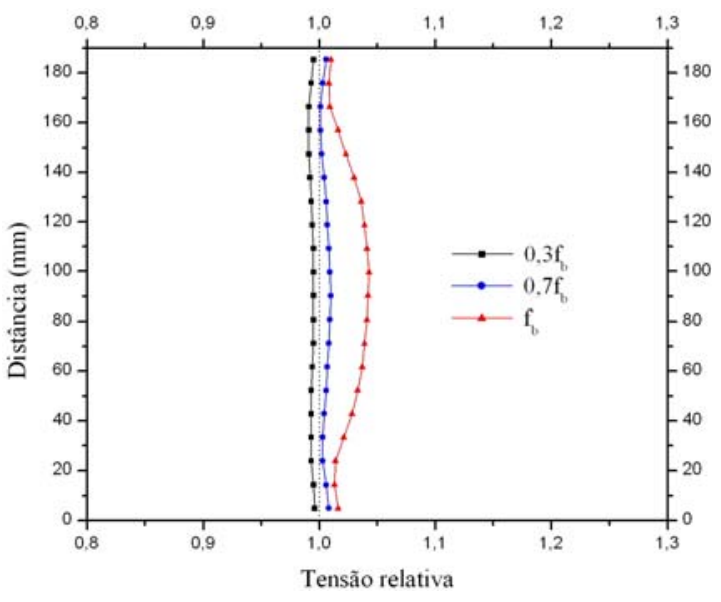

(b)

Figura 6.26 - Perfis V3 das tensões principais mínimas relativas: modelo A (a) e modelo B (b).

$\mathrm{Na}$ análise do perfil vertical V4, observa-se no septo transversal externo o aumento das tensões relativas à meia-altura do bloco. Contudo, os valores proporcionais das tensões reduzem com o aumento dos níveis de carregamento, com valores menores que 1 no nível de carregamento 3, conforme ilustra a Figura 6.27. Este comportamento é similar ao obtido no perfil V1, indicando, portanto, a seguinte redistribuição de tensões no bloco:

- na região do septo transversal externo e extremidade da parede longitudinal, onde há alívio do confinamento, ocorre decréscimo dos valores de tensão com o aumento do carregamento, com os valores relativos, muitas vezes, inferiores à unidade;

- na região central da parede longitudinal até o septo transversal central, onde as tensões transversais são mais acentuadas, os valores de tensão crescem 
com o aumento do nível de carregamento e os valores proporcionais são maiores que a unidade.

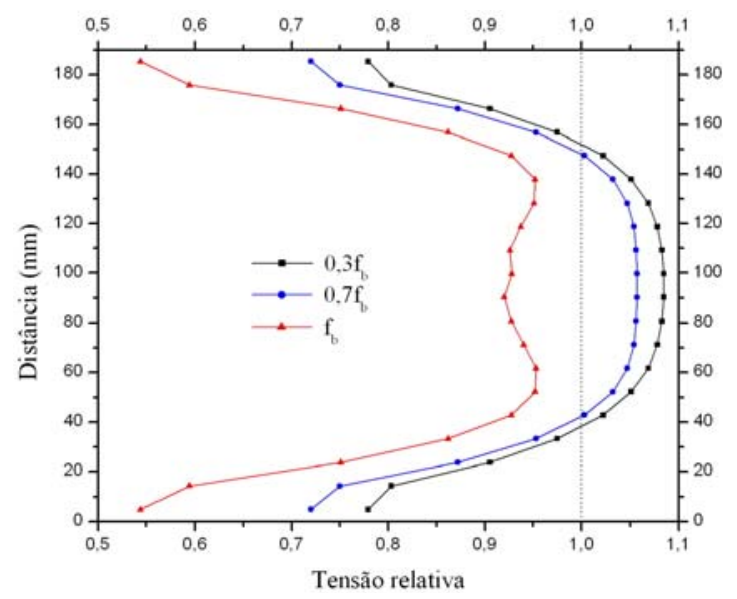

(a)

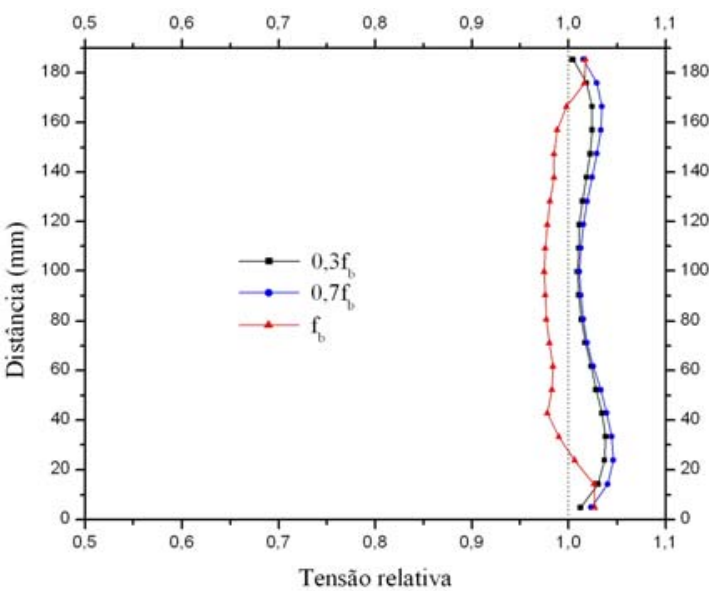

(b)

Figura 6.27 - Perfis V4 das tensões principais mínimas relativas: modelo A (a) e modelo B (b).

No modelo A, que considera o confinamento perfeito, os valores de tensão na direção transversal (Figura 6.28a), no sentido do eixo x e paralelas a maior dimensão do bloco, decrescem do centro da parede longitudinal para as extremidades, apresentando valores próximos a zero na região do septo transversal externo. Essa queda de tensão também ocorre na região do septo transversal central, porém de forma menos acentuada, devida à continuidade da parede longitudinal. Comportamento similar foi observado em relação às tensões de compressão na direção vertical, indicando que as regiões com maior efeito de confinamento estão sob os maiores níveis de tensão vertical. No modelo B, o nível das tensões transversais é reduzido de forma significante, inclusive com o surgimento de tensões de tração de pequena intensidade, conforme ilustra a Figura $6.28 \mathrm{~b}$.

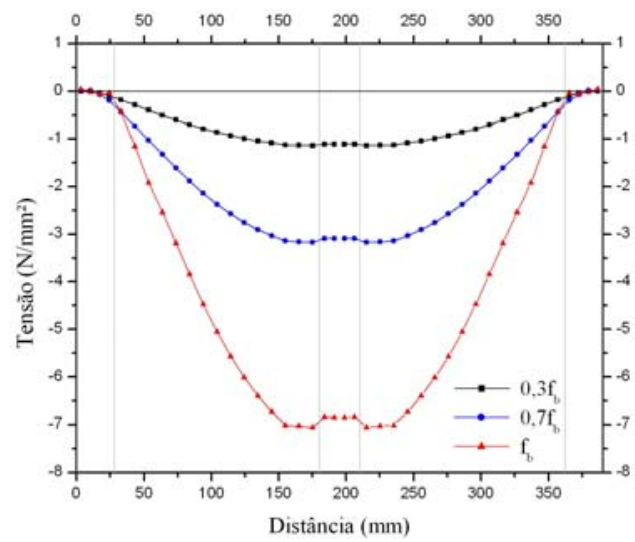

(a)

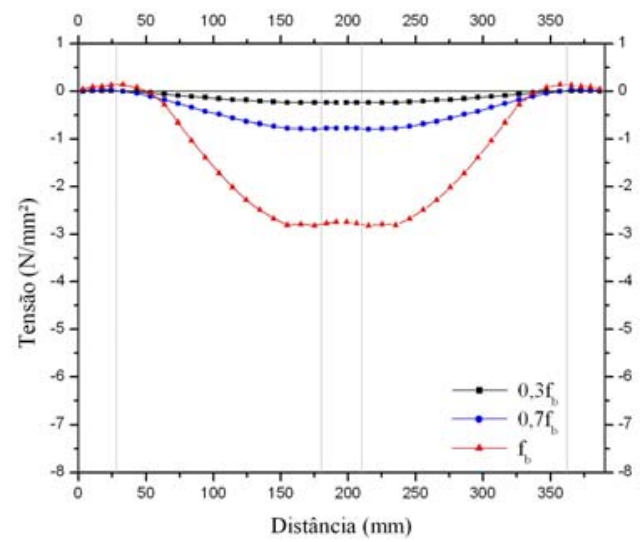

(b)

Figura 6.28 - Perfis H1 das tensões transversais efetivas (eixo x): modelo A (a) e modelo B (b). 
A análise dos valores de tensão transversal relativa (normalizada pela tensão vertical no topo do bloco) mostra que a diferença entre os valores de tensão transversal no centro e na extremidade cresce com o aumento dos níveis de carregamento. $\mathrm{O}$ valor máximo de tensão, relativo ao modelo A, passa de $0,13 \sigma_{\mathrm{y}}$ para $0,27 \sigma_{\mathrm{y}}$ do nível de carregamento 1 para o 3 , como indica a Figura 6.29a. A redução do efeito de confinamento no modelo B é nítida na Figura 6.29b.

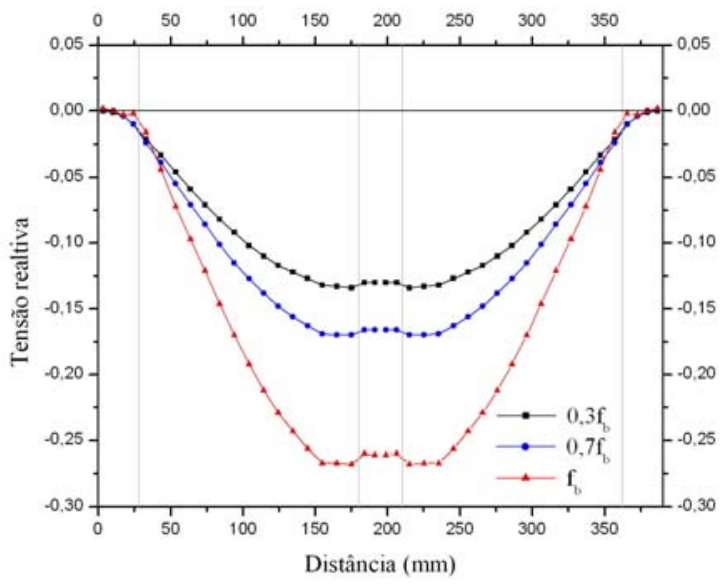

(a)

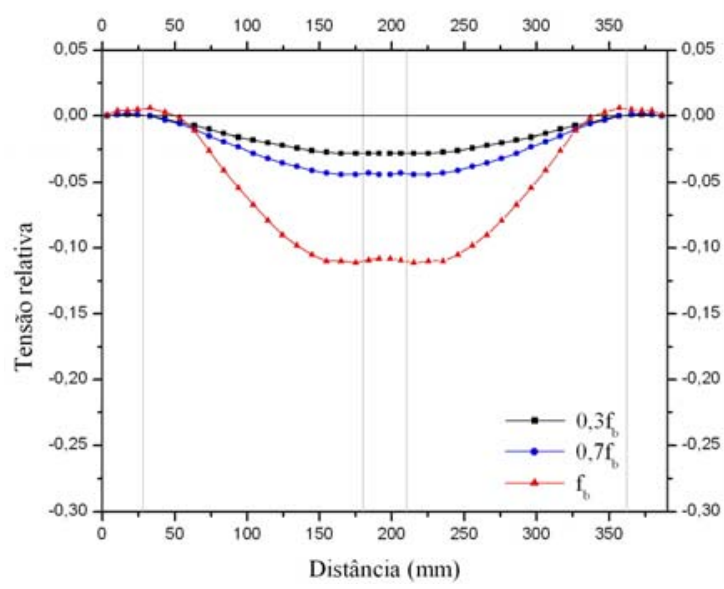

(b)

Figura 6.29 - Perfis H1 das tensões transversais relativas (eixo x): modelo A (a) e modelo B (b).

Comparando-se a Figura 6.28 e a Figura 6.30, nota-se que a tensão transversal, na direção do eixo $\mathrm{z}$ do perfil H2, é bem inferior às obtidas na análise do perfil H1 (na direção do eixo x), ainda assim, com decréscimo junto às extremidades. Os modelos A e B apresentam níveis de tensão próximos, além do mesmo comportamento dos perfis, indicando que o efeito de confinamento, nessa região, atua de forma similar em ambas as situações.

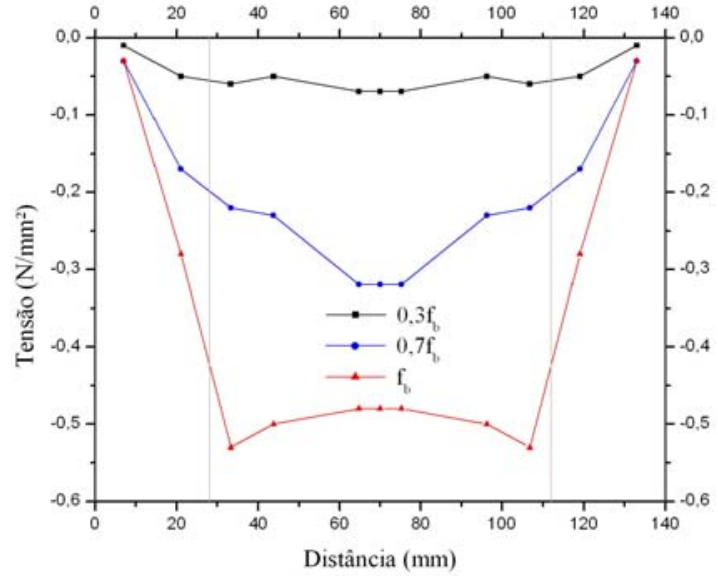

(a)

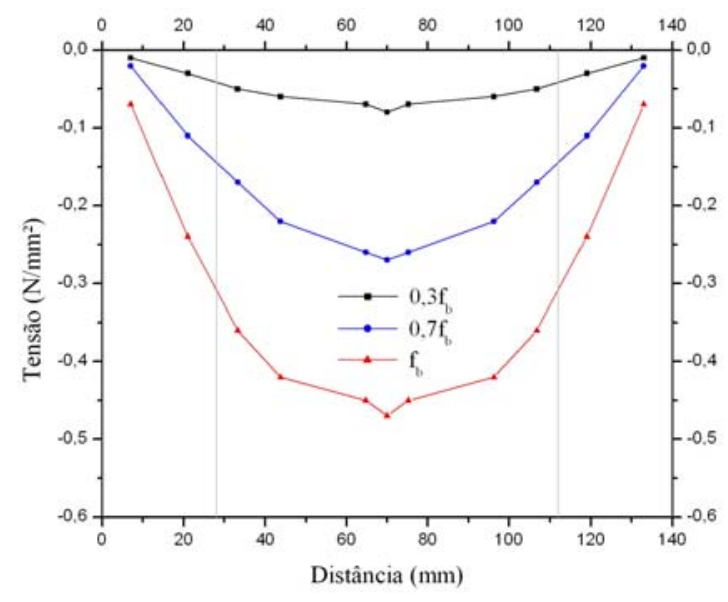

(b)

Figura 6.30 - Perfis H2 das tensões transversais efetivas (eixo z): modelo A (a) e modelo B (b). 
A Figura 6.31 apresenta a distribuição de tensões transversais por meio de níveis de contorno na parede longitudinal do bloco e em seu septo transversal (modelo A). As tensões de compressão transversal decrescem do topo e base, onde o efeito de confinamento é máximo, para a meia-altura do bloco. Mesmo nesta região, onde o valor mínimo é atingido, as tensões são maiores que zero, indicando a presença do confinamento. Mesmo comportamento é observado no septo transversal externo, entretanto, as tensões de confinamento transversais apresentam menores valores e, na região próxima à meia-altura do bloco, a compressão transversal é praticamente nula.

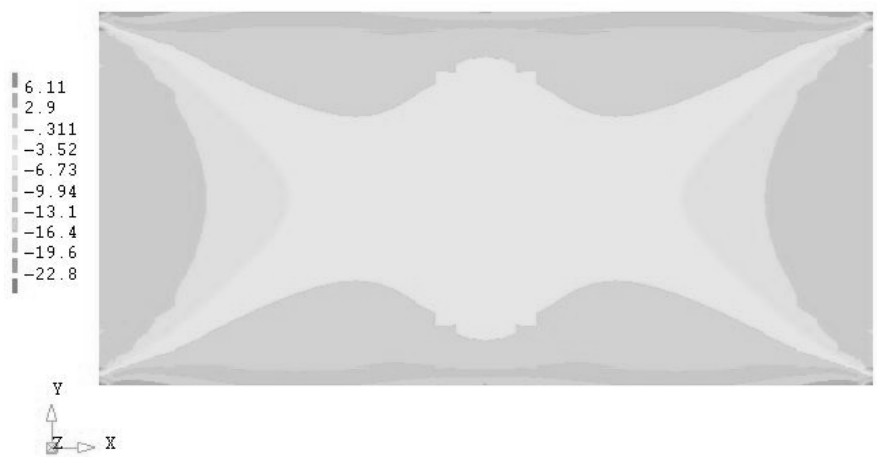

(a)

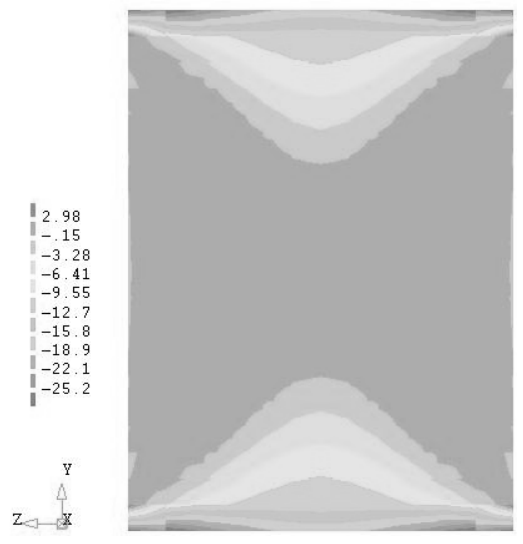

(b)

Figura 6.31 - Distribuição das tensões transversais na parede longitudinal (a) e no septo transversal externo (b) do bloco vazado de concreto do modelo A (valores em N/mm²).

A partir das análises referentes à distribuição de tensões, pode-se caracterizar o efeito de confinamento atuante em bloco vazado de concreto conforme ilustração da Figura 6.32. Este croqui representa apenas uma tendência, de compressão transversal e alívio de sua intensidade, sem nenhuma indicação das magnitudes.

O comportamento observado na extremidade da parede longitudinal, que apresenta baixos valores de compressão e tensões de tração no sentido transversal, mostra-se coerente 
com aquele analisado no septo transversal externo, na direção do eixo z, onde as tensões são praticamente nulas. Destaca-se ainda a continuidade da região confinada resultante das tensões transversais no topo e base do bloco, que se dispersam ao longo da sua altura, com tendência de valores menores à meia-altura do bloco.

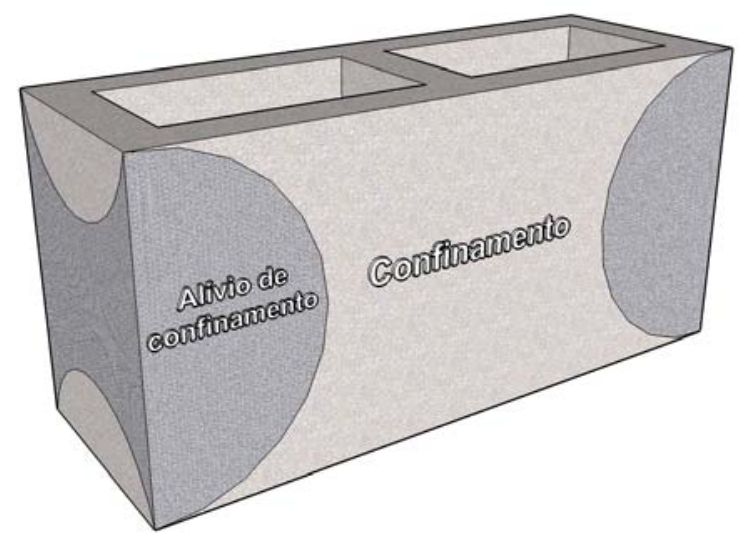

Figura 6.32 - Croqui ilustrativo do efeito de arqueamento do "caminho das cargas", decorrente do confinamento de topo e base num ensaio de compressão axial.

\subsubsection{Distribuição das deformações no bloco vazado de concreto}

O perfil de deformações verticais segue o comportamento das tensões de compressão axial, com valores nos septos externos menores que os obtidos na região central do bloco (Figura 6.33). Os valores de deformação são também influenciados pelo efeito de confinamento na direção transversal, não sendo, evidentemente, dependentes unicamente do módulo de elasticidade e da tensão vertical aplicada, mas também das tensões transversais e do coeficiente de Poisson do material. Por isso, o modelo B apresenta maior uniformidade nos perfis de deformação.

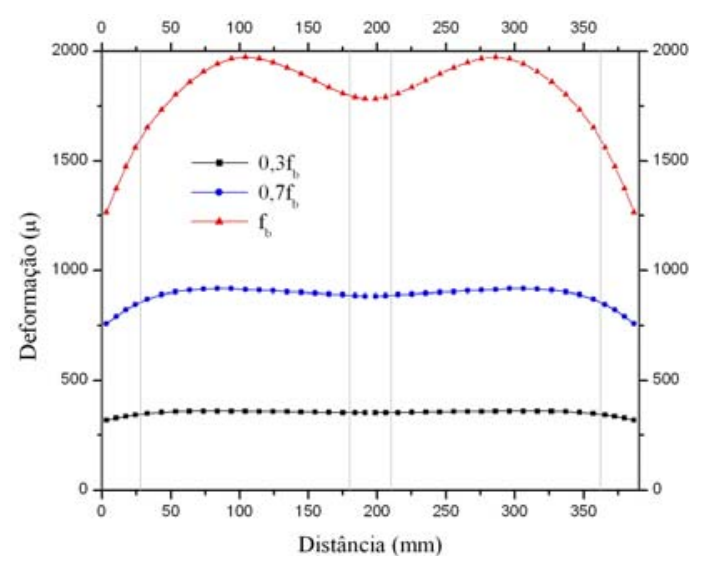

(a)

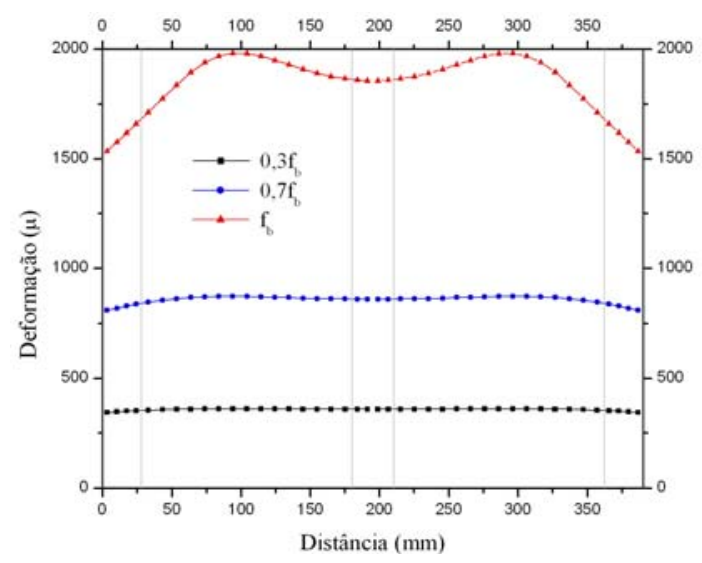

(b)

Figura 6.33 - Perfis H1 das deformações verticais efetivas: modelo A (a) e modelo B (b). 
A análise dos valores relativos é realizada com referência ao máximo valor de deformação do perfil, em cada nível de carregamento. Nota-se a proximidade dos perfis referente aos níveis de carregamento 1 e 2 nos modelos A e B, apresentados na Figura 6.34. Essa similaridade é decorrente do nível de plastificação do material ainda relativamente baixo, em contraste com os valores mais elevados constatados no nível de carregamento 3. O ponto de máxima deformação situa-se na região próxima à extremidade do bloco, com largura da ordem de $100 \mathrm{~mm}$, em todos os níveis de carregamento, sendo possível notar quedas mais acentuadas junto às extremidades. No modelo $\mathrm{A}$, mesmo no início do carregamento, constatase uma diferença entre os valores de deformação máxima e mínima de aproximadamente $20 \%$, enquanto que com o alívio de confinamento, admitido no modelo B, essa proporção é reduzida para $8 \%$. Na iminência da ruína, as diferenças atingem $56 \%$ e $29 \%$ analisando-se o confinamento perfeito (Figura 6.34a) e o reduzido (Figura 6.34b), respectivamente.

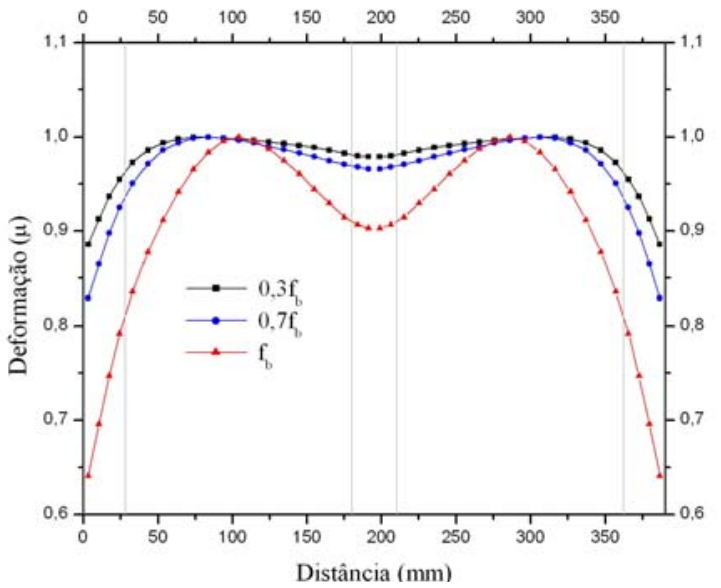

(a)

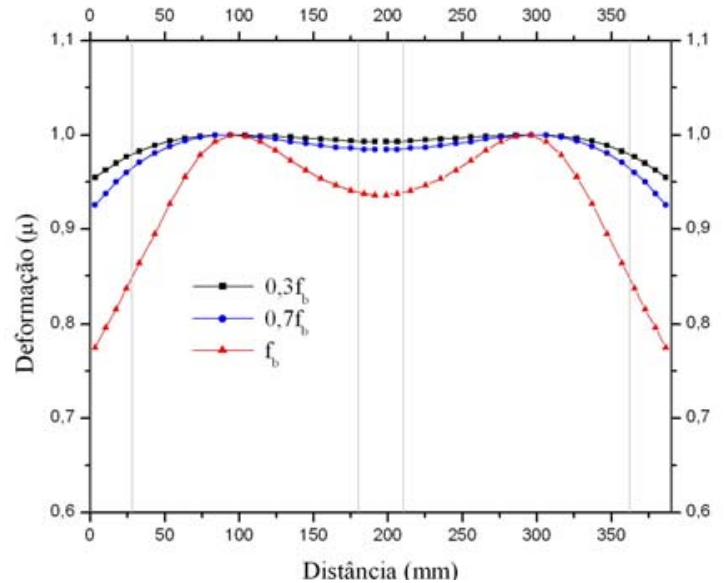

(b)

Figura 6.34 - Perfis H1 das deformações verticais relativas: modelo A (a) e modelo B (b).

Por analogia com o modelo experimental e com a forma de obtenção do valor do módulo de elasticidade, tem-se que tal parâmetro é obtido diretamente pela razão entre a tensão, tomada como o valor médio resultante da aplicação da força no topo do bloco, e a respectiva deformação em um determinado ponto. No entanto, são notadas significativas diferenças entre os valores de deformação no modelo A (Figura 6.34a) que, em uma análise experimental, resultaria em diferentes valores de módulo de elasticidade, já que a tensão considerada é sempre uniforme.

Na Figura 6.35 estão apresentados os perfis de deformações axiais no septo externo do bloco (seção H2). As análises das deformações relativas referem-se ao valor máximo 
obtido na análise em H1. Os valores de deformações máximas são 13\% e $8 \%$ maiores que os valores mínimos obtidos no perfil H2, para o modelo A e B, respectivamente (Figura 6.36).

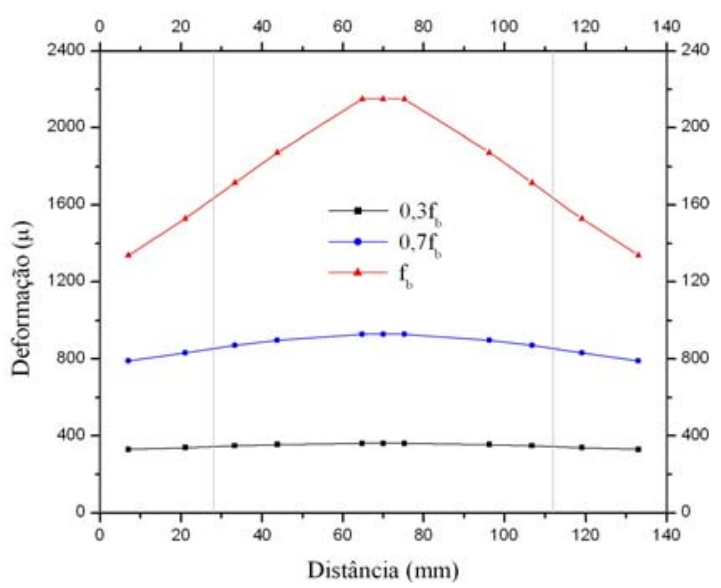

(a)

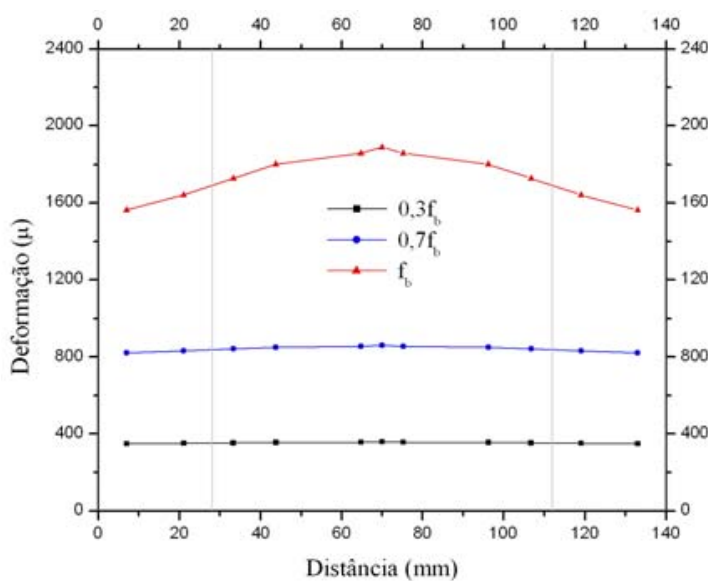

(b)

Figura 6.35 - Perfis H2 das deformações verticais efetivas: modelo A (a) e modelo B (b).

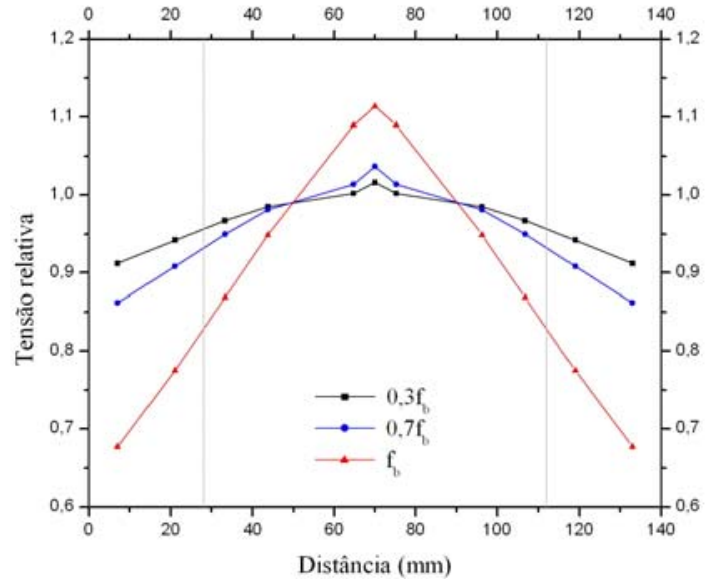

(a)

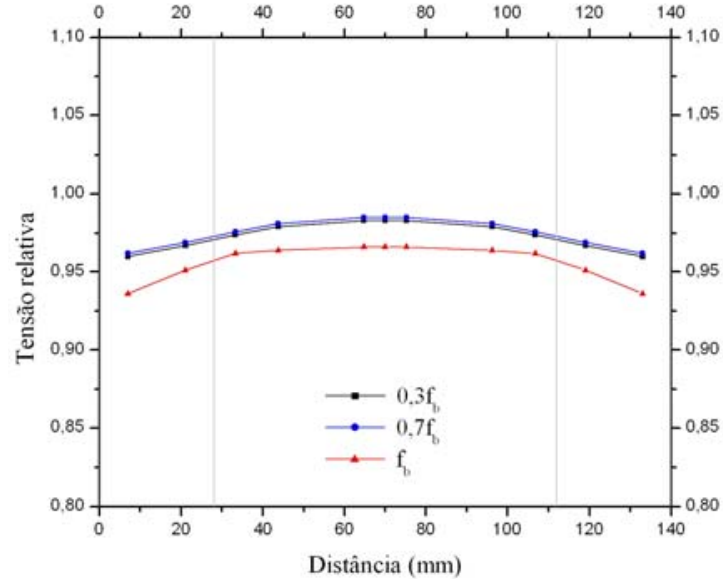

(b)

Figura 6.36 - Perfis H2 das deformações verticais relativas: modelo A (a) e modelo B (b).

Outra forma de se avaliar o efeito de confinamento é por meio das deformações transversais das seções H1 e H2, representadas na Figura 6.37 e Figura 6.38, respectivamente. As maiores deformações transversais ocorrem nas extremidades do bloco e, no modelo B (Figura 6.37b) os valores, além de serem mais uniformes, apresentam maior magnitude que os obtidos no modelo A (Figura 6.37a). Os maiores valores de tensão transversal indicam os menores níveis de tensões confinantes.

No septo transversal, em ambos os casos, os valores da magnitude das tensões são próximos, reforçando a existência de um nível inferior de confinamento, equivalente nos modelos A e B, como ilustra a Figura 6.37b. 


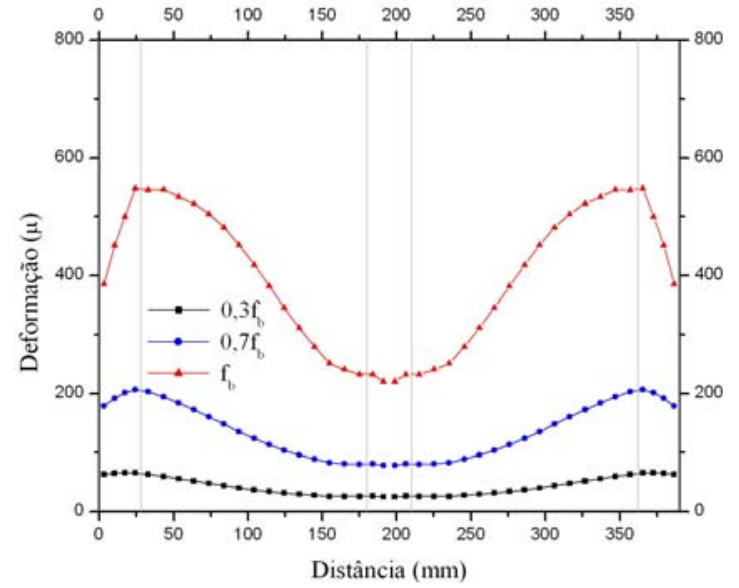

(a)

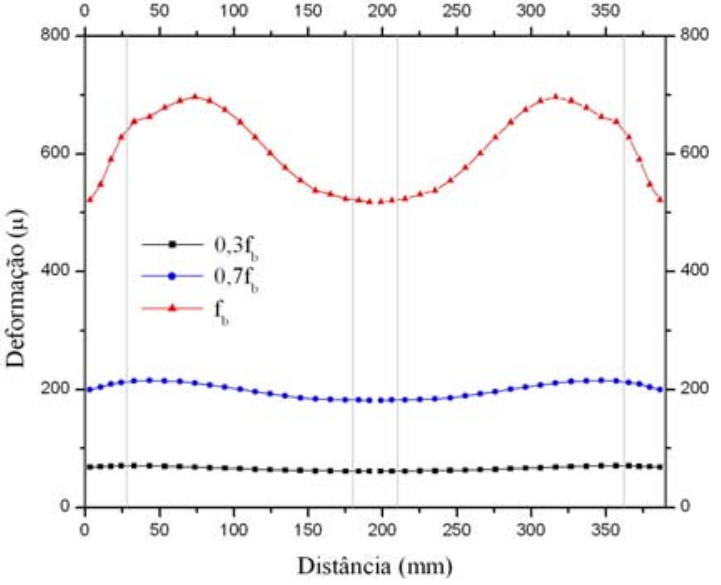

(b)

Figura 6.37 - Perfis H1 das deformações transversais efetivas: caso A (a) e caso B (b).

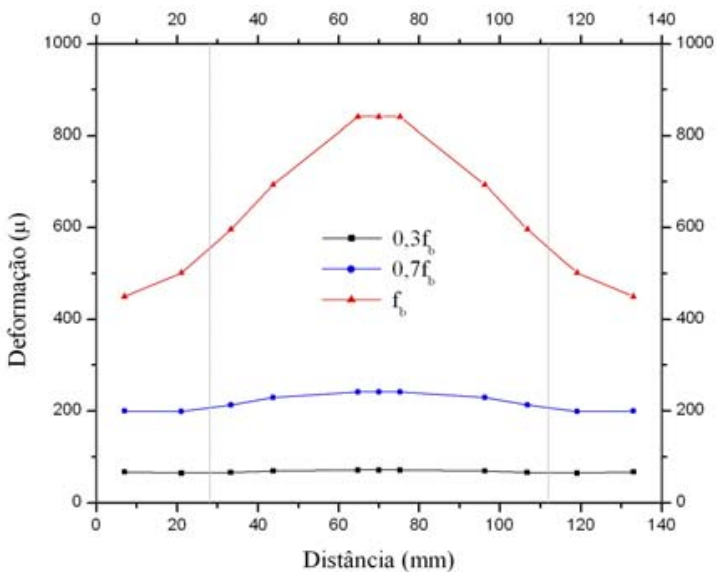

(a)

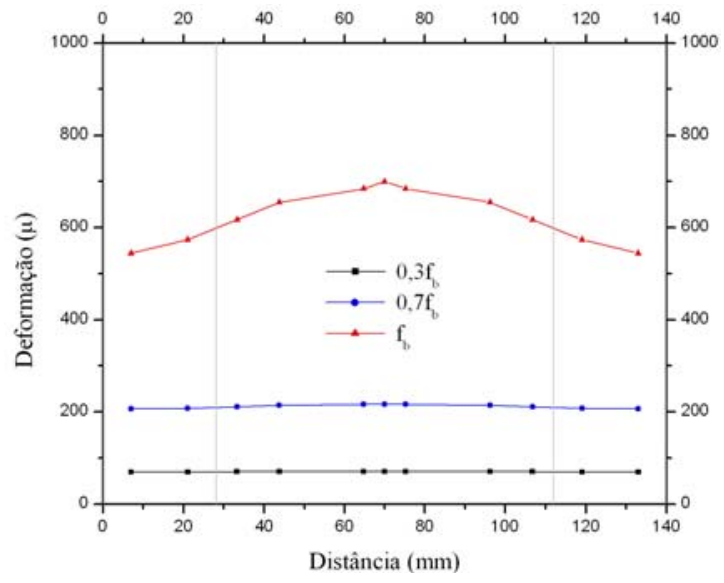

(b)

Figura 6.38 - Perfis H2 das deformações transversais efetivas: caso A (a) e caso B (b).

As deformações plásticas só aparecem em um nível de carregamento superior a 30\% da tensão média aplicada no topo do bloco e apresentam a mesma tendência de redução em direção às extremidades e ao centro do bloco. Os valores de deformação plástica na extremidade dos blocos são inferiores aos obtidos na região central, já que as tensões de confinamento são menores nessa região. Os gráficos apresentados na Figura 6.39 referem-se à relação entre a deformação plástica e a deformação total em distintos níveis de carregamento. 


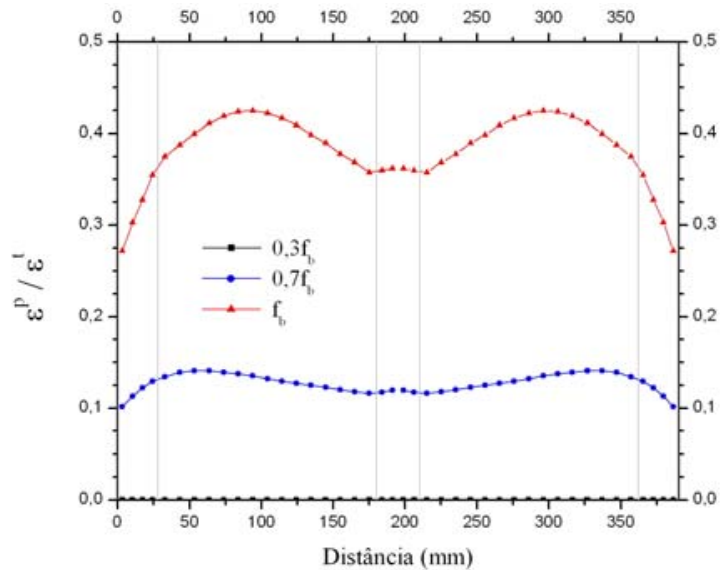

(a)

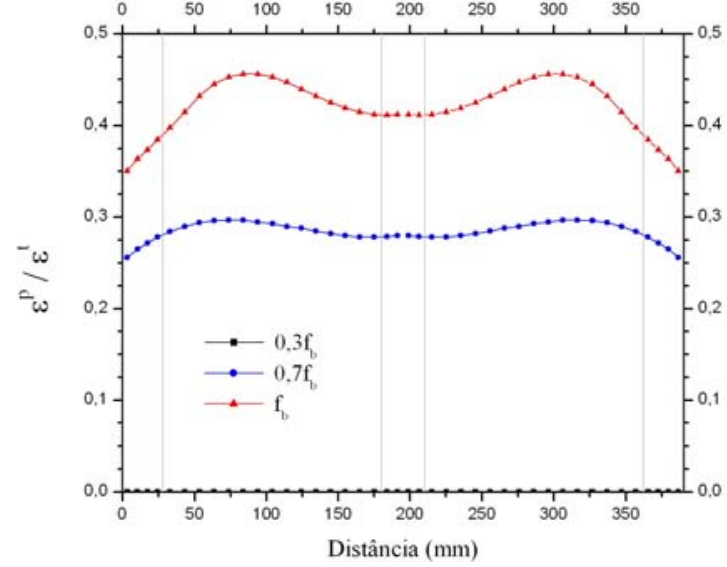

(b)

Figura 6.39 - Perfis H1 da relação entre a deformação plástica e a deformação total: modelo $A$ (a) e modelo B (b).

No septo transversal, a tendência de queda das deformações plásticas é semelhante em direção às extremidades do bloco. Analisando-se esse comportamento de forma relativa, nota-se que a redução de tensão junto às extremidades é mais intensa com o aumento do nível de carregamento (Figura 6.40).

Destaca-se ainda que nas seções H1 e H2 as deformações plásticas apresentam maior parcela em relação à deformação total, justificando, dessa forma, a ruína antecipada do modelo B.

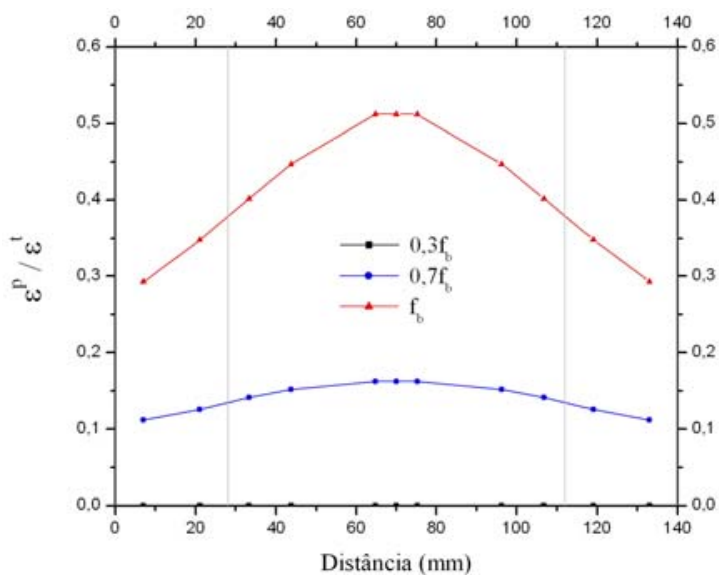

(a)

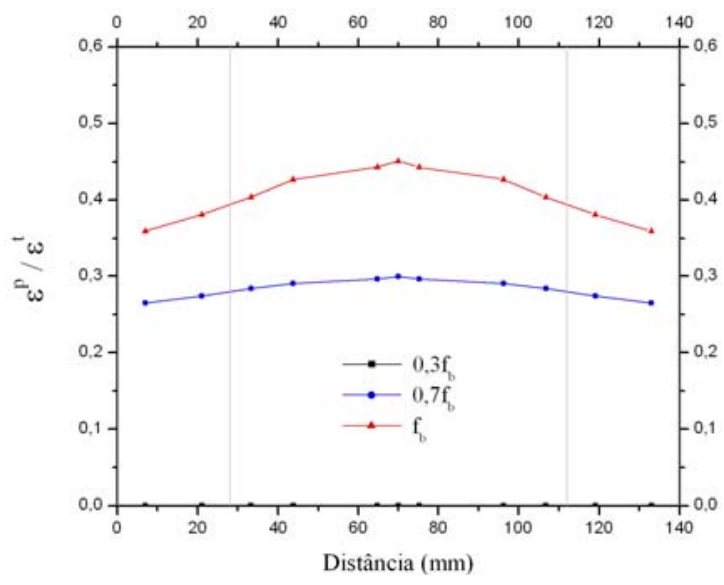

(b)

Figura 6.40 - Perfil H2 da relação entre a deformação plástica e a deformação total: modelo $\mathrm{A}$ (a) e modelo B (b).

O estado de tensões no septo transversal externo, com menores valores de confinamento, origina maiores deformações que as obtidas na parede longitudinal, conforme 
pode ser observado nos campos de deformações apresentados na Figura 6.41. Nesta ilustração apresenta-se também a deformada incremental do bloco na ruína, vista em sua parte interna.

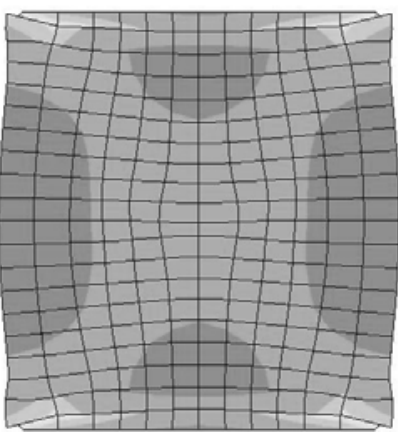

(a)

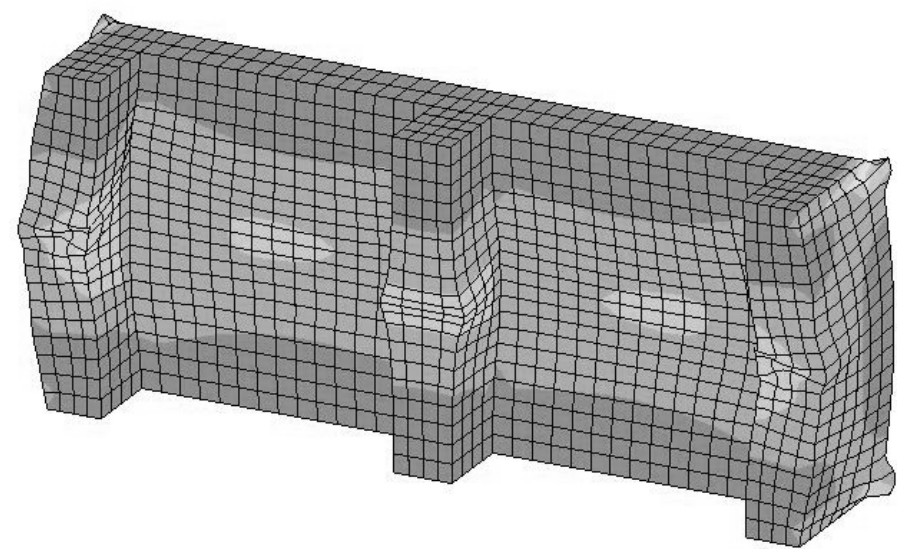

(b)
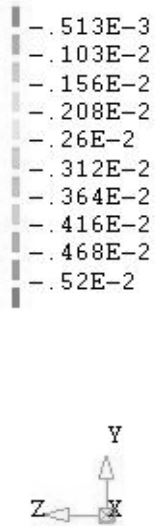

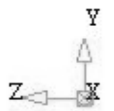

Figura 6.41 - Distribuição de deformações plásticas na ruína, com deformada incremental da malha: vista do septo transversal externo (a) e vista da parte interna do bloco (b).

É definido um parâmetro para avaliação da rigidez do bloco relacionado com a tensão e a deformação axial dos perfis das seções H1 e H2 em distintas etapas de carregamento, reapresentado na Figura 6.42 e na Figura 6.43. Considerando-se um modelo livre de tensões transversais e com distribuição uniforme da tensão proveniente do topo do bloco, esta relação representaria o valor do módulo de elasticidade do material no regime elástico-linear. Entretanto, em decorrência das tensões transversais de confinamento, este parâmetro de rigidez depende da intensidade destas. Com o aumento dos níveis de carregamento, ocorre ainda a penalização do módulo de elasticidade, ocasionando redução deste parâmetro. Nesta análise os valores são relativos ao módulo de elasticidade do concreto utilizado como dado de entrada do modelo numérico. 
Identifica-se maior perda de rigidez no modelo B, tanto na parede longitudinal (seção H1) quanto no septo transversal externo (seção H2). A redução do efeito de confinamento indica maior uniformidade dos perfis do modelo B.

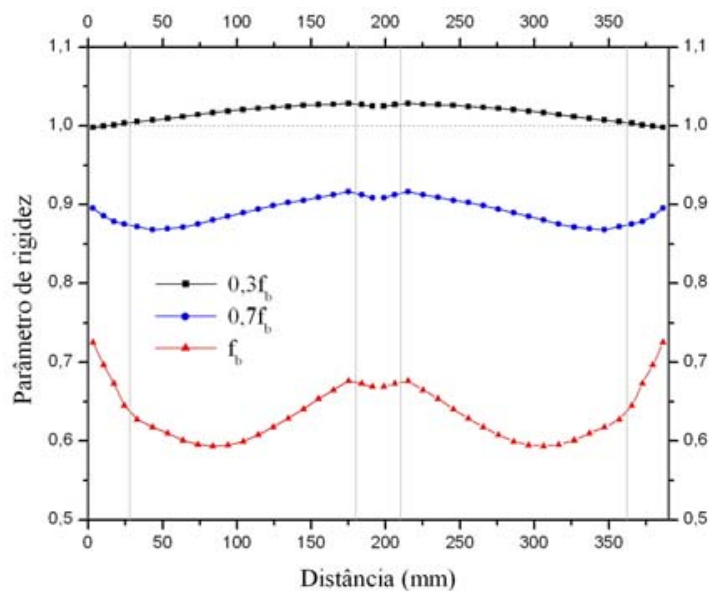

(a)

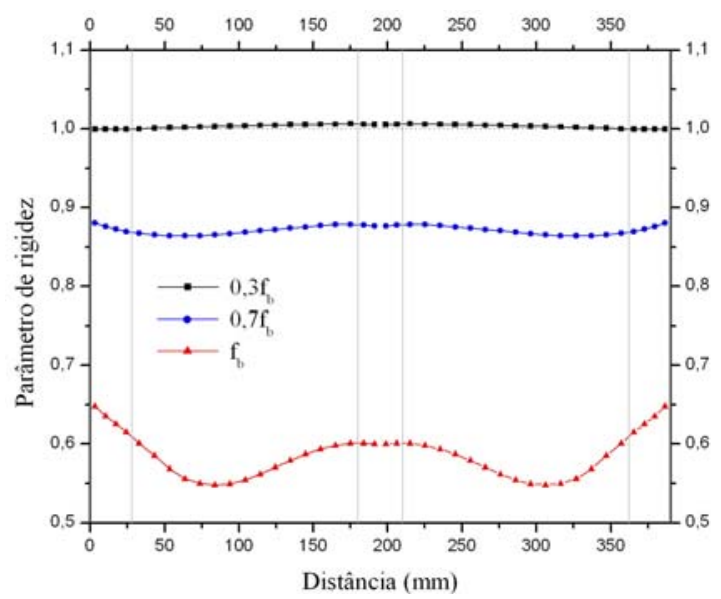

(b)

Figura 6.42 - Perfis H1 do parâmetro de rigidez: modelo A (a) e modelo B (b).

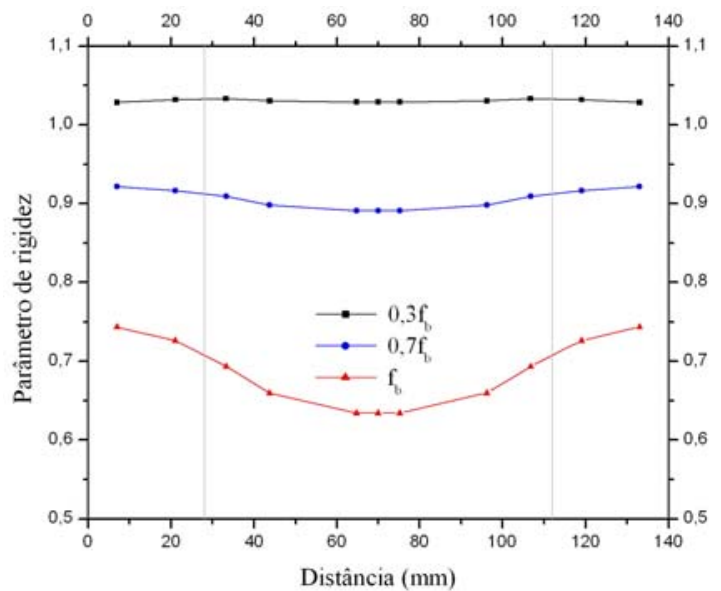

(a)

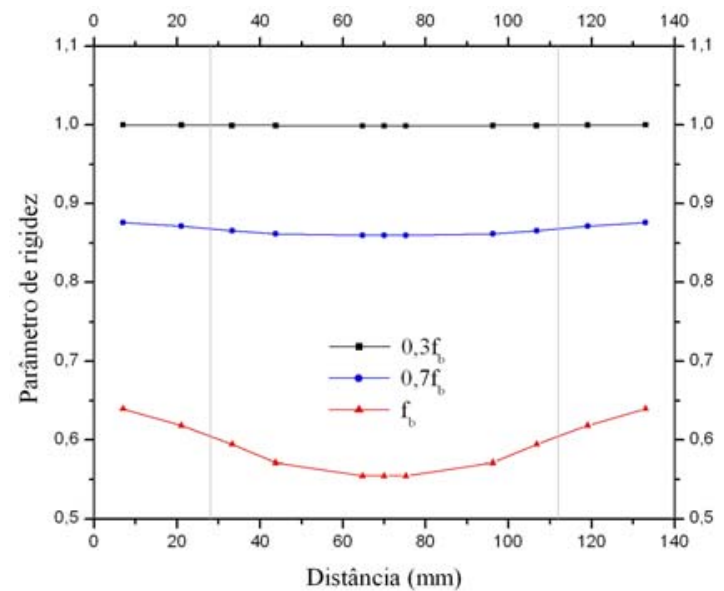

(b)

Figura 6.43 - Perfis H2 do parâmetro de rigidez: modelo A (a) e modelo B (b).

Observa-se no modelo A que as regiões com valores do parâmetro de rigidez mais próximo à unidade são as extremidades da parede longitudinal, enquanto no modelo $\mathrm{B}$ esse valor é praticamente uniforme ao longo dos perfis de H1 e H2, no nível de carregamento 1, indicando menor efeito de confinamento. A maior penalização do parâmetro ocorre na região entre os septos transversais externos e central, na parede longitudinal, e entre as paredes longitudinais no septo transversal externo, regiões onde existem as maiores magnitudes de tensão vertical. 
Apesar de constituído por um mesmo concreto, os blocos quando submetidos à compressão axial com distintas condições de contorno apresentam diferentes distribuições de tensões e deformações, fato que leva à alteração do valor de sua resistência "aparente". Com as análises anteriores é possível prever que a alteração da geometria do bloco pode levar às distintas condições de confinamento, o que poderia ser positivo para um determinado caso, em decorrência do aumento de sua resistência à compressão. Contudo, tal efeito não permaneceria num ensaio com prismas constituídos por esses blocos, levando, provavelmente a um fator de eficiência baixo. Assim, enfatiza-se a importância dos ensaios com prismas para a previsão da resistência de uma estrutura de alvenaria.

Por fim, apresenta-se na Figura 6.44 a distribuição de tensões principais mínimas e do parâmetro de rigidez obtidos no modelo $\mathrm{C}$, com o maior alívio de confinamento. A uniformidade caracteriza a distribuição de tensões em todos os níveis de carregamento, assim como o parâmetro de rigidez nos níveis de carregamento 1 e 2. No nível de carregamento 3, observa-se a maior perda de rigidez na região entre os septos transversais.

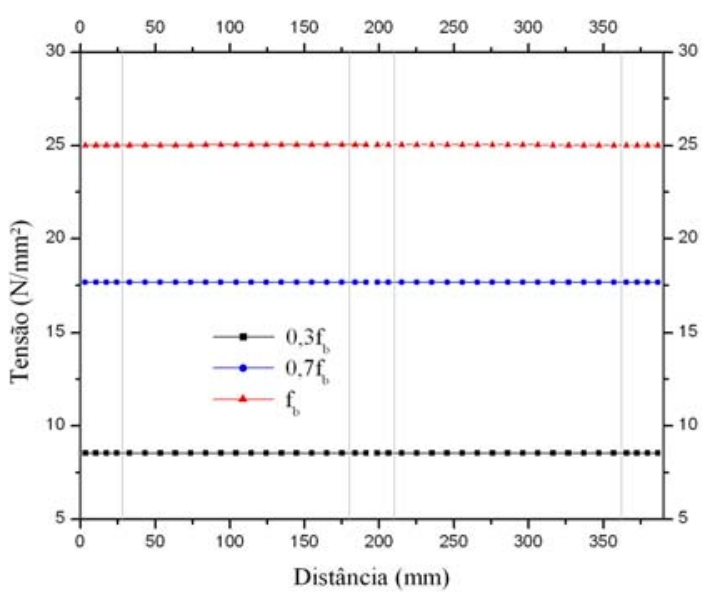

(a)

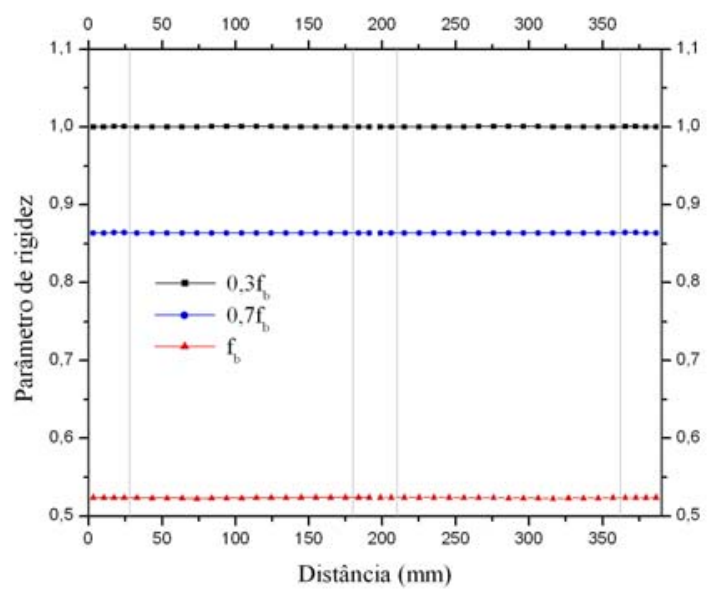

(b)

Figura 6.44 - Perfis H1 das tensões principais mínimas (a) e do parâmetro de rigidez (b) do modelo C.

Assim, um modelo livre do efeito de confinamento apresenta uniformidade dos valores de tensão ao longo das paredes dos blocos e, portanto, a determinação do módulo de elasticidade do material que constitui o bloco poderia ser efetuada medindo-se as deformações em qualquer região.

\subsection{Prismas de blocos vazados de concreto}

A estratégia numérica de micromodelagem é introduzida na análise dos prismas com a discretização da junta de argamassa e dos blocos de concreto, representados por uma malha 
de elementos finitos contínuos estruturados. A não-linearidade baseia-se na plasticidade e fissuração dos materiais, conforme descrito no item 6.1. Realizam-se três abordagens: estado plano de tensões (EPT), estado plano de deformações (EPD) e uma abordagem tridimensional (3D), com quatro modelos de prismas de blocos vazados de concreto, denominados P1, P2, P3 e P4, os quais têm propriedades mecânicas do concreto e argamassa distintas. As análises no estado plano de tensões são efetuadas com a consideração da parede longitudinal e septo transversal do prisma.

Decide-se, em seguida, pela utilização da abordagem tridimensional quando é analisada a distribuição de tensões, de deformações e os modos de ruína em diversas regiões dos prismas.

Os valores da resistência à compressão dos prismas $\left(f_{p}\right)$ estão apresentados na Tabela 6.5 juntamente com os fatores de eficiência e a resistência à compressão dos blocos $\left(f_{b}\right)$ e corpos-de-prova de argamassa $\left(f_{a}\right)$. Esses resultados representam o valor médio obtido na análise experimental, todos em relação à área líquida.

Tabela 6.5 - Resistência à compressão dos blocos,
prismas e argamassas.

Os parâmetros elásticos e inelásticos para a implementação do modelo, que também foram obtidos durante o programa experimental - exceto o ângulo de atrito e o ângulo de dilatância - estão apresentados na Tabela 6.6.

Adota-se para o concreto e argamassa $\phi=10^{\circ}$ e $\psi=5^{\circ}$, conforme justificativa apresentada no item 6.2 . 
Tabela 6.6 - Propriedades elásticas e inelásticas do concreto e da argamassa utilizados na análise numérica com prisma.

\begin{tabular}{|c|c|c|c|c|c|c|}
\hline \multicolumn{2}{|c|}{ Componente } & $f_{\text {comp }}$ & $\begin{array}{c}\mathrm{f}_{\text {trac }} \\
\left(\mathrm{N} / \mathrm{mm}^{2}\right)\end{array}$ & $\mathrm{E}$ & $v$ & $\begin{array}{c}\mathrm{G}_{\mathrm{f}} \\
(\mathrm{N} / \mathrm{mm})\end{array}$ \\
\hline \multirow{2}{*}{$\mathrm{P} 1$} & Argamassa & 7,7 & 0,9 & 8121 & 0,13 & 0,0217 \\
\hline & Concreto & 18,6 & 1,7 & 17449 & 0,20 & 0,1063 \\
\hline \multirow{2}{*}{$\mathrm{P} 2$} & Argamassa & 9,4 & 1,1 & 9745 & 0,13 & 0,0228 \\
\hline & Concreto & 22,8 & 2,2 & 20595 & 0,20 & 0,1277 \\
\hline \multirow{2}{*}{ P3 } & Argamassa & 15,5 & 1,8 & 13195 & 0,15 & 0,0386 \\
\hline & Concreto & 24,9 & 2,4 & 22175 & 0,20 & 0,1375 \\
\hline \multirow{2}{*}{$\mathrm{P} 4$} & Argamassa & 22,2 & 2,6 & 16672 & 0,15 & 0,0653 \\
\hline & Concreto & 36,2 & 3,1 & 27104 & 0,20 & 0,1548 \\
\hline \multicolumn{7}{|c|}{$\mathrm{f}_{\text {comp }}$ : resistência à compressão; } \\
\hline \multicolumn{7}{|c|}{$\mathrm{f}_{\text {trac }}:$ resistência à tração; } \\
\hline \multicolumn{7}{|c|}{ E : módulo de elasticidade; } \\
\hline \multicolumn{7}{|c|}{$\mathrm{G}_{\mathrm{f}}$ : energia de fratura à tração. } \\
\hline
\end{tabular}

Uma área elementar representativa do modelo físico foi definida e está apresentada na Figura 6.45a. Contudo, para reduzir o esforço computacional, apenas um oitavo dessa área é modelada (Figura 6.45b), assumindo-se as condições adequadas para os contornos no plano por meio de simetrias. Procedimento semelhante é adotado quando se considera apenas o septo transversal na abordagem EPT do prisma.

A área elementar representativa foi adotada, pois se considerou um modelo suficientemente grande em que os deslocamentos são uniformes na região de análise. Por exemplo, a região central de um prisma com cinco blocos de altura aproxima-se desse comportamento, o que não estaria seguramente representado se o prisma fosse constituído por apenas dois blocos. 


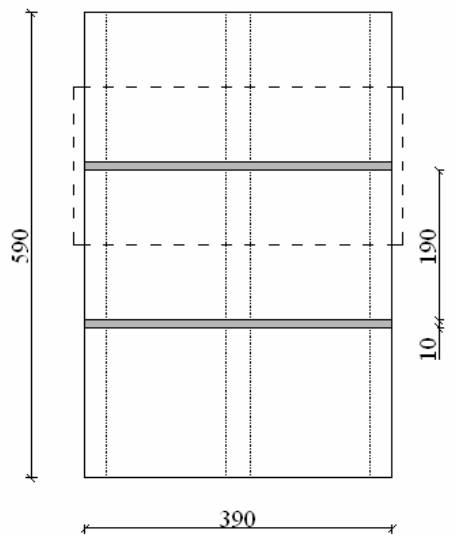

(a)

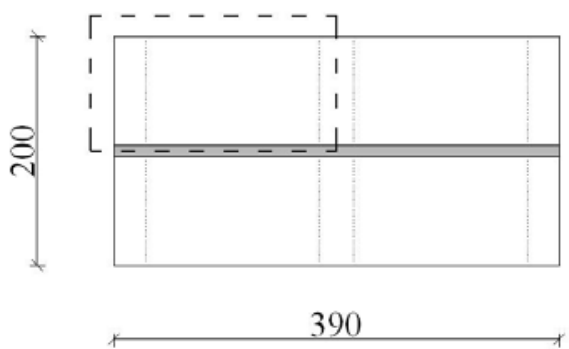

(b)

Figura 6.45 - Prisma de blocos vazados de concreto com indicação de sua área elementar representativa (a) e detalhe da região a ser modelada (b). Dimensões em milímetros.

Estas abordagens são aproximadas em relação ao modelo físico real e a resposta numérica obtida é fenomenológica, ou seja, a comparação dos modos de ruína entre o modelo experimental e numérico não são representativas em sua totalidade. Nos modelos experimentais, por exemplo, comumente observam-se fissuras de separação, sendo seus efeitos de contorno e modos de ruína assimétricos, diferindo dos obtidos na análise numérica, o que influencia, principalmente, a resposta pós-pico.

Nas análises bidimensionais, discretiza-se a parede longitudinal com 704 elementos finitos quadrilaterais, totalizando 2221 nós e 4442 graus de liberdade. Considerando-se o septo transversal, a malha gerada apresenta 308 elementos e um total de 997 nós.

No modelo tridimensional também se utilizou a simetria concernente ao caso, ilustrada na Figura 6.46. A malha é constituída por 968 elementos tridimensionais, totalizando 6429 nós e 19287 graus de liberdade.

Além da consideração da simetria, como condição de contorno restringiu-se os deslocamentos dos nós da base do modelo apenas no sentido do eixo y. No topo, todos os deslocamentos dos nós estão liberados. 


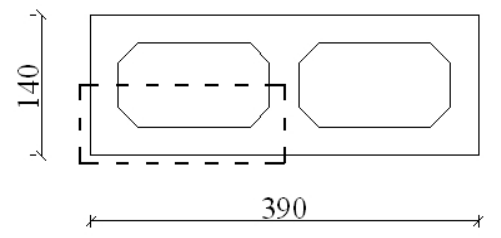

(a)

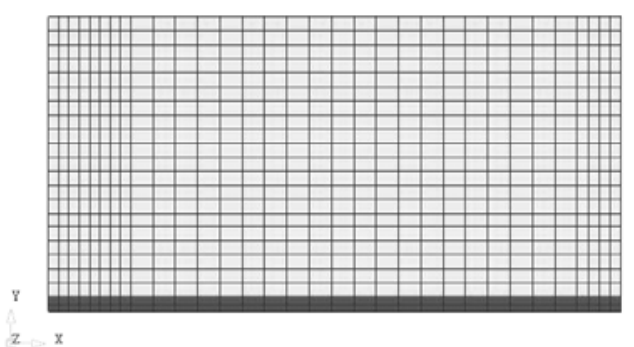

(b)

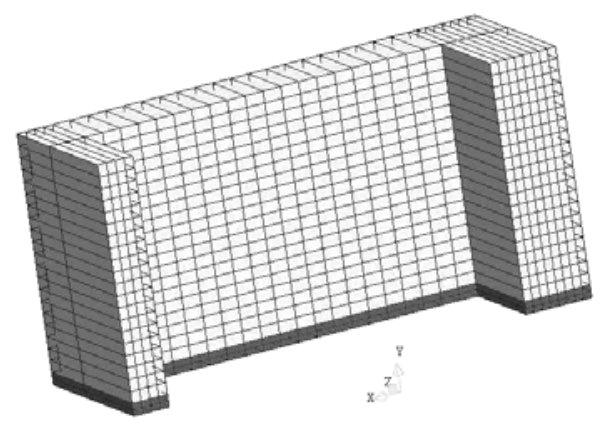

(c)

Figura 6.46 - Vista superior do com as dimensões em milímetros (a). Malha de elementos finitos correspondente a um oitavo da área elementar representativa (b e c).

\subsubsection{Discussão sobre as distintas abordagens}

Cada abordagem corresponde a um diferente nível de confinamento fora do plano xy. No EPT, as deformações na direção perpendicular a ele não são restringidas e o espécime pode deformar-se livremente. Ao contrário, no EPD as deformações são restringidas. $\mathrm{O}$ estado intermediário a essas duas condições extremas está aproximado pelo modelo $3 \mathrm{D}$, sobretudo pelo fato de uma estrutura de alvenaria de blocos vazados de concreto apresentar regiões que se aproximam desses dois estados: o centro da junta de argamassa fica sujeito a condições similares ao estado plano de deformação e as paredes do bloco a uma condição equivalente ao estado plano de tensão.

A abordagem no EPT considerou a discretização da parede longitudinal e do septo transversal, separadamente, para analisar se algum dos casos é condicionante na ruína. Obteve-se uma pequena diferença entre os modelos em relação ao valor da tensão máxima: os modelos relativos à parede longitudinal apresentam valores, aproximadamente, 5\% maiores que os obtidos considerando-se apenas o septo transversal. Assim sendo, adota-se o modelo com discretização da parede longitudinal para representar as abordagens EPT e EPD. 
Os gráficos tensão-deformação, quando consideradas as abordagens EPT, EPD e o modelo tridimensional, são apresentados na Figura 6.47, juntamente com a curva experimental. A tensão máxima obtida no EPT é sempre menor que a obtida experimentalmente; ao contrário, quando se considera o EPD, obtém-se valor mais alto. $\mathrm{Na}$ análise $3 \mathrm{D}$, a força teórica e experimental são as que mais se aproximam, como é observado nos valores da Tabela 6.7 .

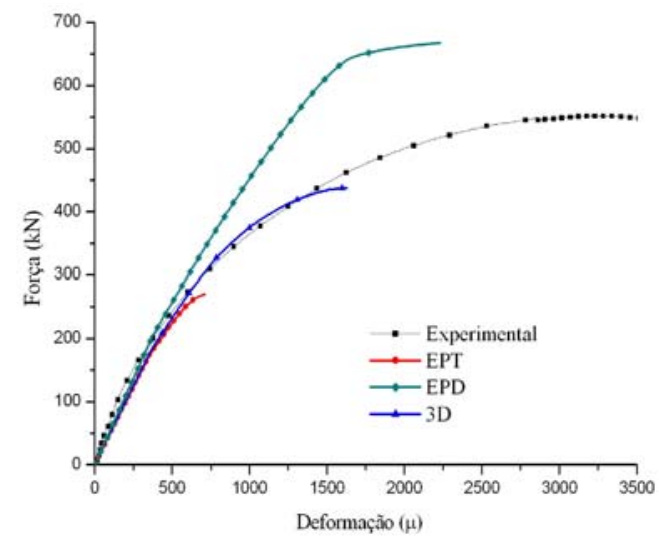

(a)

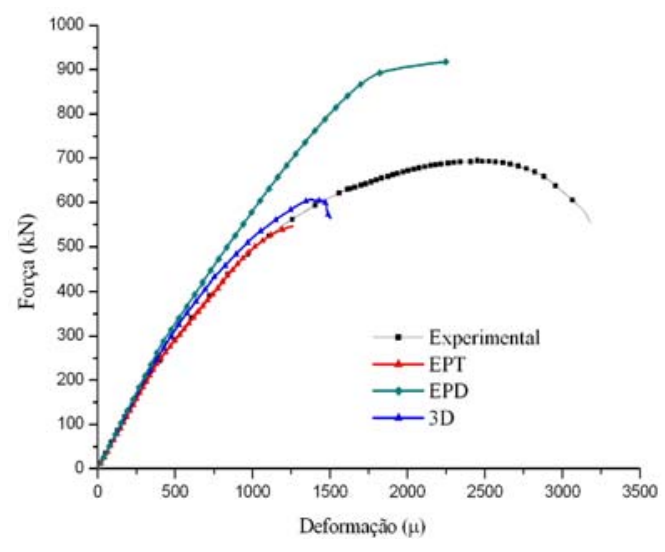

(c)

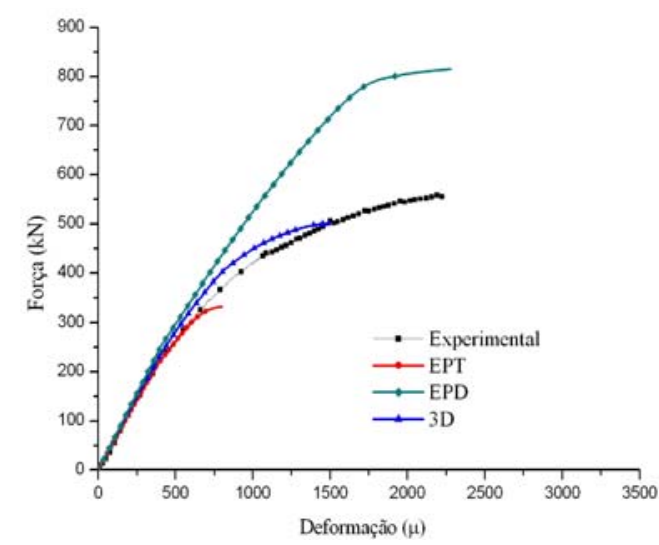

(b)

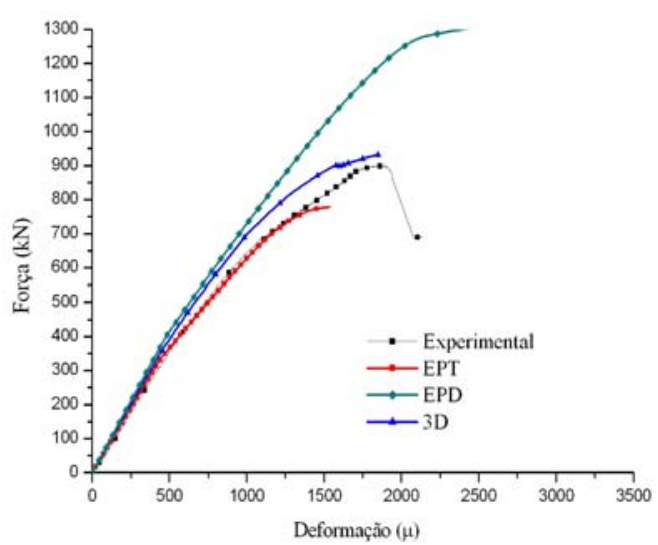

(d)

Figura 6.47 - Diagramas tensão-deformação obtidos a partir das análises numéricas e experimentais. Modelos P1 (a), P2 (b), P3 (c) e P4 (d).

O comportamento linear inicial coincide em todas as abordagens numéricas e em relação à curva experimental dos quatro modelos apresentados, contudo, a partir do trecho não-linear, as considerações EPT e 3D são as que apresentam a melhor aproximação com o modelo experimental.

As diferenças obtidas entre o modelo $3 \mathrm{D}$ e a curva experimental em relação às deformações ocorrem pela não consideração de um modelo de comportamento volumétrico. Além disso, no modelo físico, a interface entre o bloco e a junta apresenta alta porosidade em 
decorrência da migração da água de amassamento da argamassa para o bloco, tornando essa região mais deformável, fenômeno não considerado no modelo numérico.

Tabela 6.7 - Força teórica e experimental máxima obtida nas análises com prismas.

\begin{tabular}{cccccccc}
\hline & \multicolumn{2}{c}{ EPT } & \multicolumn{2}{c}{ EPD } & \multicolumn{2}{c}{$3 \mathrm{D}$} \\
Modelo & $\begin{array}{c}\mathrm{F}^{\text {exp }} \\
(\mathrm{kN})\end{array}$ & $\begin{array}{c}\mathrm{F}^{\text {num }} \\
(\mathrm{kN})\end{array}$ & $\frac{\mathrm{F}^{\text {num }}}{\mathrm{F}^{\exp }}$ & $\begin{array}{c}\mathrm{F}^{\text {num }} \\
(\mathrm{kN})\end{array}$ & $\frac{\mathrm{F}^{\text {num }}}{\mathrm{F}^{\exp }}$ & $\begin{array}{c}\mathrm{F}^{\text {num }} \\
(\mathrm{kN})\end{array}$ & $\frac{\mathrm{F}^{\text {num }}}{\mathrm{F}^{\text {exp }}}$ \\
\hline P1 & 546 & 270 & 0,50 & 668 & 1,22 & 438 & 0,80 \\
P2 & 558 & 333 & 0,60 & 816 & 1,46 & 501 & 0,90 \\
P3 & 659 & 547 & 0,83 & 918 & 1,39 & 607 & 0,92 \\
P4 & 923 & 778 & 0,84 & 1311 & 1,42 & 932 & 1,01 \\
\hline
\end{tabular}

Os modelos P1 e P2, que possuem as mais baixas resistências à compressão da argamassa, apresentam as menores relações entre as forças teórica e experimental considerando-se a abordagem no estado plano de tensões. $\mathrm{O}$ fato é justificado em virtude da desconsideração de tensões transversais na direção ortogonal ao plano de análise, o que acarretaria o efeito de confinamento, permitindo ao material alcançar maior resistência e, consequentemente, os respectivos modelos matemáticos poderiam atingir maiores resistências. Pina-Henriques (2005) destaca que encontrou em suas análises grande problema em relação à convergência do modelo devido à não-homogeneidade resultante nos campos de tensão e deformação, principalmente quando há grandes diferenças entre as propriedades mecânicas da argamassa e da unidade. Da mesma forma, os modelos P1 e P2 apresentam tal dificuldade pelo fato de possuírem as maiores diferenças entre os valores dos módulos de elasticidade do concreto e da argamassa.

A abordagem EPT, considerando-se apenas os modelos P3 e P4, mostram-se satisfatórios em relação à previsão da força teórica, se levadas em consideração as simplificações em relação ao modelo físico tridimensional e utilização do meio contínuo. A resistência mais baixa está associada à condição de confinamento na junta de argamassa.

Por não permitir deslocamentos na direção ortogonal ao plano de análise, na consideração do EPD obtêm-se maiores valores de força teórica para todos os modelos, com acréscimo de aproximadamente $40 \%$ em relação à curva experimental. Neste caso, além da consideração extrema do efeito triaxial na junta de argamassa na direção ortogonal ao plano, contempla-se também restrição de deformações do bloco de concreto, o que não representa o modelo físico, sendo, desta forma, plenamente justificado o aumento na resistência à compressão dos prismas. 
Com a abordagem 3D, os valores da força teórica sempre apresentam valores intermediários em relação às duas abordagens bidimensionais. Um estado intermediário entre o EPT e o EPD é o que melhor representa as condições de contorno a que está submetido o modelo físico. As relações forças teórica e experimental são entre 0,80 e 1,00 para todos os modelos analisados.

Apenas o modelo numérico tridimensional P4 apresentou deformação idêntica ao valor obtido na análise experimental, tendo os demais modelos valores equivalentes a $60 \%$ dos obtidos nas análises numéricas. Os modelos numéricos no estado plano de deformação apresentam estes valores mais próximos, enquanto a análise no estado plano de tensão fornece valores sempre inferiores aos modelos experimentais. A Tabela 6.8 sumariza os valores referentes à deformação última obtida nas análises numéricas e experimentais.

Tabela 6.8 - Valores de deformação última obtidos nas análises experimental e numérica.

\begin{tabular}{|c|c|c|c|c|c|c|c|}
\hline \multirow{3}{*}{ Prisma } & \multirow{3}{*}{$\begin{array}{l}\varepsilon_{\mathrm{u}}^{\exp } \\
(\mu)\end{array}$} & \multicolumn{2}{|c|}{ EPT } & \multicolumn{2}{|c|}{ EPD } & \multicolumn{2}{|c|}{$3 \mathrm{D}$} \\
\hline & & $\varepsilon_{\mathrm{u}}^{\mathrm{num}}$ & $\varepsilon^{\text {num }}$ & $\varepsilon_{\mathrm{u}}^{\mathrm{num}}$ & $\varepsilon^{\text {num }}$ & $\varepsilon_{u}^{\text {num }}$ & $\varepsilon^{\text {num }}$ \\
\hline & & $(\mu)$ & $\overline{\varepsilon^{\exp }}$ & $(\mu)$ & $\overline{\varepsilon^{\exp }}$ & $(\mu)$ & $\overline{\varepsilon^{\exp }}$ \\
\hline $\mathrm{P} 1$ & 2244 & 802 & 0,36 & 2277 & 1,01 & 1488 & 0,66 \\
\hline $\mathrm{P} 2$ & 3207 & 711 & 0,22 & 2231 & 0,70 & 1629 & 0,51 \\
\hline P3 & 2451 & 1260 & 0,51 & 2248 & 0,92 & 1503 & 0,61 \\
\hline $\mathrm{P} 4$ & 1841 & 1535 & 0,83 & 2591 & 1,41 & 1850 & 1,00 \\
\hline
\end{tabular}

No estado plano de tensões, identifica-se como causa da ruína dos prismas o esmagamento da junta de argamassa, com mesma intensidade em toda sua extensão, em decorrência da inexistência do efeito de compressão triaxial na região, como já discutido, e não é identificada fissuração significativa nos blocos de concreto, conforme ilustra a Figura $6.48 \mathrm{a}$.

Identifica-se na Figura $6.48 \mathrm{~b}$, como fator preponderante para a ruína dos prismas na abordagem no estado plano de deformações, o esmagamento da junta da argamassa associado às fissuras inclinadas nos blocos de concreto. Este comportamento ocorre devido à restrição da deformação do bloco na direção ortogonal ao plano de análise. O esmagamento da junta é proeminente no septo transversal externo, não havendo ruína nas demais regiões da parede longitudinal do bloco. 


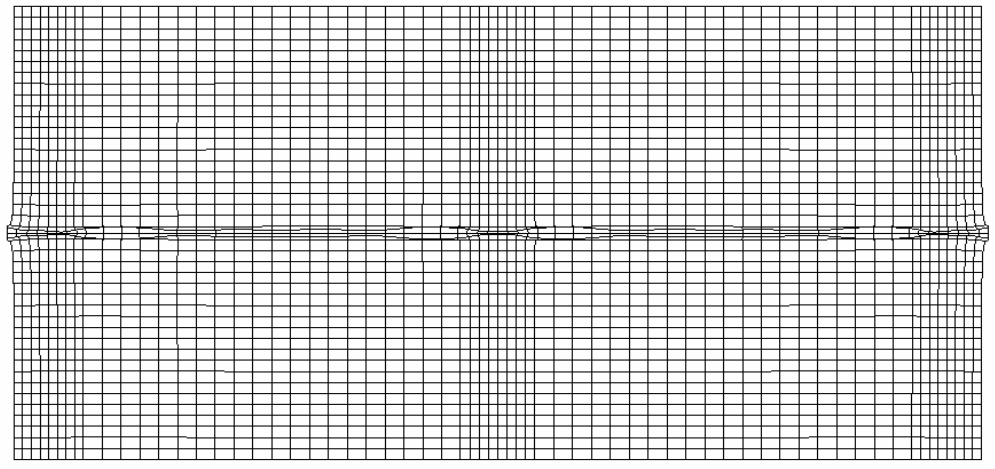

(a)

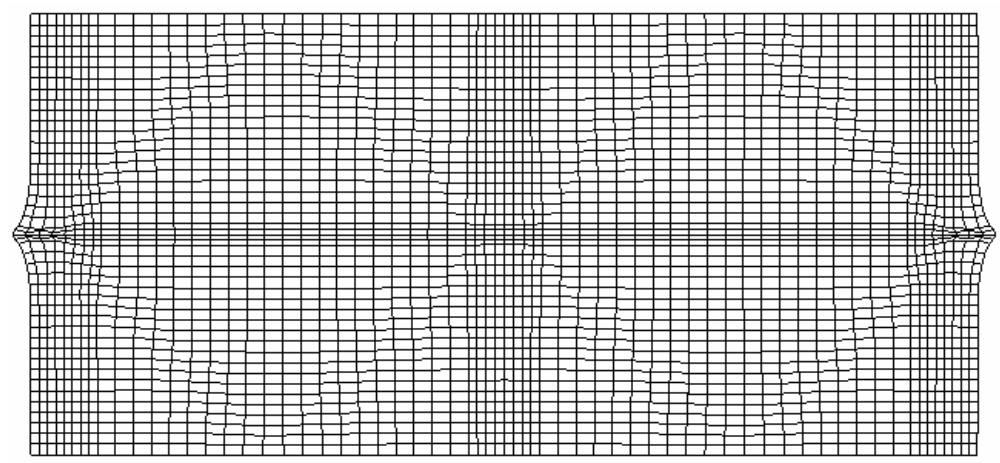

(b)

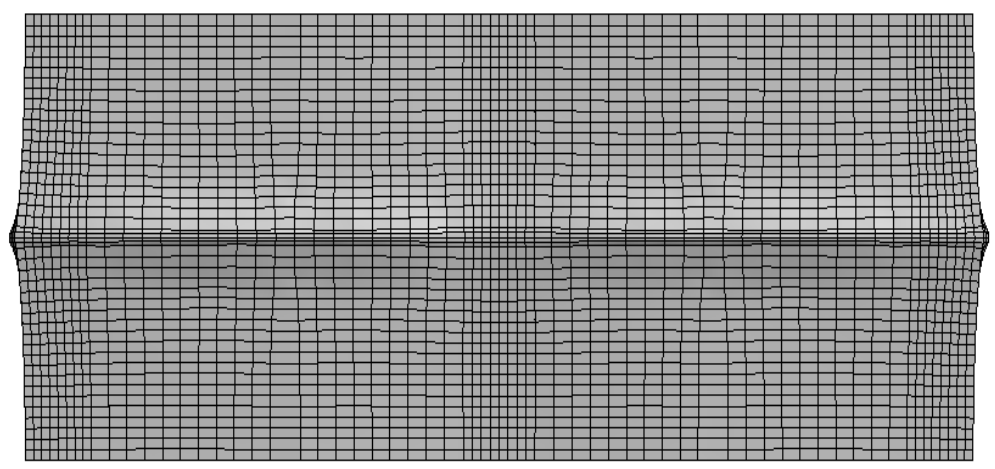

(c)

Figura 6.48 - Deformada da malha dos prismas na ruína: EPT (a), EPD(b) e 3D (c)

O modelo tridimensional também é o que melhor representa o modelo físico em relação ao modo de ruína com o aparecimento de fissuras verticais na parede longitudinal e o esmagamento da junta de argamassa, conforme se representa na Figura 6.48c. Cabe enfatizar que o mecanismo de ruína obtido depende da estratégia de modelagem adotada, a qual, mesmo sendo numericamente correta, pode-se mostrar fisicamente não realística. 
Portanto, deve-se enfatizar que as análises planas não representam bem o comportamento de prismas submetidos à compressão, devendo ser priorizados os modelos tridimensionais.

O modelo de prisma P4 é adotado para a realização das análises subseqüentes.

\subsubsection{Comportamento dos prismas na abordagem tridimensional}

Na Figura 6.49a estão apresentados os gráficos da deformação vertical do bloco de concreto, da junta de argamassa e do prisma em função da força aplicada na superfície superior do modelo numérico. Nota-se que o bloco não atinge o patamar de ruína à compressão e a argamassa apresenta valores elevados de deformação em decorrência do efeito de confinamento triaxial, situação que permite que as deformações últimas alcancem valores mais altos do que quando o material é solicitado à compressão uniaxial. Como esperado, a curva referente ao prisma apresenta menor rigidez que a do bloco, influenciada pela alta deformabilidade da argamassa.

A ruína do bloco é identificada pelo aumento significativo das deformações transversais, sem aumento significativo do nível de força, em virtude da ocorrência de tensões de tração (Figura 6.49b).

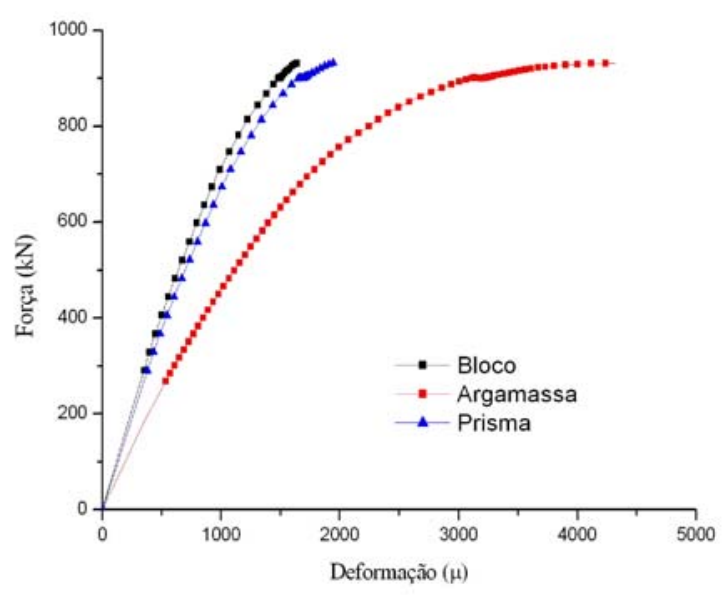

(a)

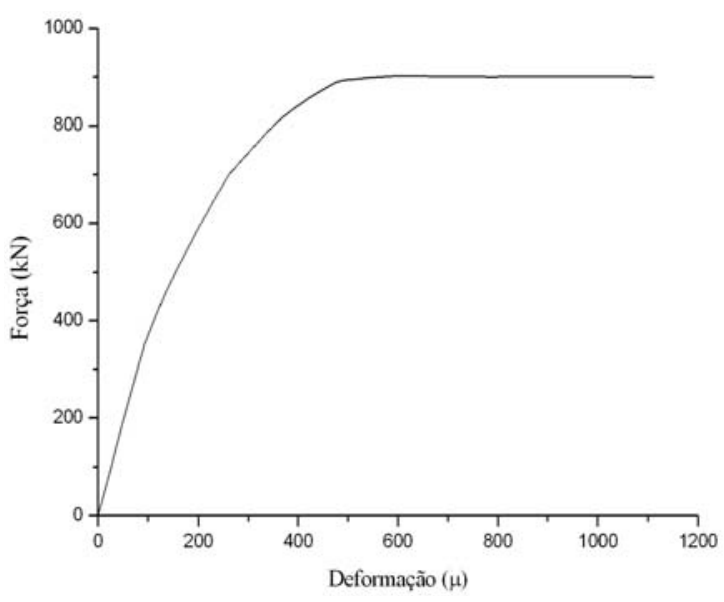

(b)

Figura 6.49 - Curvas força-deformação do bloco, argamassa e prisma (a). Curva forçadeformação transversal do bloco de concreto (b).

O comportamento da argamassa nas distintas regiões do bloco apresenta pequenas diferenças a partir de $80 \%$ da carga máxima, estando os diferentes valores de deformação última relacionados aos níveis de confinamento que surgem nessas regiões (Figura 6.50). 


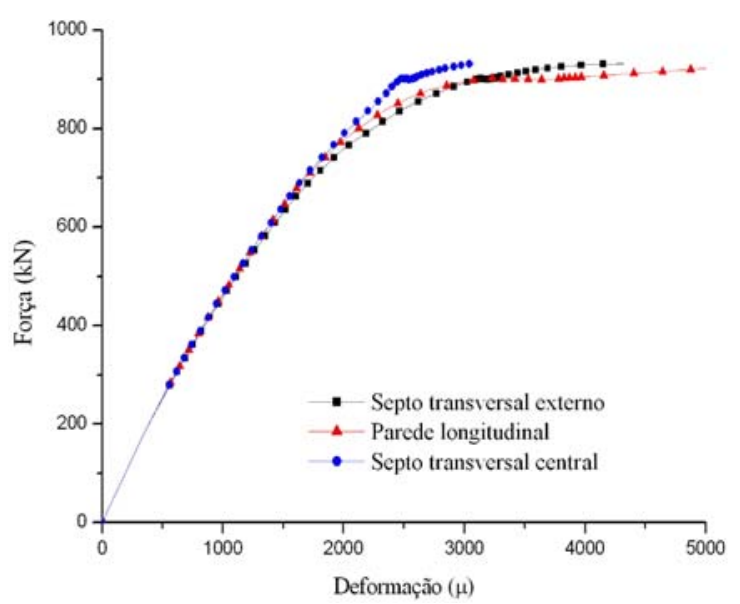

Figura 6.50 - Curvas força-deformação vertical da argamassa obtidas em distintas regiões do prisma.

\subsubsection{Distribuição de tensões e deformações}

A distribuição de tensões e deformações é analisada por meio das seções apresentadas na Figura 6.51, para três níveis de carregamento referentes à resistência obtida no modelo numérico dos prismas: $0,3 \mathrm{f}_{\mathrm{p}}, 0,6 \mathrm{f}_{\mathrm{p}}$ e $0,95 \mathrm{f}_{\mathrm{p}}$.

As linhas verticais na cor cinza nos gráficos das seções S1 e S1E representam as dimensões dos septos transversais ao longo da parede longitudinal do bloco. Já as linhas horizontais, na mesma cor, representam a junta de argamassa quando apresentadas as seções S4, S5 e S6E.
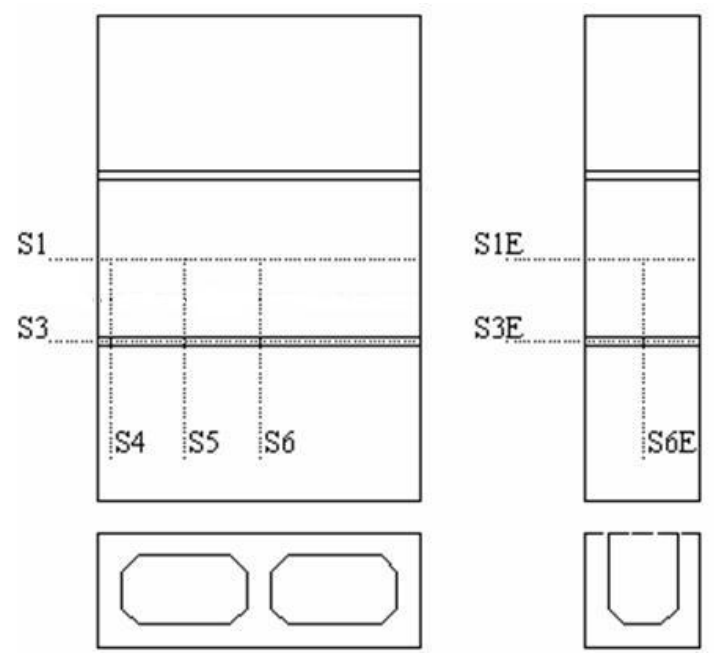

Figura 6.51 - Seções para análise relativas à vista frontal e septo transversal externo (E). 


\subsubsection{Análise das tensões}

A distribuição de tensões transversais nos sentidos eixos $x$ e $z$ na junta de argamassa apresenta valores praticamente uniformes na região da parede longitudinal, ficando menores na proximidade dos septos transversais. $\mathrm{O}$ confinamento atuante no sentido do eixo $\mathrm{x}$, ao longo da parede longitudinal, é mais intenso que o obtido no sentido do eixo $z$, em conseqüência da menor dimensão da junta de argamassa. Os perfis das tensões efetivas estão apresentados na Figura 6.52.

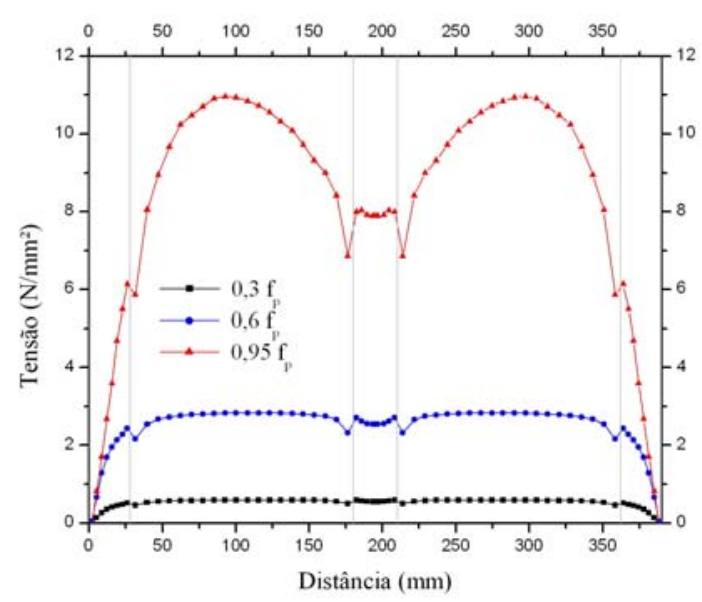

(a)

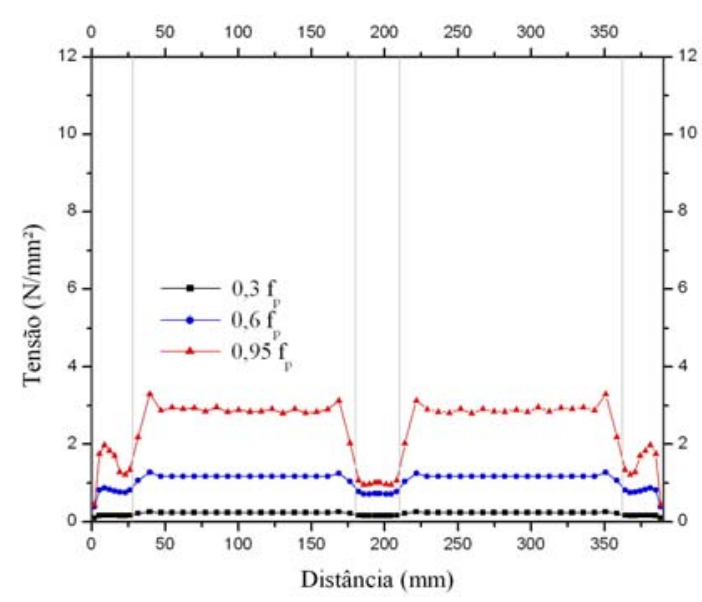

(b)

Figura 6.52 - Perfis S3, na junta de argamassa, das tensões transversais efetivas $\sigma_{x}$ (a) e $\sigma_{z}$ (b).

As tensões de confinamento no septo transversal externo, na direção do eixo $\mathrm{x}$, apresentam valores bem inferiores do que os encontrados na respectiva análise ao longo da parede longitudinal, conforme indicam os perfis da Figura 6.53a.

A Equação (6.9) define o fator de confinamento, utilizado para quantificar esse fenômeno na junta de argamassa levando em consideração a magnitude das tensões transversais $\sigma_{\mathrm{x}}$ e $\sigma_{\mathrm{z}}$. Na Figura $6.53 \mathrm{~b}$ está apresentada a evolução desse parâmetro, relativo à tensão vertical no topo do prisma, em distintas regiões. Como se observa nos perfis da Figura 6.52, menor intensidade do efeito de confinamento é alcançada nos septos transversais externos.

$$
\sqrt{\sigma_{x}^{2}+\sigma_{z}^{2}}
$$




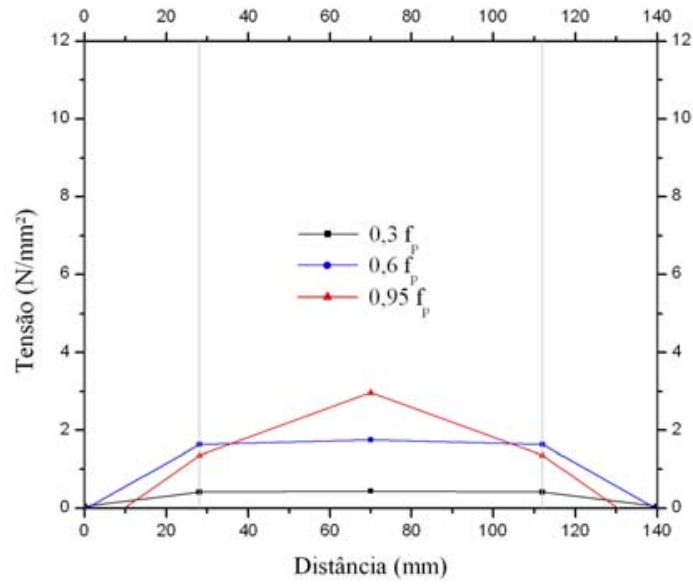

(a)

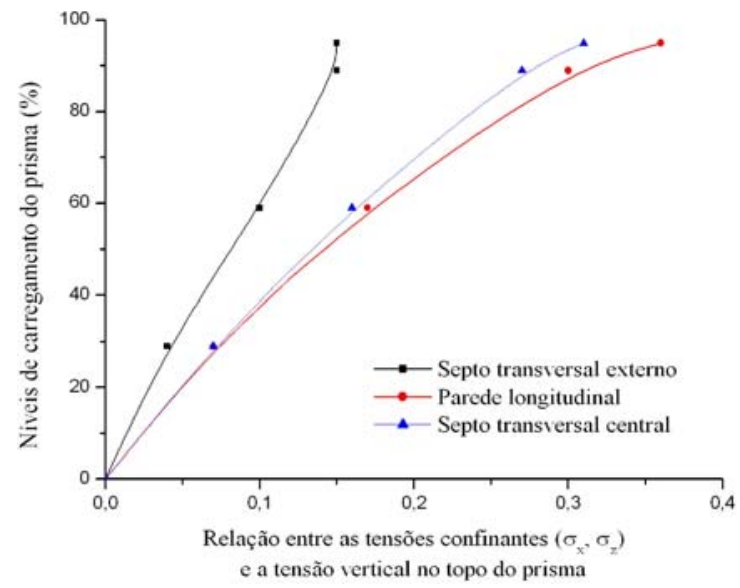

(b)

Figura 6.53 - Perfis S3E, na junta de argamassa, das tensões transversais efetivas $\sigma_{\mathrm{z}}$ (a).

Evolução do fator de confinamento (b).

As tensões transversais no bloco de concreto central do prisma não atuam de forma a confiná-lo, conforme se ilustra na Figura 6.54. Observa-se que a maior parte da parede longitudinal apresenta tensões de tração em todos os níveis de carregamento. De maneira oposta à observada na junta de argamassa, as tensões transversais de compressão crescem nas proximidades dos septos transversais.

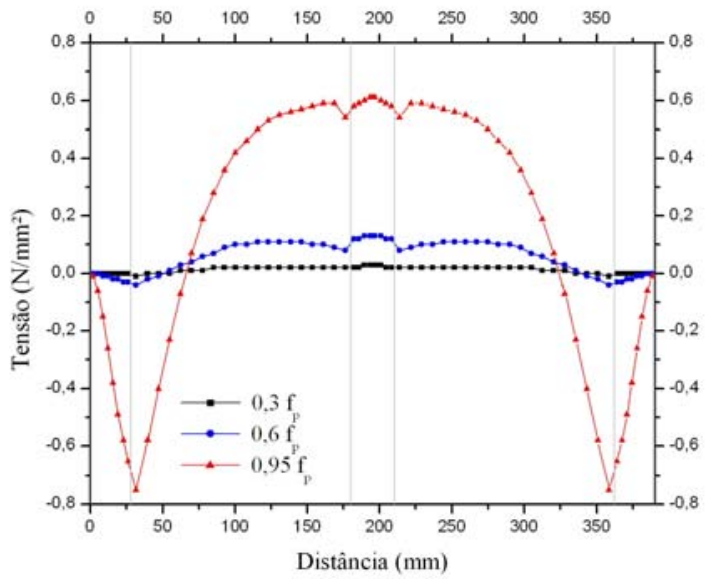

Figura 6.54 - Perfis S1, no bloco de concreto, das tensões transversais efetivas $\sigma_{x}(b)$.

Na Figura 6.55a, é possível observar que nas seções horizontais do bloco central não ocorre variação significativa de tensões principais mínimas - associadas à compressão no sentido do eixo y (vertical) até aproximadamente $60 \%$ da carga máxima. Próximo à ruína, são identificados maiores valores no septo transversal externo, os quais sofrem redução à medida que se aproximam do centro da parede longitudinal; a partir deste ponto, os valores 
novamente aumentam até o septo transversal central. A variação dos valores de tensão é pequena, atingindo no máximo $5 \%$ no nível de carregamento 3, conforme Figura 6.56a que ilustra as tensões relativas à tensão uniforme aplicada no topo do prisma.

De acordo com a Figura 6.55b, na junta de argamassa, a partir do nível de carregamento de $0,3 \mathrm{f}_{\mathrm{p}}$ há uma tendência de redução dessa tensão para as extremidades, contrastando com a uniformidade ao longo da parede longitudinal. Em relação à parede longitudinal, a redução atinge $16 \%$ e $44 \%$, respectivamente, para os níveis de carregamento $0,6 f_{p}$ e $0,95 f_{p}$ (Figura 6.56b).
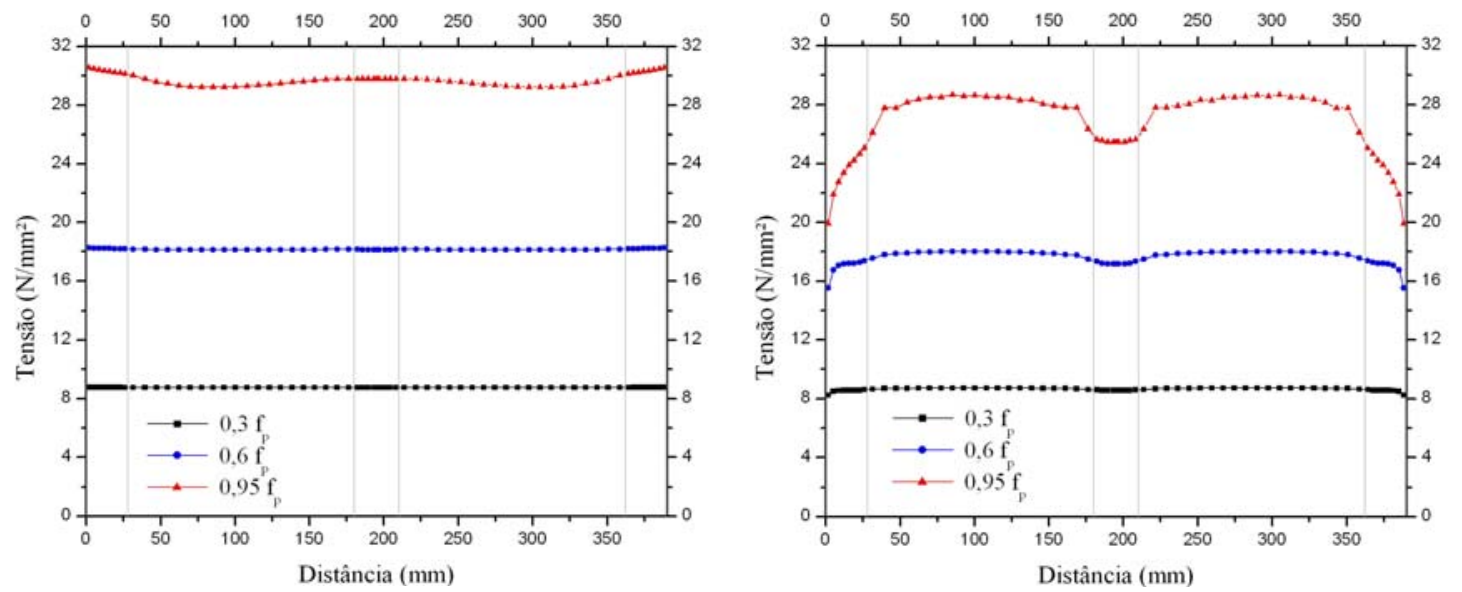

Figura 6.55 - Perfis S2 e S3 das tensões mínimas principais do bloco de concreto (a) e da junta de argamassa (b), respectivamente.

A comparação entre os distintos perfis de distribuição das tensões verticais do bloco de concreto e da junta de argamassa mostra que até o nível de carregamento de $0,3 \mathrm{f}_{\mathrm{p}}$, a distribuição uniforme caracteriza ambos os perfis. Diferentemente, a partir de $0,6 \mathrm{f}_{\mathrm{p}}$ ocorre acentuada redistribuição de tensões com alívio do carregamento vertical na junta de argamassa dos septos transversais e aumento suave desses valores no bloco de concreto. As tensões verticais no bloco de concreto e na junta de argamassa apresentam valores próximos, indicando o aumento da resistência à compressão da argamassa em virtude do efeito de confinamento.

Próximo à ruína, é evidente que enquanto as extremidades da parede longitudinal do bloco apresentam nível de tensão superior (aproximadamente 5\%) ao existente no topo do prisma, na junta de argamassa essa redução é superior a $20 \%$. 

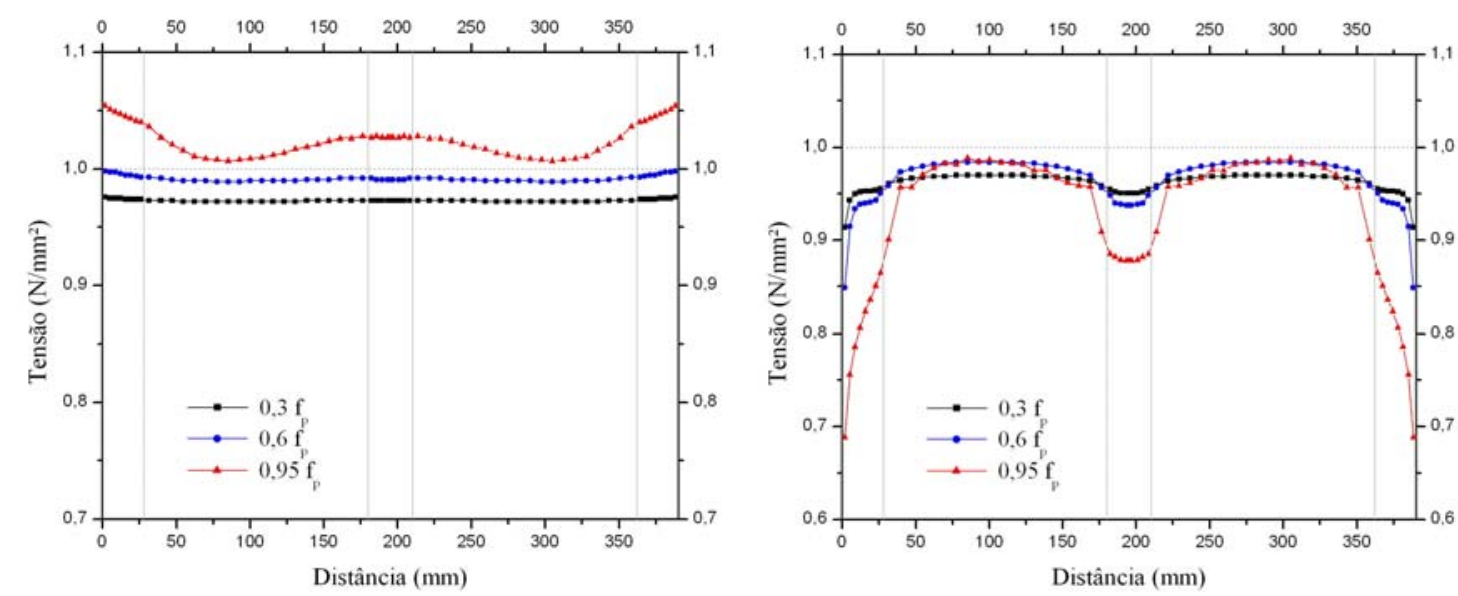

Figura 6.56 - Perfis S2 e S3 das tensões verticais relativas do bloco de concreto (a) e da junta de argamassa (b), respectivamente.

Na região dos septos transversais, permanece a tendência de aumento das tensões verticais do centro para as extremidades do bloco e comportamento oposto na junta de argamassa, com uma propensão de decréscimo em direção às extremidades, conforme os perfis apresentados na Figura 6.57.

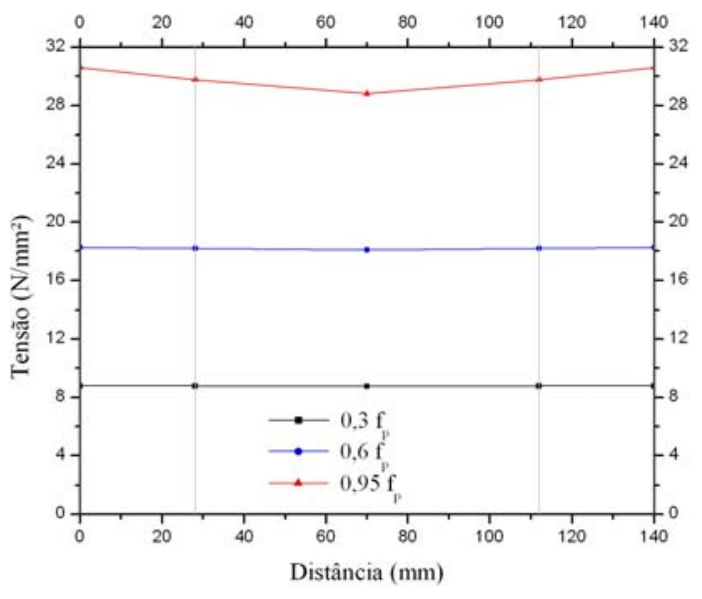

(a)

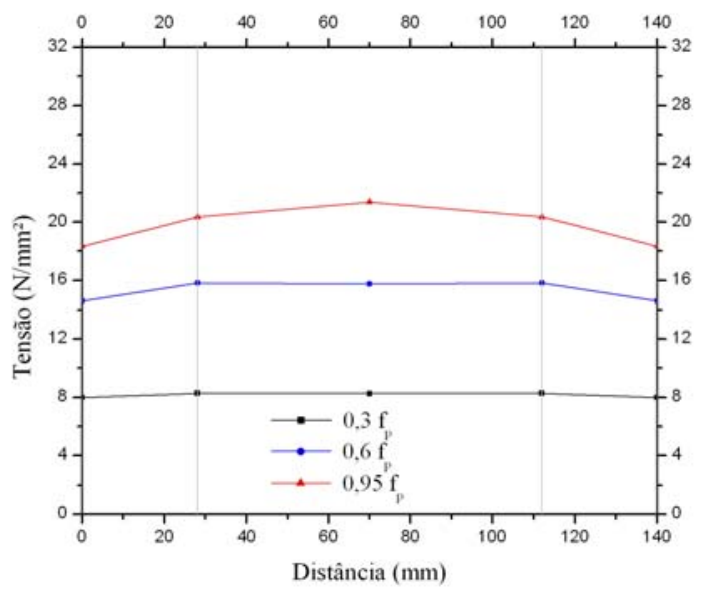

(b)

Figura 6.57 - Perfis S1E e S3E das tensões principais mínimas do bloco de concreto (a) e da junta de argamassa (b), respectivamente.

$\mathrm{Na}$ junta de argamassa no septo transversal externo, os valores das tensões chegam a diminuir $25 \%$ em relação às atuantes no topo do prisma. Os valores relativos estão apresentados na Figura 6.58, em que se destaca menor nível de tensões que o obtido na junta de argamassa ao longo da parede longitudinal. 


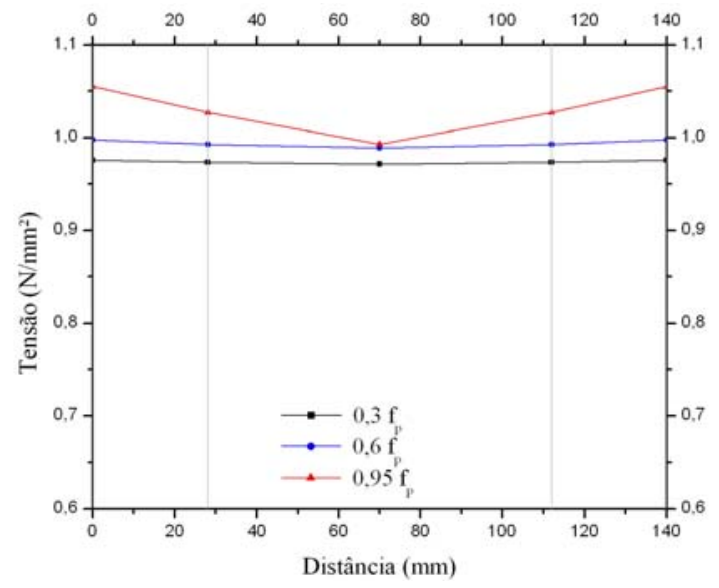

(a)

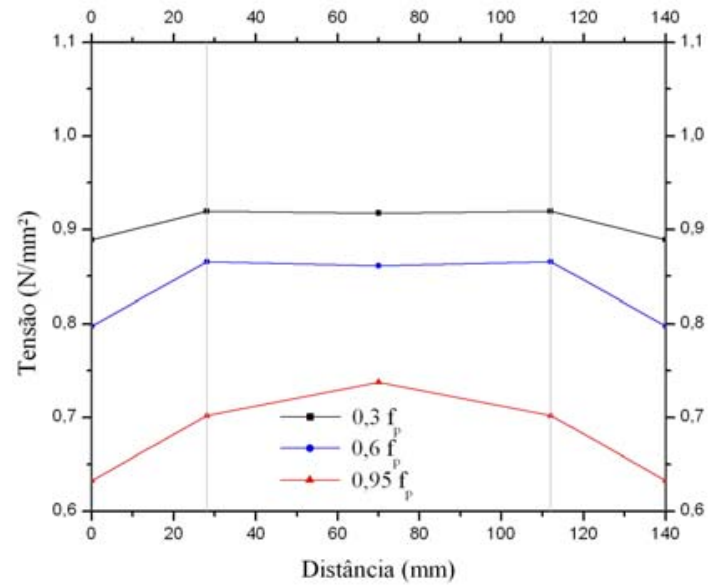

(b)

Figura 6.58 - Perfis S1E e S3E das tensões verticais relativas do bloco de concreto (a) e da junta de argamassa (b), respectivamente.

A análise dos perfis verticais, apresentados com valores relativos de tensões, indica a redução das tensões no bloco na proximidade da junta de argamassa. Até o nível de carregamento de $0,6 \mathrm{f}_{\mathrm{p}}$, a redução é de no máximo de $6 \%$, contudo, o aumento do carregamento acarreta diferenças que atingem 27\%. Assim, ao longo do perfil S4, por exemplo, a tensão verificada na junta de argamassa é $80 \%$ do valor efetivo no topo do modelo. Esse comportamento é claramente observado nos septos transversais, o que se contrapõe à distribuição mais uniforme obtida na parede longitudinal, conforme ilustração dos gráficos da Figura 6.59.

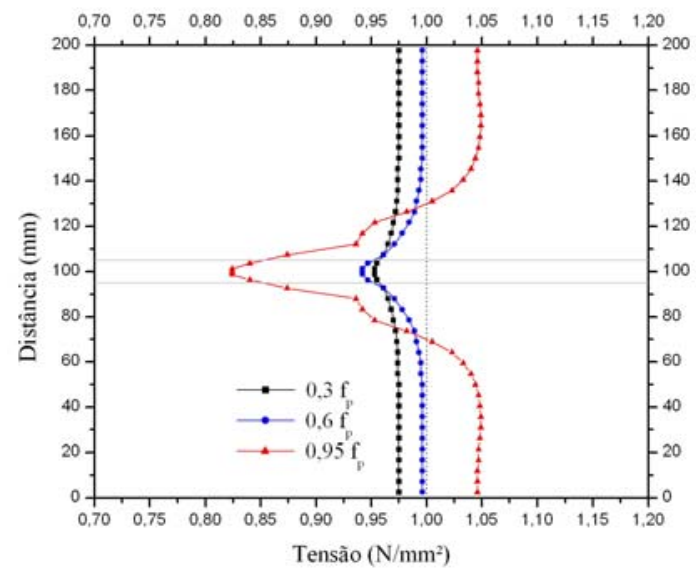

(a)

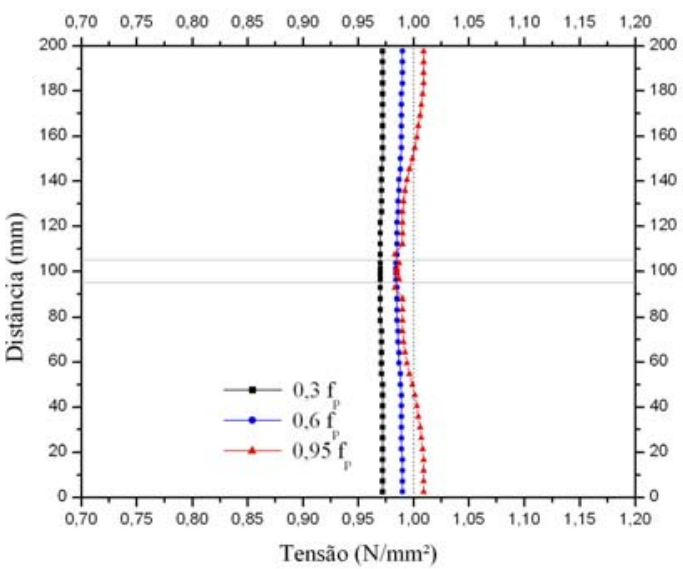

(b)

Figura 6.59 - Perfis S4 (a) e S5 (b) das tensões verticais relativas.

Os perfis verticais referentes aos septos transversais são apresentados na Figura 6.60a, indicando comportamento semelhante ao obtido na parede longitudinal (S4), com a 
redução da tensão relativa na proximidade da junta de argamassa. No nível de carregamento $0,95 \mathrm{f}_{\mathrm{p}}$ é nítido o menor valor relativo. Os perfis das tensões principais máximas são apresentados na Figura 6.60b, indicando tensões de tração elevadas junto à interface blocoargamassa, onde se inicia a fissuração do bloco, a qual influencia a ruína do prisma.

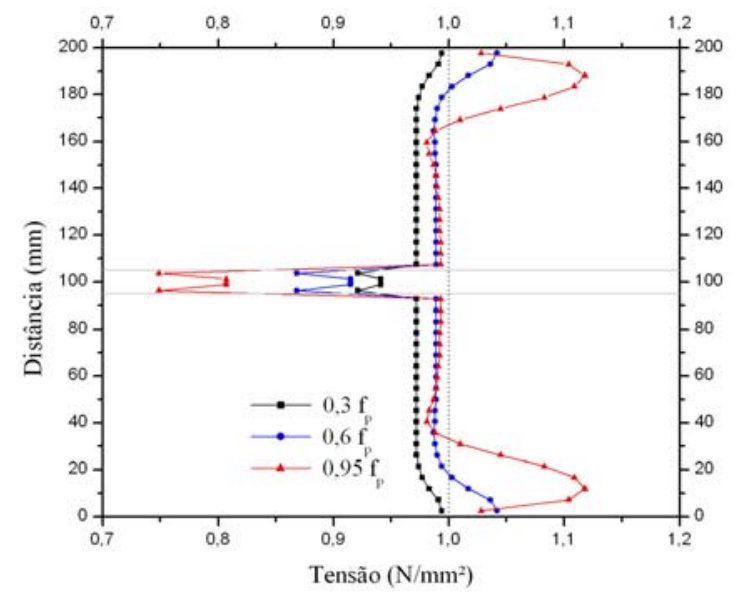

(a)

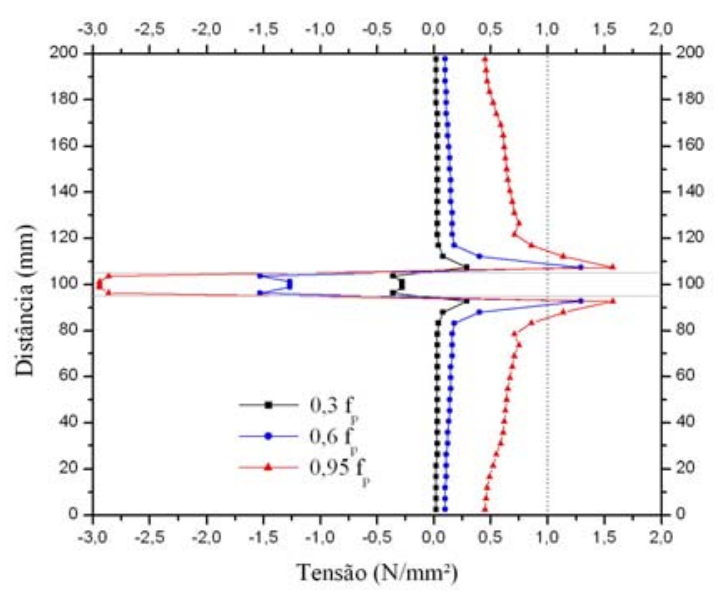

(b)

Figura 6.60 - Perfis S6E das tensões verticais (a) e S5 das tensões principais máximas (b).

Sob compressão uniaxial do prisma, os blocos de concreto e a junta de argamassa são caracterizados pelo comportamento não-linear e pela redistribuição de tensões, originando um estado triaxial na argamassa e o estado biaxial de compressão-tração nos blocos de concreto, que foram satisfatoriamente previstos pelo modelo numérico.

\subsubsection{Análise das deformações plásticas}

O nível de deformação plástica principal mínima que ocorre no bloco de concreto é muito baixo, principalmente se comparado com a junta de argamassa, onde os valores atingem $2000 \mu$, o que corresponde a aproximadamente 50\% da deformação total nesta região. Nos blocos, as deformações plásticas à compressão surgem somente após $0,3 \mathrm{f}_{\mathrm{p}}$, mas não os conduzem à ruína (Figura 6.61a). Já na junta, a ruína ocorre por esmagamento da argamassa, como se ilustra na Figura $6.61 \mathrm{~b}$, com as deformações plásticas já presentes no nível de carregamento 1. Nota-se ainda intensa não-uniformidade dos valores de deformação em $0,95 \mathrm{f}_{\mathrm{p}}$, com valores nos septos transversais externos e central $40 \%$ menores que os obtidos na parede longitudinal. 


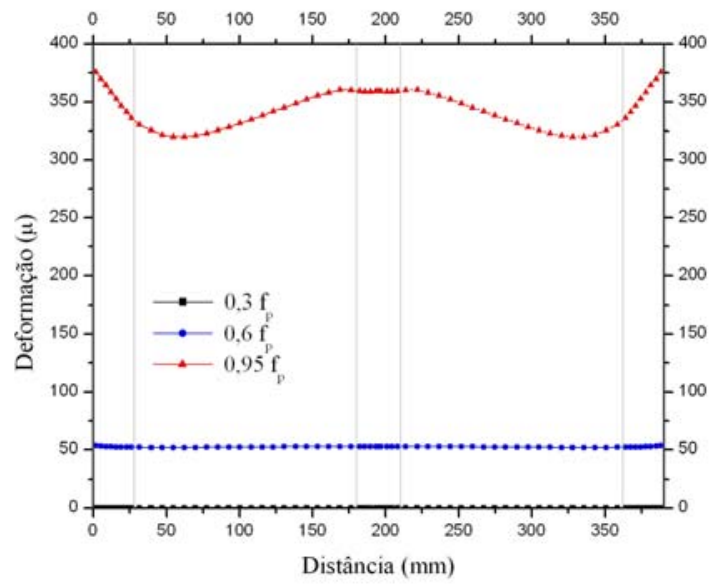

(a)

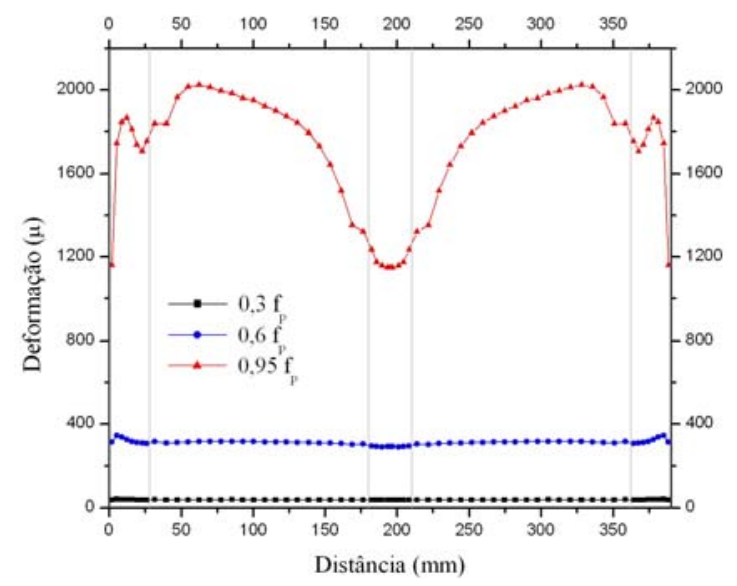

(b)

Figura 6.61 - Perfis S1 (a) e S3 (b) das deformações plásticas principais mínimas do bloco de concreto e da junta de argamassa, respectivamente.

No septo transversal, as deformações plásticas, ilustradas na Figura 6.62, permanecem no mesmo nível daquelas no bloco de concreto, porém com menores valores na junta de argamassa.

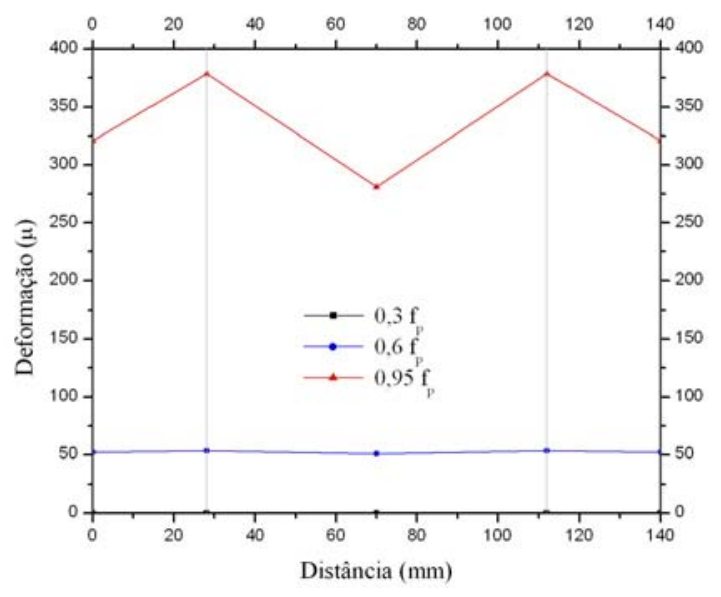

(a)

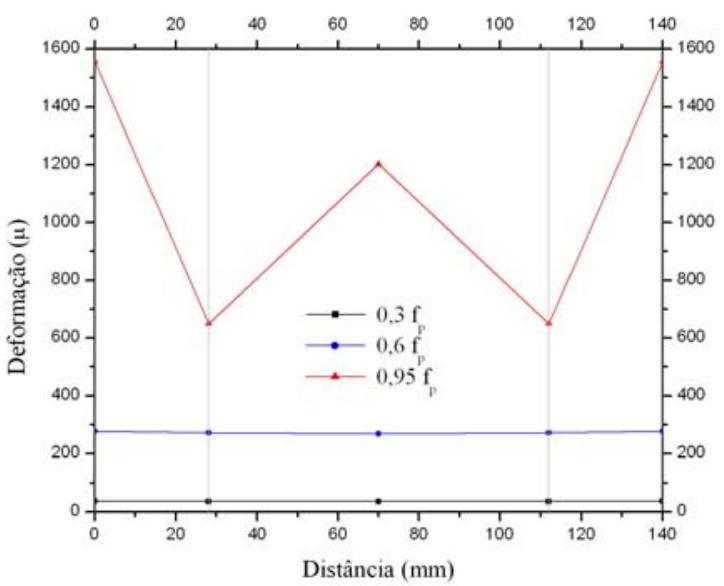

(b)

Figura 6.62 - Perfis S1E (a) e S3E (b) das deformações plásticas principais mínimas do bloco de concreto e da junta de argamassa, respectivamente.

As distintas magnitudes de deformação plástica no bloco de concreto e na junta de argamassa são observadas na Figura 6.63 e Figura 6.64, destacando-se a deformação plástica na junta de argamassa em todas as seções apresentadas e em todos os níveis de carregamento. Entretanto, podem-se destacar os menores valores obtidos no septo transversal central (SE6). 


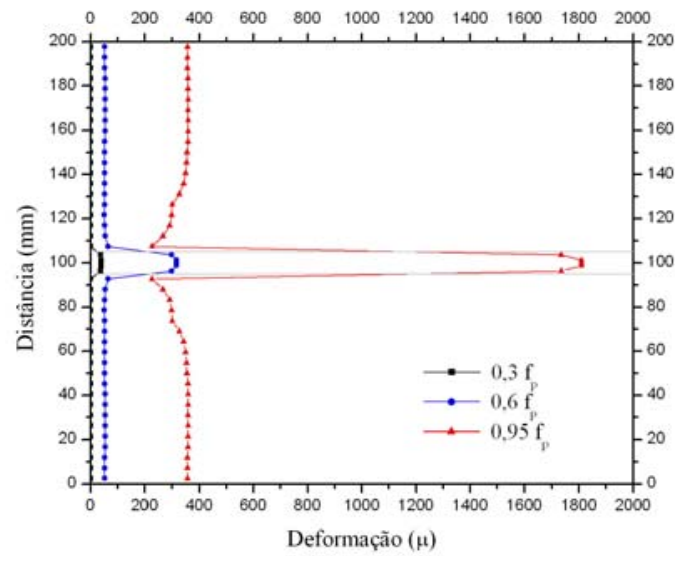

(a)

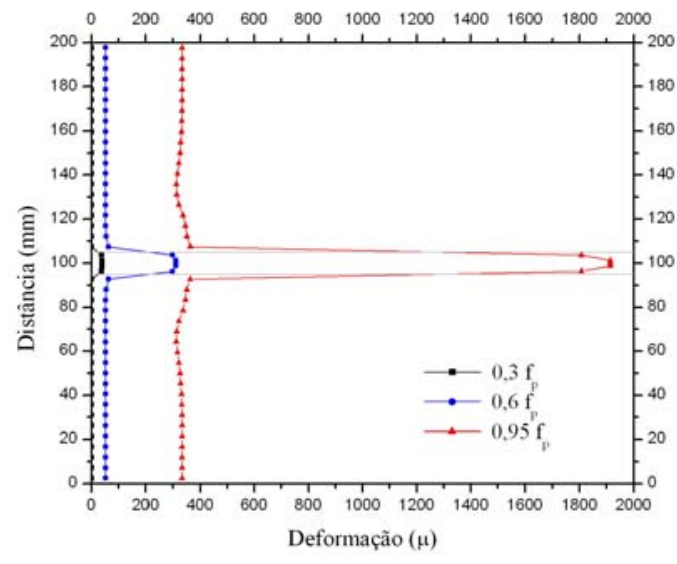

(b)

Figura 6.63 - Perfis S4 (a) e S5 (b) das deformações plásticas principais mínimas.

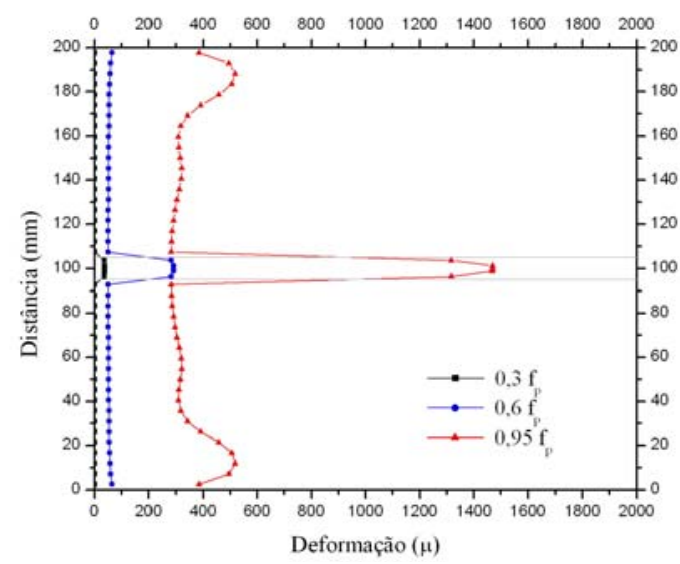

Figura 6.64 - Perfis S6E das deformações plásticas principais mínimas.

\subsubsection{Ilustração da distribuição de tensões e deformações na ruína}

Apresenta-se a seguir a distribuição de tensões e deformações, por meio de níveis de contorno, para facilitar a sua visualização global.

As maiores deformações plásticas de compressão são identificadas na junta de argamassa (Figura 6.65a), bastante distintas dos valores encontrados no bloco de concreto.

Em relação às tensões principais mínimas, de acordo com a Figura 6.65b, os maiores valores absolutos são identificados nos septos transversais externos e no septo transversal central dos blocos, o que se contrapõe aos menores valores absolutos encontrados na região central entre os septos, na qual também surgem os maiores valores de tensão principal máxima (Figura 6.65c). Fica claro também o alívio de carregamento localizado na junta de argamassa do septo transversal externo. 
Observa-se que a concentração de tensão principal mínima ocorre também no centro dos septos transversais dos blocos, na região próxima às juntas de argamassa, assim como, ao longo desses septos, o alívio das tensões na junta de argamassa (Figura 6.66a). Estas regiões apresentam altos valores de tensão principal máxima, em contraste com a uniformidade de valores nas demais regiões dos blocos de concreto. Não são identificadas fissuras nos septos transversais.

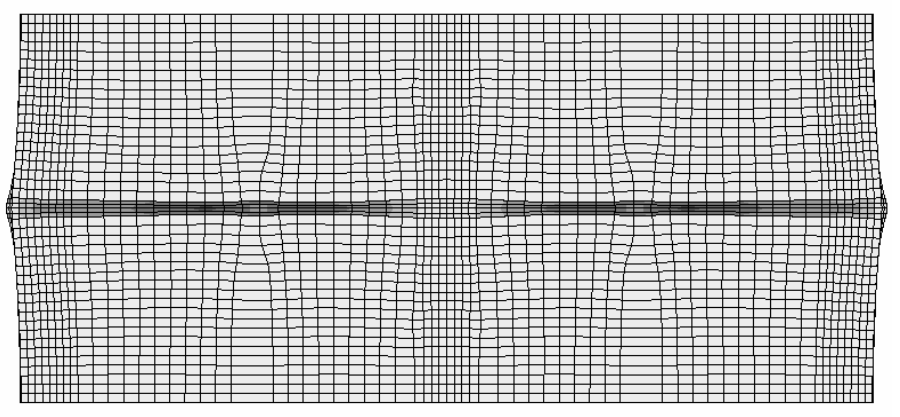

(a)

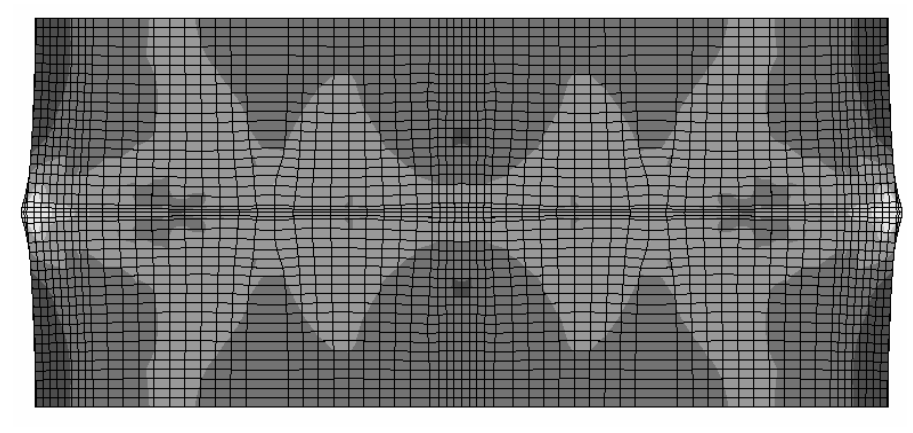

(b)

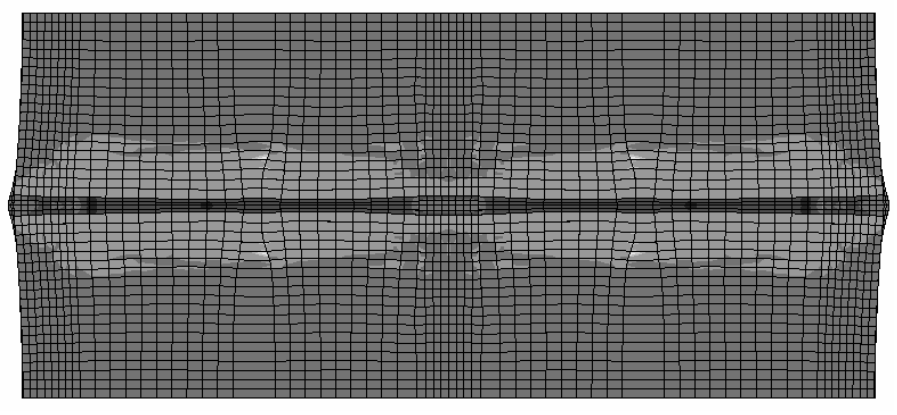

(c)

Figura 6.65 - Deformações plásticas principais mínimas (a), tensões principais mínimas (b) e tensões principais máximas (c) na parede longitudinal do prisma, com deformada incremental da malha. 

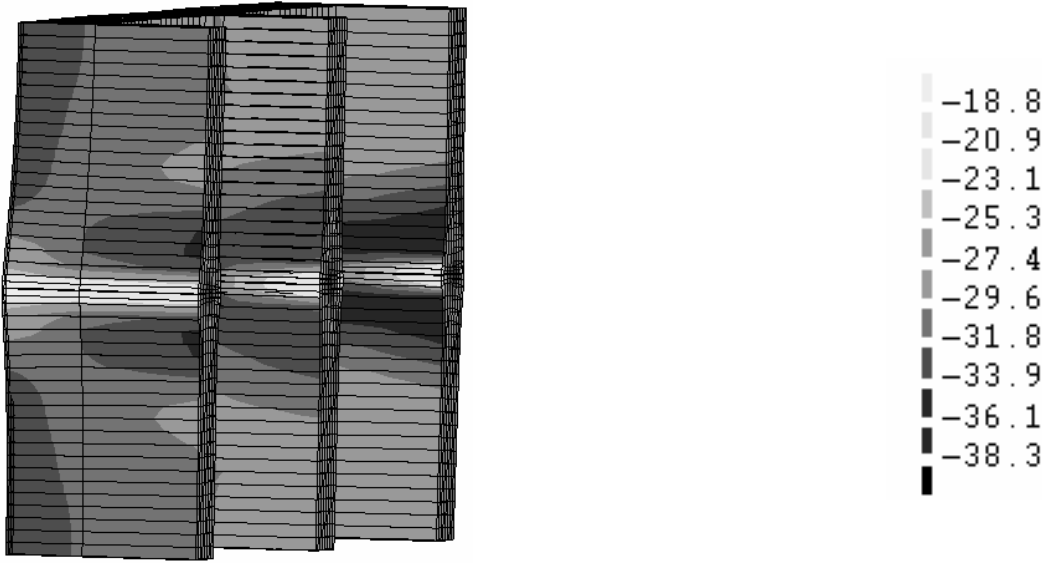

(a)

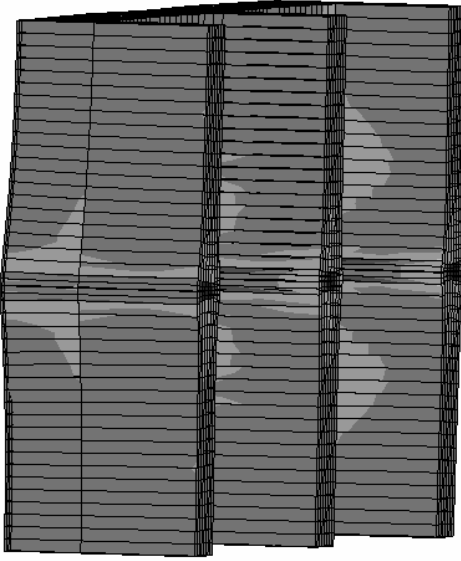

12.6

10. 2

7. 91

5.57

3. 24

.904

$-1.43$

$-3.76$

$-6.1$

$-8.43$

(b)

Figura 6.66 - Tensões principais mínimas (a) e tensões principais máximas (b) nos septos transversais do prisma.

\subsubsection{Refinamento da malha e modo de ruína}

Adicionalmente, duas discretizações complementares são apresentadas para a comparação com o modo de ruína dos prismas do grupo P4, apresentado anteriormente.

A ruína continua apresentando fissuração na parede longitudinal associada ao esmagamento da junta de argamassa. A primeira consideração corresponde ao maior refinamento da malha nos septos transversais, ainda levando em conta a área elementar representativa apresentada na Figura 6.45. A discretização de um quarto do modelo físico é outra consideração que também não alterou a forma de ruína.

Em ambas as considerações adicionais, observa-se a abertura de fissuras no bloco a partir da junta de argamassa na parede longitudinal, sem qualquer deformação indicativa de ruína no septo transversal externo. Destaca-se também a deformação na parede lateral dos 
blocos na direção do eixo z, acompanhando a tendência de expulsão de argamassa da junta nessa direção (Figura 6.67).

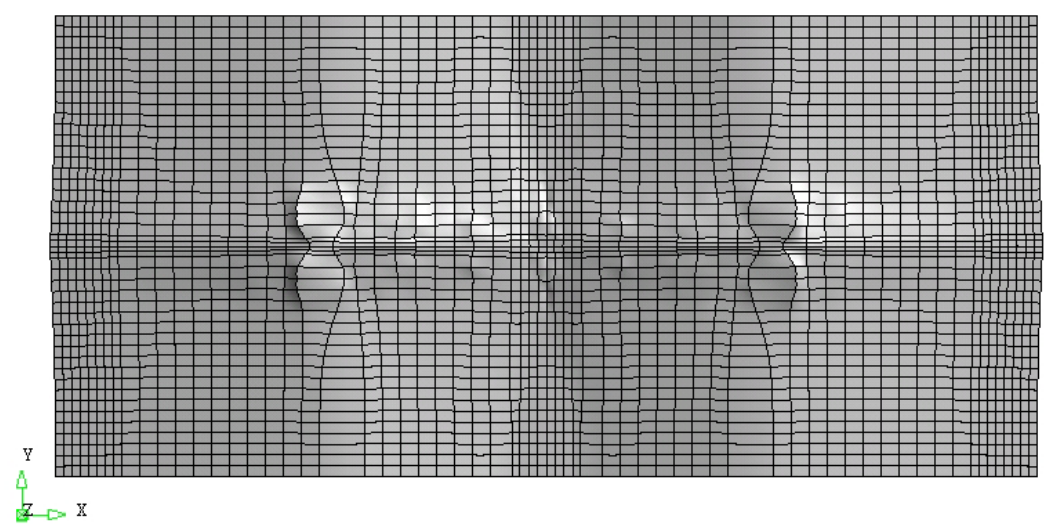

(a)

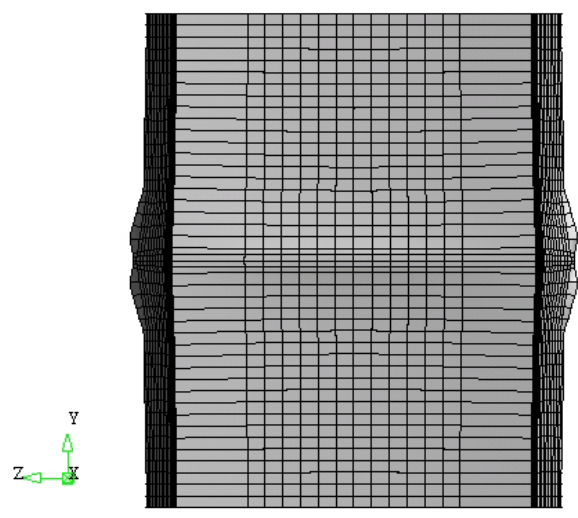

(b)

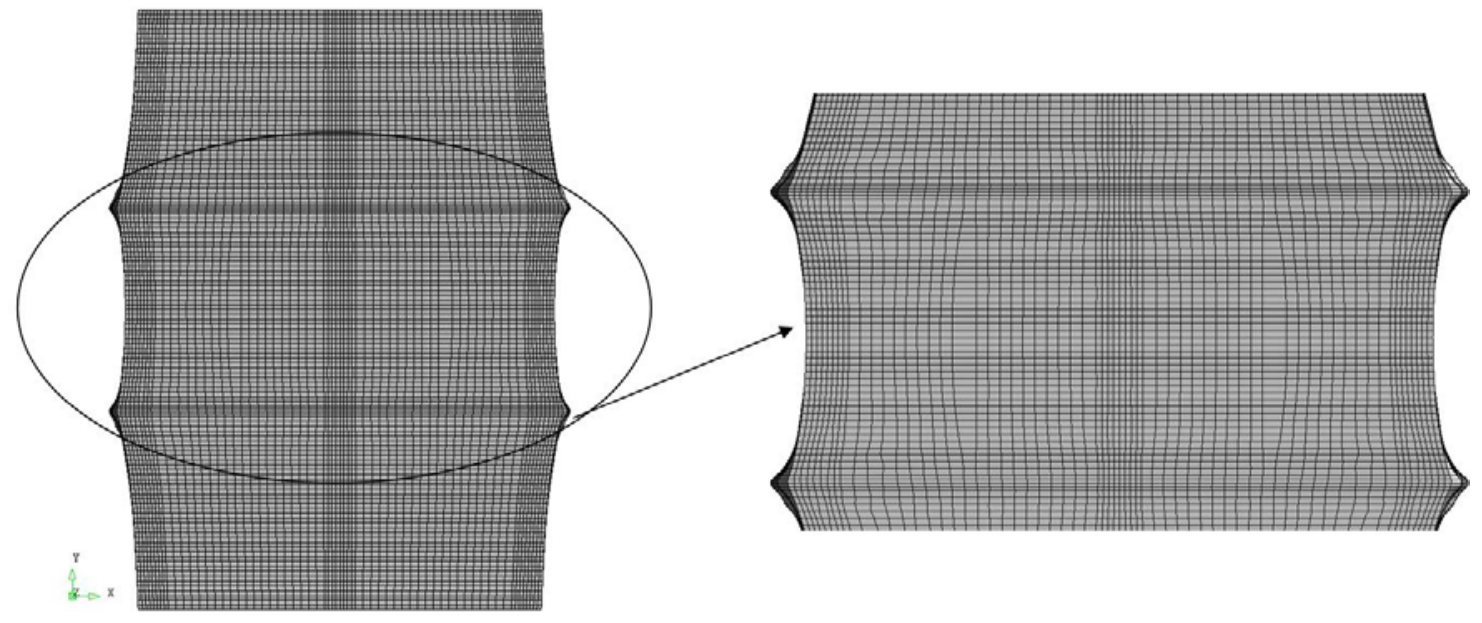

(c)

Figura 6.67 - Deformada incremental da malha do prisma na ruína: considerando-se a área elementar representativa e o maior refinamento da malha no septo transversal $(a, b)$ e com a discretização de um quarto do modelo físico (c). 


\subsection{Argamassa submetida ao comportamento triaxial}

A partir de um ensaio uniaxial com corpos-de-prova de argamassa, analisa-se um modelo matemático para verificar sua eficiência quanto à representação do comportamento à compressão triaxial desse material.

Utilizou-se o programa em elementos finitos ABAQUS, versão 6.2, com a sub-rotina UMAT já implementada. Esta sub-rotina representa o modelo constitutivo de GRASSL et al. $(2002)^{3}$, modificado por Carrazedo (2005), que fornece como principal contribuição ao modelo a elaboração de uma nova função de endurecimento - subdivididas em duas funções, uma para o trecho ascendente e outra para o trecho descendente. A argamassa foi modelada com elementos tridimensionais tipo C3D8R, com 8 nós, três graus de liberdade por nó e integração reduzida.

$\mathrm{Na}$ Tabela 6.9 são apresentadas as propriedades mecânicas obtidas no programa experimental (Capítulo 3) que são adotadas como dados de entrada da sub-rotina UMAT. Utiliza-se na simulação um único elemento cúbico, ao qual se aplicou, primeiramente, tensão uniforme lateral e, em seguida, deslocamento prescrito na parte superior do elemento.

Tabela 6.9 - Propriedades mecânicas da argamassa sob compressão uniaxial.

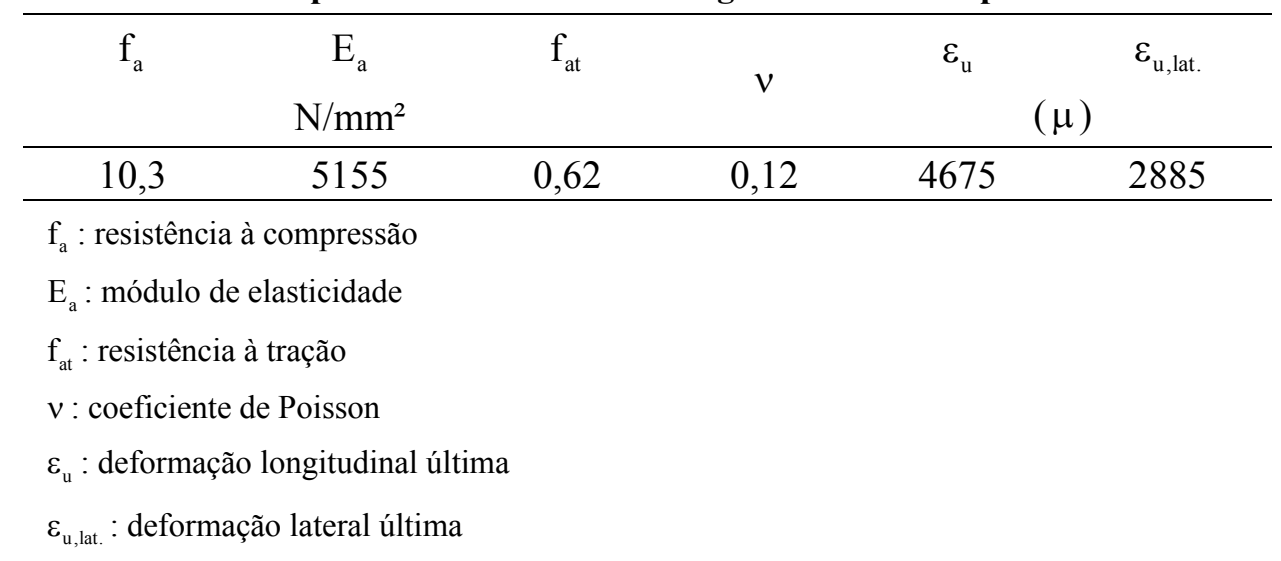

Os valores obtidos em cada análise estão na Tabela 6.10. As curvas teóricas e experimentais apresentam comportamentos semelhantes em todos os níveis de tensão lateral, em relação às deformações laterais e longitudinais, conforme ilustração na Figura 6.68 e na Figura 6.69. Entretanto, ressalta-se que as curvas experimentais são interrompidas antecipadamente em decorrência da fissuração dos corpos-de-prova e conseqüente danificação dos extensômetros de deformação, não representando o valor máximo em alguns casos.

\footnotetext{
${ }^{3}$ GRASSL, P.; LUNDGREN, K.; GYLLTOFT, K. (2002). Concrete in compression: a plasticity theory with a novel hardening law. International Journal of Solids and Structures. v. 39, p. 5205-23.
} 
Tabela 6.10 - Tensões máximas obtidas nas análises teóricas e experimentais com corpos-de-prova de argamassa sob compressão triaxial.

\begin{tabular}{cccc}
$\sigma_{3}$ & $\sigma_{1}^{\text {exp }}$ & $\sigma_{1}^{\text {num }}$ & $\frac{\sigma_{1}^{\text {num }}}{\sigma_{1}^{\text {exp }}}$ \\
\hline 0 & $\left(\mathrm{~N} / \mathrm{mm}^{2}\right)$ & & 1,00 \\
1,5 & 10,3 & 10,3 & 0,88 \\
3,0 & 14,9 & 17,0 & 0,94 \\
4,5 & 21,0 & 22,3 & 0,81 \\
\hline
\end{tabular}

$\sigma_{1}$ : resistência à compressão.

$\sigma_{3}$ : tensão lateral de confinamento.

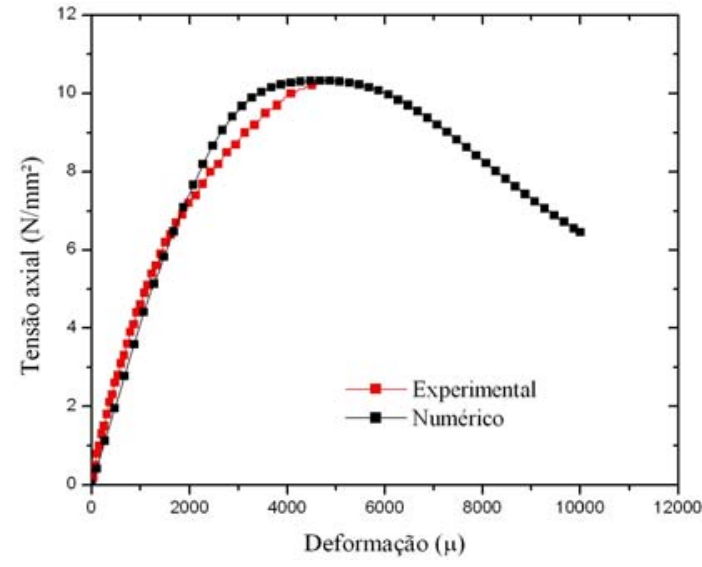

(a)

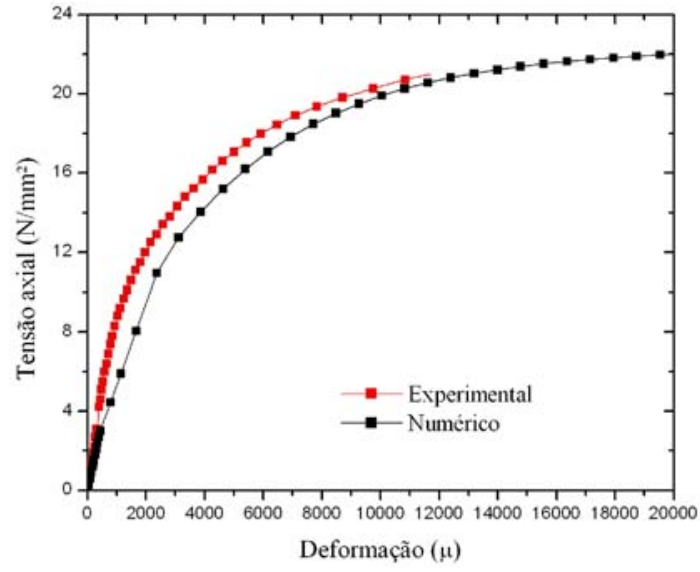

(c)

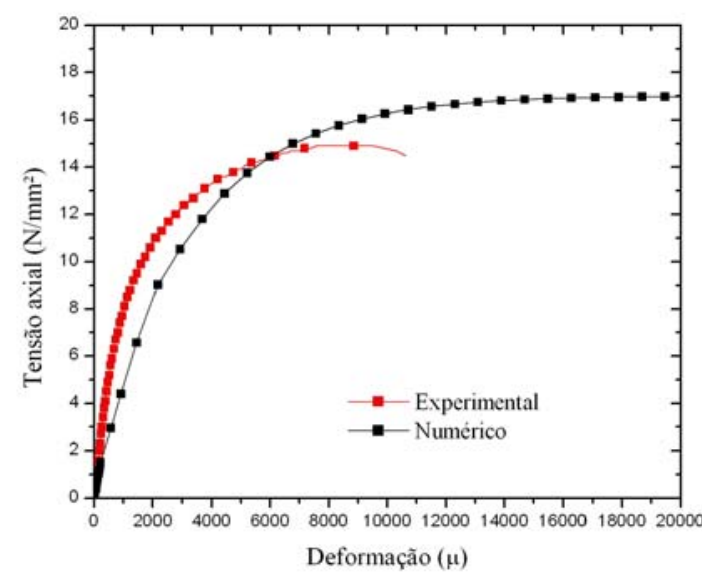

(b)

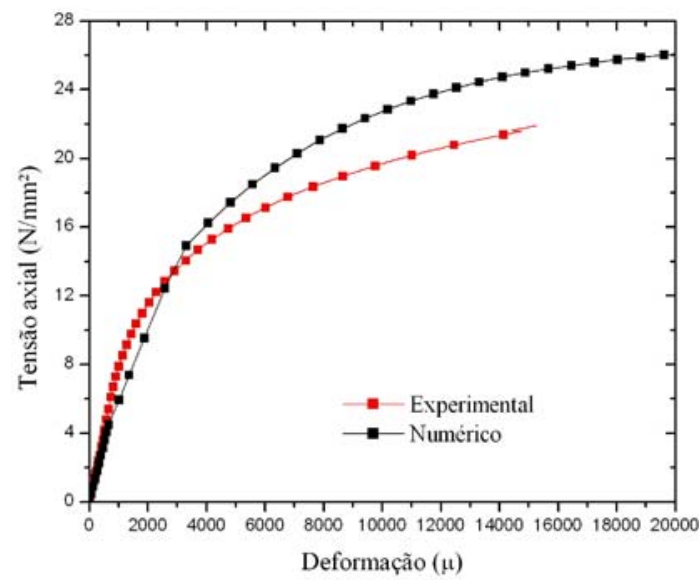

(d)

Figura 6.68 - Diagramas tensão-deformação longitudinal de corpos-de-prova de argamassa sob compressão uniaxial (a) e com tensão lateral de $1,5 \mathrm{~N} / \mathrm{mm}^{2}$ (b), 3,0 N/mm e $4,5 \mathrm{~N} / \mathrm{mm}^{2}$ (d). 


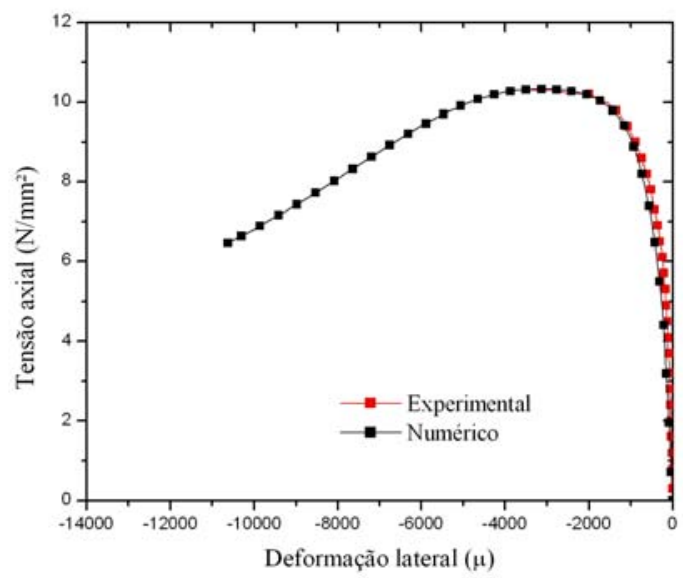

(a)

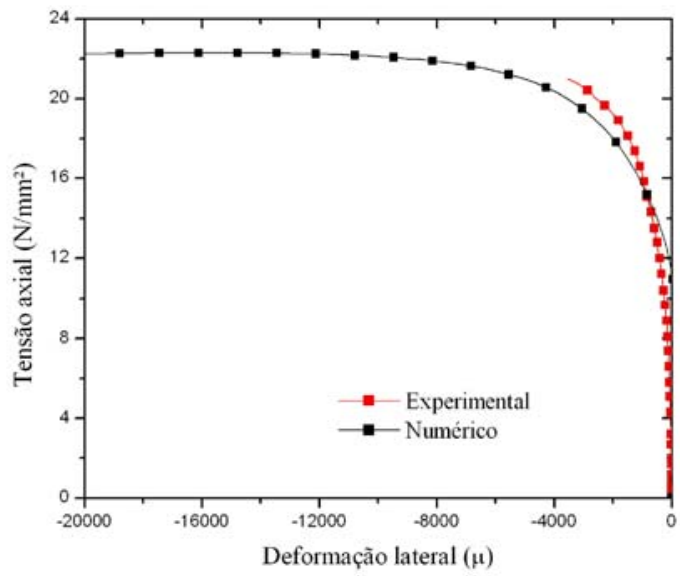

(c)

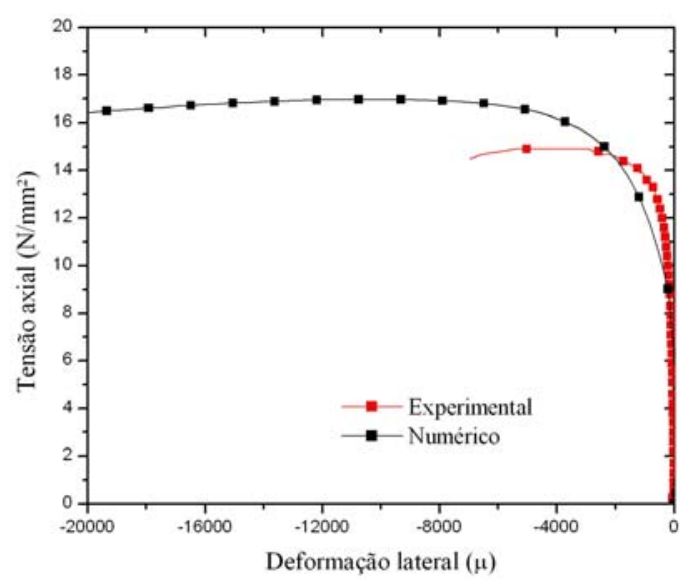

(b)

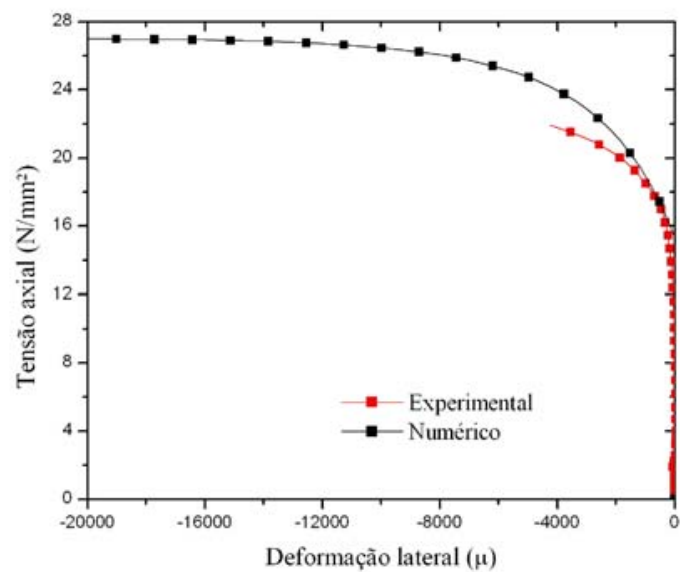

(d)

Figura 6.69 - Diagramas tensão-deformação lateral de corpos-de-prova de argamassa sob compressão uniaxial (a) e com tensão lateral de $1,5 \mathrm{~N} / \mathrm{mm}^{2}$ (b), 3,0 N/mm e $4,5 \mathrm{~N} / \mathrm{mm}^{2}$ (d).

\subsection{Miniparedes}

A modelagem numérica tridimensional das miniparedes segue a mesma estratégia adotada na análise com blocos vazados de concreto e prismas. Definiram-se três modelos com distintas propriedades mecânicas dos materiais: PAR 1, PAR 2 e PAR 3. O modelo numérico PAR 3 foi implementado com as propriedades mecânicas dos materiais do grupo de prismas P4.

O resumo dos valores experimentais obtidos na análise com as paredes e com seus componentes é apresentado na Tabela 6.11. 
Tabela 6.11 - Resistência à compressão do bloco, da argamassa, do prisma e das miniparedes de cada grupo.

\begin{tabular}{ccccc}
\hline Grupo & $\mathrm{f}_{\mathrm{par}}$ & $\mathrm{f}_{\mathrm{p}}$ & $\mathrm{f}_{\mathrm{a}}$ & $\mathrm{f}_{\mathrm{b}}$ \\
& \multicolumn{4}{c}{$\mathrm{N} / \mathrm{mm}^{2}$} \\
\hline PAR 1 & 15,5 & 19,3 & 10,4 & 24,9 \\
PAR 2 & 16,5 & 20,5 & 18,1 & 23,7 \\
PAR 3 & - & 30,1 & 22,2 & 38,9 \\
\hline
\end{tabular}

Os parâmetros elásticos e inelásticos, provenientes da análise experimental, são apresentados na Tabela 6.12. O ângulo de atrito $(\phi)$ e de dilatância $(\psi)$, definidos para o concreto e a argamassa, são constantes e valem $10^{\circ}$ e $5^{\circ}$, respectivamente.

Tabela 6.12 - Propriedades elásticas e inelásticas do concreto e da argamassa utilizados na análise numérica com miniparedes.

\begin{tabular}{ccccccc}
\hline \multicolumn{2}{c}{ Componente } & $\mathrm{f}_{\text {comp }}$ & $\begin{array}{c}\mathrm{f}_{\text {trac }} \\
\left(\mathrm{N} / \mathrm{mm}^{2}\right)\end{array}$ & $\mathrm{E}$ & $v$ & $\begin{array}{c}\mathrm{G}_{\mathrm{f}} \\
(\mathrm{N} / \mathrm{mm})\end{array}$ \\
\hline \multirow{2}{*}{ PAR 1 } & Argamassa & 9,4 & 1,1 & 9745 & 0,13 & 0,0228 \\
& Concreto & 22,8 & 2,2 & 20595 & 0,20 & 0,1277 \\
& Argamassa & 18,1 & 1,6 & 17553 & 0,15 & 0,0386 \\
PAR 2 & Concreto & 21,5 & 2,1 & 22447 & 0,20 & 0,1375 \\
& Argamassa & 22,2 & 2,6 & 16672 & 0,15 & 0,0653 \\
& Concreto & 36,2 & 3,1 & 27104 & 0,20 & 0,1548 \\
\hline
\end{tabular}

O modelo matemático da estrutura é obtido por meio de uma área elementar representativa composta por juntas verticais e horizontais. A discretização em elementos finitos é realizada em apenas uma quarto desta área, utilizando-se a simetria concernente ao caso. Tais considerações são apresentadas na Figura 6.70. 


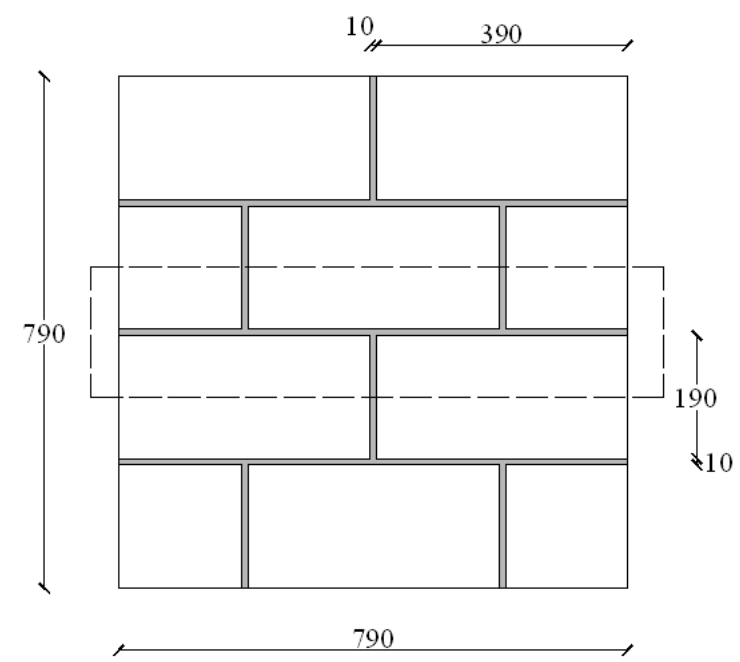

(a)

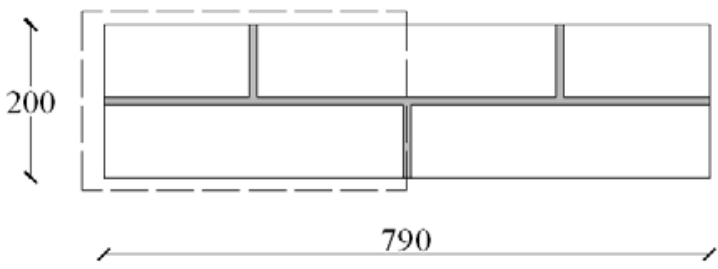

(b)

Figura 6.70 - Área elementar representativa adotada para a miniparede (a) e detalhe da região a ser discretizada (b). Dimensões em milímetros.

O modelo tridimensional é constituído por 2144 elementos sólidos e 11789 nós, totalizando 35367 graus de liberdade. Esta discretização é ilustrada na Figura 6.71, sendo as diferentes colorações utilizadas para distinguir os blocos de concreto das juntas de argamassa.

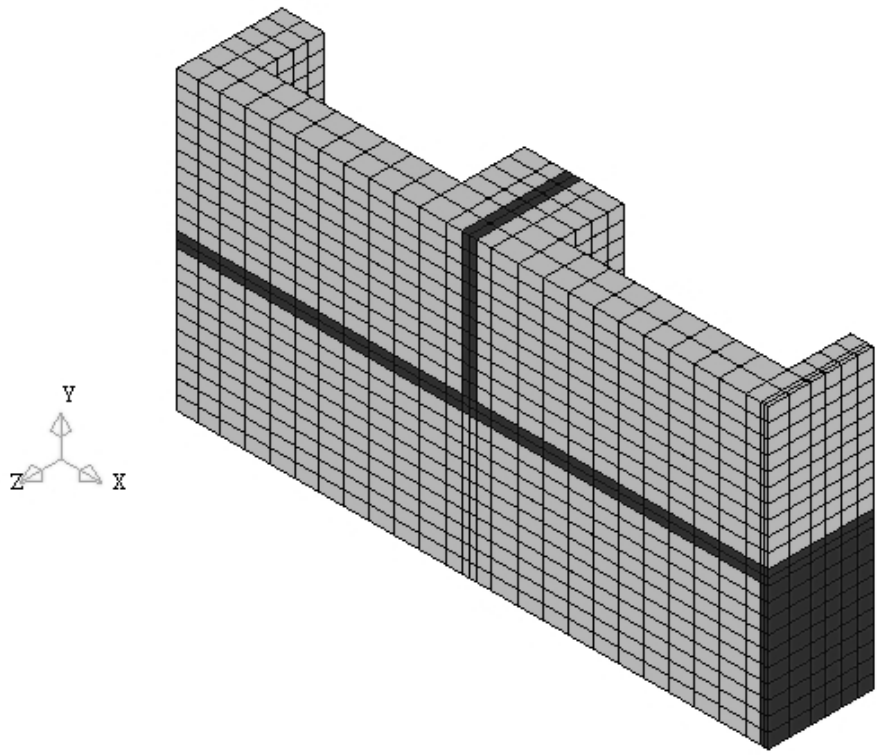

Figura 6.71 - Malha em elementos finitos correspondente a um quarto da área elementar representativa.

Na Figura 6.72a estão apresentados os gráficos tensão-deformação do modelo PAR 2, obtidos na análise numérica e experimental. Essas relações, obtidas para os três grupos de resistência, são ilustradas na Figura $6.72 b$. 


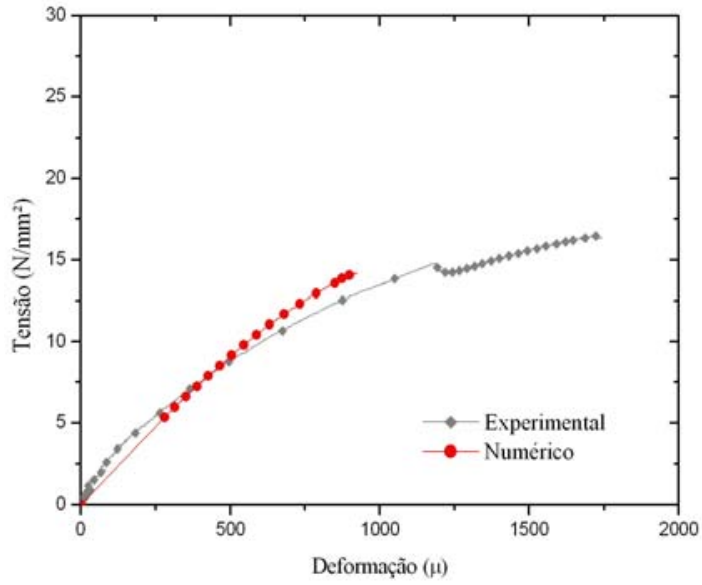

(a)

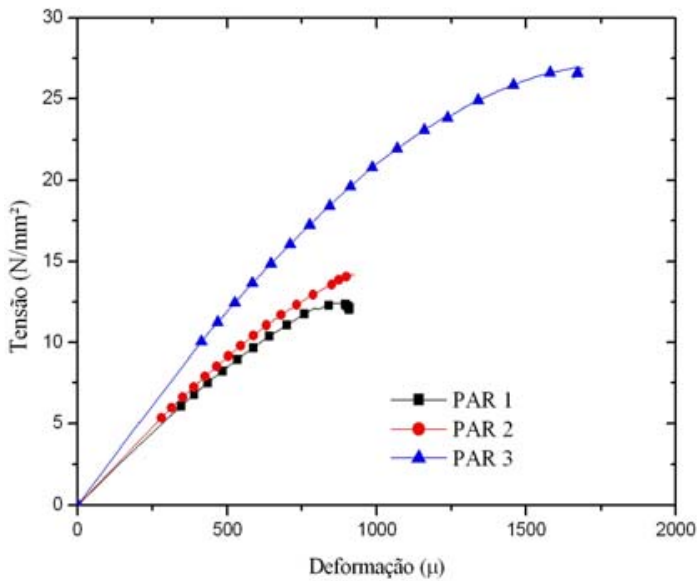

(b)

Figura 6.72 - Diagramas tensão-deformação obtidos para o grupo PAR 2 (a). Diagramas tensãodeformação obtidos na análise numérica $(b)$.

As curvas experimental e numérica do grupo PAR 2 apresentam comportamentos coincidentes, com exceção da interrupção prematura das relações obtidas por meio do modelo numérico. As curvas numéricas dos grupos PAR 1 e PAR 2 são próximas em função das propriedades mecânicas dos materiais que constituem a estrutura. A diferença entre elas refere-se apenas aos parâmetros introduzidos para a argamassa, que apresenta maior deformabilidade no modelo PAR 1.

Na Tabela 6.13 são apresentadas a força máxima obtida, para cada um dos grupos, nos modelos numéricos e experimentais.

Tabela 6.13 - Força teórica e experimental máxima obtida nas análises com miniparedes.

\begin{tabular}{cccc}
\hline Grupo & $\mathrm{F}^{\exp }$ & $\mathrm{F}^{\text {num }}$ & $\frac{\mathrm{F}^{\text {num }}}{\mathrm{F}^{\exp }}$ \\
\hline PAR 1 & 950,6 & 761,4 & 0,800 \\
PAR 2 & 1010,1 & 869,0 & 0,860 \\
PAR 3 & - & 1654,7 & - \\
\hline
\end{tabular}

A variação máxima entre as capacidades resistentes obtidas na análise numérica e na experimental é de $14 \%$. Essa diferença, apesar de ser maior que as obtidas nas análises com corpos-de-prova, blocos vazados e prismas, não deixa de ser uma boa representação diante das simplificações adotadas na representação teórica. 
As análises seguintes referem-se ao modelo PAR 3, que apresenta modo de ruína decorrente da intensa fissuração na parede longitudinal dos blocos e do esmagamento da junta de argamassa em menor intensidade (Tabela 6.13).

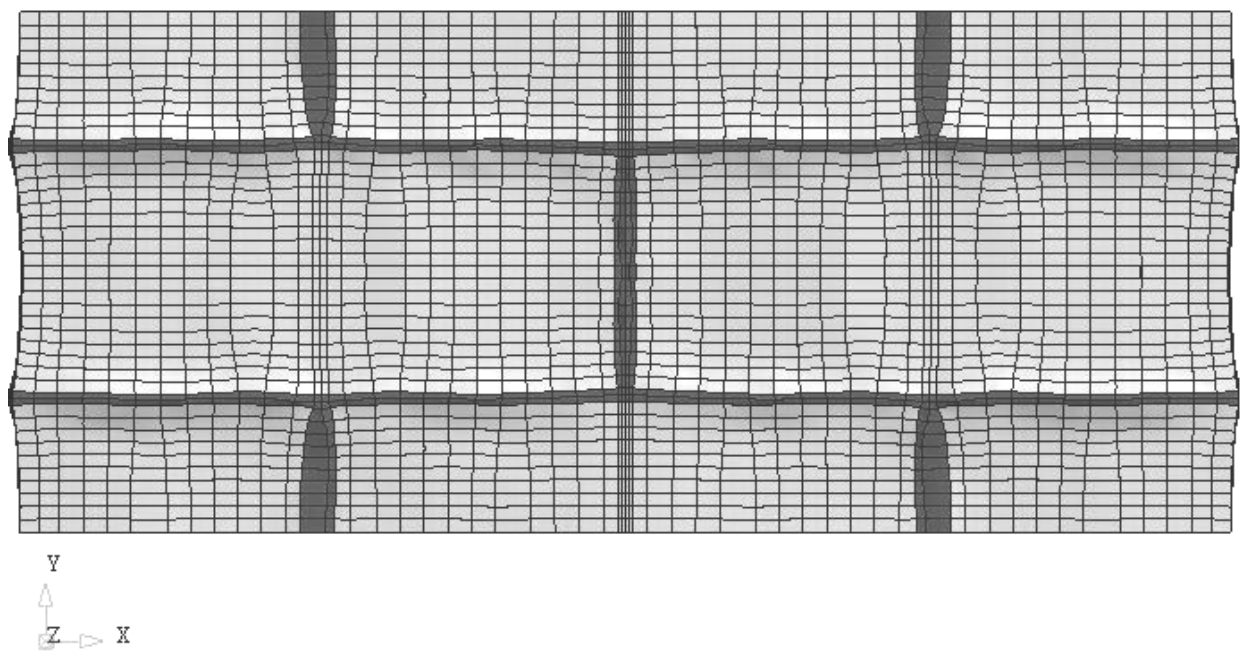

Figura 6.73 - Deformada da malha da parede na ruína: grupo PAR 3.

A distribuição das tensões principais mínimas na ruína da parede é apresentada na Figura 6.74. As juntas verticais são menos solicitadas que as juntas horizontais e os blocos de concreto.

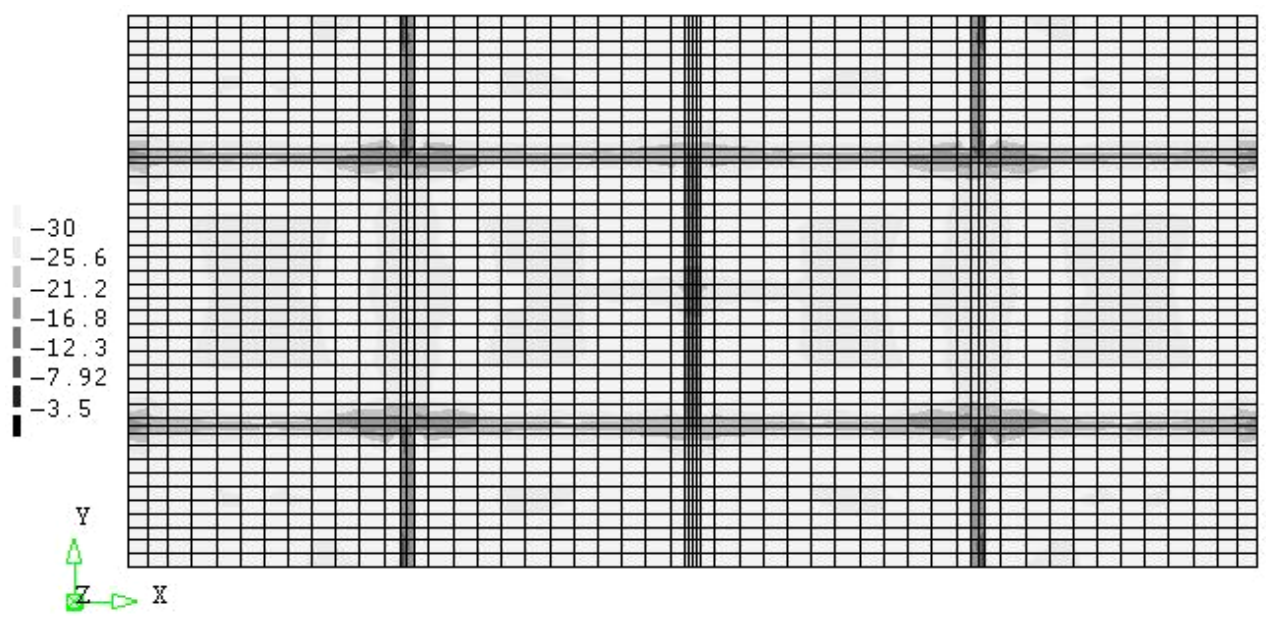

Figura 6.74 - Tensões principais mínimas na parede: grupo PAR 3.

Detalham-se a distribuição de tensões e deformações por meio dos perfis horizontais e verticais definidos na Figura 6.75. 


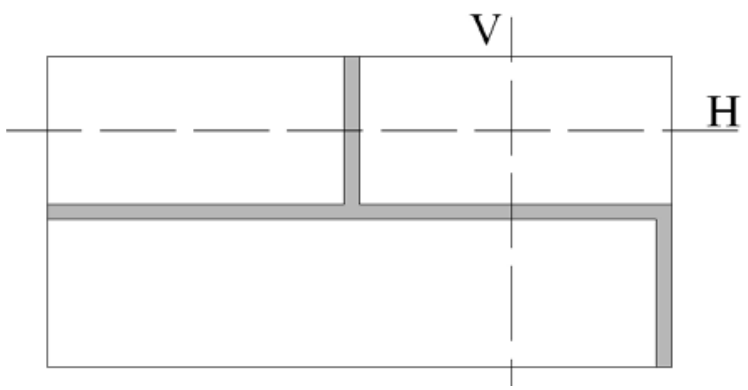

Figura 6.75 - Seções para análise da distribuição de tensões e deformações nas paredes.

Os perfis horizontais ao longo da parede são ilustrados na Figura 6.76. Observa-se queda acentuada de tensão na região da junta vertical, local em que são observadas as maiores deformações plásticas. Não é observada plastificação na junta de argamassa e no bloco de concreto no nível de carregamento igual a $0,30 \mathrm{f}_{\text {par }}$. Os blocos de concreto apresentam distribuição uniforme de tensões.

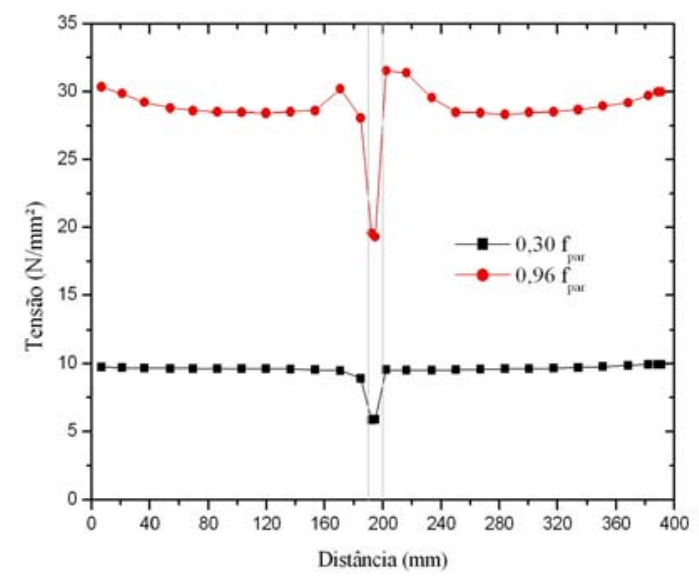

(a)

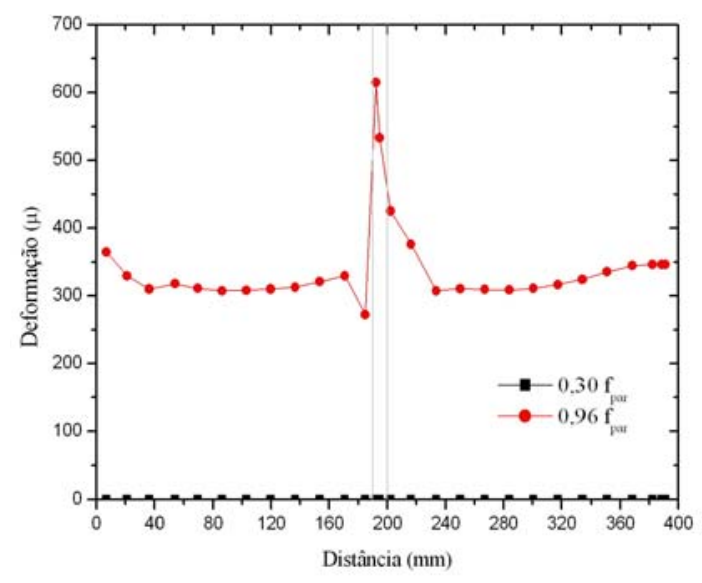

(b)

Figura 6.76 - Perfis H das tensões principais mínimas (a) e deformações plásticas verticais (b).

A queda de tensão também é verificada, em menor intensidade, na junta horizontal (Figura 6.77a). Nesses perfis é possível identificar deformações plásticas na junta horizontal a partir de $0,3 \mathrm{f}_{\text {par }}$ (Figura $6.77 \mathrm{~b}$ ), assim como a uniformidade de tensões no bloco de concreto. 


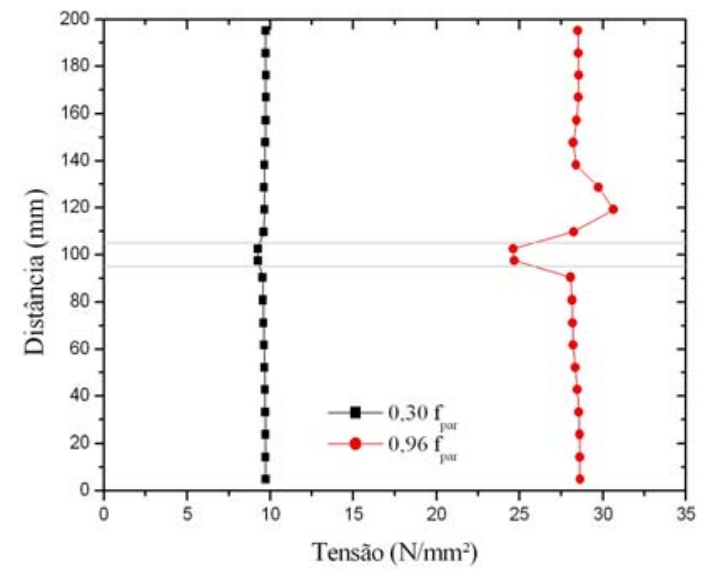

(a)

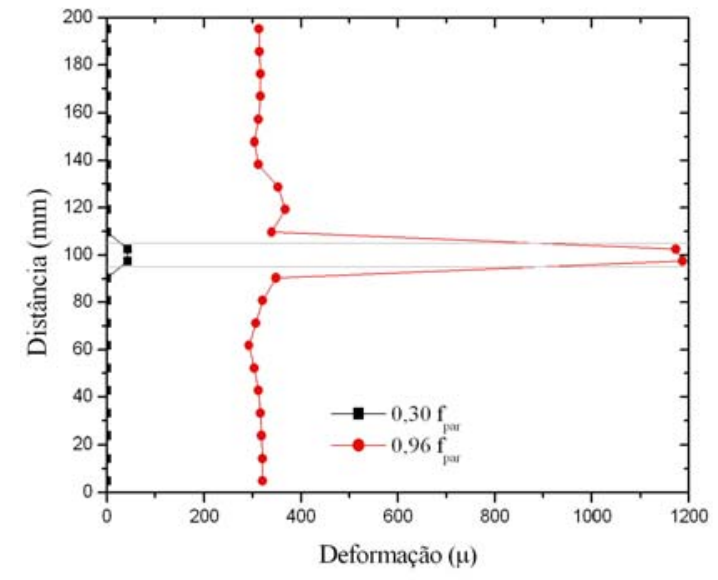

(b)

Figura 6.77 - Perfis V das tensões principais mínimas (a) e deformações plásticas verticais (b). 


\section{ANÁLISE TEÓRICA COM APLICAÇÃO DE MODELOS ALGÉBRICOS}

Apresenta-se neste capítulo um estudo teórico, por meio de modelos algébricos, sobre a resistência e deformabilidade de blocos vazados de concreto e prismas. Também se realiza análise por associação de resultados experimentais com os obtidos durante a micromodelagem numérica.

É utilizada uma forma peculiar para avaliar o comportamento estrutural dos elementos de alvenaria a partir dos parâmetros mecânicos usuais referentes aos materiais, procurando-se destacar os fatores interdependentes da estrutura e dos materiais que a constituem.

Por fim, apresentam-se os fatores de eficiência de paredes obtidos por meio da análise numérica e experimental.

As ponderações apresentadas são relativas à geometria desses elementos e particularizações relativas à quantidade de ensaios e processos produtivos por ora analisados, devendo ser de forma criteriosa a aplicação em quaisquer outras análises.

\subsection{Sobre os blocos vazados de concreto}

Discute-se a resistência e a deformabilidade do concreto que constitui o bloco vazado e propõe-se uma metodologia para aquisição de dados na análise experimental.

Em função da configuração geométrica dos blocos vazados de concreto, optou-se por discretizar sua área líquida em regiões distintas, representativas do comportamento sob compressão axial e apresentadas na Figura 7.1. O valor da soma das áreas de cada região idêntica está apresentado na Tabela 7.1. 


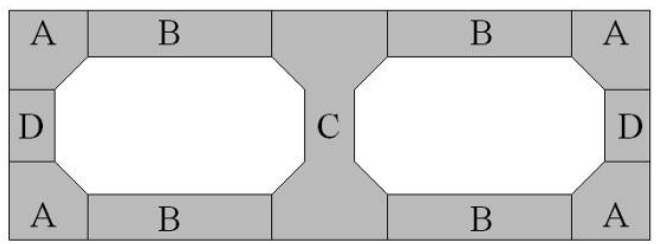

Figura 7.1 - Áreas representativas do bloco.

Tabela 7.1 - Soma das áreas das regiões.

\begin{tabular}{cc}
\hline A & $8416 \mathrm{~mm}^{2}$ \\
B & $12543 \mathrm{~mm}^{2}$ \\
C & $7240 \mathrm{~mm}^{2}$ \\
D & $2464 \mathrm{~mm}^{2}$ \\
\hline
\end{tabular}

Ressalta-se que nem todas as regiões apresentadas na Figura 7.1 dispunham de instrumento de medição nas análises experimentais, portanto, os valores aplicados a cada uma delas são referentes à média obtida.

\subsubsection{Resistência do concreto que constitui o bloco vazado}

Os valores numéricos $\left(f^{\text {num }}\right)$ e experimentais $\left(f^{\exp }\right)$ da resistência à compressão do bloco vazado $\left(f_{b}\right)$ e do concreto $\left(f_{c}\right)$ que o constitui estão apresentados na Tabela 7.2.

Tabela 7.2 - Resistência à compressão de blocos vazados e do seu material constituinte.

\begin{tabular}{|c|c|c|c|c|c|c|}
\hline \multirow{3}{*}{ Grupo } & \multicolumn{2}{|c|}{ Corpo-de-prova } & \multicolumn{2}{|c|}{ Bloco } & \multirow{3}{*}{$\frac{f_{b}^{\exp }}{f_{c}^{\exp }}$} & \multirow{3}{*}{$\frac{\mathrm{f}_{\mathrm{b}}^{\text {num }}}{\mathrm{f}_{\mathrm{c}}^{\text {num }}}$} \\
\hline & $f^{\exp }$ & $\mathrm{f}^{\text {num }}$ & $f^{\exp }$ & $\mathrm{f}^{\text {num }}$ & & \\
\hline & \multicolumn{2}{|c|}{$\left(\mathrm{N} / \mathrm{mm}^{2}\right)$} & \multicolumn{2}{|c|}{$\left(\mathrm{N} / \mathrm{mm}^{2}\right)$} & & \\
\hline CP1/B1 & 13,4 & 12,1 & 12,7 & 13,0 & 0,949 & 1,076 \\
\hline $\mathrm{CP} 2 / \mathrm{B} 2$ & 22,2 & 19,6 & 26,5 & 21,2 & 1,197 & 1,081 \\
\hline CP3/B3 & 26,0 & 25,2 & 28,4 & 26,8 & 1,094 & 1,056 \\
\hline \multirow[t]{3}{*}{$\mathrm{CP} 4 / \mathrm{B} 4$} & 30,9 & 30,6 & 30,5 & 32,7 & 0,986 & 1,070 \\
\hline & & & & Média & $1,075^{1}$ & 1,071 \\
\hline & & & & C.V. ${ }^{2}$ & $7,9 \%{ }^{1}$ & $1,0 \%$ \\
\hline
\end{tabular}

${ }^{1}$ São considerados para cálculo, além dos valores apresentados, a relação obtida nos grupos GA, GB e GC.

${ }^{2}$ C.V.: coeficiente de variação.

As relações obtidas por meio da análise experimental apresentam maior variabilidade que as encontradas nos modelos numéricos em conseqüência da heterogeneidade do concreto 
e das imperfeições existentes no modelo físico, as quais não são representadas na análise teórica. Apesar disso, essas relações $f_{b} / f_{c}$ são próximas em ambos os casos.

Portanto, com base nos resultados experimentais, ratificado pela resposta numérica, pode-se afirmar que a resistência à compressão do concreto está relacionada com a resistência do bloco segundo a Equação (7.1). Esta relação restringe-se à dimensão do bloco apresentada.

$$
\mathrm{f}_{\mathrm{c}}=\frac{\mathrm{f}_{\mathrm{b}}}{1,07}
$$

\subsubsection{Disposição de instrumentos de medição nos ensaios com blocos vazados}

A não-uniformidade dos valores experimentais de deformação ao longo das paredes dos blocos foi atribuída à distribuição de tensões no elemento sob o efeito de confinamento. Por meio de modelos numéricos, em que a interface entre a placa de ensaio e o topo e base do bloco de concreto são consideradas para a análise desse fenômeno, observa-se que a distribuição de tensões e deformações é realmente alterada em função do atrito.

O efeito de confinamento ocasiona uma distribuição de tensões que apresenta queda de intensidade quando se aproxima das extremidades. Esse comportamento é alterado conforme o nível de confinamento, tendendo à uniformidade quanto menor for a influência do atrito na interface placa de ensaio-superfície de carregamento. Reportam-se aos perfís de tensões e deformações relativas para a ilustração dessa situação: na Figura 7.2 estão apresentados os perfis de tensões considerando-se o confinamento perfeito e a sua redução.

Para os três níveis de carregamento da situação com confinamento perfeito (Figura 7.2a), observa-se que há a intersecção dos perfis a $53 \mathrm{~mm}$ das extremidades, iniciando-se a partir daí uma tendência de uniformização nos níveis $0,3 \mathrm{f}_{\mathrm{b}}$ e $0,7 \mathrm{f}_{\mathrm{b}}$. Com o alívio do confinamento essa intersecção está mais próxima ao centro da parede longitudinal, a $84 \mathrm{~mm}$ das extremidades (Figura 7.2b). A distribuição uniforme de tensões obtida em um modelo com uma redução ainda maior do atrito está representada nos perfis da Figura 7.2c. 


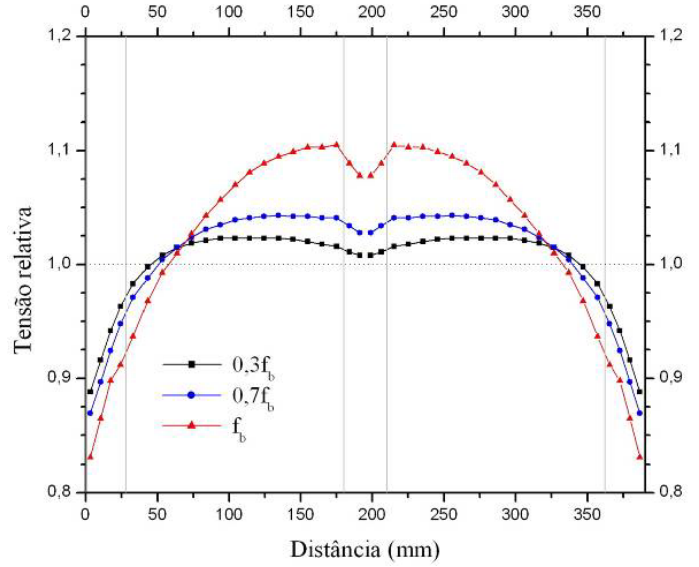

(a)

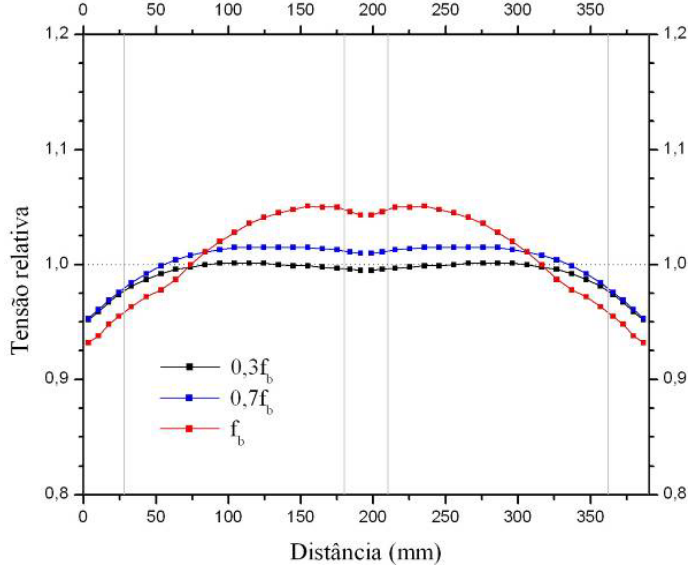

(b)

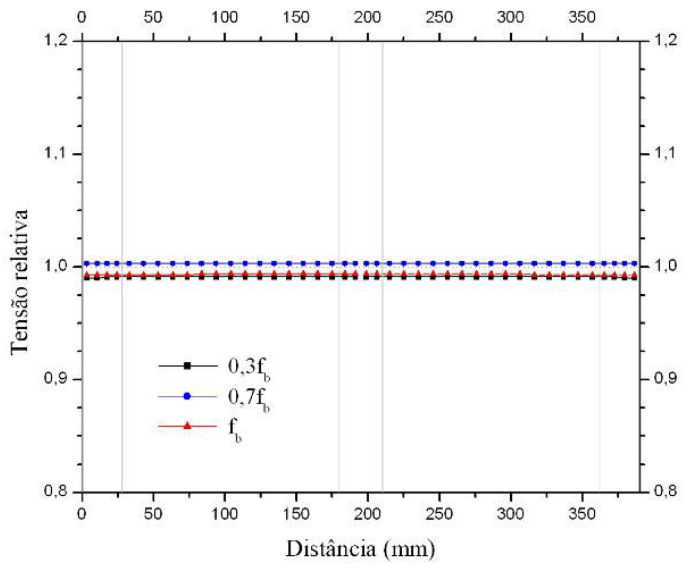

(c)

Figura 7.2 - Perfis ao longo da parede longitudinal das tensões principais mínimas relativas: modelo com confinamento perfeito (a), intermediário (b) e mínimo (c).

Em uma região afastada $84 \mathrm{~mm}$ das extremidades são identificados os maiores valores de deformação, conforme ilustra a Figura 7.3. 


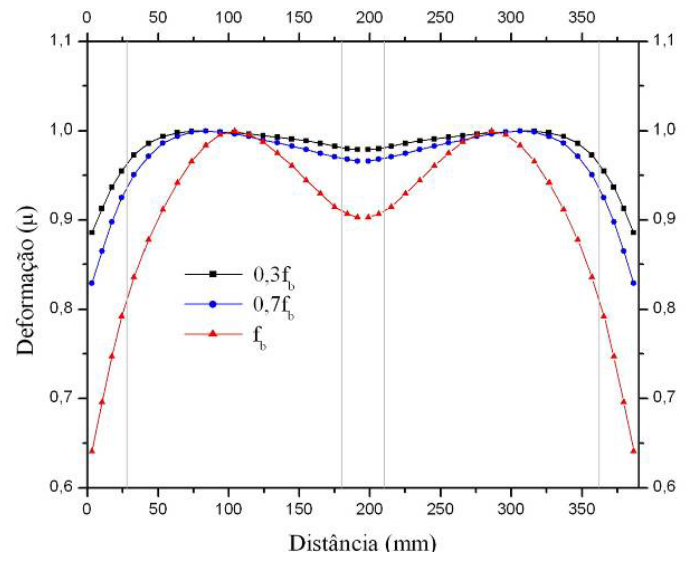

(a)

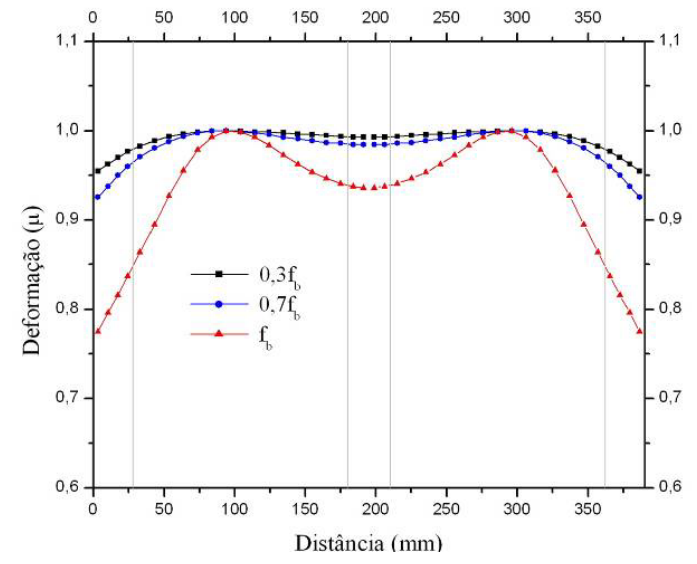

(b)

Figura 7.3 - Perfis ao longo da parede longitudinal das deformações verticais: modelo com confinamento perfeito (a) e intermediário (b).

O conceito de módulo de elasticidade aparente, introduzido no Capítulo 5 e utilizado para ponderar o nível de deformação em distintas regiões do bloco, refere-se à relação entre a tensão de referência - obtida pela razão entre a força aplicada no topo do bloco e sua área líquida - e a deformação obtida em um determinado ponto. Esse conceito (Equação (7.2)) foi aplicado para análise dos resultados de ensaios nos quais se utilizaram instrumentos de medição de deslocamentos.

$$
\mathrm{E}_{\mathrm{b}, \mathrm{ap} .}=\frac{\sigma_{\text {ref }}}{\varepsilon}
$$

É possível utilizar essa relação para avaliar os resultados numéricos, tomando-se o perfil de deformações, da Figura 7.3, por exemplo, e o valor da tensão de referência. Dessa forma, encontram-se diferenças superiores a $10 \%$ ao longo da parede longitudinal, ou seja, uma instrumentação disposta ao longo dessa região forneceria valores do módulo de elasticidade aparente distintos.

Portanto, quando um trecho do perfil de tensões $0,3 \mathrm{f}_{\mathrm{b}}$ apresentado na Figura $7.2 \mathrm{a}$ for próximo ao valor $\sigma_{\text {ref }}$, o módulo de elasticidade aparente do bloco $\left(\mathrm{E}_{\mathrm{b}, \mathrm{ap} .}\right)$ será similar ao valor do módulo de elasticidade do material que constitui o bloco. Essa região é compreendida entre $84 \mathrm{~mm}$ e $306 \mathrm{~mm}$, tomando-se uma das extremidades da parede longitudinal como o ponto de origem.

Nas análises experimentais, a partir de $100 \mathrm{~mm}$ da extremidade, obtém-se os valores do módulo de elasticidade aparente mais próximos ao valor obtido em um corpo-de-prova cilíndrico de concreto. 
A partir do desenvolvimento seqüenciado anteriormente e de forma que seja garantida a melhor caracterização possível na estimativa do valor do módulo de elasticidade do material, recomenda-se a disposição de instrumentos de medição em uma faixa entre 100 $\mathrm{mm}$ e $290 \mathrm{~mm}$ da parede longitudinal do bloco de concreto, conforme ilustra a Figura 7.4.

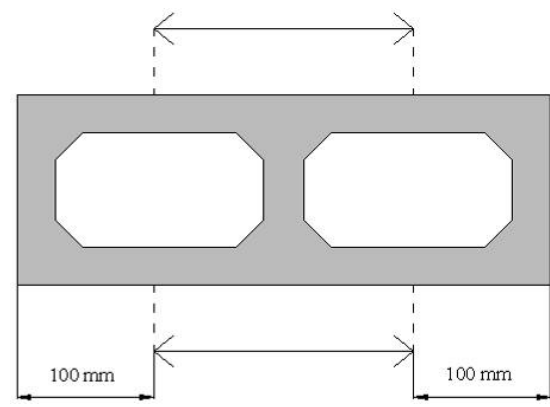

Figura 7.4 - Região definida para a disposição dos instrumentos de medição de deslocamentos nos ensaios com blocos vazados de concreto.

\subsubsection{Deformabilidade do concreto que constitui o bloco vazado}

Os perfis de tensão e deformação provenientes da análise numérica de um modelo com confinamento perfeito são apresentados na Figura 7.5.

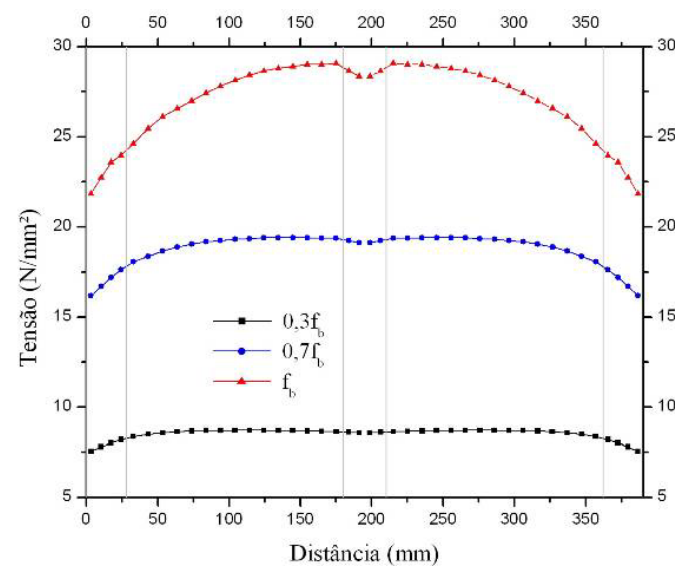

(a)

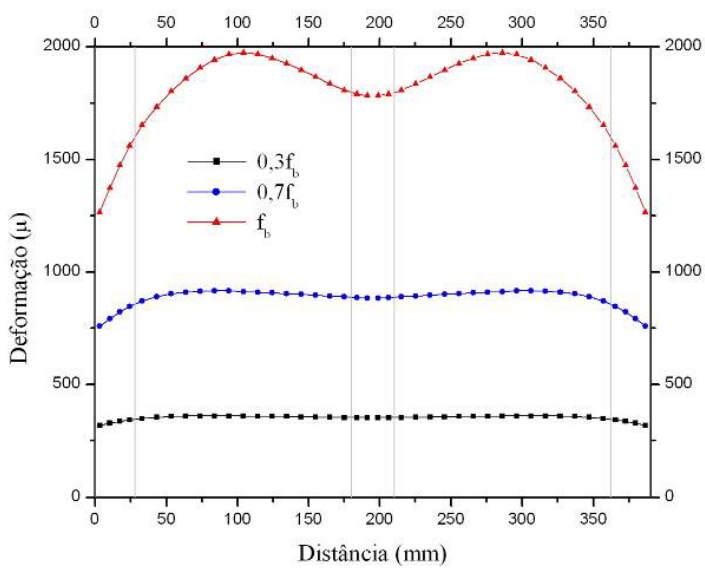

(b)

Figura 7.5 - Perfis ao longo da parede longitudinal do modelo com confinamento perfeito: tensões (a) e deformações verticais (b).

A divisão dos valores de tensão e deformação de cada ponto ao longo do perfil, para o nível de carregamento de $0,3 \mathrm{f}_{\mathrm{b}}$, fornece o valor do módulo de elasticidade do material que constitui o bloco $\left(\mathrm{E}_{\mathrm{c} \text {,bloco }}\right)$. Esses valores são próximos a $24463 \mathrm{~N} / \mathrm{mm}^{2}$, adotado no modelo numérico como a propriedade mecânica do concreto. 
Esta análise em um modelo experimental não se mostra adequada, tendo em vista a não possibilidade de aquisição de valores de tensão ao longo de um determinado perfil. Por esse motivo adota-se comumente a tensão de referência $\sigma_{\text {ref }}$ para o cálculo do parâmetro denominado módulo de elasticidade aparente e que apresentará valores distintos ao $\mathrm{E}_{\mathrm{c}}$.

Os perfis dos valores relativos à $\mathrm{E}_{\mathrm{c}}$ nessas duas situações são apresentados na Figura 7.6a. Assim, a razão entre esses dois perfis fornece uma curva que representa em cada ponto o valor do coeficiente de ponderação do confinamento (Figura 7.6b).

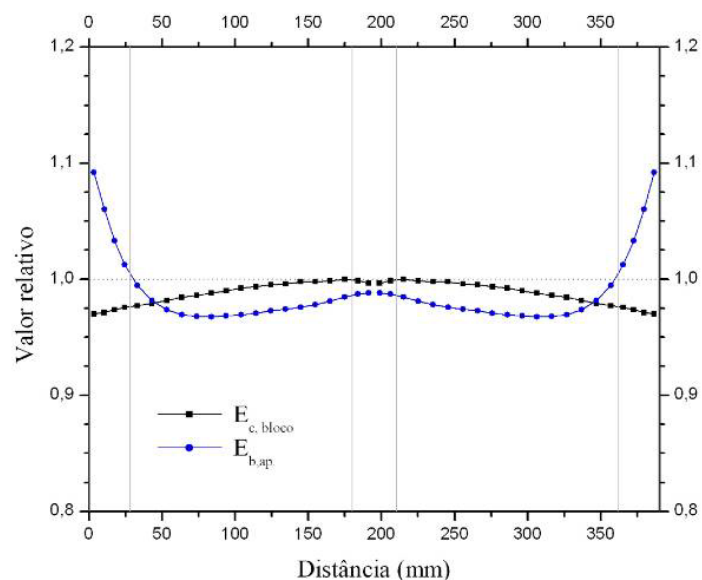

(a)

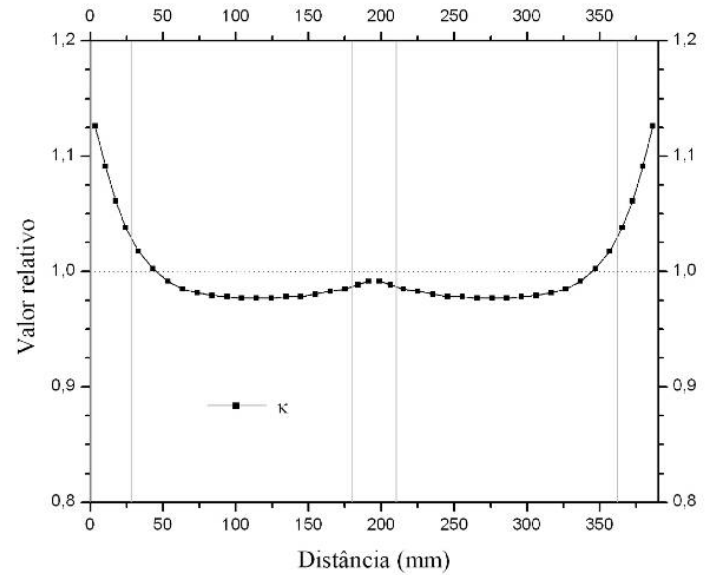

(b)

Figura 7.6 - Distintas abordagens para a obtenção do módulo de elasticidade (a). Coeficiente de ponderação do confinamento (b).

A curva de ponderação do confinamento ( $\kappa$ ) é definida pela Equação (7.3). Caso seja procedida a multiplicação de cada ponto ao longo do perfil da curva de ponderação pelo perfil de deformações, obter-se-iam valores mais uniformes e próximos ao módulo de elasticidade do material que constitui o bloco.

$$
\kappa=\left(9 \cdot 10^{-10} \cdot d^{4}\right)-\left(4 \cdot 10^{-7} \cdot d^{3}\right)+\left(7 \cdot 10^{-5} \cdot d^{2}\right)-(0,0058 \cdot d)+1,144
$$

Assim, a aplicação da curva de ponderação aproxima o parâmetro denominado módulo de elasticidade aparente do valor do módulo de elasticidade do material que constitui o bloco. Esta aplicação é valida quando as considerações entre os modelos experimentais e numéricos forem próximas, como neste caso, em relação às condições de contorno e deslocamento uniforme do topo do bloco.

Uma análise prática pode ser realizada considerando-se as distintas regiões definidas na Figura 7.1 para associação dos resultados numéricos e experimentais. A influência de cada região sobre o comportamento do conjunto é considerada por meio de fatores de ponderação 
$(\chi)$ das áreas - definidos como sendo a proporção de cada uma sobre a área total. Na Tabela 7.3 são apresentados os coeficientes de ponderação $\kappa$ e $\chi$.

Tabela 7.3 - Coeficientes de ponderação definidos para as distintas regiões do bloco.

\begin{tabular}{ccc}
\hline Região & $\kappa$ & $\chi$ \\
\hline A & 1,09 & 0,274 \\
B & 0,98 & 0,409 \\
C & 0,99 & 0,236 \\
D & 1,13 & 0,081 \\
\hline
\end{tabular}

\subsubsection{Previsão da resistência e deformabilidade do concreto que constitui o bloco vazado}

Utilizando-se a Equação (7.1) e os coeficiente de ponderação da Tabela 7.3, apresenta-se um forma peculiar para caracterização mecânica do concreto que compõe o bloco vazado, conforme descrito a seguir:

1. A partir da curvas tensão-deformação obtida para o bloco vazado de concreto, corrigem-se os valores de tensão de referência;

2. Em seguida, aplicam-se os coeficientes de ponderação do confinamento e das áreas para as curvas representativas de cada área;

3. O somatório das deformações de cada uma das curvas ponderadas, já tendo sua tensão relativa corrigida, representa a curva tensão-deformação do material que constitui o bloco.

Na Figura 7.7 e na Figura 7.8 estão ilustradas as curvas tensão-deformação obtidas em distintos pontos dos blocos e a comparação da curva corrigida com a obtida no ensaio de corpo-de-prova de concreto. 


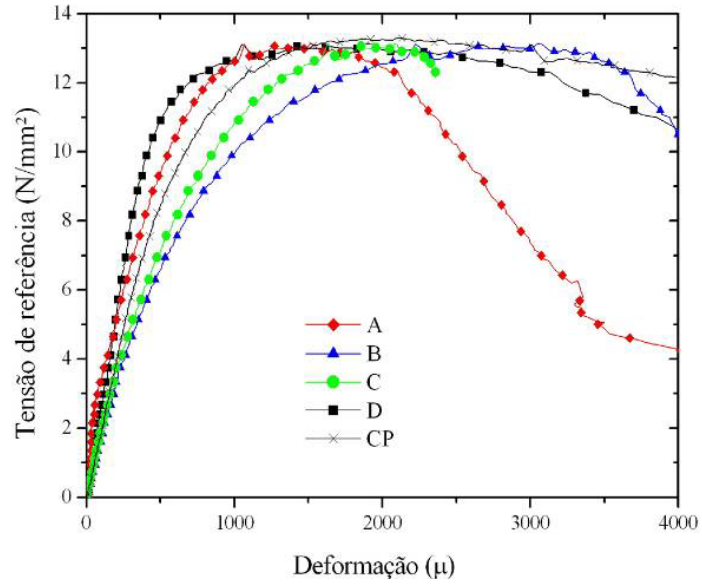

(a)

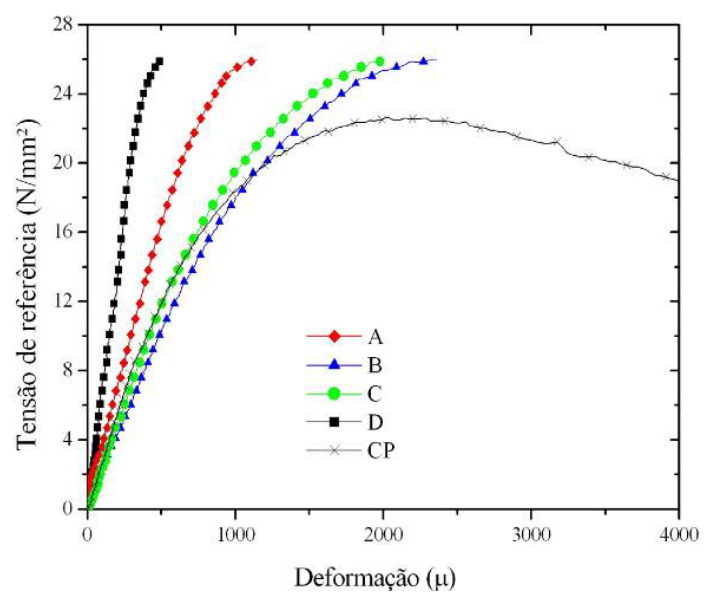

(c)

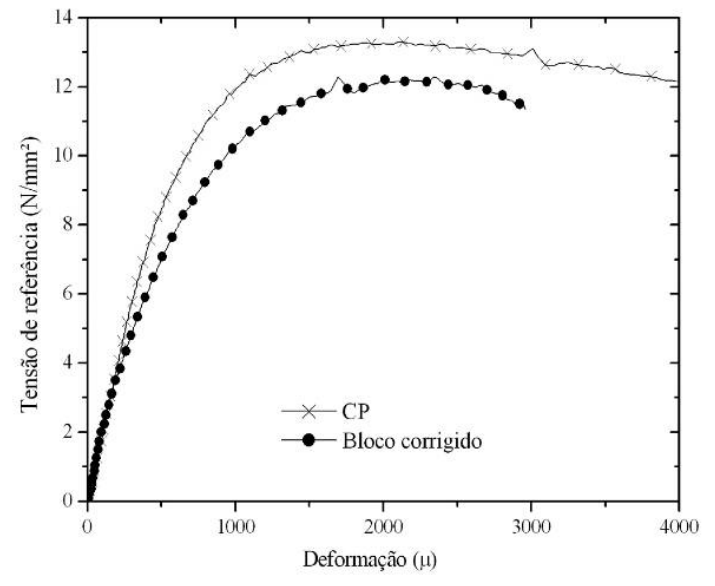

(b)

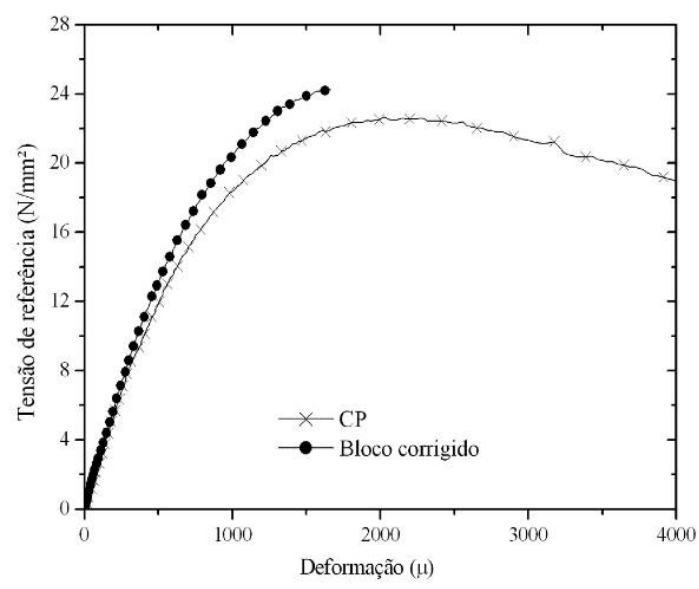

(d)

Figura 7.7 - Relação tensão-deformação obtida nos distintos pontos do bloco e no corpo-deprova: grupo B1 (a) e B2 (c). Curva tensão-deformação do corpo-de-prova e corrigida do bloco: grupo B1 (b) e B2 (c). 


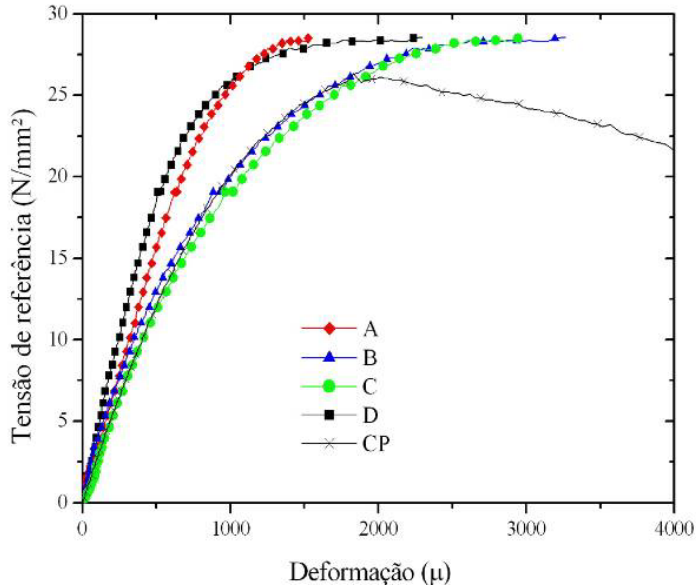

(a)

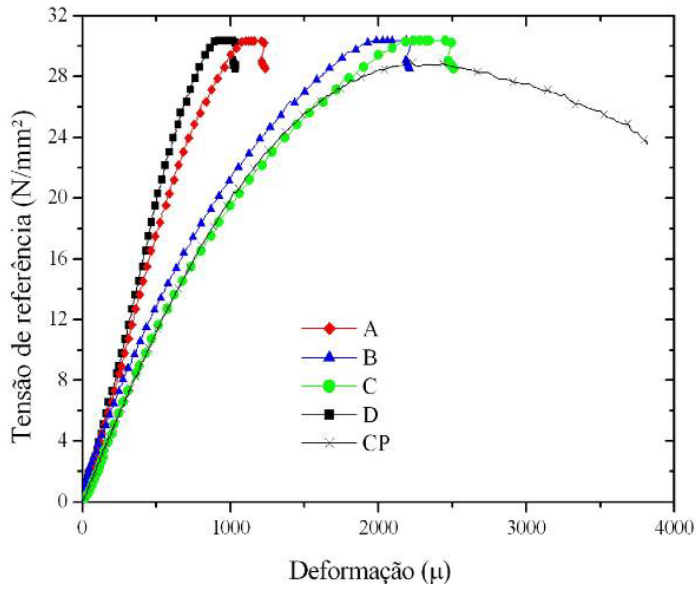

(c)

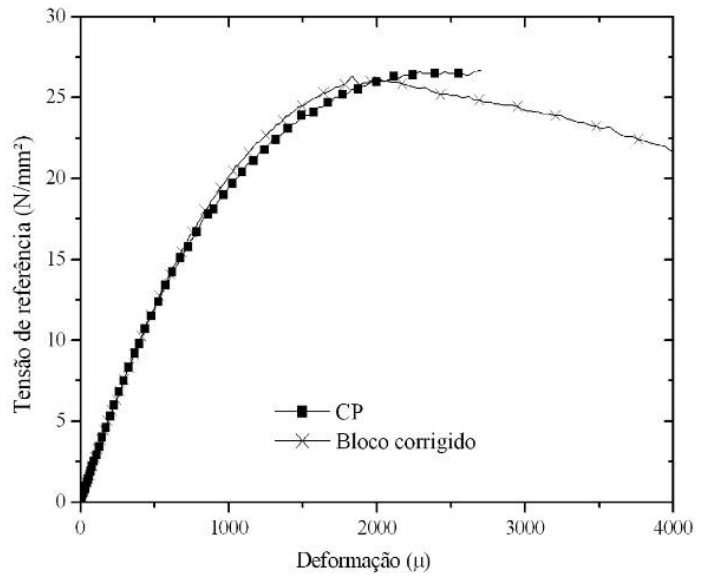

(b)

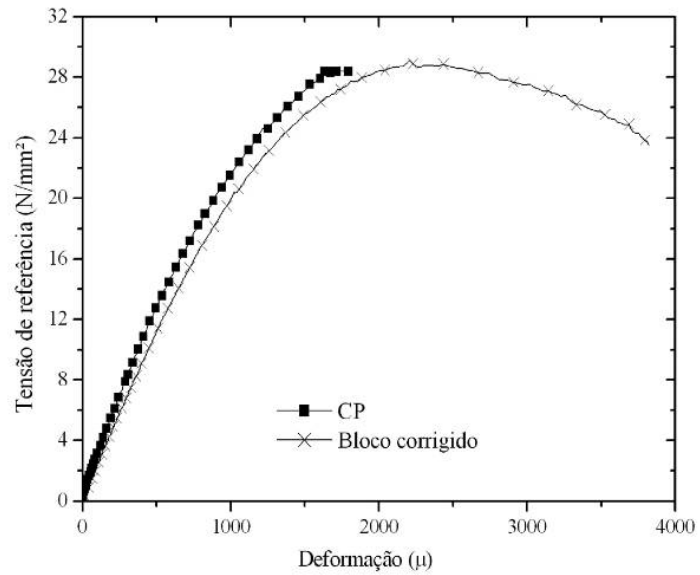

(d)

Figura 7.8 - Relação tensão-deformação obtida nos distintos pontos do bloco e no corpo-deprova: grupo B3 (a) e B4 (c). Curva tensão-deformação do corpo-de-prova e corrigida do bloco: grupo B3 (b) e B4 (c).

Observa-se que as curvas do concreto obtidas pela correção a partir das curvas dos blocos apresentam boa correlação com as provenientes do ensaio com corpos-de-prova de concreto. As relações entre as resistências à compressão apresentam valor médio igual à unidade, com variação máxima de $14 \%$, enquanto que a relação entre os módulos de elasticidade apresenta variação máxima de $18 \%$ e valor médio de 1,06 . O resumo desses valores para cada grupo de resistência é apresentado na Tabela 7.4. 
Tabela 7.4 - Resistência à compressão e módulo de elasticidade: ensaio de corpos-de-prova e correção dos valores obtidos com o bloco.

\begin{tabular}{ccccccc}
\hline Grupo & $\mathrm{f}_{\mathrm{c}}$ & $\begin{array}{c}\mathrm{E}_{\mathrm{c}} \\
\left(\mathrm{N} / \mathrm{mm}^{2}\right)\end{array}$ & $\begin{array}{c}\mathrm{f}_{\mathrm{c}, \text { corr. }} \\
\mathrm{C}\end{array}$ & $\mathrm{E}_{\mathrm{c}, \text { corr. }}$ & $\frac{\mathrm{f}_{\mathrm{c}, \text { corr }}}{\mathrm{f}_{\mathrm{c}}}$ & $\frac{\mathrm{E}_{\mathrm{c}, \text { corr }}}{\mathrm{E}_{\mathrm{c}}}$ \\
\hline $\mathrm{CP} 1 / \mathrm{B} 1$ & 13,4 & 18080 & 12,3 & 17434 & 0,918 & 0,964 \\
$\mathrm{CP} 2 / \mathrm{B} 2$ & 22,1 & 24476 & 25,1 & 28807 & 1,136 & 1,177 \\
$\mathrm{CP} 3 / \mathrm{B} 3$ & 26,0 & 23956 & 27,0 & 22072 & 1,038 & 0,921 \\
$\mathrm{CP} 4 / \mathrm{B} 4$ & 30,9 & 23004 & 28,4 & 27012 & 0,919 & 1,174 \\
\hline
\end{tabular}

$\mathrm{f}_{\mathrm{c} \text {,corr. }}$ : resistência à compressão do concreto corrigida a partir de $\mathrm{f}_{\mathrm{b}}$.

$\mathrm{E}_{\mathrm{c}, \text { corr. }}$ : módulo de elasticidade do concreto corrigido pela ponderação das diversas curvas tensão -deformação obtidas em distintos pontos do bloco.

\subsubsection{Propriedades mecânicas do concreto que constitui o bloco vazado}

Apresenta-se na Tabela 7.5 um resumo das propriedades mecânicas do concreto que constitui o bloco vazado. As correlações propostas foram definidas a partir dos resultados experimentais e das análises numéricas.

Tabela 7.5 - Propriedades mecânicas do concreto que constitui o bloco vazado.

\begin{tabular}{cccccc}
\hline $\mathrm{f}_{\mathrm{c}}$ & $\mathrm{E}_{\mathrm{c}}$ & $\mathrm{f}_{\mathrm{ct}}$ & $\mathrm{v}$ & $\mathrm{G}_{\mathrm{f}}$ & $\mathrm{G}_{\mathrm{f}_{\mathrm{c}}}$ \\
\hline$\frac{\mathrm{f}_{\mathrm{b}}}{1,07} \quad \kappa$ e $\chi$ & $0,21 \cdot \mathrm{f}_{\mathrm{c}}^{0,77}$ & 0,20 & $\mathrm{~d}_{\mathrm{u}}=0,029 \mathrm{~mm}$ & $1,5+0,43 \mathrm{f}_{\mathrm{c}}-0,0036 \mathrm{f}_{\mathrm{c}}^{2}$ \\
\hline $\mathrm{d}_{\mathrm{u}}=\frac{\mathrm{G}_{\mathrm{f}}}{1,9 \mathrm{f}_{\mathrm{ct}}}$ & & & & &
\end{tabular}

\subsection{Prismas constituídos por três blocos}

É enfatizada a dependência da resistência e deformabilidade dos prismas em função das propriedades mecânicas do concreto e argamassa que os constituem, além de ponderar o efeito da perda de água e confinamento na junta de argamassa.

\subsubsection{Resistência do prisma e de seus materiais constituintes}

A resistência à compressão do bloco vazado e da argamassa é apresentada na Tabela 7.6 juntamente com os valores resistentes dos prismas obtidos na análise experimental $\left(\mathrm{f}_{\mathrm{p}}^{\exp }\right)$ e numérica $\left(\mathrm{f}_{\mathrm{p}}^{\text {num }}\right)$. 
Tabela 7.6 - Resistência à compressão do prisma e de seus materiais constituintes.

\begin{tabular}{clcccc} 
& \multicolumn{2}{c}{ Componentes } & \multicolumn{2}{c}{ Prisma } & \\
Grupo & $\mathrm{f}_{\mathrm{b}}$ & $\mathrm{f}_{\mathrm{a}}$ & $\mathrm{f}_{\mathrm{p}}^{\exp }$ & $\mathrm{f}_{\mathrm{p}}^{\text {num }}$ & $\frac{\mathrm{f}_{\mathrm{p}}^{\text {num }}}{\mathrm{f}_{\mathrm{p}}^{\exp }}$ \\
& \multicolumn{2}{c}{$\left(\mathrm{N} / \mathrm{mm}^{2}\right)$} & \multicolumn{2}{c}{$\left(\mathrm{N} / \mathrm{mm}^{2}\right)$} & 0,803 \\
\hline P1 & 20,0 & 7,5 & 17,8 & 14,3 & 0,896 \\
P2 & 24,5 & 9,4 & 18,2 & 16,3 & 0,921 \\
P3 & 26,8 & 15,5 & 21,5 & 19,8 & 1,010 \\
P4 & 38,9 & 22,2 & 30,1 & 30,4 & \\
\hline
\end{tabular}

É possível observar que todas as relações entre os valores numéricos e experimentais apresentam variações inferiores a 10\%, com exceção do grupo P1. Neste grupo, apesar dos valores de resistência à compressão dos componentes serem inferiores, aproximadamente, $23 \%$ em relação aos obtidos no grupo $\mathrm{P} 2$, os valores de resistência à compressão dos prismas diferem em apenas $2 \%$. Considerando-se que o valor obtido nas análises experimentais $\left(\mathrm{f}_{\mathrm{p}}^{\exp }\right)$ com prismas do grupo P1 seja 6\% superior ao valor obtido por meio de análises numéricas $\left(f_{p}^{\text {num }}\right)$ - média obtida para os demais grupos -, ter-se-ia, para este grupo, $f_{p}^{\exp } \sim 15,2 \mathrm{~N} / \mathrm{mm}^{2}$. Este valor, comparando-se com o obtido no grupo P2, já apresenta uma redução de $16 \%$, que é mais condizente com os valores de resistência dos componentes. Portanto, há probabilidade de que fatores externos tenham afetado a análise experimental quando utilizado o grupo P1, influenciando na resistência dos componentes e/ou do prisma.

A partir de uma regressão linear dos valores obtidos no ensaio à compressão da argamassa, prisma e concreto, pode-se formular a Equação (7.4) que indica a interdependência desses parâmetros.

$$
\mathrm{f}_{\mathrm{p}}=0,54 \cdot \mathrm{f}_{\mathrm{b}}+0,40 \cdot \mathrm{f}_{\mathrm{a}}
$$

Enfatiza-se que nessa relação já estão considerados os efeitos positivos sobre a resistência da argamassa em decorrência da perda de água e confinamento. Entretanto, a formulação proposta restringe-se à geometria de blocos de concreto utilizada e características de sucção dos tipos de concreto que os constituem.

$\mathrm{Na}$ Tabela 7.7 está apresentada a comparação entre os valores obtidos experimentalmente e resultantes da formulação algébrica proposta, a qual apresenta boa correlação, com valor médio de 0,95 e diferença máxima de 9,2\%. 
Tabela 7.7 - Valores da resistência do prisma: experimental e algébrico.

\begin{tabular}{cccc}
\hline Grupo & $\mathrm{f}_{\mathrm{p}}^{\text {exp }}$ & $\mathrm{f}_{\mathrm{p}}^{\text {alg }}$ & $\frac{\mathrm{f}_{\mathrm{p}}^{\text {alg }}}{\mathrm{f}_{\mathrm{p}}^{\exp }}$ \\
\hline P1 & \multicolumn{2}{c}{$\left(\mathrm{N} / \mathrm{mm}^{2}\right)$} & 0,908 \\
P2 & 18,2 & 13,8 & 0,923 \\
P3 & 21,5 & 20,6 & 0,958 \\
P4 & 30,1 & 29,8 & 0,990 \\
& & Média & 0,95 \\
& & C.V. & $3,8 \%$ \\
\hline
\end{tabular}

${ }^{1}$ Valor previsto por meio da análise numérica

${ }^{2}$ C.V.: coeficiente de variação

\subsubsection{Avaliação da perda de água da argamassa durante a cura}

A perda de água da argamassa para o bloco depende das propriedades físicas do concreto, que definirá o índice de sucção, e da retenção da argamassa, que depende das propriedades físicas dos materiais que a compõem. Portanto, a quantificação desse fenômeno depende simultaneamente dos materiais que constituem as estruturas de alvenaria. No processo modificado, em que se utilizam fôrmas absorventes para avaliação da perda de água da argamassa durante a cura, observa-se que o fator de forma influencia na quantificação, já que a área em contato com as fôrmas interfere no fenômeno.

Logo, os valores obtidos na análise experimental apresentam grande variação, sendo a resistência da argamassa obtida no ensaio modificado com corpos-de-prova cilíndricos maior entre 1,3 a 2,1 vezes que as obtidas no ensaio padrão. Utilizando-se corpos-de-prova cúbicos, essa relação fica entre 1,8 e 2,1. Sugere-se que seja considerado um incremento de $30 \%$ na resistência à compressão da argamassa em função da perda de água durante a cura.

Em relação ao módulo de elasticidade, nota-se o aumento de duas vezes do valor obtido por meio do processo modificado. No entanto, como foi observado nas análises experimentais com prismas e corpos-de-prova padronizados de argamassa, a relação entre a deformabilidade obtida em um CP e diretamente na junta do prisma é 1,9, sendo a junta mais deformável.

Dessa forma, para este parâmetro, nenhuma correção é adotada, pois o incremento na rigidez a ser obtido pela perda de água será compensado pela alteração da forma geométrica. 
Na junta dos prismas existe ainda a formação de uma região diferenciada na interface argamassa-bloco, que surge em função da movimentação da água da argamassa para o bloco e que não foi analisada no presente trabalho. Essa região é caracterizada por sua porosidade e, consequentemente, menor rigidez e deve ser analisada de forma mais detalhada para o completo entendimento de seu comportamento.

\subsubsection{Avaliação do efeito de confinamento da argamassa}

A partir dos resultados obtidos nas análises experimentais em análise conjunta com os resultados de outros pesquisadores, é possível estabelecer uma relação (Equação (7.5)) para previsão da resistência da argamassa sob efeito triaxial de tensões.

$$
\frac{\sigma_{1}}{\sigma_{0}}=1,03+3,35 \frac{\sigma_{3}}{\sigma_{0}}-0,43\left(\frac{\sigma_{3}}{\sigma_{0}}\right)^{2}
$$

sendo:

$\sigma_{0}:$ a resistência à compressão uniaxial da argamassa;

$\sigma_{1}:$ a resistência à compressão triaxial da argamassa;

$\sigma_{3}:$ a tensão lateral de confinamento.

Os valores resultantes da análise experimental desta pesquisa, da análise numérica e os obtidos por meio da formulação proposta são apresentados na Tabela 7.8. Observa-se que as relações obtidas comparando-se a formulação proposta e as análises numéricas e experimentais são, em média, inferiores a 10\%, o que ratifica a formulação algébrica proposta. 
Tabela 7.8 - Resistência da argamassa sob compressão triaxial.

\begin{tabular}{|c|c|c|c|c|c|c|}
\hline$\sigma_{0}$ & $\sigma_{3}$ & $\sigma_{1}^{\exp }$ & $\sigma_{1}^{\mathrm{alg}}$ & $\sigma_{1}^{\text {num }}$ & $\frac{\sigma_{1}^{\mathrm{alg}}}{\sigma_{1}^{\exp }}$ & $\frac{\sigma_{1}^{\mathrm{alg}}}{\sigma_{1}^{\text {num }}}$ \\
\hline \multirow{6}{*}{10,3} & 0 & 10,3 & 10,6 & 10,3 & 1,030 & 1,030 \\
\hline & 1,5 & 14,9 & 15,5 & 17,0 & 1,043 & 0,914 \\
\hline & 3 & 21,0 & 20,3 & 22,3 & 0,966 & 0,910 \\
\hline & 4,5 & 21,9 & 24,8 & 27,0 & 1,134 & 0,920 \\
\hline & & & \multicolumn{2}{|c|}{ Média } & 1,043 & 0,943 \\
\hline & & & \multicolumn{2}{|c|}{ C.V. } & $6,6 \%$ & $6,1 \%$ \\
\hline
\end{tabular}

$\sigma_{1}^{\exp }$ : obtido na análise experimental

$\sigma_{1}^{\text {alg }}$ : obtido por meio da Equação (7.5)

$\sigma_{1}^{\text {num }}:$ obtido na simulação numérica

O efeito de confinamento na junta de argamassa do prisma não é uniforme (Figura 7.9a), com diferenças inclusive em ambos os sentidos transversais. Como pode ser observado na Figura 7.9b, referente ao modelo numérico do prisma $\mathrm{P} 4$, as tensões transversais de compressão atingem facilmente $2 \mathrm{~N} / \mathrm{mm}^{2}$.

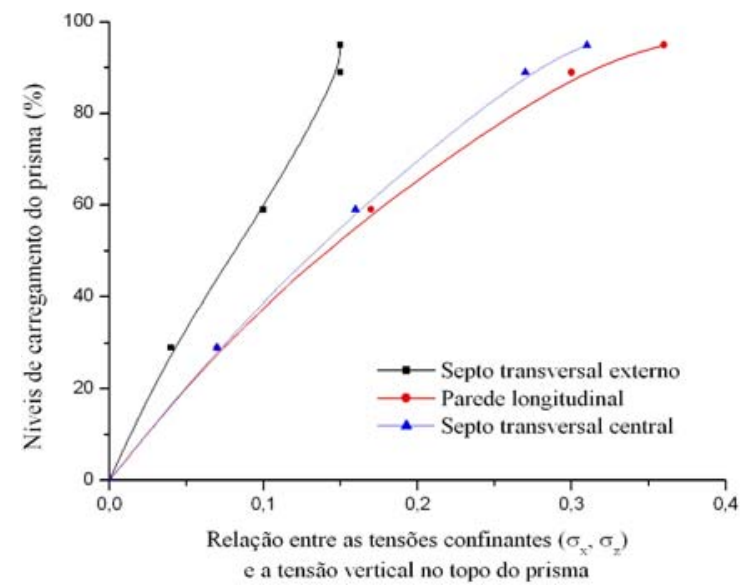

(a)

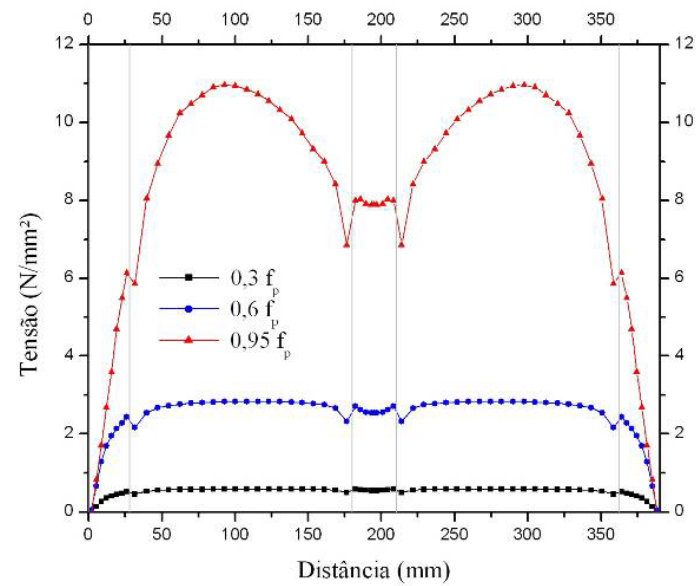

(b)

Figura 7.9 - Variação do confinamento nas distintas regiões da junta (a). Valores efetivos das tensões transversais (b).

A resistência à compressão de uma argamassa pode ser avaliada, de forma empírica, por meio da resistência do prisma, pois, no mínimo, esse material sob forma de junta suporta a tensão equivalente à resistência do prisma. $\mathrm{O}$ que pode ocorrer é que a capacidade resistente da argamassa seja maior, já que o prisma pode ruir em decorrência das tensões de tração no bloco de concreto. 
Na Tabela 7.9 estão apresentados os valores da resistência à compressão dos prismas e os obtidos nos ensaios à compressão uniaxial com corpos-de-prova de argamassa. Deste modo, a resistência do prisma fornece a resistência mínima da argamassa sob confinamento e após a perda de água durante a cura.

As argamassas dos grupos $\mathrm{P} 1$ e P2, por apresentar resistência inferior aos blocos de concreto, governam a ruína dos blocos. Nesse caso, a junta de argamassa apresenta capacidade resistente maior, em torno de duas vezes, que a obtida nos corpos-de-prova cilíndricos. Já as argamassas dos grupos P3 e P4, as quais têm cerca de 60\% da resistência dos blocos, não atingem a sua capacidade máxima.

Portanto, atribui-se a ruína dos prismas P1 e P2 ao esmagamento da junta de argamassa, enquanto que nos prismas P3 e P4 a fissuração dos blocos acarreta a ruína.

Tabela 7.9 - Resistência à compressão dos prismas e da argamassa.

\begin{tabular}{|c|c|c|c|}
\hline Grupo & $\mathrm{f}_{\mathrm{p}}$ & $\mathrm{f}^{2}$ & $\frac{f_{p}}{f_{a}}$ \\
\hline $\mathrm{P} 1$ & 15,7 & 7,7 & 2,04 \\
\hline $\mathrm{P} 2$ & 18,2 & 9,4 & 1,94 \\
\hline P3 & 21,5 & 15,5 & 1,39 \\
\hline P4 & 30,1 & 22,2 & 1,36 \\
\hline
\end{tabular}

Com base na formulação proposta, é possível observar que o efeito de confinamento com uma tensão de lateral de $4,5 \mathrm{~N} / \mathrm{mm}^{2}$ permite um incremento de resistência de até 2,4 vezes. Observa-se que esse nível de confinamento é facilmente atingido, contudo, em apenas uma das direções da junta. Se adotado, a favor da segurança, um aumento médio da resistência de 1,5 vezes (tensão lateral de 1,5 N/mm²) e atribuindo-se o fator de 1,3 vezes para a perda de água, chega-se a um incremento total de resistência próximo a 2 vezes, que são os valores máximos obtidos nas análises experimentais.

\subsubsection{Deformabilidade dos materiais que constituem os prismas}

O concreto e argamassa que compõem o prisma constituído por três blocos de concreto, unidos por juntas horizontais, influenciam a deformabilidade do conjunto conforme ilustra a Figura 7.10. Nota-se que a curva considerando-se a altura total dos prismas apresenta uma deformabilidade intermediária entre a da argamassa e a do bloco, com maior proximidade do valor deste. 


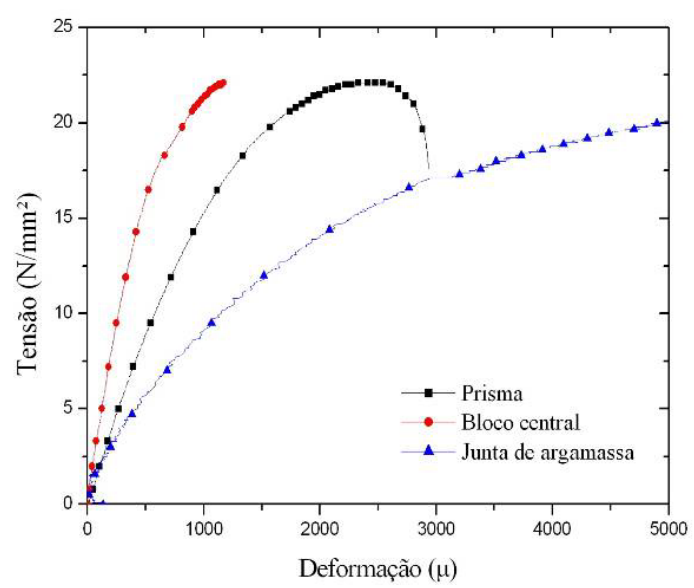

Figura 7.10 - Curvas tensão de referência-deformação obtidas com instrumentação com distintas bases de medida.

Na Tabela 7.10 estão apresentados os valores dos módulos de elasticidade da argamassa e do concreto. Apresenta-se também o valor do parâmetro de deformabilidade do prisma $\left(\mathrm{E}_{\mathrm{p}}\right)$, referente ao regime elástico-linear, obtido considerando-se as deformações de toda a altura do prisma.

Tabela 7.10 - Parâmetros de deformabilidade dos prismas e de seus materiais constituintes.

\begin{tabular}{ccccccc}
\hline Grupo & $\begin{array}{c}\mathrm{E}_{\mathrm{a}} \\
\left(\mathrm{N} / \mathrm{mm}^{2}\right)\end{array}$ & $\mathrm{E}_{\mathrm{c}}$ & $\frac{\mathrm{E}_{\mathrm{a}}}{\mathrm{E}_{\mathrm{c}}}$ & $\begin{array}{c}\mathrm{E}_{\mathrm{p}}^{\exp } \\
\left(\mathrm{N} / \mathrm{mm}^{2}\right)\end{array}$ & $\begin{array}{c}\mathrm{E}_{\mathrm{p}}^{\text {num }} \\
\frac{\mathrm{E}_{\mathrm{p}}^{\text {exp }}}{\text { num }}\end{array}$ \\
\hline P1 & 8121 & 17449 & 0,465 & 18954 & 16228 & 0,856 \\
P2 & 9745 & 20595 & 0,473 & 18198 & 19196 & 1,055 \\
P3 & 13195 & 22175 & 0,595 & 20255 & 21583 & 1,066 \\
P4 & 16672 & 27104 & 0,615 & 23429 & 26194 & 1,118 \\
\hline
\end{tabular}

$\mathrm{E}_{\mathrm{p}}^{\mathrm{exp}}$ : obtido por meio da análise experimental

$\mathrm{E}_{\mathrm{p}}^{\mathrm{num}}$ : obtido por meio da análise numérica

As relações obtidas entre os valores numéricos e experimentais dos prismas são bem próximas, sendo assim, utilizam-se os valores numéricos para a definição da Equação (7.6), obtida por meio de uma regressão linear.

$$
\mathrm{E}_{\mathrm{p}}=0,81 \mathrm{E}_{\mathrm{c}}+0,27 \mathrm{E}_{\mathrm{a}}
$$

Aplicando-se a formulação algébrica e comparando esses resultados com os obtidos por meio do modelo experimental, obtêm-se boas relações com baixo coeficiente de variação (Tabela 7.11). 
Tabela 7.11 - Previsão da deformação do prisma.

\begin{tabular}{cccc}
\hline Grupo & $\mathrm{E}_{\mathrm{p}}^{\mathrm{exp}}$ & $\mathrm{E}_{\mathrm{p}}^{\mathrm{alg}}$ & $\frac{\mathrm{E}_{\mathrm{p}}^{\mathrm{alg}}}{\mathrm{E}_{\mathrm{p}}^{\exp }}$ \\
\hline P1 & 18954 & 16238 & 0,861 \\
P2 & 18198 & 19209 & 1,061 \\
P3 & 20255 & 21409 & 1,063 \\
P4 & 23429 & 26313 & 1,129 \\
& & Média & 1,029 \\
& & C.V. & $11,3 \%$ \\
\hline E & \multicolumn{3}{c}{ alg }
\end{tabular}

Observa-se que o módulo de elasticidade da argamassa cresce duas vezes devido à perda de água, já o efeito de confinamento não influencia neste parâmetro. Quando sob forma de junta, a deformabilidade da argamassa é aumentada em duas vezes, ou seja, os módulos de elasticidade obtido por meio de CP's apresentam boa correlação com a deformabilidade obtida na junta de argamassa.

\subsubsection{Propriedades mecânicas dos materiais que constituem o prisma}

A previsão das propriedades mecânicas da argamassa, quando sob forma de junta, é apresentada na Tabela 7.5. As correlações propostas são definidas a partir dos resultados experimentais associados aos modelos numéricos.

Tabela 7.12 - Propriedades mecânicas da argamassa da junta de um prisma.

\begin{tabular}{ccccc}
\hline $\mathrm{E}_{\mathrm{a}}$ & $\mathrm{f}_{\mathrm{at}}$ & $v$ & $\mathrm{G}_{\mathrm{f}}$ & $\mathrm{G}_{\mathrm{f}_{\mathrm{c}}}$ \\
\hline $2121 \cdot \mathrm{f}_{\mathrm{a}}^{0,66}$ & $0,118 \cdot \mathrm{f}_{\mathrm{a}}$ & $0,13-0,15$ & $\mathrm{~d}_{\mathrm{u}}=0,023 \mathrm{~mm}$ & $2,5 \mathrm{f}_{\mathrm{a}}^{0,64}$ \\
\hline $\mathrm{d}_{\mathrm{u}}=\frac{\mathrm{G}_{\mathrm{f}}}{1,3 \mathrm{f}_{\mathrm{at}}}$ & & & &
\end{tabular}

Esses valores podem ser obtidos pode meio da análise experimental com corpos-deprova de argamassa sendo os parâmetros relativos ao concreto definidos por meio das Equações (7.4) e (7.6).

Com os parâmetros mecânicos de ambos os materiais é possível prever a resistência e deformabilidade do prisma. Alternativamente, de posse dos valores obtidos no ensaio com prisma e argamassa, podem-se prever as propriedades mecânicas do concreto que constitui o bloco. 
Já os parâmetros mecânicos obtidos na junta de argamassa $\left(f_{a, \text { junta }}\right)$ são definidos pelas Equações (7.7) e (7.8).

$$
\begin{gathered}
\mathrm{f}_{\mathrm{a}, \text { junta }}=\alpha_{\mathrm{s}} \cdot \alpha_{\mathrm{c}} \cdot \mathrm{f}_{\mathrm{a}} \\
\mathrm{E}_{\mathrm{a}, \text { junta }}=\mathrm{E}_{\mathrm{a}}
\end{gathered}
$$

$\alpha_{\mathrm{s}} \sim 1,3$ : coeficiente de ponderação em função da perda de água durante a cura;

$\alpha_{c} \sim 1,5$ : coefíciente de ponderação em função do efeito de confinamento.

\subsection{Miniparedes}

Esta análise é restrita à discussão sobre os fatores de eficiência obtidos nas análises experimentais e numéricas. As ponderações apresentadas nas análises com prismas, relativas à modificação das propriedades mecânicas da argamassa em decorrência da perda de água durante a cura e do efeito de confinamento, são aplicáveis às paredes.

A redução da capacidade resistente das paredes em relação ao prisma é em função da presença de juntas verticais e alternância de blocos e meio-blocos, o que aumenta a ortotropia e heterogeneidade da estrutura. Em função da similaridade das propriedades mecânicas do concreto e argamassa, associa-se o grupo PAR 1 e PAR 2 aos grupos de prismas P2 e P4, respectivamente.

Tabela 7.13 - Fator de eficiência das paredes.

\begin{tabular}{ccccccc}
\hline & \multicolumn{3}{c}{ Experimental } & \multicolumn{3}{c}{ Numérica } \\
Grupo & $\mathrm{f}_{\mathrm{p}}$ & $\mathrm{f}_{\mathrm{par}}$ & $\frac{\mathrm{f}_{\mathrm{par}}}{\mathrm{f}_{\mathrm{p}}}$ & $\mathrm{f}_{\mathrm{p}}$ & $\mathrm{f}_{\mathrm{par}}$ & $\frac{\mathrm{f}_{\mathrm{par}}}{\mathrm{f}_{\mathrm{p}}}$ \\
& \multicolumn{2}{c}{$\mathrm{N} / \mathrm{mm}^{2}$} & $\mathrm{~N} / \mathrm{mm}^{2}$ & 0,670 \\
PAR 1 & 19,3 & 15,5 & 0,803 & 18,2 & 12,2 & 0 \\
PAR 2 & 20,5 & 16,5 & 0,805 & - & 14,2 & - \\
PAR 3 & 30,1 & - & - & 30,1 & 27,0 & 0,897 \\
\hline
\end{tabular}

A análise desses grupos de paredes e prismas indica que as estruturas constituídas por argamassa que apresentam relação com a resistência do concreto inferior a 0,55 , proporcionam fator de eficiência entre a parede e o prisma próximo a 0,8 . Já uma argamassa mais resistente, em que a relação com a resistência do concreto é 0,7 , constitui estruturas com fator de eficiência próximo a 0,9. Assim, conforme discutido, enquanto estas estruturas atingem a ruína em conseqüência do esmagamento da argamassa que compõe a junta 
horizontal dos elementos de alvenaria, essas são mais dependentes da resistência à tração do concreto e sua ruína dar-se-á por fissuração vertical dos blocos.

É importante ressaltar que o comportamento das estruturas de alvenaria é governado pela relação entre os módulos de elasticidade e coeficientes de Poisson dos materiais que as constituem. O parâmetro "resistência à compressão" foi utilizado como referência, já que há interdependência entre eles. 


\section{CONCLUSÃO}

A caracterização mecânica dos materiais que compõem as estruturas de alvenaria mostra-se uma tarefa complexa, que exige precisão, especialmente quando se pretende desenvolver modelos matemáticos, em virtude da influência de diversos fatores que intervêm no comportamento dos seus componentes, como a forma geométrica dos corpos-de-prova, suas condições de contorno e os fenômenos relacionados ao processo de sua produção.

Em relação aos blocos, diversas pesquisas que objetivaram obter a resistência do concreto que os constitui resultaram em valores em uma extensa faixa de variação, em função da geometria da unidade considerada e da forma de obtenção dos corpos-de-prova. Além disso, as condições de contorno, que dependem das placas de ensaio e do tipo de acabamento das superfícies do elemento analisado, influenciam a distribuição de tensões e deformações, dificultando ainda mais a definição dos parâmetros mecânicos desejados. Da mesma forma, as propriedades mecânicas da argamassa, na forma de junta, são influenciadas pela perda de água e pelo efeito de confinamento a que ela está sujeita, portanto, em condições muito diferentes daquelas que ocorrem nos ensaios de corpos-de-prova usualmente empregados para sua caracterização.

Assim, os modelos numéricos destinados à previsão da capacidade portante e da deformabilidade de estruturas de alvenaria - habitualmente complexos, custosos e que demandam elevado nível de conhecimento - são elaborados com a utilização de alguns parâmetros de entrada duvidosos, acentuando ainda mais as dificuldades de representação teórica do comportamento da alvenaria.

O presente trabalho traz, nesse sentido, contribuições ao estudo da Tecnologia da Alvenaria, destacando-se a caracterização mecânica dos materiais constituintes e suas 
implicações na análise do comportamento de corpos-de-prova e elementos estruturais. Tais contribuições advieram de abordagens teóricas e experimentais, dentre as quais sobressai a extensa análise experimental que explorou a idéia central e diferenciada da utilização de um mesmo concreto, de consistência plástica, para moldagem de blocos vazados de concreto e corpos-de-prova cilíndricos. Seguindo essa mesma metodologia, realizaram-se investigações detalhadas com prismas, miniparedes e argamassa.

Assim, foi possível a obtenção precisa dos parâmetros mecânicos, elásticos e inelásticos do concreto e da argamassa que constituem os blocos e as juntas de assentamento, e, em seguida, a avaliação do comportamento do conjunto com a utilização de modelos numéricos. Desenvolveu-se um modelo numérico que permite a análise do comportamento dos diversos elementos de alvenaria submetidos à compressão, com bons resultados na predição da resistência, deformabilidade e modo de ruína.

O estudo algébrico, elaborado em seguida pela associação dos resultados numéricos e experimentais, identificou e relacionou os fatores interdependentes que afetam a resistência e a deformabilidade dos blocos vazados de concreto, prismas e paredes e as propriedades mecânicas dos materiais que os constituem.

\subsection{Comportamento dos blocos vazados de concreto}

O efeito de confinamento presente nos ensaios à compressão axial de blocos vazados permite que estes alcancem uma resistência maior que a do próprio material que os constitui. Esse incremento na resistência depende da geometria do bloco e de suas condições de contorno. Eliminando-se o efeito do tipo de capeamento utilizado para regularização das superfícies, obtém-se um aumento da ordem de $10 \%$.

Também se nota uma redução de cerca de $20 \%$ do valor da resistência à compressão do bloco de concreto quando se alivia o atrito entre as placas de ensaio e as superfícies de carregamento dos blocos.

É possível observar que a distribuição de tensões e deformações no bloco, quando ocorre o efeito de confinamento, não é uniforme, apresentando distintos valores ao longo de suas paredes longitudinais e septos transversais. O alívio do confinamento permite uma maior uniformização dos valores de deformação. As análises numéricas confirmam que, ao se excluir totalmente o confinamento, essas diferenças são praticamente nulas, ou seja, em função do nível de confinamento pode-se interpretar erroneamente os parâmetros de rigidez, inclusive dentro do regime elástico-linear do comportamento do material. O comportamento 
dos blocos, com a variação do nível de atrito entre as placas de ensaio e suas extremidades, também foi bem representado pelo modelo numérico proposto.

Portanto, a determinação da rigidez axial de blocos vazados deve ser realizada com cautela já que, durante a análise experimental, os valores de deformação são distintos nas diversas regiões, o que exige cuidados especiais na determinação do módulo de elasticidade do material a partir do ensaio de blocos. Para minimizar eventuais equívocos, estabeleceu-se um procedimento para obtenção da rigidez axial dos blocos vazados de concreto, com a definição de uma região mais adequada para a instalação dos instrumentos de medição, evitando assim uma maior influência de tensões confinantes.

Por meio da associação dos resultados experimentais e numéricos, foi possível avaliar mais criteriosamente a resistência do concreto que constitui o bloco a partir da sua capacidade resistente. Por fim, sugere-se uma forma peculiar para avaliação das propriedades mecânicas do concreto que constitui o bloco vazado a partir dos valores obtidos em seu ensaio.

\subsection{Comportamento dos prismas}

A diferenciação das propriedades mecânicas da argamassa, quando nas juntas de assentamento dos blocos, em relação àquelas obtidas em ensaios de corpos-de-prova padronizados, foi efetuada experimentalmente. A perda de água durante a cura eleva os valores da resistência à compressão e do módulo de elasticidade em, aproximadamente 2,3 e 2 vezes, respectivamente. Todavia, a deformabilidade da argamassa, quando analisada diretamente na junta, é aumentada também em duas vezes. Da mesma forma, quanto maior a tensão de confinamento atuante, maior será sua capacidade resistente. Entretanto, as tensões confinantes na junta vertical não são uniformes, além de serem distintas nas direções perpendiculares ao eixo axial, conforme demonstram os modelos numéricos. Obtém-se assim aumento da capacidade resistente de, pelo menos, duas vezes, em função das condições de confinamento.

A forma de ruína dos prismas depende diretamente dessas condições, ou seja, do comportamento diferenciado da argamassa de assentamento perante esses fenômenos. Por exemplo, não se pode associar a ruína de uma estrutura apenas à relação entre a resistência da argamassa e a do bloco, devendo-se também ser avaliar a capacidade de retenção de água da argamassa e o nível de confinamento a que estará sujeita. 
O comportamento dos prismas, observado durante a análise experimental, é bem representado pelo modelo numérico tridimensional quanto à resistência, deformabilidade do conjunto e modo de ruína. Quanto mais baixa a relação entre as propriedades mecânicas da argamassa e do concreto que constitui o bloco, maior será a tendência de ruína por esmagamento da junta. $\mathrm{O}$ oposto indica a ruína do prisma por fissuração dos blocos.

Ao contrário das análises tridimensionais, os modelos planos utilizados para avaliação da capacidade resistente de prismas de blocos vazados de concreto podem superestimar ou subestimar a capacidade resistente em virtude das condições de confinamento atuante sobre os componentes da estrutura.

O estudo algébrico fornece parâmetros para a ponderação das propriedades mecânicas da junta da argamassa a partir das obtidas no ensaio padronizado. Além disso, apresenta-se uma forma razoável para a previsão da resistência e deformabilidade dos prismas a partir das propriedades mecânicas dos materiais que os constituem.

\subsection{Comportamento das miniparedes}

A partir da análise experimental e numérica foi possível identificar a influência das juntas verticais na distribuição de tensões e deformações. A resistência de paredes é menor que a observada nos ensaios com prismas, em decorrência da alteração da configuração geométrica, com a existência de juntas verticais e meio-blocos. O efeito de confinamento na junta horizontal e a perda de água da argamassa ocorrem de maneira similar à constatada nos prismas.

Os modelos numéricos forneceram uma previsão razoável da capacidade resistente e da deformabilidade das paredes.

\subsection{Proposta para pesquisas futuras}

No decorrer do presente trabalho, algumas lacunas foram observadas, identificandose a necessidade de estudos adicionais que poderiam completar ou dar prosseguimento a esta investigação, tais como:

- Determinar experimentalmente e representar numericamente o comportamento da interface entre junta de argamassa e bloco;

- Analisar o comportamento do concreto e da argamassa em uma faixa mais extensa de resistência à compressão, inclusive com a determinação dos ângulos de dilatância e de atrito, necessários para modelagem numérica; 
- Obter o comportamento de distintos materiais de capeamento e dos blocos vazados submetidos à compressão. O estudo seria complementado com simulações numéricas para avaliação da influência dos distintos materiais de capeamento no comportamento do bloco;

- Realizar análises paramétricas com os modelos numéricos disponíveis, atentando ao fator de forma do bloco, ao índice de vazios, à espessura das paredes, às dimensões externas e à resistência dos blocos. Da mesma forma, analisar modelos de prismas e paredes variando-se as propriedades mecânicas dos materiais;

- Simular numericamente as estruturas de alvenaria por meio de elementos finitos reticulados (discretos);

- Obter o comportamento dos elementos de alvenaria por meio da aplicação de deslocamento prescrito nos modelos numéricos com aquisição do trecho descendente completo da curva tensão-deformação;

- Introduzir nos modelos numéricos de prismas e paredes as propriedades mecânicas da argamassa sob efeito de confinamento e após a perda de água com discretização da interface bloco-argamassa;

- Comparar os resultados numéricos e experimentais em relação à predição da resistência dos elementos fornecidas pelos códigos de alvenaria;

- Realizar retro-análise a partir dos parâmetros obtidos em ensaios com blocos comerciais para a caracterização das propriedades mecânicas do material que o constitui, utilizando as formulações algébricas e modelos numéricos propostos neste trabalho.

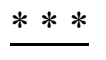

Esta Tese traz algumas contribuições ao desenvolvimento científico da Tecnologia de Alvenaria Estrutural, indicando parâmetros para, em um horizonte mais distante, o aperfeiçoamento de modelos estatísticos e determinísticos. Com isso, espera-se que esse clássico sistema construtivo, eficiente e racional, possa contribuir ainda mais para o desenvolvimento da sociedade brasileira. 



\section{REFERÊNCIAS BIBLIOGRÁFICAS}

ALI, S.; PAGE, A. W. (1988). Finite element models for masonry subjected to concentrated loads. Journal Structural Division, Proceedings ASCE, v.114, pp. 1761- 84.

AMERICAN SOCIETY FOR TESTING AND MATERIALS. (1996). ASTM $\boldsymbol{C}$ 140: Standard test methods of sampling and testing concrete masonry units. Philadelphia.

(1996). ASTM C 1006: Standard test methods for splitting tensile strength of masonry units. Philadelphia.

ANDOLFATO, R.P. (2006). Estudo teórico e experimental da interação de paredes em edifícios de alvenaria estrutural. Tese (Doutorado). 203p. Escola de Engenharia de São Carlos, Universidade de São Paulo. São Carlos. 2006.

ANDREAUS, U. (1996). Failure criteria for masonry panels under in-plane loading. Journal of Structural Engineering, v.122, n.1, p.37-46, jan.

ARANTES, C.A; DONIN, C; GOMES, H.M; CAVALHEIRO, O.P. (2003). Modelamento por elementos finitos 3D do comportamento da alvenaria estrutural cerâmica grauteada. In: Iberian Latin-American Congress on Computational Methods in Engineering, 24., 2003, Ouro Preto, Minas Gerais. Proceedings. v. 1. p. 1-5.

ASSOCIAÇÃO BRASILEIRA DE NORMAS TÉCNICAS (1982). NBR 7251: Massa unitária de agregados em estado solto. Rio de Janeiro. 
(1983). NBR 8215: Prismas de blocos vazados de concreto simples para Alvenaria Estrutural - Preparo e ensaio à compressão. Rio de Janeiro.

(1985). NBR 8949: Paredes de alvenaria estrutural - Ensaio a compressão simples. Rio de Janeiro.

(1987). NBR 7217: Agregados - Determinação da composição granulométrica. Rio de Janeiro.

(1987). NBR 9776: Massa específica de agregado miúdo - Frasco de Chapman. Rio de Janeiro.

(1989). NBR 10837: Cálculo de alvenaria estrutural de blocos vazados de concreto.

Rio de Janeiro.

(1992). NBR 7184: Blocos vazados de concreto simples para alvenaria Determinação da resistência à compressão. Rio de Janeiro.

(2003). NBR 6118: Projeto de estruturas de concreto - Procedimento. Rio de Janeiro.

(2003). NBR 7175: Cal hidratada para argamassas. Rio de Janeiro.

(2007). NBR 6136: Bloco vazado de concreto simples para alvenaria estrutural. Rio de Janeiro.

ATKINSON, R.H. (1991). Effect of loading platen thickness on masonry unit and prism strengths. The Masonry Society Journal, v.10, n.1, p.86-94, aug.

AUSTRALIAN STANDARD (1998). AS 3700: Masonry Structures.

BARBO, R.R.C.; HANAI, J.B; BARBOSA, C.S. Influência da absorção das unidades e do processo de cura nas propriedades mecânicas da argamassa de assentamento em alvenaria de blocos de concreto. In: JORNADAS SUDAMERICANAS DE INGENIERÍA ESTRUCTURAL, 31., Mendonza. Anais.

BARBOSA C.S. (2004). Resistência e deformabilidade de blocos vazados de concreto e suas correlações com as propriedades mecânicas do material constituinte. Dissertação (Mestrado). 153p. Escola de Engenharia de São Carlos, Universidade de São Paulo. São Carlos. 2004. 
BARBOSA, C.S.; HANAI, J.B. (2008a). Comparison of standard test results and in-place mechanical properties of embedding mortars and concrete blocks. In: INTERNATIONAL BRICK \& BLOCK MASONRY CONFERENCE, 14., 2008, Sydney, Australia. Proceedings.

BARBOSA, C.S.; HANAI, J.B. (2008b). Deformability of hollow concrete blocks and platen effect on axial compression tests. In: INTERNATIONAL BRICK \& BLOCK MASONRY CONFERENCE, 14., 2008, Sydney, Australia. Proceedings.

BARBOSA, C.S.; HANAI, J.B.; BARBO, R.C.C. (2005a) Efeito da perda de água nas propriedades mecânicas da argamassa de assentamento para alvenaria estrutural de blocos de concreto. In: CONGRESSO BRASILEIRO DO CONCRETO, 47., 2005, Recife. Anais.

BARBOSA, C.S.; HANAI, J.B.; BARBO, R.C.C. (2005b) Influência do processo de cura nas propriedades mecânicas da argamassa de assentamento para alvenaria estrutural. In: SIMPÓSIO BRASILEIRO DE TECNOLOGIA DE ARGAMASSAS, 6., 2005, Florianópolis. Anais.

BAZANT, Z. P.; PLANAS, J. (1997). Fracture and size effect in concrete and other quasi brittle materials. Boca Raton, FL (USA): CRC Press, 1997.

BECICA, I.J.; HARRIS, H.G. (1983). Behavior of hollow concrete masonry prisms under axial load and bending. The Masonry Society Journal, v.2, n.2, pp.T1-T26, jan-jun.

BENINGFIELD, N.E. (1986). Mortar for structural masonry. In: Practical design of masonry structures. TTL: London, 1986.

BERTO, L.; SAETTA, A., SCOTTA, R.; VITALIANI, R. (2005). Failure mechanism of masonry prism loaded in axial compression: computational aspects. Materials and Structures, v.38, p.249-56. mar.

BERTRAM, G.; MARTENS, D.R.W. (2005). Understanding deformations of mortar embedded in masonry. In: SIMPÓSIO BRASILEIRO DE TECNOLOGIA DAS ARGAMASSAS, 6., 2005, Florianópolis. Anais. 1 CD-ROM. p.433-42.

BIERWIRTH, H.; STÖCKL, S; KUPFER, H. (1993). Triaxial tests on mortar specimens taken from bed joints. In: NORTH AMERICAN MASONRY CONFERENCE, 6., 1993, Philadelphia, Pennsylvania. Proceedings. p.995-1007. 
BITTENCOURT, T.N. (1999). Fraturamento do concreto experimental: Aspectos teóricos, computacionais e experimentais, e suas aplicações. Tese (Doutorado). 226p. Escola Politécnica, Universidade de São Paulo. São Paulo. 1999.

BRAMESHUBER, W.; BEER, I.; SCHMIDT, U. (2007). German investigations on shape factors for masonry units and high precisison elements. . Masonry International, v.20, n.2. pp. 61-68.

BUTTLER, A.M. (2007). Uso de agregados reciclados de concreto em blocos de alvenaria estrutural. 499p. Tese (Doutorado). Escola de Engenharia de São Carlos, Universidade de São Paulo, São Carlos. 2007.

CAPUZZO NETO, V. (2005). Interação de paredes em alvenaria estrutural cerâmica sob ações verticais. Tese (Doutorado). 322p. Escola de Engenharia de São Carlos, Universidade de São Paulo. São Carlos. 2005.

CARRAZEDO, R. (2005). Mecanismos de confinamento em pilares de concreto encamisados com polímeros reforçados com fibras submetidos à flexo-compressão. 243p.+apêndice. Tese (Doutorado). Escola de Engenharia de São Carlos, Universidade de São Paulo, São Carlos. 2005.

CASALI, J.M. (2003). Estudo comparativo dos diferentes tipos de argamassas de assentamento para alvenaria estrutural de blocos de concreto. 184p. Dissertação (Mestrado) - Universidade Federal de Santa Catarina, Florianópolis. 2003.

CASALI, J.M.; WEIDMANN, D.F; PRUDÊNCIO JÚNIOR, L.R. (2005). Determinação da resistência da argamassa na junta de alvenaria estrutural por meio do ensaio de resistência à penetração de pino. In: SIMPÓSIO BRASILEIRO DE TECNOLOGIA DAS ARGAMASSAS, 6., 2005, Florianópolis. Anais. 1 CD-ROM. p.423-32.

CAVALHEIRO, O.P.; GOMES, N.G. (2002). Alvenaria estrutural de blocos vazados: resultados de ensaios de elementos e redutores de resistência à compressão. In: INTERNATIONAL SEMINAR ON STRUCTURAL MASONRY FOR DEVELOPING COUNTRIES, 7., 2002, Belo Horizonte. Proceedings. p.411-19.

CHEEMA, T.S.; KLINGNER, R E. (1986). Compressive strength of masonry prisms. $\boldsymbol{A C I}$ Journal, vol. 83, n.1, pp. 88-97. 
CHEN, W.F.; HAN, D.J. (1988). Plasticity for structural engineers. New York: Spinger. $606 \mathrm{p}$.

COMITÉ EURO-INTERNACIONAL DO BETÓN (1993). CEB-FIP Model Code 90. Bulletin d'Information.

CRISFIELD, M.A. (1981). A fast incremental/iterative solution procedure that handles "snapthrough". Computers and Structures. v.13. pp. 55-62.

CROUCH, L.K.; BROGDON, J.F.; HENDERSON, R.C.; LANHAM, D. (1998). Effect of capping technique on observed compressive strength of facing brick. The Masonry Society Journal, v.16, n.1. pp. 9-13.

DAVIDSON, J.I. (1961). Loss of moisture from fresh mortars to brick. Material, Research and Standards, American Society for Testing and Materials. v.1.

DHANASEKAR, M.; PAGE, A.W.; KLEEMAN, P.W. (1984). A Finite Element Model for the in-plane behavior of brick masonry. In: AUSTRALASIAN CONFERENCE ON MECHANISMS OF STRUCTURES, 9., 1984. Proceedings. pp. 262-67.

DIANA (2005). Finite Element Code: User's Manual - Release 9. TNO Building and Construction Research, Delft, The Netherlands.

DROBIEC, L. (2005). FEM micro model of masonry. In: INTERNATIONAL CONFERENCE AMCM, 5., 2005, Gliwice, Poland. Proceedings.

DROBIEC, L. (2006). FEM micro model of masonry reinforced in bed joints. In: INTERNATIONAL MASONRY CONFERENCE, 10., London. Proceedings.

DRYSDALE, R.G.; HAMID, A.A.; BAKER, L.R. (1994). Masonry structures: behavior and design. Englewood Cliffs, New Jersey: Prentice Hall.

EUROCODE 6 (2005). ENV 1996-1-1: Design of masonry structures: General rules for reinforced and unreinforced masonry structures. Brussels, Belgium.

FERREIRA, L.E.T.; HANAI, J.B.; BITTENCOURT, T.N. (2008). Computational evolution of flexural toughness of FRC and fracture properties of plain concrete. Materials and Structures, v.41, n.2, pp. 391-405. 
FERRO, G. (2006). On dissipated energy density in compression for concrete. Engineering Fracture Mechanics, v.73, pp. 1510-30.

FRASSON JÚNIOR, A.F. (2000). Metodologia de dosagem e controle do processo produtivo de blocos de concreto para a alvenaria estrutural. 146p. Dissertação (Mestrado) Universidade Federal de Santa Catarina, Florianópolis, 2000.

FREITAS, A.A. (2006). Estudo numérico e experimental da compressão de peças de alvenaria. 171p. Texto apresentado ao Exame de Qualificação (Doutorado) - Escola de Engenharia de São Carlos, Universidade de São Paulo. São Carlos.

FREITAS, A.A.; RAMALHO, M.A.; CORRÊA, M.R.S.; TALIERCIO, A. (2008). Numerical and experimental analysis of concrete block prisms under compression. In: INTERNATIONAL BRICK \& BLOCK MASONRY CONFERENCE, 14., 2008, Sydney, Australia. Proceedings.

GALLEGOS, H. (1991). Albañilería estructural. 2.ed. Lima : Pontificia Universidad Catolica del Peru. 483p.

GALLEGOS, H. (1995). Adhesion entre el mortero y las unidades de albañilería. In: SIMPÓSIO BRASILEIRO DE TECNOLOGIA DAS ARGAMASSAS, 1., 1995, Goiânia. Anais. p.117-33.

GANESAN, T.P.; KALAYANASUNDARAM, P. AMBALAVANAN, R. (1990). A study of the behaviour of concrete hollow block masonry walls using a three-dimensional finite element analysis. Masonry International, v.4, n.1. pp. 31-35.

GANESAN, T.P.; RAMAMURTHY, K. (1992). Behavior of concrete hollow-block masonry prisms under axial compression. Journal of Structural Engineering, vol. 118, n.7, pp. 175169.

GANZERLI, S. et al. (2003). Compression strength testing for nonstandard concrete masonry units. In: NORTH AMERICAN MASONRY CONFERENCE, 9., 2003, Clemson, South Carolina. Proceedings. p.60-71. 
GEYER, A.L.B.; GREVEN, H.A. (1996). Concreto em fôrmas absorventes. In: CONGRESSO BRASILEIRO DO CONCRETO, 38., 1996, Ribeirão Preto. Anais. p.139-50. São Paulo: IBRACON.

GOMES, I.R. (2001) Simulação numérica do ensaio de compressão de prismas de alvenaria pelo método dos elementos finitos com comportamento de interface. 160p. Tese (Doutorado) - Universidade Federal de Santa Catarina, Florianópolis, 2001.

GRAUBNER, C.A.; GLOWIENKA, S. (2008). Stochastic modelling of modern masonry. In: INTERNATIONAL BRICK \& BLOCK MASONRY CONFERENCE, 14., 2008, Sydney, Australia. Proceedings.

GRAUBOHM, M.; ZACHERT, H.; BRAMESHUBER, W. (2008). Theoretical and practical investigations on the determination of calcium silicate and autoclaved aerated concrete masonry compressive strength. In: INTERNATIONAL BRICK \& BLOCK MASONRY CONFERENCE, 14., 2008, Sydney, Australia. Proceedings.

GREGORIE, Y. (2007). Compressive strength of masonry according to Eurocode 6: A contribution to the study of the influence of shape factors. Masonry International, v.20, n.2. pp. 69-74.

GUIMARÃES, T.A.C.; BARBOSA, C.S.; HANAI, J.B. Efeito da perda de água e do confinamento na argamassa de assentamento de blocos de concreto em alvenaria estrutural. In: CONGRESSO BRASILEIRO DO CONCRETO, 48., 2006, Rio de Janeiro. Anais. 2006.

GUO, P.; DRYSDALE, R.G. (1995). Properties of grout under uniaxial and triaxial compression. In: CANADIAN MASONRY SYMPOSIUM, 7., 1995, Hamilton, Ontario. Proceedings. pp.1214-25.

HAMID, A.A.; CHUKWUNENYE, A.O. (1985). Effect of type of mortar bedding on the behavior of axially loaded hollow block masonry prisms. In: NORTH AMERICAN MASONRY CONFERENCE, 3., 1985, Texas. Proceedings. pp.16-1/16-11.

HAMID, A.A.; CHUKWUNENYE, A.O. (1986). Compression behavior of concrete masonry prisms. Journal of Structural Engineering, v.112, n.3, p.605-13, mar. 
HAWK, S.W.; McLEAN, D.I.; YOUNG, T.C. (1997). Compressive behavior of insulated concrete masonry prisms. The Masonry Society Journal, v.15, n.2, pp.53-60, dec.

HAYEN, R.; van BALEN, K. and van GEMERT D. (2004). The mechanical behavior of mortars in triaxial compression. Arch Bridge: Advances in Assessment, Structural Design and Construction, 4., Proceedings. Barcelona. pp.395-404.

HENDRY, A.W. (1998). Structural Masonry. 2.ed. Hong Kong : Macmillan Press Ltd.

IOPPI, P.R.; PRUDÊNCIO JÚNIOR, L.R.; IRIYAMA, W.J. (1995). Estudo da absorção inicial de substratos e concreto: metodologias de ensaio e influência na aderência das argamassas de revestimento. In: SIMPÓSIO BRASILEIRO DE TECNOLOGIA DAS ARGAMASSAS, 1., 1995, Goiânia. Anais. p.93-102.

JENNINGS, V.A.; WERNER, A.M., PARK, C.W.; LANGE, D.A. (2000). The role of transport between brick and mortar. The Masonry Society Journal, v.18, n.2, dec. pp.61-74.

JUSTE, A.E. (2001). Estudo da resistência e da deformabilidade da alvenaria de blocos de concreto submetida a esforços de compressão. 236p .Dissertação (Mestrado) - Escola de Engenharia de São Carlos, Universidade de São Paulo, São Carlos. 2001.

KHALAF, F.M.; HENDRY, A.W. (1990). Effect of bed-face preparation in compressive testing of masonry units. British Masonry Society Proceedings, n.4, jul. pp. 129-30.

KHOO, C.L. (1972). A failure criterion for brickwork in axial compression. 110p. Tese (Doutorado). University of Endiburgh. 1972.

KINGSLEY, G.R.; TULIN, L.G.; NOLAND, J.L. (1985). The influence of water content and unit absorption properties on grout compressive strength and bond strength in hollow clay unit masonry. In: NORTH AMERICAN MASONRY CONFERENCE, 3., 1985, Texas. Proceedings. p.7-1/7-12.

KLEEMAN, P.W.; PAGE, A.W. (1990). The in-situ properties of packing materials used in compression tests. Masonry International, v.4, n.2, p.68-74.

KÖKSAL H.O.; KARAKOÇ C.; YILDIRIM H. (2005). Compression behavior and failure mechanisms of concrete masonry prisms. Journal of Materials in Civil Engineering, v.17, n.1, pp. 107-15. 
LANGE., D.A.; DEFORD, H.D.; WERNER, A.M. (1999). Microstrutural investigation of mortar/unit interaction. The Masonry Society Journal, v.17, n.1, nov. pp.31-42.

LITEWKA, A.; SZOJDA, L. (2005). Tri-axial tests for brittle materials: motivation, technique, results. Civil and Environmental Engineering Reports: University of Zielona Góra Press, Poland. n.1, pp. 169-88.

LITEWKA, A.; SZOJDA, L. (2006). Damage, plasticity and failure of ceramics and cementitious composites subjects to multi-axial state of stress. International Journal of Plasticity, n.22, pp.2048-65.

LOTFI, H.R.; SHING, P.B. (1994). Interface model applied to fracture of masonry structures. Journal of Structural Engineering, v.120, n.1, p.63-80, jan.

LOURENÇO, P.B (1996). Computational strategies for masonry structures. Delft University Press: The Netherlands. 210p.

LOURENÇO, P.B. (2006). Publicação eletrônica [mensagem pessoal]. Mensagem recebida por<claudius@civil.uminho.pt> em 20 out.

LOURENÇO, P.B. (2008). Structural masonry analysis: recent developments and prospects. In: INTERNATIONAL BRICK \& BLOCK MASONRY CONFERENCE, 14., 2008, Sydney, Australia. Proceedings. (Invited Lecture).

LOURENÇO, P.B.; BARROS, J.O.; OLIVEIRA, J.T. (2004). Shear testing of stack bonded masonry, Construction and Building Materials, 18, p.125-132.

LOURENÇO, P.B.; DE BORST, R.; ROTS, J.G. (1997). A plane stress softening plasticity model for orthotropic materials. International Journal for Numerical Methods in Engineering, v.40, p.4033-57.

LOURENÇO, P.B.; PINA-HENRIQUES, J. (2006). Validation of analytical and continuum numerical methods for estimating compressive strength of masonry. Computers and Structures, v.84, 1977-89.

LOURENÇO, P.B.; ROTS, J.G. (1997a). Multisurface interface model for analysis of masonry structures. Journal of Engineering Mechanics, v.123, n.7, p.660-68, jul. 
LOURENÇO, P.B.; ROTS, J.G. (1997b). On the use of homogenization techniques for the analysis of masonry structures. Masonry International, London, v.11, n.1, p.26-32.

LOURENÇO, P.B.; ROTS, J.G.; BLAAYWENDRAAD, J. (1997). Current possibilities of masonry modelling. In: INTERNATIONAL DIANA CONFERENCE, 2., Amsterdam, The Netherlands, 1997. Proceedings. p.285-95.

LOURENÇO, P.B.; ROTS, J.G.; BLAAUWENDRAAD, J. (1998). Continuum model for masonry: parameter estimation and validation. Journal of Structural Engineering, v.124, n.6, p.642-52, jun.

MANOS, G.C.; SOULIS, V.; THAWABTEH, J. (2003). Numerical investigation of mortarjoint modes of in-plane failure utilizing unreinforced masonry assemblages. In: NORTH AMERICAN MASONRY CONFERENCE, 9., 2003, Clemson, South Carolina, USA. Proceedings. pp. 767-78.

MARZAHN, G.A. (2003). Extended investigation of mechanical properties of masonry units. In: NORTH AMERICAN MASONRY CONFERENCE, 9., 2003, Clemson, South Carolina. Proceedings. pp.813-24.

MAURENBRECHER, A.H.P. (1978). Use of the prism test to determine compressive strength of masonry. In: NORTH AMERICAN MASONRY CONFERENCE, 1., 1978, Boulder. Proceedings.

MAURÍCIO, R.M. (2003). Investigação experimental da influência do capeamento na resistência de blocos de concreto para alvenaria estrutural. 52p. Relatório Final de Iniciação Científica apresentado à FAPESP - Faculdade de Engenharia de Ilha Solteira, Universidade Estadual Paulista, Ilha Solteira. 2003.

McNARY, W.S. (1984). Basic properties of clay-unit masonry in compression. 163p. Tese (Mestrado). University of Colorado. 1984.

MEDEIROS, J.S. (1993). Alvenaria estrutural não armada de blocos de concreto: produção de componentes e parâmetros de projeto. 449p. Dissertação (Mestrado) - Escola Politécnica, Universidade de São Paulo, São Paulo. 1993. 
MOHAMAD, G. (1998). Comportamento mecânico na ruptura de prismas de blocos de concreto. $117 \mathrm{p}$. Dissertação (Mestrado) - Universidade Federal de Santa Catarina, Florianópolis. 1998.

MOHAMAD, G. (2007). Mecanismo de ruptura da alvenaria de blocos à compressão. 290p. Tese (Doutorado) - Universidade do Minho, Guimarães, Portugal. 2007.

MOHAMAD, G.; LOURENÇO, P.B.; ROMAN, H.R. (2006). Poisson behavior of bedding mortar under multiaxial stress state. In: INTERNATIONAL MASONRY CONFERENCE, 7., Proceedings. London, England.

MOREIRA, E.M.S. (2007). Análise experimental em escala reduzida de ligações entre paredes de alvenaria estrutural de blocos cerâmicos submetidas a ações verticais. Dissertação (Mestrado). 126p. Escola de Engenharia de São Carlos, Universidade de São Paulo. São Carlos. 2007.

NASCIMENTO NETO, J.A. (2003). Estudo de painéis com abertura constituídos por alvenaria estrutural de bloco. Tese (Doutorado). 319p. Escola de Engenharia de São Carlos, Universidade de São Paulo. São Carlos. 2003.

NEVILLE, A.M. (1997). Propriedades do concreto. Tradução Eng. Salvador E. Giammusso. 2ed. São Paulo: Pini.

OLIVEIRA, F.L. (2001). Reabilitação de paredes de alvenaria pela aplicação de revestimentos resistentes de argamassa armada. 195p.+anexos. Tese (Doutorado) - Escola de Engenharia de São Carlos, Universidade de São Paulo, São Carlos. 2001.

PAES, I.L.; BAUER, E.; CARASEK, H. (2005). Influência da estrutura de poros de argamassas mistas e de blocos de concreto e cerâmico no desempenho dos revestimentos. In: SIMPÓSIO BRASILEIRO DE TECNOLOGIA DAS ARGAMASSAS, 6., 2005, Florianópolis. Anais. 1 CD-ROM. p.466-76.

PAGE, A.; SHRIVE, N. (1988). Critical assessment of compression tests for hollow block masonry. Masonry International, v.2, pp. 64-70.

PAGE, A.W. (1978). Finite Element Model for masonry. Journal Structural Division, v. 104, 1978, pp. 1267-85. 
PAGE, A.W.; KLEEMAN, P.W. (1991). The influence of capping material and platen restraint on the failure of hollow masonry units and prisms. In: INTERNATIONAL BRICK/BLOCK MASONRY CONFERENCE, 9., 1991, Berlin. Proceedings. pp.662-70.

PAGE, A.W.; LAWRENCE, S.J. (1998). An integrated study of masonry bond strength. In: AUSTRALASIAN MASONRY CONFERENCE, 5., 1998, Gladstone. Proceedings. p.30917.

PELETEIRO, S.C. (2002). Contribuições à modelagem numérica de Alvenaria Estrutural. 143p. Tese (Doutorado) - Escola de Engenharia de São Carlos, Universidade de São Paulo. 2002.

PEREIRA, J.P.A. (2005). Comparative study of line search techniques. Midterm exam. University of Illinois at Urbana-Champaign. $34 \mathrm{p}$.

PINA-HENRIQUES, J.L. (2005). Masonry under compression: Failure analysis and longterm effects. 186p. Tese (Doutorado) - Escola de Engenharia, Universidade do Minho. Guimarães. 2005.

PINA-HENRIQUES, J.L., LOURENÇO, P.B. (2006). Masonry compression: a numerical investigation at the meso-level. Engineering Computations: International Journal for Computer-Aided Engineering and Software, v. 23, n.4, pp. 382-407.

PRADO, D.M. (2006). Propriedades físicas e mecânicas de blocos estruturais produzidos com agregados reciclados de concreto. 130p. Dissertação (Mestrado). Escola de Engenharia de São Carlos, Universidade de São Paulo, São Carlos. 2006.

PRUDÊNCIO JÚNIOR., L.R. (2003). Publicação eletrônica [mensagem pessoal]. Mensagem recebida por<claudius@sc.usp.br> em 5 ago.

RILEM (1985). TC 50-FMC. Determination of the fracture energy of mortar and concrete by means of three-point bend tests on notched beams. Materials and Structures.

RILEM (1998). TC 127-MS: Tests for masonry materials and structures. MS.A.6: Method for triaxial compression tests on mortar specimens taken from bed joints. Material and Structures, v.31, july, 1998. p.363-77. 
ROCHA, M.F.P.; OLIVEIRA, L.A.P (1999). Influência da absorção capilar dos blocos cerâmicos na resistência de aderência da argamassa de assentamento. In: SIMPÓSIO BRASILEIRO DE TECNOLOGIA DAS ARGAMASSAS, 3., 1999, Vitória. Anais. p.47787.

ROMAGNA, R.H. (2000) Resistência à compressão de prismas de blocos de concreto grauteados e não grauteados. 195p. Dissertação (Mestrado) - Universidade Federal de Santa Catarina, Florianópolis, 2000.

ROTS, J.G. (1993). Computational modelling of concrete fracture. Ph.D. Thesis. Delft University of Technology. Delft, The Netherlands. 1993.

SABBATINI, F.H. O processo construtivo de edificios de alvenaria estrutural sílicocalcária. 298p. Dissertação (Mestrado) - Escola Politécnica, Universidade de São Paulo, São Paulo. 1984.

SAHLIN, S. (2007). Fisher's tests on chasing revisted "The effect of chasing on the compressive strength of brickwork, (3.IBMAC, Essen 1973)”. Masonry International, v.20, n.2. pp. 85-90.

SARANGAPANI, G.; REDDY, B.V.V.; GROOT, C.J.W.P. (2002). Water loss from fresh mortars and bond strength development in low strength masonry. Masonry International, v.15, n.2, pp.42-7.

SATHISH, V.; RAMAMURTHY, K.; AMBALAVANAN, R. (1998). A study towards redesignation of masonry mortar. In: AUSTRALASIAN MASONRY CONFERENCE, 5., 1998, Gladstone. Proceedings. p.345-53.

SAYED-AHMED, E.Y.; SHRIVE, N.G. (1996a). Nonlinear finite-element model of hollow masonry. Journal of Structural Engineering, v.122, n.6, p.683-90, jun.

SELF, M.W. (1975). Structural properties of load bearing concrete masonry. In: MASONRY: PAST AND PRESENT. Philadelphia: ASTM. Special technical publication 589. pp.233-54. 
SOLÓRZANO, M.G.P. Características e desempenho de juntas de argamassa na alvenaria estrutural de blocos de concreto. 203p. Dissertação (Mestrado) - Escola Politécnica, Universidade de São Paulo, São Paulo. 1994.

SOUZA, R.A. (2004). Concreto estrutural: análise e dimensionamento de elementos com descontinuidades. 379p. + Apêndices. Escola Politécnica, Universidade de São Paulo. São Paulo. 2004.

STEWART, M.G.; LAWRENCE, S.J. (2007). Model error, structural reliability and partial safety factors for structural masonry in compression. Masonry International, v.20, n.3. pp. 107-16.

STÖCKL, S.; BECKHAUS, K.; FRITSCHE, TH. (1998). Influence of test method on the results of deformation measurements on uniaxially loaded mortars specimens. Masonry International, v.12, n.1. pp.32-8.

TZAMTZIS, A.D.; ASTERIS, P.G. (2003a). Finite element analysis of masonry structures: Part I - Review of previous work. In: NORTH AMERICAN MASONRY CONFERENCE, 9., 2003, Clemson, South Carolina. Proceedings. p.101-11.

TZAMTZIS, A.D.; ASTERIS, P.G. (2003b). Finite element analysis of masonry structures: Part II - Proposed 3-D nonlinear microscopic model. In: NORTH AMERICAN MASONRY CONFERENCE, 9., 2003, Clemson, South Carolina. Proceedings. p.146-55.

VASCONCELOS, G. (2005). Experimental investigation on the mechanics of stone masonry. Thesis (PhD). 228p. + Appendixes. University of Minho. Guimaraes, Portugal. 2005.

VERMEER, P.A.; de BORST, R. (1984). Non-associated plasticity for soils, concrete and rock. Heron, 29 (3), 1-64.

VERMELTFOORT, A.T. (2007). Shape factors for calcium silicate and aircrete based on experimental results. Masonry International, v.20, n.2. pp. 75-84.

WAKEFIELD, D.A. (1996). Mortar and it's effect on masonry. In: NORTH AMERICAN MASONRY CONFERENCE, 7., 1996, South Bend. Proceedings. pp.153-66. 
WANG, T.K. (2002). Estudo da Propagação de Fissuras Arbitrárias no Concreto Armado

Utilizando o Modelo Reticulado da Microestrutura. 165p. Tese (Doutorado), Escola Politécnica, Universidade de São Paulo. São Paulo. 2002.

WAWRZYNEK, A.; CIÑCIO, A. FEDOROWICZ, J. (2006). Numerical verification of the Barcelona Model adapted for brick walls. In: INTERNATIONAL MASONRY CONFERENCE, 7., 2006, London. Proceedings.

WU, C.; HAO, H. (2007). Numerical derivation of averaged material properties of hollow concrete block masonry. Engineering Structures. (in press) doi:10.1016/j.engstruct.2007.05.017 . Masonry International, v.4, n.1. pp. 31-35. 



\section{BIBLIOGRAFIA COMPLEMENTAR}

ANDOLFATO, R.P.; CAMACHO, J.S.; RAMALHO, M.A. (2007). Brazilian results on structural masonry concrete blocks. ACI Materials Journal. jan-feb. pp. 33-39.

ATKINSON, R; NOLAND, J; ABRAMS, D. (1985). A deformation failure theory for stackbond brick masonry prisms in compression. In: INTERNATIONAL BRICK/BLOCK MASONRY CONFERENCE, 7., 1985, Melbourne, Australia, p. 577-92. Proceedings.

BARRETO, A.S.P.; OLIVEIRA, R.A. (2002). Análise de tensões em um painel de alvenaria estrutural utilizando técnica de homogeneização. In: CONGRESSO BRASILEIRO DO CONCRETO, 44., 2002, Belo Horizonte Anais.

BARTOLOMÉ, A.S.; QUIUN, D. (2007). Tests for evaluation of slenderness correction factor for masonry prisms. In: NORTH AMERICAN MASONRY CONFERENCE, 10., St. Louis, Missouri. Proceedings. pp.637-48.

CAVAlHEIRO, O.P.; POZZOBON, M.; SANTOS, M. (2003). Digaonal tensile and compressive strengths of hollow clay and concrete block specimens. In: NORTH AMERICAN MASONRY CONFERENCE, 9., Clemson, South Carolina. Proceedings. pp. 801-812. jun.

COLVILlE, J.; MILTENBERGER, M.A.; WOLDE-TINSAE, A.M. (1993). Hollow concrete masonry modulus of elasticity. In: NORTH AMERICAN MASONRY CONFERENCE, 6., Philadelphia, Pennsylvania. Proceedings. jun. pp. 1995-1207. 
COLVILlE, J.; WOLDE-TINSAE, A.M. (1991). Compressive strength of hollow concrete masonry. The Masonry Society Journal, feb. pp. 89-93.

CORMEAU, A.; SHRIVE, N.G. (1995). Fracture mechanics and the future strength design of masonry. In: CANADIAN MASONRY SYMPOSIUM, 7., Hamilton, Ontario. Proceedings. jun. pp. 477-88.

CORMEAU, A.F; SHRIVE, N.G. (1996). Development of a fracture mechanics approach for masonry. In: NORTH AMERICAN MASONRY CONFERENCE, 7., South Band, Indiana. Proceedings. jun. pp. 279-87.

DIAS, M.D. (2005). Susceptibility for cracking of masonry mortar joints when subject to compression. In: CANADIAN MASONRY SYMPOSIUM, 10., Banff, Alberta. Proceedings. pp. 801-812. jun.

DUKUZE, A.; DAWE, J.L. (1993). Evaluation of fracture toughness of clay bricks by threepoint bending test. In: NORTH AMERICAN MASONRY CONFERENCE, 6., Philadelphia, pennsylvania. Proceedings. jun.

DYMIOTIS, C.; GUTLEDERER, B.M. (2002). Allowing for uncertainties in the modelling of masonry compressive strength. Construction and Building Materials, v.16. pp. 443-452.

ELICES, M ; GUINEA, G.V; PLANAS, J. (1992). Measurement of the fracture energy using three-point bend test: Part 1 - Influence of cutting the $\mathrm{P}-\delta$ tail. Materials and Structures, v.25. pp. 327-34.

ELICES, M.; GUINEA, G.V; PLANAS, J. (1997). On the measurement of concrete fracture energy using three-point bend tests. Materials and Structures. vol. 30, p. 375-76.

EL-NAWAWY, O.A.; EL-HADDAD, M.H. (1990). Prediction of strength and fracture behavior of concrete masonry wall units. In: NORTH AMERICAN MASONRY CONFERENCE, 5., Urbana-Champaign, Illinois. Proceedings. jun. 563-79.

GODOY, E.H.P; BARROS, M.M.S.B. (1999). Proposta de procedimento de ensaio para avaliação do módulo de deformação de argamassas. In: SIMPÓSIO BRASILEIRO DE TECNOLOGIA DAS ARGAMASSAS, 3., 1999, Vitória. Anais. p.159-67. 
GROOT, C.J.W.P. (1995). Qualitative modeling of water loss of fresh mortars immediately after bricklaying. In: CANADIAN MASONRY SYMPOSIUM, 7., 1995, Hamilton, Ontario. Proceedings. p.689-99.

GUINEA, G.V. (1995). Modelling the fracture of concrete: the cohesive crack. Materials and Strucutures, n.28, p.187-94.

GUINEA, G.V.; HUSSEIN, G.; ELICES, M.; PLANAS, J. (2000). Micromechanical modeling of brick-masonry fracture. Cement and Concrete Research, v. 30, pp. 731-37.

GUINEA, G.V.; PLANAS, J.; ELICES, M. (1992). Measurement of the fracture energy using three-point bend test: Part 1 - Influence of experimental proceures. Materials and Structures, v.25. pp. 212-18.

HILSDORF, H. (1969). An investigation into the failure mechanism of brick masonry loaded in uniaxial compression. Designing, engineering and construction with masonry products. Houston: F.B. Jonhson, 1969.

JANSEN, D.C.; SHAH, S.P. (1997). Effect of length on compressive strain softening of concrete. Journal of Engineering Mechanics. jan. pp.25-35.

KHOO, C.; HENDRY, A. (1973). A failure criterion for brickwork in axial compression. In: INTERNATIONAL BRICK/BLOCK MASONRY CONFERENCE, 3., 1973, Essen, Germany. p. 139-45. Proceedings.

LAGOMARSINO, S.; CALDERINI, C. (2004). A micromechanical demage model for complex masonry structures. In: INTERNATIONAL BRICK/BLOCK MASONRY CONFERENCE, 13., Amsterdam, The Netherlands. Proceedings.

LANGE, D.A.; DEFORD, H.D.; AHMED, A. (1996). Microstructure and mechanisms of bond in masonry. In: NORTH AMERICAN MASONRY CONFERENCE, 7., Indiana, Proceedings. p.167-74.

LOURENÇO, P.B. (1996). A user/programmer guide for the micro-modelling of masonry structures. Report 03.21.1.31.35. Delft University of Technology. 
LU, S.; HEUER, H.; FLESCH, R. (2005). Material model for unreinforced masonry based on plasticity theory. In: CANADIAN MASONRY SYMPOSIUM, 10., Banff, Alberta, Canada. Proceedings.

MAHER, A.; DARWIN, D. (1982). Mortar constituent of concrete in compression. $\boldsymbol{A C I}$ Journal. v.79. pp.100-109. mar.

MARKSET, G.; HILLERBORG, A. (1995). Softening of concrete in compression localization and size effects. Cement and Concrete Research. v.25, n.4. pp.702-708.

MILTENBERGER, M.A.; COLVILlE, J.; WOLD-TINSAE, A.M. (1993). Relationship between cube and cylinder compressive strength of mortar. In: NORTH AMERICAN MASONRY CONFERENCE, 6., 1993, Pennsylvania. Proceedings. p.1002-1036.

MOHAMAD, G.; LOURENÇO, P.B.; ROMAN, H.R. (2006). Propriedades mecânicas das argamassas sob compressão triaxial - análise e previsão. In: JORNADAS SULAMERICANAS DE ENGENHARIA ESTRUTURAL, 32., Anais. Campinas, São Paulo.

MOHAMAD, G.; LOURENÇO, P.B.; ROMAN, H.R. (2007). Mechanics of hollow concrete blocks under compression: Review and prospects. Cement and concrete composites. v.29. pp.181-192.

NAGUIB, E.M.F.; SUTER, G.T. (1991). Stresses in a running bond brick masonry 3-D finite element model under axial compression. Masonry International, v.5, n.2. pp. 48-54.

NAKAKURA, E.H.; BASTOS, P.K.X; CINCOTTO, M.A. (2005). Influência da velocidade de carregamento na determinação da resistência à tração e da resistência à compressão de argamassas. In: SIMPÓSIO BRASILEIRO DE TECNOLOGIA DAS ARGAMASSAS, 6., 2005, Florianópolis. Anais. 1 CD-ROM. p.785-94.

NEVILLE, A.M. (1997). Propriedades do concreto. Tradução Eng. Salvador E. Giammusso. 2ed. São Paulo: Pini.

NICHOLS, A.B.; LANGE, D.A. (2007). Fracture behavior and mechanics modeling for mortars. In: NORTH AMERICAN MASONRY CONFERENCE, 10., St. Louis, Missouri. Proceedings. pp.779-90. 
OLIVEIRA, M.L.L.; GLEIZE, P.J.P.; ROMAN, H.R. (2003). Ensaio de resistência à compressão em argamassas: NBR vs Rilem. In: SIMPÓSIO BRASILEIRO DE TECNOLOGIA DAS ARGAMASSAS, 5., 2003, São Paulo. Anais. 1 CD-ROM. p.725-27.

PAGE, A.W.; SHRIVE, N.G. (1990). Concentrated loads on hollow concrete masonry. $\boldsymbol{A C I}$ Structural Journal, vol. 87, n.4, pp.436-444.

PARYS, L.V.; DAGRAIN, F.; COUDYZER, C.; DESCAMPS, T. (2005). The scratching test for on-site determination of the compressive strength of historical mortars: method and preliminary results. In: SIMPÓSIO BRASILEIRO DE TECNOLOGIA DAS ARGAMASSAS, 6., 2005, Florianópolis. Anais. 1 CD-ROM. p.746-56.

PELETEIRO, S.C.; CORRÊA, M.R.S.; RAMALHO, M.A. (2001) Analysis of masonry panels using an equivalent homogeneous material. In: CANADIAN MASONRY SYMPOSIUM, 9., Fredericton, Canada. Proceedings.

PIERNAS, R.; CAMACHO, J.S.; RAMALHO, M.A. (2007). Brazilian results on structural masonry concrete blocks. ACI Materials Journal. jan.-feb. pp. 33-39.

PLANAS, J.; ELICES, M.; GUINEA, G.V.; (1992). Measurement of the fracture energy using three-point bend test: Part 1 - Influence of bulk energy dissipation. Materials and Structures, v.25. pp. 305-12.

RENDER, S. (1986). The compressive strength of masonry walls built using blocks laid flat. Pratical Design of Masonry Structures. TTL: London. pp. 319-35.

ROTS, J.G. (Ed.) (1997). Structural Masonry: An experimental/numerical basis for practical design rules. TNO Building and Contruction Research : The Netherlands.

RUTLAND, C.A.; WANGB, M.L. (1997). The effects of confinement on the failure orientation in cementitious materials experimental observations. Cement and concrete research, v.19. pp.149-60.

SALIBA, J.E.; AL-AKKAD, R.S.; SAWAYA, G.E. (1996). Use of finite elements in masonry structures. The Masonry Society Journal, Boulder, v.14, n.2, p.9-16, dec.

SATHISH, V.; RAMAMURTHY, K.; AMBALAVANAN, R. (2000) Behavior of masonry mortars - a factorial design approach. The Masonry Society Journal, v.18, n.2. dec. 
SAYED-AHMED E.Y.; SHRIVE N.G. (1996b). Design of face-shell bedded hollow masonry subject to concentrated loads. Canadian Journal of Civil Engineering, vol. 23, n.1, pp.98106.

THANOON, W.A.; ALWATHAF, A.H.; NOORZAEI, J.; JAAFAR, M.S.; ABDULKADIR, M.R. (2007). Nonlinear finite element analysis of grouted and ungrouted hollow interlocking mortarless block masonry system. Journal of Engineering Structures, doi:10.1016/j.engstruct.2007.10.014.

van der PLUIJM, R. (1997). Non-linear Behavior of masonry under tension. Heron. v.42, n.1. pp. 25-54.

WINKLER, B.; HOSFSTETTER, G.; NIEDERWAGNER, G. (2001). Experimental verification of a constitutive model for concrete cracking. Proceedings of the Institution of Mechanical Engineers, Part L: Journal of Materials: Design and Applications. vol. 215 (2). pp.75-86.

WOLDE-TINSAE, A.M.; ATKINSON, R.H.; HAMID, A.A. (1993). State-of-art of modulus of elasticity of masonry. In: North American Masonry Conference, 6., Philadelphia, Pennsylvania. Proceedings. pp.1209-20.

XIAO, X.; SHRIVE, N. (2001). Masonry fracture mechanics three points bending test of brick. In: CANADIAN MASONRY SYMPOSIUM, 9., Fredericton, New Brunswick. Proceedings.

XIAO, X.; SHRIVE, N. (2005a). Compressive fracture of masonry - experimental study. In: CANADIAN MASONRY SYMPOSIUM, 10., Banff, Alberta. Proceedings.

XIAO, X.; SHRIVE, N. (2005b). Mixed mode fracture brick. In: INTERNATIONAL BRICK AND BLOCK MASONRY CONFERENCE, 13., Amsterdam. Proceedings.

YURTDAS, I.; BURLION, N.; SKOCZYLAS, F. (2004). Triaxial mechanical behaviour of mortar: Effects of drying. Cement and concrete research, v.34. pp.1131-1143. 